\title{
EDYTA PAŁUSZYŃSKA
}
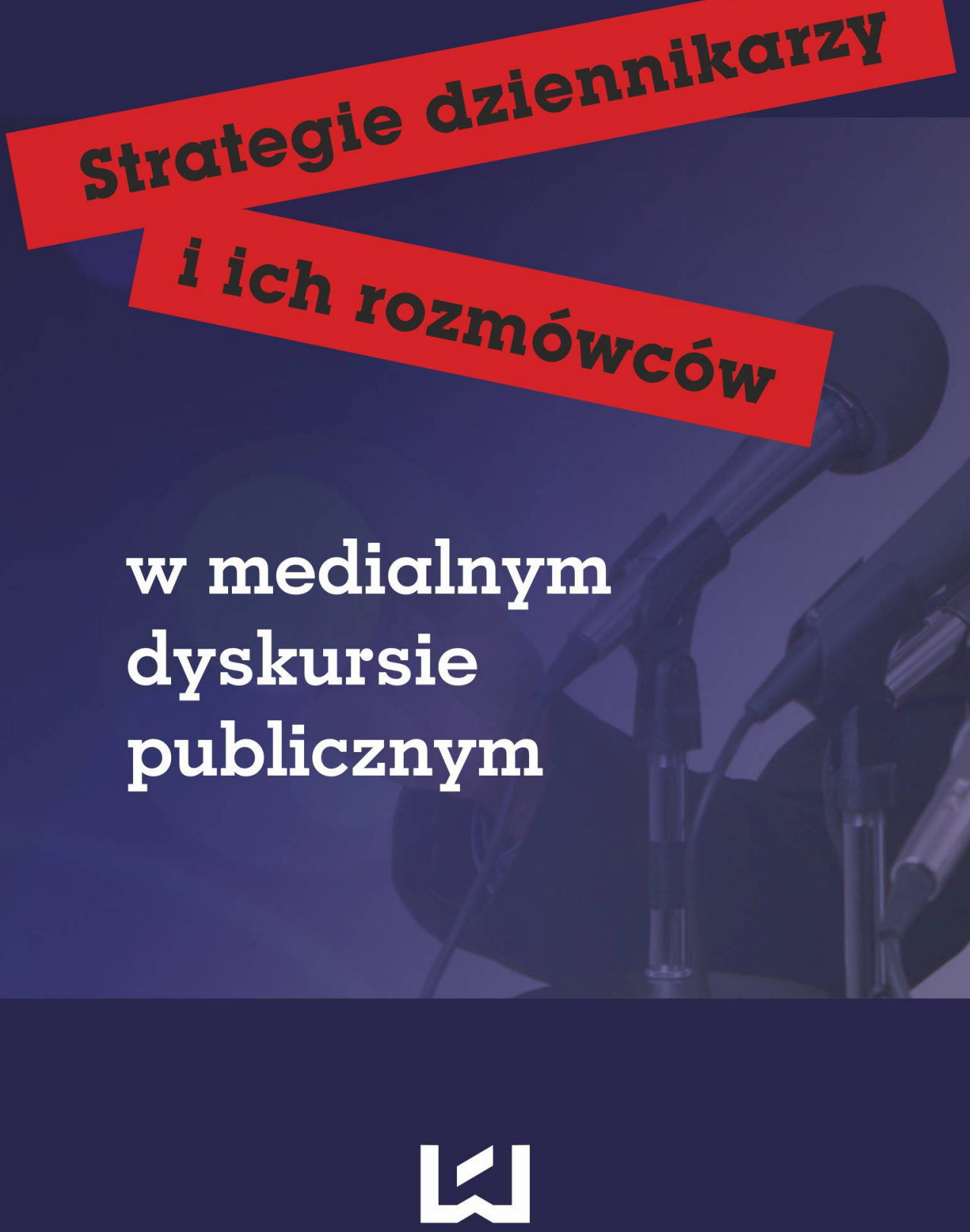


\title{
EDYTA PAŁUSZYŃSKA
}

strategie dziennikarzy

i ich rozmówców

\author{
w medialnym \\ dyskursie \\ publicznym
}

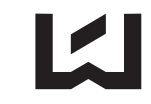

WYDAWNICTWO

UNIWERSYTETU

ŁÓDZKIEGO

ŁÓDŹ 2012 
Edyta Pałuszyńska - Katedra Lingwistyki Stosowanej i Kulturowej, Instytut Filologii Polskiej Wydział Filologiczny, Uniwersytet Łódzki, 90-514 Łódź, al. Kościuszki 65 edyta.paluszynska@gmail.com

\author{
RECENZENT \\ Urszula Żydek-Bednarczuk \\ REDAKTOR WYDAWNICTWA UŁ \\ Katarzyna Gorzkowska \\ SKŁAD I ŁAMANIE \\ ESUS - Agnieszka Buszewska \\ PROJEKT OKŁADKI \\ Barbara Grzejszczak
}

(C) Copyright by Uniwersytet Łódzki, Łódź 2012

Wydane przez Wydawnictwo Uniwersytetu Łódzkiego

Wydanie I. 5071/2012

ISBN 978-83-7525-749-6

https://doi.org/10.18778/7525-749-6
Wydawnictwo Uniwersytetu Łódzkiego
90-131 Łódź, ul. Lindleya 8
www.wydawnictwo.uni.lodz.pl
e-mail: ksiegarnia@uni.lodz.pl
tel. (42) 66558 63, faks (42) 6655862




\section{Spis treści}

Wstęp

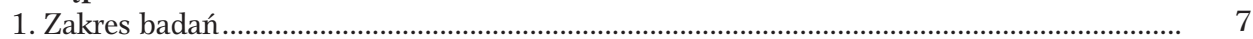

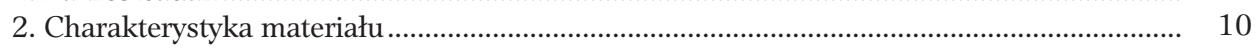

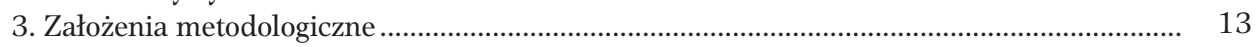

3.1. Pojęcie dyskursu................................................................................................... 13

3.2. Medialny dyskurs publiczny i polityczny ................................................................. 22

3.3. Pojęcia sytuacji i kontekstu .............................................................................................. 27

3.4. Sytuacje i konteksty w medialnym dyskursie publicznym i politycznym ....................... 33

3.5. Pojęcie strategii ............................................................................................................. 38

3.6. Strategie w medialnym dyskursie publicznym i politycznym ...................................... 46

\section{Część I \\ STRATEGIE I ICH UWARUNKOWANIA}

Rozdział 1. Strategie i ich uwarunkowania związane z typem komunikowania ...................... 51

1.1. Strategie i ich uwarunkowania ze względu na organizację systemów komunikowania ... 54

1.2. Strategie i ich uwarunkowania ze względu na zasięg komunikowania .......................... 66

1.2.1. Wpływ norm sfery publicznej na zachowania komunikacyjne regulujące dostęp podmiotów ........................................................................................................ 70

1.2.1.1. Strategie legitymizacji podmiotów sfery publicznej............................... 70

1.2.1.2. Strategie delegitymizacji..................................................................... 74

1.2.1.3. Dopasowanie strategii ...................................................................... 78

1.2.2. Wpływ norm sfery publicznej na zachowania komunikacyjne regulujące skuteczność działań podmiotów

1.2.2.1. Strategie legitymizacji podmiotów sfery publicznej............................... 85

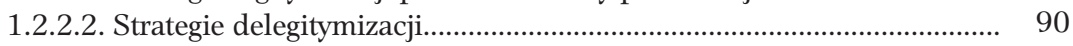

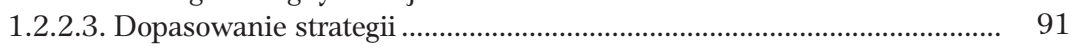

1.3. Strategie i ich uwarunkowania ze względu na sposób komunikowania ......................... 97

1.3.1. Działania dziennikarza związane z makrosytuacyjnymi uwarunkowaniami formy przekazu (organizacja strukturalna programu)............................................ 103

1.3.1.1. Działania związane z delimitacją ramową tekstu.................................... 103

1.3.1.2. Działania związane z delimitacją środkową tekstu ................................. 106

1.3.2. Działania dziennikarzy i rozmówców związane z makrosytuacyjnymi uwarunkowaniami treści przekazu............................................................................ 111

1.3.2.1. Strategie nadawczo-odbiorcze polegające na dostosowaniu przekazu do kompetencji odbiorcy (przyjęcie perspektywy widza) ....................... 112

1.3.2.2. Strategie nadawczo-odbiorcze polegające na kształtowaniu kompetencji odbiorcy masowego .......................................................................... 117

Rozdział 2. Strategie i ich uwarunkowania związane z działalnością pozajęzykową roz-

mówców................................................................................................ nikacyjnych 
2.2. Uwarunkowania strategii związane z dziedziną działalności pozajęzykowej rozmówców ... 139

2.2.1. Schemat interpretacyjny: polityka jako spektakl .................................................. 140

2.2.2. Schemat interpretacyjny: polityka jako gra rywalizacyjna .................................. 144

2.2.3. Kontaminacja schematów interpretacyjnych (spektaklu i gry rywalizacyjnej)... 149

2.3. Uwarunkowania strategii związane ze stereotypem roli społecznej rozmówców ............ 153

Rozdział 3. Uwarunkowania strategii związane z charakterem sytuacji ................................... 165

3.1. Dostosowanie zachowań dziennikarza do charakteru sytuacji ...................................... 166

3.2. Dostosowanie zachowań gości do charakteru sytuacji .................................................... 168

3.3. Sfera prywatna (osobista, intymna) w interakcjach........................................................... 173

Rozdział 4. Strategie i ich uwarunkowania wynikające $\mathrm{z}$ organizacji tekstu mówionego......... 181

4.1. Uwarunkowania wynikające z sekwencyjności .............................................................. 181

4.2. Uwarunkowania wynikające z dialogowości................................................................. 185

4.3. Uwarunkowania wynikające $z$ sytuacyjności ................................................................. 193

\section{Część II \\ STRATEGIE W PROGRAMIE „DEBATA”}

Rozdział 5. Ogólne techniki budowania struktury tekstu - strategie tekstotwórcze................. 203

5.1. Działania o charakterze prospektywnym ..................................................................... 204

5.2. Działania o charakterze retrospektywnym ................................................................. 208

Rozdział 6. Strategie strukturalne ....................................................................................... 213

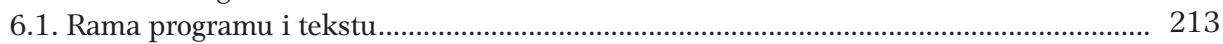

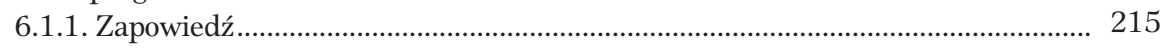

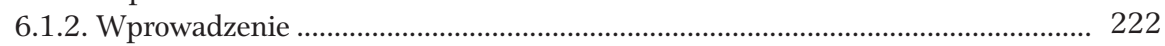

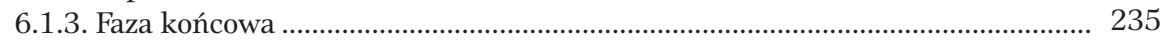

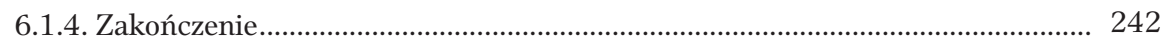

6.2. Segment z udziałem publiczności .................................................................................... 254

6.2.1. Gatunkowe i dyskursywne uwarunkowania wprowadzenia segmentu z pu-

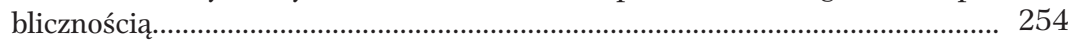

6.2.2. Charakterystyka publiczności jako grupy uczestników....................................... 255

6.2.3. Delimitacja segmentu z publicznością.................................................................. 264

6.2.4. Konstytuowanie grup proponentów i oponentów przez dziennikarza .................. 268 6.2.4.1. Działania podstawowe zmierzające do eksplikacji stanowiska rozmówcy 269 6.2.4.2. Działania wspomagające eksplikację stanowiska rozmówcy ................. 275

6.2.4.3. Działania korygujące zachowanie rozmówców ......................................... 280

6.3. Segment z udziałem gości..................................................................................... 284

6.3.1. Gatunkowe i dyskursywne uwarunkowania wprowadzenia segmentu z udzia-

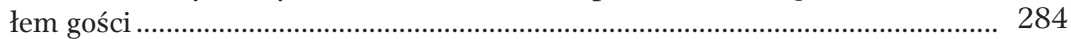

6.3.2. Charakterystyka gości jako grupy uczestników .................................................. 286

6.3.3. Delimitacja segmentu z udziałem gości............................................................... 294

6.3.4. Organizacja segmentu ze względu na liczbę i rodzaj uczestników ...................... 296

6.3.5. Organizacja problemowa segmentu z udziałem gości........................................... 302

6.3.5.1. Etapy organizacji problemowej............................................................. 304

6.3.5.2. Sygnały organizacji problemowej .......................................................... 314

6.3.5.3. Stopień realizacji schematu organizacji problemowej............................ 324

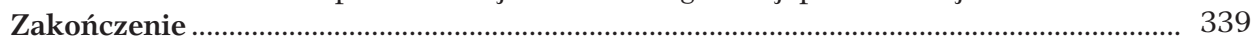

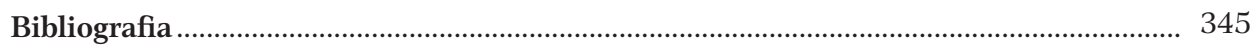

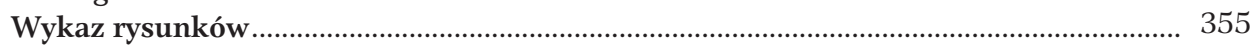

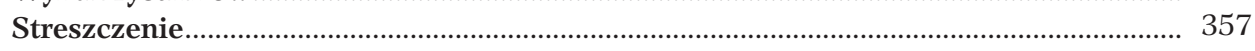

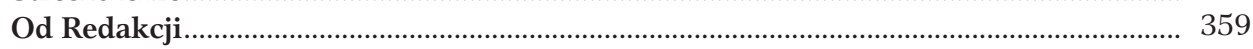




\section{Wstęp}

Medialne programy publicystyczne o formie dialogu włączają się w proces społeczny, którego głównym aktem jest debata publiczna. Wypełniają ją jawne dyskusje i spory o charakterze ciągłym, obejmujące możliwie najszerszy krąg aktorów politycznych, tzn. polityków, media i obywateli. Sfera publiczna ulega nieustannym przekształceniom, a dynamika zmian ma wpływ na dyskurs publiczny, którego częścią jest dyskurs polityczny. Istotnym czynnikiem w tym procesie jest rozwój technologii komunikacyjnych, $\mathrm{z}$ czym wiąże się zastępowanie interakcji bezpośrednich interakcjami zapośredniczonymi przez media oraz wzrost znaczenia masowych audytoriów. Na zmiany w sferze publicznej ma również wpływ instytucjonalizacja coraz większych obszarów życia społecznego. Nasila się zjawisko mediatyzacji polityki i profesjonalizacji komunikowania politycznego. Wszystko to sprawia, że podejmowanie jakiejkolwiek aktywności w sferze publicznej wymaga coraz wyższych kompetencji komunikacyjnych i wiedzy na temat uwarunkowań w systemach komunikowania.

Celem podjętych w pracy badań jest analiza językowych form komunikowania publicznego, w tym form komunikowania politycznego, które realizowane jest za pośrednictwem mediów. Teksty pojawiające się we wskazanej przestrzeni komunikacyjnej są pojmowane jako zdarzenia komunikacyjne. Oznacza to, że są rozpatrywane w szeroko rozumianej sytuacji komunikacyjnej, z uwzględnieniem uwarunkowań instytucjonalnych, społecznych, kulturowych. Na pierwszy plan wysuwa się więc cecha tekstów określana jako dyskursywność. Przedmiotem zainteresowania jest opis tych parametrów dyskursu publicznego i dyskursu medialnego, które decydują o określonej formie językowej tekstów. Źródłem parametrów jest typ praktyki społecznej, w trakcie której wspólnota dyskursywna wypracowuje normy i scenariusze zachowań komunikacyjnych. Odzwierciedlają one ważne dla wspólnoty wartości i umożliwiają realizację istotnych celów społecznych.

Zakres analizy zdarzeń komunikacyjnych obejmuje uwarunkowania sytuacyjne, które przejawiają się na poziomie doboru tematów, konstrukcji świata wykreowanego w dyskursie, realizowanego potencjału illokucyjnego, projektowanego układu interakcyjnego usytuowanego w czasie i przestrzeni, odniesień ideologicznych oraz aktualizowanych konwencji gatunkowych. Uwzględnienie tych parametrów w badaniu grupy tekstów, które łączą podobne czynniki formotwórcze, pozwala dostrzec pewne regularności, powtarzalne algorytmy, 
elastyczne wzory zarówno w kreowaniu zachowań językowych, jak i ich interpretacji. Uwypuklając funkcjonalny i jednocześnie globalny charakter, można je nazwać (odwołując się do terminologii wojskowej) strategiami.

Interpretacja zachowań komunikacyjnych w kategoriach strategii uwzględnia założony cel komunikacyjny i fakultatywne sposoby jego realizacji, tj. środki do celu. Poziom ogólności w wyborze celów powoduje, że strategie tworzą zhierarchizowane układy. Opis ma charakter wieloaspektowy; jego kryteria nakładają się, przeplatają i wzajemnie warunkują. Ze względu na społeczne utrwalenie interakcyjnego modelu rywalizacji (np. w pojęciu wojny, gry) rozpoznawalne są strategie interakcyjne ataku, obrony i uniku. Strategie związane z funkcjonowaniem rozmówców w złożonych systemach komunikowania (np. strategie legitymizacji, strategie delegitymizacji) mają ograniczoną dostępność empiryczną. Nawet odniesienie ich do typu dyskursu, który stanowi przestrzeń semiotyzującą, uprawnia jedynie do postawienia hipotezy interpretacyjnej. Wartość diagnostyczną ma wobec tego powtarzalność, pewna regularność w językowych działaniach taktycznych, która kształtuje określone oczekiwania rozmówców co do nieartykułowanych założeń tkwiących w definicji sytuacji.

Szczególnie cenną weryfikacją hipotez jest obserwacja wszelkich strategii metatekstowych i metadyskursywnych, w których sami uczestnicy negocjują reguły interakcji w sposób jawny. Kluczowe w niniejszej pracy są zatem pojęcia metatekstu i metadyskursu. Przyjmujemy, że wypowiedzi (lub ich fragmenty) spełniające funkcję komentarza i regulujące przebieg bieżącej interakcji mają charakter metatekstowy, kiedy dotyczą jakiejś jednostki tekstu: wyrazu, zdania, akapitu, fragmentu tekstu; lub charakter metadyskursywny, kiedy odnoszą się bezpośrednio i całościowo do kontekstu komunikacyjnego, np. intencji nadawcy, odbiorcy, wzorów działań językowych typowych dla określonego rodzaju dyskursu.

Przeprowadzony wywód został podporządkowany odpowiedzi na globalne pytanie o wpływ szeroko rozumianej sytuacji komunikacyjnej na kształt tekstu. Praca składa się z dwóch części. W pierwszej z nich zanalizowano uwarunkowania strategii dziennikarzy i ich rozmówców wynikające z charakteru sytuacji komunikacyjnej. W części drugiej znajduje się analiza zachowań komunikacyjnych uczestników w wybranym programie publicystycznym. Materiał do części pierwszej pochodzi z całego zgromadzonego przez autorkę zbioru różnych programów publicystycznych o formie dialogu, natomiast podstawą materiałową części drugiej jest kilkanaście odcinków jednego programu.

W rozdziale 1 zanalizowano teksty pod kątem uwarunkowań wynikających z typu komunikacji masowej i komunikacji publicznej. Szczególnie ważne było ustalenie, jak formalizacja komunikowania instytucjonalnego modyfikuje zachowania komunikacyjne rozmówców i wpływa na stosowane przez nich strategie interakcyjne. W rozdziale 2 zbadano, jaki wpływ na zachowania językowe ma rodzaj zaangażowania rozmówców w działalność pozajęzykową. Ważnym 
pytaniem było, w jaki sposób działaniom ludzkim nadawany jest sens i czy w medialnej konstrukcji rzeczywistości można doszukiwać się określonych prawidłowości, które składają się na parametry dyskursu medialnego. Rozdział 3 poświęcono podstawowej kategorii socjolingwistycznej, jaką jest oficjalność sytuacji (rozpatrywana w opozycji do nieoficjalności). Pytaniem, które organizowało badania, był nie tylko problem modelowania zachowań w sytuacji oficjalnej, ale również taktyczne wykorzystanie wiedzy na temat związanych z nią standardów. W rozdziale 4 poszukiwano odpowiedzi na pytanie, jak rodzaj realizacji tekstu wpływa na zachowania uczestników programów publicystycznych, przy czym brano pod uwagę trzy wyróżniki: sekwencyjność, dialogowość i (wąsko rozumianą) sytuacyjność.

W części drugiej poddano analizie cykliczny program publicystyczny, aby zbadać regularność stosowanych w nim strategii strukturalnych, które rozpatrywano na poziomie globalnej organizacji i na poziomie lokalnym. Przedmiotem zainteresowania były przede wszystkim czynności dziennikarza związane z budowaniem ramy tekstu i kreowaniem sytuacji komunikacyjnej w mikrosytuacji według reguł gatunkowych debaty. Tak więc w rozdziale 5 szukano odpowiedzi na pytanie, jaki rodzaj działań podejmuje dziennikarz w celu zbudowania koherentnej struktury tekstu. Analizy przeprowadzone w rozdziale 6 zmierzały do odtworzenia strategii prowadzącego $\mathrm{w}$ obrębie ramy tekstu, segmentu z publicznością i segmentu z gośćmi.

\section{Zakres badań}

Dla podjętych w pracy badań istotne okazały się następujące obszary odniesienia ${ }^{1}$ : dyskurs jako zdarzenie komunikacyjne (tekst w kontekście) i dyskursywność jako kategoria tekstowa (czyli społecznie negocjowane dyrektywy, wzory zachowań językowych o charakterze instytucjonalnym, służące do regulacji form społecznego działania), komunikacja medialna, komunikacja publiczna, w tym komunikacja polityczna. Przy czym wiedza na temat uwarunkowań instytucjonalnych komunikacji ma charakter pomocniczy, służy dostrzeżeniu funkcjonalności działań językowych.

W spojrzeniu na tekst w ujęciu pragmatycznym szczególnie pomocne okazały się prace T. Dobrzyńskiej (1971, 1978), A. Wierzbickiej (1971), S. Gajdy (1982), R. A. de Beaugrande'a, U. Dresslera (1990), D. Ostaszewskiej (1991), A. Wilkonia (2002), U. Żydek-Bednarczuk (2005), J. Bartmińskiego i S. Niebrzegowskiej-Bartmińskiej (2009) oraz E. Szkudlarek-Śmiechowicz (2011). Z prac, które w sposób szczególny dotyczą tekstu mówionego, a ich

${ }^{1} \mathrm{~W}$ punkcie 1. Zakres badań wskazano jedynie najważniejsze prace i obszary badawcze, które zostały włączone do analiz. Rozważania w celu ustalenia podstawowych dla pracy pojęć zostaną przeprowadzone w punkcie 3. Założenia metodologiczne. 
autorzy przyczyniają się do wypracowania w tym zakresie standardów badań, wykorzystano opracowania K. Pisarkowej (1975), J. Mazura (1986), K. Ożoga (1990), J. Warchali (1991), U. Żydek-Bednarczuk (1994), B. Bonieckiej (1994, 1999), J. Winiarskiej (2001), D. Rancew-Sikory (2007). Przybliżenie problemów tekstu z perspektywy genologii lingwistycznej odnaleziono w pracach S. Gajdy (2004), M. Wojtak (2001, 2004) i B. Witosz (2005). Z informacjami na temat gatunków funkcjonujących w sferze mediów zapoznano się w pracach M. Kity (1998), B. Sobczak (2006), K. Kaszewskiego (2006), I. Loewe (2007), G. Ptaszka (2007) oraz W. Godzica (2004).

Spośród monografii, które eksponują dyskursywne spojrzenie na tekst, ważne okazały się teoretyczne opracowania T. A. van Dijka i W. Kintscha (1983), T. A. van Dijka (2001), A. Duszak (1998), E. Miczki (2002), H. Grzmil-Tylutki (2007), J. Labochy (2008), a także prace poświęcone określonemu typowi dyskursu autorstwa E. Laskowskiej (2004), T. Piekota (2006), J. Nocoń (2009), M. Poprawy (2009).

W badaniu zachowań językowych uczestników dialogu konieczne było zaangażowanie metod wypracowanych w ramach teorii aktów mowy i ufundowanego na tej teorii inferencyjnego modelu komunikacji (Austin 1993; Searle 1980, 1983; Grice 1980). Ważną rolę odgrywają w nim zasady kooperacji Grice’a, a dopełnia je zasada grzeczności G. N. Leecha (1983). Szczególnie przydatna dla niniejszych badań stała się pragmatyczna teoria grzeczności rozwijana w publikacjach Robin Lakoff (1973), Debory Tannen (1984) oraz w (zainspirowanej badaniami Ervinga Goffmana) pracy na temat grzeczności autorstwa Penelopy Brown i Stevena C. Levinsona (Brown, Levinson 1987). Zaproponowany przez badaczy model grzeczności pozwala identyfikować zachowania ludzkie jako działania służące obronie twarzy pozytywnej i obronie twarzy negatywnej, umożliwia identyfikowanie określonych sytuacji komunikacyjnych jako aktów zagrożenia twarzy. W kontekście tej teorii pojawiło się pojęcie strategii grzeczności (w istocie rodzaj strategii obronnych), których celem jest zachowanie twarzy pozytywnej i twarzy negatywnej.

Rodzaj materiału badawczego, który stanowią interakcje dialogowe i polilogowe, skłonił autorkę do uwzględnienia prac z zakresu socjolingwistyki. Proponowane w niej podejście interakcyjne (zapoczątkowane przez socjologów, np. Goffmana [2000], Ziółkowskiego [1981]) zakłada, że komunikowanie nie ogranicza się do przekazywania intencji, ale polega na interpretowaniu zachowania (w tym zachowania językowego) w kategoriach znakowych (Hymes 1972; Grabias 2003). Inspirujące były ujęcia interakcji jako działania strategicznego, zaproponowane w ramach gramatyki komunikacyjnej (Awdiejew 1991, 2004; Habrajska 2004; Awdiejew, Habrajska 2004, 2006). W ujmowaniu mechanizmów kreacji rzeczywistości społecznej konieczne okazało się uwzględnienie metaforyzacji jako sposobu rozumienia i doświadczania rzeczywistości (Lakoff, Johnson 1988), schematów poznawczych (Langacker 1995; Mandler 2004), 
ram poznawczych (Minsky 1981), ram interpretacyjnych (Fillmore 1985), które to wzory organizują wiedzę w spójne całości i przez to determinują poznanie.

$\mathrm{Z}$ uwagi na fakt, że debata publiczna jest miejscem ścierania się racji, negocjowania rozwiązań, ważnym zadaniem było odczytanie sygnałów struktury argumentacyjnej w wypowiedziach jej uczestników. Pomocne okazały się zatem opracowania z zakresu retoryki i teorii argumentacji (Tomlin i in. 2001; Gill, Whedbee 2001; Perelman 2004; Kochan 2005; Szymanek 2006; Tokarz 2006; Wasilewski 2006; Wasilewski, Skibiński 2008). W opracowaniu ważnych aspektów komunikacji publicznej i politycznej wykorzystano prace Z. Nęckiego (2000), P. Pawełczyka (2000), M. Mrozowskiego (2001), T. Gobana-Klasa (2002), K. Skarżyńskiej (2002), J. Reykowskiego (2002), A. Golec (2002), J. Stewarta (2002), E. Griffina (2003), J. Fras (2005), B. Dobek-Ostrowskiej (2006).

Agonistyczny wymiar komunikacji politycznej sprawia, że analiza tego typu interakcji wymaga zastosowania schematów poznawczych, które będą w stanie ująć rywalizacyjny, niejawny i manipulacyjny charakter gry politycznej. W zidentyfikowaniu różnych rodzajów działania komunikacyjnego, a więc również w ich kategoryzacji i nominacji, pomocne okazały się pozycje M. Karwata (2006b, 2007). Autor przybliża w nich dwa rodzaje działania, które można, jak sądzę, uznać za charakterystyczne dla omawianej dziedziny aktywności społecznej, a mianowicie dyskredytację i prowokację. W rozpoznaniu typów agresji wykorzystano monografię M. Peisert (2004), która opracowała zagadnienie z perspektywy językoznawczej. Na specyfikę kategorii pragmatyczno-językowych związanych z problematyką walki z przeciwnikiem politycznym wskazują autorzy artykułów z tomu Język polityki a wspótczesna kultura polityczna (Anusiewicz, Siciński 1994). Szczególnie istotne są ustalenia Ireny Kamińskiej-Szmaj, precyzującej pojęcie kultury politycznej (Kamińska-Szmaj 1994), Bogdana Walczaka, który zajmuje się statusem języka polityki (Walczak 1994) i Marii Frankowskiej, opisującej metaforykę w tekstach politycznych (Frankowska 1994).

Ważne dla ustalenia specyfiki działań komunikacyjnych podejmowanych przez polityków okazały się prace z serii Rozmowy o komunikacji (Habrajska 2009), a szczególnie artykuły o propagandzie, agitacji (Awdiejew, Habrajska 2009) i wartościowaniu w dyskursie publicznym (Laskowska 2009). W opisie języka polityki kluczowy jest zarówno jego propagandowy, jak i marketingowy wymiar, co podkreślali polscy językoznawcy (m.in. Bralczyk 1986, 2007; Kamińska-Szmaj 1994a; Ożóg 2004). Tłem niniejszych analiz stały się również opracowania o charakterze socjologicznym i filozoficznym (Czyżewski i in. 1997; Baudrillard 2005; Pratkanis, Aronson 2005).

Biorąc pod uwagę fakt, że komunikowanie publiczne jest zapośredniczone przez media (McNair 1998; McQuail 2007), włączono do analiz obszar badawczy związany z komunikowaniem masowym. Przyjęta perspektywa lingwistyczna wymagała uwzględnienia prac opisujących m.in. takie cechy języka w mediach, jak: ekspansja potoczności, zacieranie granic między oficjalnością i nieoficjalnością, dążenie do ekspresywności (emocjonalizacji, w tym wulgaryzacji) kosztem funkcji 
informacyjnej i z naruszeniem zasady stosowności (por. Satkiewicz 2000; Lewicki, Nowak 2000; Mosiołek-Kłosińska 2000; Skarżyńska 2001; Bralczyk, Mosiołek-Kłosińska 2001; Michalewski (red.) 2002; Dybalska, Kępa-Figura, Nowak 2004; Kamińska-Szmaj, Piekot, Zaśko-Zielińska (red.) 2006). Zaangażowanie środków językowych w mediach jest tylko jednym z przejawów ogólniejszych przemian dyskursu publicznego (por. Chłopicki, Gajda 2008).

\section{Charakterystyka materiału}

Materiał stanowiący podstawę rozważań podjętych w pracy gromadzony był od grudnia 2004 do marca 2009 r. $^{2}$ Nagrywano następujące cykliczne ${ }^{3}$ programy w TVP 1: „Debata” (prowadzenie Kamil Durczok), „Kwadrans po ósmej” (m.in. Maciej Zdziarski, Justyna Dobrosz-Oracz), „Pod prasą” (Tomasz Sakiewicz), „Prosto w oczy” (Monika Olejnik), „Z refleksem” (m.in. Dorota Wysocka-Sznepf), „Wywiad i opinie” (Krzysztof Skowronski); w TVP 2: „Warto rozmawiać” (Jan Pospieszalski), „Tomasz Lis na żywo” (Tomasz Lis); w TVP 3: „Kuchnia polityczna” (Igor Janke), „30 minut” (Krzysztof Leski); w Polsacie: „Co z tą Polską?” (Tomasz Lis); w TVN: „Teraz my!” (Andrzej Morozowski, Tomasz Sekielski), „Kawa na ławę” (Bogdan Rymanowski) ${ }^{4}$. Wśród nich są zarówno codzienne rozmowy medialne, trwające najczęściej do 15 minut, np. „Kwadrans po ósmej” (program poranny), „Kwadrans po jedenastej”, „Z refleksem”, „Prosto w oczy" (programy wieczorne), jak i programy cotygodniowe, trwające od 25 minut, np. „Pod prasą”, do 40 minut, np. „Warto rozmawiać”. Programy krótsze, codzienne, mają formę wywiadu, natomiast programy cotygodniowe, dłuższe, przybierają często formę dyskusji z udziałem dziennikarzy („Pod prasą”, „Wywiad i opinie”, „Kuchnia polityczna”), dyskusji z udziałem polityków i innych osób publicznych (np. „30 minut”, „Warto rozmawiać”) lub zbliżają się do gatunku talk show (,Teraz my!”, „Tomasz Lis na żywo”).

${ }^{2}$ Częstotliwość nagrań wahała się od 60 do 120 minut w miesiącu, pomijając miesiące wakacyjne, kiedy większość stacji telewizyjnych zawiesza emisję programów publicystycznych. Nagrano programy o łącznym czasie 62 godzin (zapisane na 4 taśmach VHS i 36 płytach DVD), z czego losowo wybrano próbę do zapisu o łącznej długości 675 minut z programu „Debata” (15 programów po 45 minut) i 690 minut z pozostałej puli programów. Zapis tekstu zajął ponad 450 stron maszynopisu (średnio 3 minuty programu dają 1 stronę zapisu maszynowego).

${ }^{3}$ Cykliczność jest uważana za ważną cechę przekazów masowych. Odmianą cyklu jest forma ciągła, nazywana formatem, która stanowi ciąg przekazów powiązanych tematycznie, utrzymanych w tej samej konwencji, w których występują te same postacie, często w tej samej scenerii. $\mathrm{Na}$ formule serii oparte są programy typu talk show, widowiska. Forma ciąła ma szansę zdobyć wiernych odbiorców poprzez zaznajamianie ich z konwencją programu (Mrozowski 2001: 63).

${ }^{4}$ Ciągłe zmiany na rynku medialnym powodują, że większość z tych programów zostało już zdjętych z anteny. Do końca 2011 r. emitowane są jedynie „Kwadrans po ósmej”, „Tomasz Lis na żywo”, natomiast program „Kawa na ławę” został przeniesiony do stacji TVN24. 
Programem, który wyróżniał się z oferty publicystycznej ze względu na tematykę, formułę oraz poziom był autorski program „Debata”. Jego gospodarz, Kamil Durczok, to dziennikarz wyróżniony wieloma nagrodami ${ }^{5}$. Wydawcy usytuowali „Debatę” wśród programów publicystycznych. W tekście rekomendującym program, umieszczonym na stronach internetowych TVP, pojawiało się określenie, iż jest to: „dynamiczna dyskusja o najważniejszych problemach i wydarzeniach dla Polski i Polaków. To program pełen kontrowersyjnych i często skrajnych opinii, miejsce, gdzie ścierają się ideologie, światopoglądy”. Tematyka programu dotyczy spraw publicznych, w tym kwestii politycznych, ekonomicznych, społecznych. W porównaniu z innymi programami publicystycznymi (np. „Kwadrans po ósmej”, „Prosto w oczy”, „Co z tą Polską?”) „Debatę” cechuje przyjęcie szerszej perspektywy społecznej, historycznej i kulturowej, co nadaje jej refleksyjny charakter. Punktem wyjścia dla wydawców są nie tyle bieżące wydarzenia polityczne, co ich społeczny oddźwięk, społeczne postrzeganie zjawisk życia publicznego i kształtowanie norm w tym zakresie. Niezależnie od tego, że program realizuje w jakimś stopniu cele komercyjne mediów (np. dostarcza rozrywki), to zawiera jednak stosunkowo dużo elementów edukacyjnych. Zaliczamy do nich komentarze na temat poziomu debaty publicznej, oczekiwanych zachowań jej uczestników. Powoduje to, że mimo dezaktualizacji tematów politycznych, program może stanowić ciekawy materiał badawczy w zakresie kształtowania się wzorów aktywności komunikacyjnej na forum publicznym. Stanowi też przykład aktywizacji opinii publicznej w ważnych sprawach społecznych, które mają charakter ponadczasowy (np. debata o patologiach społecznych, zakresie ingerencji instytucji w życie jednostki, wolności mediów). Tytuł programu jest charakterystyczny, ponieważ sytuuje prowokowane zdarzenie komunikacyjne w kontekście generycznym. Możliwych jest kilka odniesień, z których naturalnie nasuwające się to debata parlamentarna, debata przedwyborcza, prezydencka. Niezbyt oczywiste, ale najważniejsze - jak się okazuje po analizie zawartości - jest odniesienie do debaty publicznej, rozumianej jako główny akt komunikacji politycznej. Wszystkie konteksty gatunkowe, których indeksalizacją jest tytuł, stanowią jednak ważne czynniki formotwórcze i sensotwórcze programu.

Zapis tekstów mówionych (dokonany dla potrzeb badawczych) uwzględnia cechy ${ }^{7}$ ważne dla zrozumienia i możliwie wiernego odtworzenia zdarzenia komunikacyjnego. Program telewizyjny jest przekazem polisemiotycznym

${ }^{5}$ Kamil Durczok dostał m.in. tytuł „Dziennikarza Roku 2000”, był laureatem czterech Wiktorów, zdobywcą trzech Telekamer.

${ }^{6}$ Krótki opis programu był dostępny w okresie jego emisji na stronach internetowych Telewizji Polskiej. Program „Debata” pojawiał się w tygodniowych odstępach czasu od września 2004 do lutego 2006 r. (z przerwą na okres wakacyjny) w programie pierwszym Telewizji Polskiej. Obecnie, po wycofaniu programu $\mathrm{z}$ oferty, usunięto ze stron internetowych również jego opis.

${ }^{7} \mathrm{Z}$ uwagi na to, że autorka nie dysponowała programem do transkrypcji mowy, który rejestruje np. długość pauz, w zapisie stosowane są ogólnie przyjęte znaki przestankowe, czyli kropka, przecinek. Ich użycie nastręczało niejednokrotnie trudności. Wydzielenie jednostek było problematyczne, toteż kierowano się nie tylko kryteriami prozodycznymi, ale również semantycznymi. 
i przetransponowanie go na zapis liniowy, analityczny, wiąże się z uproszczeniem. Należy jednak uwzględnić przynajmniej te elementy, które występując najczęściej, uwydatniają bezpośredni charakter komunikacji w mikrosytuacji. Użycie choćby ograniczonego repertuaru znaków pozwala na oddanie dynamiki i interakcyjności komunikacji. Jest również elementem charakteryzującym układ interakcyjny. Tak więc w zapisie odnotowano urwanie wypowiedzi na skutek niedokończenia przez mówiącego lub przerwania mówiącemu, podejmowanie na nowo wątku przez mówiącego, dokończenie czyjejś wypowiedzi przez mówiącego, nałożenie wypowiedzi (mówienie równoczesne). Do zasygnalizowania tego typu informacji wykorzystano następujące symbole ${ }^{8}$ :

[ początek nakładania się wypowiedzi, który ma miejsce wtedy, kiedy więcej osób zaczyna jednocześnie swoje wypowiedzi lub wtedy, gdy ktoś zaczyna mówić w czasie trwania wypowiedzi poprzednika,

// przerwanie wypowiedzi drugiej osobie, gdy osoba mówiąca milknie na skutek ingerencji innego uczestnika w tok jej wypowiedzi,

/ samorzutne przerwanie wypowiedzi w nienaturalnym momencie, czasem w celu dokonania autokorekty,

- $\quad$ kontynuacja wypowiedzi przerwanej swojej lub innego rozmówcy.

Dla zobrazowania podajemy fragment zapisu z komentarzem dotyczącym interpretacji symboli.

MO: Wspólnota Kazachska/ Czy jest panu bliska Wspólnota Kazachska?

TM: Tak.

MO: -twierdzi: „Przeprosiny redaktora Gaudena za opublikowanie $w$ dzienniku «Rzeczpospolita» karykatur powinny zostać przyjęte, bo islam uczy miłości i przebaczenia” mówia muzutmanie należacy do tego stowarzyszenia. I co pan na to?

TM: Oczywiście, ja też się z nimi zgadzam, ale te przeprosiny powinny być wyraźne. Moja troska jest troska o Polskę. Ja jestem obywatelem [polskim, myślę, że//

MO: [Ale oni twierdza, że przeprosiny powinny zostać przyjęte $i$ to powinna być sprawa zamknięta.

(„Prosto w oczy”, TVP 1, 7.02.2006; MO: Monika Olejnik, TM: Tomasz Miśkiewicz)

Dziennikarka realizuje plan wywiadu. Zamierza zacytować oświadczenie, którym wprowadzi głos polemiczny do stanowiska rozmówcy. Rozpoczyna wypowiedź i przerywa ją (Wspólnota Kazachska/). Zwraca się do rozmówcy, aby podkreślić jego związek z wątkiem (Czy jest panu bliska Wspólnota Kazachska?). Po uzyskaniu odpowiedzi twierdzącej kontynuuje zawieszoną myśl (-twierdzi: „Przeprosiny redaktora Gaudena [...]). Zachowaniem ingerującym w przebieg interakcji jest nałożenie tur. Prowadząca zaczyna mówić jednocześnie z rozmówcą, nie pozwala mu skończyć wywodu i rozmówca milknie (Ja jestem obywatelem [polskim, myślę, że//).

8 W pracy wykorzystano niektóre symbole transkrypcji stosowane w etnometodologii i analizie konwersacyjnej (por. Rancew-Sikora 2007: 37-38). 
Oprócz znaków oddających dynamikę interakcji, w zapisie znajdują się znaki czynności dokonywanych przez transkrybenta, np. pominięcie fragmentu [...], fragment nieczytelny, np. na skutek nałożenia głosów, zakłóceń (?). Podawane są również istotne elementy sytuacji, takie jak gesty, mimika (np. dziennikarz wzrokiem wskazuje następnego rozmówcę, śmiech). Zapis tekstu mówionego nie podlega korekcie poprawnościowej, dla zaznaczenia szczególnie rażącego błędu używa się znaku (sic!).

Program telewizyjny w oczywisty sposób nie jest tożsamy z tekstem zapisanym. Tekst jest tylko jednym z elementów widowiska telewizyjnego. W jego organizacji współuczestniczy ekipa realizatorów obrazu, dźwięku, operatorów kamer. Na efekt końcowy widowiska składa się więc nie tylko praca dziennikarzy. Widowisko to coś więcej niż dyskusja, określa się je jako „celowo zorganizowaną strukturę całościową o określonych ramach czasowych, nadawaną w programie telewizyjnym” (Kuszewski 1971: 44). Według Kuszewskiego widowiska telewizyjne łączy użycie kamery jako interpretatora rzeczywistości, celowa kompozycja dramaturgiczna, sposób organizowania obrazu i dźwięku, masowy odbiór komunikatu, natomiast różnią je zamierzenia autorskie. Analizując widowisko telewizyjne, trzeba mieć zatem na uwadze nie tylko jego aspekt językoznawczy (tekst, gatunek), ale również aspekt medioznawczy (polisemiotyczność, masowość przekazu).

\section{Założenia metodologiczne}

Podstawowe założenia terminologiczne mieszczą się w zakresie trzech pojęć, które porządkują podjęte rozważania. Są to pojęcia dyskursu, kontekstu i strategii. Będą one rozpatrywane najpierw w sensie ogólnym, a następnie w odniesieniu do istotnego (z punktu widzenia badanego materiału) pojęcia medialnego dyskursu publicznego i politycznego.

\subsection{Pojęcie dyskursu}

Dyskurs jest pojęciem, które funkcjonuje w użyciu niespecjalistycznym ${ }^{9}$ oraz jako termin naukowy w obszarach takich, jak socjologia, socjolingwistyka, teoria komunikacji, lingwistyka tekstu, genologia, pragmatyka, gramatyka komunikacyjna, kognitywna (krytyczna) analiza dyskursu. Badania dyskursu mają

9 Leksem „dyskurs” ewokuje staranną odmianę polszczyzny, a w pewnych połączeniach nawet styl retoryczny - por. „myślenie dyskursywne” to 'myślenie logiczne, poznanie pośrednie oparte na rozumowaniu, składające się z szeregu ogniw, z których każde wiąże się logicznie z poprzednim’ (SJPSz, t. 1: 489). W SJPD leksem opatrzony został kwalifikatorem książkowy, w SJPSz kwalifikatorem dawny, natomiast w PSWP określono go jako przestarzały. W słownikach ogólnych podano definicje: 'rozmowa, dyskusja, przemowa' (SJPSz, t. 1: 488); ‘dyskusja lub wypowiedź, w której jakiś poważny temat omawiany jest w sposób uporządkowany i logiczny’ (ISJP, t. 1: 343). 
zatem charakter interdyscyplinarny. W dociekaniu istoty dyskursu pojawia się problem ustalenia jego relacji do tekstu (czy też w niektórych koncepcjach - do wypowiedzi), gatunku i stylu. Niezbędna jest kategoria szeroko rozumianej sytuacji komunikacyjnej, która podlega różnoaspektowej i wielopoziomowej parametryzacji, co umożliwia m.in. powiązanie perspektywy nadawania i odbioru. Ze względu na ontologię przedmiotu badań możliwe jest ujęcie dyskursu jako abstrakcyjnego wzorca i jako jednostkowego zdarzenia ${ }^{10}$.

Teun van Dijk, który jest uznawany za autorytet w omawianej dziedzinie (por. Wojtak 2011: 28; Grzmil-Tylutki 2007: 22), a którego badania stanowią inspirujący punkt odniesienia dla kolejnych badaczy (por. Duszak 1998), ujął dyskurs jako zdarzenie komunikacyjne rozpatrywane w trzech głównych wymiarach: a) jako użycie języka, b) jako przekazywanie idei, c) jako interakcja w sytuacjach społecznych (van Dijk 2001: 10). Dokonując schematyzującej eksplikacji, można stwierdzić, że ujmuje on dyskurs jako wypowiedź i tekst w kontekście ${ }^{11}$. Autor zwraca uwagę na to, że konsekwencją przejścia od abstrakcyjnych struktur języka do rzeczywistych użyć ${ }^{12}$ jest rozpatrywanie uczestnictwa w dyskursie jako działania strategicznego, gdyż „[...] poziomy werbalnej aktywności są zorientowane na wypełnianie istotnych społecznie zadań. Ludzie wypowiadają się, by komunikować swoje idee i zyskiwać zrozumienie, a robią to jako jednostki i jako członkowie grup społecznych, w celu informowania, przekonywania lub olśniewania innych, a także z zamiarem osiągnięcia innych celów, w ramach społecznych sytuacji, instytucji i struktur" (van Dijk 2001: 25).

Zagadnienia omawiane współcześnie w ramach teorii dyskursu nie są zupełnie nowe na gruncie polskich badań socjolingwistycznych, psycholingwistycznych i pragmatycznie zorientowanej lingwistyki tekstu ${ }^{13}$. Uczynienie przed-

10 Dyskurs jako wzorzec należy do modeli kognitywnych i jest wiązką cech (ograniczeń natury ideologicznej, kulturowej, społecznej, komunikacyjnej), natomiast na poziomie struktur aktualnych analizuje się konkretne obiekty, jakimi są jednostkowe zdarzenia komunikacyjne (por. Miczka 2002: 92-93; Wojtak 2010a: 81).

11 We francuskiej teorii dyskursu analogiczna formuła brzmi: dyskurs = wypowiedź + sytuacja komunikacyjna (Grzmil-Tylutki 2007: 22).

12 Z takim kierunkiem analizy polemizują autorzy Tekstologii, którzy postulują przyjęcie perspektywy od zdarzenia komunikacyjnego uwikłanego w kontekst sytuacyjny i strategie komunikacyjne (a więc od dyskursu) do tekstu jako wytworu działań komunikacyjnych. Tekst dziedziczy bowiem wszystkie aspekty dyskursu (relacje do nadawcy, odbiorcy, sytuacji), a dodatkowo wykazuje tendencje do utrwalenia (Bartmiński, Niebrzegowska-Bartmińska 2009: 33).

13 Bożena Witosz podaje, że termin „dyskurs” trafił do polskiej lingwistyki tekstu w znaczeniu, jakie nadał mu Emile Benveniste (1966). Francuski semiolog nazwał tak tekst, którego struktura wskazuje na jego zanurzenie w towarzyszącej mu sytuacji, czego eksponentem były tekstowe składniki deiktyczne: osobowe, temporalne oraz specjalne. W ten sposób dyskurs przeciwstawiony został narracji niespersonalizowanej, prowadzonej w tzw. trzeciej osobie. Początkowo dyskurs odpowiadał więc pojęciom i tekstu, i wypowiedzi. Jeśli zdefiniuje się dyskurs jako zdarzenie komunikacyjne, to zbliża się on bardziej do pojęcia wypowiedzi (Witosz 2009: 70). 
miotem analiz wypowiedzi mówionych (zwłaszcza w formie dialogu) wiązało się już w latach siedemdziesiątych $\mathrm{z}$ uwzględnieniem uwarunkowań sytuacyjnych $^{14}$. Pragmatyczna koncepcja tekstu wiązała jego spójność $\mathrm{z}$ aktualizacją w określonym kontekście. Podkreślano, że aktualizacja stanowi konieczny warunek interpretacji ${ }^{15}$. Wymaga nie tylko wiedzy językowej, ale również (co dziś podkreślają badacze dyskursu) - wiedzy o kulturze i społeczeństwie (Mayenowa 1974). Stanisław Gajda, rewidując potoczne przeświadczenia, akcentował, że: „tekstu nie tworzy się ze zdań, lecz za ich pomocą realizuje” (Gajda 1982: 123). Konstrukcja wyrażeń językowych staje się tekstem, kiedy wpisze się ją w cały kompleks czynników sytuacyjnych, związanych z układem nadawczo-odbiorczym, m.in. kompetencje językowe, dyskursywne, światopoglądowe, kulturowe (Witosz 2009: 74). W prototypowym obrazie tekstu sytuacyjność definiowana jako „powiązanie tekstu z sytuacją komunikowania, tj. z bliskimi okolicznościami użycia i szerszym tłem historyczno-kulturowym, zwłaszcza w sensie czasowym i przestrzennym” jest ważnym składnikiem konstytuującym tekst (Bartmiński, Niebrzegowska-Bartmińska 2009: 49). W analizie wypowiedzi sytuacja traktowana była nie tylko jako otoczenie tekstu, ale również jako czynnik tekstotwórczy (Warchala 1991; Boniecka 1999). Obecnie pojawiają się modele syntetyzujące dotychczasowe badania nad kontekstem i sytuacją komunikacyjną (Żydek-Bednarczuk 2005: 25-29).

Na gruncie socjolingwistyki Stanisław Grabias ujmował dyskurs jako: „ciąg zachowań językowych ${ }^{16}$, których postać zależy od tego, kto mówi, do kogo, w jakiej sytuacji i w jakim celu. Tak pojęty dyskurs jest rodzajem interakcji społecznej dokonującej się przy udziale języka” (Grabias 2003: 264). Interakcyjny, zdarzeniowy charakter omawianego pojęcia podkreśla również Janina Labocha (Labocha 1996b: 49-53; taż 2008: 49-62). Dyskurs definiuje jako normę ${ }^{17}$ oraz strategię

${ }^{14}$ Krystyna Pisarkowa $(1975,1978)$, opisując składnię tekstów mówionych, wprowadziła szerokie rozumienie kontekstu, mieszczące w sobie również sytuację razem z czynnikami pozajęzykowymi (tło aktu mowy wraz ze składnikami fizycznymi, społecznymi, psycholingwistycznymi, tematycznymi i in.). Jan Mazur, podkreślając rolę czynników pozajęzykowych w organizacji tekstu, zaproponował dwa ujęcia sytuacji: wąskie (uczestnicy komunikacji, czas, miejsce, temat, ranga uczestników) i szerokie, w którym usytuował czynniki pozajęzykowe, w tym socjalne (Mazur 1986: 26).

15 Współcześnie zasada ta uległa maksymalizacji do tego stopnia, że podważa się w ogóle możliwość interpretacji, zrozumienia tekstu poza jakąkolwiek sytuacją. Dotyczy to nawet tekstów pisanych, co do których zakładano względną autonomię (por. Labocha 2004).

${ }^{16}$ Koncepcja Stanisława Grabiasa została twórczo rozwinięta na gruncie gramatyki komunikacyjnej. Elżbieta Laskowska przyjmuje, że: „dyskurs jest ciągiem zachowań językowych, powiązanych tematem, celem i sposobem ukształtowania wypowiedzi; temat, sposób i cel warunkują zaś i zarazem są warunkowane przez styl, gatunek mowy oraz sytuację komunikacyjną (Laskowska 2004: 14).

17 Norma ma charakter społecznej i kulturowej regulacji, czuwa nad kształtem wypowiedzi i zapewnia powodzenie komunikacyjne. Strategia ma w tym ujęciu charakter indywidualny (Labocha 2008: 61). 
zastosowaną w procesie tworzenia tekstu i wypowiedzi ${ }^{18}$. Podstawą tej strategii są wzorce społeczne i kulturowe, składające się na tę normę, a jej efektem - tekst lub wypowiedź o określonych cechach gatunkowych. W odróżnieniu od tekstu i wypowiedzi, które mają charakter indywidualny, dyskurs należy do płaszczyzny pośredniej między systemem języka a realizacją tego systemu w konkretnych aktach mowy. Janina Labocha postuluje traktowanie dyskursu jako kategorii tekstowej, która implikuje odniesienie do sytuacji aktu mowy, intencji nadawcy, przewidywanego odbiorcy. Dyskurs „jest jakby okiem kamery, przez którą widzimy przedstawiony świat tak, jak zaprojektował go nadawca tekstu lub/i odczytał (zinterpretował) odbiorca. To spojrzenie podmiotu tekstu (nadawcy lub/i odbiorcy), czyli strategia dyskursywna, nie jest jednak zjawiskiem całkiem indywidualnym, lecz jedną z form i norm społecznego, typowego dla danej wspólnoty kulturowej, obcowania za pomocą języka” (Labocha 2008: 61).

Psychologizujące ujęcie dyskursu z perspektywy mechanizmów przetwarzania informacji, które pojawiło się u Teuna van Dijka i Janiny Labochy, zostało doprecyzowane i rozwinięte przez Annę Duszak w propozycji typologizacji zdarzeń komunikacyjnych (Duszak 1998: 173-198). Badaczka wyodrębnia dwa główne typy struktur globalnych w dyskursie: o charakterze makrostrukturalnym (semantyka komunikatu) i superstrukturalnym (formalna organizacja). Konsekwencją procesualnego i dynamicznego modelu dyskursu przyjętego przez autorkę było zrelatywizowanie wykładników tekstowości: „tekstowość powstaje w wyniku ocen uczestników komunikacji. Jest ona sprawą stopnia [...] stanem umysłu jednostki” (tamże: 19), choć podlega również w jakimś stopniu obiektywizacji o charakterze społecznym. Biorąc pod uwagę fakt, że przetwarzanie informacji na poziomie globalnym wymaga uruchomienia bardziej złożonych typów operacji mentalnych niż na poziomie lokalnym, można przyjąć, że jest ono zależne od poziomu kompetencji komunikacyjnej uczestników oraz pozostaje pod kontrolą jakiejś strategii komunikacyjnej. Tak więc związki między mówieniem a działaniem, a zwłaszcza cel, jaki nadawca chce osiągnąć za pomocą tekstu, powodują, że o strukturach globalnych dyskursu można mówić, zdaniem Anny Duszak, w kategoriach strategii (ze względu na ich elastyczność, nastawienie na cel komunikacyjny, zrelatywizowanie do konkretnego układu nadawczo-odbiorczego, wiedzy i kompetencji podmiotu interpretującego).

18 Janina Labocha wprowadza rozróżnienie między tekstem a wypowiedzią. Wypowiedź nagrana w trakcie opowiadania zawiera składnik pragmatyczny i tematyczny. Składnik pragmatyczny jest zakotwiczony w sytuacji komunikacyjnej i tylko na jej tle zrozumiały. Składnik tematyczny to ta część wypowiedzi, która ma charakter autonomiczny i jest zrozumiała również w oderwaniu od sytuacji komunikacyjnej. Przez tekst Labocha rozumie składnik tematyczny wypowiedzi mówionej, utrwalony i opracowany w taki sposób, żeby przy najmniejszej ingerencji redakcyjnej mógł zaistnieć we wtórnej komunikacji, np. jako tekst przeznaczony do czytania lub ponownego słuchania w innej sytuacji komunikacyjnej. Takie teksty zalicza do tekstów zapisanych i opracowanych, ponieważ ich podstawą jest wypowiedź mówiona (Labocha 2004: 5-10). 
W przytoczonych ujęciach dyskurs uznano za termin szerszy, tekst natomiast jest ujmowany wąsko, jako sama werbalizacja (por. „dyskurs obejmuje całość danego aktu komunikacji, a więc zarówno określoną werbalizację (tekst), jak i czynniki pozajęzykowe, które jej towarzyszą, tj. przede wszystkim określoną sytuację użycia oraz jej uczestników” - Duszak 1998: 19). Bożena Witosz zauważa, że w powstającym dopiero paradygmacie analizy dyskursu pojęcie tekstu ulega nieuprawnionej redukcji - tekst zostaje uznany za twór statyczny, autonomiczny, sztucznie wypreparowany z kontekstu (Witosz 2009: 69-77). Badaczka słusznie stwierdza, że: „różnicy (bo taka zachodzi bezspornie) między lingwistyką tekstu a badaniami dyskursu należy poszukiwać nie tyle w samej koncepcji obiektu badań, ile w postawie i preferencjach badawczych. Cechy wiązane dziś na ogół z dyskursem - interakcyjność, procesualność, szeroko rozumianą sytuacyjność - odnajdujemy także w 'tekście' ” (Witosz 2009: 77). Tym, jak sądzę, można tłumaczyć synonimiczne traktowanie terminów „dyskurs” i „tekst” w pracach niektórych językoznawców (Boniecka 1999: 37; Miczka 2002: 95; Żydek-Bednarczuk 2005: 29). Reasumując, wąskie ujmowanie tekstu sprzyja wyostrzeniu opozycji dyskurs/tekst, natomiast przyjęcie pragmatycznej koncepcji tekstu włącza dyskurs do kategorii tekstowych, co oczywiście nie musi oznaczać pominięcia nowych obszarów badawczych.

Niewątpliwie należą do nich możliwości, jakie wynikają z rozpatrywania dyskursu jako zinstytucjonalizowanego społecznie typu praktyki. Oznacza to badanie wypowiedzi w relacji podmiotów, która np. w tzw. francuskiej szkole dyskursu $^{19}$ nazwana została oddzielnym terminem „kontrakt” (co świadczy o jej ważności). Kontrakt można rozumieć jako instytucjonalizację intersubiektywnej relacji między uczestnikami komunikacji; jako formalizację, która jest przez nich akceptowana i która wyznacza partnerom role i obowiązujące reguły komunikacyjne w danym typie sytuacji (Maingueneau 1998, 2002, za: Grzmil-Tylutki 2007: 22-26). Instytucjonalny wymiar dyskursu oznacza również to, że interpretacja, czyli negocjowanie znaczenia tekstu, dokonuje się zawsze w ramach 'wspólnoty interpretacyjnej"20, wedle wyznaczonych zasad, które umożliwiają odczytywanie znaczeń, regulują akt interpretacji, zapobiegając błędnym lub całkowicie dowolnym odczytaniom (Fish 2002, za: Witosz 2009: 75). Zasady te (o naturze pragmatycznej, socjolingwistycznej, komunikacyjnej)

19 Nurt w badaniach tekstów pisanych i ustnych, rozwijający we francuskim kręgu językowym od początku lat siedemdziesiątych XX w., do którego badaczy Halina Grzmil-Tylutki zalicza Dominique’a Maingueneau i Patricka Charaudeau (Grzmil-Tylutki 2007: 21).

${ }^{20}$ Pojęcie wspólnoty interpretacyjnej bliskie jest pojęciu instytucji, która w ujęciu Stanleya Fisha oznacza „formy społecznie zorganizowanego działania, zespoły intersubiektywnie istniejących konwencji, których poznanie i użycie umożliwia jednostkom funkcjonowanie w społeczeństwie” (S. Fish 2002, za: Witosz 2009: 75). U Stanisława Gajdy pojawia się określenie „społeczność dyskursywna”, którą cechuje wspólnota ideowo-kulturowa zbudowana na określonej wizji świata (Gajda 2001: 8). 
rządzą przepływem treści implicytnych i eksplicytnych między nadawcą i potencjalnym odbiorcą. Ich zbiór stanowi część wiedzy o naturze komunikacji, która jako wspólna, nie musi być każdorazowo werbalizowana: „Ta wiedza, którą można by nazwać metadysursywną czy metakomunikacyjną, stanowi warunek konieczny realizacji i interpretacji jakiejkolwiek wypowiedzi” (Miczka 2002: 43). Z tej perspektywy dyskurs można określić jako wypowiedź rozpatrywaną ze względu na mechanizmy warunkujące jej powstanie (Maingueneau 1991: 15, za: Miczka 2002: 42).

Wyraźna semiotyzacja kontekstu, która odpowiada za możliwość zgodnego $^{21}$ tworzenia wyobrażeń na temat zachowań w danej sytuacji dyskursywnej, uprawnia do wyodrębnienia typów dyskursów na podstawie różnych kryteriów. Ze względu na pozycję ideologiczną zajmowaną w obrębie pola dyskursywnego można wyodrębnić np. dyskurs egzystencjalny w filozofii, dyskurs lewicowy w polityce; ze względu na obszar aktywności społecznej - dyskurs dziennikarski, religijny, wojskowy, uniwersytecki; ze względu na kategorię podmiotową - np. dyskurs uczniów, sędziów, matek; ze względu na dominującą funkcję języka np. dyskurs polemiczny, ludyczny, fatyczny, informacyjny (por. Grzmil-Tylutki 2007: 23). Typologia ma charakter otwarty, a kryteria mogą się krzyżować22. Teksty podobne pod pewnym względem (dyskurs sejmowy, dyskurs sądowy, dyskurs polityczny) można traktować jako archiwum wiedzy o normach i wartościach grup, które scala przynależność do wspólnoty działania i myślenia w ramach aktywności społecznych, kulturowych, ideologicznych, profesjonalnych (Labocha 2009: 53).

Tak więc dyskurs jest często odnoszony do zbioru wypowiedzi konstruowanych z określonych pozycji społecznych, ponieważ koncentruje się na propagowanych przez grupy ideologiach, postawach, normach zachowań oraz ich społecznych efektach. Próby określenia relacji między językiem a innymi elementami zjawisk i procesów społecznych podejmowane są w ramach krytycznej analizy dyskursu (KAD). Podstawowym celem w tych badaniach jest łączenie analizy tekstu $\mathrm{z}$ analizą społecznego kontekstu, rozumianego jako kognitywna reprezentacja, rodzaj wiedzy budowanej przez użytkowników języka (por. Duszak 2010: 33-43). Anna Duszak określa KAD jako interdyscyplinarny projekt badawczy, czerpiący z różnych teorii, trendów i metod analizy, lub jako formę krytycznych

${ }^{21}$ Największa zgodność i jednocześnie przewidywalność cechuje dyskursy zrytualizowane, wyraziste pod jakimś względem, np. dyskursy ideologiczne. W przebiegu komunikacji mogą wystąpić przypadki niewłaściwego semiotyzowania sytuacji lub próby negocjowania kontraktu dyskursywnego, kiedy np. rozmówca pragnie zmienić relację formalną w prywatną lub odbiera działanie w ramach roli jako prywatną inicjatywę.

22 Jako przykład Halina Grzmil-Tylutki podaje dyskurs religijny, który ze względu na pozycję może być katolicki, ortodoksyjny, przedsoborowy; ze względu na podmiot może być dyskursem księdza, pastora, wiernego; ze względu na funkcję językową - dyskursem magicznym, symbolicznym (Grzmil-Tylutki 2007: 23). 
badań społecznych, w których zakłada się, że dyskurs odzwierciedla i jednocześnie tworzy rzeczywistość społeczną (system semiozy społecznej). Główny nurt tworzą badania, w których analizuje się zmiany społeczne i komunikacyjne, rolę ideologii, rozumianej jako normy, przekonania, wierzenia lub - w sensie krytycznym - jako narzędzie władzy symbolicznej. W centrum zainteresowań znajduje się komunikacja publiczna, a szczególnie media, które dystrybuują różne ideologie i dyskursy klas dominujących ${ }^{23}$. Ważnym celem KAD jest zatem m.in. demaskowanie represyjnego i fałszującego aspektu praktyk językowych (por. Fairclough, Duszak 2008: 12).

Przykładem tego typu analizy jest model proksymizacji, opracowany przez Piotra Capa i zastosowany do zbadania retoryki amerykańskiego zaangażowania wojskowego w Iraku od 2003 r. (Cap 2008: 245-265). Dzięki zastosowaniu terminu „proksymizacji”, który oznacza techniki przybliżania problematyki związanej z wojną $\mathrm{w}$ aspekcie przestrzennym, czasowym i aksjologicznym, udało się zidentyfikować strategię legitymizacji (podjęcia i kontynuowania) działań wojennych. O perswazyjnym charakterze tego typu strategii świadczy według autora fakt, że weryfikacja istotnych danych (utrata argumentu domniemanego posiadania broni masowego rażenia przez reżim Saddama Husajna) nie powoduje weryfikacji kierunku działań (ewentualne przerwanie wojny), a jedynie zmianę proporcji strategii w modelu proksymizacji (rozbudowanie podstrategii aksjologicznej kosztem przestrzennej) (por. tamże: 264). Należy podkreślić, że tego typu badania, w których pokazana zostaje strategiczność działań władzy, posiadają walor społecznej użyteczności, gdyż realizują cele edukacyjne, przyczyniając się do zwiększania świadomości społecznej.

W krytycznej analizie wskazuje się zatem wyraźnie na związki dyskursu z wiedzą i władzą. Socjologiczną, w tym również filozoficzną, historyczną i kulturową analizę tych relacji można odnaleźć w twórczości Michaela Foucaulta ${ }^{24}$. Definiował on dyskurs jako sposób ujmowania świata w kategorie poznawcze i językowe, który jest determinowany przez dziedzinę życia społecznego i historyczno-kulturowy charakter epoki. Władza dyskursu przejawia się w narzucaniu podziałów społecznych, definiowaniu prawdy i fałszu, dobra i zła, normalności i patologii. Jest to jednak władza specyficzna („,bez podmiotu”), gdyż wszyscy ją sprawują i wszyscy jej podlegają ${ }^{25}$. Foucault, powołując się na liczne przykłady, dowodzi, że władza dyskursu przejawia się w tworzonej wiedzy, kolonizowaniu, wykorzystywaniu procedur lokalnych do konstruowania coraz ogólniejszych

23 Teun van Dijk określa wprost badania w nurcie KAD jako wyraz zaangażowania naukowców w ważne problemy społeczne (van Dijk 2001: 32). Ich celem jest odsłanianie i demistyfikowanie struktur dominacji; pokazywanie, jak mowa utrwala nierówności społeczne i jest narzędziem wykluczenia. Temu właśnie nastawieniu analiza dyskursu zawdzięcza określenie „krytyczna”.

${ }^{24}$ Por. Foucault 1977, 1995.

25 Por. Ziółkowski 2006: 452. 
mechanizmów i form dominacji globalnej. Tak więc dyskurs stanowi (obok prawodawstwa) ważny element władzy, który wytwarza „aparat wiedzy i wielorakie obszary poznania” oraz reguły naturalne, tzn. normy (Foucault 2006: 521). Według badacza, techniki wiedzy i strategie władzy nie są wobec siebie zewnętrzne. Drobne, lokalne schematy poznawcze wpisują się w strategię całości i na odwrót: żadna strategia nie mogłaby gwarantować globalnych skutków, gdyby nie związki podpierające. Taktyczna funkcja segmentów dyskursu nie jest jednolita ani stała. Wielość elementów dyskursywnych znajduje zastosowanie w rozmaitych strategiach. W analizie dyskursu należy brać pod uwagę to, co wyrażone i zatajone, jego narzucone i zakazane wypowiedzi, warianty różnicujące się w zależności od osoby mówiącego, jego udziału we władzy, instytucjonalnego kontekstu, w jakim jest osadzony, a także wszelkie przesunięcia i spożytkowanie identycznych formuł w przeciwnych celach (Foucault 1995: 86-91). Można więc zauważyć, że badania socjologiczne, akcentując rolę dyskursu w kształtowaniu stosunków społecznych, są zbieżne z kierunkiem współczesnych badań językoznawczych.

Pomimo istniejących rozbieżności terminologicznych (naturalnych $\mathrm{w}$ ramach różnych dyscyplin) istotę dyskursu udało się uchwycić Marii Wojtak, która dookreśla go jako „sposób zorganizowania ludzkiej aktywności, a więc także praktyki komunikacyjnej określonej społeczności (wspólnoty), która w trakcie różnorodnych interakcji ustala i uzgadnia istotne dla siebie treści, konserwuje stosowne scenariusze zachowań komunikacyjnych oraz reguły ich wypełniania za pośrednictwem wypowiedzi (i/lub środków niewerbalnych)” (Wojtak 2011: 29). Badaczka podkreśla, że w obrębie dyskursu mieszczą się zbiory gatunków wypowiedzi, które służą wyprofilowaniu i utekstowieniu określonych idei, ocen i postaw, a „gatunek rozpatrywany na tle dyskursu jest postrzegany nie przez pryzmat wyznaczników morfologicznych, lecz w uwikłaniach komunikacyjnych i kulturowych" (tamże).

Porządkujący charakter ma również postulat badaczki, aby oddzielić dyskurs jako wzorzec od dyskursu jako jednostkowego zdarzenia komunikacyjnego $^{26}$. Rozróżnienie to pozwala uniknąć wielu dylematów dotyczących ontologii dyskursu, np. krzyżowania się jego zakresu z tekstem czy wypowiedzią. Wiadomo bowiem, że wypowiedź jest zawsze konkretnym zdarzeniem komunikacyjnym, natomiast tekst może być rozpatrywany zarówno jako wzorzec tekstu (tekstem), jak i jednostkowe użycie języka (Bartmiński, Niebrzegowska-Bartmińska 2009:

${ }^{26}$ Wzorzec dyskursu nie jest w językoznawstwie czymś osobliwym. Maria Wojtak stworzyła nowoczesną teorię wzorca gatunkowego, który dzięki elastyczności jest w stanie ująć przeobrażenia gatunków. Wzorzec ma charakter kompleksowego zbioru reguł, dookreślających najważniejsze poziomy organizacji w aspekcie strukturalnym, pragmatycznym, poznawczym i stylistycznym, a realizowany jest w trzech zasadniczych wariantach: jako wzorzec kanoniczny, alternacyjny i adaptacyjny (Wojtak 2004). 
39-40). Dyskurs rozumiany jako wzorzec, a jednocześnie jako punkt odniesienia dla jednostkowych realizacji, stanowi wiązkę cech, którą (w zależności od priorytetów badawczych) można dobierać, selekcjonować, precyzować, hierarchizować w kilku zakresach. Obejmują one ogólne dyrektywy (reguły, ograniczenia, wyznaczniki), odnoszące się do zaplecza ideologicznego, wyboru formacji ideologicznej popieranej i odrzucanej przez nadawcę, typu aktu illokucyjnego realizowanego za pomocą danej sekwencji, globalnego przesłania komunikacji, wyznaczników kulturowych, struktur instytucjonalnych i organizacyjnych, cech uczestników aktu komunikacji, ich ról społecznych, typowego usytuowania czasowego i przestrzennego ${ }^{27}$.

Wydaje się, że analiza zdarzenia komunikacyjnego powinna polegać na szukaniu śladów określonego dyskursu w tekście, identyfikowaniu jego elementów na różnych poziomach opisu jako sygnałów dyskursywności. Semantyzacja tego typu struktur tekstowych jest jednak możliwa tylko przez odniesienie ich do całego ciągu innych tekstów i sytuacji komunikacyjnej, co Wofgang Heinemann nazywa obrazowo „pragmatycznym zanurzeniem” (Heinemann 2009: 366). Jeśli przyjąć, że dyskursy są wiązkami złożonych relacji między wypowiedzenia$\mathrm{mi}$ a procesami i normami społecznymi ${ }^{28}$, to zależności takie ujawniają się tylko w dużych zespołach tekstów. Dyskurs jako instrument społecznych praktyk i sprawowania władzy jest jednostką o charakterze transtekstualnym, co oznacza, że pojedynczy tekst otrzymuje właściwe znaczenie i funkcję dopiero na tle współdeterminujących go innych tekstów. Można powtórzyć za Heinemannem, że: „dyskurs staje się obligatoryjnym punktem odniesienia przy opisie pojedynczych tekstów [...] dyskursywność musi zostać włączona jako dodatkowa konstytutywna cecha do szeregu znanych wskaźników tekstualności” (Heinemann 2009: 373).

Współczesny człowiek żyje w warunkach psychospołecznego, kulturowego i komunikacyjnojęzykowego wieloświata (Gajda 2001: 7). Jest członkiem różnych społeczności, które współuczestniczą w tworzeniu, reprodukowaniu i odbieraniu dyskursów. Wymaga to edukacji komunikacyjnej przez świadome działania instytucjonalne, które przygotują ludzi do funkcjonowania w określonych społecznościach dyskursywnych. Ważną rolę w tym procesie odgrywają media, ponieważ za ich pośrednictwem prowadzony jest główny nurt dyskursu publicznego ${ }^{29}$, którego częścią jest dyskurs polityczny.

27 Rozważania na temat wyznaczników dyskursywności, reguł dyskursu, dyrektyw, ograniczeń dyskursu znajdują się w wielu opracowaniach (van Dijk 2001: 39-42; Duszak 1998: 242-263; Miczka 2002: 93; Wojtak 2011: 30; Fleischer 2003: 6-45).

${ }^{28}$ Por. Foucault 1977: 244.

${ }^{29}$ W ramach dyskursu publicznego realizowane są dyskursy o charakterze tematycznym (np. dyskurs na temat oceny stanu wojennego, zaangażowania polskich wojsk w Iraku, stosunków polsko-ukraińskich, eutanazji, narkomanii, aborcji). 


\subsection{Medialny dyskurs publiczny i polityczny}

Na dyskursywność tekstów analizowanych w niniejszej pracy największy wpływ mają uwarunkowania wynikające z systemu komunikowania i specyfiki działalności publicznej, w tym działalności politycznej podmiotów. Ważne zatem będzie scharakteryzowanie dyskursów: publicznego (w odróżnieniu od dyskursu niepublicznego, tj. potocznego, prywatnego) oraz politycznego, które toczone są w mediach ${ }^{30}$. Istotne wydaje się również zderzenie aspektu normatywnego - a więc odpowiedź na pytanie, jaki powinien być dyskurs publiczny - z aspektem opisowym, który pozwoli stwierdzić, jaki jest stan obecny i jak zmienił się współczesny dyskurs publiczny i polityczny po przełomie roku 1989. Należy też uwzględnić, jaki wpływ na zmiany sfery publicznej mają media. Zmiany te determinują bowiem zachowania komunikacyjne uczestników dyskursu i rzutują na stosowane przez nich strategie.

Publiczny charakter przekazu w podstawowym rozumieniu jest funkcją jego dostępności. Właśnie ze względu na dostępność buduje się podstawowa opozycja: przekaz niepubliczny/przekaz publiczny. Przekaz publiczny - to znaczy taki, który z założenia i świadomie jest skierowany do odbiorcy zbiorowego ${ }^{31}$. Brak ograniczeń dystrybucyjnych wymusza większy stopień sformalizowania i zinstytucjonalizowania takich przekazów, co wpływa na językowy sposób ukształtowania wypowiedzi. Z kolei przekaz niepubliczny ma ograniczoną dostępność ze względu na charakter prywatny, stąd większa wariantywność w doborze środków językowych. Publiczny lub niepubliczny charakter komunikacji jest skorelowany z podziałem ogółu stosunków społecznych na dwie sfery: sferę prywatną, czyli sferę stosunków i interesów osobisto-rodzinnych, oraz sferę publiczną, czyli sferę stosunków i wartości szerszej wspólnoty (Chłopicki, Gajda 2008: 16).

Biorąc pod uwagę przede wszystkim kryterium dostępności, definiuję dyskurs publiczny, odwołując się do jego zasięgu i struktury: jest to dyskurs dostępny publicznie, do którego należą wszelkie przekazy skierowane do różnorodnych audytoriów i powstające z myślą o nich. W ramach dyskursu publicznego

${ }^{30}$ Odróżniając dyskurs publiczny od politycznego i medialnego, zdajemy sobie sprawę z częstego utożsamiania tych pojęć i nakładania się ich zakresów. Przychylamy się jednak do opinii uczestników dyskusji panelowej na temat dyskursu publicznego, którzy podają w wątpliwość całkowite ich utożsamienie, nazywając je „zubożeniem” i „zawężeniem” (por. Chłopicki, Gajda 2008: 15).

31 Na nieredukowalność tego założenia wskazuje Elżbieta Laskowska, według której „istotą dyskursu publicznego jest założenie istnienia odbiorcy zbiorowego i zamierzonego”. Brak zgody na nieograniczony odbiór zmienia dyskurs z publicznego na upubliczniony (np. podstępne nagranie prywatnej rozmowy i opublikowanie jej bez zgody rozmówcy) (Laskowska 2009: 62). Odróżnienie dyskursu publicznego od dyskursu potocznego o charakterze prywatnym postuluje również Marek Czyżewski. Oprócz odmiennych konwencji komunikacyjnych i stylowych zwraca uwagę na wzrost znaczenia audytoriów dla komunikacji publicznej, co powoduje inscenizację i dramaturgię wystąpień oraz dyskusję nad prawomocnością określonych zagadnień i stanowisk (Czyżewski i in. 1997: 12). 
usytuowane są dyskursy instytucjonalne (parlamentarny, szkolny, sądowy), dyskursy związane z typami działalności społecznej (naukowy, artystyczny, polityczny, biznesu, religijny, subkultur). Coraz pokaźniejsza część dyskursu publicznego przenosi się do mediów, które z przekaźnika stają się przestrzenią semiotyczną ${ }^{32}$. W obrębie dyskursu publicznego można zatem mówić o dyskursie mediów (określonych bądź w ogólności).

W społecznym obiegu pojęcie dyskursu publicznego ulega wzbogaceniu o postulaty normatywne, które odzwierciedlają wartości demokratyczne i obywatelskie. Sferę publiczną proponuje się jako społeczną przestrzeń, w której możliwa jest racjonalna dyskusja o sprawach publicznych między elitami politycznymi, gospodarczymi oraz społecznościami obywatelskimi (Mrozowski 2001: 62). Publiczna sytuacja dyskursu powinna implikować jego zakres tematyczny (głównie troska o dobro publiczne, np. wychowanie młodzieży, zakres ingerencji państwa, wolność słowa), funkcję (sprawny instrument rozumu publicznego) i poziom (prezentowanie wyważonych stanowisk wolnych od partykularyzmu, otwartość na dialog i kompromis, powściągliwość w eskalowaniu form rywalizacji) ${ }^{33}$. To właśnie z ujęcia normatywnego wywodzą się reguły dyskursu publicznego, których przestrzeganie jest elementem kompetencji komunikacyjnej uczestników. Tak zdefiniowany dyskurs publiczny na poziomie normatywnym jest (powinien być) jakościowo różny od dyskursu potocznego, w którym dominują sprawy życia codziennego, o charakterze osobistym, a rozmówców łączą relacje nieoficjalne, familiarne.

Ze względu na zasięg, dyskurs odnoszący się do polityki jest pojęciem węższym od dyskursu publicznego. Polityka pojmowana jest jako sztuka osiągania celów, co do których nie ma społecznej zgodności, zarówno w sferze wartości, jak i środków (Pawełczyk 2000: 19), lub też ogólniej - jako dziedzina, której zadaniem jest regulowanie życia społecznego (Cetwiński, Karwat 2001: 18). Jest ona sferą umowną o dość dużym stopniu komplikacji zagadnieńn ${ }^{34}$. Dyskurs polityki to część dyskursu publicznego, która obejmuje wypowiedzi polityków w ramach ról przypisanych im w obrębie instytucji politycznych. Są to wypowiedzi osób należących do elity władzy. Część dyskursu polityki przekazują media.

32 Media nie są ani przezroczystym, ani neutralnym pośrednikiem w komunikacji publicznej. Realizują zadania, kierując się własną poetyką i własnymi interesami (Mrozowski 2001: 134). Współczesny odbiorca dąży do utożsamienia tekstów medialnych z rzeczywistością. Tymczasem mediatyzacja zaciera cechy odzwierciedlenia, jest raczej symulacją efektu realności. Granica między fikcją a rzeczywistością ulega zatarciu (Szczęsna 2007: 27).

${ }^{33}$ Na normatywny wymiar dyskursu publicznego w świadomości obywateli wskazywali uczestnicy dyskusji panelowej Wspótczesny polski dyskurs publiczny w perspektywie międzykulturowej: Marek Zybura, Jerzy Mikułowski Pomorski, Andrzej Zoll, Walery Pisarek (Chłopicki, Gajda 2008).

34 Wynikają one stąd, że rolę polityka, a zwłaszcza przywódcy politycznego, cechuje znaczna różnorodność celów (np. reprezentowanie interesów określonej grupy społecznej, sformułowanie programu działania, reorganizacja gospodarki i systemu prawno-administracyjnego) oraz wysoka ranga decyzji, które wpływają na funkcjonowanie całych społeczności, zdrowie, pracę obywateli, a nawet ich życie (Skarżyńska 2002: 86). 
Dyskusje z udziałem polityków aranżowane przez środki masowego przekazu (czyli poza bezpośrednim kontekstem ról związanych z uczestnictwem w elicie władzy) należą do dyskursu politycznego (Czyżewski i in. 1997: 16-20). Socjolodzy podkreślają udział elit symbolicznych ${ }^{35} \mathrm{w}$ dyskursie politycznym oraz jego medialny charakter. Dyskurs polityczny jest zatem (w odróżnieniu od komunikowania politycznego ${ }^{36}$ ) na trwałe związany z mediami masowymi, które stanowią współcześnie centrum wszelkich procesów społecznych.

Relacje między dyskursem publicznym w sensie węższym (aspekt normatywny) a dyskursem polityki mogą przybrać postać alternatywy, co znajduje odzwierciedlenie w typie argumentacji i strategiach stosowanych przez uczestników. Otóż dyskurs polityki jest toczony w sferze publicznej, ale charakteryzuje się swoistymi celami, do których należą: zaspokajanie politycznych interesów i potrzeb określonej grupy, dążenie do zdobycia i utrzymania władzy. Uczestnicy dyskursu polityki występują (nie zawsze jawnie) z pozycji rywalizacji, dominacji i władzy. Natomiast uczestnicy dyskursu publicznego powołują się na służbę publiczną, interes społeczny, dobro wspólne. W idealnym modelu demokracji dyskurs polityki dochodzi do głosu w trakcie procesu wyborczego, a po wyborach powinien ustąpić dyskursowi publicznemu ${ }^{37}$. Tak więc dyskurs publiczny rozumiany wąsko - jako dyskurs, którego celem jest dobro publiczne - nie jest utożsamiany powszechnie $\mathrm{z}$ dyskursem elit władzy, w którym według społecznego przeświadczenia dominuje partykularyzm. Zjawiskiem widocznym natomiast jest zawłaszczanie przez dyskurs polityczny sfery publicznej.

Wszelkie ustalenia dotyczące treści oraz zadań dyskursu publicznego i politycznego muszą być ostatecznie odniesione do reguł dyskursu medialnego, który stanowi najważniejszy punkt odniesienia niniejszych analiz. Jakość dyskursu medialnego wynika z natury mediów. Jak twierdzi Dobek-Ostrowska: „Współczesne

35 Pojęcie elit symbolicznych pojawia się w pracach z zakresu socjologii dla określenia grup i osób, które sprawują bezpośrednią kontrolę nad publicznie dostępną wiedzą, publicznie prawomocnymi przekonaniami, nad kształtem i treściami dyskursu publicznego. Elity symboliczne - do których należą publicyści, dziennikarze, redaktorzy, pisarze, duchowni, naukowcy, eksperci, ludzie biznesu, intelektualiści, politycy występujący w mediach - odgrywają szczególną rolę w ustalaniu hierarchii spraw ważnych i nieważnych, publicznie prawomocnych hierarchii wartości moralnych i estetycznych, wzorów recepcji prawd naukowych. Elity symboliczne sprawują władzę w zakresie dyskursu publicznego, a więc sferze symbolicznej, co różni je od elity władzy, mającej realny wpływ na decyzje polityczne (Czyżewski i in. 1997: 17).

${ }^{36}$ Komunikowanie polityczne ma na celu publiczne przekazywanie i wymianę komunikatów o polityce między aktorami politycznymi i obywatelami przy włączeniu na szeroką skalę mediów masowych (Dobek-Ostrowska 2006: 155). Jest zatem przestrzeń społeczna poza mediami, w której takie komunikowanie może zachodzić (np. spotkania polityków z wyborcami, wiece, petycje obywateli do władz).

37 Por. Dobek-Ostrowska 2006: 119-124. Również uczestnicy dyskusji panelowej na temat dyskursu publicznego wykazywali troskę o dobro wspólne i zaniepokojenie częstym sprowadzaniem tego dyskursu do polityki (Chłopicki, Gajda 2008: 22). 
media masowe $\mathrm{w}$ systemach demokratycznych mają potrójną, niekompatybilną naturę. Po pierwsze - są to wielkie przedsiębiorstwa produkcyjne, które muszą być rentowne, aby utrzymać się na rynku. [...] Po drugie - tworzą całą gamę usług publicznych, spełniając funkcję informacyjną, edukacyjną, rozrywkową. Po trzecie - urastają do rangi instytucji politycznej, będąc ważnym aktorem w systemie komunikowania politycznego" (Dobek-Ostrowska 2006: 118). Media pośredniczą i uczestniczą jako podmiot w komunikowaniu politycznym (choć jednocześnie są zainteresowane w podtrzymaniu mitu obiektywizmu ${ }^{38}$ ). Ich rola, polegająca na zbieraniu, przetwarzaniu i dystrybuowaniu informacji, przyczynia się do tłumaczenia odbiorcom decyzji politycznych, a przez to - legitymizacji systemu politycznego.

Podlegająca różnym hierarchizacjom konfiguracja funkcji, zadań i celów mediów (informowanie, interpretowanie, edukowanie, perswazja, mobilizacja, rozrywka) konstytuuje specyficzny dyskurs mediów. Niezależnie od rodzaju medium, istotą tego dyskursu jest kreowanie wizji świata dalekiej od prostej referencji, dostosowanie przekazu do preferencji odbiorców, przezwyciężanie ograniczeń komunikacji masowej poprzez interakcyjny styl komunikacji, zakorzenienie w kulturze popularnej ${ }^{39}$. Reprezentatywnym zjawiskiem w tym zakresie jest infotainment, czyli hybryda gatunkowa łącząca informację z rozrywką. Składają się na nią takie elementy, jak: fragmentacja (zdarzenia ukazywane są poza motywującym je kontekstem społecznym), konkretyzacja (brak odwołań do ogólniejszych praw i wiedzy teoretycznej), personalizacja (koncentrowanie się nie na abstrakcyjnych procesach, lecz na ludziach, którzy podlegają emocjom), sensacjonizm (eksponowanie elementów szokujących, tragicznych, tragikomicznych) (Mrozowski 2001: 253-254). Połączenie informacji z rozrywką idzie w parze z zacieraniem różnicy między informacją a komentarzem ${ }^{40}$. Czysta informacja staje się mniej pożądana, gdyż minimalizuje perswazyjne oddziaływanie dziennikarza i zwiększa dystans. Stąd dziennikarze nie stronią od środków o mniej lub bardziej wyraźnym potencjale perswazyjnym. Tendencje te nasilają się w obrębie paratekstu, zapowiedzi, tytułów, lidów, które w sposób szczególny pełnią funkcję fatyczną, reklamową. Trafnym określeniem tego zjawiska jest „podkręcanie” informacji (Wojtak 2010b: 32).

38 Niezależnie od tego, że interesy mediów są zbieżne z interesami elit władzy i elit ekonomicznych, media muszą się jednocześnie od nich dystansować, gdyż w przeciwnym razie utraciłyby wiarygodność w oczach odbiorców (Mrozowski 2001: 223).

39 Por. Wojtak 2010a: 81-89.

40 Zasada oddzielania informacji od komentarza jest dla dyskursu dziennikarskiego fundamentalna, co znajduje odzwierciedlenie w podziale gatunków na informacyjne i publicystyczne (Wojtak 2004: 29-38). Wypowiedź dziennikarska ma umożliwić odbiorcy odróżnienie faktów od opinii i poglądów. Postulat ten jest istotnym elementem paktu faktograficznego (Bauer 2000: 146-147). Inną sprawą jest relatywizacja informacji i komentarza, zważywszy na fakt, że w pewnym sensie każdy tekst stanowi interpretację rzeczywistości. Odróżnienie jest zatem sprawą stopnia obecności nadawcy (Krzemiński 2010: 157-166). 
Infotainment jako przejaw funkcji ludycznej w dyskursie medialnym jest związany ze zwrotem mediów ku tzw. szerszej publiczności. Nadawcy medialni wkładają wiele wysiłku w to, aby zniwelować typowy dla komunikacji masowej dystans przestrzenny i czasowy oraz podważyć jej jednokierunkowośćc ${ }^{41}$. Dziennikarze programów telewizyjnych zwracają się bezpośrednio do odbiorców, pozorując interakcję twarzą w twarz; zapraszają do studia przedstawicieli społeczeństwa, z którymi odbiorca może się identyfikować. Przyjmują perspektywę szarego człowieka, starając się nadać interakcji osobisty i prywatny charakter w celu zmniejszenia dystansu. Widoczna jest zatem koncentracja na funkcji fatycznej. Nadawca stara się w ten sposób zrekompensować jednostronność komunikowania poprzez wysiłek włożony w budowanie wspólnoty z odbiorcą, systemu wzajemnych relacji opartych na podzielanych wartościach, doświadczeniach. W interesie mediów, ale i z potrzeb psychologicznych odbiorcy, kształtuje się coś w rodzaju interakcji paraspołecznej, która ma stanowić namiastkę prawdziwych interakcji (Cwalina 1999: 53-78).

Zmiany $\mathrm{w}$ dyskursie medialnym są zbieżne $\mathrm{z}$ załamaniem się obowiązującego do lat osiemdziesiątych paradygmatu oficjalności w kontakcie ogólnym i przyzwalają na stosowanie w nim struktur jezzykowych charakterystycznych dotychczas tylko dla kontaktu indywidualnego ${ }^{42}$. Nastąpiła zmiana ${ }^{43}$ modelu porozumiewania się: z modelu dominacji nadawcy (model autorytarny) na model dominacji odbiorcy (model liberalny) (Warchala 2003: 210). Decentracja i pluralizacja nadawców, interaktywizacja procesów komunikacyjnych spowodowana nowymi technologiami komunikacyjnymi sprawiają, że „publiczność zyskuje podmiotowość i prawa, jakich nigdy dotąd nie miała - staje się V władzą” (Gajda 2010b: 27). Działający w warunkach konkurencji wolnorynkowej nadawca medialny dostosowuje przekaz do kompetencji i wymagań odbiorcy, stara się dotrzeć do przeciętnego widza (raczej już konsumenta niż obywatela), mówić jego językiem. Prowadzi to do poszerzania się sfery potoczności rozumianej zarówno jako wartość stylistyczna języka, jak i perspektywa poznawcza. W wymiarze

41 Prymarnie komunikacja masowa miała charakter tylko jednokierunkowy i niesymetryczny, tzn. z jednego centrum do wielu odbiorców, bez możliwości zmiany ról, była pozbawiona kontaktu bezpośredniego, tzn. z oddzieleniem przestrzennym i czasowym nadawcy od odbiorcy (Cockiewicz 1994: 188-189; Goban-Klas 2004: 111; Bugajski 2006: 475). Włączanie wypowiedzi widzów (telefony, SMS-y, sondy, sondaże) do struktury programów (tzw. moduły makrosytuacyjne) przełamuje jednostronność komunikacji (Szkudlarek-Śmiechowicz 2010: 61-92).

${ }^{42}$ W socjolingwistyce odróżnia się społeczny kontakt ogólny od indywidualnego, łącząc go $\mathrm{z}$ asymetrią rangi nadawcy względem odbiorcy i wariantywnością struktur językowych. Dla kontaktu ogólnego typowa jest instytucjonalizacja i oficjalność (Grabias 2003: 264-272).

43 Zmiany w modelu komunikacji badacze wiążą ze zmianami modelu dyskursu politycznego po dwóch przełomach 1980/1981 i 1989 r. Konwencje użycia języka przeobrażają się pod wpływem transformacji ustrojowych i ekonomicznych procesów rynkowych. Język dotyczący polityki z narzędzia propagandy staje się wielogłosem, środkiem wyrażania różnorodnych poglądów, idei, opinii (Walczak 1994; Warchala 2003: 200; Kamińska-Szmaj 2001: 7-11). 
kulturowym te procesy skutkują deprecjonowaniem kultury wyższej i w efekcie przyczyniają się do dewaluacji elit symbolicznych.

Popularyzacja i komercjalizacja mediów w liberalnej gospodarce rynkowej jest analizowana w kategoriach tabloidyzacji. Pojęcie to, używane początkowo w odniesieniu do prasy, przeniesiono na inne media, w tym telewizję. Do przejawów procesu zalicza się m.in.: upraszczanie wizji rzeczywistości, jej polaryzację, dwubiegunową aksjologię, moralizację, potoczny język, emocjonalizację, schlebianie publiczności poprzez krytykę elit, a zwłaszcza polityków, koncentrację na celebrytach, preferowanie krótkich, wręcz sloganowych przekazów, przewagę obrazu nad słowem, a więc wizualizację komunikacji (Fras 2010: 70).

Biorąc pod uwagę powyższe ustalenia, zakładamy, że dyskurs publiczny i polityczny toczony w mediach stanowi całościowe zjawisko, którego jakość ma niewiele wspólnego $\mathrm{z}$ wyidealizowanym wzorem działalności publicznej. Jego poziom i treści zależą głównie od logiki mediów ${ }^{44}$, czyli wymogów atrakcyjnego widowiska i są spowodowane instrumentalizacją mediów przez świat polityki oraz fasadowością demokratycznych mechanizmów decyzyjnych ${ }^{45}$. Ponieważ rzeczywiste problemy polityczne są zbyt specjalistyczne i należą do dyskursu eksperckiego, odbiorca medialny otrzymuje zamiast tego treści określane jako politainment (powiązanie polityki, dziennikarstwa i rozrywki) ${ }^{46}$.

\subsection{Pojęcia sytuacji i kontekstu}

Okoliczności, w jakich człowiek podejmuje działania językowe, mają na nie różnoraki wpływ. Można rozpatrywać okoliczności jako te, które towarzyszą nadawaniu komunikatu, wraz ze wszystkimi uwarunkowaniami, dotyczącymi wyboru stosownej i skutecznej formy językowej. Wówczas na pierwszy

${ }^{44}$ Logika mediów to determinowanie zawartości przekazów medialnych przez strategię i sposoby działania instytucji medialnej na rynku. Reguły tej logiki zależą od praw rynku (dążenia do zwiększenia zysków i zmniejszenia kosztów, zwiększenia liczby odbiorców kosztem dążenia do wysokiej jakości przekazów, niedziałania wbrew reklamodawcom i publiczności), rozwoju technologii, zmian w kulturze (np. zmian wzorców zaspokajania potrzeb odbiorców) (Fras 2010: 69).

45 Badania medioznawców odsłaniają obraz daleki od idealnych założeń. Instytucje władzy tworzą rozmaite bariery utrudniające dostęp mediów do pewnych informacji. Są zainteresowane przekazywaniem jawnej propagandy lub w najlepszym razie kreowaniem pozytywnego wizerunku, co ma zagwarantować pokazywanie polityków w sposób korzystny. Decyzje polityczne zapadają za zamkniętymi drzwiami, a zapadłe tam uzgodnienia są następnie odgrywane publicznie w debacie parlamentarnej, w sposób odpowiadający wymogom widowiska (oratorskie popisy, utarczki słowne, zajadłe spory, dramatyczne głosowania) (Mrozowski 2001: 130-131).

${ }^{46}$ Ewa Szkudlarek-Śmiechowicz, powołując się na Andreasa Dörnera, definiuje politainment jako formę publicznej, medialnej komunikacji, w której tematy polityczne i procesy polityczne oraz ich interpretacja zostają pokazane w konwencji rozrywki, dzięki temu tworzą obszar doświadczeń społecznych, w których polityka staje się dostępna dla odbiorców (Szkudlarek-Śmiechowicz 2010: 22-23). 
plan wysuwa się funkcja regulacyjna otoczenia aktu komunikacji, wraz z preferencjami typowych wzorców stylowych, gatunkowych, odpowiednich w danych okolicznościach oraz z ograniczeniami zachowań uznanych za niestosowne. Funkcja regulacyjna wiąże się więc $z$ wyborem, którym kierują preferencje i ograniczenia, wynikające $\mathrm{z}$ dostosowania zachowań do okoliczności mowy. Można również rozpatrywać okoliczności wypowiedzi jako te, które towarzyszą jej odbiorowi, a wówczas mają one za zadanie wspomagać interpretację tekstu (w analizie dyskursu mówi się precyzyjniej o integracji dyskursu). Ich rolę można określić jako sensotwórczą. Zadaniem nadawcy jest powiązanie określonej formy komunikatu z uwarunkowaniami, które przesądziły o takim, a nie innym kształcie tekstu ${ }^{47}$.

Z jeszcze inną perspektywą analizy mamy do czynienia wówczas, kiedy okoliczności wypowiedzi stają się jej tematem, a więc nadawca w sposób bezpośredni wskazuje na elementy otoczenia fizycznego, definiuje wprost układ interakcyjny, negocjuje role nietrwałe uczestników, podważa pozwolenie na dany rodzaj działań komunikacyjnych, wskazuje na zależność zachowań komunikacyjnych od relacji instytucjonalnych itd. W takim przypadku okoliczności wypowiedzi mają charakter tekstotwórczy. Tego typu działania językowe są dla badacza szczególnie cenne, gdyż ukazują mechanizmy komunikacji, a niektóre z nich ujawniają nawet implicytne zasady dyskursu.

Tak więc wszystko to, co znajduje się poza fizycznością samego tekstu zostaje włączone w dynamiczny proces komunikacji na etapie nadawania i odbioru. Reguły tego włączenia stają się jawne wtedy, gdy kodowanie przechodzi na metapoziom komunikacji.

Okoliczności aktu komunikacji bywają nazywane tłem pozajęzykowym, sytuacją, kontekstem sytuacyjnym, kontekstem. Terminu „sytuacja” używano w filozofii na oznaczenie 'stanu rzeczy jako fragmentów rzeczywistości, znajdujących swe odbicie w zdaniach języka naturalnego', i tak też to pojęcie jest rozumiane potocznie ${ }^{48}$. Słusznie zauważa jednak Aleksy Awdiejew, że sytuacja jest zaledwie uproszczonym modelem stanu rzeczy, rzeczywistości, gdyż zawiera tylko te elementy, które są obecne w świadomości mówiącego w momencie wypowiadania się i - co najważniejsze - które wpływają na wybór środków językowych podczas tworzenia wypowiedzi (Awdiejew 1984: 103-104). Badacz w celu wskazania zależności między rzeczywistością, sytuacją a wypowiedze-

47 Odbiorca może np. różnie zinterpretować ten sam komunikat, w zależności od uwarunkowań roli społecznej nadawcy: raz jako groźbę (jeśli nadawca pozostaje w relacji władzy), a innym razem jako narzekanie (kiedy pozostaje w relacji podrzędnej). Interpretacja działań podlega zmianom w ramach instytucji, np. rozmowy polityka z biznesmenem na gruncie prywatnym są inaczej interpretowane niż wtedy, gdy nazwie się je interwencją poselską.

${ }_{48}$ Sytuacja jest ogólnie definiowana przez związek z miejscem, które implikuje określone warunki, por. 'zespół okoliczności, położenie, w jakim się ktoś znajduje, ogół warunków, w których coś się dzieje, coś się rozwija' (SJPSz, t. 3: 387). 
niem używa określenia sytuacji jako struktury sensu ${ }^{49}$. Oddaje ona pewien stan przedwerbalny, który jest podstawą dla realizacji językowej. Autor rozpatruje zatem sytuację ze względu na mechanizm werbalizacji, czyli obiera kierunek od rzeczywistości, poprzez sytuację, do wypowiedzi.

Dla logików i językoznawców (zwłaszcza zajmujących się składnią) ważne jest zagadnienie odniesienia grup nominalnych i zdań do rzeczywistości, czyli zagadnienie referencji (Topolińska 1984; Wolniewicz 1985; Lyons 1989; Grzegorczykowa 1995). Przyjmują więc kierunek analizy od zdania do sytuacji, od grupy nominalnej do argumentu. W logice sytuacja jest rozumiana jako odniesienie przedmiotowe (korelat semantyczny) zdania, od którego zależy jego wartość logiczna. Zdanie jest prawdziwe, o ile zachodzi sytuacja, która zdanie to opisuje; jeśli nie zachodzi, zdanie jest fałszywe. W tym ujęciu sytuacja jest fragmentem rzeczywistości, który weryfikuje zdanie ${ }^{50}$. Założenia logiki zasadniczo przejęła składnia predykatowo-argumentowa, w ramach której sytuacja określana jest jako zbiór tych elementów (przedmiotów i ich właściwości lub przedmiotów i relacji między nimi), do których odsyła zdanie (Topolińska 1984: 20) ${ }^{51}$.

W filozofii i logice sytuacja była zatem rozumiana raczej w kategoriach konkretnej, obserwowalnej zmysłowo rzeczywistości (ad oculos). Pojawia się jednak potrzeba rozszerzenia koncepcji sytuacji jako jedynie fizycznego otoczenia nadawcy. Argumentów dostarcza np. analiza składniowa. Wśród jednostek opisu składniowego, jakimi są wyrażenia argumentowe, wyróżnia się bowiem takie, które odsyłają do przedmiotów materialnych (przestrzennie wymiernych, wyróżnianych w procesie nazywania części otaczającego nas materialnego świata, np. kamień, kamień przydrożny, człowiek) i do przedmiotów niematerialnych (np. spacer, codzienny spacer całej szkoły). Jak twierdzi Zuzanna Topolińska, predykaty, które otwierają pozycje tylko dla argumentów przedmiotowych (predykaty pierwszego rzędu), tworzą struktury będące odbiciem relacji obserwowa-

${ }^{49} \mathrm{~W}$ procesie konceptualizacji podmiot dokonuje rozczłonkowania danego odcinka rzeczywistości, a w jego świadomości powstaje określona struktura pojęć (konceptów). Każdy składnik takiej struktury (pojęcie proste) oraz sama struktura w całości mogą być zastąpione przez wyraz, grupę wyrazów lub wypowiedzeń. Zastąpienie pojęć w strukturze sytuacji przez wyrazy, połączenia wyrazów, wypowiedzenia Aleksy Awdiejew nazywa werbalizacją (Awdiejew 1984: 104).

${ }^{50}$ Oprócz zdań analitycznych, które są prawdziwe na mocy znaczenia występujących w nim słów, wszystkie inne zdania w logice mają charakter syntetyczny, a więc wymagają weryfikacji przez odniesienie ich do rzeczywistości (por. Szymanek 2004: 338-341).

${ }^{51}$ Niezbędne jest zatem, aby w zdaniu został sprecyzowany przedmiot lub zbiór przedmiotów tego fragmentu rzeczywistości, do którego się ono odnosi, który denotuje. Przedmioty zastępuje się w zdaniu argumentami, które stanowią ich językowe korelaty. Obok wskazania przedmiotu niezbędne jest wyrażenie w nim tego, co się o tych przedmiotach stwierdza, czyli przypisanie im cech, właściwości lub relacji, które je łączą. Do tego celu służą predykaty. Wyrażenia argumentowe służą do wskazywania przedmiotów, czyli pełnią funkcję referencyjną. Wyrażenia predykatywne służą do opisywania, charakterystyki wskazanych przedmiotów i są używane askryptywnie (Topolińska 1984: 20-22). 
nych przez człowieka w świecie materialnym (podmiot obserwujący). Predykaty implikujące, obok przedmiotowych, również argumenty nieprzedmiotowe noszą miano predykatów wyższego rzędu. „Struktury predykatowo-argumentowe z predykatami wyższego rzędu to językowe odbicie psychicznej działalności, myślowej spekulacji człowieka, wyraz i odbicie umiejętności tworzenia wtórnych, fikcyjnych światów, a także wydawania ocen zjawisk obserwowalnych w świecie materialnym” (Topolińska 1984: 302).

Owa spekulacyjność myślowa człowieka musiała zostać uwzględniona w odpowiednio pojemnych definicjach sytuacji. Według Barbary Bonieckiej „sytuacją jest to wszystko, co dla mówiących ma znaczenie wtedy, gdy konstruują teksty, czy też to, co powinni brać pod uwagę, gdy mówią inni, wreszcie to wszystko, z czego powinni zdawać sobie sprawę, wchodząc w interakcję, przy założeniu, że stronom zależy na osiągnięciu konkretnych celów” (Boniecka 1999: 49). Autorka podkreśla zatem rolę sytuacji w tworzeniu i odbieraniu tekstów oraz jej wpływ na skuteczność działań interakcyjnych.

Taką funkcję językoznawcy przypisują również szeroko rozumianemu kontekstowi $^{52}$. Stanisław Gajda nazywa „kontekstem” określone kulturowo okoliczności, które determinują wypowiedź i wyróżnia trzy rodzaje kontekstu. Najbliższy stanowi sytuacja komunikacyjna, następnie jest kontekst socjokulturowy (obejmuje on m.in. typy sytuacji, kategorie uczestników - ich funkcje i role społeczne oraz konwencje zachowań) i najszerszy - kontekst ogólnokulturowy (wiąże się z takimi czynnikami, jak rodzaje i cele działalności społecznej). Za czynniki kontekstowe, które decydują o formie, stosowności i znaczeniu tekstu badacz uznaje: parametry komunikacyjne z ich właściwościami społecznymi, biologicznymi i językowymi; warunki czasowe i przestrzenne przebiegu komunikacji; dziedzinę życia społecznego, do której należy akt komunikacji językowej; temat komunikacji; kanał przekazu; stopień oficjalności; intencje nadawcy (Gajda 2004: 147). W zaproponowanym ujęciu kontekst i sytuacja różnią się głównie zakresami - sytuacja jest rozumiana wąsko, kontekst zaś szeroko.

Głębsza analiza systemu odniesień referencjalnych (np. wyznaczoności grup imiennych, wyznaczania czasowo-przestrzennych parametrów relacji) i odniesień wewnątrztekstowych (np. anafory) rodzi pytania o ontologię sytuacji.

52 Por. stwierdzenie Stanisława Gajdy: „w badaniach działalności językowej za kluczowe przyjmuje się kategorie «kontekstu» $\mathrm{i}$ «aktu komunikacji językowej», a nawet «kodeksu komunikacyjnego»" (Gajda 2004: 146). Wydaje się, że mówienie o „kodeksie” jest trafnym odczytaniem kierunku poszukiwań badawczych, gdyż w istocie zmierzają one do formalizacji parametrów kontekstowych, tak aby nadać im większą wymierność (por. Miczka 2002; Wojtak 2011). W opracowaniach akademickich, podręcznikach (por. Mikołajczuk 2003: 31-38) mówi się już o kodach społecznych, pragmatycznych, kulturowych w ramach tzw. kodowego zaplecza komunikacji. Jakkolwiek można dyskutować, czy już mamy do czynienia z kodem czy nie, to kierunek poszukiwań jest taki, aby z kontekstu wydobywać w sposób powtarzalny i coraz bardziej systematyczny to, co kształtuje znaczenie tekstu. 
Urszula Żydek-Bednarczuk postuluje w związku z tym odróżnienie sytuacji od kontekstu. Wprowadza definicję regulującą, w myśl której sytuacja byłaby zewnętrzną ramą dla tekstu, determinującą go w polu tematycznych, społecznych i instytucjonalnych oraz kulturowych odniesień ${ }^{53}$. Kontekst zaś jest wyznacznikiem tekstowości, zostaje zakodowany w tekście, a buduje się w nim poprzez odniesienia referencjalne - $\mathrm{w}$ tym deiksę miejsca, czasu, osoby - oraz przez anaforę $^{54}$ (Żydek-Bednarczuk 2005: 231-253). Również Jacek Warchala widzi potrzebę zarezerwowania terminu „kontekst” dla nazwania otoczenia tekstowego danego wyrażenia, aktu mowy, znaku, aczkolwiek zauważa, że w praktyce językoznawcy stosują go zamiennie z terminem „sytuacja” oraz „łło pozajęzykowe”. Badacz odnotowuje trzy rozumienia pojęcia sytuacji: sytuacja jako horyzont życia, który wyznacza podstawowe warunki działania komunikacyjnego, ale nie podlega interpretacji bezpośredniej; sytuacja, o której się mówi (świat przedstawiany) to tematyzowane stany rzeczy, i wreszcie sytuacja, w której się mówi, rozumiana jako interpretant znaczenia (Warchala 2003: 89-90).

Za swoiste przeniesienie i adaptację pojęcia czynników sytuacyjnych na grunt analizy dyskursu można uznać wprowadzenie pojęcia parametrów dyskursu (Wojtak 2011: 30). Może za tym przemawiać funkcja, jaką się im przypisuje, chociaż zakres został znacznie poszerzony, a sam opis uszczegółowiony. Maria Wojtak wyodrębnia następujące parametry dyskursu: dziedzinę tematyczną (tematy globalne i cząstkowe oraz sposoby ich prezentacji), dziedzinę ontologiczną (stosunek świata dyskursu do rzeczywistości, a więc świat odzwierciedlany czy też obraz świata), dziedzinę funkcjonalną (dominujące illokucje czyli cele komunikacyjne), dziedzinę wypowiedzeniową (związki między nadawcą i odbiorcą, czas i miejsce komunikacji), dziedzinę aksjologiczną (system wartości przyjęty i system zwalczany) oraz dziedzinę konwencji gatunkowych (Wojtak 2011: 30).

Parametry dyskursu zostały wyodrębnione na podstawie dziedzin poznawczych reprezentacji dyskursu, które stanowią swoiste zbiory danych (Miczka 2002: 100-109). Dane te konsekwentnie odróżnia się od miejsca ${ }^{55}$, z którego pochodzą.

53 Pole to autorka określa jako umowne, gdyż sytuację należałoby rozpatrywać z punktu widzenia interlokutorów w danym miejscu i czasie. Doborem składników rządzi zasada relewancji, ponieważ uczestnicy wybierają te elementy, które służą realizacji celów (por. Żydek-Bednarczuk 2005: 231).

54 Anafora jest wtórnym systemem odniesienia, który nawarstwia się na system podstawowy (odniesień do wyróżnionych i nazywanych przez nadawcę tekstu fragmentów rzeczywistości pozatekstowej). Polega na nawiązaniu do spraw i przedmiotów już w tekście wspomnianych. Anaforyzowane mogą być nie tylko grupy imienne, ale treści sformalizowane w całym zdaniu. Jest to zabieg uspójniający tekst (Topolińska 1984: 236). Lyons upatruje w anaforze ważny mechanizm kontekstualizacji, a więc przeinterpretowanie odniesienia deiktycznego na odniesienie anaforyczne, wewnątrztekstowe (Lyons 1989: 270-273).

55 Pojęcie kontekstu jest właśnie pod tym względem niejednoznaczne, ponieważ może oznaczać zarówno źródło informacji kontekstualnych, jak i same te informacje (Miczka 2002: 110). 
Mają charakter potencjalnych wyznaczników w interpretacji dyskursu, podczas gdy parametry mogą już stanowić wskaźniki charakteryzujące określony dyskurs.

Przybliżając sposób pozyskiwania danych cząstkowych, Ewa Miczka podaje pomocnicze pytania heurystyczne. W dziedzinie informacyjnej należy ustalić: o czym w dyskursie jest mowa, jaki jest jego temat globalny, jakiej dekompozycji można go poddać w celu wyodrębnienia tematów cząstkowych, jakie relacje mogą zachodzić między tematem globalnym a tematami cząstkowymi ${ }^{56}$ (w grę wchodzi np. relacja: element/klasa elementów, element/element, część/całość, zjawisko/przejaw zjawiska, relacja inkluzji, przyległości, relacje o charakterze czasowym, przestrzennym, relacja przyczynowo-skutkowa, relacja signans/ signatum), co powiedziano o obiektach wybranych na temat globalny i tematy cząstkowe, z jakich cech i relacji są zbudowane wiązki rematów oraz jak są uporządkowane. Dziedzina ontologiczna reprezentacji dyskursu wyznacza stosunek świata dyskursu do rzeczywistości (ewentualnie rzeczywistości zakładanej jako standardowa). Pojawiają się pytania: czy dyskurs oddaje rzeczywistość standardową, czy robi to w sposób wierny, czy świadomie ją przekształca. W dziedzinie funkcjonalnej chodzi o ustalenie, jaki globalny akt illokucji realizuje dyskurs; jaka jest główna funkcja dyskursu, czyli jaką zakłada reakcję odbiorcy; jakich instrukcji dostarcza dyskurs odnośnie do przewidywanych czy też pożądanych zachowań i postaw potencjalnego odbiorcy. Dziedzina wypowiedzeniowa rodzi pytania o to, kto jest nadawca, jakie są językowe wykładniki jego obecności, do kogo dyskurs jest adresowany, jaka relacja wiąże uczestników aktu komunikacji, czy nadawca w specjalny sposób modeluje układ nadawczo-odbiorczy. W dziedzinie aksjologicznej trzeba ustalić, jaki system wartości obowiązuje; czy dyskurs projektuje jakiś system konkurencyjny, zwalczany; jakie zdarzenia, stany, procesy, osoby i rzeczy są oceniane pozytywnie, negatywnie lub nie podlegają wartościowaniu. Dziedzina konwencji gatunkowych jest reprezentacją dyskursu, w której należy określić, jaką formę gatunkową realizuje wypowiedź (Miczka 2002: 104-108). Ciąg pytań stanowi podstawę operacji kognitywnych, które pozwolą na wypełnienie miejsc i tym samym określenie parametrów dyskursu. Zbiór parametrów dyskursu, tworzący na poziomie wzorca luźną wiązkę cech, w konkretnych tekstach podlega hierarchizacji. Oznacza to, że pewne zabiegi można uznać za dominujące z perspektywy celów strategicznych nadawcy.

Problem udziału czynników sytuacyjnych w nadawaniu i odbieraniu tekstów jest stale obecny w badaniach lingwistycznych, gdyż wiedza na temat parametrów dyskursu stanowi ważny element kompetencji komunikacyjnej człowieka. Tak więc w warunkach złożonych układów komunikacyjnych istnieje zapotrzebowanie na systematyczne analizy uwarunkowań komunikacji.

56 Por. omówienie różnych rodzajów relacji w artykule Sytuacja - tekst - rozumienie tekstu (Miczka 1996), uruchomienie typów relacji w budowaniu argumentów (Perelman 2004), szczegółowe omówienie relacji między zdaniami składowymi zdań złożonych (Topolińska 1984). 


\subsection{Sytuacje i konteksty w medialnym dyskursie publicznym i politycznym}

Sytuację tworzenia i odbioru tekstów w medialnym dyskursie publicznym i politycznym zdefiniowano w niniejszej pracy jako uporządkowany zbiór okoliczności i uwarunkowan, które regulują dobór środków językowych i determinują sensowny odbiór tekstu. Przy czym regulacja dotyczy zarówno preferencji, jak i ograniczeń w stosowaniu tych środków. Sytuacja w dyskursie ma funkcję sensotwórczą, to znaczy, że wiedza na temat uwarunkowań sytuacyjnych jest konieczna do fortunnego, optymalnego zrozumienia wypowiedzi.

Sytuacja, jako wycinek rzeczywistości (konkretnej i mentalnej), nie może być przedmiotem wyczerpującego opisu, gdyż zawiera nieskończony zbiór elementów i relacji. Dla potrzeb analizy autorka przyjmuje jeden z możliwych modeli sytuacji, który posłuży do uporządkowania strategii językowych. Zostały w nim wyeksponowane czynniki szczególnie ważne w analizie językoznawczej: substancjalna odmiana języka, w jakiej realizowany jest tekst; typ kontaktu językowego; uwarunkowania pragmatyczne i komunikacyjne.

Elementy systemu komunikowania:

- kontrola zawartości komunikatów przekazywanych w systemie,

- sposoby ich dystrybucji,

- charakter kontaktów i rodzaj styczności między członkami systemu,

- zadania, jakie mają do wykonania,

- reguły, normy i wzory rządzące zachowaniem członków,

- uwarunkowania sytuacyjne ze względu na zasięg i sposób komunikowania,

- podwójna sytuacyjność komunikacji medialnej

Dziedzina działalności pozajęzykowej i role społeczne uczestników:

- kontekst zawodowy/niezawodowy,

- instytucjonalny/nieinstytucjonalny,

- potoczny/ekspercki (specjalistyczny),

- polityczny, medialny, naukowy (np. historyczny, bioetyczny), religijny,

- jednostkowy, lokalny, globalny

Oficjalność sytuacji:

opozycja: sfera prywatna/sfera publiczna

Ustność realizacji tekstu

(sekwencyjność, dialogowość,

wąsko rozumiana sytuacyjność)

Rys. 1. Schemat czynników sytuacyjnych (zastosowany do analizy tekstu z wykorzystaniem strategii) 
Najbardziej elementarnym czynnikiem sytuacyjnym, mającym wpływ na organizację analizowanych w pracy tekstów, jest ich ustność. Zakładamy, że tekst mówiony (z uwagi na właściwości percepcyjne) wymaga szczególnych sygnałów segmentacji, spójności i podtrzymania kontaktu. Z ustnością tekstu związane są takie cechy, jak: sekwencyjność i linearność, dialogowość, sytuacyjność (strategiom tekstotwórczym związanym ze wskazanymi uwarunkowaniami poświęcono rozdział 4).

Kolejnym czynnikiem jest oficjalność sytuacji, rozpatrywana w opozycji do nieoficjalności. W socjolingwistyce stanowi ona ważną kategorię służącą rozmówcom do budowania statusu. Dodatkowo, norma dyskursu mówiąca o oddzieleniu sfery publicznej od sfery prywatnej jest wykorzystywana strategicznie (strategie związane w sposób szczególny ze wskazaną kategorią omówiono w rozdziale 3$)$.

Dość rozbudowany zbiór możliwych odniesień wypowiedzi implikuje jej rozpatrywanie w sytuacji wspólnego działania. Działanie to może mieć charakter zawodowy (profesjonalny) bądź niezawodowy, instytucjonalny lub nieinstytucjonalny. Ze względu na rodzaj działania można wyróżnić kontekst: polityczny, naukowy (np. historyczny, filozoficzny, bioetyczny), religijny, medialny. Ze względu na poziom ogólności odniesienia można wskazać poziom jednostkowy (indywidualny), ponadjednostkowy poziom lokalny (grupa społeczna, naród), ponadjednostkowy poziom globalny (stosunki międzynarodowe). Dziedzina wspólnego działania dostarcza informacji, które mniej lub bardziej bezpośrednio decydują o sensie wypowiedzi, regulują zasady komunikowania się, są źródłem konwencji porozumiewania, których znajomość warunkuje udział w dyskursie (strategie sensotwórcze związane z interpretacją zachowań komunikacyjnych, jak również strategie interakcyjne typowe dla danej dziedziny i ról społecznych zaprezentowano w rozdziale 2).

Najbardziej skomplikowany układ elementów sytuacyjnych wiąże się z rozpatrywaniem wypowiedzi w kontekście komunikacyjnym. Instytucjonalny i medialny typ systemu komunikowania wymaga uwzględnienia m.in. takich elementów przynależnych do definicji sytuacji, jak: kontrola zawartości komunikatów przekazywanych w systemie; sposoby ich dystrybucji; charakter kontaktów i rodzaj styczności między członkami systemu; zadania, jakie mają do wykonania; reguły, normy i wzory rządzące zachowaniem członków. Ważnymi cechami sytuacji w aspekcie komunikacyjnym są: zasięg komunikowania (w szczególności chodzi o dostęp podmiotów i skuteczność działań) oraz sposób komunikowania (strategie wynikające z typów komunikowania omówiono w rozdziale 1).

Czynniki sytuacyjne i kontekstowe decydują o parametryzacji dyskursu w zakresie dziedziny tematycznej, ontologicznej, funkcjonalnej, wypowiedzeniowej, aksjologicznej i konwencji gatunkowych. Parametry te porządkują zbiory informacji pochodzących z wiedzy o uwarunkowaniach sytuacyjnych w sposób właściwy dla określonego dyskursu. Jak już wspomniano w punkcie 3.2, w niniejszej pracy potraktowano dyskurs publiczny i polityczny toczony w mediach 
jako zjawisko całościowe. Stopień podporządkowania tego dyskursu logice mediów jest bowiem tak duży, że wpływa na jakościowe zmiany sfery publicznej, a przede wszystkim na formuły komunikowania się w tej sferze.

Według badań socjologicznych, komunikowanie publiczne ulega deformacji, przyjmując formułę rytualnego chaosu ${ }^{57}$ i wykazując cechy „uwiedzenia” środków masowego przekazu przez masy ${ }^{58}$. Nasila się proces „zużywania” elit symbolicznych w mediach, które stają się dostarczycielem podniet dla masowej publiczności i ulegają instrumentalizacji ${ }^{59}$.

Zjawiska te wpływają na funkcjonalną dziedzinę dyskursu, gdyż nadawcy medialnemu chodzi nie tyle o kształtowanie społecznego ładu (dzięki organizowaniu dialogu różnych stron, opartego na wzajemnym uwzględnianiu cudzych racji), ile o aranżowanie przed kamerami konfliktu niemożliwych do pogodzenia racji. Stosuje się więc poetykę przejaskrawienia i intensyfikacji doznań. Tego rodzaju przekaz jest w stanie wywrzeć na odbiorcy silne wrażenie i przykuć jego uwagę. „Fatyczna funkcja języka, służąca ustanowieniu kontaktu i podtrzymaniu rozmowy $[\ldots]$ w telewymiarze sieci nabiera cech hipertroficznych. Kontakt dla samego kontaktu przyjmuje postać swego rodzaju czystego, językowego samouwiedzenia” (Baudrillard 2005a: 161). Makrointencją przekazów medialnych jest „bycie słuchanym, oglądanym, czytanym” oraz wywieranie wpływu (makrointencja perswazyjna) (Nowak, Tokarski 2007: 14).

Dziedzina funkcjonalna rzutuje na dziedzinę wypowiedzeniową. Interakcje, które reżyserowane są przez dziennikarzy, polegają często na podsycaniu konfliktów,

${ }^{57}$ Rytualny chaos polega na tym, że: „świadek sporów na scenie politycznej lub w środkach masowego przekazu odnosi nieodparte wrażenie, że porozumienie między przeciwstawnymi stronami jest z gruntu niemożliwe, a stronom tym nie chodzi o nic więcej, aniżeli o nagłaśnianie własnych racji” (Czyżewski i in. 1997: 53). Chaos to bezład i bezkonkluzyjność, które decydują o wewnętrznej sprzeczności i nieczytelności przekazu. Rytualizacja zaś polega na utrwaleniu się zestalonych, powtarzalnych i nie podatnych na zmianę wzorów działania.

58 Teza Jeana Baudrillarda odwraca kierunek wpływu: to nie elity i media manipulują masowym odbiorcą, ale masowy odbiorca staje się dysponentem mediów, które dopasowują się mimowolnie do oczekiwań mas. Potrzeby mas podlegają stabilizacji, odpolitycznieniu, a nastawione są głównie na rozrywkę. Według Baudrillarda żyjemy w erze uwiedzenia, w której relacja uwiedzenia jest przeciwieństwem stosunków produkcji. W erze tej: „pan został uwiedziony przez niewolnika, a niewolnik przez pana [...] zdegenerowany język uwiedzenia, zmieszany ze zdegenerowanym językiem polityki, wszędzie się sprawdza [...] uwodzenie staje się nieformalną formą polityki, pomniejszoną ramą dla nieuchwytnej polityki poświęconej niekończącej się reprodukcji formy bez treści” (Baudrillard 2005a: 173-176).

${ }^{59}$ Reprezentanci elit uczestniczą w audycjach i dyskusjach telewizyjnych, ale „udział w nich wiąże się w nieunikniony sposób ze zgodą na właściwe dla nich mechanizmy streszczania, spłaszczania, stereotypizacji oraz ceremonialnego ujednolicenia lub sztucznie aranżowanej polaryzacji stanowisk. [...] Niezmiernie rzadko zdarza się, by w telewizyjnych dyskusjach studyjnych udało się uniknać obydwu nagminnych wad tego rodzaju audycji: z jednej strony ceremonialnej sztampy, z drugiej, bezproduktywnej i pospiesznej prezentacji rozbieżnych stanowisk" (Czyżewski i in. 1997: 21). 
napuszczaniu na siebie przeciwników w pogoni za uatrakcyjnieniem programu. Następuje więc intensyfikacja cech dramaturgicznych interakcji publicznej (polegających na dynamice kontrolowanych i niekontrolowanych ekspresji ${ }^{60}$ ) pod wpływem medialnej widowni. Dla dziedziny wypowiedzeniowej dyskursu istotny jest zatem model medialnej sytuacji nadawczo-odbiorczej: rozmawiający na scenie aktorzy pozostają w kontakcie bezpośrednim „twarzą w twarz”, ale ich działania prowadzone są z myślą o pośrednio dostępnej publiczności.

Właściwość tę określa się jako podwójną sytuacyjność, gdyż tekst medialny jest osadzony w dwu sytuacjach: sytuacji traktowanej globalnie, czyli makrosytuacji, i sytuacji traktowanej lokalnie, czyli mikrosytuacji. W studiu aranżowana jest mikrosytuacja (z udziałem uczestników interakcji: dziennikarzy, polityków, ekspertów $\left.{ }^{61}\right)$. Elementami makrosytuacji są: instytucjonalny nadawca medialny, odbiorca masowy i zachodzące między nimi relacje. Podział ról nadawcy i odbiorcy jest trwały, a przestrzenne oddzielenie uniemożliwia bezpośredni kontakt (Miodunka, Ropa 1979: 63-75). Z perspektywy ukonstytuowania tekstu istotny jest stopień scalenia makro- i mikrosytuacji (Krupska-Perek 2002: 493-499). Pod uwagę bierze się zmienność dystansu pomiędzy makro- i mikrosytuacją, która jest zależna od roli dziennikarza i formuły programu. Styczność obu sytuacji zachodzi wówczas, kiedy widz „podsłuchuje” rzeczywisty dialog. Jeśli dziennikarz kieruje dialogiem, porządkuje go wokół tematu, a zwłaszcza prowadzi pozorowany dialog z widzem, wówczas następuje bardziej widoczne osadzenie mikrosytuacji w ujawnionej makrosytuacji, która tym samym staje się pełną strukturą komunikacyjną.

Pod względem zawartości informacyjnej dyskurs mediów jest politematyczny (Wojtak 2010a: 82). Jednak nie wszystkie tematy uzyskują akceptację na forum publicznym ${ }^{62}$. Instytucje medialne dokonują selekcji63 i ramowania prze-

60 Por. Goffman 2000.

61 Charakterystyczną cechą dyskursu medialnego jest dekompozycja autorytetów. Sytuacja telewizyjna zrównuje wszystkich obecnych w studiu, a osoba medialnie atrakcyjna (sprawna komunikacyjnie, plastyczna, dynamiczna) może uzyskać sytuacyjną przewagę, stąd telewizyjna popularność nie musi odpowiadać statusowi zewnętrznemu. Ucieleśnieniem nowych reprezentantów elit symbolicznych jest „pseudointelektualna gwiazda środków masowego przekazu” lub zarządzający projektami badawczymi manager naukowy (por. Czyżewski i in. 1997: 15, 67).

62 Ważną cechą dyskursu publicznego jest określanie jego granic, czyli spór o dopuszczenie rejestru możliwych tematów. Socjolodzy wprowadzają kategorie sepizacji (unieważniania) i desepizacji (uważniania) dla nazwania wyciszania i nagłaśniania zagadnień w dyskursie publicznym (Czyżewski i in. 1997: 70).

${ }^{63}$ Istnieje wiele takich zniekształceń treści informacyjnych, które nie są jeszcze kłamstwem, propagandą czy ideologią, ale często zakrawają na nie, np. nadreprezentowanie głosów osób „wyżej postawionych” i stanowisk oficjalnych, informacje na temat przestępczości wyolbrzymiają skalę przestępstw brutalnych i bezpośrednich kosztem faktycznego ryzyka, informacje dotyczące zdrowia skupiają się na chorobach wzbudzających najsilniejszy lęk i na nowych metodach leczenia kosztem profilaktyki i in. Por. McQuail 2007: 354. 
kazywanych treści, ponieważ posługują się ustalonymi postaciami ujmowania rzeczywistości, np. specjalną metaforyką, doborem słów. Ramowanie określa, jak treści mediów są zorganizowane, aby wywołać pożądane skutki (Mikułowski Pomorski 2006: 232; McQuail 2007: 326; Pratkanis, Aronson 2005: 63-130). Za sytuacyjnie uruchamiane zasoby interpretacji uważa się ideologie. Są one: „względnie płynnymi zasobami interpretacji, czyli dostarczanymi przez kulturę repertuarami kategoryzacji, symboli i argumentacji, które uzyskują konkretny sens tylko wówczas, gdy zostają w określonej sytuacji zastosowane («uruchomione») oraz odpowiednio dopasowane do sytuacji” (Czyżewski i in. 1997: 25). $\mathrm{Z}$ wartościowaniem związane jest również komunikowanie informacyjno-perswazyjne, które często przyjmuje w mediach postać propagandy ${ }^{64}$. Zwłaszcza telewizja jest uważana za najważniejszy kanał jej dystrybucji w związku z rozwojem marketingu politycznego ${ }^{65}$ i pojawianiem się zawodowych konsultantów politycznych.

Stronniczość, perswazyjność treści informacyjnych prowadzi do zniekształcania obrazu rzeczywistości, co determinuje dziedzinę ontologiczną dyskursu. Obraz świata w mediach jest różnorodny, fragmentaryczny, przypadkowy i zmienny. Oddają to popularne metafory: media jako krzywe zwierciadło rzeczywistości, mozaika, kalejdoskop (Mrozowski 2001: 303). Parametr ten jest o tyle ważny dla kompetencji uczestników dyskursu, że pojawia się często jako podstawa strategii obrony na zasadzie podważenia wiarygodności mediów, a więc i faktyczności przekazu. Jean Baudrillard głosi ontologię hiperrealności mediów (Baudrillard 2005b), które określa jako maszyny znakotwórcze produkujące symulakra, czyli znaki bez odniesienia. Symulakra tworzą światy oderwane od tzw. standardowej rzeczywistości, a podlegając stałej dekontekstualizcji i zwielokrotnieniu, oddają się grze z innymi znakami ${ }^{66}$.

Dla dziedziny aksjologicznej dyskursu, która ustala, jaki system wartości w nim obowiązuje, istotna jest normatywna teoria mediów. Składają się na nią obowiązki mediów w realizacji interesu publicznego, zasady profesjonalizmu

${ }^{64}$ Definiując propagandę, Dobek-Ostrowska powołuje się na G. S. Jowetta i V. O’Donnnella: „Propaganda jest celową i systematyczną próbą kształtowania percepcji, manipulowania wiedzą i bezpośrednimi zachowaniami, aby wywołać reakcję, która będzie zgodna z intencjami propagandzisty” (Dobek-Ostrowska 2006: 205). Z kolei Mrozowski twierdzi, że propaganda polityczna ustępuje dziś miejsca marketingowi politycznemu oraz reklamie politycznej, a inne formy publicznej perswazji stają się marketingiem społecznym i reklamą społeczną (Mrozowski 2001: 180).

65 Marketing polityczny jest konsekwencją legitymizacji medialnej polityków, profesjonalizacji komunikowania politycznego, urynkowienia polityki. Ma prowadzić różnymi technikami i metodami do wyboru kandydata. Nie ma na celu edukacji politycznej ani obywatelskiej (Dobek-Ostrowska 2006: 271-336).

66 Przykładem symulakrum może być fikcyjna postać z telenoweli, która poza serialem podlega dekonstrukcji i metamorfozie, stając się obiektem gier interpretacyjnych internautów (por. Skowronek, Rutkowski 2010: 164-177). 
dziennikarskiego i etyka mediów (McQuail 2007: 175-198). Interes publiczny różni się od interesów partykularnych, jest przedkładany nad interes polityczny. Jego rozpoznanie jest gwarantowane przez odniesienie do dominującej ideologii lub przez debatę i demokratyczny proces decyzyjny. W praktyce jako dobro wspólne, którego media mają strzec, identyfikuje się: wolność, pluralizm, porządek i bezpieczeństwo publiczne, procesy demokratyczne (Drożdż 2010; Mazurek 2010). Kodeksy etyki dziennikarskiej zawierają zasady, które są szczególnie istotne dla zapewnienia odpowiedniego poziomu profesjonalnego: prawdziwość, jasność informacji, obiektywizm, niezależność, obrona praw odbiorców. Równolegle $\mathrm{z}$ analizą normatywną są prowadzone analizy krytyczne mediów, które piętnują ich tendencyjność, wybiórczość, komercjalizację, poruszają kwestie klasowe, etniczne, stosunków władzy (McQuail 2007: 339).

Dziedzinę konwencji gatunkowych medialnego dyskursu publicznego i politycznego wypełniają przede wszystkim formy dialogowe i polilogowe, takie jak: rozmowa publiczna, konwersacja, wywiad, dyskusja, debata, talk show, maga$\mathrm{zyn}^{67}$. Z perspektywy producenta mówi się natomiast nie o gatunkach, lecz o formatach, czyli praktycznych regułach pozwalających tworzyć cykliczne audycje i mogących stanowić przedmiot handlu (Uszyński 2004: 25). Najnowsze badania wskazują, że w genologii medialnej następuje zacieranie wyrazistości gatunkowej dialogowych form publicystyki politycznej. Wywiady, poprzez zmianę roli dziennikarza, stają się podobne do dyskusji lub rozmowy publicznej (rozmowa $\rightarrow$ wywiad $\leftarrow$ dyskusja), a dyskusje, poprzez większy stopień formalizacji, zbliżają się do debaty (rozmowa $\rightarrow$ dyskusja $\leftarrow$ debata) (Szkudlarek-Śmiechowicz 2010: 45-59). Jednocześnie $\mathrm{w}$ wielu programach odnaleźć można cechy gatunku talk show (o czym świadczy skupienie na postaci prowadzącego, prowokacyjny charakter, tworzenie iluzji intymności) (Ptaszek 2007: 36-43). Globalnym gatunkiem o charakterze pierwotnym dla pozostałych gatunków medialnych jest jednak rozmowa (Żydek-Bednarczuk 2004: 424-437). Pod wpływem konkurencji rynkowej widoczne stają się procesy konwergencji, które polegają na upodabnianiu struktury gatunkowej oferty mediów publicznych i komercyjnych (Mrozowski 2001: 324).

\subsection{Pojęcie strategii}

Wszelkie zachowania człowieka są wyrazem jego aktywności wobec otoczenia i mogą mieć charakter reaktywnych odruchów bądź celowych czynności. Komunikowanie jako rodzaj czynności ma charakter celowościowy,

${ }^{67}$ Dyskusje i debaty często przekształcają się w spór nacechowany moralistyczną retoryką. Brak poszukiwania punktów wspólnych, przy jednoczesnym wyostrzaniu różnic, podziałów i opozycji przedstawianych jako nieusuwalne, prowadzi wręcz do kłótni. Publiczne konfrontacje polityków tracą własności dialogu, polemiki, przekształcając się w ciągi monologów, zrytualizowanych przez wielokrotne powtarzanie tych samych tematów i argumentów (Czyżewski i in. 1997: 30). 
instrumentalny i spełnia funkcję regulacyjną, ponieważ umożliwia planowanie i koordynację działalności praktycznej (Gajda 1982: 17). Pojęcie strategii, które prymarnie związane jest $\mathrm{z}$ działaniem pozajęzykowym i planowaniem tego działania, dzięki związkom działania i komunikowania będzie można ekstrapolować również na obszar komunikacji. Jednak wielokierunkowość i wielopoziomowość powiązań między działaniem i komunikowaniem znacznie komplikuje opis oraz powoduje, że strategie komunikacyjne można badać z różnych perspektyw.

Na poziomie lokalnym komunikacji, rozumianej jako ciąg aktów mowy, użycie języka jest jednocześnie rodzajem działania (Austin 1962: 543-708). Realizowane intencje mają jednak charakter elementarny, cząstkowy, np. powiadomienie, pytanie, żądanie, zobowiązanie (Searle 1980: 244; Awdiejew 2004: 94). W realizacji długofalowych celów komunikacyjnych relacje między komunikowaniem i działaniem wydają się bardziej złożone. Osiąganie celów w działalności pozajęzykowej nie byłoby niejednokrotnie możliwe bez zaplanowania kompleksowych i skutecznych strategii komunikacyjnych. Można zatem postawić tezę, że strategie działań w rzeczywistości pozajęzykowej znajdują odzwierciedlenie w strategiach działań komunikacyjnych. Na poziomie globalnym mamy więc do czynienia raczej z korelacją niż utożsamieniem.

Wywodzące się $\mathrm{z}$ dziedziny wojskowości pojęcie strategii jest rejestrowane przez współczesne słowniki ogólne języka polskiego ${ }^{68}$. Zestawienie definicji w porządku czasowym wskazuje na rozszerzający się zakres tego pojęcia na obszary takie, jak: polityka, ekonomia, finanse, gry komputerowe ${ }^{69}$. Pojęciem

${ }^{68}$ W Stowniku języka polskiego pod red. W. Doroszewskiego strategia to 'teoria i praktyka przygotowania i prowadzenia wojny, jej poszczególnych kampanii i najważniejszych operacji; główna część składowa sztuki wojennej’ (SJPD, t. 8: 802). W Praktycznym słowniku wspótczesnej polszczyzny pod red. H. Zgółkowej i w Stowniku wspótczesnego języka polskiego pod red. B. Dunaja dodano (obok wojskowego) drugie znaczenie, określając strategię ogólniej, jako 'sposób postępowania służący osiągnięciu określonego celu, stosowany świadomie i konsekwentnie' (PSWP, t. 40: 326); 'sposób prowadzenia jakichś działań (zwykle na większą skalę); perspektywiczny plan działań (SJPDun: 1067). W Uniwersalnym słowniku języka polskiego pod red. S. Dubisza i w Innym stowniku języka polskiego pod red. M. Bańki znaczenie ogólniejsze, niewojskowe strategii jest już umieszczone jako pierwsze: 'sposób postępowania mający doprowadzić do osiągnięcia określonego celu, działanie zgodne z opracowanymi założeniami, perspektywiczny plan działania' (USJP, t. 4: 551); 'przemyślany plan działań prowadzących do osiągnięcia jakiegoś istotnego celu, zwykle dość odległego, często w dziedzinie polityki, zarządzania lub ekonomii' (ISJP: 699).

${ }^{69}$ Początkowo połączenia z rzeczownikami odsyłającymi do realiów innych niż wojenne określane były jako przenośne, np. strategia teatru, strategia niewieścia, strategia finansowa (SJPD, t. 8: 802). Obecnie w słownikach pojawiają się takie połączenia, jak: strategia polityczna, ekonomiczna, strategia przedsiębiorstwa (SJPDun: 1067), strategia wyborcza, strategia gospodarcza, strategia przekazywania i zdobywania wiedzy, strategia marketingowa przedsiębiorstwa, strategia finansowa, strategia pracy, produkcji (PSWP, t. 40: 326). Praktyczny słownik wspótczesnej polszczyzny wprowadza jako trzecią w kolejności definicję z kwalifikatorem: środowiskowy: 'gatunek gry komputerowej, która opiera się na zasadach regulujących ruchy i potencjał bohaterów gry 
nadrzędnym względem strategii jest sposób działania, plan $^{70}$. Do cech prototypowych pojęcia można zaliczyć: celowość działania, jego intencjonalność, całościowość, kompleksowość. Analiza przykładów użycia wskazuje na cechy kojarzone z pojęciem, jak np.: uprzednie przygotowanie strategii, konieczność zmierzenia się z problemami, trudnościami, uporządkowanie działań, konsekwencja w realizacji strategii, możliwe ukrywanie intencji, wymóg kompetencji (profesjonalizmu i talentu) od realizatora, a nawet pewnej przebiegłości i sprytu. Przeciwieństwem strategii byłby chaos, przypadkowość, brak kompetencji osoby działającej (określenie kogoś „strategiem” jest bowiem wartościowane pozytywnie pod względem wartości perfekcjonistycznych, choć już niekoniecznie pod względem wartości etycznych ${ }^{71}$ ). Określenia jakościowe (przymiotnik i przysłówek), będące derywatami odrzeczownikowymi, tworzą ciągi synonimiczne, które wydobywają cechy kojarzone z pojęciem: „strategiczn(y)” to podstawowy, prymarny, zasadniczy, istotny, priorytetowy, newralgiczny, węzłowy; „strategicznie” to sprytnie, dwuznacznie, układnie, taktycznie, taktownie, oględnie (por. PSWP, t. 40: 326-327).

Pojęcie strategii jest kluczowe w dziedzinie nauki zajmującej się ludzkimi czynnościami jako działaniami świadomymi i celowymi, a mianowicie prakseologii. Jej zadaniem jest badanie warunków sprawności działań m.in. przez analizę wykorzystania zasobów do osiągnięcia celów i sprawdzanie efektywności. Prakseologia jest wykorzystywana m.in. w teorii walki, teorii organizacji, logistyce (do badań operacyjnych), w teorii gier. Wybitnym przedstawicielem tej nauki był Tadeusz Kotarbiński, którego rozważania na temat strategii współpracy (kooperacji) i strategii walki (rywalizacji) są do dziś aktualne ${ }^{72}$.

Pojawienie się strategii jako narzędzia $w$ badaniach językowych wiąże się z rozwojem teorii funkcjonalistycznych ${ }^{73}$, a w Polsce jej wprowadzenie zawdzięczamy twórcom gramatyki komunikacyjnej ${ }^{74}$. Tu okazała się przydatna

w sposób możliwie jak najlepiej symulujący rzeczywiste, historyczne, ekonomiczne, obyczajowe prawidłowości' (PSWP, t. 40: 326).

70 Praktyczny stownik wspótczesnej polszczyzny pod red. H. Zgółkowej podaje wyrazy bliskoznaczne względem pojęcia strategii, a są to: sposób, procedura, tryb, środek, przepis, technika, taktyka, metoda, droga (PSWP, t. 40: 326).

${ }^{71}$ Elżbieta Laskowska wyodrębniła jedenaście typów wartości: pragmatyczne, ekonomiczne, hedonistyczne, witalne, społeczne, odczuć, perfekcjonistyczne, estetyczne, poznawcze, etyczne, sakralne (Laskowska 1992: 14; Laskowska 2004: 147).

72 Por. T. Kotarbiński, Traktat o dobrej robocie, Warszawa 1955; tegoż, Abecadto praktyczności, Warszawa 1972; P. Cabała, Wprowadzenie do prakseologii, Kraków 2007.

${ }^{73} \mathrm{~W}$ dziedzictwo funkcjonalizmu wpisuje się model systemowo-funkcjonalny M. A. K. Halliday’a (Halliday 1973). Według badacza połączenie między danymi społecznymi a formami językowymi dokonuje się dzięki metafunkcjom: ideacyjnej, interpersonalnej i tekstowej (por. Paveau, Sarfati 2009: 158).

${ }^{74}$ Współcześnie koncepcję Hallidayowską rozwija gramatyka komunikacyjna (Awdiejew, Habrajska 2004, 2006; Laskowska 2004). Korzystają z niej również językoznawcy badający 
wyodrębniona przez Halliday’a metafunkcja interpersonalna, która ukierunkowała analizy języka jako narzędzia interakcji. Aleksy Awdiejew mówi już o poziomie interakcyjnym języka, który pozwala na nawiązanie, utrzymanie i organizowanie komunikacji w ramach określonego układu interakcyjnego (Awdiejew 2004: 17). Podstawowymi jednostkami na poziomie interakcyjnym są akty mowy, które układają się w sekwencje umożliwiające realizację intencji strategicznej każdego z interlokutorów. Za mikrojednostkę konwersacji Awdiejew przyjmuje parę przylegającą (minimalny odcinek danej strategii konwersacyjnej), składającą się z dwóch kroków strategicznych (dwóch aktów mowy). Za makrojednostkę interakcji uznaje konwersację ${ }^{75}$ i stąd wywodzi się termin „strategia konwersacyjna ${ }^{76 ”, ~ k t o ́ r y ~ j e s t ~ d e f i n i o w a n y ~ j a k o: ~ „ s ́ w i a d o m i e ~ k i e r o w a n y ~ p r z e z ~ n a d a w c e ̨ ~ i ~ i n-~}$ terpretowany przez odbiorcę spójny ciąg aktów mowy, za pomocą którego dążą oni do osiągnięcia wspólnie akceptowanego celu ${ }^{77}$ komunikacyjnego" (Awdiejew 2004: 71).

Zastosowanie kryterium celów komunikacyjnych i dwóch płaszczyzn odniesienia (pozajęzykowej i tekstowej) doprowadziło do wyodrębnienia czterech typów strategii konwersacyjnych: informacyjno-weryfikacyjnych, aksjologiczno-emotywnych, behawioralnych (odnoszących się do rzeczywistości pozajęzykowej) i metadyskursywnych (odnoszących się do samego przebiegu konwersacji) (Awdiejew 1991: 7-20, tenże 2004: 73-86; Awdiejew, Habrajska 2006: 54-70). Podstawowym celem nadawcy w strategiach informacyjno-weryfikacyjnych jest uzyskanie informacji zawartej w wiedzy operacyjnej partnera (partnerów) albo

zachowania niewerbalne (np. Aneta Załazińska 2006). Trójpoziomowe podejście do komunikacji pojawia się w lingwistyce tekstu, np. Anna Duszak w typologizacji zdarzeń komunikacyjnych wydziela trzy typy znaczeń: kognitywne, interakcyjne i tekstowe (Duszak 1998: 174).

75 Jest to szerokie rozumienie pojęcia konwersacji, właściwie tożsame z dialogiem. Inaczej określa konwersację Aleksander Wilkoń, który odróżnia konwersację od rozmowy na podstawie cech takich, jak: sztuczny i wysublimowany język, brak spontaniczności, posługiwanie się elitarnym kodem rozwiniętym, tematy z kręgu bloków semantycznych „kultura” (por. Wilkoń 2002: 231).

76 Aleksy Awdiejew, używając określenia „konwersacja”, powołuje się na opracowane przez H. P. Grice'a postulaty, zasady, maksymy konwersacyjne, implikatury konwersacyjne (Grice 1975: 41-58) kluczowe w inferencyjnym modelu komunikacji (por. Żydek-Bednarczuk 2005: 168-169; Szwabe 2008: 11-27).

77 Można przyjąć za Urszulą Żydek-Bednarczuk, że rozmówcy dążą również do osiągnięcia własnych celów, a nie tylko celów wspólnych (Żydek-Bednarczuk 2005: 167). Każda bowiem wypowiedź ma charakter polifunkcyjny, a więc realizuje więcej niż jedną funkcję pragmatyczną. $\mathrm{Z}$ drugiej strony rozbieżność celów nie musi powodować zerwania kooperacji, lecz może zainicjować ciągi negocjacyjne. Ze względu na tego typu kryterium Aleksy Awdiejew wprowadza dwie grupy strategii: nieantagonistyczne (cele rozmówców są zgodne) i antagonistyczne (cele rozmówców nie są zgodne, co prowadzi do negocjacji, wycofania się lub kłótni). Za przydatne w dyskursie politycznym należy uznać wyodrębnienie takich zachowań, które polegają na blokowaniu posunięć oponenta (antystrategie) (Awdiejew 2004: 71). W psychologii politycznej na określenie braku kooperacji między stronami używa się terminu strategia rywalizacyjna (Reykowski 2002a: 212). 
zaproponowanie informacji, jaką sam posiada i ustalenie prawdziwości lub stopnia pewności uzyskanej wiedzy. Do realizacji celu wykorzystuje się takie akty mowy, jak: pytanie, potwierdzenie, zaprzeczenie, przypuszczenie, pewność, wątpliwość, wykluczenie, stwierdzenie. Stosując strategie aksjologiczno-emotywne, nadawca dąży do wprowadzenia i uzgodnienia z partnerem opinii wartościujących na temat różnych obiektów. Do sterowania zachowaniem interlokutorów służą strategie behawioralne, realizowane przez akty mowy prośby, żądania, propozycji, obietnicy, groźby, rady. Zupełnie inny typ reprezentują strategie metadyskursywne ${ }^{78}$, które, odnosząc się do działań werbalnych (a nie rzeczywistości pozajęzykowej), wspomagają przebieg komunikacji. Propozycja badawcza twórców gramatyki komunikacyjnej odnosiła się w dużej mierze do płaszczyzny pragmatycznej opisu językowego, ale jednocześnie, poprzez zwrócenie uwagi na strategie metadyskursywne, umożliwiła zastosowanie tego narzędzia do lingwistycznej analizy tekstu.

Wraz z rozszerzaniem się zakresu badań nad tekstem i komunikacją rozpatruje się pojęcie strategii również na płaszczyźnie socjolingwistycznej i psycholingwistycznej. Pojawiły się propozycje adaptacji pojęcia do analizy gatunków mowy i dyskursu. Jeszcze w prekursorskich pracach Teuna van Dijka i Waltera Kintscha (van Dijk, Kintsch 1983) (na temat tworzenia reprezentacji dyskursu w umyśle) autorzy w zaproponowanym modelu rozumienia dyskursu uznają pojęcie strategii za kluczowe. Jest ono jednak rozumiane bardzo szeroko ${ }^{79}-$ jako „sposób rozumienia i produkcji”, procedura odpowiadająca za łączenie informacji z różnych źródeł, przetwarzanie i integrację danych od poziomu jednostek słownych do poziomu tematu i makrostruktury dyskursu. Strategie w modelu proceduralnym mają charakter hierarchiczny, stopniowalny i współzależny (najprostsze są strategie ideacyjne, które polegają na przedstawieniu treści propozycjonalnej, następnie strategie lokalnej spójności tekstowej i bardziej globalne makrostrategie; wspomagający charakter mają strategie uruchomienia gotowych schematów interpretacyjnych, określane jako superstruktury; autorzy wspominają jeszcze m.in. o strategiach stylistycznych, retorycznych, strategiach przetwarzania informacji niewerbalnych ${ }^{80}$. W późniejszych pracach van Dijk

78 Wydaje się, że właśnie typ strategii metadyskursywnych okazał się najbardziej inspirujący dla badań w obrębie lingwistyki tekstu, a zwłaszcza dyskursu. Mówi się o potrzebie sygnałów kontekstualizujących i antycypujących przebieg zdarzenia komunikacyjnego, sygnałach orientacji w strukturze dyskursu, strategicznych pozycjach w tekście, strategiach nadawczo-odbiorczych mających ułatwić odbiorcy dekodowanie komunikatu (por. Duszak 1998: 126-173; Żydek-Bednarczuk 2005: 165-197).

79 Tak szeroko rozumiana strategia odpowiada właściwie pojęciu kompetencji komunikacyjnej ze względu na jej funkcje regulujące i koordynujące wszelkie działania mowne.

${ }^{80}$ Por. próby włączenia koncepcji modelu rozumienia dyskursu do badań psycholingwistycznych, w szczególności ukazania relacji między wiedzą językową a wiedzą o świecie, pokazania deskryptywnego i proceduralnego charakteru wiedzy (Kurcz 1987: 301-334). Do modelu 
podaje już dwa determinanty przetwarzania informacji w dyskursie, odróżniając (bardziej zobiektywizowane, podzielane społecznie) reguły od (stosowanych doraźnie, alternatywnych, choć również schematycznych) strategii: „Oprócz reguł uczestnicy komunikacji znają też i wykorzystują stosowne strategie mentalne i interakcyjne, umożliwiające efektywne zrozumienie i wytwarzanie dyskursu, a także realizowanie celów komunikacyjnych i społecznych. Znaczenie owych strategii można ukazać poprzez analogię do gry w szachy: gracze przede wszystkim muszą znać reguły, jeśli w ogóle chcą grać, ale będą też stosować rozmaite taktyki, gambity i specjalne posunięcia, składające się na całościowe strategie obronne lub prowadzące do wygranej” (van Dijk 2001: 42).

Stanisław Gajda łączy pojęcie strategii z komunikacyjno-działaniowym paradygmatem językoznawstwa, który ujmuje język jako narzędzie ludzi w różnych dziedzinach ich działalności. „Uwaga kieruje się zwłaszcza na motywy i cele działań, które mają charakter intencjonalny. Niewystarczająca okazała się tu teoria aktów mowy, która nie wykracza poza doraźne intencje nadawców. Nie daje ona badaczowi narzędzi do opisu długotrwałych, stabilnych zamiarów i nastawień, strategii” (Gajda 2004: 145). Celem badań w tak szeroko rozumianym językoznawstwie, wykorzystującym teorię komunikacji społecznej, socjolingwistykę, psycholingwistykę, ma być zatem analiza rzeczywistych zachowań i działań językowych w powiązaniu z szeroko rozumianą sytuacją komunikacyjną, w celu odkrycia swoistego „kodeksu komunikacyjnego”, a więc reguł, konwencji, rytuałów, które wchodzą w skład strategii komunikacyjnych.

Podobne przeświadczenie o konieczności odejścia od ujęcia ściśle atomistycznego odnajdujemy w monografii Bożeny Witosz, która stwierdza, że wypowiedź (będąca aktualizacją określonego gatunku) jako całość nie może być rozpatrywana jako suma poszczególnych aktów illokucyjnych. W analizie gatunku trzeba wziąć pod uwagę jego globalny cel komunikacyjny, który bywa określany jako zamysł komunikacyjny, orientacja wypowiedzi lub strategia (Witosz 2005: 52). Globalny charakter strategii byłby więc trwale związany z całościowym celem wypowiedzi, która wynika ze specyfiki działalności człowieka i dlatego jest istotnym wskaźnikiem jej kształtu gatunkowego.

W pewnych ujęciach metodologicznych pojęcie strategii bywa używane dla podkreślenia dynamiki opisu wypowiedzi, w odróżnieniu od statycznych opisów ujmujących tekst jako stabilną strukturę hierarchiczną (Witosz 2005: 82). Koncentracja na strategiach umożliwia spojrzenie na tekst jako proces, czyli interakcję komunikujących się podmiotów; pokazanie przenikania się różnych płaszczyzn wypowiedzi, zjawisk językowych i pozajęzykowych. W tym ujęciu strategia - dzięki swojej elastyczności i dynamice - byłaby bardziej odpowiednim narzędziem do analizy tekstu rozumianego jako proces.

van Dijka i Kintscha odwołuje się również Anna Duszak w swojej typologizacji zdarzeń komunikacyjnych (Duszak 1998: 173-242). 
Właściwość tę wykorzystują badacze tekstu rozpatrywanego jako zdarzenie komunikacyjne. Janina Labocha, definiując dyskurs, określa go jako normę oraz strategię zastosowaną w procesie tworzenia tekstu o określonych cechach gatunkowych (Labocha 1996b: 51-52). Anna Duszak akcentuje strategiczny charakter wyborów, jakich nadawca dokonuje w akcie komunikacji i wobec tego wprowadza pojęcie tekstu strategicznego (Duszak 1998: 54-61). Słusznie zauważa Tomasz Piekot, że współczesna lingwistyka nie zrezygnowała z tradycyjnych kategorii tekstowych (por. de Beaugrande, Dressler 1990), ale dokonała ich reinterpretacji, tzn. uznała wyznaczniki tekstu za pewne strategie tekstowe (Piekot 2006: 25). Wyraźne jest przy tym nastawienie na łączenie struktury i funkcji danego typu tekstu ze znajomością szerokich uwarunkowań danego typu interakcji społecznej. „Znajomość ta jest potrzebna, aby móc lepiej ocenić czynniki motywacyjne, które regulują określone formy i strategie tekstowe” (Duszak 1998: 63).

Uaktywnienie społecznego i sytuacyjnego kontekstu zdarzenia komunikacyjnego pozwoliło spojrzeć na tekst jak na rezultat określonych mechanizmów oraz procesów organizujących plan wyrażania i plan treści w sposób możliwy do zinterpretowania, a także zaakceptowania przez odbiorcę (Labocha 1996b: 52; Duszak 1998: 54). W tym podejściu strategie nazywane nadawczo-odbiorczymi zajmują centralne miejsce. Sterują bowiem procesem organizowania wypowiedzi i odpowiadają za rekonstrukcję dyskursu lub (w sytuacji mniejszej przejrzystości intencji) za tworzenie hipotez na jego temat. Hipotetyczność jest związana z faktem, że tekst, będący zapisem decyzji nadawcy, jest zależną od uwarunkowań formą działania językowego, którego sens podlega interpretacji („tekst jest superznakiem, którego odbiór wymaga uruchomienia szczególnie złożonych mechanizmów interpretacji” (Duszak 1998: 325).

$\mathrm{Z}$ pojęciem strategii wiąże się zatem element niejawności, implicytności planów działania komunikacyjnego. Barbara Boniecka zwraca np. uwagę na pewien rodzaj gry dialogowej w wywiadach prasowych i radiowo-telewizyjnych, polegający na gotowości rozmówcy do rozwijania tematu mimo braku eksplicytnych sygnałów zachęty. Nieujawniana wprost intencja pytajna repliki dziennikarza jest nazwana „intencją strategiczną nadawcy”. Powinna ona zostać odczytana przez odbiorcę: „Odbiorca orientuje się doskonale w tym, że inicjator wywiadu często pozoruje tylko swoją niepewność czy bezradność w rozwiązywaniu problemów. On wie, że nadawca chciał zapytać, ale nie chciał użyć formy pytajnej” (Boniecka 1991: 37). Oczywiste jest przy tym, że nie dochodzi do zakłóceń między uczestnikami komunikacji, ponieważ łączy ich wspólny cel, jakim jest zaspokojenie ciekawości odbiorcy medialnego. Można więc powiedzieć, że konwencje wypracowane na użytek określonej sytuacji komunikacyjnej umożliwiają pominięcie tych treści, które są w nią wpisane. Barbara Boniecka wskazuje dodatkowo na świadomy charakter strategii, które są wynikiem preferencji i selekcji wynikających z możliwości dokonywania wyboru w języku. 
Do pojęć preferencji i wyboru odwołują się również Katarzyna Wyrwas i Katarzyna Sobisz-Sujkowska w ogólnej definicji strategii. Według autorek strategia to „pewna preferencja w wyborze tematów lub stylów wypowiedzi, dekodowaniu aktów mowy czy w wykorzystaniu gestów" (Wyrwas, Sobisz-Sujkowska 2005: 164). Rozwijając tę myśl, można stwierdzić, że w analizie strategii najciekawsze są właśnie owe preferencje, które nakazują uruchamianie różnorodnych kontekstów tworzenia i rozumienia działań komunikacyjnych.

Stosowanie i odczytywanie preferencji może być ułatwione dzięki trafnemu usytuowaniu zachowań komunikacyjnych nie tylko w obrębie typu dyskursu, ale również w obrębie typu tekstu, jakim jest gatunek mowy. Przypisanie tekstowi kwalifikacji generycznej jest koniecznym warunkiem jego fortunnego odbioru. Gatunek stanowi bowiem konwencjonalne rozwiązanie określonego problemu komunikacyjnego, zaakceptowane społecznie, utrwalone w kompetencji użytkowników. Zastosowanie pojęcia strategii w opisie wzorca gatunkowego uwypukla dodatkowo jego elastyczny charakter, co usystematyzowała i opisała Maria Wojtak w monografii Gatunki prasowe. W artykule pt. Strategie dyskursywne $w$ pewnym typie tekstu dydaktycznego badaczka zaproponowała bardzo precyzyjną definicję strategii dyskursywnych. Jest to zbiór reguł determinujących wybór modelu strukturalnego (formy wypowiedzi), sposobów realizacji potencjału illokucyjnego wypowiedzi, relacji nadawczo-odbiorczych, kreowanego w tekście obrazu świata i stylistycznego wymiaru dyskursu (Wojtak 2001: 16). Strategie dyskursywne (inaczej gatunkowe) można rozpatrywać w obrębie strategii dyskursu (które rozumiemy jako strategie związane każdorazowo z określonym typem dyskursu, np. z dyskursem dydaktycznym, medialnym, publicznym, politycznym). Relacja ta jest, jak się wydaje, analogiczna do relacji między typem dyskursu a podległymi mu gatunkami (np. wywiad w dyskursie medialnym, debata w dyskursie publicznym).

Niezależnie od tego, na jakim tle i w relacji do jakich pojęć rozpatruje się strategię, nieredukowalnym elementem jest jej instrumentalny charakter. Strategia jest bowiem środkiem do osiągnięcia określonego celu (Żydek-Bednarczuk 2005: 232). Wszystkie określenia doprecyzowujące rodzaj strategii (strategie komunikacyjne, językowe, interakcyjne, konwersacyjne, strategie tekstowe, dyskursu, dyskursywne, strategie kulturowe i społeczne, strategie grzeczności językowej, strategie ataku i obrony) wynikają z wyboru domeny celów i wiążą się ze środkami realizacji o zróżnicowanym stopniu komplikacji i jawności. Biegłość w stosowaniu i identyfikowaniu strategii językowych jest uzależniona od bardzo wielu czynników. Przy czym ważne jest trafne rozpoznanie sytuacji komunikacyjnej wraz z jej parametrami, wiedza na temat uwarunkowań kulturowych i społecznych komunikacji, znajomość kodu językowego wraz z typowymi wzorami gatunkowymi, wreszcie - umiejętność ich skutecznego zastosowania. 


\subsection{Strategie w medialnym dyskursie publicznym i politycznym}

Strategię w niniejszej pracy definiuje się jako sposób (lub plan) działania językowego zmierzający do osiągnięcia określonego celu. Jest to definicja szersza niż rozumienie strategii jako ciągu aktów mowy i węższa niż utożsamienie jej z kompetencją (sposób produkcji i rozumienia dyskursu). Strategia jako narzędzie badawcze ma kilka aspektów, które stały się podstawą typologii: aspekt tekstowy, interakcyjny i sytuacyjno-kontekstowy. Ich oddzielenie ma wartość jedynie diagnostyczno-analityczną, gdyż w konkretnych realizacjach aspekty te zazębiają się, co znajduje odzwierciedlenie w całościowej analizie.

Strategie tekstotwórcze są związane z organizacją tekstu jako spójnej, całościowej struktury. W grę wchodzi integracja segmentów tekstu wyodrębnionych ze względu na kryterium tematyczne, skład rozmówców, formę interakcji. Odbywa się to za pomocą środków spójności, takich jak: powtórzenie, nawiązanie, parafrazowanie, komentowanie wypowiedzi. Utekstowieniu mogą zatem podlegać elementy sytuacji dostępnej zmysłowo, w tym również działania komunikacyjne uczestników interakcji. $\mathrm{W}$ ramach strategii tekstotwórczych wyodrębniono dwie techniki: działania o charakterze prospektywnym i działania o charakterze retrospektywnym. Pierwsza technika polega na zapowiadaniu elementów strukturalnych wraz z podaniem charakterystyki rozmówców i/lub (cząstki) tematu. Działania retrospektywne polegają na streszczaniu wątków, przypisywaniu im kwalifikacji stylistycznej, gatunkowej. W obu technikach uwyraźnieniu sytuacji dyskusji/debaty służy nadanie elementom strukturalnym funkcji retorycznej.

Strategie tekstotwórcze znacznie zwiększają swoją efektywność dzięki wprowadzeniu metatekstu, czyli tego, co „tekst mówi o sobie”. Uruchomienie tego typu informacji może mieć charakter strategiczny ${ }^{81}$ i pełnić funkcję identyfikowania określonych fragmentów tekstu w kategoriach makrostrukturalnych lub superstrukturalnych (np. problem/rozwiązanie, przyczyna/skutek, odniesienie/porównanie). Jeszcze efektywniejsze sygnalizowanie funkcji retorycznych elementów tekstowych gwarantuje metadyskurs, czyli odnoszenie wypowiedzi do reguł dyskursu. Metadyskurs wspomaga zrozumienie tekstu jako spójnego zdarzenia komunikacyjnego ze względu na jego pojawienie się w określonym kontekście sytuacyjnym. Śledzenie metatekstu pozwala obserwować, jakie czynności podejmuje nadawca w trakcie jego tworzenia (np. problematyzowanie sytuacji, budowanie relacji przyczynowo-skutkowych, porównywanie), jakie ma dylematy, jaki jest jego stosunek do tworzonej właśnie wypowiedzi. Z kolei metadyskurs stanowi swoisty podgląd tego, jak tekst wpasowuje się w sytuację użycia, jak realizuje konwencje wypowiedzi wynikające $\mathrm{z}$ danego typu dyskursu (np. czy nadawca występujący w danej roli społecznej ma pozwolenie na określony

81 Por. Duszak 1998. 
typ działania językowego, jak należy rozumieć określone działanie językowe w danej sytuacji). Biorąc pod uwagę fakt, że dyskursywność jest kategorią tekstową, można potraktować metadyksurs jako wzbogacenie, a nawet rozszerzenie metatekstu.

- strategie dyskursu (nadanie tekstowi cech dyskursu, np. medialnego, publicznego)

- strategie medialnego dyskursu publicznego (strategie legitymizacji, delegitymizacji)

- strategie medialnego dyskursu politycznego:

- strategie kooperacyjne,

- strategie rywalizacyjne (taktyki prowokacji, np. demobilizacyjnej, dyskredytacyjnej, legitymizacyjnej, manipulacyjnej, prewencyjnej; taktyki dyskredytacji, np. demaskatorskiej, identyfikacyjnej, komunikacyjnej, poznawczej, prześmiewczej, zawodowej),

- strategie kreowania wizerunku,

- strategie perswazyjne, propagandowe, agitacyjne

- strategie dyskursywne (gatunkowe) (nadanie tekstowi cech gatunkowych, np. dyskusji/debaty)

- strategie konwersacyjne:

- strategie a antystrategie,

- strategie antagonistyczne, nieantagonistyczne,

- informacyjno-weryfikacyjne, aksjologiczno-emotywne, behawioralne

- strategie w sytuacji rywalizacji (strategie ataku, obrony, uniku)

- strategie grzecznościowe (obrony twarzy pozytywnej, obrony twarzy negatywnej)

- strategie zagrożenia twarzy

- strategie strukturalne (globalna organizacja programu, którego tekst jest częścią):

- kształtowanie ramy widowiska (zapowiedź, wprowadzenie, faza końcowa, zakończenie),

- kształtowanie części środkowej widowiska (delimitacja i konstytuowanie segmentów środkowych, np. debaty z udziałem publiczności, dyskusji z udziałem ekspertów i polityków)

- strategie tekstotwórcze (organizacja tekstu jako spójnej, całościowej struktury):

- działania o charakterze prospektywnym (zapowiadanie),

- działania o charakterze retrospektywnym (powtarzanie, nawiązywanie, streszczanie, kwalifikowanie)

- strategie metatekstowe (wykorzystanie metatekstu do tworzenia, a co najmniej uwyraźniania, makrostruktury i superstrunktury tekstu)

- strategie metadyskursywne (wykorzystanie metadyskursu do kreowania zdarzenia komunikacyjnego zgodnie z celem nadawcy)

- strategie nadawczo-odbiorcze - sposoby działania językowego nadawcy (kierowanie interakcją, organizacja tekstu) podejmowane ze względu na odbiorcę (zwłaszcza w relacji: nadawca medialny - odbiorca masowy)

Rys. 2. Typy strategii w aspekcie tekstu, interakcji i sytuacji (jako determinanta dyskursu) 
Zważywszy na rolę metatekstu i metadyskursu w tworzeniu tekstu spójnego i zharmonizowanego z sytuacją, a jednocześnie zaangażowanego w proces intencjonalnego działania językowego, należy wyodrębnić strategie metatekstowe i metadyskursywne. Polegają one na strategicznym uruchomieniu informacji o tekście i o dyskursie. Strategie metadyskursywne dostarczają sygnałów interpretacji tekstu jako zdarzenia komunikacyjnego, dzięki werbalizowaniu sytuacyjnych uwarunkowań wypowiedzi (np. kiedy nadawca asekuracyjnie zaznacza, że mówi jako osoba prywatna, a nie dziennikarz; kiedy historyk dyskwalifikuje wypowiedź urzędnika jako przekroczenie uprawnień; kiedy wyklucza się rozmówcę ze względu na brak kompetencji komunikacyjnych). Realizując strategie metadyskursywne, rozmówcy zwracają uwagę na normy mówienia wynikające z określonego typu dyskursu. Dzięki tym strategiom realizują swoje cele komunikacyjne, a jednocześnie uwyraźnia się dyskurs jako zinstytucjonalizowany typ interakcji. Strategie te pozwalają na zwerbalizowanie, odsłonięcie uwarunkowań oraz motywacji o podłożu kulturowym i społecznym, które decydują o określonej formie tekstu.

$\mathrm{Z}$ uwagi na to, że tekst nie jest jedynym elementem przekazu medialnego, pojawiła się potrzeba wyodrębnienia ogólniejszych (niż tekstotwórcze) strategii strukturalnych, które są w większym stopniu zależne od koncepcji nadawcy medialnego, powtarzalnej formuły programu (czegoś w rodzaju formatu), a więc mają charakter seryjny, organizacyjny i globalny (w ramach strategii strukturalnych strategie tekstotwórcze podlegają więc ukierunkowaniu, doprecyzowaniu i sfunkcjonalizowaniu). W analizowanym programie „Debata” w zakres strategii strukturalnych wchodzi kształtowanie ramy widowiska (zapowiedź, wprowadzenie, faza końcowa, zakończenie) oraz kształtowanie jego części środkowej. Szczególną regularność wykazują działania dziennikarza w segmencie z udziałem publiczności, w którym konstytuuje on grupy proponentów i oponentów (por. rozdział 6).

Sytuacja, w której co najmniej dwie osoby kontaktują się językowo ze sobą, są w ten kontakt zaangażowane, a więc starają się zrozumieć działania partnera i do nich dostosować, jest rodzajem interakcji. Jej uczestnicy występują jako osoby działające intencjonalnie, a ich wypowiedzi są wzajemnie zdeterminowane. Strategie konwersacyjne różnicują interakcję ze względu na cel (strategie informacyjno-weryfikacyjne, aksjologiczno-emotywne, behawioralne), ze względu na zbieżność celów (antagonistyczne, nieantagonistyczne), ze względu na zachowanie zasady kooperacji (strategie, antystrategie ${ }^{82}$ ). Dość istotne jest założenie, że rozbieżność celów, przy zachowaniu zasady kooperacji (strategie antagonistyczne), uruchamia ciągi negacyjne $\mathrm{z}$ argumentacją rzeczową lub aksjologiczną ${ }^{83}$.

\footnotetext{
82 Antystrategię, która polega na blokowaniu posunięć rozmówcy, można też uznać za rodzaj strategii ataku, gdyż występuje w sytuacji rywalizacji, konfliktu, prowadzi do kłótni.

83 Por. Awdiejew, Habrajska 2006: 54-70; Awdiejew, Habrajska 2009: 9-18. Przy rozbieżnych celach, w strategiach informacyjno-weryfikacyjnych pojawia się argumentacja rzeczowa,
} 
Oprócz celu, dwa najważniejsze parametry mające wpływ na interakcję to ustosunkowanie i siła $^{84}$. Są one istotne w opisie dynamiki sytuacji konfliktowych. Przy negatywnym ustosunkowaniu i dużej sile, przekaz jest odbierany jako atak (strategia jest realizowana jako komunikowanie lub przejawianie: agresji, kontroli, wrogości, poniżania, dezaprobaty, dominacji, obwiniania, negatywnych domniemań). Strategia obrony, w zależności od ustosunkowania, może przyjąć formę: sprzeciwiania się, odrzucania, oporu lub przybrać formę ataku. Strona konfliktu może uchylać się przed otwartą konfrontacją, realizując strategię uniku, poprzez wycofanie się, odwlekanie, niezaangażowanie, próbę zmiany tematu, rozważania proceduralne.

Interakcję można również analizować jako konwencjonalną grę grzecznościową, która jest prowadzona z myślą o zachowaniu twarzy pozytywnej i negatywnej rozmówców. W tym sensie strategie ataku można jednocześnie traktować jako strategie zagrożenia twarzy rozmówcy (np. krytykowanie, obrażanie, wyśmiewanie). Dochodzi bowiem do naruszenia pozytywnego obrazu osoby. Obraz ten przedstawia się metaforycznie jako „twarz”, czyli publiczny wizerunek osoby, jaki sama stwarza i jakiego gotowa jest bronić. Ma on dwa aspekty: twarz pozytywną (która symbolizuje prawo do pozytywnego obrazu samego siebie i prawo do tego, aby ten obraz był doceniany oraz akceptowany przez innych) oraz twarz negatywną (która symbolizuje prawo do własnej przestrzeni, niezakłóconej swobody, nieingerencji i samostanowienia) ${ }^{85}$. Konstrukty te okazują się niezwykle przydatne w wyjaśnianiu zachowań językowych uczestników medialnego dyskursu publicznego.

Rozpatrywanie strategii w aspekcie interakcji stanowi bazę, punkt wyjścia dla strategii rozpatrywanych w aspekcie sytuacji (dyskursu), chociaż ujęto je na różnych poziomach schematu. Założono bowiem, że podstawowe wzory działań interakcyjnych (np. strategie informacyjno-weryfikacyjne, strategie zachowania twarzy, strategie ataku), które występują pierwotnie w układach nieoficjalnych, nieinstytucjonalnych, są realizowane również w bardziej skomplikowanych systemach komunikowania. Różnica jest jednak taka, że wraz ze wzrostem złożoności sytuacji, wzrasta również złożoność strategii. I tak, dla przykładu, strategie informacyjno-weryfikacyjne, które przeprowadzane są w sytuacji dyskusji publicznej, wymagają zaangażowania bardziej skomplikowanych strategii

\footnotetext{
która pozwala określić stopień wiarygodności sądów. W analogicznej sytuacji, podczas realizowania strategii aksjologiczno-emotywnej stosowana jest argumentacja aksjologiczna. Przesłanki ogólne tej argumentacji mają charakter ideologiczny, czyli przyjmują postać uogólnionych sądów oceniających.

${ }^{84}$ Por. omówienie koncepcji R. Penmana przez Zbigniewa Nęckiego (Nęcki 2000: 82-87). Autor podaje typologię ukrytych i obserwowalnych aktów komunikacji, biorąc pod uwagę dwa kryteria: ustosunkowanie (od negatywnego poprzez obojętne do pozytywnego) oraz siłę (od uległości i niepewności do dominacji i pewności siebie).
}

${ }^{85}$ Por. Goffman 2000; Antas 2000; Kita 2005. 
argumentacyjnych (w których wykorzystuje się np. funkcjonalizację tła pozajęzykowego, budowanie relacji między jego elementami na zasadzie następstwa, współistnienia, przyczynowości, niezgodności). Strategie zachowania twarzy pozytywnej są punktem wyjścia dla strategii kreowania wizerunku i strategii legitymizacji osób pełniących funkcje publiczne lub do nich pretendujących. Strategie ataku ulegają natomiast sformalizowaniu, przyjmując postać różnorodnych prowokacji i dyskredytacji ${ }^{86}$. Strategie aksjologiczno-emotywne i behawioralne znajdują zastosowanie w propagandzie, która stanowi typ komunikowania politycznego.

Przyjęte założenie o hierarchicznym uporządkowaniu skłania do uznania strategii dyskursu za nadrzędne. To właśnie na poziomie dyskursu funkcjonalnie włączane są czynniki sytuacyjne i kontekstowe. Omówione w punkcie 3.4 parametry medialnego dyskursu publicznego i politycznego dostarczają członkom wspólnoty dyskursywnej wskazówek odnośnie do tworzenia i odbioru tekstów pojawiających się $\mathrm{w}$ jego przestrzeni. Poziom profesjonalizmu nadawcy medialnego, który organizuje interakcję w mikrosytuacji, określa biegłość w stosowaniu strategii nadawczo-odbiorczych, istotnych z kolei dla kreowania makrosytuacji. Strategie gatunkowe (dyskursywne - w rozumieniu Marii Wojtak) stanowią natomiast doprecyzowanie wskazanych parametrów w obrębie skonwencjonalizowanych form wypowiedzi, jakimi są gatunki.

Cel analizy, jakim jest interpretacja działań komunikacyjnych w kategoriach strategii, wymaga zastosowania szerokiej metodologii. Należy jednak zaznaczyć, że wykorzystanie elementów teorii komunikacji, medioznawstwa, socjologii, politologii ma jedynie charakter pomocniczy wobec dominującego ujęcia lingwistycznego o nachyleniu pragmatycznym. W centrum zainteresowania niezmiennie pozostaje tekst, ze względu na cechę określaną jako dyskursywność. Pozwala ona powiązać formę przekazu z sytuacją jego użycia w ramach omówionych wcześniej parametrów medialnego dyskursu publicznego, nie tracąc z pola widzenia perspektywy genologicznej. Instrumentalny charakter omawianego dyskursu umożliwia również zastosowanie narzędzi analizy retorycznej. Chodzi przede wszystkim o zwrócenie uwagi na dobór treści informacyjnych i świadome tworzenie relacji między nimi w celu zbudowania argumentacji; na uporządkowanie etapów przebiegu interakcji oraz budowanie więzi z audytorium. Podjęte (w kilku fragmentach) próby zdemaskowania niejawnych strategii delegitymizacji noszą znamiona krytycznej analizy dyskursu.

86 Typy dyskredytacji i prowokacji omawia obszernie Mirosław Karwat (Karwat 2006b, 2007). W analizach przeprowadzonych w niniejszej pracy wielokrotnie stosowano te techniki do szczegółowego opisu konkretnych działań językowych w medialnym dyskursie politycznym. 


\title{
Czę̧Ś́ I \\ STRATEGIE I ICH UWARUNKOWANIA
}

\author{
RozDZIAє 1 \\ Strategie $\mathrm{i}$ ich uwarunkowania związane $\mathrm{z}$ typem \\ komunikowania
}

Strategie podejmowane przez uczestników medialnych programów publicystycznych są zdeterminowane przez kontekst społeczny i sytuacyjny komunikacji. Czynniki te wpływają na podejmowane tematy i sposoby ich prezentacji, kreowanie układu interakcyjnego, realizację przez rozmówców celów pragmatycznych oraz ogólną strukturę programów. Prześledzenie drogi od złożonego układu uwarunkowań komunikacyjnych do strategii jest niezbędnym etapem ich trafnej identyfikacji.

Wiedza uczestników komunikacji na temat warunków, w jakich się ona odbywa, jest ważnym elementem zrozumienia ich wypowiedzi, również w kategoriach działań ${ }^{1}$. Działania te są podejmowane w ramach relacji istniejących między podmiotami sfery publicznej. Należy zaznaczyć, iż relacje wynikają z organizacji życia społecznego i są uprzednie względem komunikacji. Jeśli działania kryją w sobie powtarzalny (a przy tym odtwarzany) schemat postępowania i można przypisać im konkretny cel, to uzasadnione jest dopatrywanie się w takim działaniu określonej strategii. W skrócie można przedstawić następujący łańcuch zależności: relacje istniejące $\mathrm{w}$ systemach komunikowania $\rightarrow$ podjęcie $\mathrm{w}$ ich ramach działań $\rightarrow$ nadanie działaniom charakteru strategicznego. Nadawca nie tworzy więc wypowiedzi całkowicie dowolnie, ale działa w ramach relacji, reguł i norm przewidzianych przez wymogi dyskursu. Odpowiedni poziom kompetencji dyskursywnej pozwala mu na stosowanie strategii komunikacyjnych nastawionych na osiąganie własnych celów. Odbiorca, chcący trafnie zinterpretować zachowania komunikacyjne nadawcy, musi zdawać sobie sprawę z całej złożoności kontekstu.

W odbiorze do pewnego stopnia pomocne są wszelkie uwagi metatekstowe i metadyskursywne, które mogą stanowić sygnały kontekstualizacji czy werbalizacji intencji. Należy jednak rozpatrywać je w całej złożoności sytuacji rywalizacyjnej

${ }^{1}$ Działanie to można różnie rozumieć: jako produkowanie wypowiedzi o określonej intencji, działanie słowami. Według Mrozowskiego komunikowanie jest nieprzerwaną ludzką działalnością, praktyką społeczną (Mrozowski 2001: 14). 
- nie tyle jako rzeczywiste kierowanie odbiorem, ile często jako manipulowanie nim. W analizie będziemy zatem traktować strategie metatekstowe, a zwłaszcza metadyskursywne, raczej jako potwierdzenie repertuaru możliwych środków i sposobów działania niż adekwatną diagnozę w konkretnym przypadku.

Analiza strategii metatekstowych i metadyskursywnych stanowi mimo wszystko ważny etap badania zachowań komunikacyjnych. Relatywnie duży udział tych strategii stanowi widoczną cechę tekstów ze względu na ich dialogowość, oficjalność, a zwłaszcza medialność. Strategie metadyskursywne ujawniają standardy zachowań związane z funkcjonowaniem w przestrzeni społecznej, które stanowią rodzaj wiedzy wspólnej dla rozmówców o zbliżonych kompetencjach. W debacie pozastudyjnej wiedza ta jest uznawana za oczywistą do tego stopnia, że najczęściej nie musi być werbalizowana. Poziom jej uświadomienia u rozmówców wpływa na merytoryczność, jakość i kształt debaty publicznej. W publicystycznych programach telewizyjnych, jak można przypuszczać, ze względu na odbiorcę medialnego (wypowiedź retoryczna) wypowiedzi na temat zasad funkcjonowania podmiotów w sferze publicznej, w tym politycznej, pojawiają się częściej. Należałoby jednak postawić pytanie, czy werbalizowanie norm komunikacyjnych, które powinny być implicytne, jest tylko przejawem redundancji, a jeśli nie, to jaka jest funkcja tego typu zachowań komunikacyjnych.

Metatekst i metadyskurs, uwyraźniając intencje rozmówców, ujawniają mechanizmy wiązania tekstu z kontekstem i przez to pomagają w odbiorze określonego typu tekstów. Przejście w badaniach od tekstu jednostkowego do typu tekstu jest tu konieczne, gdyż stopień autotematyczności poszczególnych realizacji tekstowych jest różny. Dopiero analiza korpusu tekstów daje podgląd stosowanych strategii komunikacyjnych. Niezależnie od stopnia jej ujawnienia tekst charakteryzuje się określoną strukturą semantyczną.

Wprowadzone przez T. A. van Dijka dla tekstów narracyjnych pojęcie makrostruktury okazało się przydatne dla tekstu w ogóle (van Dijk 1980). Jest ono związane z głęboką strukturą semantyczną tekstu i powstaje na skutek działań redukcyjnych, przekształcania oraz uogólniania jego znaczeń. Jak twierdzi Anna Duszak, przypisywanie tekstom makrostruktury wymaga aktywizacji potencjału kognitywnego odbiorcy (Duszak 1998: 194). Dla potrzeb niniejszej analizy zakładamy, że zrekonstruowanie znaczeń poszczególnych wypowiedzi, traktowanych jako działania komunikacyjne, jest zależne m.in. od ogólnej wiedzy odbiorcy na temat zasad funkcjonowania sfery publicznej. Zwłaszcza etap interpretacji, polegający na uogólnianiu i przekształcaniu informacji, wymaga uwzględnienia złożonego kontekstu.

Przestrzeń społeczna, w jakiej działają media masowe, „to układ złożony, poddany działaniu sprzecznych sił w rozmaity sposób determinujących organizację i funkcjonowanie poszczególnych obszarów tego układu" (Mrozowski 2001: 117). Do kluczowych pojęć, które organizują treści kognitywne, pozwalają kategoryzować zachowania komunikacyjne jako działania, należą: sfera publiczna, sfera prywatna, sfera instytucjonalna, interes publiczny, interes prywatny (jednostkowy). Pojęcia te pojawiają się $\mathrm{w}$ analizach zachowań $\mathrm{w}$ ramach komunikowania społecznego. 
Komunikowanie społeczne to proces porozumiewania się jednostek, grup lub instytucji, którego celem jest wymiana myśli, dzielenie się wiedzą, informacjami, ideami. Proces ten jest charakteryzowany przez liczbę i zasięg uczestników, rodzaj środków komunikowania, realizowane funkcje (Dobek-Ostrowska 2006: 60-89). Podkreśla się m.in. jego kreatywność, dynamiczność, ciągłość, symboliczność, interakcyjność, celowość, nieuchronność i - co istotne dla niniejszych rozważań - kontekstualność. Jest ona rozumiana jako zależność od rodzaju kontekstu społecznego, w którym komunikacja przebiega (kontekst interpersonalny, grupowy, instytucjonalny, publiczny, masowy, międzykulturowy).

Badane teksty jako komunikaty powstały w ramach komunikowania masowego, ale kumulują w sobie również elementy innych typów komunikowania. Ze względu na zasięg komunikowanie masowe pozostaje w relacji z komunikowaniem intrapersonalnym, interpersonalnym, grupowym, instytucjonalnym. Ze względu na sposób porozumiewania się, jako komunikowanie pośrednie wchodzi w relacje z komunikowaniem interpersonalnym, które ma charakter bezpośredni. McQuail zobrazował poziomy komunikowania w postaci piramidy.

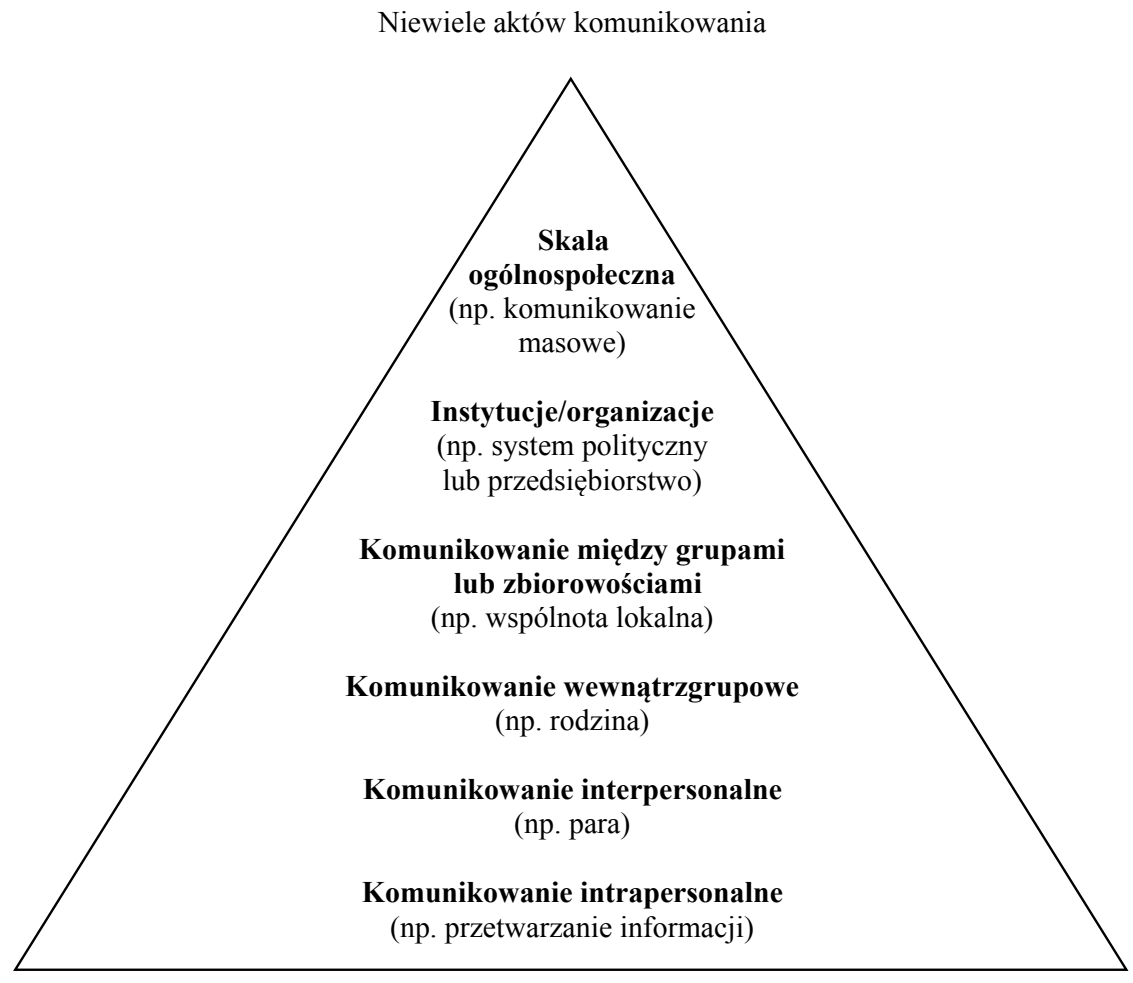

Wiele aktów komunikowania

Rys. 3. Piramida komunikacji (za: McQuail 2007: 36) 
Komunikowanie interpersonalne to komunikowanie społeczne zachodzące między jednostkami ludzkimi. Jego cechą jest jedność nadawania i odbioru, spowodowana bezpośrednim kontaktem „twarzą w twarz” i powodująca natychmiastowe sprzężenie zwrotne. Komunikowanie interpersonalne jest dwustronne, co skutkuje wymiennością ról nadawcy i odbiorcy. Relacje, jakie łączą uczestników, mogą mieć zarówno charakter nieformalny, jak i formalny. Komunikowanie wewnątrz grupy i między grupami wiąże się już z kształtowaniem hierarchii, powiązań, kontroli (Dobek-Ostrowska 2006: 72). Niezwykle istotne dla naszych rozważań jest stwierdzenie, że począwszy od poziomu komunikowania wewnątrzgrupowego wzwyż, wzrasta rola form i wzorów ludzkich interakcji, zaczynają obowiązywać normy, zarysowują się granice. Komunikowanie instytucjonalne jest wysoce sformalizowane, władza i kontrola - jasno zdefiniowane, role nadawcy i odbiorcy - jednoznacznie określone, a zagadnienie formowania się norm i standardów staje się pierwszoplanowe.

\subsection{Strategie i ich uwarunkowania ze względu na organizację systemów komunikowania}

Nie sposób zrozumieć działań komunikacyjnych uczestników debat, jeśli się je rozpatruje jako proste porozumiewanie się interpersonalne jednostek. Stopień skomplikowania relacji nadawczo-odbiorczych w medialnych programach politycznych (podwójna sytuacyjność), złożone konteksty przekazów sprawiają, że najbardziej adekwatnym ujęciem zachodzącej tam komunikacji jest rozpatrywanie jej w ramach systemów komunikowania.

Uczestnikami takich systemów mogą być nie tylko jednostki, ale również grupy i instytucje. Dobek-Ostrowska wskazuje na takie elementy systemu komunikowania, jak: uczestnicy systemu, ich skład, struktura i cechy; kontrola zawartości komunikatów przekazywanych w systemie; źródła i drogi dopływu informacji do systemu, charakter kontaktów i rodzaj styczności między członkami systemu; zadania, jakie mają do wykonania członkowie systemu; reguły, wzory i normy rządzące zachowaniem członków systemu; charakter sprzężenia zwrotnego (Dobek-Ostrowska 2006: 104).

Rola, jaką odgrywają wskazane wyżej elementy w analizowanych interakcjach, jest wielopłaszczyznowa: system wyznacza zakres niezbędnych działań i aktywności uczestników, zapewnia racjonalność podejmowanych działań, pozwala wydobyć ich sens oraz dostarcza wzorów i norm rządzących zachowaniem członków. Uwarunkowania te ujawniają się z różnym natężeniem niezależnie od konkretnego typu systemu (czy jest to system komunikowania społecznego, publicznego, politycznego, masowego, organizacyjnego), stąd w niniejszym punkcie dominuje ujęcie ogólne.

Interpretacja zachowań uczestników debat z uwzględnieniem elementów systemu zbliża również odbiorcę do odkrycia makrostruktury tekstu. Za ważne 
z tej perspektywy kategorie makrostrukturalne uznano elementy systemu komunikowania. Przyjęto założenie o korelacji między elementami systemu komunikowania a makrostrukturą tekstu powstającego w jego ramach.

Celem analizy jest zatem ukazanie wpływu elementów systemu na przebieg interakcji, np. jak rodzaj styczności między członkami systemu rozszerza inwentarz sytuacji zagrożenia twarzy; w jaki sposób wiedza na temat kontroli zawartości komunikatów służy strategii obrony; jak wykorzystywana jest wiedza na temat reguł dyskursu do strategii ataku, obrony, uniku; jak cele i zadania członków systemu determinują podejmowane strategie; jak wykorzystywane są strategie metadyskursywne do sterowania interpretacją zdarzeń (np. zmiana aspektu karno-prawnego sprawy na polityczny, zmiana aspektu indywidualnego sprawy na instytucjonalny).

TS: Pani marszałek, czy pani styszała to, co mówiła pani Aneta Krawczyk? [pytanie dotyczy oskarżenia A. Krawczyk wobec dwóch członków Samoobrony, a skierowane jest do innej członkini tej partii - G. Wiśniowskiej]

GW: Tak, styszatam.

TS: I co pani na to?

GW: Ja myślę, że narodziła nam się, czy tė̇ powstała, nowa Anastazja P. Tylko z Anastazji P. Samoobrona miała pożytek pewien, bo przynajmniej ulotki roznosita. A tutaj, jak widzę, otrzymywata zapłatę, $i$ to nie najgorsza, bo byta $i$ w radzie nadzorczej, poza tym jeszcze jako radna. I zadaję sobie pytanie: skończyło się petnienie funkcji radnej i nagle teraz jest pretensja.

(„Teraz my!”, TVN, 5.12.2006; dziennikarze - AM: Andrzej Morozowski, TS: Tomasz Sekielski; goście - GW: Genowefa Wiśniowska, JS: Joanna Senyszyn, JSz: Jolanta Szczypińska)

Dziennikarz kreuje sytuację komunikacyjną zgodnie z wymogami dyskursu medialnego (w odmianie komercyjnej) i stosuje strategię prowokacji dyskredytacyjnej, która powoduje zagrożenie twarzy pozytywnej rozmówcy. Działanie dziennikarza jest racjonalne ze względu na specyfikę dyskursu politycznego: traktowanie partii politycznej jako grupy osób powiązanej wspólnym interesem. Zatem zarzut wobec jednego z członków aktywizuje także wszystkich pozostałych. Jest to przykład wpływu reguł komunikacji politycznej na kreowanie układu interakcyjnego - dochodzi do rozszerzenia inwentarza sytuacji zagrożenia twarzy, które dotyczyć mogą osób publicznych.

Rozmówczyni dopasowuje swoją strategię komunikacyjną i konstruuje wypowiedź mającą na celu obronę twarzy pozytywnej. Podstawową taktyką jest dyskredytacja moralna oskarżycielki (potocznie mówi się o „obronie przez atak”). Służy temu porównanie, które ma zmienić kreowany przez część mediów konstrukt postaci (nie ofiara przestępstwa, ale oszustka, intrygantka, skandalistka). Dodatkowo rozmówczyni strategicznie wykorzystuje wiedzę na temat systemów komunikowania. Otóż, na mocy zadań, jakie mają do wykonania członkowie systemu, kształtuje się stereotyp roli osoby, która pełni służbę publiczną (tu: radna). Zakłada się, że działa ona w interesie publicznym. Oskarżenie o prywatne 
motywacje, wręcz wyrachowanie (skończyło się petnienie funkcji radnej i nagle teraz jest pretensja) pozbawia obiekt ataku ochrony, jaką zapewnia występowanie w roli społecznej. Taktykę można najkrócej określić jako mającą na celu symboliczne wyparcie problemu ze sfery publicznej (całkowite pominięcie wątku nadużycia władzy przez członków Samoobrony) do sfery prywatnej (zemsta z wyrachowania). Tak więc chodzi o przedefiniowanie wydarzenia, swoistą reinterpretację, która jest tym skuteczniejsza, im trafniej wykorzystuje wiedzę na temat podsystemów komunikacji społecznej.

Na poziomie aktów mowy wypowiedź realizuje globalną intencję obrazy, w której pojawia się dyskredytacja moralna, szyderstwo i pogarda (otrzymywała zaptatę; Tylko z Anastazji P. Samoobrona miała pożytek pewien, bo przynajmniej ulotki roznosiła). Na intencję obrazy wskazuje rodzaj antagonistycznej relacji między nadawcą a obiektem działań językowych, sytuacja komunikacyjna rywalizacji politycznej, a przede wszystkim treść i ukształtowanie językowe.

TS: A nie jest pani oburzona zachowaniem, jeśli tak było, swoich partyjnych kolegów?

GW: Panie redaktorze//

TS: I swojego szefa?

GW: Złe pytanie. To nie chodzi w tej chwili akurat o/ Przede wszystkim prokuratura musi wyjaśnić. I na to pytanie powinniśmy sobie/ to znaczy poczekać na odpowiedź, i tego powinniśmy się trzymać. Niedopuszczalne jest to, co w tej chwili jest stosowane, czyli media wszem i wobec mówia, rozgłaszaja, pokazuja tylko z jednego punktu spojrzenia, a nie czekamy na efekt końcowy prokuratury.

TS: Małe wyjaśnienie: zapraszaliśmy Andrzeja Leppera dzisiaj tutaj do studia. Chcieliśmy, aby byt naszym gościem. Niestety, pan przewodniczący Lepper, pan wicepremier, nie mógt dzisiaj być tutaj, więc to nie jest tak, że jedna strona jest prezentowana.

Dziennikarz kontynuuje strategię prowokacji, eskalując środki. Jego pytanie jest sugestywne, gdyż zawiera ocenę zjawiska (nie jest pani oburzona). Tym razem pojawiają się już wyraźne sygnały, świadczące o uwikłaniu rozmówczyni w sytuację zagrożenia twarzy (swoich partyjnych kolegów $i$ swojego szefa). Prowokacyjne, ostre zachowanie dziennikarza wywołuje protest rozmówczyni, która przechodząc na poziom metatekstowy, komentuje je (złe pytanie) oraz stara się negocjować kierunek rozwoju tematu (To nie chodzi w tej chwili akurat o/). Rozmówczyni stosuje strategię obrony, w której wyraźnie wykorzystuje wiedzę o procedurach komunikowania w sferze publicznej i politycznej. Chodzi o zasadę podziału kompetencji, która mówi o zrzeczeniu się części władzy na rzecz niezależnych instytucji (prokuratura musi wyjaśnić). Taktyka dyskredytacji mediów z powodu braku obiektywizmu (media [...] pokazuja tylko $z$ jednego punktu spojrzenia) okazuje się celnym atakiem, gdyż godzi w profesjonalizm dziennikarzy (normatywna teoria mediów). Dziennikarz odczytuje taktykę dyskredytacji i usprawiedliwia się podaniem okoliczności niezależnych, zewnętrznych. Widać zatem, że zachowanie dziennikarza oraz rozmówczyni jest zdeterminowane tematem - emocjonującym i sensacyjnym 
dla komercyjnych mediów, ale niekorzystnym dla rozmówczyni, stąd strategie uniku i obrony przez atak. Ich efektywność jest uzależniona od wiedzy na temat reguł komunikowania w sferze publicznej (procedury prawne, profesjonalne wymogi dziennikarstwa).

TS: Jak panie oceniaja to, co ustyszały dzisiaj tutaj?

JS: Ja myślę, że na to trzeba spojrzeć z dwóch stron. Po pierwsze jest kwestia, czy zostało popetnione przestępstwo. Molestowanie seksualne, zmuszanie do czynów tego rodzaju pod presja jest przestępstwem. Natomiast druga sprawa to jest pózniejszy romans. No, romansuja politycy, polityka jest afrodyzjakiem, we Francji ostatnio sa takie znane sprawy//

TS: Pani poset, stuchała pani Anety Krawczyk. Co pani myślata?

JS: Myślę, że jeżeli takie rzeczy się zdarzaja, to kobiety powinny to ujawniać. My żyjemy $w$ spoteczeństwie patriarchalnym, gdzie kiedyś byto prawo pierwszej nocy i części mężczyzn wydaje się, że maja prawo do tego rodzaju zachowania. I niestety $w$ społeczeństwie jest pewna, no nie powiem, aprobata, ale $w$ każdym badź razie takie pewne patrzenie łagodne na tego rodzaju zachowanie mężczyzn. I być może trzeba z tym skończyć. I wtaśnie kobiety powinny ujawniać wszystkie takie przypadki.

Dziennikarz kieruje pytanie ogólne do rozmówczyni, która jest politykiem nieuwikłanym w sprawę. Nie jest zatem postawiona w sytuacji zagrożenia twarzy, co wpływa na jej strategię. Oskarżenie partii konkurencyjnej jest dla niej pretekstem do kreowania wizerunku i formułowania oferty politycznej. Buduje swój wizerunek jako osoby o wysokich kompetencjach poznawczych, posiadającej umiejętność wyodrębniania różnych aspektów jednej sprawy (aspekt prawno-karny, aspekt obyczajowy), osoby dowcipnej, nawet rubasznej (polityka jest afrodyzjakiem, prawo pierwszej nocy). Wykorzystuje kod kulturowy, przede wszystkim stereotypy, aby ukazać jednostkowe wydarzenie jako przejaw negatywnych tendencji. Wszystkie te działania wizerunkowe mają na celu stworzenie wrażenia reprezentatywności, czyli występowania w imieniu grupy społecznej, grupy interesu. Jak wynika z przedstawionego fragmentu, nieuwikłanie w sprawę wpływa na zachowanie komunikacyjne rozmówczyni, która wykorzystuje sytuację do zdobywania politycznego poparcia dla swojej partii. Jest to możliwe dzięki ukazaniu jednostkowego wydarzenia jako przejawu głębszego mechanizmu społecznego (relacja: zjawisko/przejaw zjawiska).

AM: Pani poset, a na pani to zrobito wrażenie? Pani uważa, że pani Aneta jest wiarygodna, czy też nie? Widziała pani tę kobietę. Ja powiem szczerze, że ja bytem wstrzaśnięty.

JSz: Ja powiem panu, panie redaktorze, że bytam też wstrzaśnięta [...] powiedziała, że gdyby tego nie uczynita, czyli gdyby nie wybrała tej metody, musiałaby zostać „jakąs tam sprzataczka”, prawda? To bytoby uwtaczajace dla niej, wobec tego wybrata metode tego najstarszego zawodu świata, który jest nam znany.

AM: Czyli kobieta ambitna, która próbuje uwiktać mężczyznę na stanowisku, żeby dzięki niemu zrobić karierę. Czy dobrze zrozumiatem, że tak pani widzi pania Anetę?

JSz: Widzę takie przestanki. Ja nie znam pani Anety prywatnie, więc tutaj/ Czy nie rozmawiałam z nia osobiście, więc nie chcę oceniać, ale takie odniostam wrażenie. Co nie oznacza oczywiście, że/ Mam nadzieję, że prokuratura jak najszybciej oceni i tutaj zbada ta sytuację. 
TS: A jak pani się dzisiaj czuje będąc w koalicji z Samoobroną? [...] Pani poset, czy jako kobieta czuje się pani dzisiaj dobrze, że jest pani w koalicji z Samoobrona, z takimi mężczyznami?

JSz: Wie pan, to nie ma nic do rzeczy, bo ja przebywam $w$ Sejmie, w Sejmie jest 460 postów, tak? Ja nie znam wszystkich posłów, ja nie znam wszystkich mężczyzn, natomiast ja bym prosita o nieuogólnianie.

Dziennikarz, kreując sytuację zgodnie z dyskursem medialnym jako emocjonującą, wręcz dramatyczną (bytem wstrząśnięty), kieruje pytanie do polityka z partii będącej w koalicji z partią uwikłaną w omawianą sprawę. Związek z sytuacją zagrożenia twarzy jest więc luźniejszy niż w przypadku pierwszej rozmówczyni (GW). Mimo to dochodzi po raz kolejny do obrazy (wybrała metodę tego najstarszego zawodu świata). Dziennikarz dokonuje quasi-podsumowania, będącego w rzeczywistości zmianą treści wypowiedzi. Jego celem jest złagodzenie porównania nieodpowiedniego w dyskursie publicznym. Tego typu niestosowne zachowania są spowodowane $\mathrm{z}$ jednej strony spontanicznym przebiegiem interakcji, z drugiej - niewystarczającą kompetencją komunikacyjną. Rozmówczyni, chcąc zatrzeć niekorzystne wrażenie, stosuje szereg asekurantów (nie znam pani Anety prywatnie, nie chcę oceniać, prokuratura oceni), które świadczą o rozpoznaniu sytuacji jako zagrożenia twarzy pozytywnej z powodu naruszenia standardów debaty publicznej.

Następnie dziennikarz wysuwa pytanie sugestywne, które ma na celu sprowokowanie rozmówczyni do powiedzenia czegoś, co obciążyłoby jej grupę, wywołanie emocji wstydu (czy jako kobieta czuje się pani dzisiaj dobrze, że jest pani $w$ koalicji $z$ Samoobrona, $z$ takimi mężczyznami?). Ze względu na postawienie w sytuacji zagrożenia twarzy rozmówczyni stosuje unik, posługując się strategią metatekstową. Wykorzystuje wiedzę na temat zasad konwersacji i argumentacji w celu dyskredytacji komunikacyjnej dziennikarza. Zarzuca mu mianowicie brak spójności wypowiedzi, odejście od tematu (to nie ma nic do rzeczy) oraz błędne wnioskowanie (natomiast ja bym prosiła o nieuogólnianie). Trafność zarzutów wobec dziennikarza jest dyskusyjna, ale nie o trafność tu chodzi. Celem jest bowiem uzyskanie optymalnej pozycji dyskursywnej w sytuacji zagrożenia twarzy (zwłaszcza wobec widzów). Używając metaforyki wojennej - chodzi o opuszczenie pozycji zagrożonej i przejście na pole przeciwnika, tak aby to on poczuł się zagrożony. Przy czym przeciwnikiem nie nazywamy tu konkretnie dziennikarza, ale raczej hipotetycznych wyrazicieli poglądów, które dziennikarz formułuje i przekazuje w imieniu widzów.

GW: Jeżeli mogę, no ja myślę, że przede wszystkim należy pokłonić się tutaj panu przewodniczacemu, panu premierowi, mówię o przewodniczącym PiS-u, panu premierowi Kaczyńskiemu, który wyraźnie powiedziat: „Poczekajmy do zbadania sprawy”. Więc wtedy, kiedy będzie orzeczenie, wtedy możemy decydować. Ale ja myślę, że jeżeli Prawo i Sprawiedliwość ma świadomość, że to jest celowe uderzenie w nasza koalicje, jeżeli chce realizować program „Solidarne państwo”, to na pewno powinno stanąć murem i/ albo poczekać do wyroku, czyli/ mówię o efekcie końcowym prokuratury, a tak nie możemy przecież sobie pozwolić, bo zapędzamy się w kozi róg. 
Gatunek mowy, jakim jest podziękowanie, został użyty instrumentalnie. Najistotniejsza z punktu widzenia obrony twarzy nadawcy jest implikatura konwersacyjna, skierowana $\mathrm{w}$ istocie do widzów-wyborców (implikatura: premier nas nie oskarża). Polepszeniu pozycji dyskursywnej rozmówczyni służy rozszerzenie kontekstu politycznego, w którym wydarzenie zyskuje nową, polityczną motywację (udaremnić program „Solidarne państwo”), a przez to i nowy sens (celowe uderzenie $w$ koalicję). Wydarzenie zostaje zatem wpisane w schemat rywalizacji politycznej, co jest bardzo częstą strategią obrony we wszelkich sprawach o charakterze karno-prawnym. Dzięki temu oskarżony ma szansę zamienić rolę (nietrwałą) oskarżonego na rolę osoby nękanej przez przeciwników politycznych. Warto dodać, że przytoczona wypowiedź jest bardzo znamienna z powodu dysproporcji między nieporadnością językową a trafnie stosowanymi strategiami. Świadczy to o udziale profesjonalistów w przygotowaniu telewizyjnych wystąpień polityków; swoistym treningu, któremu są poddawani. Jak widać, nie jest on jednak w stanie zapobiec nieudolnemu wykonaniu.

JS: Chciałam zwrócić uwagę na to, że nie zdarzają się takie sprawy [molestowanie w pracy] $w$ stosunku do mężczyzn. I to jest wtaśnie główny problem naszego spoteczeństwa patriarchalnego, $\dot{z}$ e to tylko kobiety sa wykorzystywane.

TS: Mężczyźni się boja przyznać.

JS: Bo to nie chodzi o ten konkretny przypadek, ale takie rzeczy się zdarzaja, a w stosunku do mężczyzn nie.

GW: Pani poset, ja myślę, że ta audycja nie ma na celu, żebyśmy dyskutowali na temat sytuacji kobiet, bo rzeczywiście jest to temat ważny, ale proszę tego nie tączyć z Samoobrona i nijak się to $\mathrm{ma} / /$

JS: Ale ja nie łączę tego, mówię tylko, że to jest problem naszego społeczeństwa.

Rozmówczyni kontynuuje strategię kreowania wizerunku i zabiegania o poparcie określonych grup elektoratu (np. kobiet, które czują się zdominowane przez mężczyzn). Instrumentalizacja tematu zostaje jednak rozpoznana. Kolejna rozmówczyni, stosując strategię metadyskursywną, protestuje przeciwko uogólnianiu (proszę tego nie łączyć z Samoobrona), a więc łączeniu sprawy konkretnej kobiety z sytuacją kobiet w ogóle. Przedstawienie sprawy jako przejawu dyskryminacji kobiet mogłoby stanowić wzmocnienie oskarżenia, dlatego próbuje się je udaremnić. W rzeczywistości każde działanie czy wydarzenie ma zarówno aspekt jednostkowy, jak i ogólny. Nie zawsze jednak oba aspekty są w równym stopniu korzystne dla strategii komunikacyjnych rozmówców, stąd konieczne jest neutralizowanie niepożądanych skojarzeń.

W całym programie dominują zatem trzy makrostrategie komunikacyjne, skorelowane z rolą społeczną rozmówców i stopniem ich uwikłania w sprawę. Dominującą strategią dziennikarzy jest prowokacja, która aktywizuje rozmówczynie. Jest ona możliwa ze względu na system komunikowania organizacyjnego, który nakłada na jednostki obowiązek lojalności wobec grupy. Na mocy zasady 
powiązania członków partii politycznej, rozmówczynie z tej samej partii i koalicji zostają postawione w sytuacji zagrożenia twarzy pozytywnej. $Z$ tego względu stosują strategie obrony o różnym stopniu fortunności. Najskuteczniejsze są te, w których wykorzystują wiedzę o systemach komunikowania (np. zasadę podziału kompetencji, zasadę obiektywizmu mediów) oraz wiedzę o zasadach dyskusji (spójności tematycznej, poprawności wnioskowania). Dyskredytacje moralne, akty obrazy nie są akceptowane w dyskursie publicznym (o czym świadczą zachowania asekuracyjne dziennikarza i rozmówczyni), co jednak nie musi wpływać na skuteczność ich oddziaływania wobec określonej kategorii odbiorców. Rozmówczyni nieuwikłana bezpośrednio w sprawę wykorzystuje program do kreowania wizerunku i formułowania oferty politycznej do grupy wyborców (strategia legitymizacji). Uczestnicy chętnie posługują się strategią metatekstową i metadyskursywną w celu uzyskania przewagi w bieżącej sytuacji komunikacyjnej i sterowania odbiorem ze względu na odbiorcę medialnego (Zte pytanie; to nie ma nic do rzeczy, ja bym prosiła o nieuogólnianie).

W kolejnym przykładzie rozmówca również zostaje postawiony w sytuacji zagrożenia twarzy i wykorzystuje w strategii obrony wiedzę o komunikowaniu w ramach systemów: powołuje się na hierarchię uczestników systemu, kontrolę zawartości komunikatów przekazywanych w systemie, zadania, jakie mają do wykonania członkowie systemu oraz normy rządzące ich zachowaniem.

TL: Panie prezydencie, czy pan czytat ksiażkę 24-letniego historyka, pana Zyzaka, w której dzieli się z nami fantastycznymi rewelacjami na temat pana życia typu: „siedziat pan na płocie i pit piwo"?

LW: Wie pan, nie czytatem, bo, bo/ ale czytałem wszystkie te komentarze, a więc skróty tych najważniejszych peretek. No wie pan, to jest nieprawdopodobne, i to co Centkiewicz zrobit, to jeszcze gdzieś tam z IPN-u jakieś donosy, jakieś relacje SB-eków, prawdopodobne sytuacje. Wiesz, a ten się powoła na Centkiewicza i dopisat wszelkie fantazje, jakie można napisać. I dlatego proszę pana to jest tak obrzydliwe, to jest tak nieprawdopodobne tam/ to jest tam świętokradztwo, to jest/ niemożliwe rzeczy i dlatego ja przewidziatem to. Stad zwracatem sie dawno temu już do ministra sprawiedliwości, Ziobro wtedy byt ministrem, i wcześniej zwracałem się do prokuratur, $w$ tym do gdańskiej, i zwracatem sie do marszatka Sejmu: „Panowie, zróbcie coś, aby te wszystkie sprawy niejasne, wątpliwe, gdzie są dwie wersje historii, uporządkować, bo jeśli nie uporządkujecie, no to będa wtaśnie paranoicy wyżywać się, będa pisać i świat będzie komentowat” [...]. I stąd/ stad jeszcze raz apeluje do demokratycznych struktur państwa, że albo te struktury sa demokratyczne i prawo szanuja, albo musimy coś zrobić, albo ja naprawdę jestem takim złym, że muszę wszystko oddać [...].

TL: Panie prezydencie, a do kogo za brak reakcji w sprawie tego, co, umówmy się, nie zaczęto się wczoraj, przedwczoraj i 5 miesięcy temu, do kogo ma pan największe pretensje o to, że to się dzieje i $w$ zasadzie nikt nie jest $w$ stanie albo nie próbuje tego zastopować?

LW: No wie pan, no jeśli prezydent państwa, w tym ja jako prezydent, przysięgałem, że będę stat na straży prawa/ no i popatrzmy teraz, prezydent państwa Kaczyński wie, że jest wyrok sadu, a więc prawo, które mówi, że Lech Watęsa mówit prawdę, a on występuje przeciwko tej prawdzie. Daje przykład innym: w IPN-ie przyjmuje Wyszkowskich, Gwiazdów i innych, wiadomo paranoicy. No to wie pan, no to do kogo mieć tu pretensje. No, demokratyczne państwo, które się dopiero buduje, pewno, że nie zdą̇a. Pewno, że nie robi tego wszystkiego jakoś/ no ale czas jest zajać się. 
A więc najmniej mam pretensji do dzisiejszej władzy, chociaż mam/ zaczynam już mieć pretensje $i$ do tej, bo nic nie robi w tym kierunku, aby porzadkować struktury, porzadkować instytucje, by państwo nie tamało prawa i można wyrok ruszyć, i można sprawę nowa założyć, ale dopóki jest wyrok, nie wolno jest inaczej postępować.

TL: Panie prezydencie, ale o tych pseudorewelacjach z ksiażki pana Zyzaka, części z nich typu „jakieś nieślubne dziecko” to, to wiadomo byto bardzo wiele miesięcy temu skad/skad/ chciat pan prezydent coś powiedzieć?

LW: Proszę pana, no przecież dżentelmeni po pięćdziesięciu latach nawet nie mówią coś podobnego. No przecież ta pani jest babcia, ja jestem dziadkiem. Ta pani wyszła wcześniej za maż, ta pani miała wcześniej/ aniżeli ja pomyślałem o mojej rodzinie, miała dzieci. No przecież nie można czegoś podobnego pisać! [...]

TL: Panie prezydencie, ja w ogóle nie chcę brnąć w te, jak powiedziałem pseudo/ pseudorewelacje. Pytanie dotyczy czegoś innego, bo mówię, o niektórych, znowu cudzystów, pseudorewelcjach słyszeliśmy wiele miesięcy temu i nagle wczoraj pojawia się pana dość dramatyczny wpis na blogu: „Oddam nagrody, nie wezmę udziału w żadnych uroczystościach rocznicowych, a jak sprawy pój$d a$ w tym kierunku, w którym ida cały czas, to być może wyemigruję z Polski”. Co spowodowało, co byto tym bezpośrednim impulsem, że napisat pan to, co pan napisat?

LW: Proszę pana, dlatego że coraz bardziej zauważam, że struktury wol/ demokratycznego państwa/ bo IPN jest struktura, więc nikt nie mówi o tych strukturach, które tak postępują. Mało tego, za ta ksiązkę dostat tytut naukowy, za ta książkę zostat przyjęty do IPN-u. Ja się dopiero dowiaduję przecież z prasy. Ja nie wiedziałem o tym, nie słyszałem, że ktoś tam sobie pisze, niech sobie pisze, więc to lekceważytem, ale jak się dowiedziatem, że zostat $w$ nagrodę/ dostat dyplom jakiś naukowy//

TL: Panie prezydencie, nie „jakiš”, tylko z Uniwersytetu Jagiellońskiego!

LW: No wie pan, ale, no, jakie bzdury, no przecież to sa/ [...] a ten nie ma nic, żadnego/ $i$ kompletne bzdury/ $i$ ma 24 lata/ Co on może powiedzieć o życiu żab!? No $i$ żeby coś takiego zrobić $i$ jeszcze $w$ nagrodę do struktur państwa się dostać? No i wie pan, no to musi niecierpliwić, to musi niepokoić to/ ja jestem zmuszony, ja nie mam wyboru. A mato tego, teraz mnie zapraszaja na uroczystości i do Sejmu, do którego się zwracatem: „No weźcie się, jeszcze świadkowie żyją, wyjaśnijcie. No, nie może być dwóch prawd historycznych, to sa rzeczy proste, sq świadkowie, ale nie robia $w$ tym kierunku, więc teraz jestem zaproszony, więc jak się będę/ jako zdrajca, jako agent, jako obrzydliwy cztowiek? [...]

TL: Ale panie prezydencie, pan sprawia wrażenie, jakby się pan bardzo przejąt tym, co napisat pan Zyzak: 24-latek z młodzieżówki PiS-u. To jest człowiek, który swego czasu napisat, cytuję: „Homoseksualiści to zwierzęta i wystannicy diabła”. Czy warto sie przejmować kimś, kto je/ kto pisze takie bzdety, brednie?

LW: Nie, ja się tym człowiekiem w ogóle nie przejmuję. No, niepoważny człowiek, chciat zaistnieć, ale ja mówię: Kurtyka go przyjąt do IPN-u! No wie pan, IPN to poważna instytucja, poważne zadanie. No jeśli on robi takie niepoważne ruchy, to proszę pana, cała ta praca, cała te wyjaśniania [sic!], walka o prawdę o Sikorskim i innym, proszę pana, w takich rękach. To jest/ ja się tym przejmuję, państwo, struktury państwa demokratycznego [...].

TL: [...] co premier Tusk, co marszatek Komorowski, do którego pan się zwracat, co inni polscy przywódcy powinni zrobić $w$ tej sprawie i w sprawie IPN-u, o czym pan mówi?

LW: No proszę pana, po pierwsze: odpowiedzialność jest tak daleko, że trzeba to wszystko sprawdzić, bo Watęsa może nie mówić do końcal trzeba to wszystko wyjaśnić. Ja się zwracatem na piśmie, jak mówiłem, do wszystkich instytucji i prositem: „Stuchajcie, żyją świadkowie”. Powolutku, żeby/ przewidując, że będa paranoicy robić takie rzeczy, jakie robia dzisiaj i zwracatem się wcześniej, by pewne rzeczy byty przesądzone, sprawdzone, udokumentowane. Pieczątka, świadkowie, papiery i koniec. I gdyby to wszystko zafunkcjonowato, to nie pojawiłby się żaden 
Centkiewicz i nie żaden Zygzak, bo to bytoby niemożliwe, bo wszystko udokumentowane, udowodnione/ to jest jeszcze wszystko do zrobienia. I dlatego tutaj musimy coś wymyśleć, musza wymyśleć, żeby ktoś się zająt na poważnie, przestuchat świadków, sprawdził dokumentację i powiedziat, $\dot{z}$ e skok przez płot to byt, a nie żadna motorówka. I wszystko inne, z początkiem strajku, z końcem, ze spóźnieniem/ wszystko to/ i z tym, co Zygzaki napisaty $i$ Centkiewicze - to wszystko musi być wyrok w imieniu instytucji państwa. A jak instytucje państwa awansuja, przyjmuja do pracy i jeszcze oświadczaja bzdurne kłamstwa przy wyrokach sadu, no to wszystko dlatego tak wyglada.

(„Tomasz Lis na żywo”, TVP 2, 30.03.2009; dziennikarz - TL: Tomasz Lis; gość - LW: Lech Wałęsa)

Punktem wyjścia dla dziennikarza jest pytanie o książkę, której bohaterem jest rozmówca ${ }^{2}$. Na tej podstawie przewidywanym elementem tła pozajęzykowego powinien być układ interakcyjny: jednostka - jednostka (tzn. autor książki - jej bohater). Jednak w całym wywiadzie obserwuje się wyraźną taktykę rozmówcy, zmierzającą do przedefiniowania tego układu. Otóż rozmówca niewiele uwagi poświęca autorowi książki o sobie (są to głównie dyskredytacje), właściwie można powiedzieć, że pomija go i zwraca się bezpośrednio do instytucji państwa, w tym przełożonych autora książki. Kreuje więc alternatywny układ interakcyjny: jednostka - instytucja (instytucje). Układ ten polepsza pozycję rozmówcy w bieżącej sytuacji komunikacyjnej. Pozwala wyjść z roli bohatera książki, zredukowanego do obiektu ataku, i przyjać rolę poszkodowanego obywatela, zwracającego się z żądaniem do instytucji państwowych oraz skargą z powodu braku odpowiedniego nadzoru. Cała misterna strategia obrony twarzy pozytywnej rozmówcy jest możliwa dzięki kontekstowi. W tym przypadku nie mamy bowiem do czynienia z prostym interpersonalnym porozumiewaniem się jednostek, ale z komunikowaniem w ramach systemu.

W części wypowiedzi rozmówca dostosowuje się do prowokacyjnych pytań dziennikarza i podejmuje strategię aksjologiczno-emotywną. Negatywnej ocenie aksjologicznej (niesamodzielność autora, nierzetelność) towarzyszą silne emocje, które przejawiają się w doborze słów (fantazje, obrzydliwe, świętokradztwo, paranoicy, bzdury) i chaotycznym przebiegu wypowiedzi. Dominującymi aktami mowy są akty oburzenia ${ }^{3}$. Dodatkowo rozmówca przekręca nazwiska, co może być odebrane jako dyskredytacja prześmiewcza (Centkiewicz zamiast Cenckiewicz i Zygzak zamiast Zyzak), a w dalszej rozmowie stosuje kontekstową apelatywizację nazw osobowych (Zygzaki i Centkiewicze w sensie - z pogardą: „ludzie ich pokroju”).

Równolegle do jawnych aktów oburzenia i dyskredytacji odbiorca obserwuje bardziej wyrafinowaną strategię obrony twarzy negatywnej przez zwiększanie dystansu do przeciwnika. Rozmówca zapewnia, że nie czytał książki i zna tylko komentarze (argument z niewiedzy), natomiast autora oskarża o prowokację

2 P. Zyzak, Lech Watęsa. Idea i historia, Wyd. Arcana, Kraków 2009.

3 Por. Awdiejew, Habrajska 2006: 103. 
legitymizacyjną (ja się tym człowiekiem w ogóle nie przejmuję. No, niepoważny człowiek, chciat zaistnieć). Podobną taktykę zwiększania dystansu stosuje dziennikarz (Panie prezydencie, ja w ogóle nie chcę brnać w te, jak powiedziatem pseudo/ pseudorewelacje. Pytanie dotyczy czegoś innego [...]. Czy warto się przejmować kimś, kto je/ kto pisze takie bzdety, brednie?).

Najskuteczniejsze zwiększenie dystansu i jednocześnie siły gwarantuje rozmówcy wykorzystanie wiedzy na temat systemów komunikowania. Rozmówca zakłada, że komunikacja odbywająca się w ramach systemu musi uwzględniać hierarchiczne relacje między podmiotami komunikującymi się i ich instytucjonalny charakter. Osoba działająca w ramach roli społecznej, np. student piszący pracę magisterską, pracownik IPN-u publikujący książkę, nie reprezentuje tylko siebie, ale całą instytucję. Zatem za jego działania w jakimś stopniu odpowiada również zwierzchnik. Znacznie skuteczniejsze niż polemika z autorem książki (układ: jednostka - jednostka) jest zwrócenie się do instytucji państwa z żądaniem działania i skargą na rzekome zaniedbania odpowiedzialnych urzędów (układ jednostka instytucja). Strategię realizują wypowiedzi: Stąd zwracałem się dawno temu już do ministra sprawiedliwości, Ziobro wtedy byt ministrem, i wcześniej zwracałem się do prokuratur, w tym do gdańskiej, i zwracatem się do marszatka Sejmu; I stąd/ stąd jeszcze raz apeluję do demokratycznych struktur państwa, że albo te struktury sa demokratyczne i prawo szanuja, albo musimy coś zrobić; coraz bardziej zauważam, że struktury wol/ demokratycznego państwa/ bo IPN jest struktura, więc nikt nie mówi o tych strukturach, które tak postępują.

Wejście broniącego się rozmówcy w sferę komunikacji nie tylko społecznej, publicznej, ale i instytucjonalnej zmienia rangę jego sprawy. Zamiast o jednostkowym naruszeniu dóbr osobistych, spowodowanym zagrożeniem wizerunku bohatera (siedział pan na płocie i pił piwo; jakieś nieślubne dziec$k o$ ), odbiorca medialny dowiaduje się, że nastąpiło zaniedbanie instytucji, na których ciąży odpowiedzialność za zaistniały stan rzeczy (Panowie, zróbcie coś, aby te wszystkie sprawy niejasne, watpliwe, gdzie sa dwie wersje historii, uporządkować, bo jeśli nie uporządkujecie, no to będa wtaśnie paranoicy wyżywać się, będa pisać $i$ świat będzie komentowat). Kontekst międzynarodowy sprawy również zwiększa jej rangę, gdyż pojawia się sugestia jej wpływu na opinię o Polsce.

Odwoływanie się rozmówcy do systemu komunikowania publicznego i instytucjonalnego nie tylko podnosi rangę sprawy, ale - używając metaforyki wojennej - poszerza repertuar środków rażenia przeciwnika. System komunikowania dostarcza reguł, norm i wzorców, rządzących zachowaniem jego członków. Naruszenie norm jest obwarowane sankcjami, których dotkliwość podlega stopniowaniu (od utraty twarzy do wyroku sądowego). Rozmówca wskazuje na naruszenie prawa (i można wyrok ruszyć, i można sprawę nowa założyć, ale dopóki jest wyrok, nie wolno jest inaczej postępować) oraz domaga się kontroli zawartości komunikatów przekazywanych w systemie. Strategię 
obrony realizuje przez akty mowy: żądania (No weźcie się, jeszcze świadkowie żyja, wyjaśnijcie) i skargi (Kurtyka go przyjąt do IPN-u! [...] to są rzeczy proste, sa świadkowie, ale nie robia $w$ tym kierunku [...] Ja się zwracałem na piśmie, jak mówiłem, do wszystkich instytucji i prosiłem: „Stuchajcie, żyja świadkowie". Powolutku, żeby/ przewidujacc, że będa paranoicy robić takie rzeczy, jakie robia dzisiaj $i$ zwracałem się wcześniej, by pewne rzeczy byty przesądzone, sprawdzone, udokumentowane. Pieczątka, świadkowie, papiery i koniec. I gdyby to wszystko zafunkcjonowato, to nie pojawitby się żaden Centkiewicz $i$ nie żaden Zygzak, bo to byłoby niemożliwe). Fortunność aktów mowy żądania i zasadność skarg jest gwarantowana właśnie przez normy systemu komunikowania. Poza systemem tego typu działania komunikacyjne nie byłyby wiarygodne ani racjonalne.

Przynależność do systemu komunikowania gwarantuje jego uczestnikom poczucie więzi. Jest to funkcja integracyjna systemu. Również ten element kontekstu zostaje wykorzystany strategicznie przez rozmówcę w akcie mowy działania, jakim jest groźba.

TL: [...] nagle wczoraj pojawia się pana dość dramatyczny wpis na blogu: „Oddam nagrody, nie wezmę udziatu $w$ żadnych uroczystościach rocznicowych, a jak sprawy pójdą $w$ tym kierunku, $w$ którym ida cały czas, to być może wyemigruję z Polski”. Co spowodowało, co było tym bezpośrednim impulsem, że napisat pan to, co pan napisat?

LW: Proszę pana, dlatego że coraz bardziej zauważam, że struktury wol/ demokratycznego państwa/ bo IPN jest struktura, więc nikt nie mówi o tych strukturach, które tak postępują. Mało tego, za ta książkę dostat tytut naukowy, za tą książkę zostat przyjęty do IPN-u. Ja się dopiero dowiaduję przecież z prasy. Ja nie wiedziałem o tym, nie styszatem, że ktoś tam sobie pisze, niech sobie pisze, więc to lekceważytem, ale jak się dowiedziatem, że zostat $w$ nagrodę/ dostat dyplom jakiś naukowy//

TL: Panie prezydencie, nie „jakiš”, tylko z Uniwersytetu Jagiellońskiego!

Groźba wycofania się z życia publicznego i emigracji jest częścią strategii obrony twarzy rozmówcy. Fortunność aktu mowy jest zagwarantowana przez normy systemu komunikowania. Wynika z rozłożenia odpowiedzialności za zaistniały stan rzeczy na instytucje państwa. Wymiar jednostkowy (ktoś tam sobie pisze, niech sobie pisze, więc to lekceważytem), który obciąża autora, jest pomniejszany, natomiast eksponowany jest kontekst instytucjonalny. Akty mowy oburzenia i skargi zyskują uzasadnienie dzięki implicytnej wiedzy wspólnej rozmówców. Uzyskanie tytułu naukowego jest (lub może być) bowiem społecznie odebrane jako forma uznania wartości książki, a przyjęcie do pracy w państwowej instytucji - jako akceptacja i osłona działań jej autora (za ta książkę dostat tytut naukowy, za ta ksią̇̇kę zostat przyjęty do IPN-u). Oczywiście mamy tutaj do czynienia ze strategiczną funkcjonalizacją tła pozajęzykowego przez rozmówcę, a więc specjalnym porządkowaniem elementów rzeczywistości pozajęzykowej. Nie byłoby ono jednak możliwe, gdyby nie uporządkowanie relacji między podmiotami w ramach systemu komunikowania. 


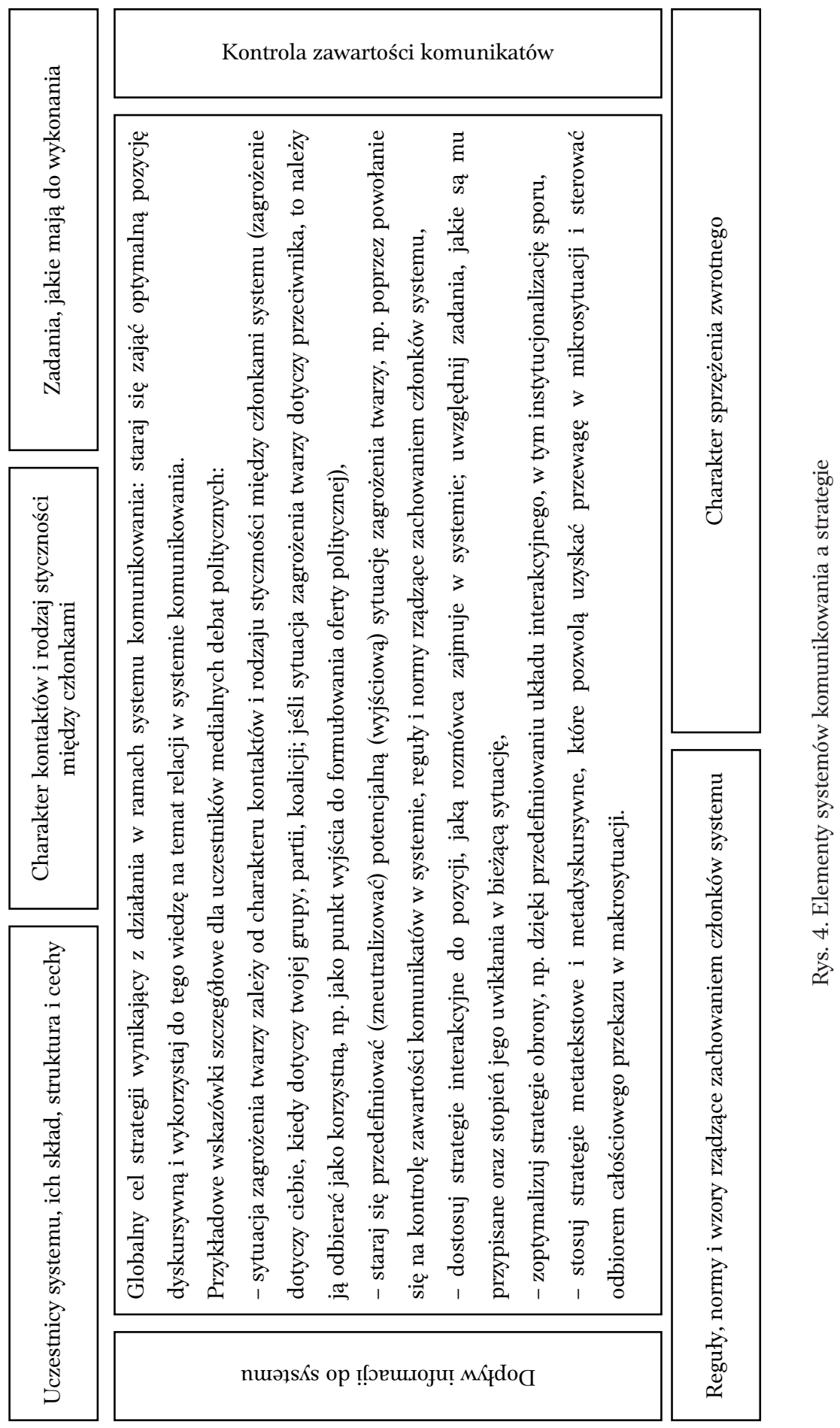


Działania rozmówcy zmierzają do ukazania jednostkowego wydarzenia (publikacja książki) w jak najszerszym kontekście instytucjonalnym, publicznym, a nawet międzynarodowym. Ze względu na funkcję można nazwać go kontekstem balansującym, gdyż został wprowadzony dla zrównoważenia krytyki pod swoim adresem. Dzięki wiedzy na temat systemów komunikowania rozmówca steruje odbiorem wydarzenia w taki sposób, aby przedstawić je jako naruszenie reguł systemu i wynik niewystarczającej kontroli przepływu komunikatów. Strategia obrony twarzy pozytywnej polega na wykorzystaniu wiedzy o normach komunikowania. Dzięki temu rozmówca uzyskuje korzystniejszą pozycję dyskursywną, stosując nie tylko powszechnie znaną taktykę dyskredytacji przeciwnika, ale bardziej wyrafinowaną taktykę zwiększania dystansu i siły w antagonistycznym układzie interakcyjnym.

Systemy komunikowania przez swoją organizację i uporządkowanie modyfikują zachowania komunikacyjne rozmówców. W sytuację komunikacyjną wpisane są specyficzne relacje nadawczo-odbiorcze, cele pragmatyczne rozmówców, normy rządzące działaniem. Typowe dla społecznych, ale nieoficjalnych sytuacji komunikacyjnych strategie kooperacyjne i rywalizacyjne ulegają skomplikowaniu, i wymagają od rozmówców wyższych kompetencji komunikacyjnych. Jak wynika z analizy, istota budowania relacji społecznych, takich jak równorzędność, podrzędność, współpraca, rywalizacja, jest być może stała w różnych układach, ale środki i narzędzia realizacji są uzależnione od kontekstu komunikacyjnego.

\subsection{Strategie i ich uwarunkowania ze względu na zasięg komunikowania}

Zasięg komunikowania, który jest rozumiany jako liczba przypadków lub skala występowania danego sposobu komunikowania, jest podstawą wyodrębnienia jego poziomów, m.in. poziomu interpersonalnego, wewnątrzgrupowego, międzygrupowego, instytucjonalnego, masowego (por. s. 53). Okazuje się, że parametr ilościowy (liczebność, częstotliwość) ma decydujący wpływ również na cechy jakościowe procesu, tzn. decyduje o jego formach, wzorach, normach. Różnice związane z zasięgiem komunikowania nie oznaczają całkowitego oddzielenia poziomów (co mógłby sugerować schemat w postaci piramidy), ale raczej wzajemne nakładanie się i modyfikację prostszych form w ramach form coraz bardziej skomplikowanych. Stąd analiza komunikatów masowych powinna uwzględniać również pozostałe poziomy komunikowania.

Efekt nałożenia i modyfikacji poziomów został uwzględniony w koncepcji systemów komunikowania, które odpowiadają konkretnym jego obszarom. 


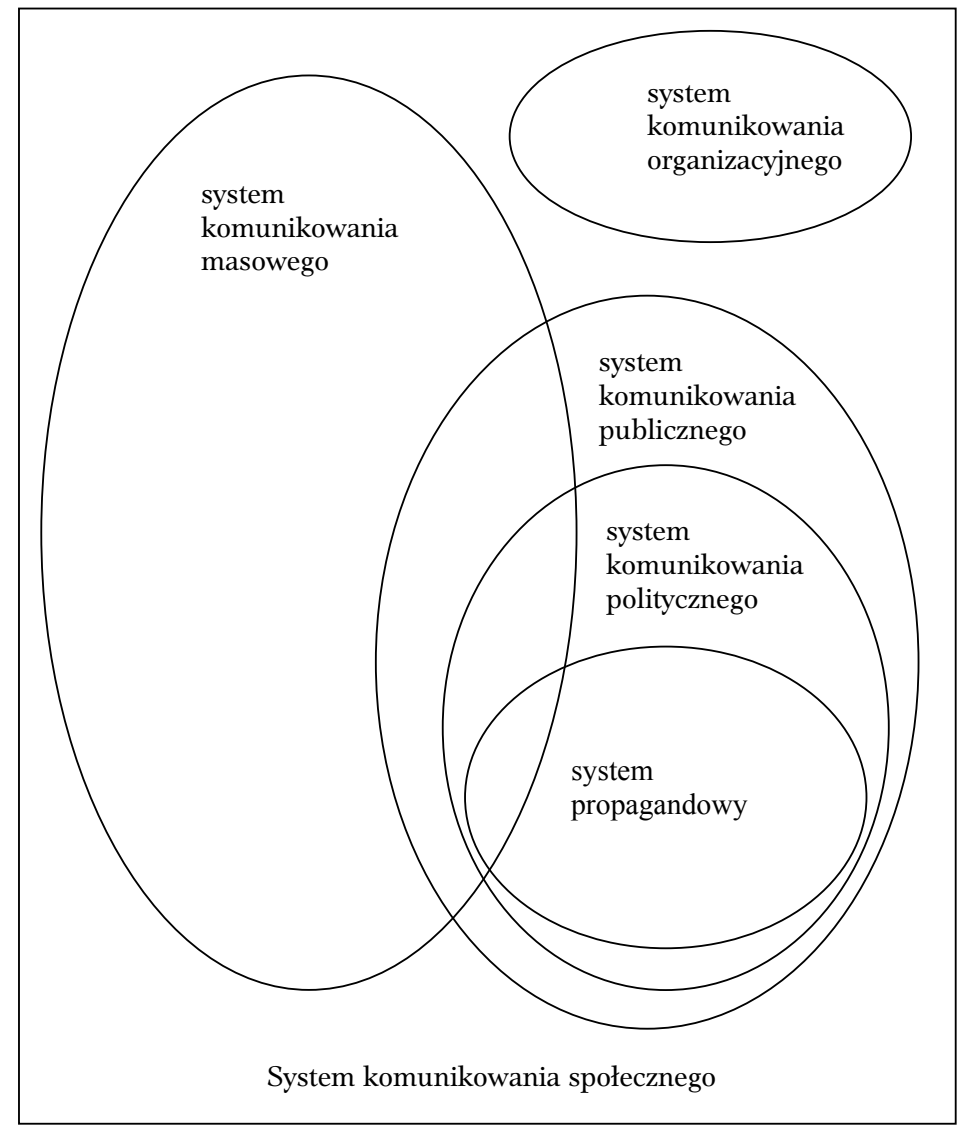

Rys. 5. Relacje systemów komunikowania w systemie społecznym (za: Dobek-Ostrowska 2006: 104)

Najszerszy jest system komunikowania społecznego, który określa się jako ogół relacji komunikacyjnych, polegających na tworzeniu, gromadzeniu i odbieraniu informacji między uczestnikami systemu, którymi jest ogół społeczeństwa. Jednostka, będąc członkiem społeczeństwa, należy do wielu grup formalnych i nieformalnych, które się wzajemnie zazębiają, kontaktują, wymieniają opinie, przesyłają informacje (Dobek-Ostrowska 2006: 107). Jürgen Habermas przestrzeń, w której działają jednostki ludzkie, nazywa „społecznym światem życia” w odróżnieniu od obszaru działania instytucji (Habermas 2001: 685-690). Najbardziej nieformalną część tej przestrzeni zajmuje sfera prywatna. Pomiędzy sferą prywatną a sferą instytucji (i systemem komunikowania instytucjonalnego, które ma najwęższy zasięg, ponieważ obejmuje procesy komunikowania wewnątrz zamkniętej struktury organizacyjnej) znajduje się sfera publiczna oraz system komunikowania publicznego. 
Fundamentem tego systemu są instytucje o charakterze publicznym, w tym organy władzy wybierane w wyniku rywalizacji politycznej (Dobek-Ostrowska 2006: 122). Z powodu podwójnej natury (publicznej i politycznej) instytucji władzy często dochodzi do interferencji systemów komunikowania publicznego i politycznego. Niezależnie od tego nie utożsamiamy tych pojęć, choć przyjmujemy założenie, że komunikowanie polityczne jest częścią komunikowania publicznego.

Komunikowanie publiczne to komunikowanie formalne, zachodzące w określonej przestrzeni komunikacyjnej (informacyjnej), mające na celu przekazywanie i wymianę informacji o publicznym zastosowaniu oraz podtrzymywanie więzi społecznych przez odpowiedzialne za ten proces instytucje publiczne (tamże: 122). Komunikowanie publiczne zajmuje pozycję uprzywilejowaną i nie powinno być wciągane w obszar polityki.

Komunikowanie polityczne zachodzi w określonej przestrzeni komunikacyjnej i jest komunikowaniem formalnym. Wykorzystuje wszelkie dostępne kanały komunikacyjne, może być zapośredniczone przez media. Ma na celu przekazywanie i wymianę komunikatów o polityce między aktorami politycznymi, tworzącymi politykę oraz obywatelami, których dotyczy tworzenie polityki, przy włączeniu na szeroką skalę mediów masowych, odpowiedzialnych za przedstawienie tej polityki (tamże: 155). Komunikowanie polityczne zajmuje się formułowaniem oferty politycznej i przekonywaniem do jej słuszności za pomocą technik marketingowych. $\mathrm{Z}$ tego względu dominującą cechą jest tu perswazyjność, rozumiana jako dążenie do zmiany opinii, wywieranie wpływu na innych poprzez modyfikowanie ich postaw, przekonań i systemu wartości (Tokarz 2006: 194-200), zdobycie czyjejś akceptacji dla proponowanych poglądów, sposobu zachowania, decyzji (Szymanek 2004: 228). Specyficzną techniką perswazyjną jest manipulacja, którą określa się jako ukryty, zakamuflowany sposób narzucania jednostce poglądów, postaw, wartości i decyzji. Obiekt zostaje poddany presji psychicznej i społecznej, nie ma świadomości manipulacji, a więc pozbawia się go wolnego wyboru (Kudra, Kudra 2004: 93-94). Różnica między perswazją a manipulacją znajduje odzwierciedlenie w strategiach dyskursu politycznego, a mianowicie w różnicy między merytoryczną argumentacją a nieetycznymi, nieuczciwymi chwytami erystycznymi. Należy przy tym zaznaczyć, że standardy merytorycznej dyskusji ${ }^{4}$ tworzą raczej idealny punkt odniesienia dla częstszych (bo bardziej spektakularnych) potyczek słownych na dyskredytacje i prowokacje.

${ }^{4}$ Marek Tokarz, powołując się na twórców pragmadialektyki (van Eemerena i Grootendorsta), przedstawił 10 reguł racjonalnej dyskusji (Tokarz 2006: 164). Są one jednak notorycznie łamane w medialnych potyczkach między politykami (np. reguła mówiąca o tym, że atak na tezę drugiej strony musi rzeczywiście dotyczyć tej tezy, którą druga strona sformułowała - tymczasem obserwuje się, że polityk często polemizuje nie z tezą rozmówcy, ale z jej manipulacyjnym przetworzeniem). 
System komunikowania masowego jest częścią systemu komunikowania społecznego, a zazębia się z systemami komunikowania publicznego i politycznego. Rola komunikowania masowego w całym systemie społecznym polega na zapewnieniu efektywnego przepływu informacji między sferami prywatną, publiczną oraz sferą instytucji. Sfera publiczna jest usytuowana pomiędzy sferą prywatną i sferą instytucji. Do najważniejszych problemów i zadań (również mediów) w związku z jej funkcjonowaniem należą: regulowanie ram prawnych życia społecznego, dostarczanie informacji pomocnych w podejmowaniu przez obywateli racjonalnych decyzji, kontrola struktur instytucjonalnych państwa, kontrola zakresu ingerencji państwa w życie społeczne, realizowanie interesów grup społecznych i dbanie o to, by swoboda jednych nie naruszała praw innych (Giddens 1998).

Przekazy masowe wprowadzane są do obiegu w sferze publicznej, jednak graniczne sfery - prywatna i instytucji - również wpływają na ich ukształtowanie. Na globalne uwarunkowania komunikacji nakłada się dodatkowo czynnik indywidualny. Stopień dopasowania zachowań rozmówców do wymogów komunikacji publicznej zależy bowiem od poziomu ich kompetencji komunikacyjnej.

Dzięki szerokiemu rozpatrywaniu zachowań komunikacyjnych uczestników medialnych programów publicystycznych ujmujemy je jako rodzaj działania w sferze publicznej. Nie można jednak tracić z pola widzenia perspektywy tekstologicznej. Działanie to jest bowiem realizowane przez konkretne wypowiedzi. Ich zapis stanowi rodzaj tekstu, określanego jako tekst wtórnie zapisany (Labocha 2008: 167). Tekst dialogowy jest tworem dwu lub większej liczby rozmówców, z których każdy realizuje własne cele (tamże: 169). Podejmuje strategie kooperacyjne lub rywalizacyjne. Zrozumienie takiego przekazu medialnego jako całościowego tekstu polega na odtworzeniu jego globalnej struktury semantycznej.

Stworzenie reprezentacji makrostrukturalnej tekstu wymaga działań redukcyjnych, przekształcania i uogólniania znaczeń. Ogólnych kategorii pojęciowych pomocnych w uporządkowaniu aktywności mownej nadawców należy szukać w opisie norm funkcjonowania sfery publicznej. Charakteryzuje ją powszechna dostępność, otwartość oraz regulacja przez prawo. Ważność jej instytucji wynika z funkcji zabezpieczenia interesu publicznego.

W punkcie 1.2 zostaną omówione determinanty zachowań komunikacyjnych związane z zasięgiem procesu komunikowania, a zwłaszcza zbadany zostanie wpływ reguł funkcjonowania sfery publicznej na zachowania komunikacyjne rozmówców (przede wszystkim gości, natomiast zachowania dziennikarzy zostaną zanalizowane w punkcie 1.3). Szczególnie będą nas interesować normy regulujące dostęp podmiotów do komunikowania publicznego (punkt 1.2.1) oraz normy decydujące o skuteczności zachowań komunikacyjnych podejmowanych w jego ramach (punkt 1.2.2). 


\subsubsection{Wpływ norm sfery publicznej na zachowania komunikacyjne regulujące dostęp podmiotów}

Jak wynika z analizy materiału, szczególnie ważna dla uczestników życia publicznego jest norma mówiąca o otwartości i dostępności sfery publicznej oraz jej regulacji przez normy prawne i/lub etyczne. Sfera publiczna jest definiowana jako przestrzeń otwarta i dostępna dla wszystkich podmiotów, które nie naruszają prawa. Grupy, których celem jest zaznaczenie swojego stanowiska w debacie publicznej, chętnie powołują się na otwartość sfery publicznej, co przyczynia się do uprawomocnienia ich głosu.

\subsubsection{Strategie legitymizacji podmiotów sfery publicznej}

W sferze publicznej istnieje przemożna potrzeba uprawomocnienia podmiotów działających i komunikujących się. Niektóre dyskursy, np. dydaktyczny, zapewniają autorytet pozycji nadawcy na mocy kontraktu, rozumianego jako instytucjonalizacja relacji interpersonalnych (Grzmil-Tylutki 2007: 33). Wówczas taki autorytet jest wpisany w miejsce, bez względu na wizerunek kształtowany przez nadawcę, natomiast od odbiorcy wymaga on zaufania (jest to legitymizacja miejsc). Dyskurs publiczny, a zwłaszcza polityczny, nie odznacza się podobnymi właściwościami, ponieważ kredyt zaufania nie jest wpisany w pozycję nadawcy. Stąd podmioty dyskursu odczuwają silną potrzebę legitymizacji swojej wypowiedzi. Budują więc obraz nadawcy wypowiadającego się w imieniu obdarzonej zaufaniem grupy, powołują się na normy społeczne, w tym normy etyczne, prawne.

Uprawomocnienie, zwane także legitymizacją, polega na stworzeniu wrażenia reprezentatywności, prawowitości, posiadania mandatu społecznego. Swoistą legitymizacją działań polityków są demokratyczne wybory oraz sondaże opinii publicznej. W działaniu komunikacyjnym stosuje się kategorię legitymizacji wszędzie tam, gdzie rozmówca dąży do uzyskania wiarygodności, występuje w imieniu grup, w obronie norm i wartości. Swoistą legitymizacją, a więc uzyskaniem akceptacji, pozwolenia na dany rodzaj działania komunikacyjnego jest wystąpienie w ramach roli dyskursywnej lub społecznej.

Najbardziej ogólną i powszechną strategią legitymizacji jest domaganie się prawa głosu ze względu na otwartość sfery publicznej. Strategia staje się jawna, kiedy rozmówcy czynią tematem rozmowy ogólne zasady komunikacji publicznej. Dopóki uczestnicy życia publicznego przestrzegają tych zasad, dopóty pozostają one implicytną wiedzą wspólną - wiedzą, której się nie werbalizuje, ale według której się postępuje. Przejście rozmówców na poziom metadyskursywny - czyli rozmowy nie na temat rzeczywistości pozajęzykowej, ale na temat rzeczywistości dyskursywnej - jest zawsze istotnym sygnałem skomplikowania sytuacji komunikacyjnej, ale przede wszystkim jej uwyraźnienia. Sygnał może wskazywać na niejawne cele pragmatyczne, ukryte intencje. Należy je brać pod 
uwagę zwłaszcza w sytuacji rywalizacji politycznej i sytuacji przekazu medialnego. Rozpatrzmy przykład, w którym norma jest wykorzystana w interakcyjnej strategii obrony.

MS: Przepraszam, ale ja zostałam obrażona. Najpierw przez pania jako pseudohumanista, teraz przez pana, jako osobę sfiksowana [sic!]. Ja stanowczo protestuję [...].

AF: Proszę państwa, ja też chciatbym stanać tutaj niejako wobronie pani profesor i przy catej też swojej sympatii, chociażby nawet $z$ tego względu, że ja znam, powiedzmy sobie, dorobek pani profesor. Razem tė̇ mieliśmy chyba wspólnych profesorów. Natomiast chciałbym powiedzieć tak, $\dot{z} e \underline{w}$ społeczeństwie żyjemy pluralistycznym, $w$ społeczeństwie, gdzie panuje trochę inna zasada niż panowała kiedyś: „quius reggio eius religio”. I wydaje mi się, że zdrowe reguty demokracji wymagaja też od nas pewnej uczciwości, żeby pozwolić wszelkim głosom, mojemu głosowi, pani profesor, panu te $\dot{z}$ docentowi i panom, na wypowiadanie jasnych, rzeczowych, konkretnych racji. No, temu celowi stuży debata racjonalna.

(„Debata”, TVP 1, 24.02.2005; goście - AF: Artur Filipowicz, MS: Maria Szyszkowska)

Rozmówca wyraża wprost intencję obrony osoby atakowanej, powołując się na normę otwartości debaty. Trafnie odczytuje obrazę jako dyskredytację, mającą na celu usunięcie głosu polemicznego. Sformułowanie żeby pozwolić wszelkim głosom na wypowiadanie racji zawiera bowiem presupozycję, że ktoś nie chce pozwolić. Tak więc na poziomie interakcyjnym celem nadawcy jest obrona rozmówczyni i upomnienie rozmówcy naruszającego standardy. Jednocześnie w relacji do widzów (podwójna sytuacyjność przekazu medialnego) jest to komunikat o funkcji edukacyjnej (przypomnijmy, na czym polega debata). Propagowanie dobrych wzorów debaty przyczynia się również do wykreowania pozytywnego wizerunku samego nadawcy.

Jak widać, uwagi dotyczące zasad funkcjonowania podmiotów w sferze publicznej mogą mieć intencję upomnienia i być reakcją na zachowania odbiegające od normy. Niezależnie od doraźnej funkcji interakcyjnej, wypowiedzi są przekazem na poziomie ogólnym, świadectwem pojmowania sfery publicznej przez rozmówców. Na tym poziomie są przejawem dbałości o jakość debaty publicznej i pełnią funkcję edukacyjną względem widzów.

Norma mająca zagwarantować otwartość sfery publicznej nie implikuje jej homogeniczności. Każda społeczność wyróżnia bowiem wartości, ideologie uznane za normalne i takie, które nie znajdują akceptacji większości. Ważną rolę w kategoryzacji poglądów w tej sferze odgrywa zatem opozycja: typowy (normalny, tradycyjny)/nietypowy (kontrowersyjny, dziwaczny). Pogląd zaliczony do kategorii dziwacznych, kontrowersyjnych może mieć mniejszą siłę oddziaływania. Wówczas stosuje się strategie legitymizacji przez powołanie się na normę dostępności.

JK: [...] tolerancja to jest cierpliwe znoszenie odrębności czy inności, ale wcale to nie wymaga akceptacji tej odrębności. Tyle, że to dokładnie oznacza tolerancję wobec tego, do czego ma się 
prawo: prawo do przemarszu, prawo do wyrażenia swoich poglądów, nawet jeżeli są inne, $i$ bardzo często/ bo inaczej po cóż by byto wtaściwie chodzić!

KD: Inaczej, jak byśmy akceptowali, nie byłoby problemu.

JK: [...] Zgadzamy się, że nie należy rzucać kamieniem, ale czy to znaczy, że pan profesor uważa, oni, omijam stowo tolerancja, $\dot{z}$ e oni nie maja prawa przejść i wypowiedzieć publicznie na wolnej przestrzeni publicznej tego, co uważaja? Ja uważam, że tak. Dla mnie granica, o jaka pan pytat, jest kodeks karny. Jak ktoś chce coś, co jest sprzeczne z kodeksem karnym: propagować komunizm czy faszyzm - to już jest zakazane, natomiast wszystko inne jest dozwolone do wypowiedzenia, nawet jeżeli ja się z tym nie zgadzam. To jest pewna podstawa, która wedtug mnie jest jedna z podstawowych elementów tego tadu.

(„Debata”, TVP 1, 9.12.2004; dziennikarz - KD: Kamil Durczok; gość - JK: Jacek Kurczewski)

Fragment odnosi się wprost do norm sfery publicznej. Jej otwartość jest wyrażana językowo jako prawo do wypowiedzenia na wolnej przestrzeni publicznej tego, co się uważa i prawo do wyrażenia swoich poglądów. Rozmówca określa również parametry sytuacji komunikacyjnej, w której dochodzi częściej do tego typu aktów. Jest ona mianowicie związana z marginalizowaniem grup społecznych. Właśnie brak akceptacji, a często nawet dyskryminacja, jest racjonalnym uzasadnieniem domagania się głosu. Werbalizowanie normy natomiast jest odpowiedzią na zachowania $\mathrm{z}$ nią niezgodne, na odmawianie prawa głosu grupom uznanym za inne, odrębne. Jeśli chodzi o podanie regulatorów aktywności komunikacyjnej podmiotów, to można zauważyć, że rozmówca posługuje się argumentem z przeciwieństwa (argumentum a contrario) (Szymanek 2004: 47). Jako dyrektywa interpretacji przepisów prawnych argument wskazuje, że jeśli przepis orzeka np. zakaz propagowania określonych treści, to zakaz ten odnosi się tylko i wyłącznie do treści wskazanych, i nie dotyczy zakazu propagowania innych treści. Powoduje to, że zasada otwartości i dostępności sfery publicznej ma charakter prymarny, a dopiero jej ograniczenie musi być przeprowadzone prawnie.

Oprócz powołania się wprost na prawo do zaistnienia w przestrzeni publicznej, podmioty stosują liczne strategie legitymizacji, w których mniej jawnie wykorzystują tzw. kody komunikacji, np. stereotypy.

Przyjrzyjmy się, w jaki sposób uzasadnia swoje zaistnienie na scenie politycznej rozmówczyni, która występuje w roli liderki nowej partii ${ }^{5}$. Stosowane przez nią strategie są podporządkowane legitymizacji nadawcy.

CSz: „Kwadrans po ósmej”. Witam państwa. Dziś moimi gośćmi sa Manuela Gretkowska, liderka Partii Kobiet i poset Tadeusz Cymański z Prawa i Sprawiedliwości. Dzień dobry. Pani Manuelo, ma pani żadzę wtadzy w sobie?

MG: Mam żądzę udziału we władzy, tak jak wszyscy, którzy żyjemy w demokracji. Chcemy decydować o sobie. Po to jest ten ustrój. Nareszcie.

CSz: Panie pośle, a pan? Pan ma coś takiego, jak żądza wtadzy? Potrzebne jest takie coś?

${ }^{5}$ Partia Kobiet jest partią polityczną, która została zarejestrowana 11 stycznia 2007 r. 
TC: Też tak badawczo śledzę wzrokiem, czy ma pani tę żądzę, czy nie [śmiech]. To jest stereotyp, ale to jest bardzo ważne, to, co pani powiedziała. Jest demokracja. Kiedyś u nas się tak mówito: „Musi to na Rusi”, „Wolność Tomku w swoim domku”. Jest wolny rynek w handlu, gospodarce

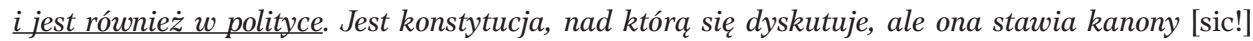
$i$ jest możliwość korzystania $z$ demokracji $w$ różny sposób. Nawet $w$ oryginalny, bo tak uważam ta inicjatywę [sic!], że jest spektakularna, kontrowersyjna z uwagi na ten ryt ptci. No ale to jest cata/ może cały wabik tego//

CSz: Ale to jest jedyny zarzut, panie pośle, jeśli chodzi o płeć?

TC: To nie jest zarzut.

CSz: Powiedziat pan: „kontrowersyjny”.

TC: Czy kontrowersyjny? Ciekawy, spektakularny. Jakie tu stowo użyć? Ale na pewno nie jest typowe, kiedy partia/ byta kiedyś Partia Piwa, piwo, piwosze/ ja nie chciałbym tutaj porównywać, bo to może dotknać kogoś. Jest program, jest statut, ale jeżeli tym wyznacznikiem $i$, jak rozumiem, sita napędowa ma być pteć i ponoć limity, nawet nie wiem, czy to jest prawda [w obecności mężczyzn//

(„Kwadrans po ósmej”, TVP 1, 13.02.2007; dziennikarz - CSz: Cezary Szymanek; goście - MG: Manuela Gretkowska, TC: Tadeusz Cymański)

Dziennikarz rozpoczyna dyskusję od pytania pozornie żartobliwego, ale $\mathrm{w}$ istocie dotyczącego ważnego zagadnienia $\mathrm{z}$ zakresu komunikowania politycznego. Chodzi o motywacje przywódców politycznych, którzy mogą dwojako pojmować swoją rolę: dla jednych jest to służba publiczna, której celem jest realizowanie określonych zadań, a dla innych najważniejszym motywem jest dążenie do prestiżu, władzy i związanych z nią profitów (Jakubowska 2002: 83). Tak więc dziennikarz nawiązuje w pytaniu do motywacji ukrytej, zgodnej z potocznymi spostrzeżeniami ludzi (żartobliwie określonej jako „żądza władzy”). Zarówno rozmówczyni, jak i jej dyskutant z partii konkurencyjnej powołują się początkowo zgodnie na dostępność sfery publicznej i równość jej podmiotów (to jest bardzo ważne, co pani powiedziała; jest możliwość korzystania z demokracji $w$ różny sposób). W dalszej interakcji strategia kooperacyjna przeradza się w strategię rywalizacyjną. Konkurent, nie mogąc odmówić prawa głosu nowej partii, stara się ją zmarginalizować, używając określeń „kontrowersyjny, nietypowy, oryginalny", sugerując, że wyborcy mają do czynienia z czymś w rodzaju folkloru politycznego. Wywołaniu takiego wrażenia służy porównanie do ruchu quasi-politycznego, Polskiej Partii Przyjaciół Piwa. Ważnym sygnałem kreowania sytuacji na wyższym poziomie jest użycie asekurantu grzecznościowego (ja nie chciałbym tutaj porównywać, bo to może dotknać kogoś). Posunięcie to bynajmniej nie neutralizuje obraźliwego porównania, ale pozwala nadawcy zachować twarz. Stanowi coś w rodzaju komunikatu: „znam zasady funkcjonowania w sferze publicznej, ale skojarzenie jest nieodparte”.

MG: Ja myślę, że rzeczywiście to jest na pewno oryginalna inicjatywa, ma pan poset rację, skoro $w$ państwie 40-milionowym kobiety od wielu lat, od kilkunastu, sa ograniczane w swoich prawach zarówno przez lewicę, SLD, jak i przez prawice, jej pomysty, do tego stopnia, że musi powstać partia kobiet. Ale jest naprawdę partia ludzi, partia potrzeb, nie partia ideologiczną. Jeśli to jest oryginalne, to tak. Bo w naszym kraju, tak się złożyto przez te kilkanaście lat, że kobiety 
nie znajduja $w$ prawie, $w$ opiece swojego miejsca, mimo że ptacimy podatki. Jest do tego stopnia oryginalne, że tyle kobiet i mężczyzn zebrato się, żeby coś z tym zrobić. Mieć udziat we władzy, $w$ decydowaniu o sobie [...]. Od 2005 roku, co ONZ, komisja do spraw dyskryminacji kobiet wtaśnie do rzadu polskiego wniosła zalecenia, żeby to zmienić, $w 2005$ roku o 9 procent spadta ilość kobiet $w$ życiu politycznym, parlamentarnym, a już jesteśmy na 108. miejscu $w$ świecie: „udziat Polek w życiu politycznym". Daleko, daleko za Afryka. Więc dzieje się coraz gorzej. Nic dziwnego, że kobiety postanowity pójść do przodu, tak jak w całej Europie, gdzie są parytety [...]. Ileś tysięcy lat panów przewagi w życiu aktywnym, społecznym/ [...].

CSz: Panie pośle, czy pan nie czutby się dyskryminowany, 10 procent na listach wyborczych?

TC: Ja się tego obawiam, bo ja rozumiem, że pani jednak broni tej tezy o dyskryminacji, że $\underline{w}$ dzisiejszym systemie politycznym, prawnym jest dyskryminacja i kobieta nie ma szansy awansu. rozwoju?

MG: Nie mówię, że dyskryminacja. Równość nie daje równości szans. My rodzimy dzieci, prowadzimy dom, wychowujemy i mamy przerwę. Mamy równość, ale nie mamy szans. [...] $\underline{\text { Ale }}$ my nie jesteśmy partia ideologiczna i nie mówimy tego, co partie przy wyborach, że będziecie mieli 3 miliony mieszkań, że będziecie mieli to i to. Nie, my mówimy kobietom jak w Irlandii, jeżeli zgodzicie się na nasze reformy, będzie ciężko przez pierwsze parę lat, ale potem gospodarka ruszy. My nie jesteśmy na kadencję, bo my rodzimy dzieci na 18 lat. [...] Mamy te przewage, że nie będziemy obiecywać nic na wybory. Mówimy prawde, tak jak matka mówi prawdé w domu.

Rozmówczyni, liderka nowej partii, stosuje różne chwyty, mające uzasadnić pojawienie się nowej oferty politycznej. Należą do niej: wskazanie grupy społecznej, której interesy nie są zadowalająco reprezentowane, określenie jej sytuacji społeczno-prawnej jako niezadowalającej, przedstawienie oferty politycznej zmian jako przejawu postępowych tendencji w świecie. Ważnym elementem legitymizacji jest wskazanie istotnej różnicy z innymi partiami (nie jesteśmy partia ideologiczną; nie mówimy tego, co partie przy wyborach). Oryginalna strategia uwiarygodnienia polega na wykorzystaniu pozytywnego stereotypu matki, dzięki któremu relacja: matka - dziecko jest projektowana na relację: nowa partia wyborcy (My nie jesteśmy na kadencję, bo my rodzimy dzieci na 18 lat; Mówimy prawdę, tak jak matka mówi prawdę w domu). To wykorzystanie tzw. kodu ról społecznych oraz kodu kulturowego w strategii legitymizacji podmiotów życia publicznego i politycznego.

\subsubsection{Strategie delegitymizacji}

Istniejące normy nie znoszą w sposób automatyczny wszelkich niezgodności i konfliktu interesów, które są nieuniknione w zróżnicowanych wspólnotach. Stąd sytuacje publiczne stanowią częściej pole rywalizacji niż kooperacji. Wpływ normy mówiącej o otwartości debaty publicznej dla różnych podmiotów polega m.in. na modyfikacji strategii rywalizacyjnych. Fakt, że przeciwnika nie można wyeliminować fizycznie, pozbawić go głosu, skłania do wysubtelnienia taktyki ataku i wpływa na stosowane dyskredytacje.

Zjawiska te są szczególnie widoczne w programach, których tematem są normy publicznego zabierania głosu. Nie tylko bowiem działania pozajęzykowe 
są poddawane kategoryzacji w ramach funkcjonowania w sferze publicznej, lecz także działania językowe. Tu oprócz wiedzy prawnej wykorzystywana jest wiedza na temat gatunków wypowiedzi, dlatego takie przykłady są dla niniejszych rozważań szczególnie ciekawe. Rozpatrzmy próbkę dyskusji na temat wyroku sądowego dotyczącego opublikowanej wypowiedzi. Wyrok stał się punktem wyjścia do rozważań na temat wolności słowa, reguł zabierania głosu w debacie publicznej, instrumentalizacji tych reguł, a więc uczynienia z nich narzędzia rywalizacji i wykluczenia.

MZ: [...] Profesor Andrzej Zybertowicz, socjolog, zostat skazany prawomocnym wyrokiem $\underline{z a}$ zdanie $z$ publicystycznego tekstu z „Rzeczpospolitej”. Andrzej Zybertowicz napisat: „Adam Michnik wielokrotnie powtarzat: ja tyle lat siedziatem w więzieniu - to teraz mam rację". $\underline{\text { Co }}$ oznacza taki wyrok sadu?

BW: Oznacza to, że sad będzie decydowat, jakie zdania publicysty sa trafne. W tym wypadku ja zawieszam, na ile to zdanie jest trafne, bo w liście, który podpisałem $w$ „Rzeczpospolitej” byto napisane, że niektórzy podpisujący moga uważać je za przesadne, niektórzy za adekwatne. Natomiast to oznacza, że trafność publicystyki bedzie oceniana przez sad.

(„Kwadrans po ósmej”, TVP 1, 1.12.2008; dziennikarz - MZ: Maciej Zdziarski; goście - AZ: Andrzej Zybertowicz, BW: Bronisław Wildstein, MŚ: Magdalena Środa)

Dziennikarz wprowadza temat rozmowy, jakim jest jednostkowe wydarzenie z życia publicznego (skazanie przez sąd autora publikacji). Zarówno publikacja w „Rzeczpospolitej”, jak i zaangażowanie sądu w jego ocenę są elementami walki politycznej (stronnictwo „Gazety Wyborczej”, Adam Michnik kontra stronnictwo PiS, Andrzej Zybertowicz, Bronisław Wildstein). Podmioty debaty ukrywają jednak rzeczywisty motyw rywalizacji (co najwyżej przypisując go drugiej stronie, nigdy sobie). Kontekst polityczny wydarzenia, który jest tu decydujący, zostaje zastępczo przeniesiony na płaszczyznę publicznej dyskusji o normach debaty, co odczytujemy jako zwiększanie siły i polepszanie pozycji dyskursywnej. Niezależnie od celów doraźnych, właśnie politycznych, rozmówcy uszlachetniają swoje motywacje, sugerując, że kierują się dbałością o standardy debaty publicznej.

Pytanie dziennikarza zmierza do osadzenia wydarzenia jednostkowego w kontekście reguł funkcjonowania sfery publicznej (Co oznacza taki wyrok sądu?). Widać, że sens wydarzenia może być trafnie wyeksplikowany jedynie przez odniesienie do standardów tej sfery. Perspektywa oglądu (interes polityczny) decyduje o tym, czy działanie sądu zostanie ocenione jako sprawiedliwy wyrok, czy nadużycie. $Z$ perspektywy jednostki zaangażowanie sądu może zostać ocenione jako realizacja jej praw do obrony wizerunku (perspektywa oskarżyciela) lub represjonowanie przeciwników (perspektywa pokrzywdzonego).

Rozmówca polemizujący z wyrokiem sądu dystansuje się od prawdziwości zdania stanowiącego przyczynę procesu ( $w$ tym wypadku ja zawieszam, na ile to zdanie jest trafne), lecz podważa w ogóle prawomocność ingerencji sądu 
(to oznacza, że trafność publicystyki będzie oceniana przez sąd). Tym samym polepsza swoją pozycję dyskursywną, gdyż nie występuje w obronie jednostkowej sprawy (winny/niewinny), lecz w obronie wolności wypowiedzi i standardów debaty publicznej. Jest to strategia rywalizacyjna, która ma na celu zdominowanie przeciwnika. Jej mechanizm polega na odwołaniu się do coraz ogólniejszych i ważniejszych zasad. Pozostając w metaforyce gry, która jest punktem odniesienia dla strategii, można stwierdzić, że przeciwnik nie ocenia wartości samego posunięcia w grze, ale zasadę, która reguluje całość rywalizacji: „nie chodzi o to, że zagrałeś dobrze/źle, ale o to, że nie wolno ci wykonać tego ruchu”. Ze względu na większą wagę przywoływanych norm nazywamy tę strategię zwiększaniem siły.

\footnotetext{
MZ: No tak, ale Adam Michnik i jego petnomocnik prawny mówia, że nigdy to zdanie nie padto.

BW: To byta interpretacja. Tam nie byto przytoczone $w$ cudzystowie stwierdzenie, że tymi słowy się wypowiadat. To jest zabawa, ale mająca daleko idace konsekwencje. Mówię o zabawie ze strony Adama Michnika i jego rzecznika, bo on doskonale wie, że interpretacja to jest parafraza. nie polega na przytoczeniu, na cytowaniu, tylko na próbie oddania argumentacji.
}

Dziennikarz, chcąc skłonić rozmówcę do dalszego uzasadnienia stanowiska, zadaje pytanie polemiczne, w którym przypomina argument przeciwników. Argument ten odwołuje się do norm kulturowych (nie można publicznie wygłaszać kłamstw). Rozmówca stosuje dość wyrafinowaną strategię obrony twarzy, w której wykorzystuje (instrumentalnie) konwencje gatunkowe tekstu publicystycznego. Posługując się strategią metadyskursywną, wyjaśnia, jakie są reguły odbioru, rozumienia wypowiedzi w ramach tekstu publicystycznego. Otóż prymarnie należy rozumieć taką wypowiedź jako parafrazę, interpretację, argumentację. Dosłowne rozumienie wypowiedzi w ramach wskazanego typu tekstu jest wtórne i wobec tego musi być specjalnie zaznaczone znakiem cytatu (Tam nie byto przytoczone w cudzystowie stwierdzenie, że tymi słowy się wypowiadat). Co więcej, rozmówca sugeruje, że antagonista zdaje sobie sprawę z konwencji gatunkowych tekstu publicystycznego, które muszą być brane pod uwagę przy jego odbiorze, ale manipulacyjnie je ignoruje. $\mathrm{W}$ ten sposób następuje dostosowanie strategii komunikacyjnych obu rywalizujących stron. Pierwsza strona oskarża drugą o kłamstwo, a druga oskarża pierwszą o manipulację, o rozmyślne ignorowanie gatunkowych konwencji odbioru. Tak więc oba ataki polegają na zarzucie naruszenia norm etycznych (dyskredytacja moralna).

MZ: Być może jest to dyskusja o stowach, ale być może jest to dyskusja o tym, co wolno pisać, o czym nie wolno pisać. Czy pani profesor czuje się zaniepokojona tym wyrokiem sądu?

Dziennikarz przechodzi od jednostkowego wydarzenia o charakterze językowym (dyskusja o [czyichś] słowach) do normy rządzącej komunikowaniem w sferze publicznej (strategia uogólnienia). Sformułowanie „co wolno pisać” 
należy bowiem rozumieć: „co wolno pisać i podawać do ogólnej wiadomości”. Jest to jednocześnie przejście z poziomu języka, konwencji gatunkowych, na poziom reguł funkcjonowania sfery publicznej, a więc norm prawnych rządzących aktywnością komunikacyjną obywateli. Dziennikarz realizuje niniejszym funkcję perswazyjną ${ }^{6}$. Kategoryzuje wydarzenie (wyrok sądu) jako przypadek kontroli zawartości komunikatów przekazywanych w sferze publicznej (o czym wolno pisać). Użycie sformułowania zaniepokojona jest przejawem sterowania odbiorem wydarzenia. Narzuca widzom jego negatywną ocenę.

MŚ: Jeśli się mówi, że ktoś coś stwierdzit, a ten ktoś tego nie twierdzit i można to udowodnić, no to ktoś powiedziat nieprawdę. I to jest rzeczywiście granica wolności stowa. Nie można mówić nieprawdy. To wszystko. Jeśli nie lubi się Michnika, bądź też zasadnie sie go krytykuje, do

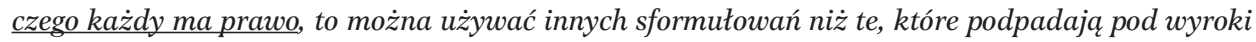
sądowe. Można powiedzieć na różne sposoby, że „Michnik swoim etosem”, albo „Michnik swoja udawana martyrologia"/ nie wiem, można mnóstwo rzeczy napisać, wyrażając tę sama myśl i tee sama opinię, nie postugując się zdaniem, które ewidentnie ma predykat prawdy albo fatszu.

Rozmówczyni pomija argument wynikający z gatunkowych konwencji odbioru i rozpatruje wypowiedź na poziomie odbioru dosłownego. Powołuje się na konwencje kulturowe i społeczne, zakazujące kłamstwa. Jest to działanie strategiczne, polegające na zapewnieniu sobie optymalnej pozycji dyskursywnej, a mianowicie takiej, w której bezzasadny staje się zarzut ograniczania wolności słowa. Używając metaforyki wojennej - pozycja ta powoduje, że atak z perspektywy ograniczenia wolności słowa będzie chybiony.

Wynika stąd, że reguły funkcjonowania sfery publicznej determinują strategie komunikacyjne uczestników dyskursu. Wyznaczają możliwe pozycje ataku i obrony, przez co wymagają wysokich kompetencji komunikacyjnych; uwzględnienia konwencji społecznych, dyskursywnych, gatunkowych. Instrumentalne operowanie konwencjami pozwala np. na doraźne zmiany pozycji dyskursywnej i zwiększanie siły. Nieznajomość konwencji grozi natomiast wyeliminowaniem głosu z debaty, nawet bez konieczności merytorycznego odniesienia do proble$\mathrm{mu}$, jedynie na podstawie (rzeczywistego lub sugerowanego) braku kompetencji komunikacyjnych przeciwnika.

Doraźność i strategiczność działań jest zresztą zauważana przez samych rozmówców. Komunikacyjna sytuacja rywalizacji powoduje jednak, że dotyczy to zawsze strony przeciwnej (my opisujemy rzeczywistość, a to oni manipulują). Tego typu uwikłanie nie umniejsza jednak dla badacza ogólnej wartości diagnostycznej samych uwag.

${ }^{6}$ Jak zaznaczono we wstępie pracy i rozdziału, perswazyjność jest cechą dyskursu politycznego w ogólności. Odnotowujemy tę cechę w działaniu dziennikarza, aby zwrócić uwagę na perswazyjność przekazu medialnego, która przyjmuje formy mniej widoczne, np. selekcjonowanie, uogólnianie, zadawanie sugestywnych pytań. 
MZ: Od pewnego czasu mamy taka sytuację, że Adam Michnik kolejne osoby pozywa do sądu. Czy jest tak, że sąd staje się miejscem, w którym ta granica debaty publicznej jest rozstrzygana? Czy rzeczywiście kolejne procesy pokazuja, że czegoś nie wolno?

MŚ: W pewnych krańcowych przypadkach tak. Nie można po prostu o innych ludziach mówić rzeczy nieprawdziwe. Mamy prawo do tego, żeby wyrażać opinie i mamy prawo do tego, żeby krytykować, ale nie mamy prawa do nieprawdy.

BW: To [wypowiedź w tekście publicystycznym] jest par exellence interpretacja. To jest opis pewnej argumentacji. Podpisujacy ten list zwracali uwage, że nie chodzi o to, czy ta interpretacja jest wtaściwa, bo to była interpretacja. Jeżeli pani chce, żeby przy każdym zdaniu w publicystyce byto napisane „Mniemam, że...” albo „Przypuszczam, że...”, to pani powiem, że nikt w ten sposób publicystyki na świecie nie pisze.

W dalszej części programu uczestnicy powtarzają i rozwijają wcześniejszą argumentację. Dziennikarz wzmacnia przekaz perswazyjny o ograniczaniu wolności słowa. Wzmocnienie polega na rozszerzeniu kontekstu (pojedyncze działanie seria działań), a wykładnikiem rozszerzenia jest użycie czasowników niedokonanych (pozywa, staje się, pokazuja). Perswazyjność polega tu na uogólnieniu, na sugestii, że zachowanie nie jest jednostkowe, ale ma charakter stałej dyspozycji. Rozmówczyni również powtarza wcześniejsze argumenty, powołując się na normy społeczne. Prawdopodobnie dostrzega jednak konflikt wartości (prawo do obrony wizerunku kontra prawo do wolności słowa), stąd obiera strategię balansu. Na poziomie ogólnym przyznaje prawo do wolności słowa, ale kwestionuje konkretny sposób jego realizacji (dobrze, ale nie w ten sposób). Strategia balansu pozwala rozmówczyni uniknąć etykietki osoby popierającej nieformalną cenzurę. Widać zatem, że normy obowiązujące w sferze publicznej determinują strategie komunikacyjne rozmówców. Nawet kiedy nie są respektowane, nie mogą być zupełnie ignorowane. Narzucają obowiązek wytłumaczenia się, zneutralizowania zarzutów strony przeciwnej. Rozmówca, wykorzystujący uprzednio konwencje gatunkowe do obrony, powtarza również swoje argumenty. Dodatkowo stosuje strategię dyskredytacji prześmiewczej - kpinę (jeżeli pani chce, żeby przy każdym zdaniu w publicystyce było napisane „Mniemam, że...” albo „Przypuszczam, że...”, to pani powiem, że nikt w ten sposób publicystyki na świecie nie pisze).

Jak wynika z przykładu, komunikowanie w sferze publicznej poddane jest licznym rygorom. Rozmówcy nie zawsze im się poddają, ale są zobligowani do stosowania technik uniku i modyfikacji strategii rywalizacyjnych. Wiedza na temat konwencji komunikacyjnych jest tu niezwykle przydatna. Służy do zmiany pola dyskusji, do przejścia z pozycji, w której obrona jest niemożliwa, na pozycję dogodniejszą. Korzystne jest również zwiększanie siły, które polega na występowaniu w obronie norm, a nie interesu jednostkowego.

\subsubsection{Dopasowanie strategii}

Rozmowa, dyskusja publiczna jest procesem dynamicznym, w którym działające podmioty wpływają na sytuację komunikacyjną, prowokują sytuacje zagrożenia twarzy, realizują obronę twarzy pozytywnej. W sytuacji rywalizacyjnej 
mamy do czynienia ze strategiami dopasowanymi, np. legitymizacja - delegitymizacja lub delegitymizacja - delegitymizacja. Jeśli jeden z rozmówców stara się uprawomocnić określone działania, to rozmówca rywalizujący z nim będzie zmierzał wszelkimi metodami do pozbawienia go prawomocności. Kolejną prawidłowością rywalizacji jest to, że najczęstszą odpowiedzią na atak jest również atak, który można też określić jako obronę przez atak.

W poniższym przykładzie rozmówcy, komentując wydarzenie polityczne, w tym rozmowę polityków, negocjują tożsamość gatunkową ich wypowiedzi, odwołują się do wzorów i standardów komunikacji w sferze politycznej, uwzględniają charakter i rodzaj styczności między członkami systemu, motywację ich działań. Wiedza z tego zakresu jest wykorzystana taktycznie do sterowania odbiorem wydarzenia ze względu na odbiorcę masowego.

[Felieton filmowy, głos z offu]: Europarlamentarzyści z wizyta u prezydenta Czech, Wactawa Klausa. W btysku fleszy przyjacielskie uściski, uśmiechy. Za zamkniętymi drzwiami - ostra wymiana zdań. „Muszę przyznać, że taki styl $w$ rozmowie $z$ głowa państwa nie byt styszany od dekad”. Najpierw szef frakcji Zielonych, Daniel Cohn-Bendit, wręcza Wactawowi Klausowi flagę Unii Europejskiej, potem zaczyna mówić o traktacie lizbońskim, którego Czechy dotąd nie ratyfikowaty $i$ atakuje prezydenta: „Pana poglądy mnie nie interesują. Chcę wiedzieć, co pan zrobi, aby zatwierdzity go czeski Sejm i Senat. Czy będzie pan respektowat demokratyczna wolę przedstawicieli narodu? Będzie pan musiat to podpisać”. „Muszę powiedzieć, że w ten sposób i tym tonem nikt jeszcze ze mna nie rozmawiat przez 6 lat mojej prezydentury. Nie jest pan tutaj na paryskich barykadach. Sądzitem, że taki styl komunikacji wobec nas skończyt się 19 lat temu. Widzę, że się mylitem”.

(„Pod prasą”, TVP 1, 13.12.2008; dziennikarz - TS: Tomasz Sakiewicz; goście - JJ: Jerzy Jachowicz, PG: Piotr Gabryel, RK: Roman Kurkiewicz)

Felieton filmowy zawiera tekst od nadawcy medialnego, przygotowany i opracowany uprzednio. Jego funkcją jest wprowadzenie widza w omawiany temat. Neutralny tytuł nie współgra z perswazyjnym tekstem. Negocjacje polityczne zostają przedstawione według racjonalności potocznej, jako przejaw fałszu i udawania przyjaźni. Tymczasem w dyskursie politycznym podział na scenę i kulisy jest akceptowaną formą interakcji (Pawełczyk 2000). Nazwanie aktywności komunikacyjnej jednej ze stron konfliktu politycznego „atakiem” jest przejawem sterowania odbiorem wydarzenia, które wykreowano jako naruszające standardy komunikacji politycznej (tym tonem nikt jeszcze ze mna nie rozmawiat; nie jest pan tutaj na paryskich barykadach). W tej sytuacji dochodzi do zagrożenia twarzy pozytywnej eurodeputowanego, gdyż jego zachowanie jest przedstawione jako dominacyjne, aroganckie (Pana poglady mnie nie interesuja), naruszające normy społeczne. Dobór wypowiedzi i komentarzy wskazuje na taktykę dyskredytacji komunikacyjnej, realizowaną wobec eurodeputowanego $\mathrm{w}$ felietonie nadawcy medialnego.

RK: No, ja uważam, że świetnie się stato, że Cohn-Bendit zadat te pytania $w$ takiej formie prezydentowi Klausowi, bo go wytrącił $z$ takiego samozadowolenia, z takiej nietykalności, z tego, 
że nie należy odpowiadać na ważne pytania. To jest pewna cecha niektórych polityków, zasadniczo prawicowych. Powiem mocno - naszego prezydenta, prezydenta Klausa, że oni otaczaja się, powiedziałbym, pewna aureola niedostępności.

TS: [Że się szanują.

RK: [Nie rozmawiaja z dziennikarzami, którzy moga im zadać ważne, aczkolwiek trudne pytania, tylko rozmawiaja ze swoimi dziennikarzami [w tym sensie//

TS: [Mówi pan o Monice Olejnik.

RK: Mówię o tym, że kiedy europarlamentarzysta wybrany, tak, wybrany w demokratycznych wyborach/ jeśli ktoś nie chce wybrać Cohn-Bendita, to by go nie wybierat, zostat wybrany, ma prawo pytać o rzeczy ważne - pytat [o procedury demokratyczne, o to, w jaki sposób//

Rozmówca, który przyjął rolę obrońcy eurodeputowanego, stosuje taktykę redefinicji wydarzenia. Zmierza do przesunięcia ${ }^{7}$ go ze sfery półoficjalnej (ponieważ zostało przedstawione jako odbywające się za zamkniętymi drzwiami) do sfery publicznej, gdzie zyskuje rangę działania zgodnego z procedurami komunikacji publicznej. Zostaje nazwane zadawaniem pytań, pytaniem o procedury demokratyczne, co w komunikowaniu publicznym jest uznane za egzekwowanie odpowiedzialności instytucji, na których ciąży realizacja interesu publicznego (Czy będzie pan respektowat demokratyczna wolę przedstawicieli narodu?). Działanie mowne, określone zatem poprzednio jako atak, nieuprawniony nacisk, żądanie (Będzie pan musiat to podpisać), zostaje przedstawione jako uprawnione zadawanie pytań w ramach regulacji działań instytucji publicznych. Posunięcie to uznajemy za legitymizację podmiotu na podstawie działań w ramach roli społecznej parlamentarzysty (europarlamentarzysta wybrany [...] w demokratycznych wyborach [...] ma prawo pytać o rzeczy ważne). Najskuteczniejszym sposobem legitymizacji jest bowiem przypomnienie o społecznym mandacie polityka, o poparciu wyborców.

Równolegle do legitymizacji europarlamentarzysty rozmówca stosuje strategię dyskredytacji wobec prezydenta Czech. Jest to nie tylko dyskredytacja komunikacyjna (ironiczne oskarżenie o to, że jest nietykalny, otacza się aureolą niedostępności), lecz także zawodowa. Jej podstawą jest oskarżenie o odmowę informacji, uchylanie się od trudnych pytań. Rodzaj zarzutu wskazuje na naruszenie zasady dostępności sfery publicznej, ponieważ odmawianie odpowiedzi na pytania oznacza odmawianie obywatelom prawa do informacji.

Analiza wskazuje, że sens zachowań komunikacyjnych jest negocjowany przez podanie motywacji i odniesienie do kontekstu. Motywacja, wynikająca z cech indywidualnych lub grupowych (odniesienie do płaszczyzny społecznej), nie stanowi wiarygodnego uzasadnienia działań. Uszlachetnianie motywacji jako wynikającej z realizacji ról w sferze publicznej, politycznej, zwiększa prestiż rozmówcy i ważność jego działań. Ciekawe, że parametry te nie zależą od

7 Użycie sformułowania „przesunięcie” ze sfery do sfery jest określeniem metaforycznym; skrótem, który oznacza zmianę kontekstu i ogólnej konceptualizacji wydarzenia, zmianę jego kategoryzacji. Działanie takie ma charakter taktyczny i należy do strategii kognitywnych. 
przebiegu wydarzenia, ale od interesów osób rywalizujących. Można zauważyć następującą prawidłowość: działania przeciwników są przedstawiane jako motywowane cechami indywidualnymi, a więc jako wynik trwałych, najczęściej negatywnych cech charakteru, natomiast działania własne są przedstawiane jako wynikające z pełnienia ról społecznych. Kontekst publiczny ma zawsze działanie balansujące, asekuracyjne, uzasadniające nawet wątpliwe z innej perspektywy zachowania (zamiana racjonalności etycznej na profesjonalną). I tak, w oczach przeciwników działanie prezydenta wynika z tego, że jest bezkrytyczny, wyniosły, i cechy te zostały przypisane innym politykom prawicowym (wytracit $z$ takiego samozadowolenia; To jest pewna cecha niektórych polityków, zasadniczo prawicowych). Natomiast napastliwe działania eurodeputowanego zostały usprawiedliwione wypełnianiem obowiązków wobec wyborców (społeczna kategoria słusznego gniewu).

JJ: Ale pytat czy dyktowat? [...] Bo udajesz, bo udajesz naprawde gtuchego. Ale Roman, to jest nierówna dyskusja, jeżeli ty udajesz głuchego, że pewnych zdań nie styszysz. Pomijasz je i wytaczasz armaty, [których//

RK: [Ja powiedziatem prosta rzecz, ja uważam, że Cohn-Bendit miat prawo zadać pytania. Uważam, że dobrze sie stato, że zadat je za ostro. [...]

PG: No wtaśnie, ja/ rzecz $w$ tym, że pan Roman nie chce rzeczywiście zauważyć, że pan Cohn-Bendit nie pytat. On wygtaszat oracje, on pouczat, strofowat. Można sobie oczywiście wyobrazić, że również na prezydenta można krzyczeć//

RK: Trzeba [krzyczeć na prezydenta.

PG: [-że również prezydenta można strofować. Natomiast ja mam wrażenie, że to nie jest przyjęte $w$ świecie dyplomacji.

TS: Ale być może w świecie polityki jest przyjęte. Polityka to jest twarda zabawa. Dziwi mnie, $\dot{z}$ e tak twardy, prawicowy, mocny prezydent jak Klaus, rozpłakat się, że maty Cohn-Bendit zadaje mu nieprzyjemnym tonem nieprzyjemne i trudne dla niego pytania.

Strategia rozmówcy zostaje zdemaskowana, poddane krytyce jest manipulacyjne nazwanie działania komunikacyjnego (nie pytał, ale dyktował, pouczał, strofował), pomijanie pewnych elementów, zmiana ich proporcji. Rozmówcy krytykujący zachowanie eurodeputowanego przechodzą na poziom metadyskursywny i krytykują z kolei zachowanie jego obrońcy. Odkrycie strategii nazywamy tu posunięciem: „odkryłem twoją grę”. Są to ważne sygnały wysyłane przez samych rozmówców, które potwierdzają stosowanie strategii w sterowaniu odbiorem zachowań komunikacyjnych. Do posunięć strategicznych zostaje zaliczone negocjowanie kwalifikacji gatunkowej działań komunikacyjnych (pytat czy dyktowat?; pan Cohn-Bendit nie pytat. On wygłaszat oracje, on pouczat, strofowat; na prezydenta można krzyczeć), pomijanie pewnych elementów sytuacji (udajesz głuchego, że pewnych zdań nie styszysz. Pomijasz je), zmiana proporcji elementów, wyolbrzymianie (wytaczasz armaty) i wreszcie pomijanie kontekstu rozmowy, który dodatkowo wskazuje na niedopasowanie zachowania do sytuacji (to nie jest przyjęte w świecie dyplomacji). 
W wyniku stosowanych strategii równowaga zostaje zachwiana na niekorzyść jednego z uczestników interakcji, który jest zmuszony do obrony. W tym celu wybiera taktykę zmiany wartościowania przez odwrócenie argumentu (retorsio argumenti). Chwyt jest efektowny i skuteczny, ponieważ polega na wyzyskaniu przesłanek, na które powołuje się przeciwnik lub jego sposobu myślenia ujawnionego w argumentacji, do skonstruowania argumentu o konkluzji przeciwstawnej (Szymanek 2004: 286). Argumentacja wyjściowa wygląda następująco: „[konkluzja] Nie można krzyczeć na prezydenta, strofować go, ponieważ [przesłanka] to nie jest przyjęte w świecie dyplomacji”. Odwrócenie argumentu polega na rozumowaniu: „[przesłanka] Nawet jeśli nie jest przyjęte w świecie dyplomacji, to jest przyjęte w świecie polityki, a więc [konkluzja] można krzyczeć na prezydenta”.

Dodatkowo argumentacja została wzmocniona zastosowaniem dyskredytacji prześmiewczej - kpiny, która polega na infantylizacji polityka (rozptakat się), na modelowaniu relacji: polityk - polityk na wzór relacji: dorosły - dziecko.

Obie strony rywalizacji stosują różne rodzaje dyskredytacji (komunikacyjnej, prześmiewczej). Na poziomie ogólnym funkcjonowania sfery publicznej i politycznej, gdzie prawomocność i wiarygodność nadawcy jest szczególnie ważna, należy je odczytywać jako rodzaj delegitymizacji. Dyskredytowanie osoby publicznej jest sygnałem skierowanym do odbiorcy masowego, że osoba ta nie ma wystarczających kompetencji do pełnienia powierzonej funkcji. Zobrazowaniem podanych prawidłowości niech będzie schemat, w którym zestawiono dwie perspektywy ujęcia tego samego wydarzenia (w zakresie nazywania aktów i gatunków mowy, kreowania układu interakcyjnego, przypisywania intencji i motywacji) w zależności od realizowanej strategii: legitymizacji bądź delegitymizacji.

Opisane mechanizmy są stosowane w ramach strategicznej gry uprawianej przez uczestników medialnych debat publicznych. W kolejnym przykładzie wykorzystano taktycznie zmiany takich parametrów sytuacji komunikacyjnej, jak: publiczny - prywatny, poważny - niepoważny.

IK: $W$ dwóch wypowiedziach prezesa Kaczyńskiego są dwa/ dwie zupetnie różne definicje sytuacji. I to jest coś, co wtaściwie PiS robi od samego początku. To powoduje catkowita destabilizację, taka, nawet bym powiedział emocjonalna, no już nie tylko nas widzów, dziennikarzy, ale samych polityków//

BW: Kto jest zdestabilizowany emocjonalnie, ten jest.

(„Debata”, TVP 1, 18.01.2006; goście - BW: Bronisław Wildstein, IK: Ireneusz Krzemiński)

8 Określenie „krzyczeć na prezydenta” jest potocznym nazwaniem sposobu wyrażania językowej ekspresji, który jest relatywizowany ze względu na rodzaj dyskursu. Wyrażanie gniewu (bo w istocie ta emocja kryje się za określeniem „krzyczeć na kogoś”) jest kulturowo ograniczane i musi być specjalnie uzasadnione. W sferze publicznej pojawia się społeczna kategoria słusznego gniewu, która nie jest sprawą prywatną, ale narzędziem wywierania słusznej presji i regulowania stosunków społecznych (Basiuk 2003: 208). 


\begin{tabular}{|l|l|l|}
\hline $\begin{array}{l}\text { charakterystyka interakcji, } \\
\text { identyfikacja aktu mowy, } \\
\text { gatunku mowy }\end{array}$ & $\begin{array}{l}\text { negocjacje polityczne, zadawanie } \\
\text { trudnych, ważnych pytań w imie- } \\
\text { niu wyborców, interwencja poselska } \\
\text { w ramach roli społecznej eurodepu- } \\
\text { towanego }\end{array}$ & $\begin{array}{l}\text { bycie obiektem obrazy, } \\
\text { wyrażanie oburzenia }\end{array}$ \\
\hline $\begin{array}{l}\text { kreacja układu interakcyj- } \\
\text { nego }\end{array}$ & $\begin{array}{l}\text { układ równorzędny, w którym pod- } \\
\text { mioty działają w ramach swoich ról }\end{array}$ & $\begin{array}{l}\text { układ równorzędny, w któ- } \\
\text { rym prezydent suwerenne- } \\
\text { go państwa ma prawo do } \\
\text { szacunku }\end{array}$ \\
\hline $\begin{array}{l}\text { przypisywane intencje i mo- } \\
\text { tywacje }\end{array}$ & $\begin{array}{l}\text { egzekwowanie odpowiedzialności } \\
\text { instytucji, dbanie o zachowanie pro- } \\
\text { cedur demokratycznych }\end{array}$ & $\begin{array}{l}\text { zachowanie niezależno- } \\
\text { ściepoddawanie się } \\
\text { dominacji }\end{array}$ \\
\hline
\end{tabular}

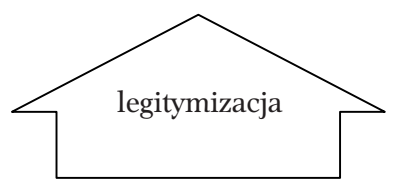

wydarzenie polityczne (rozmowa eurodeputowanego z prezydentem Czech), w której występują różnice w nazywaniu działań i kreowaniu sytuacji

w zależności od celu strategii

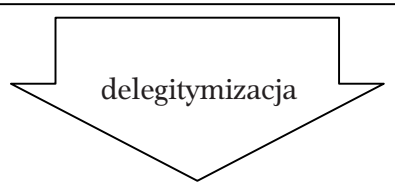

\begin{tabular}{|l|l|l|}
\hline $\begin{array}{l}\text { charakterystyka interakcji, } \\
\text { identyfikacja aktu mowy, } \\
\text { gatunku mowy }\end{array}$ & $\begin{array}{l}\text { podwójne standardy, udawanie } \\
\text { (w błysku fleszy przyjacielskie } \\
\text { uściski, za zamkniętymi drzwia- } \\
\text { mi ostra wymiana zdań); nieod- } \\
\text { powiedni styl komunikacji; żą- } \\
\text { danie, zmuszanie, oskarżanie, } \\
\text { pouczanie, strofowanie }\end{array}$ & $\begin{array}{l}\text { złe rozpoznanie sytuacji (poli- } \\
\text { odmowa tod truarda zabawa), } \\
\text { się od trudnch pytań }\end{array}$ \\
\hline $\begin{array}{l}\text { kreacja układu interakcyj- } \\
\text { nego }\end{array}$ & $\begin{array}{l}\text { układ nierównorzędny, atak, } \\
\text { aroganckie zachowanie }\end{array}$ & $\begin{array}{l}\text { układ nierównorzędny, bier- } \\
\text { nośćnstans, otaczanie się } \\
\text { aureolą niedostępności, niety- } \\
\text { kalności, infantylizacja (Klaus } \\
\text { rozpłakat się) }\end{array}$ \\
\hline $\begin{array}{l}\text { przypisywane intencje i mo- } \\
\text { tywacje }\end{array}$ & $\begin{array}{l}\text { próba zdominowania, narzuce-- } \\
\text { nia rozwiązania siłą }\end{array}$ & $\begin{array}{l}\text { ignorowanie procedur demo- } \\
\text { kratycznych, bierny opór, eks- } \\
\text { ponowanie uwarunkowań in- } \\
\text { dywidualnych, cech charakteru }\end{array}$ \\
\hline
\end{tabular}

Rys. 6. Perspektywy ujęcia wydarzenia w zależności od celu strategii 
Rozmówca stawia politykowi (spoza studia) zarzut niezgodności dwóch jego wypowiedzi odnoszących się do jednej sytuacji. Zasada niesprzeczności jest ważną zasadą dyskusji, a zatem stwierdzenie tego rodzaju jest strategią dyskredytacji komunikacyjnej. Na mocy reguł systemu komunikowania politycznego, według którego działania polityków mają poważne konsekwencje i moc sprawczą, rozmówca oskarża polityka o destabilizację (takie wypowiedzi w ustach osoby niesprawującej władzy nie byłyby odbierane jako mające moc sprawczą, co najwyżej świadczyłyby o cechach nadawcy). Jest to przykład taktycznego wykorzystania koncepcji komunikowania politycznego jako działania. Polityk - z racji sprawowania władzy - mówiąc, jednocześnie zmienia rzeczywistość. Następnie rozmówca stosuje strategię legitymizacji, polegającą na przedstawieniu swojej opinii jako opinii publicznej. Zwiększa siłę przez powołanie się na odczucia widzów, dziennikarzy i polityków. Czyni się wyrazicielem ich odczuć. Znamienne jest pośrednie utożsamienie wyborców, czyli społeczeństwa, z odbiorcami mediów masowych (nas widzów).

Przy analizie dopasowania strategii warto zwrócić uwagę na to, do jakiego elementu wypowiedzi nawiąże rozmówca. Przeciwnik najczęściej reaguje na najcelniejszy zarzut; stara się odeprzeć ten atak, który najbardziej zagraża twarzy pozytywnej (przy czym zagrożony może być wizerunek własny lub osoby z własnej grupy). W rozpatrywanym przykładzie najcelniejsze okazuje się negatywne określenie skutków działań polityka, nazwanie ich destabilizacją. Jest to krytyka z perspektywy roli społecznej, oczekiwań z nią związanych. Zostaje zatem przeprowadzona w poważnej tonacji i pozostaje w sferze komunikowania publicznego.

Odrzucenie krytyki polega na zmianie tych parametrów sytuacji komunikacyjnej, które stanowiły punkt oparcia przeciwnika. Przede wszystkim ten, kto odpiera atak, zmienia płaszczyznę odniesienia na prywatną (Kto jest zdestabilizowany emocjonalnie, ten jest), sugerując, że stan nie jest skutkiem działań polityka, lecz problemem indywidualnym (w domyśle - psychicznym). Powoduje to zmniejszenie siły, obniżenie rangi zarzutu. Jednocześnie następuje zmiana tonacji z poważnej na ironiczną. Dodatkowo wypowiedź wyraźnie przerywa atak, a więc pełni funkcję dywersyjną. Takie zachowanie komunikacyjne nie jest właściwe dla merytorycznej dyskusji. Poszukując kwalifikacji gatunkowej, można nazwać je potocznym dogadywaniem. Podobne działania komunikacyjne można zaobserwować w kolejnym przykładzie.

MO-K: [...] Ja widzę, że moje koleżanki zaczynają rodzić dzieci. Widzę, że jest wręcz moda na dzieci.

MŚ: Znaczy, ja myślę, że warto przyjrzeć się po prostu, czy te koleżanki maja pracę. Bo to tak naprawdę nie jest, $\dot{z}$ ludzie się przestali kochać, albo maja jakiś lęki egzystencjalne i dlatego nie mają dzieci. Moje studentki, jak pytam się: „Kiedy byście urodzity dzieci?”, to one mówia: „Kiedy będziemy miały gwarancję na rynkach pracy, dlatego, że to, cośmy zainwestowały w nasze studia, nie może pójść na marne”. Mówią również taka rzecz, że na świecie jest bardzo wielu mężczyzn, ale niewielu partnerów. I one mają kłopot// 
KSz: To sa te pani studentki. No to niech pani weźmie poprawkę. [śmiech]

MŚ: Znaczy myślę, że jeśli panowie nie przyjma takich problemów jako poważnych, to te problemy, które będziemy mieli, będa coraz większe. Bo tak naprawdę, to sa właśnie te problemy.

(„Warto rozmawiać”, TVP 2, 9.01.2006; goście - KSz: Konrad Szamański, MO-K: Małgorzata Ostrowska-Królikowska, MŚ: Magdalena Środa)

Rozmówczyni wprowadza do debaty głos kobiet, których temat bezpośrednio dotyczy (kobiety w wieku prokreacyjnym, oskarżone o brak chęci rodzenia dzieci z powodu kariery). Tym samym umacnia swoją pozycję dyskursywną, czyniąc się reprezentantką nieformalnej grupy społecznej, występując w jej imieniu. Wykorzystuje prawo do otwartości debaty w sferze publicznej. Właśnie ze względu na to prawo przeciwnik musi wysłuchać głosu i odnieść się do niewygodnych dla niego argumentów. Nie podejmuje jednak merytorycznej strategii argumentacyjnej, ale stosuje strategię dyskredytacji alienacyjnej, towarzyskiej (To sa te pani studentki. No to niech pani weźmie poprawkę). Polega ona na wywołaniu wrażenia, że ktoś przebywa w dziwnym, szemranym towarzystwie i przez to staje się obcy, odległy, niezrozumiały (Karwat 2006b: 230). Strategia służy wykluczeniu, a więc jest rodzajem delegitymizacji.

\subsubsection{Wpływ norm sfery publicznej na zachowania komunikacyjne regulujące skuteczność działań podmiotów}

Główną ideą sfery współistnienia jednostek i grup społecznych jest realizowanie ich interesów. Stąd zachowania komunikacyjne podmiotów sfery publicznej muszą uwzględniać te kategorie w kontekstualizacji tła pozajęzykowego. Oznacza to, że sposób jego prezentacji jest czynnością strategiczną, nastawioną na uzyskanie publicznej akceptacji. W niniejszym punkcie zostaną zanalizowane przykłady pod kątem skuteczności działań podmiotów debaty publicznej. Szczególnie chodzi o zyskiwanie lub utratę prawomocności z uwagi na uwzględnienie w argumentacji celów funkcjonowania sfery publicznej.

\subsubsection{Strategie legitymizacji podmiotów sfery publicznej}

Przeanalizujmy przykład, który pokazuje, jak zachowania komunikacyjne rozmówców zostają ukierunkowane ze względu na cele zadań w sferze publicznej. Szczególnie interesuje nas, jakim ogólnym kategoriom pojęciowym, właściwym dla funkcjonowania sfery publicznej, można przyporządkować konkretne wątki. Tym samym stawiamy pytanie, czy (niezależnie od zmienności tematów typu: prostytucja, narkomania, eutanazja, aborcja) można uschematyzować argumentację w debacie publicznej, nadając poszczególnym argumentom kategorie poznawcze o większym stopniu ogólności. Zwracamy również uwagę na postrzeganie relacji sfery publicznej do sfery prywatnej oraz instytucjonalnej. 
W analizie taktycznych posunięć rozmówców (prawa strona tabeli) operujemy ograniczonym inwentarzem pojęć, takich jak: proponent, oponent, sfera publiczna, sfera instytucjonalna, sfera prywatna, regulacja prawna, interes publiczny, interes grupowy, interes jednostkowy, kategoryzacja.

\begin{tabular}{|c|c|}
\hline PB: Dlaczego zalegalizować prostytucję? & $\begin{array}{l}\text { Dziennikarz wprowadza temat rozmowy, któ- } \\
\text { rym jest propozycja nowej regulacji prawnej. }\end{array}$ \\
\hline $\begin{array}{l}\text { BW: Ze względów społecznych. Kobiety, które } \\
\text { pracuja, świadcza ustugi seksualne, nie maja } \\
\text { ubezpieczenia, nie sa pod żadna kontrola me- } \\
\text { dyczna [...]. W momencie, kiedy to nie jest za- } \\
\text { legalizowane, bądź kiedy to jest zupetnie poza } \\
\text { jakimkolwiek systemem prawnym, normami } \\
\text { prawnymi, to się wdziera tam kryminalizacja } \\
\text { tego zjawiska. }\end{array}$ & $\begin{array}{l}\text { Proponent w uzasadnieniu powołuje się na } \\
\text { interes jednostkowy (prawo do opieki me- } \\
\text { dycznej) i interes publiczny (dążenie do ogra- } \\
\text { niczenia kryminalizacji zjawiska). }\end{array}$ \\
\hline $\begin{array}{l}\text { Rop: Chciatem się odnieść do wypowiedzi, } \\
\text { prawda, przeciwnika, który stwierdzit, że te } \\
\text { kobiety nie miatyby opieki lekarskiej. Oczywi- } \\
\text { ście miatyby, ponieważ konstytucja RP gwa- } \\
\text { rantuje każdemu taka opiekę, bez względu na } \\
\text { to, co on robi, czy pracuje, czy nie. }\end{array}$ & $\begin{array}{l}\text { Oponent uznaje zasadność interesu jednost- } \\
\text { kowego (prawo do opieki medycznej), chociaż } \\
\text { uważa dotychczasowe regulacje za wystar- } \\
\text { czające. }\end{array}$ \\
\hline $\begin{array}{l}\text { WG: Chyba nie ma między nami różnic co } \\
\text { do stwierdzenia faktu, że prostytucja jest zła, } \\
\text { prawda i/ i ja myślę, że wszyscy, jak tu siedzi- } \\
\text { my, nie chcielibyśmy/ no wtaśnie, czy chcieli- } \\
\text { byśmy, żeby nasze siostry, koleżanki byty pro- } \\
\text { stytutkami? }\end{array}$ & $\begin{array}{l}\text { Oponent odwołuje się do relacji w sferze pry- } \\
\text { watnej (nasze siostry, koleżanki), aby uzasad- } \\
\text { nić naruszenie interesu jednostkowego. }\end{array}$ \\
\hline $\begin{array}{l}\text { PM: [...] możemy opodatkować podatkiem } \\
\text { zryczattowanym prostytutki. [...] Załóżmy, } \\
\dot{z} \text { e każdy klient zostawia } 100 \text { zt w agencji, to } \\
\text { daje jakieś } 2 \text { miliony złotych, jeżeli odejmiemy } \\
\text { koszty, to zostaje jakieś } 600 \text { tysięcy. }\end{array}$ & $\begin{array}{l}\text { Proponent, pozostając w sferze instytucjo- } \\
\text { nalnej (urząd skarbowy), przedstawia nową } \\
\text { regulację (legalizacja prostytucji) jako realizu- } \\
\text { jącą interes społeczny (ściąganie podatków). }\end{array}$ \\
\hline $\begin{array}{l}\text { KD: Myśli pan, że naprawdę można zarabiać } \\
\text { na wszystkim, także na ludzkiej krzywdzie, } \\
\text { na dramatach, na tragediach? }\end{array}$ & $\begin{array}{l}\text { Dziennikarz, odgrywając rolę oponenta, przed- } \\
\text { stawia rzekomo zgodne z interesem publicz- } \\
\text { nym rozwiązanie jako niezgodne z interesem } \\
\text { jednostkowym (krzywda, dramat, tragedia). }\end{array}$ \\
\hline $\begin{array}{l}\text { PM: Dzięki temu, że prostytucja zostanie za- } \\
\text { legalizowana, to przestępcy nie będa czerpać } \\
\text { z niej korzyści. [...] } \\
\text { MW: To dlatego legalizując prostytucję, sute- } \\
\text { nerów pozbawiamy szans. W tym momencie } \\
\text { sutener jest pod ochrona. [...] legalne domy pu- } \\
\text { bliczne dadza to, że policja nie będzie musiała } \\
\text { interweniować, tak jak dzisiaj interweniuje. }\end{array}$ & $\begin{array}{l}\text { Proponenci przedstawiają rozwiązanie jako } \\
\text { zgodne z interesem społecznym (ograniczenie } \\
\text { kryminalizacji, walka z przestępczością). }\end{array}$ \\
\hline
\end{tabular}


PP: [...] uważamy, że w tej chwili państwo, Rzeczpospolita Polska, niestety, tym obywatelom [osobom prostytuującym się], którzy stanowia jakaś część nas tutaj społeczeństwa, państwo nie gwarantuje im tego [ochrony życia, wolności, mienia i zdrowia], nie chroni ich.

TK: [...] jeżeli ktoś popetnia zbrodnię, również nie jest do tego zmuszany. To jest zło, które nie może być legalizowane. Tak samo jest z prostytucja $[\ldots]$.

Rop: One ponosza konsekwencje zła.

KD: Ale zaraz, sądzi pan, że w zasadniczej swojej części prostytutki bytyby bardziej zadowolone, gdyby to byt zalegalizowany zawód, gdyby miały ubezpieczenie, ptacity podatki, i tak dalej, i tak dalej?

RE: To nie chodzi o kwestie zadowolenia.

$\mathrm{KD}$ : Zabezpieczenia?

RE: Zabezpieczenia, tu chodzi o kwestie zabezpieczenia, zabezpieczenia również przyszłości, zabezpieczenia ich rodzin. To sa bardzo często osoby, które maja normalne rodziny, dzieci.

KD: Mnie interesuje jeszcze jeden aspekt catej tej sprawy, czy legalizowanie i opodatkowanie, nawet gdyby zostato wprowadzone, zlikwiduje te wszystkie zjawiska, o których opowiadat pan poset Jurek. Mówit/ które towarzysza prostytucji: handel żywym towarem, przestępczość, mafia i tak dalej?

ZI: [...] niewatpliwie ze względów i problemów dotyczacych zagadnień epidemiologicznych i problematyki dotyczacej kwestii socjalnej znacznie korzystniejsza bytaby formuta legalizacji. To przyczyniłoby się również do tego, że agencje mogłyby dziatać może $w$ innych miejscach niż na dzień dzisiejszy funkcjonuja. Ponieważ na dzień dzisiejszy, musimy sobie zdawać sprawę $z$ tego, że one moga zaktócać porządek społeczny.
Proponent sygnalizuje naruszenie interesu określonej grupy społecznej. Domaga się ingerencji instytucji państwowych w celu zabezpieczenia interesu grupowego.

Oponenci kategoryzują negatywne skutki prostytucji (zagrożenie życia, zdrowia) nie jako oskarżenie państwa (czyli w odniesieniu do sfery instytucjonalnej), ale jako konsekwencję wyboru zła przez jednostkę. W ten sposób problem zostaje przeniesiony (a właściwie zepchnięty) do sfery prywatnej.

Dziennikarz pyta, czy proponowane regulacje prawne są zgodne z oczekiwaniem grupy społecznej, czy lepiej gwarantują jej prawa.

Proponent przyznaje, że przedłożone rozwiązanie prawne jest zgodne $\mathrm{z}$ interesem grupowym i jednostkowym.

Dziennikarz ustala, czy proponowana regulacja prawna będzie skutecznie realizowała interes społeczny (likwidacja przestępczości).
Rozmówca, ekspert, przedstawia proponowane rozwiązanie prawne jako realizujące nie tylko interes grupy osób prostytuujących się (zagadnienia epidemiologiczne, socjalne), ale również interes społeczny (przywrócenie porządku społecznego).

(„Debata” [o prostytucji], TVP 1, 13.01.2005; dziennikarze - KD: Kamil Durczok, PB: Piotr Baron; goście - BW: Bartek Widawski, PM: Piotr Mieśnik, PP: Paulina Piecha, RŁ: Robert Łukasik, Rop: rozmówca, anonimowy przedstawiciel oponentów, TK: Tomasz Kot, WG: Wojciech Gałązka, ZI: Zbigniew Izdebski) 
Media, czyniąc tematem debat ważne problemy społeczne, ukierunkowują jego rozwój w ten sposób, aby był zbieżny z celami funkcjonowania sfery publicznej. Są nimi: regulacja ram prawnych życia społecznego, zakres ingerencji państwa w życie społeczne, realizowanie interesów grup społecznych. Jeśli potraktujemy wypowiedzi jako działania realizujące globalną intencję strategiczną, związaną z funkcjonowaniem sfery publicznej, jaką jest rozwiązywanie problemów społecznych, to okazuje się, że rozmówcy argumentują w określony sposób. Mianowicie, powołują się na realizację interesu jednostkowego, grupowego w relacji do interesu publicznego (ogólnego, społecznego). Występowanie w imieniu grup społecznych stanowi strategię legitymizacji tych, którzy podejmują się takiego działania. Kiedy określona siła chce uzasadnić swoje funkcjonowanie w sferze publicznej (mniej lub bardziej sformalizowane), występuje $\mathrm{z}$ ofertą obrony interesów: jednostkowego, grupowego, publicznego.

Strategie argumentacyjne proponentów i oponentów są również dostosowane do reguł funkcjonowania sfery publicznej. Proponenci, chcąc wprowadzić nowe rozwiązania prawne, argumentują w ten sposób, że realizują one interes jednostkowy, grupowy i - co najważniejsze - że są zbieżne z interesem publicznym. Strategia proponenta zakłada dodatkowo funkcjonalizację tła pozajęzykowego. Polega ona na budowaniu relacji przyczynowo-skutkowych, gdyż negatywne zjawiska są uznawane za skutek braku postulowanych przez proponenta rozwiązań. Jednocześnie zjawiska te mogą być opisywane w relacji do sfery instytucjonalnej, jako skutek zaniedbań odpowiedzialnych instytucji państwowych. Strategia oponentów musi być dostosowana nie tylko do sytuacji, ale również do strategii proponentów. Oponenci wskazują na niezgodność propozycji zmian prawnych z interesem publicznym. Obie strony uwzględniają w argumentacji sferę prywatną i instytucjonalną. Wartość perswazyjną ma np. uznanie negatywnych zjawisk społecznych za prywatną sprawę jednostki, a nie skutek braku ingerencji państwa w życie społeczne.

Tak więc wpływ funkcjonowania sfery publicznej na zachowania rozmówców polega na konieczności odnoszenia (relatywizowania) rozwiązań kwestii społecznych do interesu publicznego. Równie często pojawia się kategoria interesu jednostkowego.

PB: Zwolennicy eutanazji uważaja, że to prawo to jeden z obszarów naszej wolności. Chciatem pana zapytać, panie Arturze, na czym ta wolność polega?

AC: Uważamy, że prawo do eutanazji, że problem eutanazji jest bardzo skomplikowany $i$ niejednoznaczny, $i$ delikatny. Jest to kwestia $w$ naszym społeczeństwie, natomiast uważamy, że naszym koronnym argumentem jest prawo każdego człowieka do decydowania o wtasnym życiu, również o jego zakończeniu.

(„Debata”, TVP 1, 24.02.2005; dziennikarz - PB: Piotr Baron; goście - AC: Artur Chludziński, MSz: Maria Szyszkowska) 
Realizacja interesu jednostkowego jest często przedstawiana jako obszar wolności, który faktycznie poszerza zakres sfery prywatnej. Dążenie do realizowania własnych zamiarów i preferencji jest oczywistą potrzebą, niewymagającą specjalnych wyjaśnień czy uzasadnień. Z tego powodu przedstawienie przez stronę debaty określonej propozycji jako tej, która gwarantuje jednostce wolność i jest zabezpieczeniem jej interesu, zawsze stanowi skuteczny argument w debacie. Skuteczność argumentu wykorzystują grupy nieformalne, ale przede wszystkim politycy.

MSz: [...] Prawo w ustroju demokratycznym ma gwarantować każdemu wolność dokonywania wyboru: wyborów światopogladowych, a w tym wyborów moralnych. Jeżeli więc nawet teoretycznie założymy, że jedna czy dwie osoby rocznie $w$ Polsce $w$ petni wtadz umysłowych świadomie pragnetyby aktu eutanazji, bytoby rzecza, moim zdaniem, ograniczajaca ich wolność, rzecza haniebna, niezezwolenie na to. Pod warunkiem sprawdzenia oczywiście, czy działaja dobrowolnie, czy nie jest to wyraz jakiegoś nacisku rodziny, która jest zmęczona zajmowaniem się jakimś człowiekiem chorym.

Nowe rozwiązania prawne, które są przygotowywane przez określone partie jako spełnienie obietnic wyborczych (tu przygotowana przez SLD ustawa o dopuszczeniu eutanazji), są prezentowane z jednej strony jako realizacja interesu jednostkowego, z drugiej - jako niezagrażające interesowi jednostkowemu. Realizacja interesu jednostkowego często ulega skomplikowaniu z powodu konieczności negocjowania zakresu ingerencji państwa w życie obywateli. Określone rozwiązania prawne mogą być również odrzucane z pozycji argumentu mówiącego o naruszeniu wolności osobistej, jak w poniższym przykładzie.

KD: A, jak pani styszała, tutaj tė̇ się pojawit taki gtos: lewica chce tego, prawica chce tego. My rozmawiamy o bardzo indywidualnych, bardzo intymnych i niezwykle skomplikowanych decyzjach.

WN: Ja chciatabym zwrócić uwagę na to, że nie we wszystkich krajach kwestia przerywania ciązy jest regulowana prawem. W Kanadzie na przyktad od nie/ od bardzo/ od paru lat wprowadzono takie prawo, że nie ma prawa, że tak/ te kwestie po prostu nie podlegaja regulacjom prawnym, sa wytacznie $w$ gestii medycyny, lekarzy, procedur medycznych. [...] przecież w większości krajów rozwiniętych w Unii Europejskiej, w Kanadzie, w Stanach Zjednoczonych właśnie tak jest, że kobieta po prostu mówi, czy chce kontynuować cią̇ę, czy nie, i zgodnie z tym ciąża jest przerwana albo kontynuowana, tu nie ma nic bulwersujacego, dziwnego, to raczej my stanowimy taki skansen, w którym ciagle jeszcze się zastanawiamy nad tym, kto powinien decydować o tym zamiast kobiety.

(„Debata”, TVP 1, 18.11.2004; dziennikarz - KD: Kamil Durczok; gość - WN: Wanda Nowicka)

Dziennikarz ujawnia instrumentalizację problemów społecznych i sygnalizuje upolitycznienie sporów w sferze publicznej (lewica chce tego, prawica chce tego). Dzieje się tak, ponieważ w debacie publicznej największe poparcie gwarantują te propozycje rozwiązań ważnych spraw społecznych, które realizują interes jednostkowy, interes grupowy oraz nadrzędny interes publiczny (lub sa 
jako takie przedstawiane). Skuteczne działanie komunikacyjne jest z kolei optymalnym sposobem legitymizacji osób publicznych. Wskazywanie przez dziennikarza na interes partykularny jest już działaniem w kierunku delegitymizacji.

\subsubsection{Strategie delegitymizacji}

Delegitymizacja podmiotów życia publicznego, przede wszystkim władzy, jest odwrotnością legitymizacji i polega na utracie aprobaty społecznej, wycofaniu poparcia, akceptacji społeczeństwa. Może mieć różny zakres (całościowy, fragmentaryczny) i różne przyczyny. Najczęściej wynika ze spadku zdolności systemu do zaspokajania potrzeb społecznych i związanego z tym niezadowolenia obywateli (Żyro 2004), co uzewnętrznia się w wypowiedziach o charakterze wartościującym.

Podejmowanie strategii aksjologiczno-emotywnych przez uczestników dyskusji publicystycznych wiąże się z poznawczym opanowaniem rzeczywistości społecznej o znacznym stopniu skomplikowania. Wielopłaszczyznowość komunikowania, która była uprzednio sygnalizowana (płaszczyzny, systemy komunikowania, sfery życia społecznego), powoduje, że na zjawiska społeczne można patrzeć z różnych perspektyw. Oznacza to, że wiele zależy od konceptualizacji zjawiska, kategoryzacji, nominacji. Duży zakres zmienności społecznego odbioru rzeczywistości ujawnia się w dyskusjach.

Jak wykazano w punkcie 1.2.2.1, najskuteczniejszym działaniem komunikacyjnym, które zapewnia legitymizację podmiotów sfery publicznej jest przedstawianie propozycji regulacji jako tych, które realizują interes społeczny i nie są sprzeczne $\mathrm{z}$ interesem jednostkowym. Zgoda co do priorytetów nie gwarantuje porozumienia, gdyż dość ogólna kategoria interesu publicznego może być odmiennie postrzegana i werbalizowana. Różnice zależą od poziomu kompetencji poznawczych, ale również od interesów politycznych (które są jednak ukrywane).

Złożony kontekst komunikacyjny zawęża zakres możliwych punktów, z perspektywy których można podjąć kontrargumentację. Negatywna ocena może dotyczyć zdolności poznawczych przeciwnika (dyskredytacja poznawcza) lub czystości intencji (dyskredytacja moralna). W obu przypadkach chodzi o wykazanie, że przeciwnik nie jest wart poparcia, ponieważ albo nie rozumie, czego wymaga interes społeczny, albo działa wręcz z rozmysłem przeciwko niemu, mając na uwadze jedynie własną korzyść. W poniższym przykładzie rozmówca stosuje strategię aksjologiczno-emotywną, negatywnie ocenia propozycję partii rządzącej (zła metoda). Uzasadnia to dbałością o system prawny, co można rozumieć jako realizację interesu publicznego (podtrzymanie zaufania do państwa prawnego).

MS: [...] $w$ tej chwili, jeśli stawiamy jedno pytanie generalne: co zrobić, żeby nie doszło do przedawnienia procesu, to bardzo zła metoda, żeby na tle tej konkretnej sprawy doprowadzać do wprowadzenia w systemie prawnym środków nadzwyczajnych, ekstraordynaryjnych, które maja// 
KD: Krótko mówiąc, panie profesorze, nie podoba się panu to, co proponuje PiS.

MS: Nie podoba mi się ze względu na to, że mamy do czynienia ze środkiem, który jest interwencja związana $z$ doraźnie tocząca się sprawa, z konkretnym toczacym się postępowaniem. To jest niedobry obyczaj, ponieważ, bez względu oczywiście na intencje, które jak sądzę wymagają docenienia, chodzi o zakończenie procesu, który bulwersuje opinię publiczna, i potrzebne są te środki być może nadzwyczajne, ale nie w ten sposób, ponieważ to burzy zaufanie do państwa prawnego. Burzy zaufanie, ponieważ stwarza sytuację, kiedy mamy do czynienia z nieprzewidywalnościa regut prawa $i$ to $w$ odniesieniu do prawa karnego.

(„Debata”, TVP 1, 3.03.2005; dziennikarz - KD: Kamil Durczok; gość - MS: Marek Safian)

Rozmówca, który bierze udział w konflikcie politycznym (nie podoba się panu to, co proponuje PiS) wie, że uzasadnianie stanowiska z perspektywy interesu politycznego jest mniej skuteczne ${ }^{9}$. Powołuje się więc na niezgodność nowych regulacji prawnych z interesem publicznym, jakim jest, według niego, budowanie zaufania do państwa prawa. Ze względu na emocjonalne zaangażowanie opinii publicznej, oponent nie odmawia całkowicie racji proponentom. Obiera strategię balansu i miękkiego oponowania. Można ją określić opisowo jako strategię: „Dobrze, ale nie w ten sposób”. Rozmówca dostrzega konflikt wartości: z jednej strony poczucie sprawiedliwości społecznej, konieczność osądzenia winnych; z drugiej - norma polegająca na niezmienianiu reguł prawa dla jednej sprawy. Strategia balansu pozwala dokonać hierarchizacji wartości, ale nie zrazić do siebie opinii publicznej. W konflikcie politycznym pozwala nie zgodzić się na rozwiązania konkurencji, choć nie oznacza pomijania problemu. Mamy tu więc do czynienia z dyskredytacją poznawczą, polegającą na sygnalizowaniu, że przeciwnik źle rozpoznał sytuację z powodu niewystarczających kompetencji: to, co identyfikuje jako doraźną realizację interesu społecznego, w dłuższej perspektywie nią nie jest. Rozmówca występuje z pozycji nauczyciela, osoby pouczającej rozmówców. W przypadku konfliktu interesów partykularnych, politycznych dochodzi więc do uszlachetnienia motywacji, ponieważ argumentacja oponenta jest znacznie skuteczniejsza, jeśli odwoła się on do interesu publicznego. Taktyczność tego typu działań jest wyraźna w dopasowaniu strategii.

\subsubsection{Dopasowanie strategii}

Dopasowanie strategii legitymizacji i delegitymizacji obserwujemy głównie w sytuacji rywalizacji, kiedy nie ma zgodności poglądów, a żadna ze stron nie dąży do porozumienia. Wówczas działania rozmówców zmierzają do umocnienia własnej pozycji i pogrążenia przeciwnika. Dopasowanie strategii polega

${ }^{9}$ Interes polityczny jest traktowany jako partykularny, a więc taki, który służy interesom wąskiej grupy dążącej do władzy, a nie zawsze społeczeństwu. Nasze badania pokazują, że wskazanie na polityczny interes przeciwnika ma w dyskusji wartość oskarżenia. Przekonania te nie pokrywają się z wiedzą politologów, którzy traktują politykę szerzej i bez ujemnego wartościowania. 
zatem na odpowiedniości zachowań według schematu: akcja - reakcja. Jeśli na przykład strona inicjująca wprowadza jako pierwsze posunięcie taktykę dyskredytacji moralnej przeciwnika z powodu skutków podjętych przez niego działań (naruszenie interesu jednostkowego), to druga strona stara się zneutralizować zarzut i uprawomocnić sposób działania. Równolegle do tych zabiegów stara się podważyć pozycję i prawomocność przeciwnika. Poniżej zaprezentowano tabelę, w której działania komunikacyjne proponentów i oponentów zostały opisane jako kroki taktyczne podjęte w celu realizacji określonych zadań. W opisie wykorzystano uogólnione kategorie poznawcze typowe dla dyskursu publicznego, takie jak: sfera prywatna/sfera publiczna, interes jednostkowy/interes publiczny.

PS: [...] Niedtugo mamy kampanię wyborczą. Być może dlatego téz pojawit się [temat lustracji]. Ja uważam, że tak naprawdę jest to temat, który budzi duże kontrowersje, po pierwsze dlatego, gdyż może ranić osoby, które tak naprawdę nie braty udziału świadomie $w$ tych wszystkich akcjach [...].

MD: [...] teczki powinny zostać ujawnione, ale tylko $i$ wytacznie tych osób, które będa sprawować misję publiczna, czyli polityków, dziennikarzy, prawników. I jeżeli ktoś nie chce, żeby jego dane zostały udostępnione do oceny wtaśnie spoteczeństwa, wówczas nie powinien zajmować się działalnościa publiczna. $W$ przeciwnym razie wszystko to powinno być jawne, wtaśnie żeby nie manipulować.

PB: Czyli podnosi pan tę kwestię, że przy okazji wrzucania tych wszystkich teczek do jednego worka i potem wysypania tych teczek, można bardzo wiele osób skrzywdzić. Co państwo na to?

PZ: Ujawnienie tych materiałów jest konieczne chociażby dlatego, żeby skończyć wreszcie tak zwana „wojnę teczkowa” w naszym kraju. Jeżeli tego nie załatwimy teraz, będzie się to jeszcze przez dtugie lata/ będzie się to czkawka odbijało. Dzisiaj ci, którzy maja dostęp do tych materiałów, korzystaja $z$ tego, postuguja się szantażem i tylko ujawnienie tych materiałów może doprowadzić do tego, że tym nieuczciwym politykom wytracimy argumenty $z$ ręki. Myślę, że przeciwnicy, ludzie, którzy się boją ujawnienia tych teczek, to albo coś mają na sumieniu, albo po prostu mają $w$ tym jakiś interes i postugują się wtaśnie szantażem.
Oponent wskazuje na polityczną instrumentalizację tematu.

Odrzuca proponowane rozwiązanie prawne jako to, które godzi w interes jednostkowy; innymi słowy, jest wtargnięciem w sferę prywatną. Pośrednio jest to dyskredytacja moralna proponentów.

Proponent dokonuje symbolicznej transpozycji zagadnienia ze sfery prywatnej do sfery publicznej - lustrację przedstawia nie jako krzywdę jednostki, lecz jako kontrolę osób publicznych. Dzięki temu neutralizuje zarzut naruszenia interesu jednostkowego w wyniku nowych regulacji. Uzasadniając regulację prawną, przedstawia ją jako realizację interesu społecznego.

Dziennikarz powtarza argument oponentów, występując w roli rzecznika interesu jednostkowego.

Proponent uzasadnia konieczność lustracji dbałością o interes publiczny.

Jednocześnie oskarża przeciwników o interesy partykularne, manipulację, chęć szantażu. Stosuje zatem taktykę moralnej dyskredytacji przeciwnika. 
\begin{tabular}{|l|l|}
\hline MB: Musimy pamiętać, że to nie jest tak, że te & Proponent uzasadnia proponowane rozwiąza- \\
teczki sa niedostępne $i$ ich nie ma po prostu. & nia prawne realizacją interesu publicznego, po- \\
Teczki są i wglad ma do nich waska grupa lu- & legającego na ograniczeniu nieprawidłowości, \\
dzi, którzy operuja tym, zbieraja haki. I poka- & wyeliminowaniu kryminalizacji życia publicz- \\
zuja to wszystkie afery po kolei, że sa te teczki & nego. \\
i przy jakiejś tam okazji można wyciagną́, & \\
można kogoś szantażować. Jeżeli/ wybiórczo & \\
właśnie. I jeżeli to odtajnimy, jeżeli to będzie & \\
powszechnie wiadomo, nie będzie żadnego ma- & \\
teriału do nieczystej walki. & \\
\hline
\end{tabular}

(„Debata”, TVP 1, 20.01.2005; dziennikarz - PB: Piotr Baron; goście - MD: Marcin Domagała, PS: Paweł Sochacki, PZ: Paweł Zanin)

Rywalizujące strony działają w sposób przewidywalny i uschematyzowany w celu uzyskania społecznego poparcia i obniżenia wiarygodności przeciwnika. Działania te można opisać jako strategie o ograniczonym inwentarzu posunięć. Proponenci przedstawiają własne rozwiązanie prawne (tu: lustrację) jako to, które odpowiada interesowi publicznemu i starają się zneutralizować zarzut o naruszeniu interesu jednostkowego. Neutralizacji służy zmiana kategoryzacji. Ingerencję prawną, czyli lustrację, kategoryzują nie jako naruszenie prywatności, ale jako procedurę sprawdzenia, która również ma na celu realizację interesu publicznego (żeby nie manipulować, szantażować). Oponenci natomiast wskazują na niezgodność nowych rozwiązań z interesem jednostkowym (krzywda, niesprawiedliwość).

Dodatkowo obie strony stosują strategię dyskredytacji moralnej, która odsłania kulisy rywalizacji. Proponenci oskarżają przeciwników lustracji o ukryte cele partykularne. Sugerują więc, że występowanie pod sztandarami obrony praw jednostki należy uznać za chwyt taktyczny. Oponenci też dopatrują się ukrytych intencji u zwolenników lustracji, a mianowicie instrumentalizacji tematu, który ma służyć ich politycznej legitymizacji.

W kolejnym przykładzie, mimo innego tematu, również odnajdujemy podobne działania.

MC: [...] bytem goracym orędownikiem wprowadzenia dwóch zapisów, które w jakimś stopniu mogtyby dyscyplinować adwokatów. Pierwsza kwestia to dotyczyta nakładania kar pieniężnych porzadkowych za nieusprawiedliwione niestawiennictwo na rozprawie, a wiemy o tym doskonale, że jest to plaga. Druga kwestia: obciażanie kosztami postępowania [...]. Natomiast okazato się, niestety, że w komisji sejmowej ta kwestia upadta. Wiadoma jest rzecza, że sędziowie nie moga być członkami parlamentu, natomiast adwokaci tak. No i nie będę tego ukrywat, że lobby [adwokatów odrzucito// [...]

PK: Szanowni państwo, sięganie do metod autorytarnych wobec adwokatów, [ja wiem//

MC: [Ale to nie sa metody autorytarne.

PK: -chwileczke, jest bardzo efektowne, ale pamiętajmy o jednej rzeczy, że adwokat, żeby efektywnie wykonywać swoje prawo do obrony, nie może się bać. Jeśli on się będzie bać, że/ różnie 
jest $z$ sędziami, panie sędzio. Ja mam ogromny szacunek dla polskich sędziów, ale tak jak w każdym środowisku są też osoby, które nie powinny tego zawodu wykonywać. Jeżeli da się tego typu broń do ręki, zwtaszcza sędziom młodym, asesorom niedoświadczonym, to boję się, że prawo do obrony staje sie fikcja. Dla mnie większym dobrem jest zagwarantowanie adwokatowi swobodnego wykonywania zawodu, niż czessto iluzoryczna obrona przed iluzorycznym nadużywaniem funkcji przez adwokata.

(„Debata”, TVP 1, 3.03.2005; goście - MC: Marek Celej, PK: Piotr Kruszyński)

Proponent, w celu uzyskania aprobaty społecznej, prezentuje określone regulacje prawne jako zgodne z interesem społecznym. Nazywa je dyscyplinowaniem adwokatów. Jednocześnie dyskredytuje oponentów, zarzucając im obronę interesów partykularnych, niezgodnych z interesem społecznym. Reprezentant oponentów podejmuje działania komunikacyjne w celu odzyskania społecznego poparcia dla działań swojej grupy. W tym celu zmienia kategoryzację działań proponentów, nazywając je sięganiem do metod autorytarnych. Wskazuje na niezgodność nowych regulacji z interesem społecznym (prawo do obrony staje się fikcja). W przykładzie tym mamy do czynienia z dwoma skrajnie różnymi odbiorami rzeczywistości, w których zarówno pojęcia, jak i relacje między nimi są rozbieżne. W kolejnym przykładzie rozmówcy zachowują zgodność co do kategoryzacji pojęć, chociaż inaczej je porządkują.

KD: [No dobrze, ale mówicie „legalizować miękkie narkotyki”. Sa przykłady na to, że od miękkich się zaczyna, a na twardych się kończy i wpada się w jakieś dno i dramat.

Gpr: To dlatego, że rynki//

KD: No wtaśnie o to chcę zapytać. Dlaczego waszym zdaniem chcecie/

Gpr: To dlatego, że rynki sa nierozdzielone. Dlatego, że ta sama osoba, która diluje trawę, diluje też twarde narkotyki i $w$ jej interesie leży zaproponować swoim klientom te narkotyki, które spowoduja gorsze dla nich skutki.

KD: Ale to [pan tylko potwierdza, że to jest naturalna droga od miękkich do twardych. [...]

$\mathrm{JH}$ : Ale w Holandii, od kiedy sa coffee shopy, zmniejszyło się zużycie twardych narkotyków. Poza tym kontrola państwa w tej kwestii doprowadziłaby do tego, że twoje dziecko [do oponenta] kiedyś może nie sięgnie po jakiś środek nie widomo czym nafaszerowany, tylko coś, co jest bardziej bezpieczne.

(„Debata”, TVP 1, 10.02.2005; dziennikarz - KD: Kamil Durczok; goście - Gpr: gość anonimowy z grupy proponentów, JH: Jadwiga Hermanowicz)

Celem dziennikarza jest wykazanie nieracjonalności działania, polegającego na wprowadzeniu określonej regulacji prawnej. W tym celu porządkuje relacje między istotnymi pojęciami, takimi jak używanie narkotyków miękkich, używanie narkotyków twardych. Stosuje schematy poznawcze oparte na relacji łączenia i wynikania (jeśli zaczniesz od narkotyków miękkich, to skończysz na twardych). Proponent stosuje inny schemat poznawczy w celu racjonalizacji działania: oddzielenie, rozłączność (zalegalizowanie miękkich narkotyków rozdzieli rynki, oddzieli użytkowników narkotyków twardych; legalność kontrolowanych narkotyków miękkich stanowi alternatywę dla nielegalnych narkotyków 
twardych i niekontrolowanych domieszek). Aczkolwiek strategie porządkowania relacji między pojęciami są różne, to można je uznać za dopasowane pod względem przeciwstawności (oponent buduje relację łączenia, wynikania, a proponent buduje relację oddzielenia, rozłączności). Obaj rozmówcy starają się wykazać, że tylko ich propozycje są zbieżne $\mathrm{z}$ interesem publicznym, jeśli przyjąć, że jest nim eliminowanie, ograniczanie lub co najmniej kontrolowanie zjawiska narkomanii. Tak więc dążenie do optymalnej realizacji interesu publicznego jest elementem trwałym w debacie, różnice powstają na tle odmiennych dróg realizacji.

Większą złożonością poznawczą cechują się działania, w których rozmówcy biorą pod uwagę jednocześnie interes jednostkowy oraz publiczny. Wówczas można dostrzec pewną prawidłowość. Otóż w argumentacji zmierzającej w kierunku poparcia określonych rozwiązań wykazuje się zbieżność interesu jednostkowego, grupowego i interesu społecznego. W argumentacji podważającej sensowność rozwiązań dowodzi się niezgodności interesu jednostkowego i interesu publicznego.

JH: Gdy chodzi o Holandię, to bardzo dobrze wiadomo, co się robi z tymi ludźmi, natomiast $w$ krajach, $w$ których eutanazja nie jest prawnie uregulowana $i$ po prostu jest dokonywana „na dziko”, nie bardzo wiadomo, co sie z ludźmi robi. Nie tylko eutanazja w czystej postaci jest problemem. Jeszcze bardziej tak zwane znieczulenie przedśmiertne, które, no, jest przypadkiem wątpliwym i jest nieostra granica między nim a taka klasyczna eutanazją. Prawo stuży wtaśnie uregulowaniu tego. [...] Chodzi o to, żeby po prostu uregulować te $i$ inne sprawy, zwiazane $z$ opieka paliatywna, $z$ ostatnim okresem życia pacjenta. I $w$ krajach, gdzie ona jest nieuregulowana, wszystko jest pozostawione sumieniom lekarzy i często przypadkowi. [...] potrzebne jest prawo, które to ureguluje. I w niektórych bardzo rozwiniętych krajach takie prawo jest stanowione, $\underline{\text { bo }}$ takie jest/ oczekiwania społeczeństwa. Takie jest żadanie ludzi. I jakoś to działa.

(„Debata”, TVP 1, 24.02.2005; goście - ADz: Andrzej Dziedziul, JH: Jan Hartman)

Regulacje prawne są przedstawione jako realizujące interes społeczny (bo takie jest/ oczekiwania społeczeństwa) i jednocześnie zabezpieczenie praw jednostki, polegające na eliminowaniu sytuacji niepożądanych (eutanazja [...] jest dokonywana „na dziko”, nie bardzo wiadomo, co się z ludźmi robi; [kiedy] wszystko jest pozostawione sumieniom lekarzy i często przypadkowi).

ADz: Ja się zawsze boję, że taka dyskusja jest ustawiona na poziomie, że można pomóc tylko środkiem medycznym. Hospicja mają doświadczenie, że człowiek po prostu cierpi catościowo $i$ dyskusja o eutanazji powoduje, że my mamy większe problemy z chorymi którzy/ których trzeba więcej przekonać, że oni nie sa tak zupetnie odrzuceni. [...] Znaczy, ja styszę coraz częściej i tak jak mówitem/ i to jest wynik dyskusji o eutanazji, dlatego że prawo ksztattuje nasze widzenie, kim jest człowiek. [...] Ja towarzyszytem, przygotowatem do śmierci kilka tysięcy osób i sytuacje sa często dramatyczne. Jeżeli my prawnie dajemy prawo, mówimy: „Nie warto o nich walczyć, bo się nie moga rozwijać".

Oponent przeciwstawia interes jednostkowy osób, które dyskutują o eutanazji, bo źle rozumieją, na czym polega pomoc pacjentowi (taka dyskusja jest ustawiona na poziomie, że można pomóc tylko środkiem medycznym) - interesowi 
publicznemu, jakim jest ochrona ludzi chorych. Wskazuje na niezgodność między prawem do eutanazji a społeczną akceptacją chorych terminalnie (Jeżeli my prawnie dajemy prawo, mówimy: „Nie warto o nich walczyć, bo się nie moga rozwijać”). Widać zatem, że to, z czym nie zgadza się oponent, jest przedstawiane co najwyżej jako interes jednostkowy, i to niezgodny z interesem ogólnym. Te same propozycje regulacji prawnych są przedstawione przez proponenta jako realizacja zarówno interesu publicznego, jak i jednostkowego. Zatem strategie proponentów i oponentów obejmują takie działania taktyczne, jak: pomniejszanie/ powiększanie (np. rangi problemu), zawężanie/rozszerzanie (zakresu problemu) i zgodność/niezgodność (np. interesów na różnych poziomach odniesienia).

Działania dziennikarzy i ich rozmówców przebiegają w przestrzeni społecznej, ale poddane są również rygorom komunikowania masowego, uwzględniają normy komunikacji publicznej i cele komunikacji politycznej. Sfera prywatna i sfera instytucjonalna stanowią także ważne punkty odniesienia dla działających podmiotów sfery publicznej. Złożony kontekst komunikacyjny dostarcza ogólnych kategorii pojęciowych, koniecznych do uporządkowania i uschematyzowania aktywności komunikacyjnej rozmówców. Niezależnie od jednostkowych, konkretnych i zmiennych elementów treściowych, wszelkie działania rozmówców podejmowane są w ramach relacji, które wyznaczają systemy komunikowania. Strategie, które stanowią pewne uschematyzowanie działań, są nastawione na realizację celów pragmatycznych, ale muszą respektować normy coraz bardziej skomplikowanych systemów komunikowania.

Wpływ sfery publicznej na debaty medialne polega na tym, że zachowania komunikacyjne jej uczestników są odnoszone do standardów zachowań w tej sferze. Problemy jej funkcjonowania stają się źródłem tematów. Zależności są jednak dwustronne: publiczny charakter przekazów masowych wymusza ich formę, a przekazy te biorą udział w kształtowaniu sfery publicznej. Typowe dla najprostszych relacji społecznych strategie kooperacji, rywalizacji, strategie grzecznościowe (strategie zagrożenia twarzy pozytywnej, negatywnej, strategie obrony twarzy) odnajdujemy również w komunikowaniu publicznym, ale zwielokrotnienie uwarunkowań skutkuje większą złożonością strategii. Rywalizacja polityczna, działalność publiczna, formułowanie komunikatów medialnych wymaga więc specyficznych kompetencji komunikacyjnych w realizowaniu bardziej skomplikowanych strategii.

Biorąc pod uwagę zasięg komunikowania, należy zatem uwzględnić normy funkcjonowania sfery publicznej. W regulacji dostępu do niej i zapewnieniu skuteczności podmiotom zaangażowane są dwie przeciwstawne (chociaż dopasowane) strategie: legitymizacji i delegitymizacji.

Strategie legitymizacji, których celem jest uprawomocnienie, stworzenie wrażenia reprezentatywności, prawowitości, są realizowane przez:

- powoływanie się na otwartość sfery publicznej, jej regulację przez normy prawne (np. argumenty mówiące o obronie wolności słowa, argumenty z przeciwieństwa), 
- występowanie w roli społecznej, reprezentowanie (rzeczywistych lub hipotetycznych) interesów grup społecznych, odwoływanie się do pozytywnego stereotypu roli (np. stereotypu matki),

- powoływanie się na zasługi (np. działalność opozycyjną dysydentów), doświadczenie i wiedzę,

- prezentację nowych rozwiązań jako realizujących interes jednostkowy $\mathrm{i}$ interes publiczny, lub przynajmniej niesprzecznych z tymi interesami.

Strategie delegitymizacji, których celem jest pozbawienie aprobaty społecznej, wycofanie poparcia, symboliczne wyeliminowanie przeciwnika, są realizowane przez:

- dyskredytację moralną (oskarżanie o kłamstwo, manipulację, złe intencje, niskie pobudki, partykularne interesy, ograniczanie wolności słowa, nadużycie władzy),

- dyskredytację prześmiewczą (kpinę, etykietowanie, obraźliwe porównania, marginalizujące, ośmieszające kategoryzacje),

- dyskredytację alienacyjną, towarzyską (sugerowanie obcości, niezrozumiałości z powodu przebywania $\mathrm{w}$ dziwnym, podejrzanym towarzystwie),

- dyskredytację komunikacyjną (oskarżanie o brak kompetencji, nieznajomość i nieprzestrzeganie reguł debaty publicznej, nieznajomość konwencji gatunkowych, arogancję, brak ogłady i dyplomacji),

- dyskredytację zawodową, np. rozpatrywanie czyjegoś działania z pominięciem roli społecznej (czyli jako prywatną napastliwość, złośliwość, opieszałość, pozbawienie czyjegoś działania motywacji publicznej), wykazywanie szkodliwości działania (np. destabilizacji społeczeństwa),

- wykazywanie, że rozwiązania proponowane przez przeciwnika są niezgodne z interesem publicznym i/lub naruszają interes jednostkowy.

\subsection{Strategie i ich uwarunkowania ze względu na sposób komunikowania}

Ze względu na sposób komunikowania się wyróżniono komunikowanie interpersonalne, czyli bezpośrednie oraz komunikowanie masowe, czyli pośrednie. Cechą komunikowania interpersonalnego jest jedność nadawania i odbioru, spowodowana bezpośrednim kontaktem „twarzą w twarz” i wywołująca natychmiastowe sprzężenie zwrotne. Komunikowanie interpersonalne jest dwustronne, co skutkuje wymiennością ról nadawcy i odbiorcy. Relacje, jakie łączą uczestników, mogą mieć zarówno charakter nieformalny, jak i formalny (Dobek-Ostrowska 2006: 73). Komunikowanie masowe to proces emisji komunikatów od nadawcy medialnego do publiczności za pomocą technicznych środków masowego przekazu. W porównaniu z komunikowaniem bezpośrednim następuje zerwanie jedności przestrzeni, a często i czasu, co powoduje jednokierunkowość komunikacji i brak możliwości (w ogóle lub jednocześnie) interakcji. 
Pośredni sposób komunikowania sprawia, że program publicystyczny jako przekaz telewizyjny jest osadzony w dwu sytuacjach: sytuacji traktowanej globalnie, czyli makrosytuacji, i sytuacji traktowanej lokalnie, czyli mikrosytuacji. Elementami makrosytuacji są: instytucjonalny nadawca medialny, odbiorca masowy i zachodzące między nimi relacje. Podział ról nadawcy i odbiorcy jest trwały, a przestrzenne oddzielenie uniemożliwia bezpośredni kontakt (Miodunka, Ropa 1979: 63-75). Anna Krupska-Perek zwraca uwagę na różny stopień scalenia makro- i mikrosytuacji (Krupska-Perek 2002: 493-499). Najogólniej mikrosytuacja, którą cechuje bezpośredniość, jest zanurzona w makrosytuacji, która jako relacja między autorem, prezenterem a widzami jest zapośredniczona przez środki techniczne.

Zmienność dystansu między makro- i mikrosytuacją jest zależna od roli dziennikarza i formuły programu. W programach, w których widz „podsłuchuje” rzeczywisty dialog, mamy do czynienia zaledwie ze stycznością obu sytuacji. Wyraźne osadzenie mikrosytuacji w makrosytuacji zapewniają profesjonalne działania dziennikarza, który kieruje dialogiem, porządkuje go wokół tematu, czasem prowadzi pozorowany dialog z widzem. Osłabieniem makrosytuacji jest wycofanie się dziennikarza do roli inicjatora i organizatora, czego przykładem jest wywiad (przewaga strategii informacyjno-weryfikacyjnych). Wraz ze wzrostem dominacji autora, który realizuje własne intencje (przewaga strategii aksjologiczno-emotywnych), tworzy ramę delimitacyjną w postaci wprowadzenia, podsumowania - „makrosytuacja staje się pełną strukturą komunikacyjną” (Krupska-Perek 2002: 498).

Zabiegi tego rodzaju są stosowane z myślą o odbiorcy masowym, który jest bardzo ważny dla nadawcy medialnego. Podejmuje zatem wiele działań (i bardziej zorganizowanych strategii) $\mathrm{w}$ celu zbudowania i podtrzymania tej trudniej uchwytnej relacji. Jak twierdzi Dobek-Ostrowska, profesjonalizm nadawcy medialnego polega w dużej mierze na wykorzystaniu „fachowych umiejętności oraz talentu do wytwarzania i podtrzymywania związków z publicznością" (Dobek-Ostrowska 2006: 76). Zbudowanie oraz podtrzymanie relacji jest bowiem warunkiem wpływania na odbiorcę masowego, wszelkiego rodzaju zabiegów perswazyjnych, manipulacyjnych.

Chociaż masowy odbiorca jest anonimowy dla nadawcy, to różne sygnały pojawiające się w programach wskazują na próby jego określenia. Publiczność przed telewizorami jest projektowana w programie: najogólniej jako przedstawiciele społeczeństwa (rozumianego jako ogół lub grupy społeczne) o określonych potrzebach, oczekiwaniach (w ramach komunikowania społecznego), ale również jako wyborcy (komunikowanie polityczne), obywatele (komunikowanie publiczne), ale przede wszystkim jako widzowie (komunikowanie masowe). Proporcje między dominującymi sposobami projektowania odbiorcy masowego i podejmowanymi w związku z tym strategiami wiążą się z celami mediów, ich bardziej komercyjnym lub bardziej publicznym nachyleniem. To, jak media 
pojmują swoją rolę w demokracji liberalnej, przekłada się na rodzaj hipotez na temat odbiorcy (w dwu skrajnych ujęciach: spragniony rozrywki widz czy zatroskany o dobro publiczne obywatel).

Przeanalizujmy przykłady w celu zobrazowania tego, w jaki sposób działania w mikrosytuacji mogą być globalnie nakierowane na realizację celów makrosytuacyjnych. Badamy jednocześnie, jaki jest stopień scalenia mikro- i makrosytuacji. W poniższym przykładzie rozmówcy stosują w mikrosytuacji strategię informacyjno-weryfikacyjną. W makrosytuacji jednak można dopatrywać się również celu wyraźnie nastawionego na realizację potrzeb widza (np. w ramach poszukiwania przez niego informacji, rady).

PB: [...] Być może pan zna odpowiedź na pytanie, czy jest możliwy uchwytny taki moment. kiedy cztowiek staje sie narkomanem?

KJ: No nie. Ten moment/ $w$ zasadzie nie da się go zauważyć. To na początku jest zabawa później/ później nagle się okazuje, że stat się problem.

PB: A może zadam pytanie inaczej: w którym momencie człowiek zaczyna się bać? Bać o siebie. Czy w ogóle zaczyna się bać? Czy jest taki moment?

KJ: Ja myślę, że to/ to sa chwile, kiedy/ kiedy pojawiaja się pierwsze takie trudne sytuacje życiowe - to może być konflikt z policja, to może być, nie wiem, utrata pracy. Jakieś takie zdarzenia.

PB: Ale proszę powiedzieć, czy to jest tak, że potrzebna jest wtedy pomocna dtoń, czy można wyjść samemu. Innymi słowy, czy narkoman może poradzić sobie ze swoim problemem sam?

$\mathrm{KJ}$ : Ja osobiście nie znam narkomana, który by sobie sam poradzit z tym problemem.

PB: A kto jest wtedy najbardziej pomocny?

KJ: Pracuję w Monarze. Monar leczy narkomanów. Monar prowadzi terapię. Więc to jest instytucja, która jest chyba największym specjalista na świecie w tej dziedzinie.

PB: Zaczęliśmy od tego, kiedy człowiek staje się narkomanem i czy jest możliwy uchwytny taki moment. [...]

(„Debata”, TVP 1, 10.02.2005; dziennikarz - PB: Piotr Baron; gość - KJ: Kuba Jędrachowicz)

Rozmówcy stosują zasadę kooperacji: dziennikarz zadaje pytania, rozmówca w roli eksperta odpowiada zgodnie ze stanem swojej wiedzy. Dziennikarz dla potrzeb tej sytuacji odgrywa rolę mniej kompetentnego, aby pozyskać informacje dla widza. Jednak cały ciąg konwersacyjny globalnie wobec odbiorcy masowego ma illokucyjną wartość ostrzeżenia ${ }^{10}$. Jako realizacja strategii nadawczo-odbiorczej, sekwencja ma na celu poszerzenie grupy odbiorców programu, a więc tych, którzy mogą odnaleźć w nim istotne informacje i rady. U podstaw strategii leży organizacja pojęciowa rzeczywistości, a mianowicie zakreślenie granic

${ }^{10}$ Ostrzeżenie jest odmianą rady i należy do aktów mowy, których celem jest ustalenie sposobu działania, rozwiązania problemu życiowego. Autorzy Wprowadzenia do gramatyki komunikacyjnej eksplikują go następująco: „Stosując akt mowy, nadawca proponuje odbiorcy podjęcie korzystnego dla niego (odbiorcy) działania lub zaniechanie niekorzystnego dla niego (odbiorcy) działania, podkreślając możliwość powstania niekorzystnych dla odbiorcy warunków w przypadku niewykonania przez niego zaproponowanych działań” (Awdiejew, Habrajska 2006: 117). 
pojęć: narkoman/nienarkoman (w znaczeniu osoba używająca okazjonalnie narkotyków). Można założyć, że celem dziennikarza i rozmówcy jest przekonanie odbiorcy, iż granica między pojęciami jest nieostra. Wartość illkokucyjną ostrzeżenia kształtuje podanie skutków działań: „konflikt z policją, utrata pracy”, strategiczne powiązanie pojęć: „najpierw zabawa, potem problem” oraz wartościujące określenia, np. „bać się”. Elementy te stanowią realizację warunków pragmatycznych, niezbędnych i koniecznych dla wprowadzenia zmiany w układzie interakcyjnym (Awdiejew, Habrajska 2006: 50). Jako posunięcie strategiczne w budowaniu relacji z odbiorcą masowym sekwencja ma uprzedzić kontrargument okazjonalnego użytkownika narkotyków „ta debata mnie nie dotyczy, kontroluję zażywanie narkotyków”.

W strukturze debaty o narkomanii ten segment stanowi ekspozycje problemu w wymiarze indywidualnym, w odróżnieniu od dalszych segmentów, w których omawia się problem w wymiarze społecznym, ogólnym. Motywacja umieszczenia przytoczonej powyżej sekwencji jest typowo retoryczna i perswazyjna (chociaż dydaktyzm nie jest nachalny, przyjmuje akceptowalną formę). Jak wynika z przykładu, dziennikarz przyjmuje perspektywę widza, a dzięki podwójnemu zorientowaniu strategii prowadzonej w mikrosytuacji - również na niego oddziałuje.

Świadomość podwójnej sytuacji komunikacyjnej wpływa także na strategie gości. Odbiorca medialny jest właściwym adresatem strategii obrony twarzy pozytywnej, która jest nie tyle prowadzona wobec przeciwnika, co odgrywana teatralnie wobec widza. Strategie dyskredytacji są również bardziej dotkliwe dla rozmówców, ponieważ przeprowadzone przy zwielokrotnionej (w porównaniu z mikrosytuacją) publiczności.

MS: Przepraszam, ale ja zostałam obrażona. Najpierw przez pania jako pseudohumanista, teraz przez pana, jako osobę sfiksowana [sic!]. [Ja stanowczo protestuję.

DK: [Nie, nie, nie. Przepraszam, to stowo byto użyte//

MS: Pan pozwoli, że teraz ja [powiem kilka stów.

DK: [Nie, to ja przepraszam. Wycofuję się. [Chodziło mi o skoncentrowana//

MS: [Nie ma żadnego fanatyzmu ani zacietrzewienia w tym [...].

(„Debata”, TVP 1, 24.02.2005; goście - DK: Dariusz Karłowicz, MS: Maria Szyszkowska)

Zachowanie komunikacyjne rozmówczyni jest dobrym przykładem obrazującym podwójną sytuacyjność dyskusji telewizyjnych. Profesor Szyszkowska wskazuje na sytuację, w której nastąpiło zagrożenie jej twarzy (obraza). Nie oczekuje jednak przeprosin od rozmówcy, lecz oddania głosu, po czym kieruje wypowiedź do publiczności (teraz ja powiem kilka słów). Niepodejmowanie rozmowy z redaktorem Karłowiczem, zignorowanie jego prób autokorekty - świadczy o prymacie makrosytuacji nad interakcją w mikrosytuacji. W gruncie rzeczy bowiem rozmówczyni nie zależy na dojściu do porozumienia $\mathrm{z}$ bezpośrednim rozmówcą, sprawcą obrazy, lecz na odzyskaniu wiarygodnego wizerunku 
w oczach odbiorców zewnętrznych, do których przede wszystkim kieruje swoją wypowiedź.

W mikrosytuacji nie tylko gość może być ignorowany. W skrajnych sytuacjach, sytuacjach konfliktu, również dziennikarz, chociaż jest gospodarzem programu i odgrywa nadrzędną rolę, bywa pomijany, a nawet atakowany. Dochodzi wtedy do kłótni medialnej, w której rozmówcy blokują nawzajem swoje posunięcia komunikacyjne, uwyraźniając jednocześnie relacje w makrosytuacji.

JK: Nie przeszkadzało panu wielokrotnie wspótpracować z lewa strona sceny politycznej $i$ obiektywizm pański w tej sytuacji jest bardzo kwestionowany.

AM: I z panem też wspótpracowatem. Byt pan wielokrotnie w tym programie i mógt pan mówić, co chce.

JK: I może/ i może/ czy pan mi w ogóle pozwoli coś powiedzieć? Czy może mi pan pozwoli? Prosze państwa, sami państwo widza, że tu po prostu nic nie//

AM: Prawda, to jest $z$ panem wspótpraca i taka sama byta moja wspótpraca $z$ lewa strona.

JK: Można powiedzieć? Nic nie można powiedzieć!!

(„Teraz my!”, TVN, 3.10.2006; dziennikarze - AM: Andrzej Morozowski, TS: Tomasz Sekielski; gość - JK: Jacek Kurski)

Rozmówca atakuje dziennikarza, zarzucając mu brak obiektywizmu, co należy uznać za celny atak z perspektywy standardów zawodowych (nie rozstrzygamy zasadności ataku, a jedynie dopasowanie rodzaju zarzutu do roli społecznej dziennikarza). Nie podejmuje jednak dyskusji. Można zatem wnioskować, że nie interesuje go tłumaczenie dziennikarza. Nie chce go dopuścić do głosu. Jego strategią jest dyskredytacja dziennikarza i wygłoszenie swojego przesłania dla widzów. Nie jest zainteresowany wyjaśnieniem dziennikarza, nie nawiązuje do jego wypowiedzi, pomija je, chce wręcz zablokować jego argumenty, żeby nie trafiły do opinii publicznej. Wyraźnym sygnałem makrosytuacyjnym jest bezpośredni zwrot do widzów, których bierze za świadków (Proszę państwa, sami państwo widza, że tu po prostu nic nie//).

W kolejnym przykładzie z tego samego programu dziennikarz stosuje blokadę posunięć rozmówcy. Nie pozwala wyjaśnić tego, o co sam wcześniej pytał. Podejmuje strategię dyskredytacji prześmiewczej (szyderstwo), co powoduje kłótnię i kolejny zwrot do widzów jako odbiorców.

JK: Tusk z Gdańska i Schetyna dziś akurat z Wroctawia. Krótko mówiąc, cała czwórka Platformy i SLD byta poinformowana o waszej prowokacji, panowie.

TS: Ale panie pośle, jakie to ma znaczenie?

AM: [niewyraźny fragment] na, na pytanie, a jakie to ma znaczenie?

JK: To jest po prostu/ to jest po prostu, co pan robi teraz//

TS: Ale panie pośle, ale przepraszam bardzo, jakie to ma znaczenie?

JK: To ma takie znaczenie, prosze pana, że kiedy Solidarność rozjeżdżano gasienicami czotgów w latach osiemdziesiatych, to pan Milan, to pan Milan Subotić//

TS: To my planowaliśmy nagranie Renaty Beger, wtedy już.

JK: To Milan Subotić/ proszę pana, no strasznie pan dowcipny, ale takiego chamstwa to 
ja jeszcze nie spotkatem się w telewizji. Myśle, że podobnie to oceniaja widzowie. Niech sobie panowie//

TS: Myślę, że tak, panie pośle, myślę, że tak.

Rozmówcy nawzajem blokują swoje posunięcia komunikacyjne, stosują dyskredytację zawodową i prześmiewczą, powołują się na odbiorcę medialnego jak na arbitra sporu.

W kolejnym fragmencie dochodzi do skrajnych działań polityka, który, ignorując dziennikarzy w roli organizatorów programu, korzysta z pośrednictwa mediów, by wygłosić oświadczenia i ogłoszenia. Wyraża się negatywnie o publiczności w studiu, która reaguje śmiechem na zachowania rozmówcy i krytykuje formułę programu.

TS: Dobrze, panie pośle, kończymy. Dziękujemy za wizytę w studiu. Teraz państwo zobacza materiat//

JK: Nie proszę pana, czy pan mi pozwoli powiedzieć?

TS: Nie panie pośle, kończy się nasz czas.

JK: Otóż wyrażam nadzieje, że wasza prowokacja nie spotka się z pozytywnym odzewem spoteczeństwa.

TS: $\underline{\text { Juz sie spotkata. }}$

JK: Ludzie po tej prawdzie o Suboticiu// [śmiech widowni]

TS: Panie pośle, dziękujemy panu bardzo.

JK: Gratuluje doboru obiektywnego publiczności. Zobaczycie państwo, że ludzie po tej prawdzie, która ludzie zobaczyli z WSI, przejrza na oczy i zobacza, że to byta ohydna próba obalenia rzadu $i$ spotkamy sie 7 pazdziernika o godzinie 13:00 pod Pałacem Kultury w wiecu poparcia dla rzadu. Zobaczycie wtedy, ilu nas jest.

TS: To byta reklama. Ci, którzy chca, niech ida popierać rząd. Dziękujemy panu postowi Kurskiemu za wizytę.

JK: Ale formuta tego spotkania byta skandaliczna. Nie daliście mi dojść do głosu.

TS: Pan nam daje oczywiście.

Niezależnie od licznych naruszeń konwencji grzecznościowych i konwencji komunikowania publicznego, przytoczona kłótnia charakteryzuje się bogactwem sygnałów, które wskazują na jej makrosytuacyjne odniesienie: rozmówcy blokują nawzajem swoje posunięcia komunikacyjne, kierując właściwe przesłanie do widzów (strategie zagrożenia twarzy pozytywnej, dyskredytacja zawodowa dziennikarzy, dyskredytacja prześmiewcza gościa, obrona twarzy pozytywnej), zwracają się bezpośrednio do widzów jako świadków kłótni. Można również zauważyć duży udział strategii metatekstowych i metadyskursywnych, które mają za zadanie sterowanie odbiorem działań przeciwnika (np. Nic nie można powiedzieć; Nie daliście mi dojść do głosu).

Zważywszy na osadzenie przekazu telewizyjnego w dwóch sytuacjach, należy stwierdzić, że strategie komunikacyjne uczestników programów podejmowane są ze względu na odbiorcę medialnego, natomiast jawność odniesień, zwroty do widzów - stanowią dodatkowe uwyraźnienie złożoności sytuacji. 
W dwu kolejnych punktach zajmiemy się zatem makrosytuacyjnymi uwarunkowaniami działań dziennikarza (i w mniejszym zakresie rozmówców), które w istotny sposób determinują formę oraz treść przekazu masowego. Z racji sposobu komunikowania można założyć, że wszelka aktywność dziennikarza powinna być nastawiona na budowanie relacji z odbiorcą masowym. Jednak skuteczność i efektywność tych zabiegów jest zależna m.in. od czynników indywidualnych, w tym kompetencji dziennikarza. Punkty 1.3.1 i 1.3.2 zostaną poświęcone temu, w jaki sposób podwójna sytuacyjność determinuje cel illokucyjny w mikrosytuacji oraz jak świadomość masowego odbioru wpływa na strategie rozmówców, a przede wszystkim strategie dziennikarzy.

\subsubsection{Działania dziennikarza związane z makrosytuacyjnymi uwarun- kowaniami formy przekazu (organizacja strukturalna programu)}

Podstawową rolą dziennikarza jest organizowanie interakcji w programie telewizyjnym. Wiąże się z tym uwyraźnienie makrosytuacji komunikacyjnej poprzez formuły początkowe i końcowe, zawierające bezpośrednie zwroty do odbiorcy masowego oraz poprzez segmentację śródtekstową, mającą orientować widza w makrostrukturze tekstu.

\subsubsection{Działania związane $\mathrm{z}$ delimitacją ramową tekstu}

Działania dziennikarza w fazie otwarcia i fazie zamknięcia programu są schematyczne oraz podporządkowane konwencjom grzecznościowym. Powtarzalność formuł każe w nich widzieć zachowania rytualne, czyli czynności powtarzalne i tworzące jakiś zwyczaj (Podracki, Wszeborowska 2004: 88). Zachowania grzecznościowe, które tworzą swoistą dla sytuacji oficjalnej etykietę językową, odgrywają ważną rolę ze względu na walor pozytywnej autoprezentacji i budowanie relacji społecznych.

Powitanie i pożegnanie jest wprowadzane do programu ze względu na odbiorcę masowego ${ }^{11}$, służy nawiązaniu oraz wygaszeniu kontaktu z nim, zgodnie z przyjętymi kulturowo strategiami grzecznościowymi. Zachowania grzecznościowe są dodatkowo sygnałami początku i końca interakcji w programie. Rozpoczęcie programu (oprócz powitania) wiąże się fakultatywnie z podaniem jego tytułu, przedstawieniem gości i krótkim wprowadzeniem w tematykę. Dziennikarz może skierować osobne formuły powitalne do widzów, a następnie do gości, lub jedno ogólne powitanie.

\footnotetext{
11 Nawet kiedy dziennikarz wita się z gośćmi w studiu, to występuje jako gospodarz programu i jako reprezentant widzów. Akt powitania jest bowiem wprowadzony ze względu na makrosytuację. Według reguł grzeczności gospodarz programu powinien przywitać gości w momencie pierwszego kontaktu, a więc prawdopodobnie przed rozpoczęciem programu.
} 
KD: Witam państwa. Witam naszych gości. Gości za stołem głównym.

(„Debata”, TVP 1, 8.02.2006; dziennikarz - KD: Kamil Durczok)

KD: Dobry wieczór państwu. Już za chwilę zaczynamy „Debatę”.

(„Debata”, TVP 1, 25.01.2006)

Kolejnym sygnałem ramowym jest przedstawienie gości wraz z podaniem ich roli, funkcji.

JD-O: Witam państwa i witam naszych gości, a sa nimi dzisiaj $w$ studiu $w$ Warszawie ksiądz Józef Kloch, rzecznik Konferencji Episkopatu Polski i Tomasz Terlikowski, publicysta, a w studiu w Krakowie ksiadz Tadeusz Isakowicz-Zaleski.

(„Kwadrans po ósmej”, TVP 1, 26.11.2008; dziennikarka - JD-O: Justyna Dobrosz-Oracz)

Przedstawienie gości może przybrać bardziej rozbudowaną formę.

KL: Dobry wieczór. „30 minut”. Witam państwa. Dziś w nietypowej scenerii i formule. Nasi goście sa liczni, zatem nie stoimy za pulpitem, lecz siedzimy, co nie oznacza, że jesteśmy rozluźnieni. Temat jest na tyle goracy, że wydaje się grozić, kto wie, może nawet bijatyka na antenie. Na razie goście uśmiechaja się. Witam zatem i przedstawiam: $w$ studio $w$ Krakowie odwołany świeżo z funkcji prezesa telewizji Bronistaw Wildstein, który mówi o sobie, że zostat odwołany za niezależność. Dobry wieczór, [czy pan mnie styszy?

BW: [Dobry wieczór. Tak, tak styszę.

KL: Cieszę się. W studio w Warszawie od mojej lewej ręki pan poset Mateusz Piskorski $z$ Samoobrony, pan poset Krzysztof Bosak z Ligi Polskich Rodzin. Obaj być może udziatowcy tego, co się wydarzyto. A po mojej prawej ręce pani Janina Jankowska, szefowa Rady Programowej TVP i pan Michat Karnowski z „Dziennika”. Przypomnę Państwu, że oczekujemy/ zgodnie z zapowiedziami w naszym programie powinien wziać także udziat Jacek Kurski, który uchodzi za animatora tego wszystkiego, co się ostatnio zdarzyło, powinien pojawić się w naszym studio $w$ Gdańsku już za chwile, ale jak wiem, jeszcze $w$ tej chwili go nie ma.

$$
\begin{array}{r}
\text { („30 minut”, TVP 3, 3.03.2007; dziennikarz - KL: Krzysztof Leski; } \\
\text { gość - BW: Bronisław Wildstein) }
\end{array}
$$

Zwraca uwage dramatyczne wykreowanie sytuacji komunikacyjnej w studiu. Opis dziennikarza przypomina bowiem didaskalia sztuki teatralnej (Dziś w nietypowej scenerii $i$ formule). Sztuczność interakcji, która wiąże się z jej przeznaczeniem dla odbiorcy medialnego, polega na ograniczeniu spontaniczności zachowania (Temat jest na tyle goracy, że wydaje się grozić, kto wie, może nawet bijatyka na antenie. Na razie goście uśmiechaja się). Teatralizacji interakcji służy prezentacja gości rozbudowana o element uzasadnienia ich udziału w programie. Widać zatem, że inicjalne działania dziennikarza mogą być tyleż wprowadzeniem, ile reklamą programu. Nieneutralna forma inicjacji ma pobudzić ciekawość masowego odbiorcy. Tego typu rozbudowane działania inicjalne świadczą o postępującej karnawalizacji w dyskursie politycznym. Jej przejawem jest prymat obecności obserwatora, co skutkuje retorycznym wymiarem komunikacji, jarmarczna teatralizacją, odrzuceniem konwencji „na serio”. Przede wszystkim jednak można 
dostrzec obecność elementów metatekstowych, stanowiących wskazówkę co do odgrywanych ról (Zgółkowa, Klauzińska 2004: 255-260).

TL: „Tomasz Lis na żywo”. Witam państwa. Jeden z wielkich bohaterów antykomunistycznej opozycji. Redaktor naczelny Gazety Wyborczej. Jedna z najważniejszych postaci wspótczesnej Polski. Dziś w pierwszym telewizyjnym wywiadzie od ponad pięciu lat - Adam Michnik. O te rozmowę staratem się wiele lat, ale człowiek z którym rozmawiałem, publicznie wypowiadat się $w$ ostatnich latach niechętnie. Od ponad pięciu lat nie udzielit żadnego telewizyjnego wywiadu. Aż do dziś.

(„Tomasz Lis na żywo”, TVP 2, 8.11.2008; dziennikarz - TL: Tomasz Lis)

Oprócz stałych elementów w fazie otwarcia dziennikarz umieszcza wypowiedzi promujące program ze względu na rangę gościa i wyjątkowość samego spotkania. Jest to inicjacja nie tylko o funkcji delimitacyjnej i wprowadzającej, ale również reklamującej program. Prawie poufne zwierzenia dziennikarza, dotyczące trudów przygotowań wywiadu, są przejawem autotematyzmu mediów. Według Marii Wojtak autotematyzm i fatyczność to tendencje nasilające się w mediach (Wojtak 2002: 36). Z nimi związane jest pojawienie się zapowiedzi jako gatunku nie tylko informacyjnego, ale przede wszystkim perswazyjnego.

W porównaniu do fazy otwarcia o wiele skromniej prezentuje się faza zamknięcia. W krótkich programach, wywiadach ogranicza się do podziękowania i/ lub pożegnania.

MZ: Dziękuję bardzo za rozmowę.

(„Kwadrans po ósmej”, TVP1, 4.09.2008; dziennikarz - MZ: Maciej Zdziarski)

JD-O: Dziękuję panom serdecznie za udziat w dyskusji.

(„Kwadrans po ósmej”, TVP 1, 10.09.2008; dziennikarka - JD-O: Justyna Dobrosz-Oracz)

DW: Dziękuję panom za rozmowę. Dobranoc państwu.

(„Z refleksem”, TVP 1, 7.12.2007; dziennikarka - DW: Dorota Wysocka)

W ramie finalnej oprócz podziękowania, pożegnania może pojawić się zapowiedź kolejnych programów, co ma przedłużyć kontakt widza z mediami i konkretną stacją telewizyjną. Odpowiada to koncepcji neotelewizji (Casetti, Odin 1994), w której programy, jak w strumieniu, łączą się ze sobą poprzez nakładanie zapowiedzi na te, które się jeszcze nie skończyły. Coraz częstszą praktyką jest przenoszenie dyskusji po zakończeniu emisji telewizyjnej na strony internetowe.

TS: Dziękujemy za rozmowę. W naszym programie to wszystko, a już za chwile $w$ „Superwizjerze” o lekarzach, ale nie w charakterze korupcyjnym. Zapraszamy także na Onet.pl. Gościem specjalnego internetowego wydania „Teraz my!” będzie Nelly Rokita. Do zobaczenia.

AM: Dobranoc.

(„Teraz my!”, TVN, 8.06.2008; dziennikarze - AM: Andrzej Morozowski, TS: Tomasz Sekielski) 
AM: Kończymy teraz na antenie TVN.

TS: I już teraz zaczynamy dogrywkę na antenie TVN24 od razu bez przerwy.

(,Teraz my!”, TVN, 27.10.2008)

KD: To byta „Debata”. Bardzo państwu dziękuję za uwagę. Przypominam, że jeszcze „Debata” na stronie internetowej www.itvp.pl będzie się toczyta przez kilka minut. Tam między innymi pytania internautów. Dziękuję bardzo. Życzę dobrej nocy.

(„Debata”, TVP 1, 4.01.2006; dziennikarz - KD: Kamil Durczok)

O wyraźnie delimitacyjnej funkcji podziękowania jako sygnału zakończenia świadczy poniższy fragment ze środkowej części programu.

BW: [...] Ale ja przepraszam, ja chciatbym/ pozwolę sobie na jedna krótka rzecz. Ponieważ nie dane mi byto pożegnać się ze swoimi wspótpracownikami, pracownikami generalnie, no to chciatem bardzo podziękować tym wszystkim, z którymi miatem przyjemność pracować przez krótko, dziewięć miesięcy, no ale bardzo, myślę, intensywny i dla obu stron owocny czas. Chciałem podziękować również widzom. Tak, to na teraz.

KL: Co nie znaczy, że w tej chwili kończymy nasz program. Ja mam nadzieję, że pan Wildstein zostaje z nami jeszcze te dwadzieścia parę minut.

BW: Ależ oczywiście, oczywiście [...].

$$
\text { („30 minut”, TVP 3, 3.03.2007; dziennikarz - KL: Krzysztof Leski; }
$$
gość - BW: Bronisław Wildstein)

Rozmówca w środkowej części programu stosuje grzecznościowy akt podziękowania, skierowany do pracowników i widzów. Dziennikarz odczytuje to działanie zgodnie ze schematem strukturalnym interakcji jako sygnał zakończenia. Wobec tego czuje się w obowiązku odwołać te oczekiwania odbiorcy (Co nie znaczy, że $w$ tej chwili kończymy nasz program). Fragment ten świadczy o konwencjonalizacji i schematyzacji zachowań komunikacyjnych, z uwagi na stałe ich występowanie w obrębie ramy tekstu.

\subsubsection{Działania związane $\mathrm{z}$ delimitacją środkową tekstu}

Odbiór tekstu telewizyjnego jest swego rodzaju zadaniem poznawczym dla odbiorcy. Wspomaganie i jednocześnie sterowanie tym odbiorem jest realizowane m.in. przez delimitację tekstu. Anna Duszak zwraca uwagę na to, że segmentacja tekstu dotyczy zjawisk globalnych. Jest to uporanie się z przestrzenią tekstową, strukturalizacja znaczeń dla lepszego ich przetworzenia. Segmenty to etapy w rozwoju interakcji, które ułatwiają odbiorcy kierunek całościowej interpretacji tekstu (Duszak 1998: 126-127). Dziennikarz w ramach zwiększania sprawności oraz efektywności odbioru stosuje strategie metatekstowe i metadyskursywne, które stanowią znaki orientacji dla widza. Są to: zapowiedzi segmentów, ustalanie kolejności i czynności rozmówców, podsumowania, streszczenia wypowiedzi, kontekstualizacja (czyli uzasadnienie, jak wypowiedź 
wpasowuje się w sytuację użycia i jak wynika z wcześniejszego przebiegu rozmowy). Zobrazowaniem działań niech będą przykłady.

KD: [po rozmowie z publicznością Chciatbym, żebyśmy postuchali tego, co mają do powiedzenia dziś nasi goście. Panie profesorze, panie ministrze, doktadnie 23 lata temu strzelano do górników w kopalni „Wujek”.

(„Debata”, TVP 1, 16.12.2004; dziennikarz - KD: Kamil Durczok)

Dziennikarz stosuje sygnał delimitacji środkowej - zapowiedź dyskusji z gośćmi. Zapowiedź jest skierowana do całego audytorium, w tym również do widzów (chciatbym żebyśmy postuchali; my - czyli, jak można przypuszczać, zarówno publiczność w studiu, jak i widzowie).

KD: Ale momencik, momencik, uspokajamy i czyścimy przedpole, dobrze? Ja zadałem pytanie i państwo odpowiedza, okay? Nie przekonuje was ten przykład?

Gpr: Znaczy, ja chciatem się dowiedzieć od kolegi, dlaczego twoim zdaniem przeszedteś do narkotyków ciężkich. Jak byś mógł to troszkę rozwinać.

Gpr: Czyli musiateś zacząć od papierosów.

Gop: Nie, to jest tak, że dajesz sobie przyzwolenie, prawda. Marihuana już/ zaczęto się od marihuany, później jest amfetamina, potem//

Gpr: Ale przecież nie musisz// [wielogłos]

KD: Dobrze. Byto pytanie, byta odpowiedź. Tu byta teoria, tu byta praktyka. Wracamy/ bardzo prosze, prosze państwa, wracamy do rozmowy przy gtównym stoliku.

(„Debata”, TVP 1, 10.02.2005; dziennikarz - KD: Kamil Durczok, goście - Gop: anonimowy gość z grupy oponentów, Gpr: anonimowy gość z grupy proponentów)

Dziennikarz podejmuje działania organizacyjne, aby zapanować nad dużą grupą dyskutantów (kilkadziesiąt osób w studiu). Przebieg interakcji jest żywiołowy i pełen emocji, więc prowadzący musi jej nadać formę, która byłaby czytelna dla odbiorcy przed ekranem. W tym celu nazywa zachowania komunikacyjne (pytanie, odpowiedź), powtarza treść pytania, wskazuje na makrostrukturę tekstu (Tu byta teoria, tu byta praktyka), wygasza wątki, zapowiada zmianę rozmówców (z publiczności na gości przy głównym stoliku), co stanowi sygnał delimitacji tekstu. Bez działań organizacyjnych dziennikarza zapanowałby chaos, co mogłoby zakłócić odbiór masowy programu.

ZF: W Internecie załóżmy, że realizacja postulatu, prawda, ujawnienia całego wykazu agentury będzie oznaczała, że na przykład zostanie zamieszczona $w$ Internecie jakaś lista, powiedzmy około 200 tysięcy nazwisk z informacja, że ktoś wspótpracuje od któregoś tam roku, i koniec. Próba, że tak powiem, zweryfikowania tej informacji jest możliwa tylko w ten sposób, że się zagląda do teczki pracy agenta. Natomiast teczek pracy agenta jest nie aż tak wiele, jest około 40 tysięcy//

KD: Krótko mówiac, ja rozumiem, że pan chce powiedzieć, że przekazany zostanie opinii publicznej nieprawdziwy obraz rzeczywistości.

ZF: W dużym stopniu. I nie do zweryfikowania.

KD: Pan Czestaw Bielecki. [...]

(„Debata”, TVP 1, 20.01.2005; dziennikarz - KD: Kamil Durczok; gość - ZF: Zbigniew Fijak) 
Dziennikarz dokonuje podsumowania, streszczenia wypowiedzi, w którym globalnie ujmuje jej treść i intencję nadawcy (pan chce powiedzieć, że). W streszczeniu pojawia się również kategoria odbiorców nazwana opinia publiczną. Działanie organizacyjne dziennikarza nie tylko stanowi dla widza sygnał orientacji w odtwarzaniu makrostruktury tekstu, ale również reguluje przejęcie tury. Prowadzący dostosowuje swoje działania do sytuacji, kiedy jest wielu dyskutantów. Wówczas należy mówić krótko i formułować na koniec konkluzję, do której mogliby się odnieść pozostali rozmówcy.

RL: Przepraszam, ale dajemy się wciagać w jakieś niemadre spory ideologiczne. [...] To [rozważania na temat tolerancji] przecież jest bez sensu [...]. Ale jakie prawa? Panie redaktorze, no albo rozmawiamy//

KD: Ja panu powiem, jakie prawa. No takie prawa, jakie tydzień temu przyjąt Senat, czyli na przykład akceptację związków partnerskich osób tej samej ptci. Oni o to walcza, demonstruja w tej sprawie i w ich stronę leca kamienie. Pytanie: czy to dobrze, czy nie i czy świadczy to o, stowa pan nie lubi, ale ja go będę niestety używat - tolerancji, czy braku tolerancji.

(„Debata”, TVP 1, 9.12.2004; dziennikarz - KD: Kamil Durczok; gość - RL: Ryszard Legutko)

Dziennikarz przypomina ważne wątki dotychczasowej dyskusji oraz wyjaśnia, w jaki sposób wynika z nich pytanie makrostrukturalne. Dokonuje więc kontekstualizcji pytania, które zostało podważone przez rozmówcę (Ale jakie prawa?). Przywoływanie strategicznych punktów dyskusji jest reakcją na kilkakrotne podważenie przez rozmówcę sensu debaty. Działania strukturalne i tekstotwórcze dziennikarza mają stanowić przeciwwagę dla zabiegów dezintegracyjnych rozmówcy. Stanowią sygnał przede wszystkim dla widza, że debata przebiega zgodnie z planem i stanowi spójną całość, a nie, jak sugeruje rozmówca, bezsensowne dywagacje.

Z kolei w działaniu rozmówcy można zauważyć strategiczne wykorzystanie warunków tekstowości ${ }^{12}$. Deprecjonujące nazywanie działań komunikacyjnych proponentów (niemądre spory, to jest przecież bez sensu) jest niczym innym, jak tylko komunikacyjną dyskredytacją, która blokuje dyskusję. Odpowiedzią na strategię niekooperacyjną jest strategia metadyskursywna dziennikarza, która kontekstualizuje pytanie i zręcznie przenosi zarzuty oponenta do sfery prywatnych uwarunkowań, a właściwie uprzedzeń (stowa pan nie lubi).

MC: Proszę państwa, małe sprostowanie. Ten proces nie toczy się lat 12, bo musimy zauważyć, jakie byty przerwy w tym procesie. Otóż pierwszy akt oskarżenia wptynąt w'93 roku i zostat zwrócony prokuraturze celem uzupetnienia. I bez mała 5 lat później prokuratura wystapita ponownie z aktem oskarżenia. Przez te 5 lat badano wszystkie dokumenty. Szukano przede wszystkim odpowiednich biegłych, którzy by sobie poradzili z wyliczeniem strat, jakie ponióst fundusz.

12 Autorzy Wstępu do lingwistyki tekstu wyróżniają siedem kryteriów tekstowości, a więc warunków, które muszą być spełnione, aby tekst był funkcjonalny, skuteczny i stosowny: kohezję, koherencję, intencjonalność, akceptabilność, informatywność, sytuacyjność i intertekstowość (de Beaugrande, Dressler 1990: 15-32). 
KD: I to wszystko doprowadzito do sytuacji, w której dzisiaj jest ten wyścig, o którym mówitem na poczatku. Zdązymy przed przedawnieniem, czy nie zdązymy. Czy w tym wyścigu adwokaci walcza czysto, czy nie?

(„Debata”, TVP 1, 3.03.2005; dziennikarz - KD: Kamil Durczok; gość - MC: Marek Celej)

Dziennikarz sprawnie włącza wypowiedź rozmówcy do struktury debaty jako tło wydarzeń (zaimek anaforyczny „to”). Dokonuje kontekstualizacji pytania makrostrukturalnego (Czy w tym wyścigu adwokaci walcza czysto, czy nie?). W tym celu buduje relację przyczynowo-skutkową między elementami rzeczywistości (coś doprowadziło do czegoś), przypomina wprowadzone na początku słowo kluczowe (wyścig) i w nawiązaniu do niego stawia pytanie. Działania dziennikarza zmierzają do wywołania wrażenia, że struktura debaty jest koherentną całością. Spójność i całościowość są bowiem warunkami budowania sensownej reprezentacji tekstu w trakcie odbioru.

KD: Czy panowie nie uważaja, że sędzia Kryże trochę jest sam sobie winien? [...] Może po prostu nie trzeba byto aresztować tymczasowo oskarżonej?

MS: Myślę, że to jest zły trop. Znaczy jest ztym tropem w tej chwili analizowanie dokładne szczegótów tej sprawy i podejmowanie decyzji tutaj, w tym gronie, o tym, czy byt popetniony bład czy nie, bo my nie jesteśmy w gruncie rzeczy uprawnieni do tego, żeby tego rodzaju sady ferować.

KD: Tak, panie profesorze, ale diagnoza pozwala uniknać btędu.

(„Debata”, TVP 1, 3.03.2005; dziennikarz - KD: Kamil Durczok; gość - MS: Marek Safian)

Dziennikarz zadaje pytanie, które rozmówca odrzuca jako nieuprawnione. W strategii metadyskursywnej wykorzystuje swoją wiedzę na temat konwencji dyskursu, w ramach której trzeba mieć pozwolenie na dany rodzaj działania komunikacyjnego. Działanie to musi być dopuszczalne w ramach roli społecznej, zgodne z kompetencjami i nie może naruszać kompetencji innych podmiotów (my nie jesteśmy $w$ gruncie rzeczy uprawnieni do tego, żeby tego rodzaju sady ferować). Rozmówca strategicznie wykorzystuje zatem wiedzę na temat normy dyskursu, aby zamknąć niewygodny dla siebie wątek ${ }^{13}$. Jego działanie można więc potraktować w ramach organizacji retorycznej jako jedną ze strategii oponowania. Dziennikarz dostosowuje swoją strategię po to, aby uzasadnić racjonalność podjętych działań. Stosując, podobnie jak przedmówca, strategię metadyskursywną, nadaje bieżącemu segmentowi programu funkcję w strukturze całości. Nazywając segment „diagnozą”, wprost i dobitnie wskazuje odbiorcy, jak należy go rozumieć (nie ingerujemy w kompetencje sędziów, ale dokonujemy rozpoznania sytuacji). Schemat działań strategicznych wygląda następująco:

13 Zawsze pozostaje otwarte pytanie, czy rozmówca występuje w obronie norm i standardów, czy też wykorzystuje je strategicznie do obrony, do dyskredytacji przeciwnika, pozbawienia go argumentu. W interpretacji działań należy brać pod uwagę rodzaj układu interakcyjnego, cele rozmówców. Sytuacja rywalizacji wskazuje raczej na grę, w której normy dyskursu są wykorzystywane instrumentalnie. 
- podważenie prawa do zadania pytania z powodu braku uprawnień do określonych działań w układzie komunikacyjnym: sędzia - osoba nieuprawniona,

- odzyskanie prawa do zadania pytania na podstawie roli dziennikarza w układzie komunikacyjnym uczestników debaty publicznej: obywateli zainteresowanych kwestiami publicznymi.

KM: Proszę państwa, ta debata nie bedzie miała sensu tak dtugo, jak będziemy tylko mówić o przeszłości sprzed dwóch, trzech lat. Bardzo istotna kwestia, i być może najważniejsza, ja tak odebrałem to swoje zaproszenie na ta debatę dzisiaj, jest kwestia przyszłości, to znaczy decyzji zwiąanych z pozostaniem badź nie w Iraku. Ale jeśli pozostanie, to na jakich warunkach. [...] pytanie nie należy w tej chwili formutować: co byto przyczyna wojny, bo jest to pytanie, o które tak naprawde politycy się spieraja. Ja mam szczęście być w centrum - to raz, i nie być politykiem - to dwa. W związk z tym nie muszę/ mogę spokojnie na ten temat mówić, ale te ż ważniejsze jest w tej chwili myślenie kategoria, co w najbliższych kilku miesiacach badź kilku latach.

KD: No tak, tylko panie profesorze, tylko żeby sobie odpowiedzieć na pytanie, czy warto zostawać w Iraku, czy warto prowadzić te operacje przez pięć miesięcy jeszcze, dziesięć miesięcy, dwadzieścia miesięcy, w każdym razie w jakiejś perspektywie czasowej, to trzeba sobie odpowiedzieć na pytanie o bilans tej naszej obecności dwuletniej. I teraz, jeśli tak stawiamy kwestię, to ja sie pytam, po co tak naprawde byliśmy tam przez te dwa lata.

KM: Tego bilansu nie dokonaja politycy $w$ tej chwili, ponieważ kwestia iracka zostata upolityczniona skrajnie w momencie, kiedy doszło do wojny, a właściwie w czasie przygotowań do tej wojny. W zwiazku z tym tak dtugo będa te jałowe spory, $i$ będa to spory także na linii w tej chwili partyjnej, tak dtugo, jak trzecia strona niezależna, myślę o placówkach badawczych polskich, nie zajmie się sporzadzeniem swego rodzaju raportu bilansu. Otóż jeśli premier Marcinkiewicz miat odwagę sformutować pewna koncepcję, która wydaje się niezwykle istotna, aby pewne zamierzenia rzadu $w$ sferze na przykład ekonomicznej byty oceniane przez niezależnych ekspertów/ tak powinno być.

(„Debata”, TVP 1, 4.01.2006; dziennikarz - KD: Kamil Durczok; gość - KM: Krzysztof Michałek)

Jest to kolejny przykład, w którym dziennikarz identyfikuje zachowanie rozmówcy jako próbę ingerencji w organizację dyskusji, nawet jako próbę jej ograniczenia. Strategie metadyskursywne, które podejmuje, mają na celu uzasadnienie działań, wyjaśnienie intencji, wskazanie ich celu i funkcji w strukturze całości. Są podejmowane ze względu na odbiorcę zewnętrznego, który nie zawsze jest świadom konwencji dyskursu i mógłby nie odczytać działań rozmówcy jako strategii oponowania, ale jako rzeczywiste dezawuowanie dyskusji.

Działania dziennikarza zmierzają do nadania przekazowi telewizyjnemu, którego głównym elementem jest swoisty tekst telewizyjny, cech całościowości i sensowności. $\mathrm{W}$ ich zakresie znajdują się działania związane $\mathrm{z}$ delimitacją ramową i delimitacją śródtekstową. Ze względu na odniesienie do tekstu można w tego typu działaniach widzieć strategie tekstotwórcze. Jest to związane z formalnym kształtowaniem struktury tekstu i odgraniczaniem go. Ze względu zaś na odbiorcę, orientowanie go w strukturze tekstu, w działaniach dziennikarza 
- można również dostrzec realizację strategii nadawczo-odbiorczych. Jak wynika z analizy, strategie są pojęciami, które porządkują wielowymiarowe i wielopłaszczyznowe działania (płaszczyzna tekstu, płaszczyzna relacji nadawczo-odbiorczych).

\subsubsection{Działania dziennikarzy i rozmówców związane z makrosytuacyjnymi uwarunkowaniami treści przekazu}

Według medioznawców, odbiorcy mediów to jednostki i zbiorowości aktywne, które użytkują media w sposób celowy, dążąc do osiągnięcia określonych korzyści (Mrozowski 2001: 364). Bodźcem do aktywności odbiorczej są potrzeby. Media starają się przekazywać treści, które zaspokajają ludzkie potrzeby; czuwają nad tym, aby korzyści ${ }^{14}$ uzyskane w kontakcie z mediami były satysfakcjonujące i zapewniały stały odbiór (co przekłada się z kolei na cele komercyjne mediów, wartość ich rynku reklamowego).

$\mathrm{W}$ aspekcie językoznawczym dostosowanie treści przekazu do potrzeb, perspektyw i kompetencji odbiorcy jest przejawem interakcyjności. Maria Wojtak, mówiąc o interakcyjności $\mathrm{w}$ odniesieniu do prasy, bierze pod uwagę bogaty i urozmaicony zbiór zjawisk, które sprawiają, że czytelnik powinien się czuć aktywną stroną komunikacji, a więc osobą zapraszaną do komunikacyjnego współdziałania (Wojtak 2006: 119-129). Interakcyjność jest traktowana przez badaczkę jako strategia dyskursywna, której celem jest budowanie wspólnoty. Do technik jej tworzenia autorka zalicza: zapowiedzi (powtarzane kilkakrotnie w różnej formie), niebanalną formę komunikatu (np. koncept strukturalny) oraz poradnikowy charakter. W ramach konceptu strukturalnego pojawiają się stylizacje, narracja w drugiej osobie i inne.

Wydaje się, że na interakcyjność można spojrzeć w kontekście dwustopniowego oddziaływania: najpierw nadawca dostosowuje się do odbiorcy, wczuwa się w jego świat i przyjmuje jego perspektywę, aby następnie móc na niego oddziaływać. Efektywność oddziaływania jest bowiem zależna od umiejętności wytworzenia płaszczyzny porozumienia z widzem. Prowadzenie interakcji w studiu jest podporządkowane celom makrosytuacyjnym, z czego zdaje sobie sprawę dziennikarz oraz (w zależności od przygotowania) goście. Skuteczność tego typu oddziaływania zależy od profesjonalnych umiejętności uczestników

14 Według McQuaila korzyści widza są bardzo różnorodne: informacja (np. dowiadywanie się o istotnych zdarzeniach, poszukiwanie rady w sprawach praktycznych, zaspokajanie ciekawości), poczucie tożsamości (np. potwierdzenie słuszności indywidualnego systemu wartości, znajdywanie modeli zachowań), integracja i interakcja społeczna (np. zyskiwanie substytutu rzeczywistego towarzystwa, pomoc w wypełnianiu ról społecznych), rozrywka (ucieczka od rzeczywistości, relaks, uzyskiwanie wewnętrznego zadowolenia kulturalnego) (McQuail 1983, za: Mrozowski 2001: 366). 
medialnych programów publicystycznych, które zostaną omówione w ramach strategii nadawczo-odbiorczych. Przedmiotem zainteresowania będą dwa (dopełniające się raczej niż wykluczające) rodzaje działań: dostosowanie przekazu do kompetencji odbiorcy masowego (punkt 1.3.2.1) oraz kształtowanie jego kompetencji (punkt 1.3.2.2).

\subsubsection{Strategie nadawczo-odbiorcze polegające na dostosowaniu przekazu do kompetencji odbiorcy (przyjęcie perspektywy widza)}

$\mathrm{Na}$ rolę strategii nadawczo-odbiorczych w realizacji celów uczestników konwersacji zwraca uwagę Urszula Żydek-Bednarczuk (2005: 166-169). Autorka upatruje w interakcji i strategii konwersacyjnej główne wyznaczniki wpływające na kształt tekstu. Złożoność sytuacji sprawia, że „interakcja może być rodzajem gry, w której rozmówcy przyjmują różne role społeczne i dominujący typ aktywności” (tamże: 166). Kategoria nadawców i odbiorców uwikłanych w sytuacje społeczno-polityczne stanowi dogodny punkt wyjścia dla niniejszych rozważań.

W tym punkcie pojęcie strategii nadawczo-odbiorczej stosuje się przede wszystkim w odniesieniu do makrosytuacji. Oznacza ono taki sposób prowadzenia interakcji w studiu, który jest nastawiony na budowanie relacji z odbiorcą masowym. Rozmówcy stosują wobec siebie (w mikrosytuacji) strategie konwersacyjne, które są w istocie grą prowadzoną z myślą o odbiorcy masowym. Przeznaczenie makrosytuacyjne interakcji w studiu, które wynika z typu komunikacji masowej, bywa sygnalizowane wprost przez dziennikarzy. Prowadzący przyjmuje perspektywę widza, a nawet jawnie się na nią powołuje.

KD: Panie sędzio, tylko próbuję sobie wyobrazić widza, który siedzi teraz przed telewizorem i mówi tak: 345 milionów złotych gdzieś wyparowało. Mamy coś, co media, słusznie, niestusznie, nie spierajmy się już teraz, okrzyknęty „największa afera III Rzeczpospolitej finansowa i gospodarcza”. I nagle jest opowieść o tym, ktoś zostat ministrem, jakiś obrońca tam pojawia się, albo nie pojawia, ktoś komuś wypowiada petnomocnictwo. Krótko mówiąc - jest poważna groźba, że ten proces nie zostanie zakończony $w$ takim terminie, $w$ jakim powinien, $i$ ktoś umknie wymiarowi sprawiedliwości. Czy to jest normalne?

MC: Oczywiście, że to nie jest normalne. Ja się z panem całkowicie zgadzam.

(„Debata”, TVP 1, 3.03.2005; dziennikarz - KD: Kamil Durczok; gość - MC: Marek Celej)

Prowadzący poprzedza pytanie obszernym i na tyle sugestywnym przedstawieniem punktu widzenia odbiorcy masowego, że staje się ono właściwie retoryczne. Rozmówcy nie pozostaje nic innego, jak zgodzić się z dziennikarzem. Tak więc strategia informacyjno-weryfikacyjna, na którą składa się pytanie i odpowiedź, ma globalny cel w makrosytuacji, jakim jest realizowanie funkcji perswazyjnej wobec odbiorcy masowego. 
Dziennikarz przyjmuje rolę rzecznika widza - jego perspektywę i racjonalność. Jest to racjonalność potoczna, której wykładnikami są: ekspresywna nominacja wydarzenia (345 milionów złotych gdzieś wyparowało), ironiczna kwalifikacja generyczna ekspertyzy prawniczej jako „opowieści”, deprecjonowanie argumentów podanych przez reprezentantów wymiaru sprawiedliwości jako niejasnych, nieistotnych (pomniejszenie wartości następuje przez operowanie wyznaczonością ${ }^{15}$ grupy nominalnej: ktoś, jakiś tam, komuś), wreszcie - odwołanie się do normy i ludowego poczucia sprawiedliwości, które nie uwzględnia uwarunkowań proceduralno-prawnych. Tego typu sekwencje, w których prowadzący obiera perspektywę potoczną, uproszczone, emocjonalne widzenie sytuacji, pojawiają się często $\mathrm{w}$ programach publicystycznych. W przytoczonym przykładzie dodatkowo występuje wyraźny sygnał metadyskursywny przyjęcia takiej właśnie perspektywy (próbuję sobie wyobrazić widza, który siedzi przed telewizorem i mówi tak).

IK: [...] Chciałbym zwrócić uwage, że stopień zaufania spotecznego, to, co jest tym podstawowym/ to też takie nowe pojęcie przez socjologów bardzo ostatnio używane „kapitału społecznego" - jest zaufanie. Zaufanie jest skutkiem wtaśnie partnerstwa [...].

KD: Jeśli panowie pozwola, zostawmy na chwile te narzędzia socjologiczne i wyobraźmy sobie taka oto sytuacje, że przed telewizorami w Polsce siedzi teraz duża grupa ludzi, kilka milionów i myśli sobie tak: no, z jednej strony gra w Sejmie, rozmowy, koalicje, to wszystko, o czym my przez 40 minut tego programu dyskutujemy, a $z$ drugiej strony informacja, która się dzisiaj przebija, że sa duże tereny w Polsce i duża grupa ludzi, która żyje za dwa dolary dziennie. Informacje Banku Światowego. I oni się zastanawiaja, czy doczekaja momentu, w którym ta dyskusja o polityce będzie znacznie bliższa tym problemom dwóch dolarów dziennego wynagrodzenia i przeżycia. Czy jest jakiśs sposób na to, żeby te [dwie proste się gdzieś//

BW: [To jest taka wygodna formutka. Ja sobie wyobrażam/ ja widziatem w Stanach Zjednoczonych takie/ „Proszę bardzo, tu są politycy. Oni kłócą się o jakieśs rzeczy, a tutaj są bezdomni".

KD: To nie jest wygodna formutka. To jest pytanie, czy polityka ma być sztuką rozwiązywania realnych ludzkich problemów.

(„Debata”, TVP 1, 18.01.2006; dziennikarz - KD: Kamil Durczok; goście - BW: Bronisław Wildstein, IK: Ireneusz Krzemiński)

Ważną zasadą w tworzeniu struktury programów publicystycznych o większej liczbie rozmówców jest zmiana perspektyw. Zderzenie perspektyw zapewnia dynamikę interakcji. W powyższym przykładzie dziennikarz w reakcji na wypowiedź eksperta, który zgodnie ze swoją rolą stosuje kategorie naukowego opisu (takie nowe pojęcie przez socjologów bardzo ostatnio używane „kapitału

15 Wyznaczoność, czyli charakterystyka referencyjna grupy imiennej, odpowiada za odniesienie tej grupy do przedmiotu, który nazywa (Topolińska 1984: 302). W podanym przykładzie efekt deprecjacji został wywołany przez zamianę prymarnych wyrażeń argumentowych z nazwą własną na wyrażenia argumentowe nieidentyfikujące, np. we wcześniejszych wypowiedziach: „sędzia Piwnik została ministrem sprawiedliwości”, w podanym przykładzie: „ktoś został ministrem”. 
społecznego"), wprowadza jawnie dla odmiany inną perspektywę, co jest realizacją strategii metadyskursywnej (zostawmy na chwile te narzędzia socjologiczne i wyobraźmy sobie taka oto sytuację). Wprowadzenie perspektywy widza, nękanego problemami ekonomicznymi, sugerowanie rozbieżności między życiem a polityką jest przejawem racjonalności potocznej. Na wypowiedź dziennikarza reaguje polityk, a nie ekspert, gdyż do niego odnosił się zarzut. Polityk nie podejmuje strategii kooperacyjnej, ale stara się zablokować posunięcie dziennikarza. Rozmówca uniemożliwia realizację strategii dziennikarza w ten sposób, że przechodzi na poziom komentarza metatekstowego. Stosuje posunięcie „odkryłem twoją grę", wskazując na intencjonalność i schematyzm działań (To jest taka wygodna formutka). Zarówno działania dziennikarza, jak i rozmówcy-polityka są obudowane komentarzami metatekstowymi ze względu na odbiorcę masowego. To wobec niego demaskują nawzajem sztuczność posunięć, teatralizację działań. Jeszcze wyraźniej widać to w sprowokowanej przez dziennikarza sytuacji z publicznością, w której dziennikarz sam wykorzystuje wiedzę na temat teatralności zachowań medialnych.

KD: Jeśli panowie pozwola, pan mówit o tym, jak patrza na to wszystko wyborcy, czy jakie wrażenie powstaje u wyborców. No więc wtaśnie, [zwrot wprost do kamery] patrza na to wszystko wyborcy, oceniaja i zaraz powiemy, jaki obraz wytania się z tego świata polityki, emocji, namiętności. I już za chwilę będziemy o tym rozmawiali z nasza publicznościa.

KD: Będa przedterminowe wybory czy nie będą? [zwrot do publiczności w studiu]

G: Tak. [odpowiedź zbiorowa kilku osób]

KD: Będa. To, czy będa czy nie będa, to się okaże. Bardziej mnie interesuje, bo to będziemy $w$ stanie sprawdzić, pójdziecie do tych wyborów czy nie pójdziecie? Kto pójdzie? [wiele osób podnosi rękę w górę na znak potwierdzenia] Coś mi się wydaje, że to jednak deklaracja telewizyjna jest. [śmiech]

(„Debata”, TVP 1, 18.01.2006; dziennikarz - KD: Kamil Durczok; goście - G: anonimowy gość spośród publiczności)

W działaniu dziennikarza jest kilka sygnałów makrosytuacyjnych: reasumowanie wypowiedzi gości, mówienie wprost do kamery, zapowiedź działań komunikacyjnych. Dziennikarz zadaje pytanie publiczności, oczekując konkretnej odpowiedzi, która pasowałaby do przesłania całego programu (wyborcy są rozczarowani politykami i frekwencja wyborcza będzie niska). Otrzymuje jednak odpowiedź pozytywną. W tej sytuacji stosuje strategię metadyskursywną, aby zneutralizować komunikat publiczności. Wykorzystuje taktycznie wiedzę na temat sztuczności, teatralności sytuacji komunikacyjnej w telewizji, która wyzwala zachowania nieautentyczne, nieszczere, ponieważ jest grą (Coś mi się wydaje, $\dot{z} e$ to jednak deklaracja telewizyjna jest). Wstawienie odpowiedzi publiczności w ramę interpretacyjną, którą stanowi kontekst medialny, stanowi istotną wskazówkę dla widzów. Każe mianowicie widzieć w odpowiedzi nie szczerą deklarację, ale odgrywanie roli według oczekiwanego scenariusza. 
MO-K: Ja mam czwórkę dzieci. Ja myślę, że więcej nadziei powinniśmy mieć w życiu i więcej nadziei i optymizmu wlewać w ludzkie serca. [...]

JP: No dobrze, ale ktoś powie: „Nadzieja, miłość, ale ja chcę najpierw skończyć studia, pózniej mieć stabilna sytuacje zawodowa, później mieć mieszkanie, samochód, a o dziecku pomyśle później”.

MO-K: No tak, ale to jest takie gdybanie i takie/ takie/

(„Warto rozmawiać”, TVP 2, 9.01.2006; dziennikarz - JP: Jan Pospieszalski, gość - MO-K: Małgorzata Ostrowska-Królikowska)

W kolejnym przykładzie dziennikarz wyraźnie przyjmuje rolę oponenta w celu wydobycia przekonującej argumentacji od rozmówczyni (takie jest bowiem oczekiwanie względem rozmówców, których atutem jest doświadczenie związane $\mathrm{z}$ omawianym tematem). Realizując polifoniczność wypowiedzi, prowadzący włącza do debaty wyjaskrawione nieco stanowisko jakiejś części społeczeństwa (ktoś powie). Rozmówczyni nie formułuje jednak przekonującej kontrargumentacji, lecz ogranicza się do deprecjonującego nazwania działania komunikacyjnego „gdybaniem”. Przyjęcie przez dziennikarza roli oponenta jest swego rodzaju prowokacją wobec rozmówcy, co jeszcze wyraźniej widać w kolejnym przykładzie.

LK: [...] jeżeli pan pyta, dlaczego dotychczas te osoby [te, które strzelały do górników] nie zostaty skazane mimo dwukrotnych procesów, to dlatego, że materiat, $w$ oparciu o który orzeka sad, jest zupetnie innym materiatem, niż materiat historyka. [On ma inne//

KD: Dlatego pytam o państwo prawa, a w podtekście również o pewne, ja wiem, że to jest bardzo nielubiane przez prawników określenie, o poczucie sprawiedliwości, społecznej sprawiedliwości. I zastanawiam się, czy argumentacja, której pan minister teraz używat, jest argumentacja, która może trafić do żony albo córki zabitego na .Wujku” górnika?

(„Debata”, TVP 1, 16.12.2004; dziennikarz - KD: Kamil Durczok; gość - LK: Leszek Kubicki)

Rozmówca przytacza argumenty prawne, powołuje się na racjonalność zakodowaną w systemie komunikowania instytucjonalnego, w którym reguły postępowania są ściśle wytyczone przez sformalizowane procedury. Dziennikarz dla skontrastowania wyważonej, obiektywnej i bezosobowej wypowiedzi urzędnika wprowadza do debaty perspektywę rodzin ofiar (może trafić do żony albo córki zabitego na „Wujku” górnika). Z analizy sytuacji (brak ukarania winnych) wynika, że byłby to głos pełen emocji i subiektywizmu.

W przytoczonych przykładach polifoniczne wprowadzenie głosu jakiejś części opinii publicznej przez dziennikarza miało za zadanie uzupełnienie niereprezentowanych, ale istotnych stron debaty (grup podporządkowanych, zawiedzionych działalnością instytucji, zagrożonych nałogiem, grup o niewielkiej empatii społecznej). W strukturze debaty tego typu działania są stosowane przez prowadzących w celu sprowokowania rozmówcy, sproblematyzowania tematu, zdynamizowania interakcji. Chodzi o to, żeby, z jednej strony, nie pozwolić rozmówcom na jednoznaczne zamknięcie problemu, niestabilny konsensus, z drugiej 
- aby skłonić rozmówcę do klarowniejszej argumentacji. Uczestnicy rywalizacji wykorzystują taktycznie głos opinii publicznej jako wzmocnienie siły, a więc dodatkowo jako sposób legitymizacji.

MR: No to kto ma wtadzę?

BW: W tej chwili nikt do końca wtadzy nie ma i to jest trudna sytuacja. [...]

MR: Moim zdaniem trzeba wrócić do pierwszych miesięcy rządów PiS-u. Czy rząd wtedy sprawiat wrażenie, że nie ma petnej władzy? Przeciwnie, moim zdaniem przeciętny Polak, czy przeciętny zjadacz chleba, jak stuchat wypowiedzi polityków PiS-u, to byt przekonany, że powstat stabilny rząd, wtadza, która zmienia natychmiast szefów różnych instytucji. Przecież tak to byto.

(„Debata”, TVP 1, 18.01.2006; goście - BW: Bronisław Wildstein, MR: Mieczysław Rakowski)

Rozmówca podważa opinię poprzednika. W strategii oponowania przyjmuje perspektywę przeciętnego Polaka, który interpretuje działania polityków. Stosuje przy tym racjonalność potoczną „rządzi ten, kto podejmuje decyzje dotyczące podległych mu ludzi, instytucji”. Wypowiedź ma tonację kpiarską. Rozmówca wykpiwa twierdzenie, jakoby nikt nie miał władzy. Właśnie powołanie się na naiwną obserwację powoduje, że kpina staje się jeszcze dotkliwsza (na zasadzie, że: „nawet zwykły zjadacz chleba wie, że to nieprawda, co twierdzicie”). Zatem posłużenie się perspektywą widza utrudnia kontrargumentację i jest zwiększeniem siły rozmówcy.

KD: 30 procent zwolenników, 70 procent przeciwników. Te sondaże czytają też politycy, panie pośle. Zdecydowana większość Polaków jest przeciwko tej wojnie, przeciwko naszej obecności $w$ Iraku, ale druga już ekipa polityczna decyduje się jednak na to, żeby polskie wojska w tym kraju pozostaty [...].

JM: Panie redaktorze, patrzymy na to oczywiście z punktu widzenia obywateli i nie rozumiemy dlaczego druga ekipa pcha się w ta wojnę [...].

(„Debata”, TVP 1, 4.01.2006; dziennikarz - KD: Kamil Durczok; gość - JM: Janusz Maksymiuk)

Badania opinii publicznej zostają przytoczone dla poparcia określonego stanowiska. Jak deklaracja populistyczna brzmi zapewnienie polityka, że: patrzymy na to oczywiście z punktu widzenia obywateli.

Dziennikarz, organizując interakcję w mikrosytuacji, ma wciąż na uwadze odbiorcę masowego: liczy się z jego potrzebami i stara się wczuć w jego sposób odbioru rzeczywistości społecznej i politycznej. Działania dziennikarza można porównać do gry interakcyjnej o podwójnym odniesieniu. Prowadzący pozoruje brak wiedzy wobec eksperta, wygłasza potoczne sądy na temat wydarzeń społecznych, a jednocześnie tak prowadzi interakcję, aby zrealizować globalną intencję ze względu na widza. Może to być intencja ostrzeżenia (np. przed zgubnym nałogiem), rady (jak wyjść z nałogu), wyrażenia oburzenia (np. niesprawiedliwością sądową, ekonomiczną), wyrażenia rozczarowania (polityka$\mathrm{mi})$, zachęty (np. do posiadania dzieci). Często więc za najprostszymi strategiami 
informacyjno-weryfikacyjnymi (pytanie - odpowiedź) kryją się bardziej globalne strategie aksjologiczno-emotywne lub behawioralne, podejmowane ze względu na odbiorcę masowego.

Warto wspomnieć, że ważną rolę w sygnalizowaniu perspektywy odbiorcy masowego pełnią strategie metadyskursywne. Dziennikarz korzysta z nich, projektując makrosytuację: próbuję sobie wyobrazić widza, który siedzi teraz przed telewizorem i mówi tak; wyobraźmy sobie taka oto sytuację, że przed telewizorami w Polsce siedzi teraz duża grupa ludzi, kilka milionów i myśli sobie tak; patrza na to wszystko wyborcy, oceniaja. W ramach działalności profesjonalnej dziennikarz podejmuje zatem strategie nadawczo-odbiorcze, które mają zbudować relację z widzem. Sugerując wspólnotę interesów i perspektyw, chce pozyskać jego akceptację i zapewnić mediom możliwość wpływu. Powołanie się na opinię publiczną jest również stosowane w celach perswazyjnych przez gości. Wówczas zwiększa skuteczność ich argumentacji.

\subsubsection{Strategie nadawczo-odbiorcze polegające na kształtowaniu kompetencji odbiorcy masowego}

Dziennikarz i jego rozmówcy, powołując się na odbiorcę masowego, muszą liczyć się nie tylko z jego potrzebami i perspektywą (,zobacz, jak widz to odbiera” lub „zobacz, jak widz może to odbierać”), ale również z poziomem jego kompetencji. O ile w pierwszym przypadku celem jest przede wszystkim uświadomienie gościom, politykom, jaki jest (może być) punkt widzenia opinii publicznej, o tyle w drugim przeważa już element sterowania odbiorem rzeczywistości i sterowania odbiorem komunikatów na temat rzeczywistości, ze względu na odbiorcę masowego („wyjaśnię ci, jak powinieneś to odbierać, rozumieć”).

Kształtowanie kompetencji odbiorcy jest związane z edukacyjnym celem mediów. Można przyjąć, że edukacja ta przebiega na dwóch poziomach. Pierwszy z nich dotyczy fortunnego odbioru złożonej rzeczywistości społeczno-politycznej. W tym zakresie znajduje się informowanie o faktach politycznych i edukowanie społeczeństwa na temat roli i wagi owych faktów (McNair 1998: 41). Drugi poziom odnosi się do poznawania reguł uczestnictwa w określonej formie komunikacji medialnej (Szczęsna 2007: 23), co jest warunkiem fortunnego odbioru.

Oba aspekty są trwale połączone, gdyż (jak już wspomniano) we współczesnym świecie komunikowanie publiczne, a zwłaszcza polityczne nie istnieje bez mediów. Z tego powodu media, włączając się w nurt debaty publicznej, przyczyniają się do kreowania wyobrażeń na temat sfery publicznej i wzorów uczestnictwa w niej. Kształtowanie kompetencji komunikacyjnej powinno być zwłaszcza domeną mediów elitarnych ${ }^{16}$. Należy jednak zaznaczyć, że w dzisiej-

\footnotetext{
${ }^{16}$ Media elitarne, opiniotwórcze, przekazują inny obraz polityki niż media popularne, tabloidowe. Według Mrozowskiego wyższej kompetencji komunikacyjnej wymaga przekaz, w którym
} 
szych mediach jest to raczej zjawisko wyjątkowe. W programach publicystycznych takie cele realizują przede wszystkim eksperci i ze zmiennym zaangażowaniem dziennikarze. W poniższym przykładzie konieczność wyjaśnienia odbiorcy medialnemu mechanizmów społeczno-prawnych zostaje podana wprost jako wzmocnienie argumentacji dziennikarza.

JŁ-K: [...] ta ustawa jak mówi, że sa narkotyki nielegalne, to w stosunku do każdego, kto je ma, można zastosować różne oddziatywania i tu możemy dyskutować.

KD: Tak, tylko mamy do czynienia z taka dziwna sytuacja, w której ktoś powie, że coś jest nielegalne, a jednocześnie za to nie wymierza kary. To jak ja bẹde miat wyttumaczyć/।

JŁ-K: Ale to jest taka demagogia!

KD: Nie, nie, to nie jest demagogia. To jest prosty argument. Jak ja będe miat wyttumaczyć komuś, że coś jest nielegalne, ale w zwiazku z tym nie ponosi kary. To buduje szacunek dla prawa, racjonalność prawa, wiarę $w$ to, że ono jest dobre?

(„Debata”, TVP 1, 10.02.2005; dziennikarz - KD: Kamil Durczok; gość - JŁ-K: Jolanta Łazuga-Koczurowska)

Dziennikarz początkowo wprowadza naiwną perspektywę widza (mamy do czynienia z taka dziwna sytuacja). Jednak docelowo chce skłonić rozmówczynię do argumentacji w celu wyjaśnienia widzom złożoności poznawczej regulacji prawnej. Pozoruje brak wiedzy, aby wydobyć wyjaśnienie od eksperta. Jednak rozmówczyni nie rozpoznaje strategii nadawcy medialnego, który reprezentuje widza i traktuje dziennikarza jak równego dyskutanta (Ale to jest taka demagogia). Wobec tego dziennikarz już wprost przyznaje się do roli pośrednika (jak ja będę miat wyttumaczyć komuś, że coś jest nielegalne, ale $w$ związu $z$ tym nie ponosi kary). Czyni jawnym swoje zadanie względem odbiorcy masowego (zakodowanego w wypowiedzi jako „ktoś”), nazywa je tłumaczeniem, wytłumaczeniem czegoś. Zatem dziennikarz wprowadza do dyskusji perspektywę przeciętnego odbiorcy tylko jako punkt wyjścia do bardziej złożonego odbioru rzeczywistości społeczno-prawnej.

Strategie nadawczo-odbiorcze, które mają kształtować kompetencje odbiorcy masowego, mogą polegać na wskazywaniu złożoności komunikowania politycznego, publicznego oraz umieszczaniu w tekstach wskazówek interpretacyjnych. Widz dowiaduje się, jakim transformacjom podlega informacja w obrębie tych rodzajów komunikowania. Myślenie polityczne, do którego przejawów zalicza się formułowanie sądów diagnostycznych, wyjaśniających, prognostycznych, oceniających, normatywnych, wymaga znacznych kompetencji poznawczych (Reykowski 2002b: 110). Wydarzenia społeczne (np. zmiana regulacji prawnych i debata na ten temat, udział wojsk w misji wojskowej, przypadki naruszenia prawa, funkcjonowanie instytucji publicznych) stanowią rodzaj bodźców,

polityka jest ujmowana jako proces decyzyjny i gra sił politycznych. Nacisk jest położony na fakty oraz racjonalne wyjaśnienie ich przyczyn i kontekstu. Na politykę patrzy się przez pryzmat systemu, a nie jednostkowych afer i skandali (Mrozowski 2001: 132). 
które wchodząc w obręb komunikowania politycznego, ulegają swoistej interpretacji (w ramach strategii kognitywnych). Zakodowane językowo jako kontekst wypowiedzi podlegają instrumentalizacji (np. w ramach strategii legitymizacji i delegitymizacji). Rolą dziennikarza i gości jest zatem (między innymi) sygnalizowanie złożoności komunikowania publicznego.

Rozpatrzmy fragment, w którym dziennikarz skłania eksperta do wyjaśnienia (widzom), w jaki sposób rzeczywiste wydarzenia (udział wojsk polskich w Iraku) zyskują nową funkcję w dyskursie politycznym i czym taki ogląd różni się od dyskursu eksperckiego.

KD: Pan generat Koziej powiedziat tak: „Nie można usprawiedliwiać wykorzystywania kwestii irackiej na rzecz najzwyklejszych interesów politycznych". Rozumiem, że pan generat miat na myśli pana posta Maksymiuka, Lige Polskich Rodzin, tak?

SK: Między innymi tego typu argumentacje. Otóż ja bym bardzo goraco namawiat, aby o tym ważnym, szczególnie ważnym problemie $z$ dziedziny bezpieczeństwa międzynarodowego, a także i narodowego, bo w dzisiejszym zglobalizowanym świecie trudno oddzielić bezpieczeństwo narodowe od międzynarodowego, aby o tej sprawie rozmawiać $w$ sposób racjonalny, a nie emocjonalny. Otóż badania opinii publicznej odzwierciedlaja pewne nastroje, odzwierciedlaja emocje $i$ to jest normalne prawo opinii publicznej, natomiast rząd/ rząd nie może się kierować wytącznie głosami opinii publicznej. Rząd musi myśleć strategicznie, musi myśleć dalej.

KD: Panie generale, ale jak emocjonalnie nie rozmawiać o operacji, która kosztuje życie siedemnastu polskich żotnierzy?

SK: No, rozmawiać trzeba, ale nie można decydować pod wptywem tych ocen doraźnych, chwilowych [...].

(„Debata”, TVP 1, 4.01.2006; dziennikarz - KD: Kamil Durczok; gość - SK: Stanisław Koziej)

We fragmencie są sygnalizowane trzy perspektywy: eksperta wojskowego, polityka, zwykłego obywatela, które implikują różne typy racjonalności, a więc różne typy dyskursów (ekspercki, polityczny, potoczny). W sytuacji komunikowania publicznego dochodzi do interakcji między osobami reprezentującymi te perspektywy (dziennikarz występuje w podwójnej roli: reprezentuje publiczność, referuje argumenty politycznej opozycji). To samo wydarzenie, jakim był udział polskich wojsk w Iraku, zyskuje różny sens i funkcję w kontekście odmiennych dyskursów (instrument walki politycznej, zagadnienie z dziedziny bezpieczeństwa, wydarzenie tragiczne). Zadaniem dziennikarza i jego rozmówcy jest zintegrowanie perspektyw i nadanie im pozycji w ogólnej debacie publicznej. Odbiorca medialny dowiaduje się o instrumentalizacji tematów w dyskursie politycznym. Sfera publiczna z kolei jest według eksperta polem ścierania się racji, które nie powinny rywalizować, ale współistnieć (badania opinii publicznej odzwierciedlaja pewne nastroje, odzwierciedlaja emocje $i$ to jest normalne prawo opinii publicznej, natomiast rząd/ rząd nie może się kierować wytącznie głosami opinii publicznej. Rząd musi myśleć strategicznie, musi myśleć dalej). Postrzeganie sytuacji, a właściwie jej społeczna konstrukcja są zależne od typu dyskursu, a więc od społecznych ról podmiotów debaty. W dyskursie potocznym 
ma prawo dominować aspekt indywidualny, emocjonalny (np. śmierć żołnierzy), natomiast w dyskursie eksperckim konieczne jest poszerzenie kontekstu i większa złożoność poznawcza (np. aspekt międzynarodowy, narodowy, indywidualny; chwilowe nastroje, długofalowa strategia). Specyfika dyskursu eksperckiego polega na tym, że dochodzi do zderzenia i hierarchizacji różnych aspektów.

W ramach strategii nadawczo-odbiorczych dziennikarz i umiejętnie wprowadzani przez niego eksperci ustalają kategorię faktów, nominację wydarzeń, odnosząc je do dyskursu eksperckiego, specjalistycznego (np. wojskowego, w kolejnym przykładzie - medycznego, prawnego). Jednocześnie dziennikarz zachowuje perspektywę dyskursu potocznego.

KD: No wtaśnie, to powiedzmy, że eutanazja to może być albo dziatanie, czyli podanie takiego środka, który, no po prostu, powoduje zgon, albo może być też eutanazja przez zaniechanie podania pomocy [choremu.

JH: [Jest bardzo szerokie spektrum tzw. czynów eutanatycznych. Najpopularniejszy z nich to jest zwiększanie środka, ilości podawanych środków znieczulających aż do tzw. znieczulenia przedśmiertnego, kiedy lekarz bez zamiaru uśmiercenia pacjenta podaje mu taka ilość środka znieczulającego, że ona wprawdzie nie zabija, ale uszkadza i lekarz wie, że pacjent już się z tego nie obudzi. I chodzi o to, żeby to się działo ze świadoma zgoda pacjenta. Té żeby to było uregulowane i przede wszystkim to jest powód, dla którego w niektórych krajach [pojawia się/l

KD: [I wtedy to jest pomoc pacjentowi, a nie zabójstwo wedlug pana?

(„Debata”, TVP 1, 24.02.2005; dziennikarz - KD: Kamil Durczok; gość - JH: Jan Hartman)

Dziennikarz wraz z ekspertem, prowadząc strategię informacyjno-weryfikacyjną, wyjaśniają pojęcie, które jako temat debaty nie jest powszechnie znane. Podawane są aspekty medyczne i prawne oraz ogólne i indywidualne. Po wyjaśnieniach eksperta pytanie dziennikarza (to jest pomoc pacjentowi, a nie zabójstwo) wydaje się niespójne semantycznie, ale jest uzasadnione strategią strukturalną dziennikarza; jego zamysłem, polegającym na zderzaniu potocznych opinii z eksperckimi.

KD: Panie pośle, czy byto ztamanie zasad etycznych zawodu, czy adwokaci zachowywali się w porzadku, czy po prostu wykorzystywali wszystkie kruczki prawne? [...] Panie profesorze, to, co obserwowaliśmy na sali sądowej przy okazji afery FOZZ-u, to co to byto: upadek obyczajów, normalna gra obliczona na zabezpieczenie interesów swojego klienta? Powinniśmy się przyzwyczaić do takich postaw?

(„Debata”, TVP 1, 3.03.2005; dziennikarz - KD: Kamil Durczok)

KD: I tu dotykamy tematu, o którym dowiedzieliśmy się kilka tygodni temu, czyli śledztwa $w$ sprawie stanu wojennego prowadzonego przez katowicki oddziat Instytutu Pamięci Narodowej. I zastanawiam się, czy dla panów, dla pana Jana Lityńskiego, dla pana profesora i dla panów to jest dopetnienie sprawiedliwości, czy to jest działanie polityczne?

(„Debata”, TVP 1, 16.12.2004)

W dwu kolejnych przykładach dziennikarz, stosując strategie informacyjno-weryfikacyjne, stara się ustalić kategorię działań podmiotów w sferze publicznej 
(działanie adwokatów, wznowienie śledztwa). Decydujące dla kategoryzacji są opozycje: prawny/bezprawny, etyczny/nieetyczny i polityczny/niepolityczny, sprawiedliwy/niesprawiedliwy. Kategoryzacje wiążą się z oceną działań. Dla kształtowania kompetencji komunikacyjnej odbiorcy medialnego istotne jest już samo zwrócenie uwagi na wielointerpretacyjność działań. Trafność interpretacji może być przedmiotem dyskusji, ale ważne jest, aby widz odróżniał złożoną rzeczywistość od jej upraszczającego i podlegającego intencjonalności językowego ujęcia.

W przytoczonych przykładach punktem wyjścia były wydarzenia ze sfery publicznej, głównie o charakterze prawnym. Rozpatrzmy przykład, w którym ekspert, kooperujący z dziennikarzem, wychodzi od zjawisk ze sfery prywatnej i rozpatruje ich skutki polityczne, geopolityczne, ekonomiczne.

JP: Czy mają rację ci, którzy mówia że te konsekwencje [zmniejszenia urodzin] odczujemy już za naszego życia, że będziemy już sami obserwować te dramatyczne zmiany? Pan Konrad Szymański.

KS: Znaczy, biorąc pod uwagę, że oprócz mniejszej ilości dzieci, również żyjemy coraz dłużej, to z cata pewnościa wszyscy, jak tu żyjemy [rozgląda się po studiu], zobaczymy peten obraz tych konsekwencji. Pan profesor Misztal wspomniat o tym, że my politycznie będziemy mniej ważyć. To jest rzeczywiście prawda. Natomiast gdyby zbliżyć się do odpowiedzi o te polityczne konsekwencje, to zobaczymy takie rzeczy, do którego stowo kryzys jest za stabym stanowczo. Stowo kryzys prawie codziennie pojawia się w mediach, wydaje się, że oswoiliśmy się z nim. To jest sytuacja jakiegoś kataklizmu. I to nie chodzi o taki kataklizm w krajobrazie, że po prostu jest mniej dzieci. Chodzi o to, że nie można ożywiać gospodarki, bo budżety maja zafiksowane wydatki na opiekę społeczna $i$ na ochronę zdrowia. Możemy przejść na poziom geopolityczny. Kraje naszego kregu wobec zaniku dzieci będa miaty mniejsza zdolność do odgrywania jakiejkolwiek roli w świecie. Jeśli pomyślimy o konsekwencjach politycznych, ekonomicznych, finansowych, także geopolitycznych, to wszystkie odpowiedzi, które są dzisiaj przynoszone, są odpowiedziami katastroficznymi. I obawiam się, że my wszyscy będziemy tej katastrofy świadkami. Dodam ten watek polityczny, który wydaje się zupetnie najdalszym można powiedzieć, że z punktu widzenia takiej intymnej decyzji, jak posiadanie dzieci, zupetnie niestosowny. Ale jest prawda, że żyjemy w świecie, który jest coraz bardziej niebezpieczny. Ta sytuacja będzie się pogtębiała, a nasze stanowisko będzie coraz słabsze. Wtaśnie z uwagi na niezdolność do prowadzenia konfliktów, niezdolność do prowadzenia wojen, niezdolność do obrony. I to sa te konsekwencje najdalsze tego bardzo prostego kulturowego, indywidualnego zdecydowanie faktu, jakim jest zanik chęci posiadania dzieci przez Europejczyków.

(„Warto rozmawiać”, TVP 2, 9.01.2006; dziennikarz - JP: Jan Pospieszalski; gość - KS: Konrad Szymański)

W wypowiedzi eksperta da się zaobserwować płynne przejście od kreowania układu interakcyjnego w mikrosytuacji do kreowania układu makrosytuacyjnego. Można to rozpoznać po odniesieniu referencjalnym zaimka osobowego „my”, które da się odtworzyć z kontekstu. Jest to „my” inkluzyjne, a więc włączające odbiorcę lub odbiorców, którymi są reprezentanci coraz szerszych wspólnot: my w studiu, my Polacy, my kraje naszego kręgu, my Europejczycy. Ekspert uwzględnia w retorycznej wypowiedzi punkt widzenia przeciętnego 
obywatela, pobieżność jego obserwacji, prawo do intymnej decyzji. Jednak celem rozmówcy jest wyjaśnienie skutków w sferze politycznej i ekonomicznej tego, co jest dostępne obserwacji. Dokonuje bowiem swoistej transpozycji bodźców: wyjaśnia konsekwencje prywatnych decyzji w innych, bardziej skomplikowanych i abstrakcyjnych systemach odniesienia. Tło pozajęzykowe jest w wypowiedzi eksperta wyraźnie sfunkcjonalizowane: wydarzenia i zjawiska są porządkowane według relacji przyczynowo-skutkowych, według poziomów abstrakcyjności, ogólności (poziom obserwowalny, indywidualny i poziom abstrakcyjny, ogólny).

Udział ekspertów jako kategorii gości jest nastawiony na edukację obywatelską. Ich odpowiedzi dostarczają nie tylko wiedzy na temat bieżących zagadnień publicznych, ale - co ważniejsze - stanowią wzór zachowań komunikacyjnych alternatywny wobec propagandowych (najczęściej) wystąpień polityków.

Działania dziennikarzy i ich rozmówców, które przebiegają na poziomie komunikowania interpersonalnego i grupowego w sytuacji komunikacji bezpośredniej (mikrosytuacja w studiu), są zanurzone w sytuacji komunikowania masowego (makrosytuacja). Dodatkowo w programie odbijają się echem, to znaczy są relacjonowane, akty i procesy komunikowania interpersonalnego, komunikowania między grupami (organizacjami pozarządowymi, stowarzyszeniami), komunikowania instytucjonalnego (między instytucjami), które pojawiają się $\mathrm{w}$ przestrzeni debaty publicznej. Elementy tła pozajęzykowego, które zostają zakodowane w wypowiedziach rozmówców jako kontekst, podlegają selekcji i uporządkowaniu w sposób uwzględniający uwarunkowania typu komunikacji (płaszczyzny komunikowania), uwarunkowania związane z rolą społeczną i przyjętą postawą w interakcji (np. kooperacją lub rywalizacją).

Podsumowując, intencje komunikacyjne uczestników medialnych programów publicystycznych i realizowane przez nich strategie są wypadkową wielu uwarunkowań. Uwzględniając zarówno sposób, jak i zasięg rodzajów komunikacji, które ogniskują się w programie, można przedstawić te zależności w postaci schematu.

Rzeczywistość pozajęzykowa, którą określono jako tło pozajęzykowe, jest źródłem wiedzy na temat zjawisk, wydarzeń, zachowań, działań osób publicznych, ogólnie - spraw publicznych, politycznych, prywatnych. Elementami tej rzeczywistości są również wydarzenia o charakterze typowo komunikacyjnym, np. akty komunikowania interpersonalnego, grupowego, instytucjonalnego, które przebiegają w ramach owych wydarzen, zjawisk. Sfera publiczna jest przestrzenią nieustannych negocjacji, dotyczących społecznego odbioru i społecznej konstrukcji wydarzeń. Kontekstualizacja, a więc włączanie elementów tła pozajęzykowego do tekstu, kodowanie elementów sytuacji w tekście, odbywa się według reguł obowiązujących w tej sferze. Chodzi o normy funkcjonowania sfery publicznej (np. otwartość, dostępność, prawo do informacji), normy zachowań politycznych (np. konieczność legitymizacji, powoływanie się na interes 
publiczny, grupowy, ukrywanie dominacji). Reguły te nie są narzucone z góry, ale podlegają nieustannej społecznej negocjacji poprzez stabilizację i podważanie. Ważnym wskaźnikiem istnienia reguł jest warstwa metadyskursywna tekstu, w której rozmówcy jawnie je negocjują. Dzięki temu uwyraźnieniu ulegają stosowane przez nich strategie związane $\mathrm{z}$ typem komunikowania.

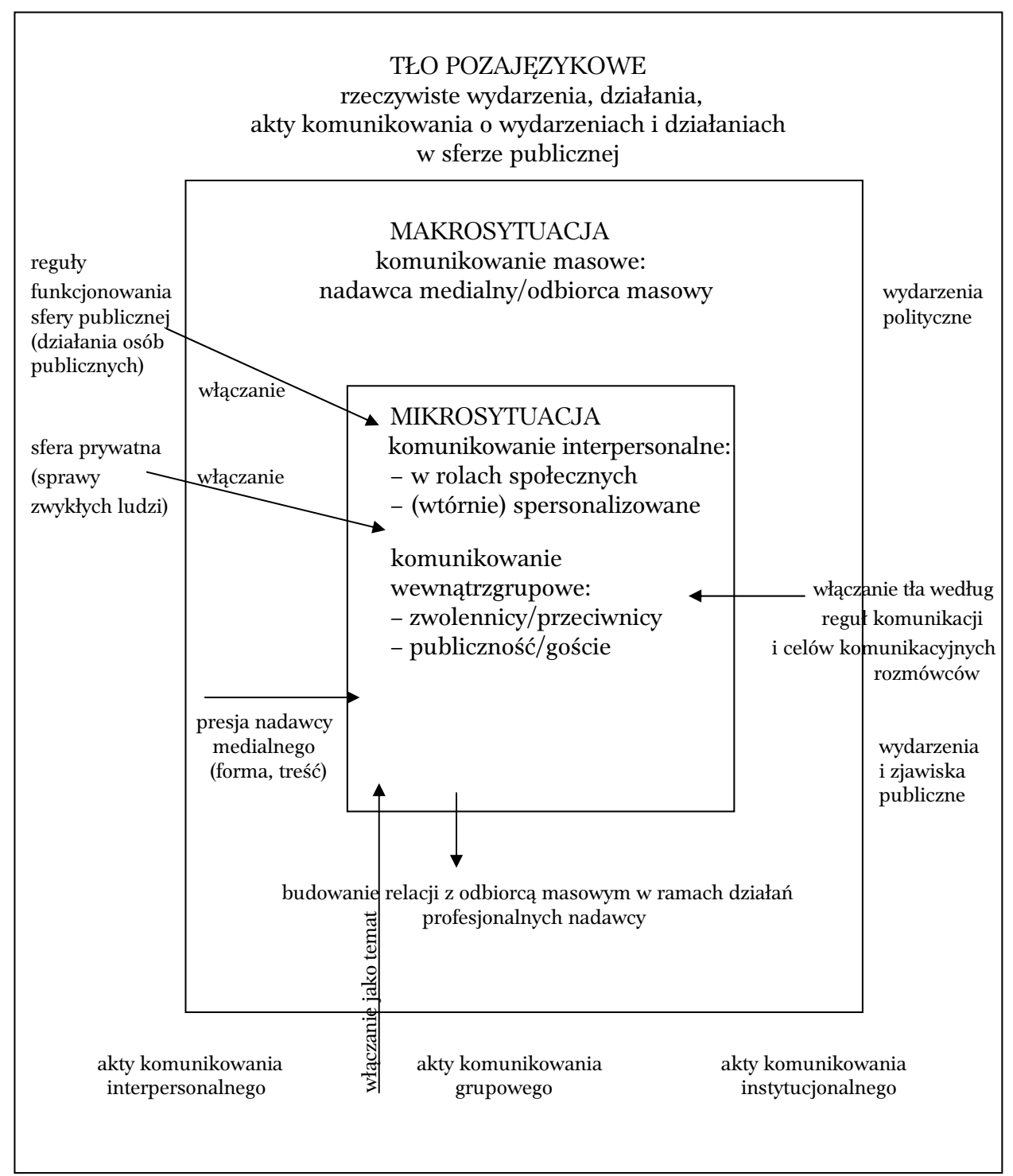

Rys. 7. Schemat medialnej komunikacji publicznej 
Znajomość uwarunkowań komunikacji i wynikających stąd reguł jest szczególnie przydatna np. w prowadzeniu strategii rywalizacyjnych (z uwagi na sytuacje zagrożenia twarzy, konieczność godzenia niezbieżnych celów). Wojskowe pochodzenie pojęcia strategii dostarcza tu przydatnych analogii. Można dostrzec: zwiększanie siły (np. poprzez występowanie z perspektywy ogólniejszych i ważniejszych reguł), ukrywanie motywacji rywalizacyjnych (dążenia do władzy i dominacji, wyeliminowania przeciwnika), zmianę pozycji dyskursywnej (takiej, z której obrona jest niemożliwa - na taką, z której da się ją przeprowadzić), demaskowanie przeciwnika, wreszcie stosowanie strategii uniku i strategii balansu. Zatem wiedza o regułach funkcjonowania sfery publicznej, w tym systemu politycznego, dostarcza instrumentów do prowadzenia skutecznej rywalizacji.

Na kształt tekstu w masowym przekazie publicznym decydujący wpływ mają uwarunkowania wynikające z natury mediów. Są one powodem przeobrażeń zarówno sfery publicznej, jak i zachodzącego w niej komunikowania politycznego. Zdarzenie komunikacyjne w mikrosytuacji przebiega w ramach nadrzędnej makrosytuacji, a profesjonalne działania nadawcy medialnego nakierowane są na budowanie relacji z odbiorcą masowym. Wskazane zależności między tłem pozajęzykowym, makrosytuacją i mikrosytuacją znajdują odzwierciedlenie w strategiach stosowanych przez uczestników analizowanych programów.

Hierarchizacja strategii ze względu na typ komunikowania

Strategiczne wykorzystanie wiedzy na temat elementów systemu komunikowania: dostosowanie strategii interakcyjnych do reguł, norm i wzorów rządzących zachowaniem uczestników systemu

\begin{tabular}{|c|c|}
\hline $\begin{array}{l}\text { Ze względu na zasięg komunikowania } \\
\text { (komunikowanie publiczne, polityczne) } \\
\text { strategie regulujące dostęp i skuteczność } \\
\text { działań podmiotów: } \\
\text { - strategie legitymizacji, których celem jest } \\
\text { uprawomocnienie, stworzenie wrażenia } \\
\text { reprezentatywności, prawowitości, } \\
\text { - strategie delegitymizacji, których celem } \\
\text { jest pozbawienie aprobaty społecznej, } \\
\text { wycofanie poparcia, symboliczne } \\
\text { wyeliminowanie przeciwnika }\end{array}$ & $\begin{array}{l}\text { Ze względu na sposób komunikowania } \\
\text { (komunikowanie masowe) strategie związane } \\
\text { z kształtowaniem formy } \\
\text { i treści przekazu: } \\
\text { - strategie strukturalne (związane z delimitacją } \\
\text { ramową i środkową tekstu), } \\
\text { - strategie tekstotwórcze (związane z organizacją } \\
\text { tekstu jako spójnej całościowej struktury) } \\
\text { - strategie nadawczo-odbiorcze polegające na } \\
\text { dostosowaniu przekazu do kompetencji } \\
\text { odbiorcy, } \\
\text { - strategie nadawczo-odbiorcze polegające na } \\
\text { kształtowaniu kompetencji odbiorcy masowego }\end{array}$ \\
\hline
\end{tabular}

Rys. 8. Typy strategii ze względu na zasięg i sposób komunikowania

Komunikacja publiczna wymaga od uczestników określonych kompetencji komunikacyjnych. Sama treść przekazu (relacja przekazu do rzeczywistości), w tym jej prawdziwość, jest tylko jednym z elementów procesu komunikacji. Równie ważne są instytucjonalne relacje między uczestnikami, które określają 
zasady funkcjonowania oraz warunki stosowności i skuteczności przekazów. To powoduje, że np. strategie konwersacyjne, które są uruchamiane w celu uzgodnienia stopnia prawdopodobieństwa, prawdziwości komunikatu, jego oceny (strategie informacyjno-weryfikacyjne, aksjologiczno-emotywne), zostają podporządkowane bardziej globalnym strategiom wynikającym z typu komunikowania. Mamy tu zatem do czynienia z hierarchizacją strategii, podporządkowaniem strategii elementarnych strategiom bardziej złożonym.

Spośród uwarunkowań typów komunikowania dwa wydają się szczególnie istotne dla strategii podejmowanych przez uczestników medialnej debaty publicznej, a są to: zasięg komunikowania i jego sposób (omówiono je w pracy osobno, ale w konkretnych realizacjach tekstowych te uwarunkowania w sposób oczywisty nakładają się na siebie). Za najważniejszy cel działalności podmiotów sfery publicznej, który poprzedza i warunkuje wszelkie inne aktywności, uznano dążenie do uprawomocnienia. Jego realizację zapewnia strategia legitymizacji. Przyjmując założenie o hierarchizacji strategii, należy ją zatem uznać za strategię nadrzędną, której w tym typie komunikowania podporządkowane są pozostałe strategie. $Z$ kolei w komunikowaniu masowym celem nadrzędnym jest budowanie relacji z odbiorcą medialnym. Jego realizację umożliwiają strategie nadawczo-odbiorcze, w tym strategie strukturalne i tekstotwórcze. Jak wynika z analizy, istnieje korelacja między typami komunikowania a rodzajami dominujących strategii, co potwierdza również ich powiązanie z działalnością pozajęzykową rozmówców. 



\section{RozDZIAŁ 2 \\ Strategie i ich uwarunkowania związane z działalnością pozajęzykową rozmówców}

W rozdziale zostaną omówione zależności komunikacyjnych zachowań uczestników medialnych programów społeczno-politycznych od kontekstu zadaniowego, czyli kontekstu wynikającego z regulacji i koordynacji działalności praktycznej (np. w sferze aktywności publicznej, w tym politycznej). Zależności te są dostrzegane i referowane wprost przez uczestników programów, jak również odczytywane na podstawie określonych symptomów przez metaobserwatora (w tym przypadku jest nim autorka opracowania). Tak więc brano pod uwage zarówno to, jak sami rozmówcy komentują zachowania komunikacyjne, jak i to, co można wywnioskować z przebiegu interakcji, na podstawie wiedzy o celach aktywności pozajęzykowej rozmówców. W przytoczonych fragmentach programów strategia pojawia się nie tylko jako kategoria interpretacji dokonywanej przez metaobserwatora na podstawie określonych symptomów, ale również jako kategoria opisu dokonywanego przez samych uczestników interakcji.

Związki komunikacji z działalnością praktyczną i teoretyczną ludzi są bardzo ścisłe. Według Stanisława Gajdy działalność językowa jest zdeterminowana strukturą całej działalności, a zwłaszcza tymi czynnościami, które poprzedziły czynność językową w akcie działalności. Stąd nie może być ona wyjaśniana poza związkami z konkretną sytuacją społeczną, z innymi czynnościami. Nie jest celem samym w sobie, lecz jedynie środkiem do osiągnięcia celu (Gajda 1982: 23). Działalność praktyczna, teoretyczna i językowa stanowią zatem elementy wzajemnie się dopełniające, a nawet warunkujące. W analizie strategii komunikacyjnych będziemy się odwoływać do czynności pozajęzykowych i praktyki społecznej, które stanowią właściwe podłoże analizy funkcjonalnej. Tu istotne są ogólne zasady funkcjonowania mediów i podmiotów politycznych.

W wielu przytoczonych fragmentach pojawiają się wypowiedzi, w których sami rozmówcy rozpatrują działania komunikacyjne na tle aktywności zawodowej, podkreślają zależność form komunikowania, strategii od roli społecznej. Są to ważne świadectwa kompetencji dyskursywnej rozmówców. Co prawda, wiedza ta może być wykorzystywana instrumentalnie w bieżącej interakcji, ale nie zmienia to faktu, że wypowiedzi te stanowią potwierdzenie istnienia konwencji komunikacyjnych. Pojawiając się w przekazie masowym, podnoszą poziom świadomości odbiorcy i realizują funkcję edukacyjną mediów. 
Materiał podzielono na trzy punkty, w których ujmuje się zagadnienie z trzech różnych perspektyw, chociaż omawiane zjawiska nie mają charakteru rozłącznego. Stanowią raczej ujęcia wzajemnie się dopełniające, które rozdzielono dla większej przejrzystości wywodu. W punkcie 2.1 wskazano na ogólne uwarunkowania strategii związane z negocjowaniem sensu zachowań komunikacyjnych. Punkt 2.2 przedstawia problematykę od strony dziedziny działalności uczestników debaty publicznej, natomiast punkt 2.3 - od strony ich roli społecznej.

\subsection{Ogólne uwarunkowania strategii związane $\mathrm{z}$ negocjowaniem sensu zachowań komunikacyjnych}

Ścisłe związki działalności pozajęzykowej rozmówców z ich aktywnością językową uwidaczniają się najwyraźniej podczas interpretowania zachowań komunikacyjnych. Jest to proces polegający na odnoszeniu zachowań do różnych czynników sytuacyjnych, w wyniku czego wnioskuje się o prawdopodobnych celach i motywach osób tworzących określone wypowiedzi. Dopiero rozpatrywanie treści wypowiedzi w kontekście zadaniowym pozwala wydobyć jej sens. Według Stanisława Gajdy „sens jest kształtowany przez konfigurację relacji między różnymi bliższymi i dalszymi czynnikami sytuacji aktu mowy a tekstem, stąd ma komunikatywno-pragmatyczny status" (Gajda 1982: 127).

Uaktywnianie określonych kontekstów interpretacyjnych pozostaje w zasięgu dwóch głównym zagadnień. Po pierwsze, jest związane ze stosowaniem specyficznych systemów znakowych ${ }^{1}$ o charakterze kulturowym w interpretacji działań ludzkich (np. wiedzy o wartościach, przekonaniach danej wspólnoty, stereotypach językowych, stereotypach związanych z rolami społecznymi). Po drugie, jest podporządkowane realizacji celów pozajęzykowych. Tak więc wprowadzanie elementów tła pozajęzykowego do tekstu nie jest wynikiem jedynie mechanicznego przyporządkowania określonych schematów. Cele działalności pozajęzykowej i funkcja perswazyjna, propagandowa języka w istotny sposób determinują odbiór rzeczywistości, a właściwie ją konstruują. Konstrukcja rzeczywistości odbywa się w ramach medialnego dyskursu. Można nawet obrazowo powiedzieć, że materiał poznawczy (percepcja, obserwacja rzeczywistości) jest formowany (w trakcie werbalizacji) według dyskursywnych parametrów sytuacyjnych.

Ważnym założeniem analizy jest zatem stwierdzenie, że interpretacja zachowania polega na podciągnięciu go pod pewną ogólniejszą kategorię, zgodną

${ }^{1}$ Stopień sformalizowania owych systemów znakowych jest problemem otwartym. W dydaktyce akademickiej pojawia się już nazwa „kod” na określenie zaplecza komunikacyjnego. Mówi się np. o kodzie poznawczo-kulturowym, kodzie pragmatyczno-społecznym (Mikołajczuk 2003: 34-38). W niniejszej pracy używamy we wspomnianym zakresie określenia „kod” ze świadomością pewnej umowności, przenośności tak użytego pojęcia. 
z dotychczasowym doświadczeniem i nabytą społecznie wiedzą oraz konkretnym praktycznym interesem (por. Grabias 2003: 252; Ziółkowski 1981: 19). Prawidłowość, która dotyczy zachowań w ogólności, jest jak najbardziej trafna w odniesieniu do zachowań językowych. Analiza przebiegu interakcji w medialnym dyskursie publicznym wskazuje na interpretację zachowań językowych zgodnie z parametrami dyskursu (np. w dziedzinie tematycznej i funkcjonalnej). Wynika z tego, że konstrukcja rzeczywistości jest zdeterminowana przez kategorie kulturowe i podlega presji praktycznego interesu. Właśnie ten ostatni determinant przesądza o możliwości strategicznego oglądu również poznawczej (a nie tylko interakcyjnej) warstwy dyskursu. Chociaż strategie konwersacyjne są realizowane $\mathrm{w}$ relacji z rozmówcą, to nie bez znaczenia dla kształtowania tejże relacji jest również sposób (strategia) ujmowania rzeczywistości pozajęzykowej, której podmioty komunikacji są częścią.

Ze względu na profesjonalną aktywność pozajęzykową, dominującym kontekstem $\mathrm{w}$ analizie medialnych programów jest kontekst pragmatyczno-społeczny, zdeterminowany przez miejsce, czas, uczestników, temat, kanał i cel komunikacji. Nie mniej ważny okazuje się kontekst kulturowo-poznawczy, który odnosi wypowiedź do wspólnego świata pojęć i wartości, utrwalonego w danej kulturze (Mikołajczuk 2003: 38). Konteksty te uaktywniają się dzięki kodowemu zapleczu komunikacji, które tworzą specyficzne systemy znakowe.

Szczególnie należy tu podkreślić rolę tzw. kodu kulturowego. Zawiera on charakterystyki przedmiotów i zjawisk obejmujące zespoły cech, które tworzą wyobrażenia tych obiektów, a także związane z nimi oceny i wzory zachowań. Owe charakterystyki to stereotypy językowe (Bartmiński, Panasiuk 2001: 371). W niniejszej analizie stereotypy tworzą płaszczyznę odniesień do ujmowania bardziej złożonych zjawisk. Nie mniej istotny jest tzw. kod poznawczy, który zawiera gotowe schematy interpretacyjne, stanowiące w umysłach uczestników komunikacji system wzorców pomocnych w organizacji doświadczenia i interpretacji komunikatów docierających do odbiorców. Z kodem poznawczym związany jest tzw. kod społeczny, który rejestruje reguły różnicowania ludzi ze względu na rangę społeczną i pełnione przez nich role. Jak twierdzi Agnieszka Mikołajczuk (2003: 37), schematy poznawcze, które cechuje większa złożoność, odnoszące się do skomplikowanych sytuacji oraz zachowań, są uwarunkowane i kulturowo, i społecznie. W interpretowaniu działalności publicznej i politycznej, która dokonuje się za pośrednictwem mediów, mamy do czynienia zarówno ze schematami prostszymi czy też upraszczającymi zjawiska skomplikowane (zgodnie z racjonalnością potoczną), jak i z budowaniem schematów złożonych, tzn. uwzględniających odmienne aspekty zjawisk na różnych płaszczyznach ogólności (bardziej odpowiadających racjonalności naukowej).

Tak więc rozmówcy włączają do przestrzeni bieżącej interakcji elementy tła pozajęzykowego, którymi są zdarzenia i działania podmiotów spoza układu interakcyjnego. Dokonują ich interpretacji, która polega na nadawaniu sensu dzięki 
zestawieniu z różnymi czynnikami sytuacyjnymi. Towarzyszy temu kategoryzowanie i nazywanie elementów, które następnie są porządkowane w sposób odpowiadający realizacji celów rozmówców.

Okazuje się, że w niektórych programach publicystycznych działania tego typu (można nazwać je w istocie działaniami „sensotwórczymi”) stają się przedmiotem negocjacji między dziennikarzem a rozmówcami. Nadawca medialny czyni bowiem tematem rozmowy właśnie sens określonych wypowiedzi, traktowanych jako działania w określonej sytuacji. W poniższym przykładzie rozmówcy nie tylko przywołują nazwy prostych aktów mowy, typu rozkaz, stwierdzenie, ostrzeżenie, żądanie, ale również odczytują działania komunikacyjne w kategoriach złożonych gatunków mowy, jak np.: negocjacje, doniesienia, pogłoski, pomówienie, wyjaśnienie. Zarówno proste, jak i złożone gatunki zostają wykorzystane w konstrukcji globalnego schematu interpretacyjnego zgodnego z poetyką mediów.

JD-O: Wtaśnie w tej chwili powinny być wznawiane negocjacje w sprawie uwolnienia ekipy TVP, która została zatrzymana w Osetii Południowej. Czy to przypadkowe zatrzymanie?

PG: Trudno powiedzieć, no nie wiemy, czy rozkaz, by nasza ekipe zatrzymać, przyszedt z samej góry, czy była to decyzja jednego $z$ dowódców niższego szczebla. To jest pewnie decydujacee. Natomiast jestem przekonany, że jeśli chodzi o procedury, które tam zostały wdrożone, to one $\underline{\text { sa }}$ takie same dla wszystkich. To znaczy Osetyńcy stwierdzili, że [Polacy] nie maja akredytacji, muszą więc ich zatrzymać. [...]

JD-O: Czy to jest tak, że ktoś boi się prawdy i dlatego dziennikarzy się zatrzymuje?

TB: Oczywiście zatrzymywanie dziennikarzy w niektórych okolicznościach czasami jest spowodowane lękiem przed prawda. Natomiast myślę, że to, co dzieje się w Gruzji i Osetii Południowej, to jest raczej konsekwencja tego, że byta tam wojna, niedawno się zakończyta i te procedury przechwytywania ludzi bez dokumentów, bez wymaganych akredytacji, stusznie czy niestusznie, przez obie strony, mogą być spowodowane ostrożnościa wojsk po obu stronach, które jeszcze miesiac temu toczyty ze soba wojnę.

JD-O: Ale wczoraj mówiło się o tym, że nasi dziennikarze to jeńcy wojenni.

KM: W tym momencie coś jest nielogiczne, bo jest ta rezolucja Rady Bezpieczeństwa ONZ, która nakazuje specyficzny sposób traktowania dziennikarzy, a nie jako jeńców wojennych.

JD-O: No wtaśnie, jeniec wojenny to jest ktoś, kto uczestniczy w konflikcie.

KM: Ktoś tutaj pomieszat. Ja nie jestem pewna, czy to nie byto zrobione celowo, ponieważ mniej więcej tydzień temu odbyło się tutaj takie spotkanie dość szeroko komentowane, na którym byt ambasador gruziński i tam między innymi pokazywano materiaty Darka Bohatkiewicza. Było to dość szeroko komentowane i znane.

JD-O: Wedtug pani może to być ostrzeżenie?

KM: Mogto to być ostrzeżenie. [...]

JD-O: Wczoraj byta konferencja prasowa poświęcona zatrzymaniu naszych dziennikarzy i na tej konferencji byli tylko rosyjscy dziennikarze, i dowiedzieli się, że nasza ekipa byta podobno pijana. Oczywiście to byta nieprawda. [...] Czy dziennikarze sa bronia w XXI wieku?

KM: Myślę, że niektórzy traktuja tak dziennikarzy. Nie jestem korespondentem, ale nawet $w$ moich prywatnych wyjazdach do wielu państw, szczególnie do państw arabskich, nie moge podać swojego zawodu. Mogę być kosmonauta, ale nie mogę być dziennikarzem, ponieważ to powoduje, że nie jestem wpuszczana, miatam takie przypadki. Pót godziny po wczorajszych wydarzeniach zażądaliśmy od ambasadora rosyjskiego wyjaśnień i mam nadzieję, że dziennikarze polscy otrzymaja to wyjaśnienie dzisiaj. 
JD-O: W Gruzji zginęto już 4 dziennikarzy. Jeden z operatorów, operator z Holandii dostownie na twoich oczach. Czy dziennikarze sa celem w Gruzji?

PG: Myślę, że dziennikarze sa celem w każdym konflikcie, który toczy się w sposób żywiotowy.

(„Kwadrans po ósmej”, TVP 1, 9.09.2008; dziennikarka - JD-O: Justyna Dobrosz-Oracz; goście - KM: Krystyna Mokrosińska, PG: Piotr Górecki, TB: Tomasz Bielecki)

Dziennikarka wprowadza do rozmowy element tła pozajęzykowego - wydarzenie, jakim było zatrzymanie ekipy TVP w Osetii Południowej. Sposób prowadzenia rozmowy jest podporządkowany temu, aby uczynić jawnym proces nadania sensu wydarzeniu i związanym z nim działaniom komunikacyjnym. Zachowanie Osetyńców (stanowiące całość werbalno-kinetyczną), jako dokonujących zatrzymania, zostaje poddane interpretacji przez osadzenie w kontekście (politycznym, międzynarodowym), przez uwzględnienie różnorakich uwarunkowań sytuacyjnych (konflikt wojenny, ranga zatrzymanych, ich zawód lub rola społeczna, narodowość). Z przebiegu rozmowy wynika, że sens zachowania nie jest oczywisty i zależy od określenia takich ekstralingwistycznych kategorii w werbalizacji zdarzeń z tła pozajęzykowego, jak: przypadkowość, celowość, intencjonalność, sprawstwo bezpośrednie lub kierownicze, interpretacja w kategoriach przyczynowo-skutkowych, strukturalno-funkcjonalnych, a więc bezosobowych, bądź w kategoriach osobowych, np. jako spisek. W rozmowie można zatem wyodrębnić pewne kroki interpretacyjne, zmierzające do nadania sensu zachowaniu ${ }^{2}$ :

- dziennikarka chce ustalić, czy zachowanie Osetyńców było przypadkowe. Rozmówca, asekurując się brakiem wystarczających danych, rozbudowuje układ symptomów o element sprawstwa. Według niego zaangażowanie władz centralnych (co implikuje sprawstwo jedynie wykonawcze Osetyńców) wskazywałoby na celowość zatrzymania i (domyślnie) kontekst polityczny (czy rozkaz, by nasza ekipe zatrzymać, przyszedt z samej góry),

- rozmówcy wskazują na możliwość interpretacji zachowania w kategoriach przyczynowo-skutkowych (to, co dzieje się w Gruzji i Osetii Południowej, to jest raczej konsekwencja tego, że byta tam wojna; [procedury] moga być spowodowane ostrożnościa wojsk po obu stronach, które jeszcze miesiąc temu toczyły ze soba wojnę) lub w kategoriach strukturalno-funkcjonalnych, czyli jako przejaw procedur typowych dla wszystkich ludzi (jestem przekonany, że jeśli chodzi o procedury, które tam zostały wdrożone, to one sa takie same dla wszystkich. To znaczy Osetyńcy stwierdzili, że [Polacy] nie mają akredytacji, muszą więc ich

\footnotetext{
${ }^{2}$ Postrzeganie świata społecznego jest złożonym zadaniem poznawczym. Jednostka musi transponować bodźce bezpośrednio obserwowalne na bodźce polityczne, to znaczy politycznie relewantne, co nigdy nie jest oczywiste (por. Skarżyńska 2002: 40). Pomocne w odbiorze i interpretacji, według założeń misji publicznej, powinny być media. Ich rzeczywista rola w tym zakresie jest przedmiotem różnych interpretacji (por. Mrozowski 2001: 345).
} 
zatrzymać). Takie interpretacje uznajemy za bezosobowe, gdyż wynikają z uwarunkowań zewnętrznych, a nie są spowodowane cechami obiektu, tzn. Osetyńcy zatrzymaliby w analogicznej sytuacji każdego, natomiast nie chodziło im specjalnie o „prześladowanie” polskich dziennikarzy,

- dziennikarka wprowadza kontekst zawodowy, związany z rolą społeczną zatrzymanych dziennikarzy, co pozwala interpretować zachowanie Osetyńców w kategoriach intencjonalnych. Intencje te według rozmówców są jednak niejawne. W rozmowie studyjnej zostają rozpoznane, zdemaskowane jako prowokacja prewencyjna ${ }^{3}$, polegająca na zastraszeniu, niedopuszczaniu do ujawnienia prawdy przez dziennikarzy (ktoś boi się prawdy i dlatego dziennikarzy się zatrzymuje; mogto to być ostrzeżenie). Dodatkowo towarzyszy temu prowokacja dyskredytacyjna $^{4}$ (że nasza ekipa byta podobno pijana) i prowokacja reaktywna ${ }^{5}$, czyli odwet za pokazanie materiałów reporterskich (domyślnie) niewygodnych dla władzy (czy to nie byto zrobione celowo, ponieważ mniej więcej tydzien temu odbyto się tutaj takie spotkanie dość szeroko komentowane, na którym byt ambasador gruziński i tam między innymi pokazywano materiały Darka Bohatkiewicza). Odbiór działań komunikacyjnych w kategoriach prowokacji i dyskredytacji jest możliwy dzięki uruchomieniu wiedzy na temat typowych schematów poznawczych, które służą interpretacji działań podmiotów medialnego dyskursu publicznego. Schematy te stanowią element wiedzy wspólnej uczestników komunikacji (choć można dyskutować na temat zasadności ich stosowania w werbalizacji jednostkowego zdarzenia).

Ostatnim etapem nadania sensu wydarzeniu jest posłużenie się nim jako instrumentem mitologizacji zawodu dziennikarza. Osetyńcy zatrzymali dziennikarzy, ponieważ dziennikarze jako grupa zawodowa sa bronia w XXI wieku. $\mathrm{Z}$ wypowiedzi uczestników programu wynika, że dziennikarze w ogóle są prześladowani, stają się jak gdyby męczennikami za prawdę (mówiło się o tym, że nasi dziennikarze to jeńcy wojenni; $w$ Gruzji zginęto już 4 dziennikarzy. Jeden $z$ operatorów, operator $z$ Holandii dosłownie na twoich oczach. Czy dziennikarze sac celem $w$ Gruzji?).

Wszystkie wspomniane sposoby usensowienia omawianego zdarzenia zmierzają do przedstawienia działań w kategoriach społecznych, politycznych, ale

${ }^{3}$ Prowokacja prewencyjna to działania zapobiegawcze, próby niedopuszczenia do niepożądanych działań przeciwnika. Polegają na uprzedzaniu posunięć rywali własnymi decyzjami lub na stwarzaniu barier, przeszkód dla jego planów (por. Karwat 2007: 239).

${ }^{4}$ Prowokacja dyskredytacyjna polega na wywołaniu specjalnymi zabiegami odruchowych reakcji i skojarzeń dotyczących negatywnych stereotypów oraz uprzedzeń w stosunku do rywali. $\mathrm{W}$ analizowanym przypadku to celnie zadany cios sytuacyjny, ugodzenie w wizerunek polskiej ekipy, przedstawienie jej w niekorzystnym świetle (por. Karwat 2007: 215).

${ }_{5}$ Prowokacja reaktywna jest typem zachowania, które zostało sprowokowane sytuacją, a zwłaszcza cudzym zachowaniem. Często wiąże się z odwetem, chęcią ukarania lub upokorzenia przeciwnika, który zadał pierwszy cios lub którego zachowanie zostało tak odebrane (por. Karwat 2007: 51). 
również w perspektywie atrakcyjnej dla mediów. Kategorie ekstralingwistyczne, charakteryzujące zachowanie bohaterów przekazu, związane są z jego interpretowaniem w różnych kontekstach odniesienia i stanowią ważne parametry medialnego dyskursu politycznego w dziedzinie tematycznej. Czasem kategorie te są niezgodne (albo przypadkowość, albo celowość), ale częściej się dopełniają (interpretacja w kategoriach przyczynowo-skutkowych, czyli jako skutek działań wojennych oraz interpretacja w kategoriach strukturalno-funkcjonalnych, czyli jako wypełnianie procedur).

Można zauważyć, że interpretacje te nie są jednakowo atrakcyjne dla dyskursu medialnego. $\mathrm{Z}$ pewnością interpretacja maksymalnie celowościowa, intencjonalna, dramatyczna, mitologizująca jest bardziej widowiskowa niż interpretacja bezosobowa. Dziennikarka za pomocą sugestywnych pytań podsuwa widzom atrakcyjniejszą wersję, w której dziennikarze są obiektem prowokacji ukrytych sił politycznych, bohaterami doznającymi ucisku, a nie przypadkowymi statystami w systemie procedur. Taką tendencję i strategię z nią związaną nazywamy narratywizowaniem rzeczywistości ${ }^{6}$. Ze względu na jej zasięg, należy ją uznać za jedną z makrostrategii komunikacyjnych dyskursu medialnego.

Drugi program dotyczy negocjowania sensu zachowań językowych: oficjalnej wypowiedzi ukraińskiego urzędnika i protestu przeciwko uhonorowaniu prezydenta Ukrainy ${ }^{7}$. Próbę łącznego interpretowania dwu różnych wydarzeń należy również uznać za przejaw narratywizowania rzeczywistości, łączenia kilku wątków w jedną, spójną opowieść.

MZ: O relacjach polsko-ukraińskich porozmawiamy dziś w kontekście dwu wydarzeń z ostatnich dni. Pierwsze z nich to wypowiedź wysokiego ranga urzednika ukrainskiej administracji o tym. że polska policja przedwojenna swoimi dziataniami byta podobna do NKWD i gestapo. Drugie wydarzenie, sprzed kilku dni również, to protest polskich środowisk kresowych przeciwko nadaniu doktoratu honoris causa KUL-u prezydentowi Ukrainy, Wiktorowi Juszczence. Te dwa wydarzenia każa zadać pytanie, w jakim stopniu polsko-ukrainska historia wptywa na nasze dzisiejsze relacje i czy możemy to fatum nieszczęsnych wydarzeń $w$ naszych wzajemnych relacjach przetamać. [...] Walentin Naliwajczenko to szef ukraińskiej stużby bezpieczeństwa. W czasie takiego spotkania, kiedy otwierano Muzeum Ofiar Totalitaryzmu we Lwowie, przyrównat polska przedwojenna policję do gestapo i do NKWD. Jaka jest reakcja na te stowa ukrainskiego urzędnika?

$\mathrm{AD}$ : Zrozumiate, że z polskiej perspektywy to może być oburzajace, dlatego, że jednak nie ma porównania między metodami, jakie stosowata polska policja $w$ okresie międzywojennym,

${ }^{6}$ Informacja dziennikarska jest formułą mityczną. Dziennikarski dyskurs buduje z oderwanych relacji i faktów, często przypadkowych, ogólniejszą opowieść o społeczeństwie, w której rzeczywistość jawi się jako względnie uporządkowana całość, zdarzeniami rządzi jakaś logika, a ludzkie działania mają sens. Opowieść dziennikarska wymaga intrygi osnutej wokół wyraźnie zarysowanego konfliktu, osadzenia narracji na osi przeciwstawnych działań antagonisty i protagonisty (por. Morozowski 2001: 315-321).

7 Do analizy wybrano przykład tylko jednego zdarzenia (wypowiedź urzędnika) ze względu na bogatszy kontekst interpretacyjny. Pominięto natomiast protest przeciwko uhonorowaniu prezydenta. 
a tym, co robiło NKWD czy gestapo. Ale trzeba też pamiętać, że z ukraińskiej perspektywy dla Narodowego Ruchu Ukraińskiego, no, rzeczywiście polska policja byta przeciwnikiem. Tam dochodziło często do wydarzeń, które dzisiaj byśmy potępiali, ze strony polskiej policji. Natomiast ja myślę, że ta wypowiedź jest przede wszystkim dlatego nieszczéśliwa, że, no, szef stużb specjalnych nie powinien się zajmować historia jako komentator $i$ w tym sensie ona wymaga sprostowania. $[\ldots]$

MZ: A jaki jest ukraiński punkt widzenia w tej sprawie? Czy ta wypowiedź to jest niezręczna wypowiedź urzędnika, który jest szefem stużb specjalnych, czy ona coś mówi o stanie ukraińskiej świadomości, jeśli chodzi na przykład o ocenę polskiej policji przedwojennej?

PT: Ja myślę, że mamy tutaj do czynienia z dwoma różnymi rzeczami. Jedna/ jedna to jest reakcja polskich mediów na to wystapienie. Temu wystapieniu nadano, wydaje mi się, za duży rozgłos $i$ zinterpretowano trochę $w$ taki histeryczny sposób.

MZ: No, ale te stowa padty.

PT: Z drugiej strony, jak powiedziat pan doktor, jest problem opisu relacji polsko-ukraińskich na ziemiach pogranicza zamieszkiwanego przez Polaków i Ukrainców. I tutaj perspektywa/ opis ukrainski jest inny. I chodzi tutaj nie tylko o to wystapienie Naliwajczenki. W publicystyce, historiografii ukraińskiej $w$ odniesieniu do lat 1921-1939 używa się określenia „okupacja polska”. Polaków to razi. Niestety, w historiografii ukraińskiej, w perspektywie części ukraińskich badaczy to jest/ tak to funkcjonuje. I z trzeciej strony mamy do czynienia z problemem widzenia relacji polsko-ukraińskich przez historyków, urzędników z Kijowa, którzy nie do końca orientuja się w niuansach okresu miedzywojennego.

MZ: A może granie ta karta jest potrzebne w bieżacej polityce? Może, zwtaszcza w takiej niestabilnej politycznej sytuacji Ukrainy, coś można wygrać, mówiąc takie rzeczy?

PT: Absolutnie bym się z tym nie zgodzit. W żadnym stopniu Kijów/ obecnej elity politycznej nie można oskarżać o to, że graja karta polska czy obsesjami antypolskimi. To jest nadinterpretacja.

MZ: I ksiadz Tadeusz Isakowicz-Zaleski. Od pewnego czasu ksiądz bardzo aktywnie zajmuje się sprawami polsko-ukraińskimi. Jak odebrat ksiądz tę wypowiedź, o której mówimy?

TI-Z: Ta wypowiedź jest zaledwie elementem relatywizowania, wręcz fatszowania historii najnowszej na Ukrainie. Dzieje sie to głównie od czasów pomarańczowej rewolucji. Bo głównym problemem jest ludobójstwo, które dokonali nacjonaliści ukrainscy, którzy wymordowali w bestialski sposób 200 tysięcy Polaków, wcześniej jeszcze Żydów, Ormian. I to wszystko powoduje, że dopóki nie powie się prawdy, czym byto to ludobójstwo i dlaczego dzisiaj na Ukrainie nie ma krzyży na grobach pomordowanych, a stawia się pomniki zbrodniarzom typu Stefan Bandera czy Roman Szuchewycz, to wszystko będzie oczywiście zaogniało. I tutaj wzorem powinny być relacje polsko-niemieckie. Bo jednak mówi sie prawde na temat zabójstwa Polaków i Żydów, i nie robi się bohaterów z Hitlera i z Himmlera. [...]

MZ: Żyjemy w kraju [mowa o Polsce], który mówi, że chce być rzecznikiem ukraińskich interesów w UE.

AD: Tutaj jeszcze mamy bieżaca politykę. Historia przeszkadza w tej bieżacej polityce. Ja myślę, że politykom bytoby łatwiej, gdyby nie to obciażenie historyczne, ale trudno. No, takie sa realia i oni muszą nauczyć się z tym działać. I dlatego od polityków szczególnie wymaga się ostrożności w tym, co mówia. W tym sensie wypowiedź pana Naliwajczenki byta wysoce niefortunna. Oni powinni być wyjątkowo ostrożni.

(„Kwadrans po ósmej”, TVP 1, 6.07.2009; dziennikarz - MZ: Maciej Zdziarski; goście - AD: Antoni Dudek, PT: Piotr Tyma, TI-Z: Tadeusz Isakowicz-Zaleski)

Dziennikarz wprowadza do rozmowy element tła pozajęzykowego - informację o wypowiedzi urzędnika ukraińskiego o tym, że przedwojenna polska 
policja była podobna w swoich działaniach do NKWD i gestapo. Ocena wypowiedzi jest możliwa dzięki zastosowaniu tzw. kodu ról społecznych, który zawiera m.in. standardy zachowań osób odgrywających określoną rolę. Negocjowanie sensu wypowiedzi dokonuje się w trakcie umieszczania jej na tle jakościowo różnych kontekstów, przechodzenia na różne poziomy ogólności kontekstu, analizowania składników aktu komunikacji. Sens wypowiedzi wyłania się zarówno dzięki uwzględnieniu jej treści, jak i wartości intencjonalnej; dzięki zestawieniu samej wypowiedzi z reakcją na nią.

Wypowiedź zostaje osadzona w kontekście historycznym (relacji polsko-ukraińskich) i politycznym (bieżącej polityki). Uwzględnione zostają takie elementy aktu komunikacji, jak: rola społeczna nadawcy, jego narodowość, okoliczności aktu komunikacji (czas, miejsce), wiedza i doświadczenie nadawcy oraz wiedza i doświadczenie odbiorcy, a także rodzaj reakcji odbiorcy. Wypowiedź rozpatrywana jest na poziomie indywidualnym (kompetencji nadawcy), poziomie lokalnym (przekonań wspólnoty narodowej, tu chodzi zwłaszcza o reprezentatywność jednostkowej wypowiedzi względem przekonań społecznych) i poziomie globalnym (wpływ przekonań społecznych, których (ewentualnie) wypowiedź jest emanacją, na politykę międzynarodową, np. rzecznictwo Polski w ramach interesów ukraińskich w UE). Komentowanie wypowiedzi może dotyczyć jej poziomu przedmiotowego, czyli treści, lub poziomu metadyskursywnego, czyli funkcjonowania wypowiedzi w dyskursie (zgoda na dany rodzaj działania komunikacyjnego, instrumentalne wykorzystywanie wypowiedzi do podsycania antagonizmów, zbijanie na tym kapitału politycznego).

Pierwsze pytanie dziennikarza dotyczy reakcji na wypowiedź urzędnika ukraińskiego, a więc jej odbioru. Historyk określa reakcję jako oburzenie ( $z$ polskiej perspektywy to może być oburzające) i dokonuje oceny wypowiedzi na poziomie przedmiotowym i poznawczym, gdyż uznaje porównanie za bezzasadne, a tym samym niosące nieprawdziwe sensy (nie ma porównania między metodami, jakie stosowata polska policja $w$ okresie międzywojennym, a tym, co robiło NKWD czy gestapo). Pomimo dyskwalifikacji poznawczej, historyk uznaje wypowiedź za możliwą psychologicznie i reprezentatywną dla części Ukraińców ( $z$ ukraińskiej perspektywy dla Narodowego Ruchu Ukraińskiego, no, rzeczywiście polska policja byta przeciwnikiem. Tam dochodziło często do wydarzeń, które dzisiaj byśmy potępiali, ze strony polskiej policji). Biorąc pod uwagę raz perspektywę odbiorcy, raz nadawcy, uwzględnia tym samym ich wiedzę i doświadczenie, to znaczy dopuszcza wpływ tych czynników na negocjowanie sensu wypowiedzi. W sumie niuansowanie oceny i uwzględnianie różnych perspektyw jest przejawem strategii kooperacyjnej. Tutaj strategia ta wynika również z roli eksperta-historyka. Po przeniesieniu się na poziom przedmiotowy wypowiedzi, rozmówca ocenia ją ze względu na skorelowanie z rolą społeczną nadawcy. W tym zakresie ocena wypada jednoznacznie negatywnie (szef stużb specjalnych nie powinien się zajmować historia jako komentator). Rozmówca uznaje 
działanie komunikacyjne za niezgodne z rolą. Jest bardzo znamienne, że wypowiedź uznana za nieprawdziwą zostaje jednocześnie określona jako psychologicznie wiarygodna $\mathrm{z}$ określonej perspektywy, ale nie do przyjęcia ze względu na wyjście z roli jej nadawcy.

W danym typie dyskursu trzeba mieć pozwolenie na określone działania komunikacyjne w ramach roli, w przeciwnym razie nadawca naraża się na dyskredytację komunikacyjną. Sensownie interpretowane mogą być tylko zachowania komunikacyjne $w$ ramach roli. Zachowanie niezgodne $\mathrm{z}$ oczekiwaniami nie jest rozpatrywane na poziomie przedmiotowym, ale na poziomie metadyskursywnym. Osoba, która rozstrzyga o tym, jakie zachowania komunikacyjne są dopuszczalne w ramach roli, a jakie nie, przyjmuje pozycję dominującą w dyskursie, ponieważ próbuje sterować jego regułami. Abstrahujemy tu od faktu, czy dominacyjne zachowanie wynika z obywatelskiej troski o jakość życia publicznego (upomnienie), czy polega na instrumentalnym wykorzystaniu reguł dyskursu do dyskredytacji przeciwnika. Niezależnie od intencji mamy tu do czynienia ze strategicznym wykorzystaniem reguł dyskursu.

Ocena zachowania komunikacyjnego nadawcy w kategoriach stosowności bądź niestosowności pozostaje na poziomie oceny indywidualnej, jednostkowej. Dziennikarz w kolejnym pytaniu przechodzi na ogólniejszy poziom (który można nazwać poziomem lokalnym) i pyta o reprezentatywność jednostkowej wypowiedzi względem przekonań społecznych (Czy ta wypowiedź to jest niezręczna wypowiedź urzędnika, który jest szefem stużb specjalnych, czy ona coś mówi o stanie ukraińskiej świadomości, jeśli chodzi na przykład o ocenę polskiej policji przedwojennej?). Widać, że przejście z poziomu jednostkowego zachowania na poziom uogólnienia, dotyczącego społecznych przekonań Ukraińców, wiąże się już z nadaniem zachowaniu znakowości - wypowiedź ma (ewentualnie) być oznaką, przejawem ukraińskiej świadomości (czy ona coś mówi o stanie ukraińskiej świadomości). Mamy tu do czynienia z relacją: zjawisko/przejaw zjawiska.

Strategia interakcyjna kolejnego rozmówcy jest dostosowana do jego roli w bieżącej interakcji. Będąc szefem Związku Ukraińców w Polsce, jest uwikłany w sytuację komunikacyjną jako rozmówca najbliżej związany z autorem wypowiedzi. W związku z tym pełni rolę odpierającego zarzuty i stosuje interakcyjną strategię obrony. Jest ona realizowana w trzech krokach:

- jako odwrócenie uwagi poprzez zmianę aspektu tematu, akcentowanie nie wypowiedzi, ale reakcji na nią (technika przesunięcia linii tematycznej) (jedna [rzecz] to jest reakcja polskich mediów na to wystapienie. Temu wystapieniu nadano, wydaje mi się, za duży rozgłos $i$ zinterpretowano trochę $w$ taki histeryczny sposób). Rozmówca dokonuje najpierw strategicznego oddzielenia wypowiedzi od reakcji na nią, po to, aby sterować odbiorem reakcji (wcześniej dziennikarz i historyk sterowali odbiorem wypowiedzi, teraz rozmówca steruje odbiorem reakcji na wypowiedź). Językowa kreacja ważnego elementu tła pozajęzykowego, jakim jest reakcja na wypowiedź, nosi znamiona kreacji strategicznej. 
Kreacja zmierza do przedstawienia reakcji jako rodzaju prowokacyjnej nagonki medialnej ${ }^{8}$, mającej na celu sterowanie naciskiem społecznym. Na strategiczną kreację wskazują wyrażenia: nadano rozgłos, za duży rozgłos, zinterpretowano $w$ histeryczny sposób. O prowokacji świadczy celowość działania i jego nakierowanie na zmianę społecznych przeświadczeń. Jednoznacznie deprecjonujące jest określenie reakcji jako „histerycznej”,

- jako wprowadzenie balansującego kontekstu na poziomie ogólnym (rozszerzenie kontekstu), w tym przykładzie - kontekstu historycznego. W celu złagodzenia wymowy wypowiedzi Naliwajczenki rozmówca tworzy strategiczną relację: część/całość. Włącza wypowiedź w nurt historiografii ukraińskiej, nadając jej swoistą legitymizację i walor oficjalności (I chodzi tutaj nie tylko o to wystapienie Naliwajczenki. W publicystyce, historiografii ukraińskiej w odniesieniu do lat 1921-1939 używa się określenia „okupacja polska”. Polaków to razi. Niestety, w historiografii ukrainskiej, w perspektywie części ukraińskich badaczy to jest/ tak to funkcjonuje),

- jako wprowadzenie balansującego kontekstu na poziomie jednostkowym (zawężenie kontekstu). Ostatecznym argumentem obrony ma być argument $\mathrm{z}$ niewiedzy ( $\mathrm{z}$ trzeciej strony mamy do czynienia z problemem widzenia relacji polsko-ukraińskich przez historyków, urzędników z Kijowa, którzy nie do końca orientuja się w niuansach okresu międzywojennego). Rozmówca wskazuje na złożoność poznawczą problemu i niewystarczające kompetencje niektórych uczestników dyskursu. Tym samym pośrednio dezawuuje odnośną wypowiedź, nie pomniejszając jednakże rangi problemu. Ogólnie mówiąc, strategia obrony rozmówcy polega na przesunięciu linii tematycznej, zmianie akcentów, operowaniu kontekstem balansującym.

Następnie dziennikarz wprowadza kontekst polityczny. Przybiera maskę polemiczną i stosuje strategię dyskredytacji wobec autora wypowiedzi oraz podobnie myślących polityków. Oskarża ich o prowadzenie prowokacyjnej gry. Można ją rozumieć np. jako prowokatorską legitymizację ${ }^{9}$, która pozwala politykom uzyskać poparcie wyborców (Może, zwłaszcza w takiej niestabilnej politycznej sytuacji Ukrainy, coś można wygrać mówiąc takie rzeczy?). Politycy, podsycając antypolskie obsesje, stwarzają wrażenie, że reprezentują interes narodowy, strzegą prawdy historycznej. Posunięcie dziennikarza można potraktować jako dostosowanie się do strategii rozmówcy, który uprzednio oskarżył media o prowokację polegającą na sterowaniu społecznym odbiorem, na wzbudzaniu niezadowolenia.

${ }^{8}$ Prowokacja o charakterze nagonki polega m.in. na wzbudzaniu histerii odpowiednio egzaltowaną tonacją przekazu, sterowaniem społecznymi ocenami i emocjami (por. Karwat 2007: 367).

${ }_{9}$ Prowokatorska legitymizacja to działanie, którego celem jest uzasadnienie roszczeń określonej formacji politycznej. Występuje ona w imieniu przodków, osób pokrzywdzonych, prawdziwych patriotów (por. Karwat 2007: 195). 
W kolejnym kroku dziennikarz kieruje pytanie o odbiór wypowiedzi do następnego rozmówcy, który zostaje przedstawiony jako uwikłany w sytuację (ksiądz bardzo aktywnie zajmuje się sprawami polsko-ukraińskimi). Rozmówca stosuje strategię rywalizacyjną, w której wykorzystuje różne techniki tworzenia relacji między pojęciami i wprowadzania kontekstów:

- budowanie relacji: część/całość, gdzie jedna wypowiedź przedstawiana jest jako część większej prowokacji manipulacyjnej ${ }^{10}$ (Ta wypowiedź jest zaledwie elementem relatywizowania, wręcz fatszowania historii najnowszej na Ukrainie),

- budowanie relacji: zjawisko/przejaw zjawiska, gdzie akty prowokacji są kumulowane, a przez to również generalizowane, jako przejaw wrogiej postawy przeciwnika (nie mówi się prawdy, nie ma krzyży na grobach, stawia się pomniki zbrodniarzom),

- wprowadzenie zaostrzającego kontekstu politycznego (Dzieje się to głównie od czasów pomarańczowej rewolucji),

- wprowadzenie zaostrzającego kontekstu historycznego (głównym problemem jest ludobójstwo dokonane przez nacjonalistów ukraińskich, którzy wymordowali w bestialski sposób 200 tysięcy Polaków, wcześniej jeszcze Żydów, Ormian),

- wprowadzenie porównania zdarzeń i osób mniej znanych do powszechnie znanych (wzorem powinny być relacje polsko-niemieckie. Bo jednak mówi się prawdę na temat zabójstwa Polaków i Żydów, i nie robi się bohaterów z Hitlera i $z$ Himmlera).

Tak więc wykładnikami strategii rywalizacyjnej są nie tyko najbardziej widoczne elementy interakcyjne, takie jak dyskredytacja moralna przeciwnika ${ }^{11}$, ale również elementy poznawcze, np. postrzeganie działań przeciwnika w kategoriach prowokacji manipulacyjnej (kłamstwo, fałszowanie), postrzeganie różnicy w kategoriach winy historycznej i winy kryminalnej.

Na koniec dziennikarz przechodzi na najbardziej ogólny z poziomów kontekstu (po jednostkowym i lokalnym) - międzynarodowy. W tym kontekście z kolei zmienia się charakter układu interakcyjnego, gdyż dotychczasowym przeciwnikom wyznaczono inne role. Mają być współpracownikami ([Polska] chce być rzecznikiem ukraińskich interesów w UE). Rozmówca, występujący w roli eksperta-historyka, stara się zintegrować wszystkie aspekty, dokonuje ich hierarchizacji. Najważniejszy według niego jest aspekt polityczny, współczesny, któremu musi się podporządkować aspekt historyczny, indywidualny. Wynika stąd charakterystyka globalnej

10 Prowokacja manipulacyjna to działania zmierzające do zdobycia przewagi taktycznej, np. poprzez zniekształcanie informacji, tworzenie pozorów, mistyfikacji. Obiekt prowokacji zostaje w jej wyniku pozbawiony podmiotowości i staje się narzędziem w rękach prowokatora (por. Karwat 2007: 62-63).

11 Dyskredytacja moralna zmierza do narzucenia wrażenia, że postawa moralna przeciwnika jest naganna. Podważa się szlachetność intencji, uczciwość postępowania, a nawet dobre intencje (Karwat 2006b: 240). 
strategii komunikacyjnej polityków w relacjach między państwami o trudnej historii: strategia powściągliwości (I dlatego od polityków szczególnie wymaga się ostrożności, w tym co mówią. W tym sensie wypowiedź pana Naliwajczenki byta wysoce niefortunna. Oni powinni być wyjątkowo ostrożni).

Do ogólnych uwarunkowań strategii komunikacyjnych dziennikarzy i rozmówców zaliczamy te związane z rodzajem ich aktywności pozajęzykowej. Są one najbardziej widoczne w programach, w których odbiorca jest świadkiem negocjowania sensu zachowań komunikacyjnych. Traktowanie zachowania językowego (powiązanego z zachowaniem pozajęzykowym) jako nośnika informacji jest możliwe dzięki odniesieniu tego zachowania do różnych kontekstów (np. zadaniowego, politycznego, historycznego, lokalnego, międzynarodowego). Parametryzacja sytuacji komunikacyjnej pozwala na zastosowanie szczegółowych kategorii ekstralingwistycznych (takich jak przypadkowość, celowość, intencjonalność, przyczynowość) do uporządkowania dziedziny tematycznej dyskursu. Niektóre działania zostają zinterpretowane dzięki nadaniu im statusu prostych gatunków mowy, np. ostrzeżenia, pomówienia, oskarżenia. Wszystkie te dane cząstkowe służą interpretacji działań komunikacyjnych w kategoriach strategicznych, jako działań długofalowych, często niejawnych, służących realizacji celów związanych z aktywnością pozajęzykową rozmówców.

\subsection{Uwarunkowania strategii związane $\mathrm{z}$ dziedziną działalności pozajęzykowej rozmówców}

Debata publiczna toczona w mediach jest miejscem komunikowania politycznego, które stanowi część ogólniejszego procesu komunikowania publicznego (Dobek-Ostrowska 2006: 104). Według Briana McNaira polityczny charakter przekazu jest determinowany przez uczestników komunikacji (polityków i innych aktorów politycznych), którzy mogą stać się także jej obiektami (McNair 1998: 25). Można to ująć jako komunikowanie realizowane przez polityków, komunikowanie do polityków oraz komunikowanie o politykach i ich działalności. Media jako organizator komunikowania politycznego, stają się jednocześnie coraz ważniejszym interpretantem działalności politycznej i procesu politycznego.

Zarówno złożoność działalności politycznej, jak i konieczność dostosowania formy przekazu do kompetencji odbiorcy masowego powodują, że nadawcy medialni podejmują określone strategie na poziomie dziedziny tematycznej i ontologicznej dyskursu. Polegają one na stosowaniu upraszczających, całościowych schematów, swoistych modeli mentalnych, pozwalających ująć abstrakcyjne i skomplikowane zjawiska w kategoriach innych zjawisk - bliższych, bardziej znanych odbiorcy.

$\mathrm{Na}$ aspekt poznawczy dyskursu zwracał uwagę Teun van Dijk, który przypisywał dużą rolę modelom mentalnym w konstruowaniu reprezentacji zdarzeń 
albo działań, o których dyskurs opowiada (van Dijk 2001: 28). W tym ujęciu zatem kształtowanie warstwy poznawczej odbywa się w ramach strategii dyskursu. Swoistym zawężeniem omawianej problematyki jest umieszczenie wykreowanego obrazu świata w obrębie gatunku, w czym Maria Wojtak upatruje jednej ze strategii dyskursywnych (Wojtak 2001: 16). Tak więc modelowanie warstwy poznawczej przekazu dokonuje się zarówno w ramach typu dyskursu, jak i gatunku.

W dyskursie politycznym, w ramach takich gatunków jak debata, dyskusja, rozmowa publiczna, spotyka się ujmowanie polityki w kategoriach gry scenicznej (polityka jako spektakl) i gry rywalizacyjnej (wojennej, sportowej, rynkowej) (Frankowska 1994: 21-47; Pawełczyk 2000: 19-52; Fras 2005: 153-196; Podracki, Trysińska 2002: 540-548). Jest to przejaw ogólniejszych mechanizmów poznawczych, którym porównanie oraz metafora dostarczają podstawowych kategorii pojęciowych ludzkiego myślenia i działania (Lakoff, Johnson 1988; Perelman 1971: 247).

Tak więc interakcyjność działań politycznych, które cechuje istnienie implicytnych reguł, skłania uczestników komunikowania politycznego do ujmowania polityki w kategoriach szeroko rozumianej gry. W punkcie 2.2.1 zostały zamieszczone przykłady ujmowania polityki jako gry scenicznej, czyli postrzegania polityki jako spektaklu. W punkcie 2.2.2 znalazły się fragmenty wypowiedzi, które są świadectwem ujmowania polityki jako gry rywalizacyjnej. Punkt 2.2.3 zawiera przykłady łącznych odwołań do metaforycznych określeń polityki jako spektaklu, rywalizacji wojennej, sportowej, rynkowej.

\subsubsection{Schemat interpretacyjny: polityka jako spektakl}

Postrzeganie w mediach masowych polityki jako gry scenicznej ma wpływ na budowę i znaczenie przekazów politycznych. Pojawiają się w nich takie charakterystyczne elementy, jak odgrywanie ról przez polityków, reżyseria spektaklu, tworzenie narracji, scena, kulisy. Odgrywanie ról nie jest zarezerwowane tylko dla polityków, ale w ich przypadku role cechuje większa świadomość, specyficzne motywacje i ograniczona dostępność (Pawełczyk 2000: 23). Autoprezentacja i zdobycie aprobaty publiczności staje się głównym celem aktorów politycznych.

Okazuje się jednak, że modelowanie warstwy poznawczej dyskursu poprzez stosowanie globalnego schematu interpretacyjnego może być wykorzystane strategicznie w rywalizacji politycznej. Rozmówcy bowiem nie tylko implicytnie przyjmują reguły uczestnictwa jako gry scenicznej ${ }^{12}$, lecz także posługują się wiedzą o tych uwarunkowaniach na poziomie metadyskursywnym. Jest to

${ }^{12}$ Na obraz polityki jako wielkiego spektaklu składają się liczne wyznaczniki teatralności, takie jak: kurtyna, scena, kulisy, spektakl, aktor, rola, scenariusz, reżyser, widownia, kostium (Frankowska 1994: 22-28). 
możliwe dzięki wartościującemu charakterowi metafory. Szczególnie często są wykorzystywane różnice między odgrywaniem ról w spektaklu a rzeczywistym uprawianiem polityki, między sceną a kulisami, między samodzielnym działaniem a działaniem sterowanym przez reżysera. Co ciekawe, te same różnice mogą być podstawą zarówno racjonalizacji określonych działań, to znaczy takiego ich przedstawienia, aby nie budziły społecznej dezaprobaty, jak i podstawą dyskredytacji.

JP: Dobry wieczór państwu. [wprost do kamery] Za nami najbardziej burzliwy tydzień w IV Rzeczpospolitej [ujawnienie nagrań Renaty Beger]. Serwisy informacyjne, programy publicystyczne pod względem oglądalności doganiaja najpopularniejsze telenowele, sitcomy, seriale telewizyjne. Być może dlatego, że świat polityki przypomina dzisiaj serial. [...] Czyli to jest tak rzeczywiście dzisiaj, że polityka zaczyna przypominać spektakl telewizyjny?

TŻ: Tak. Zaczyna przypominać. To jest nieuchronny skutek tego, że stajemy się cywilizacja medialna. Media elektroniczne dominuja $w$ tej/ debata publiczna się przenosi przede wszystkim przed kamery. Nie tylko przed kamery gdzieś tam w pokoju, ale również my tu rozmawiamy przed kamerami. Politycy/ generalnie telewizja jest głównym pośrednikiem i w konsekwencji te formy, które tu występuja w/ co więcej media jeszcze sa coraz bardziej zdominowane przez przekaz komercyjny, a nie ten publiczny, który byt dla polityków z różnych, oczywistych względów bardziej życzliwy. I konsekwencja jest to, że pewne formaty, przepraszam za stowo,z telewizji komercyjnej. z tego przekazu rozrywkowego, przechodza do polityki. To jest nieuchronne zjawisko. Problem tylko polega na tym, jak uratować przy tym realność i autentyczność rzeczywistej dyskusji politycznej.

MP: [...] chodzi tylko o jedną bardzo ważna rzecz. Otóż Eco powiedziat, że te narracje, które wykorzystuje telewizja, również i $w$ relacjach życia politycznego, one sa, jeśli by je porównywać z narracjami literackimi, raczej nizinne niż z tej wysokiej kultury, ponieważ sa do szerokiej publiczności. Ale co więcej, chodzi tė̇ $i$ o to, żeby ten sygnat przez nadawcę wysytany, byt możliwie szybko wytapywany. Inna sprawa z rozumieniem, bo nie zawsze jest tak, że publiczność rozumie to zgodnie, na przykład, $z$ intencjami aktorów czy reżyserów.

(„Warto rozmawiać”, TVP 2, 1.10.2006; dziennikarz - JP: Jan Pospieszalski; goście - MP: Mirosław Pęczak, TŻ: Tomasz Żukowski)

Dziennikarz, nawiązując do aktualnego wydarzenia politycznego, tzw. afery z taśmami Renaty Beger, porównuje politykę do serialu, a następnie do spektaklu telewizyjnego. Rozmówca, który występuje w roli eksperta, politologa, wskazuje na modelujący wpływ mediów na kształtowanie przekazu politycznego. Kierunek wpływu polega na komercyjnym, rozrywkowym uproszczeniu procesu politycznego w taki sposób, aby przekaz był dostępny dla szerokiej publiczności. Kolejny rozmówca, dziennikarz, rozwija porównanie. Twierdzi, że media, relacjonując wydarzenia polityczne, stosują narracje pochodzące z kultury niskiej. Trywializacja przekazu jest spowodowana chęcią pozyskania widzów, co jednakowoż nie gwarantuje zrozumienia.

W kontekście politycznym porównywanie polityki do spektaklu przenosi na nią cechy podstawy porównania, takie jak zawieszenie realności, podporządkowanie działań pozyskaniu publiczności. Zawsze, kiedy sytuacja polityczna jest niekorzystna dla jednej ze stron, kiedy dziennikarze ujawniają to, co nie 
świadczy o niej dobrze, pojawiają się próby dezawuowania działań politycznych w ogólności poprzez strategiczne porównania. Ich perswazyjność polega na tym, że angażują elementy dyskursu eksperckiego do bieżącej rywalizacji politycznej (na takiej zasadzie, że jeśli wynik w grze jest dla nas niekorzystny, to podważamy w ogóle reguły gry, która przecież jest nierealna, nieprawdziwa).

Konsekwencją ujmowania polityki jako spektaklu jest uwzględnienie działań zakulisowych i roli reżysera jako sterującego wydarzeniami. Opozycja: aktor/ reżyser, scena/kulisy - pozwala zracjonalizować wiele wydarzeń o charakterze politycznym. Celem porównania jest wywołanie akceptacji faktu, że za kulisami przygotowuje się występ, co stanowi normalny etap procesu politycznego, a nie przejaw patologii ${ }^{13}$.

MP: W tym przypadku [chodzi o rozmowę Beger - Lipiński, nagraną w pokoju poselskim, nazwaną przez prowokatorów korupcją polityczną, a przez przyłapanych - zwykłymi negocjacjami] mamy do czynienia $z$ polityka $w$ stanie czystym. I wiadomo, że każdy ma pewne wyobrażenie co do tego, jak może wyglądać kuchnia polityczna. Ale jednocześnie trzeba wiedzieć, że ludzie lubia konwencje. Wyborcy też lubia konwencje. W momencie, kiedy się przetamuje te konwencje, czy wchodzi w grę wtaśnie to odkrywanie kulis, zatamuje się, że tak powiem, przyjęta definicję sytuacji, jak to życie polityczne ma wygladać, to oczywiście wywołuje to zrozumiałe wzburzenie i wtedy się bardzo źle ocenia tych aktorów.

EM: Ale chyba wszystkich $w$ tym momencie, cata klasę polityczna??

JP: To znaczy, ktoś wyskakuje ze swojej roli, czyli z takiej roli, która//

JŁ: Zakładając, że takie targi polityczne odbywaty sie już wcześniej, różnica jest taka, że nikt ich nie nagrat $i$ nie pokazat w telewizji, prawda? A tutaj mamy sytuację nagrania i ogólnego oburzenia. I teraz sa ci, którzy tym oburzeniem administrują i mówią: „No, powinniśmy się oburzyć tutaj strasznie".

(„Warto rozmawiać”, TVP 2, 1.10.2006; dziennikarz - JP: Jan Pospieszalski; goście - EM: Eryk Mistewicz, JŁ: Jacek Łęski, MP: Mirosław Pęczak)

Rozmówcy przyjmują rozumienie polityki jako spektaklu, który rozgrywa się na oczach widzów, zgodnie z konwencjami oraz w sposób niejawny za kulisami (kuchnia polityczna, odkrywanie kulis). Uruchomienie takiego schematu interpretacyjnego jest pewną strategią sterowania odbiorem, gdyż pozwala kategoryzować wydarzenie początkowo oburzające opinię jako normalne (mamy do czynienia $z$ polityka $w$ stanie czystym). Legitymizuje tego rodzaju działania (zakulisowe porozumienia, targi) jako wkalkulowane w taki typ działalności, jak polityka. Można powiedzieć, że metafora konceptualna stanowi mechanizm legitymizujący pewien typ działań, które bez tej metafory mogłyby budzić opór społeczny. Innymi słowy, rozumienie polityki jako spektaklu zostaje wykorzystane strategicznie do wstawienia wydarzenia w inne ramy, do przedefiniowania

13 Naturalne i wolne od negatywnego wartościowania podejście do metafory teatralnej zawiera (pozostająca w nurcie symbolicznego interakcjonizmu) teoria Ervinga Goffmana (Goffman 2000). 
sytuacji zarejestrowanej na taśmie z takiej, która narusza normy dyskursu politycznego (korupcja) - na taką, która stanowi zaledwie odsłonięcie kulis normalnej polityki.

Ujęcie polityki jako spektaklu, który rozgrywa się na scenie, budzi ciekawość widza, co dzieje się za kulisami. Biegłość aktorskiego popisu nie idzie w parze $\mathrm{z}$ autentycznością, szczerością. Tak jak w poprzednim przykładzie opozycja scena/kulisy została wykorzystana do obrony twarzy, tak w kolejnym fragmencie służy dyskredytacji demaskatorskiej ${ }^{14}$, która ujawnia cyniczną grę. Sztuczność występu aktorskiego implikuje ważną charakterystykę działania. Otóż, aktorzy polityczni działają według reguł ekspresji i motywów gry, a nie według reguł racjonalności potocznej. To tłumaczy, dlaczego potoczne sposoby rozumienia zachowań polityków zawodzą. Dobrze ujął tę prawidłowość pracownik agencji PR w następującej anegdocie.

JŁ: Jeżeli mówimy o serialu, występach $i$ takim kreowaniu fabuty, no to ja pamiętam taki przyktad spotkania $z$ A. Lepperem, które przekonało mnie, że to jest jeden z niewielu ludzi z tego typu seriali, który świadomie gra. To znaczy on wie, w jakim przedstawieniu bierze udziat, jaka jest jego rola, gdzie się charakteryzować, gdzie potem rozdaja picie po zdjęciach na planie i tak dalej. Więc byta scena taka $w$ radiu, kiedy jeden z moich kolegów dziennikarzy w trakcie wywiadu przycisnąt go, pytając, czego się nauczyt od zbrodniarza wojennego Józefa Goebbelsa, bo Lepper opowiadat kiedyś dla „Gazety Wyborczej”, że z jego ksiązek się uczyt, i Lepper powiedziat/ nie chciat rozmawiać na ten temat. On mówi [kolega]: „No ale dobrze, chwileczkę, przecież pan to powiedziat?”. „Nie, nie powiedziałem”. Wyciaga ksero, cytat z gazety. Lepper mówi: „Nie będę odpowiadat na tego typu pytania”. „A, nie chce pan rozmawiać?” - „Nie chcę”. Czyli walkower, 1:0 dla dziennikarza. I następuje przerwa reklamowa, tak. W tej przerwie reklamowej Lepper do tego dziennikarza mówi: „No fantastycznie”, mówi, „Świetnie pan przycisnąt z tym Goebbelsem. Pan ostro pojechat, ja ostro pojechatem, świetnie się to ogląda”. I nam szczęki opadty, szczerze mówiac, no bo rzadko się zdarza, że polityk ma takie podejście do tego typu historii. Inny by się obrazit, albo tam wtaśnie domyślat się, kto stoi za dziennikarzem, który zadat mu takie pytanie. Nie, on to absolutnie w konwencji: „Bardzo fajna scena wyszła, jeszcze moglibyśmy dubla nakręcić”, ale generalnie nie ma potrzeby, bo świetnie wyszło.

EM: Bo to nie jest amator.

(„Warto rozmawiać”, TVP 2, 1.10.2006; goście - EM: Eryk Mistewicz, JŁ: Jacek Łęski)

Rozmówca, wykorzystując opozycję scena/kulisy, przytacza anegdotę mającą zobrazować trafność ujmowania polityki jako spektaklu. Przedstawia w niej polityka jako grającego świadomie pewną rolę. Gra toczy się według konwencji widowiska, a nie racjonalności rozmowy potocznej. Rozbieżność jest widoczna, kiedy inaczej zostaje odebrana sytuacja zagrożenia twarzy pozytywnej rozmówcy (Czyli walkower, 1:0 dla dziennikarza ${ }^{15}$ ) w wyniku przyłapania go na niespójnym zachowaniu („No ale dobrze, chwileczkę, przecież pan to powiedziat?”. „Nie, nie

${ }^{14}$ Dyskredytacja demaskatorska zmierza do obnażenia rzeczywistej tożsamości kogoś nieautentycznego, nieszczerego, w celu podważenia jego wiarygodności (Karwat 2006b: 56).

15 Rozmówca wykorzystuje metaforę polityki jako gry sportowej (por. Frankowska 1994: 28). 
powiedziałem”. Wyciaga ksero, cytat z gazety). Okazuje się, że widowisko kieruje się innymi regułami. Następuje zmiana hierarchii celów: najważniejszy jest efekt dramatyczny („No fantastycznie”, mówi, „Świetnie pan przycisnąt z tym Goebbelsem. Pan ostro pojechat, ja ostro pojechałem, świetnie się to oglada”). Utrata twarzy nie jest tak boleśnie odbierana, gdyż wszyscy aktorzy mają cel nadrzędny - przyciągnąć uwagę widza-wyborcy.

Media masowe przyczyniają się do upowszechnienia metaforyki teatralnej, w której pojawiają się różne pola semantyczne: nazwy uczestników (aktor, amator, gracz), określenia działań (wyskakiwać z roli, administrować oburzeniem, brać udział w przedstawieniu, występować, kreować fabułę, grać świadomie, nakręcić dubla), nazwy miejsc (scena, kulisy), nazwy gatunków i formatów medialnych (telenowela, sitcom, serial, spektakl, przedstawienie). Poszczególne elementy metaforyki wraz z wartościowaniem, opozycje między elementami, mogą być wykorzystywane strategicznie przez uczestników i organizatorów komunikacji politycznej do sterowania odbiorem, uzasadniania mechanizmów sprawowania władzy lub dyskredytacji przeciwników.

\subsubsection{Schemat interpretacyjny: polityka jako gra rywalizacyjna}

Drugim, obok spektaklu, sposobem postrzegania polityki jest jej konceptualizacja jako gry rywalizacyjnej. W tym ujęciu celem aktywności jest zdobycie roli swoiście pojmowanego negocjatora i głównego rozgrywającego (który np. decyduje o alokacji dóbr społecznie cenionych) (Pawełczyk 2000: 40). Zdobycie kontroli nad najważniejszymi sferami życia społecznego jest związane z koniecznością uzyskania poparcia, stąd również w tym ujęciu pojawia się grupa widzów, która kibicuje graczom i ze względu na którą gra w ogóle się toczy.

JF: Wydaje mi się, że jest to gra [polityka]. Gra, w której obydwie strony eskaluja te środki. którymi dysponuja po to, żeby zrobić jak największe wrażenie na widzach. To jest gra stara. Ronald Reagan, jak zostawat gubernatorem stanu Kalifornia, powiedziat: „Nie wiem, jakim będę gubernatorem. Nigdy jeszcze nie grałem gubernatora”. To jest dopust boży, którego nasza cywilizacja dożyła. Nie ma wojen światowych, to musimy się mierzyć z tym, że dyskurs publiczny jest prowa$\underline{d z o n y}$ w takich warunkach. [...] wydaje mi się, że nie ma co się rozczulać ani nad tymi, co graja w nieczystej grze, ani nad tymi, co by chcieli grać w czystej grze, ale przegrywaja. Tak naprawde. jeśli chcemy, żeby ktoś wygrat, to musi umieć w to grać, nawet jak ma czyste intencje. I powinien sobie poradzić z tymi, którzy maja zte intencje, którzy sa graczami. To nie jest tak, że rozum jest nam dany po to, żeby błyskotliwie biadolić. Po prostu trzeba wygrywać. Nawet, jak się walczy o szczytna ideę, nawet jak się chce walczyć czysto, to tez ztrzeba potrafić wygrać.

(„Warto rozmawiać”, TVP 2, 1.10.2006; gość - JF: Jarosław Flis)

Wypowiedź dotyczy ogólnej charakterystyki zachowań komunikacyjnych polityków ze względu na specyfikę ich działalności pozajęzykowej. Rozmówca konceptualizuje interakcję między politykami jako grę rywalizacyjną, w której 
obowiązuje profesjonalizm (Tak naprawdę, jeśli chcemy, żeby ktoś wygrat, to musi umieć $w$ to grać; trzeba potrafić wygrać). Gra jest prowadzona możliwymi środkami (domyślnie: nie tyle podlegającymi ocenie etycznej, co ocenie pragmatycznej) i ze względu na cel zewnętrzny, zdobycie poparcia (obydwie strony eskaluja te środki, którymi dysponuja po to, żeby zrobić jak największe wrażenie na widzach). W tego rodzaju działalności pozytywnie wartościowane są strategie komunikacyjne nastawione na skuteczność, efektywność, natomiast negatywnie odbierane będą strategie obrony twarzy odwołujące się do współczucia, kreujące wizerunek polityka jako ofiary (To nie jest tak, że rozum jest nam dany po to, żeby błyskotliwie biadolić).

Działanie według reguł ekspresji i motywów gry często jest ukrywane przez aktorów politycznych. Muszą oni godzić prawdziwe cele, np. chęć wyeliminowania przeciwnika, chęć zdobycia władzy, z kreowaniem wizerunku polityka koncyliacyjnego. Zatem stałym motywem interakcji politycznej jest demaskowanie przeciwnika i odkrywanie manipulacji (nazywamy to posunięciem „odkryłem twoją grę”). Ujawnienie jest możliwe dzięki wiedzy na temat działalności profesjonalnej rozmówcy i wynikających z niej konwencji w danym typie dyskursu.

W poniższym fragmencie sygnałami wskazującymi na konwencję są sformułowania „retoryka” jako sposób mówienia o czymś, sposób organizowania treści pojęciowych; „ubierać niechęć w jakieś szaty” - w sensie: obchodzić pewne zakazy konwencjonalne za pomocą określonych technik komunikacyjnych.

SM: Tak jak tutaj panowie mówili, problem leży w retoryce. Panom się ta retoryka nie podoba. Mniejsza o to, z jakich powodów. Znaczy, nie mniejsza o to. Sądzę, że panowie ubieraja swoja niechęć $w$ szaty, że tak powiem, ewangeliczne, bo tak to panom jest wygodnie politycznie, natomiast problem polega na tym, czy ten komentarz ma być autentyczny, to znaczy odzwierciedlać to, co ten odtam opinii publicznej na ten temat sądzi [...].

(„Debata”, TVP 1, 11.01.2006; gość - SM: Stanisław Michalkiewicz)

Rozmówca na poziomie metadyskursywnym komentuje zachowania komunikacyjne przeciwnika, stosując strategię zagrożenia twarzy. Odkrywa (lub tylko przypisuje, bo manipulacji z jego strony też nie można wykluczyć) technikę manipulacyjną, którą nazwano zwiększaniem siły (panowie ubieraja swoją niechęć $w$ szaty, że tak powiem, ewangeliczne). Zwiększanie siły to odwołanie się do istotnych argumentów, pochodzących z prestiżowych dyskursów (w tym przykładzie jest to dyskurs religijny, ale taką funkcję może pełnić również dyskurs naukowy). Technika ta, jak już wspomniano w zapowiedzi omawianego fragmentu, jest dowodem uwzględnienia konwencji komunikacyjnych właściwych dla danego dyskursu (bo tak to panom jest wygodnie politycznie). Jeśli konwencje blokują ujawnienie niechęci (która jako emocja mogłaby świadczyć o braku profesjonalizmu polityka), to należy przekazać komunikat interakcyjny akceptowanymi metodami (np. jako kontrargumentację, krytykę z pozycji dyskursu 
religijnego, krytykę pryncypialną). Ujawnienie manipulacji można porównać do zdemaskowania przeciwnika, który kreuje się na nauczyciela, apeluje o zachowanie standardów komunikacyjnych, a tymczasem w rzeczywistości realizuje partykularne cele polityczne.

Pole rywalizacji politycznej ulega do tego stopnia rozszerzeniu na całą sferę publiczną, że rywalizujące podmioty nie muszą pozostawać w bezpośrednim kontakcie. Wszak najważniejszym ogniwem w grze są widzowie, którzy rejestrują kolejne posunięcia strategiczne. W sytuacji braku bezpośredniego kontaktu między podmiotami, pierwszym posunięciem w grze może być oświadczenie będące elementem pseudowydarzenia politycznego ${ }^{16}$. Staje się ono później tematem rozmów w mediach. Strategie są rozpoznawalne m.in. dzięki analizie relacji między uczestnikami pseudowydarzenia: nadawcą komunikatu politycznego, obiektem ataku, odbiorcą.

AM: [...] pewnie pan styszat tę wypowiedź?

AG: Jaka??

AM: No, [przyszłego szefa//

AG: [Styszatem o tej wypowiedzi. Sam nie miatem tej przyjemności.

TS: No to postuchajmy. Mariusz Kamiński, przyszły szef Centralnego Biura Antykorupcyjnego. [materiał filmowy] MK: Gtównym celem, bardzo istotnym celem Centralnego Biura Antykorupcyjnego będzie przerwanie niebezpiecznego styku polityki i bez/i biznesu, niebezpiecznych, patologicznych powiazań. Chcemy jasno powiedzieć, że sa w Polsce tak zwani wielcy biznesmeni, którzy kolekcjonują w swoich spótkach bytych ministrów, bytych posłów. Widzimy te [sic!] zjawisko, dostrzegamy te zjawisko, monitorujemy $i$ chcemy tym panom powiedzieć, takim panom jak pan Kulczyk, jak pan Gudzowaty, jak pan Krauze, że jeśli licza na to, że dzięki temu będa mi odnosili korzyści w biznesie, to sa w wielkim btędzie.

TS: I co pan na to, jak pan styszat?

AG: No, tak szczerze?

TS: Szczerze.

AG: Wypowiedź bardzo arogancka i bardzo niekompetentna. To pierwsza reakcja. Po drugie, nieuprawniona. Po pierwsze, nie ma jeszcze tego urzędu, a ten pan już opowiada.

TS: No ale jest petnomocnikiem rządu do powołania tego urzędu.

AG: To niech se wpierw powota, a potem niech daje certyfikaty. A poza tym, problem polega na tym, że on tak naprawdę nic nie powiedziat, tylko pogrozit paluszkiem. Z jedna sprawa się musicie chyba panowie zgodzić, że generalnie standard w Polsce się bardzo obniżyt, we wszystkim. I takie zachowanie mieści się w tym pojęciu, niestety. Ja napisatem list do pana premiera á propos standardu, gdzie zwrócitem uwage, że to jest po pierwsze nieprawda, po drugie krzywdzace, bo my nie mamy żadnego styku $w$ tej chwili z państwem. Więc poprositem o wszczęcie postępowania wobec tego pana Kamińskiego.

TS: Ale jakiego postepowania?

AG: Administracyjnego, to przecież jest urzędnik państwowy.

AM: A dostat pan odpowiedź?

${ }^{16}$ Pseudowydarzenie to potencjalny materiał na news. Jest zaplanowane, przygotowane na użytek mediów oraz nie ma jasnego związku z odtwarzanym rzeczywistym wydarzeniem. Pseudowydarzeniami są m.in. konferencje prasowe, oświadczenia, sztucznie nagłośnione sytuacje kryzysowe mające szkodzić konkurencji (Jabłoński 2006: 76). 
AG: Nie, nie dostatem. Do niedzieli jeszcze mieliśmy sygnały, że pan Kamiński się zastanawia nad tekstem przeprosin. Byleby to nie były przeprosiny tylko takie ogólne. Ale nie przyszedt ten tekst, $w$ zwiazku z tym sprawe przekazaliśmy zgodnie z obyczajem do prokuratury.

AM: Wyglada na to, że przeprosin nie bedzie, panie prezesie, bo przyznamy sie szczerze, $\dot{z} e$ proponowaliśmy panu Kamińskiemu, żeby tutaj z panem usiadt przy naszym stole, ale nie chciat. Gdyby chciat przeprosić, to by pewnie przyszedt.

AG: On bytby w bardzo trudnej sytuacji, bo wtenczas by się tu źle poczut zapewne.

(„Teraz my!”, 24.01.2006; dziennikarze - AM: Andrzej Morozowski, TS: Tomasz Sekielski; gość - AG: Aleksander Gudzowaty; bohater materiału filmowego - MK: Mariusz Kamiński)

Tematem rozmowy jest treść publicznego oświadczenia Mariusza Kamińskiego. Jej uczestnikami są dziennikarze i biznesmen, którego nazwisko pojawiło się w tejże wypowiedzi. Dziennikarz wprowadza temat w sposób typowy raczej dla sytuacji nieoficjalnych. Zakłada wiedzę wspólną, która pochodzi z kontekstu politycznego. Rozmówca stosuje konsekwentnie strategię uniku, polegającą na unikaniu sytuacji zagrożenia twarzy, natomiast dziennikarz - strategię stopniowego budowania takiej sytuacji (strategia zagrożenia twarzy). Unikanie zagrożenia twarzy polega tu na utrzymywaniu możliwie największego dystansu do niewygodnego wątku. Jest realizowane w kilku krokach. Najpierw rozmówca udaje, że nie wie, o co jest pytany (Pewnie pan styszat tę wypowiedź? Jaką?). Następnie utrzymuje, że osobiście nie słyszał wypowiedzi (No, [przyszłego szefa// [Styszałem o tej wypowiedzi. Sam nie miatem tej przyjemności). Mamy tu jednak do czynienia z niespójnością przekazu werbalnego i niewerbalnego. Informacja komunikowana wprost jako brak wiedzy i pośrednio jako brak zainteresowania nie współgra z niecierpliwym rozpoczęciem mówienia zanim dziennikarz skończy dopowiedzenie (nałożenie tury). Przerwanie i zbyt energiczne odcinanie się świadczy właśnie o zaangażowaniu emocjonalnym. Potwierdza, że budowanie dystansu do zagrażającego wątku jest świadomą strategią.

Następnie nadawca medialny pokazuje materiał filmowy z wypowiedzią, która stanowi strategiczny punkt budowania sytuacji zagrożenia twarzy pozytywnej rozmówcy. Pomimo wyraźnych gróźb pod adresem biznesmenów wymienionych po nazwisku (chcemy tym panom powiedzieć, takim panom jak pan Kulczyk, jak pan Gudzowaty, jak pan Krauze), wypowiedź nie jest skierowana do nich. Właściwym adresatem są widzowie-wyborcy, którym dostarcza się uzasadnienia powołania nowego urzędu. Wypowiedź jest kreowaniem wizerunku poprzez prowokatorską legitymizację. Bazuje ona na prostych emocjach, takich jak zazdrość, niechęć, podejrzliwość. Pobudzanie tych emocji u wyborcy ma pomóc w zaistnieniu na scenie politycznej i stworzeniu wrażenia „reprezentatywności, prawowitości mandatu społecznego" (Karwat 2007: 195). Znane nazwiska i illokucja groźby wzmacniają jedynie efekt prowokacji, która ma być widowiskowa. Potwierdzeniem rozpoznania strategii realizowanej jako prowokatorska legitymizacja jest dopasowana reakcja zaatakowanego. Biznesmen w obronie twarzy pozytywnej dyskredytuje polityka, występując właśnie z perspektywy uprawnień 
(Wypowiedz [...] nieuprawniona. Po pierwsze, nie ma jeszcze tego urzędu, a ten pan już opowiada). Trafność obrony wynika z odczytania globalnej intencji działania komunikacyjnego, która jest wpisana w cele aktywności politycznej.

Obaj antagoniści wysyłają sygnały dominacji. Użycie zaimka „mi” może być sygnałem symbolicznego wytyczenia terytorium dominacji (jeśli licza na to, że dzięki temu będa mi odnosili korzyści w biznesie). Dominant kontroluje terytorium poprzez ustanawianie na nim praw, a wkroczenie bez pozwolenia jest odbierane jak naruszenie, inwazja (Wasilewski 2006: 148). Jeśli rozmówca kwalifikuje niepożądane działania innych jako wymierzone w siebie, to sygnalizuje je zaimkiem „sobie”, pot. „se” (To niech se wpierw powoła).

Sposobem obrony wizerunku jest pogorszenie wizerunku przeciwnika. W tym z kolei przejawia się modelowanie interakcji na wzór gry rywalizacyjnej, w której „twoja strata jest równa mojemu zyskowi” (tzw. gra o sumie zerowej ${ }^{17}$ ). Antagonista infantylizuje dominanta i przez to pozbawia powagi (że on tak naprawdę nic nie powiedziat, tylko pogrozit paluszkiem). Następnie przebudowuje relacje przyczynowo-skutkowe elementów tła pozajęzykowego w taki sposób, że wypowiedź Kamińskiego nie jest reakcją na naganne zachowanie biznesmena, tylko przejawem obniżenia standardów (generalnie standard w Polsce się bardzo obniżyt, we wszystkim. I takie zachowanie mieści się w tym pojęciu, niestety). Jest to działanie komunikacyjne będące również przejawem strategii uniku, polegającej na zwiększaniu dystansu, na przejściu z pola tematycznego dotyczącego własnej osoby - na pole tematyczne dotyczące przeciwnika (na zasadzie, że „nie chodzi konkretnie o mnie, tylko ogólnie standard się obniżył”). Można to również odebrać jako przejście od uwarunkowań wewnętrznych do uwarunkowań zewnętrznych w interpretacji działań pozajęzykowych (na zasadzie „to nie ja zrobiłem coś złego, tylko on nie potrafi się zachować”). Jest to typowy kierunek w interpretacji działań niekorzystnych dla nadawcy.

Kolejnym krokiem w realizacji strategii obrony twarzy jest wykorzystanie zasad systemu komunikowania publicznego. Zwiększanie dystansu odbywa się tu poprzez zwracanie się nie do osoby stosującej prowokację, lecz do jej zwierzchnika. Pominięcie prowokatora stawia go w pozycji podrzędnej, uniemożliwia nawiązanie relacji innej niż poprzez zwierzchnika, gdzie zwierzchnikowi narzuca się rolę osoby dyscyplinującej. Biznesmen wykorzystuje niniejszym wiedzę na temat uczestników systemu komunikowania, ich składu, struktury i cech. Ostatecznym potwierdzeniem zewnętrznego celu oświadczenia M. Kamińskiego jest odmowa kontaktu z adresatem wypowiedzi (proponowaliśmy panu Kamińskiemu, żeby tutaj z panem usiadt przy naszym stole, ale nie chciat). Unik świadczy o tym, że

17 Por. rozważania Janusza Reykowskiego na temat konfliktu (Reykowski 2002a: 221). Autor zwraca uwagę na rolę przetwarzania informacji w interpretacji sytuacji konfliktowej. Sytuacja może być ujmowana jako gra o sumie zerowej, w której korzyść jednej strony musi pociągać za sobą stratę drugiej. A więc albo zwycięstwo, albo klęska. 
był to pozorny adresat. Znane nazwiska zostały wykorzystane instrumentalnie do osiągnięcia mocniejszego efektu. Wynika stąd, że próba zastosowania standardów zachowań, właściwych dla interakcji twarzą w twarz, w sytuacji medialnego widowiska wyraźnie zawodzi (Wygląda na to, że przeprosin nie będzie, panie prezesie). Jest to spowodowane komplikacją sytuacji komunikacyjnej, zmianą hierarchii celów, odmiennymi zasadami obowiązującymi w systemach komunikowania. Jak twierdzi Dobek-Ostrowska: „proste interpersonalne porozumiewanie się jednostek i małych grup zostaje zastąpione złożonym, wieloaspektowym i wielopłaszczyznowym procesem komunikowania” (Dobek-Ostrowska 2006: 103).

Modelowanie interakcji na wzór gry rywalizacyjnej niesie daleko idące implikacje, np. rywalizacyjny model interakcji, działanie nie według reguł racjonalnej celowości, ale według reguł ekspresji i motywów gry, zamiana racjonalności aksjologicznej amatora na racjonalność instrumentalną profesjonalisty, uchylenie domniemania dobrej woli, zaawansowane strategie odbioru (nie tylko treści eksplicytnych, ale również implicytnych, ukrytych), możliwość instrumentalizacji tematów, wątków i inne. Jeśli mamy do czynienia z interakcją, która jest grą rywalizacyjną, to nie można jej analizować jak zwykłej, potocznej rozmowy, gdyż wiele treści pozostawałoby nieujawnionych, a nawet uległoby zniekształceniu. Narzucone schematy interpretacyjne dostarczają bardziej adekwatnych narzędzi do opisu ważnych makrostrategii społecznych: obrony twarzy oraz zagrożenia twarzy.

\subsubsection{Kontaminacja schematów interpretacyjnych (spektaklu i gry rywalizacyjnej)}

W wielu interakcjach dochodzi do kontaminacji schematów interpretacyjnych gry scenicznej i gry rywalizacyjnej, co wynika z nieostrości samego pojęcia wyjściowego. Grę sceniczną oraz grę rywalizacyjną łączą pewne cechy wspólne, takie jak zespołowy charakter, działanie według pewnych reguł, wymóg posiadania kompetencji. Poza tym każda z metafor ujmuje pewien istotny aspekt działalności politycznej o charakterze komplementarnym. Gra rywalizacyjna wskazuje na konieczność pokonania konkurencji politycznej, akcentuje skuteczność i dążenie do wygranej. Gra sceniczna wymaga kreowania wizerunku, podkreśla ważność relacji z odbiorcą, którego przychylność jest ostatecznym celem wszelkich działań. W poniższym przykładzie rozmówca wykorzystuje strategicznie element metaforyzowany, jakim są reguły gry, do negatywnej oceny polityki.

IK: [...] ta wspólnota [PO i PiS] polegata na deklaracji przemiany polskiej polityki. Wtaśnie z takiej polityki, która byta oparta na zakulisowych grach, na zakulisowych interesach, na zakulisowych umowach - w coś, co byto otwarte, gdzie intencje aktorów politycznych, cele polityczne byty zdefiniowane, gdzie dyskusja miałaby przebiegać w oparciu o argumenty. [...] Właściwie w gruncie rzeczy to mamy tutaj intrygi, które polegaja na grze o wtadze, o zdobycie wptywów partyjnych. Nie ma tutaj nic do rzeczy mówienie o interesach dtugofalowych, nie ma w tym nic do rzeczy z wtaczaniem opinii publicznej jako, no, elementu dyskursu, nie ma tu żadnej debaty na argumenty. Jest 
to gra, żeby wpędzić swoich przeciwników w taka sytuację, że właściwie oni nie wiedza, co maja robić. Takie właśnie te/ ze zmiennymi bodźcami, sznurki ze zmiennymi bodźcami.

(„Debata”, TVP 1, 18.01.2006; gość - IK: Ireneusz Krzemiński)

Celem rozmówcy jest dyskredytacja określonej siły politycznej przez wywołanie wrażenia, że stosuje ona niejasne, podejrzane działania, niezgodne z regułami otwartej, uczciwej gry. Mamy tu do czynienia z przewagą celu pragmatycznego nad postawą badawczą. Rozmówca nie analizuje bowiem rzeczywistych zachowań polityków, które mógłby następnie kategoryzować, ale od razu podaje ogólną diagnozę sytuacji. W wypowiedzi zostają skontrastowane dwie koncepcje uprawiania polityki i jednocześnie komunikowania politycznego, które różnią się sposobem działania (są to jakby dwie gry: jawna i niejawna, oparta na argumentach i oparta na intrygach). Różne cele działania implikują różnice w makrostrategiach komunikacyjnych. W jednej koncepcji celem jest manipulacja przeciwnikiem oraz zdobycie władzy, czemu służą zakulisowe gry i intrygi. Posunięciem w tej grze jest prowokacja demobilizacyjna (Karwat 2007: 233), która ma unieszkodliwić przeciwnika, sparaliżować jego zdolność do działania (Jest to gra, żeby wpędzić swoich przeciwników w taka sytuację, że wtaściwie oni nie wiedza, co mają robić). Druga koncepcja (podana dla kontrastu, pozostająca w sferze idealizacji) opiera się na idei konsensusu, wypracowanego w drodze debaty publicznej, rozumianej jako starcie argumentów i jawnie formułowanych tez ${ }^{18}$. Swiadczy to o schematyzacji medialnego dyskursu politycznego. Jej przejawem jest korzystanie z gotowych wzorców interpretacyjnych, które stają się narzędziami rywalizacji, nawet bez konieczności egzemplifikowania, a więc odwoływania się do konkretnych wydarzeń z życia politycznego.

Potrzeba autoprezentacji w pewnych momentach dynamicznego rozwoju interakcji staje się ważniejsza niż odnoszenie się do przeciwnika w studiu, który wobec tego jest wykluczany, ignorowany. Posunięciem w grze jest wobec tego podstępne przejęcie głosu, przeprowadzone dzięki technice prowokacyjnego podpuszczenia ${ }^{19}$. Kontaminacja schematów polega tu na połączeniu taktyki rywalizacji (pokonanie przeciwnika) z taktyką gry scenicznej (efektowność chwytów).

SM: [...] Problem polega na autentyczności, na autentyczności zaangażowania politycznego. Odnoszę nieprzyjemne wrażenie, być może, że się mylę ale//

JG: Myli się pan.

SM: -ale odnosze/ no, jeszcze pan nawet nie wie, co powiem, a już pan wie, że się pomylitem. No, gratuluję przenikliwości. [z ironią]

18 Por. koncepcje komunikowania politycznego: podejście interakcyjne i podejście dialogowe (Dobek-Ostrowska 2006: 135).

19 Wyrażenie „prowokacyjne podpuszczenie” funkcjonuje tu jako termin (mimo że zawiera słowo potoczne). Oznacza perfidne zwabienie w pułapkę, podjęcie gry, która polega na zachęcaniu do pewnych działań w złej wierze. Na przykład prowokator pozyskuje poufne informacje po to, aby wykorzystać je przeciwko ofierze, która nie wie, że jest nagrywana (por. Karwat 2007: 257-271). 
JG: Można przewidzieć.

SM: Otóż/ tak? No to niech pan powie. [śmiech widowni]

JG: Nie. Ja bym wrócit do pytania pana redaktora, skąd wziąt się problem $z$ Radiem Maryja [...].

(„Debata”, TVP 1, 11.01.2006; goście - JG: Jarosław Gowin, SM: Stanisław Michalkiewicz)

Priorytet celu zewnętrznego, jakim jest autoprezentacja, widać w sposobie traktowania przeciwnika w studiu. Jest on nie tyle partnerem dyskusji, co konkurentem w walce o czas antenowy. Politycy stosują wyrafinowane techniki przejmowania tury po to, by wyeliminować konkurenta. W podanym przykładzie polityk bezwzględnie wykorzystał czysto konwencjonalne zachowanie, służące obronie twarzy przeciwnika. Rozmówca, który miał zamiar wygłosić negatywną ocenę (Odnoszę nieprzyjemne wrażenie), chciał ją złagodzić i dlatego wprowadził asekurant grzecznościowy (być może, że się mylę). Na to przeciwnik zastosował prowokacyjne podpuszczenie (Myli się pan), którym udało mu się zmienić płaszczyznę rozmowy i zręcznie, aczkolwiek podstępnie, przejąć turę. Jak się okazuje w dalszej części, przejęcie tury miało służyć właśnie kreowaniu wizerunku.

JG: Nie. Ja bym wrócit do pytania pana redaktora, skąd wziąt się problem z Radiem Maryja, dlaczego jest to $w$ tej chwili tak dyskutowane? [...] problem nie polega na tym, że Radio Maryja popiera PiS, a nie popiera na przykład Platformy. Gdyby popierało Platformę, bytoby to równym grzechem i równym sprzeniewierzeniem się nauczaniu Kościoła. I my jesteśmy politykami akurat, $w$ tej roli występujemy tutaj. Myślę, że się zgodzimy, panie pośle [do T. Cymańskiego], że po prostu politycy powinni się trzymać $z$ dala od Kościoła. Nie powinni zawtaszczać dla siebie Kościoła, obojętnie czy chodzi o ojca Rydzyka, czy chodzi o arcybiskupa Dziwisza. Po prostu Kościót jest naszym wspólnym dobrem. Jest dobrem również dla niewierzacych, dlatego, że jest bardzo ważna instytucja wychowawcza [potrzebna//

$\mathrm{KD}$ : [Ale panie senatorze [...]

(„Debata”, TVP 1, 11.01.2006; dziennikarz - KD: Kamil Durczok; gość - JG: Jarosław Gowin)

Polityk pod pozorem przypomnienia zasad obowiązujących w systemie komunikowania społecznego (Dobek-Ostrowska 2006: 104) kreuje w istocie swój wizerunek. Mówi o czynnikach dotyczących charakteru kontaktów i rodzaju styczności między członkami systemu (partie polityczne a Kościół), zadań, jakie mają do wykonania członkowie systemu (zadania polityków a zadania Kościoła), reguł, norm i wzorów rządzących zachowaniem członków systemu (m.in. o tym, jak nie powinny wyglądać relacje między politykami a Kościołem). Polityk w celu wypromowania się stosuje dyskredytację światopoglądową ${ }^{20}$, gdyż sugeruje, że grupa przeciwników politycznych identyfikuje się religijnie (w dalszej części debaty pada oskarżenie o fundamentalizm). Dziennikarz rozpoznaje strategię

${ }^{20}$ Dyskredytacja światopoglądowa należy do typu dyskredytacji grupowych na płaszczyźnie swojskości-obcości. Podstawą dyskwalifikacji jest rzeczywista lub przypisana orientacja światopoglądowa przeciwnika (Karwat 2006b: 258). 
wizerunkową i w momencie, kiedy staje się ona zbyt jawna (kreowanie się na depozytariusza wartości takiej, jak Kościół) - przerywa wypowiedź. Właśnie reakcję dziennikarza należy uznać za dopasowaną i potwierdzającą odkrycie strategii. Strategia kreowania wizerunku staje się jeszcze wyraźniejsza w dalszej wypowiedzi.

JG: [...] Otóż w związku z tą nasza pielgrzymka, pielgrzymka parlamentarzystów Platformy Obywatelskiej do Eagiewnik, pojawity się takie sugestie ze strony prasy, że ojciec Rydzyk popiera Prawo i Sprawiedliwość, za to arcybiskup Dziwisz popiera Platformę Obywatelską. Otóż nie, proszę państwa. Ja jestem senatorem z Krakowa i muszę powiedzieć, że jako człowiek zawsze doświadczatem sympatii ze strony arcybiskupa Dziwisza, ale jako polityk nigdy [kamera pokazuje adwersarza, który wykonuje gest wzniesienia oczu do góry, który należy odczytać jako gest poirytowania]. I arcybiskup Dziwisz nigdy, również w czasie tej pielgrzymki, nigdy nie powiedział niczego, co mogłoby sugerować, że jest zwolennikiem którejkolwiek z partii, w tym przypadku Platformy Obywatelskiej. [...]

(„Debata”, TVP 1, 11.01.2006; gość - JG: Jarosław Gowin)

Polityk chwali się prestiżowymi kontaktami, uczestnictwem w obrzędach religijnych. Chwalenie się jest w naszej kulturze co najmniej niezręczne, więc rozmówca przemyca istotne treści, wykorzystując gatunek mowy, jakim jest plotka (pojawity się takie sugestie). Dodatkowo warto zwrócić uwagę na (raczej taktyczne) przemilczanie przez rozmówcę ważnej prawidłowości dotyczącej pozyskiwania wiedzy. Otóż wszystkie zachowania ludzkie są nośnikami informacji o stanach nadawcy i/lub o jego intencjach (Grabias 2003: 247). Organizowanie oficjalnych spotkań, okazywanie sympatii nawet na płaszczyźnie prywatnej może być dla wyborców oznaką poparcia równie sugestywną, co polityczne deklaracje. Ten mechanizm semiotyczny powoduje, że zapewnienia polityka odbieramy jedynie jako asekurację (jako człowiek zawsze doświadczałem sympatii ze strony arcybiskupa Dziwisza, ale jako polityk nigdy). Poza tym zachowania komunikacyjne reguluje w tym przypadku cały system, który w relacji Kościół - politycy wymusza niejawne formy komunikowania. Określone treści nie mogą być jawnie przekazywane, ponieważ naruszyłoby to konwencje społeczne.

Kontaminacja metafor gry scenicznej i gry rywalizacyjnej przejawia się m.in. w stosowaniu niejawnych technik rywalizacji, w których polityk odgrywa rolę nauczyciela, strzegącego reguł czystej gry politycznej. Gra rywalizacyjna jest więc toczona na scenie przeznaczonej dla widzów-wyborców. Celem jest nie tylko pokonanie przeciwnika, ale również wykreowanie korzystnego wizerunku kosztem jego wizerunku. Ze względu na to, że gra polityczna kieruje się swoistymi motywami i sposobami ekspresji, mamy w niej do czynienia z instrumentalnym wykorzystaniem konwencji komunikowania społecznego, np. eliminowaniem przeciwnika za pomocą różnego typu dyskredytacji. Tak więc znajomość różnych schematów interpretacyjnych zwiększa szansę na wygraną bez narażenia rozmówcy na pogorszenie wizerunku. 


\subsection{Uwarunkowania strategii związane ze stereotypem roli społecznej rozmówców}

Ranga i rola, jaką reprezentują interlokutorzy w medialnych programach publicystycznych ma dwojaki wpływ na ich zachowania komunikacyjne. Po pierwsze, wchodzi w skład kompetencji językowej, która umożliwia skuteczne komunikowanie w złożonych układach instytucjonalnych. Po drugie, wiedza na temat społecznych stereotypów związanych z rolą może być wykorzystywana strategicznie w bieżącej rywalizacji. Dzięki istnieniu tzw. kodu ról społecznych powstaje szereg oczekiwań związanych z typowym zakresem działań językowych, np. dziennikarzy, polityków, duchownych. Społeczne wyobrażenia stanowią punkt odniesienia zarówno do pozytywnych, jak i negatywnych ocen. Rozpatrzmy przykład, w którym rozmówca wypowiada się wprost na temat zależności między rolą rozmówcy, zachowaniem oczekiwanym a rzeczywistym.

BW: [...] Zreszta ja myślę, że wokót tej catej sprawy [możliwości przedterminowych wyborów] narosto zbyt dużo histerii. Opisuje się to w jakichś strasznie emocjonalnych, namiętnych określeniach. Ja rozumiem, że politykom zależy na tym, bo oni graja w ten sposób, natomiast komentatorzy [powinni mieć dystans.

KD: [A czy ta histeria tė̇ polega na tym, że sa zwolennicy tezy, że wtaściwie decyzja o tym, że będa przedterminowe wybory zapadta pod koniec grudnia, a wtaściwie po 29 grudnia, kiedy się okazało, że, jak mówi Jarosław Kaczyński, ten mechanizm się zaciąt? I że teraz się szuka sposobu. jak to dobrze sprzedać ludziom?

(„Debata”, TVP 1, 18.01.2006; dziennikarz - KD: Kamil Durczok; gość - BW: Bronisław Wildstein)

Wymiana odnosi się wprost do zachowań komunikacyjnych polityków oraz dziennikarzy, dlatego stanowi świadectwo stosowanych w tym zakresie technik interpretacyjnych. Zachowania te są komentowane jako paralelne do działań pozajęzykowych, czynności mentalnych (grać czymś, mieć dystans, podjąć decyzję, ukrywać decyzję). Rozmówca oskarża media, komentatorów o nieneutralny przekaz (opisuje się to $w$ jakichś strasznie emocjonalnych, namiętnych określeniach). Nazwanie medialnego przekazu histeria jest użyciem metaforycznym słowa, które należy do języka potocznego ${ }^{21}$. W terminologii komunikacyjnej natomiast działanie takie należałoby nazwać prowokacją o charakterze nagonki. Pojęcie implikuje chęć narzucenia nieadekwatnego obrazu sytuacji (narosło zbyt dużo histerii), manipulowanie opinią publiczną, destrukcyjne oddziaływanie komunikacyjne (por. Karwat 2007: 369). Działanie według schematu nagonki zostaje uznane przez rozmówcę za typowe dla polityków, za strategiczne posunięcie w grze (Ja rozumiem, że politykom zależy na tym, bo oni graja $w$ ten sposób), ale dyskredytujące dla dziennikarzy (komentatorzy powinni mieć dystans).

${ }^{21}$ Por. histeria '[...] potocznie: nadmiernie żywa, przesadna reakcja uczuciowa' (SJPSz, t. 1: 746). 
Oczywiście, narzucanie wyższych standardów dziennikarzom jest postulatem, a nie odzwierciedleniem rzeczywistości. W wyniku komercjalizacji mediów i mediatyzacji polityki „najlepszym towarem medialnym stały się konflikty i napaści polityczne; media zawsze to «kupią». Właśnie na to jest popyt wśród publiczności” (Karwat 2007: 379).

Użycie słowa „dystans” (komentatorzy powinni mieć dystans) stanowi bodziec włączenia kodu ról społecznych do interpretacji wypowiedzi. W kodzie tym zawarte są stereotypy ról, czyli wyobrażenia na temat tego, jak działa (powinna działać) osoba w danej roli. Wymóg dystansu w dyskursie dziennikarskim jest warunkiem bezstronności, która z kolei stanowi składową obiektywizmu.

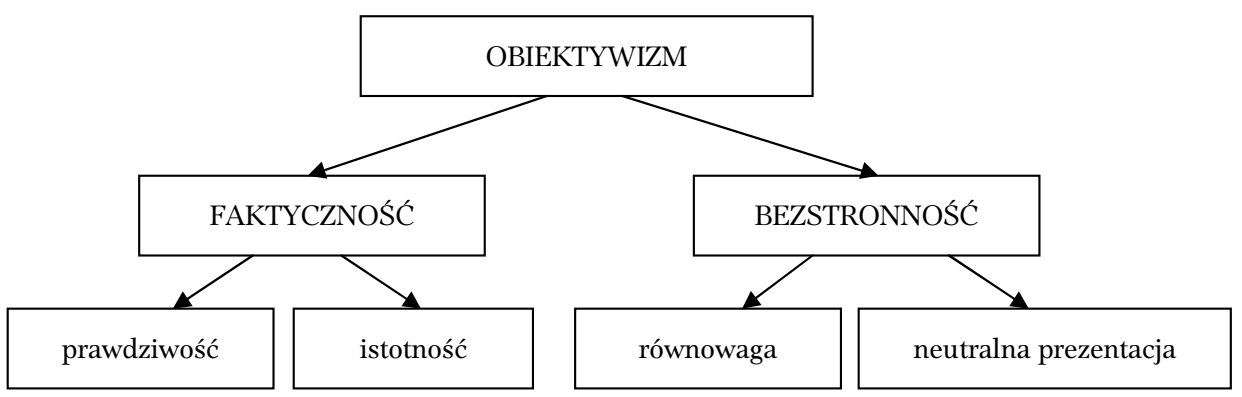

Rys. 9. Składniki obiektywizmu (Westerstahl 1983, za: Mrozowski 2001: 307)

Bezstronność relacji polega na uwzględnieniu różnych punktów widzenia czy interpretacji, traktowanych równorzędnie lub proporcjonalnie oraz prezentowanych w sposób neutralny, tzn. z zachowaniem takiego samego dystansu wobec każdej z nich i bez stosowania określeń (obrazów) nacechowanych emocjami lub wartościami (Mrozowski 2001: 307).

Posądzenie dziennikarzy o brak dystansu jest pośrednim oskarżeniem o brak obiektywizmu, który oznacza tendencyjność. Widać zatem, że typ działalności pozajęzykowej, a więc i rola społeczna, determinują ocenę strategii komunikacyjnych. Stereotyp roli społecznej, będący elementem kodu społecznego (np. przekonanie, jaki powinien być dobry dziennikarz), stanowi punkt odniesienia do kategoryzacji i oceny jednostkowych zachowań, ale bywa również wykorzystywany instrumentalnie do dyskredytacji zawodowej ${ }^{22}$. Chodzi jednak o to, aby dyskredytacja nie tyle była zasadna, co fortunna. W ferworze dyskusji przed kamerami trudno jest ocenić prawdziwość oskarżeń, ale natychmiast można zweryfikować to, czy krytykowana właściwość jest istotna dla danej roli. Gdyby okazała się nieistotna, to krytyka byłaby chybiona.

${ }^{22} \mathrm{~W}$ dyskredytacji zawodowej podważa się profesjonalizm przeciwnika, a szczególnie jego kwalifikacje, umiejętności i predyspozycje do zajmowania określonego stanowiska (Karwat 2006b: 216) 
W drugim kroku dziennikarz dostosowuje swoją strategię do strategii rozmówcy i z kolei oskarża polityków o nieetyczne zachowanie, o manipulację opinią publiczną (dyskredytacja moralna). Według niego komunikowanie polityczne rządu służy celom instrumentalnym, takim jak wykreowanie wizerunku, pozyskanie wyborców (teraz się szuka sposobu, jak to dobrze sprzedać ludziom). Użycie sformułowania „sprzedać” charakteryzuje rodzaj relacji między władzą a społeczeństwem. Wskazuje na marketingową koncepcję komunikowania politycznego. Według niej podmioty polityczne dążą do z góry określonych celów, przy maksymalizacji własnych zysków i minimalizacji kosztów. Proces polityczny opisuje się za pomocą pojęć ekonomicznych, takich jak produkt, klient, sprzedaż. Rola wyborcy jest sprowadzona do roli kupującego (Dobek-Ostrowska 2006: 140). Odpowiedzią na dyskredytację komunikacyjną i zawodową polityków jest dyskredytacja nadawców medialnych. Włączenie wiedzy o mechanizmach funkcjonowania mediów do interpretacji działań zwiększa złożoność strategii odbioru.

TŻ: Natomiast ja chciatem państwu zwrócić uwagę, że przeciė̇/ po pierwsze, mówimy o formie, a mówimy, że treści nie ma. No, treść jest, tylko tak się składa, że komentując czy debatując, i media, i część komentatorów przynajmniej, i czesść polityków koncentruje sie na formie, a nie

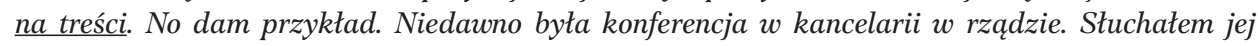
w TVN24. I tam była informacja o 3 czy 4 kwestiach merytorycznych $i$ jednej dotyczacej procedur. Dziennikarze pytali niemal wytacznie o procedurę, a potem pytali o dwie niezwykle ważne merytoryczne kwestie, dotyczace Otwartych Funduszy Emerytalnych i kwestii tączenia czy nietaczenia banków. I na te kwestie padty jakieś pytania, ale one jakoś nie interesowaty//

KD: Ryzykowna tezę pan snuje, panie doktorze, że media wykoślawiaja rzeczywistość [...]

BW: Panie redaktorze, ale ja jako pracownik mediów zauważam, że w Polsce te media rzeczywiście wykoślawiają rzeczywistość. Nie tylko w Polsce, ale w tej chwili w Polsce mam wrażenie, że te media dość mocno tą rzeczywistość wykoślawiaja.

(„Debata”, TVP 1, 18.01.2006; dziennikarz - KD: Kamil Durczok; goście - BW: Bronisław Wildstein, TŻ: Tomasz Żukowski)

Rozmówca wprowadza rozróżnienie między działaniem politycznym, nazwanym tu treścią, a przekazem medialnym o tym działaniu, nazwanym tu formą (jest to wykorzystanie schematu interpretacyjnego „treść i forma”). Zwraca uwagę na to, że sposób samego przekazywania i selekcjonowania treści podlega wpływom, wynikającym ze specyfiki dyskursu medialnego. Wpływ ten oceniany jest negatywnie i staje się narzędziem dyskredytacji zawodowej nadawcy medialnego. Rozmówca zwraca zatem uwagę na konieczność zastosowania specjalnych strategii odbioru komunikatów medialnych. Ostrzega wyborców, że na podstawie przekazu nie można wnioskować o rzeczywistości politycznej (tu: o dokonaniach rządu), bo media nie kierują się kryterium istotności. Jak wynika z przykładu o konferencji prasowej, istotne kwestie merytoryczne nie były tak interesujące dla dziennikarzy, jak marginalne kwestie proceduralne, które 
(zapewne) zawierały atrakcyjniejsze elementy. Ważność, istotność informacji jest cechą relewantną w ocenie działalności profesjonalnej dziennikarzy i ogólnie mediów. Jak już wcześniej zaznaczono, istotność jest składową faktyczności oraz obiektywizmu (Mrozowski 2001: 307). Stanowi więc ważną kategorię dziennikarskiego dyskursu, która służy uwiarygodnieniu opisu i chroni dziennikarzy przed zarzutem stronniczości.

W zależności od przypisania celu, wypowiedź można odebrać dwojako. Przy odczytaniu zgodnym z intencją nadawcy - jako zwrócenie uwagi widzom na reguły dyskursu medialnego, a właściwie konieczność wzięcia ich pod uwagę przy odbiorze przekazów (według reguły: „pamiętaj, że przekaz o rzeczywistości nie jest tożsamy z rzeczywistością”). Przy odbiorze zaawansowanym można wziąć pod uwagę również reguły dyskursu politycznego, który zakłada rywalizację podmiotów. Znajomość reguł tego rodzaju może być wykorzystana instrumentalnie do ataku lub obrony. Zatem wypowiedź można odebrać również jako dyskredytację mediów z powodu niezachowania reguły istotności, ale nie dla samych zasad, lecz w celu obrony podmiotu politycznego (na zasadzie: bronię rządu, bo podejmuje ważne działania, tylko media się tym nie interesują). Widać więc, że reguły dyskursu służą nie tylko modelowaniu zachowań komunikacyjnych, ale są wykorzystywane instrumentalnie do sprawowania kontroli społecznej, a nawet do bieżącej walki politycznej. Stają się wtedy bronią w rywalizacji z przeciwnikiem. Można je uznać za swoiste posunięcia w politycznej grze rywalizacyjnej.

O ile w poprzednim przykładzie dyskredytacja mediów nie była oczywistym, ale tylko domniemanym celem rozmówcy, o tyle w następnym fragmencie wyraźnie służy obronie twarzy pozytywnej określonej grupy. Rozmówcy idą krok dalej - już nie tylko podważają kompetencje zawodowe dziennikarzy, ale ich identyfikację w roli przedstawicieli społeczeństwa.

MP: Zresztą nawiasem mówiąc, wydaje mi się nieuprawnione stawianie aktorów sceny politycznej w jednym szeregu z dziennikarzami w tym przypadku [chodzi o aferę z nagraniami Renaty Beger i dziennikarzy TVN-u, T. Sekielskiego i A. Morozowskiego]. To sa jednak inne role i nie należałoby ich mylić.

JŁ: No tak, ale w tym wypadku te role to sa role $z$ tego samego serialu.

MP: No niezupetnie, niezupetnie.

JŁ: A czym się różni rola chóru, który mówi „Odwołać premiera” od roli na przykład dziennikarzy, którzy te taśmy, no które teraz już wszyscy znaja, jak one wygladały, opisuja w ten sposób: „Lipiński proponowat Begerowej stotek za przejście do PiS-u”, [podczas gdy sytuacja była dokładnie odwrotna, tak, a to jest cytat, leci//

MP: [To jest pewien typ dziennikarstwa, który wydaje mi się, mimo wszystko, uprawniony. Ja mogę tego osobiście nie lubić, ludzie moga tego nie lubić z tego powodu, że sa przyzwyczajeni do pewnych konwencji. Te konwencje znaja, a tutaj mieliśmy do czynienia z odkryciem kulis, a więc podważeniem.

JŁ: Ale ja nie mówię, że dziennikarze odkrywaja kulisy, a tak naprawde gra się toczy na scenie politycznej. Ja mówię o tym, że dziennikarze sami sa aktorami tej sceny, ponieważ nie tylko opisuja fakty, ale kreuja, podkręcaja, interpretuja.

MP: Ale przecież interpretacja należy te $\dot{z}$ do dziennikarzy. 
JP: My teraz też interpretujemy.

MP: Pewnie, że tak. Natomiast błąd w sztuce bytby wówczas, kiedy dziennikarz przyjmowatby na siebie role polityka.

TŻ: Chciałbym panów pogodzić w pót drogi. Dziennikarze graja role wyraźnie inna, ale to sie zaciera. Zwróćcie uwage, gdy ci dziennikarze ida do polityka i ten polityk dogaduje się z nimi, i wysyła ich przeciwko innej partii. W pewnym sensie, być może oni zaczynaja być manipulowani przez polityka.

(„Warto rozmawiać”, TVP 2, 1.10.2006; goście - JŁ: Jacek Łęski, MP: Mirosław Pęczak, TŻ: Tomasz Żukowski)

Ze zmianą hierarchii celów w polityce-spektaklu związane jest bardziej elastyczne podejście do roli. Wszak w spektaklu role rozdziela reżyser i nie są one na trwałe związane $\mathrm{z}$ aktorem. Wręcz odwrotnie: największy efekt dramatyczny powoduje „migotanie ról”, zamiana ról, która nasila efekt zaskoczenia publiczności. Ujmowanie roli społecznej dziennikarza jako jednej z ról w spektaklu politycznym ma na celu osłabienie jego pozycji. Dziennikarze w idealnym społeczeństwie demokratycznym posiadają szczególny mandat publiczny, gdyż są pośrednikami między władzą a społeczeństwem, reprezentują interes społeczny. Jeśli przypisuje się im inne intencje, to podważa się ich uprzywilejowaną pozycję (dziennikarze sami sa aktorami tej sceny, ponieważ nie tylko opisuja fakty, ale kreuja, podkręcaja, interpretują; oni [dziennikarze] zaczynaja być manipulowani przez polityka). Widać tu wyraźną strategię, służącą zachowaniu twarzy, która jest dostosowana do zaistniałej sytuacji kryzysowej. Dziennikarze dokonali podstępnego nagrania, które zostało upublicznione. Treść nagrania została odebrana nagannie przez opinię publiczną. Zaistniałym już faktom nie można zaprzeczyć, nie można podjać strategii informacyjno-weryfikacyjnej. W celu zneutralizowania negatywnego wydźwięku została podjęta technika zmiany kontekstu wydarzenia poprzez dyskredytację identyfikacyjną ${ }^{23}$ dziennikarzy, która prowadzi do zakwestionowania ich autoidentyfikacji. Stosując konwencję metaforyki wojennej, z której pierwotnie wywodzi się pojęcie strategii, można stwierdzić, że jest to rozpoznanie, a właściwie zdemaskowanie wroga (nie prawdziwy dziennikarz, tylko w gruncie rzeczy ktoś na usługach polityka, dyspozycyjny wobec niego) i pozbawienie go tarczy ochronnej (utrata mandatu społecznego). Widać zatem, że rozluźnienie sztywnej identyfikacji ról, pod wpływem ujmowania polityki jako spektaklu, może mieć strategiczne zastosowanie w politycznej rywalizacji.

W programach społeczno-politycznych występują nie tylko politycy, eksperci, dziennikarze, ale również przedstawiciele innych grup społecznych, np. duchowni, przywódcy Kościoła. Ich zachowania komunikacyjne są również ściśle uzależnione od elementów kontekstu pozajęzykowego: celu, programu, projektowanego wyniku oraz warunków działania. Także i w tego typu interakcjach można dostrzec ślady dyskursu.

${ }^{23}$ Dyskredytacja identyfikacyjna polega na podważaniu autentyczności podawanej przez podmiot tożsamości. Wywołuje się wrażenie, że osoba nie jest tą, za którą się podaje (Karwat 2006b: 200). 
JD-O: Ksiądz arcybiskup kiedyś powiedziat, że $w$ tej chwili wiernych nie towi się już $w$ sieci, tylko na wędkę. Na co biora wierni?

$\mathrm{KN}$ : Na pewno na świadectwo, czyli na autentyczne życie tego, który gtosi Chrystusa - czy to jest ksiadz, czy to jest świecki. Świadectwo, czyli po prostu głoszenie Ewangelii, najpierw sobie $i \dot{z} y c i e$ według tej Ewangelii, a potem świadectwem swojego życia, przyktadem swojego życia dawanie tego obrazu życia ewangelicznego drugiemu człowiekowi, wyzwalanie w tym drugim człowieku pytania: „Jak on to robi? Skąd u niego jest tyle dobroci, ciepta, mitości, serdeczności?”. Sądzę, że to świadectwo życia chrześcijańskiego jest warunkiem wtaśnie owego towienia na wędkę, czyli owego przyprowadzenia do Chrystusa każdego pojedynczego cztowieka, który się zgubit, czy który szuka drogi do Niego, a czasem nie bardzo sam potrafi ją odnaleźć.

(„Kwadrans po ósmej”, TVP 1, 23.12.2008; dziennikarka - JD-O: Justyna Dobrosz-Oracz; gość - KN: abp Kazimierz Nycz)

Dziennikarka nawiązuje do celu działalności pozajęzykowej gościa, jakim jest pozyskiwanie nowych wiernych. Zwraca uwagę na trudne warunki działalności ( $w$ tej chwili wiernych nie towi się już w sieci, tylko na wędkę). Pytanie dziennikarki można rozumieć jako pytanie o strategię działania w specyficznych warunkach, czyli sposób dojścia do celu, plan optymalnego działania (Na co biora wierni?). W odpowiedzi gość wskazuje zarówno na strategie działania pozajęzykowego (autentyczne życie), jak i strategie komunikacji, a mianowicie komunikowanie poprzez zachowanie (świadectwem swojego życia, przykładem swojego życia dawanie tego obrazu życia ewangelicznego drugiemu człowiekowi). Z wypowiedzi gościa wyłania się obraz rzeczywistości, w której zachowanie, działanie i komunikowanie są ściśle powiązane: zachowanie $\rightarrow$ komunikowanie czegoś tym zachowaniem $\rightarrow$ bycie bodźcem do zmiany postaw, a więc komunikowanie poprzez działanie (wyzwalanie w tym drugim człowieku pytania: „Jak on to robi? Skąd u niego jest tyle dobroci, ciepta, mitości, serdeczności?”).

Najbardziej pożądaną strategią komunikacji w tym typie działalności ma być komunikowanie poprzez szczególny rodzaj zachowania (życie zgodnie z Ewangelia).

Problem polega jednak na tym, że proces semantyzacji czy też semiozy rzeczywistości nie jest dokonywany przez jednostki samodzielnie, ale poprzez społeczne i zbiorowe doświadczenie, poprzez intersubiektywne kategorie, kody, systemy wartości. Rozpatrzmy przykład, w którym zachowanie społeczne zostało zinterpretowane jako oznaka, symptom procesów społecznych.

JD-O: A jest niestety tak, że trochę się zatracamy, że gubimy sens tych świat. Ta era konsumpcjonizmu, ta bieganina po sklepach zabija nam [sic!] to, co w tych świętach najważniejsze?

$\mathrm{KN}$ : Nie chciałbym dotaczać do grona narzekaczy, którzy narzekają na wspótczesny świat. Na pewno wiele sie zmienito $w$ przeżywaniu tych świat w stosunku do czasów, kiedy nie byto telewizji, środków masowego przekazu, tego całego gwaru zakupów i tak dalej, ale tego nie zmienimy, to się stato. My musimy się w tym zmienić. Wydaje mi się, że dzisiejszy cztowiek musi umieć szukać istoty tych świąt, żeby nie przeżyt je [sic!] catkiem powierzchownie, albo żeby nie podszedt do tych świąt tak zmęczony, że wtaściwie nie jest $w$ stanie ich przeżywać. A to jest, moim zdaniem, wyzwanie i zadanie dla nas wszystkich. I jest wiele, myślę, że większość, rodzin, które potrafia te święta 
ocalić $w$ swoich domach rodzinnych, $w$ swoich parafiach, $w$ swoim spotkaniu $z$ Bogiem i $z$ ludźmi. I sadzę, że to jest zadanie dla nas wszystkich.

Prowadząca program kształtuje wypowiedź w taki sposób, aby dostosować ją do sytuacji (okres przedświąteczny) i roli rozmówcy (duchowny). Elementy te determinują zarówno wybór tematu, jak i sposób jego prezentacji. Dziennikarka z określonej perspektywy nazywa teraźniejszość „erą konsumpcjonizmu”, a zachowanie ludzi - „bieganiną po sklepach”. Tak wyselekcjonowane i nazwane elementy tła pozajęzykowego są negatywnie wartościowane na podstawie ustanowionej relacji niezgodności ${ }^{24}$ między nimi a elementem nazwanym (religijnym) sensem świąt (Ta era konsumpcjonizmu, ta bieganina po sklepach zabija nam to, co w tych świętach najważniejsze). Mamy tu do czynienia z nadawaniem sensu zachowaniom ludzkim, takim jak np. bieganina po sklepach. Zachowanie jest oznaką pewnych procesów, takich jak zagubienie sensu świąt.

Rozpoznawanie zachowań jako oznak czegoś innego, ogólniejszego (relacja signans/signatum) jest przejawem semiotyzowania rzeczywistości społecznej, czyli nadawania jej sensu. Proces ten może być odbierany jako spontaniczny, jednostkowy i kreatywny. Jednak rozpatrywanie wypowiedzi w ciągu innych tekstów (np. o tematyce religijnej) pozwala dostrzec podobieństwa w sposobie kreowania świata. Okazuje się, że rozmówcy korzystają z gotowych ${ }^{25}$ schema- $^{2}$ tów, stereotypów, które przynależą do określonego typu dyskursu. Obserwując sposób semiotyzowania rzeczywistości (np. jakie wartości są brane pod uwagę), badacz dociera do przejawów dyskursu.

W omawianym przykładzie dziennikarka mogłaby samodzielnie odebrać zachowanie ludzi jako oznakę pewnych procesów społecznych, ale bardziej prawdopodobne jest, że reprodukuje istniejący dyskurs, powtarza znane opinie w celu wytworzenia płaszczyzny porozumienia z rozmówcą. W dyskursie religijnym „bieganina po sklepach” może zostać uznana za oznakę niereligijnego przygotowania do świąt. Dyskurs ten bowiem preferuje wyciszenie i skupienie jako optymalną formę doświadczania religijności. Już sama struktura derywatu (bieganina) z formantem -anina informuje o pewnych właściwościach komunikacyjnych czynności, takich jak: powtarzalność, wielokierunkowość, chaotyczność, a nawet negatywne emocje nadawcy (Grzegorczykowa, Puzynina

24 Językowe wykładniki relacji niezgodności mogą być różne. Tutaj mamy określenie „zabijać”, które oprócz ustanowienia relacji jest bardzo obrazowe. Niezgodność polega na niemożliwości współistnienia, wykluczaniu się elementów.

${ }^{25}$ Schematy, stereotypy są w tym sensie gotowe, że rozmówca odtwarza je w momencie stosowania (reprodukuje). Jednak nie oznacza to, że są narzucane z góry, zadekretowane. Ich status ma charakter wytworów społecznych, kształtowanych w dłuższej perspektywie czasowej przez wspólnotę dyskursywną, wspólnotę ideologiczną w procesie nieustannych negocjacji, które polegają zarówno na działaniach stabilizacyjnych, jak i destabilizacyjnych (por. Wstęp, punkt 3.1. Pojęcie dyskursu). 
1998: 397). Widać, że zachowaniu można nadać sens dzięki odpowiedniej nazwie i rozpatrywaniu go jako przejawu określonego dyskursu, w ramach którego wspólnota dyskursywna zakłada określoną wizję rzeczywistości i wartościowanie zachowań. Jak już wspomniano, dziennikarka przyjmuje normy, wartości typowe dla dyskursu religijnego w celu dostosowania się do rozmówcy. W jej kompetencji komunikacyjnej zawarta jest bowiem wiedza na temat społecznie ustabilizowanych, powtarzalnych konwencji, zasad i reguł zachowań językowych.

Rozmówca, chcąc zapewne pozyskać przychylność widzów, decyduje się na strategię kooperacyjną, ale w relacji z widzem, wiernym (Nie chciałbym dołaczać do grona narzekaczy). Wykazuje przy tym dystans do własnego dyskursu (co kontrastuje z perspektywą przyjętą przez dziennikarkę) i poczucie humoru, przejawiające się w twórczości neologicznej (narzekacz). Stosuje strategiczną kreację tła pozajęzykowego, która współgra ze strategią kooperacji: nie opisuje rzeczywistości społecznej w kategoriach pogarszania się (jest coraz gorzej), ale jedynie w kategoriach zmiany (jest inaczej); negatywnych zjawisk nie przedstawia jako zaistniałych (w wypowiedzi dziennikarki oddają to czasowniki dokonane typu zatracić, zabić), ale jako tylko potencjalne zagrożenia (oddają to zdania okolicznikowe celu: żeby nie przeżyt je catkiem powierzchownie, żeby nie podszedt do tych świąt zmęczony); kreuje obraz wiernych nie jako ludzi podlegających procesom (por. w wypowiedzi dziennikarki: trochę się zatracamy), ale jako ludzi w działaniu, wypełniających zadanie (A to jest, moim zdaniem, wyzwanie $i$ zadanie dla nas wszystkich). Zatem dwa czynniki decydują o funkcjonalizacji tła pozajęzykowego:

- zamiana opisu w kategoriach szczegółowych (gorszy) na opis w kategoriach ogólniejszych (inny); jednoczesne zrezygnowanie z wartościowania jest wyrazem stanowiska koncyliacyjnego,

- zamiana opisu w kategoriach procesualnych, a więc nieintencjonalnych (zatracić, gubić) na opis w kategoriach akcjonalnych, a więc intencjonalnych (szukać, ocalić). Opisywanie zdarzeń w kategoriach procesu implikuje bierność człowieka, bowiem „następuje niezależna od człowieka zmiana stanu fizycznego obiektu" (Habrajska 2004: 49). Zdarzenia akcjonalne dla odmiany eksponują intencjonalność podmiotu. Elementem kreowania układu interakcyjnego jest zastosowanie wspólnotowego „my”, a nawet swego rodzaju pochlebstwa (jest wiele, myślę, że większość, rodzin, które potrafia te święta ocalić $w$ swoich domach rodzinnych). Jak wynika z analizy, rozmówca jest nastawiony na budowanie relacji z widzem. Pytanie dziennikarki zostaje wykorzystane jako kontrast dla zbudowania wizerunku odbiegającego od społecznego stereotypu duchownego, który karci wiernych. Ważnym krokiem strategii kooperacyjnej jest również funkcjonalne kreowanie tła pozajęzykowego, w którym potencjalny przedmiot sporu (punkt sporny, różnica zdań, która dotyczy negatywnie wartościowanego konsumpcjonizmu) zostaje użyty 
nie jako narzędzie dyskredytacji (jak w działaniach polityków), ale przedstawiony jako zadanie do wykonania.

Z podanych przykładów wynika, że specyfika działalności pozajęzykowej wytycza ogólne ramy zachowań strategicznych, w tym działań komunikacyjnych, językowych. Motywuje i stymuluje określony rodzaj aktywności komunikacyjnej, uzasadnia racjonalność podejmowanych czynności i dostarcza kryteriów ich wartościowania. W świetle analizowanych przykładów należy zatem doprecyzować, jakie powiązania istnieją między działalnością pozajęzykową rozmówców a ich zachowaniami językowymi.

Dla klarowności wywodu, w początkowej części rozdziału przyjęto założenie o oddzieleniu działalności praktycznej od komunikacyjnej. Jednak obustronne zależności w sferze działań pozajęzykowych i działań komunikacyjnych są na tyle silne, że sfery te mogą się wzajemnie przenikać. Wówczas komunikowanie staje się działaniem, polegającym np. na stwarzaniu nowej rzeczywistości społecznej, prawnej. Z kolei semiotyczna interpretacja działań sprawia, że są one odbierane jak swoiste oznaki lub sygnały pewnych stanów rzeczy. Wszelkie zachowania językowe i ponadjęzykowe człowieka mają charakter psychofizyczny oraz „są nośnikami informacji bądź o stanach nadawcy, bądź o jego intencjach, bądź też o stanach i intencjach jednocześnie” (Grabias 2003: 247). Z punktu widzenia semiotyki można im przypisać status oznak, symptomów stanów nadawcy, albo status symboli, czyli znaków intencjonalnych. Znaki te służą do celowego i świadomego informowania o czynnościach intelektu, stanach emocjonalnych i stanach woli. Zatem granica między komunikowaniem a działaniem ulega często zatarciu. Strategie komunikacyjne należy więc rozpatrywać w trzech kontekstach:

1. W kontekście ogólnych uwarunkowań komunikacji, rozumianej jako rodzaj działalności człowieka obok działalności praktycznej. Wówczas komunikowanie jest oddzielone od działań pozajęzykowych. Można mówić o korelacji, wzajemnym warunkowaniu tych elementów. Przypadek ten można ująć jako działanie i komunikowanie (działam i komunikuję). Jako przykład można wskazać korelację między działaniami przedstawicieli wojska i dziennikarzy a komunikowaniem się ich w czasie konfliktu (por. przykł. s. 130).

2. W kontekście komunikacji rozumianej jako działanie. Bierzemy tu pod uwagę performatywny charakter aktów mowy (które stwarzają nową rzeczywistość) oraz perlokucyjny efekt zwykłych konstatacji. Przypadek ten można ująć jako działanie poprzez komunikowanie, czy też komunikowanie, będące jednocześnie działaniem (komunikując, działam). Przykładem jest wywołanie efektu obrazy przez prowokacyjne porównanie (por. przykł. s. 133) czy przez oskarżenie (por. przykł. s. 145). Zbiór konstatacji może służyć kreowaniu wizerunku przez chwalenie się i jednocześnie dyskredytacji przeciwnika (por. przykł. s. 150-151);

3. W kontekście interpretacji zachowań człowieka, nadawania sensu tym zachowaniom, działaniom. Jest to najszersze rozumienie komunikacji, bardziej 
związane z interpretacją i odbiorem. Zakładamy, że znakowy charakter mogą mieć wszelkie zachowania człowieka, jeśli odbiorca zechce je zinterpretować jako odsyłające do pewnych stanów rzeczy. Zależność można ująć w skrócie jako komunikacyjne interpretowanie zachowań i działań człowieka (odbieram zachowania jako mające sens w określonym kontekście). Przykładem jest komunikowanie przynależności religijnej poprzez określone zachowania (por. przykł. s. 158).

Strategie komunikacyjne uczestników medialnych rozmów publicznych są zdeterminowane typem aktywności pozajęzykowej i związaną z nim rolą społeczną. Rozpatrując je z tej perspektywy, należy zwróć przede wszystkim uwage na próby zrozumienia, usensowienia rzeczywistości pozajęzykowej i działań językowych dzięki wykorzystaniu intersubiektywnych schematów oraz kategorii pojęciowych właściwych określonej dziedzinie działalności. Próby te, o ile układają się w powtarzalne schematy, można nazwać strategiami sensotwórczymi.

Tak więc przyjmujemy, że strategie sensotwórcze polegają na interpretowaniu zdarzeń i działań językowych poprzez odnoszenie ich do czynników sytuacyjnych oraz stosowanie w interpretacji funkcjonalnych schematów i kategorii pojęciowych. Polityka ujmowana jest najczęściej jako spektakl i/lub gra rywalizacyjna.

W ramach schematu pojęciowego polityki jako spektaklu, czynności polityka odbierane są w kategoriach nadrzędnej strategii kreowania wizerunku, którą można rozpatrywać jako bardziej zaawansowaną i złożoną formę pierwotnej strategii obrony twarzy. W analizowanych przykładach pojawiały się takie jej techniki, jak: chwalenie się, powoływanie się na racjonalność ekspercką, profesjonalne standardy działania. Niejawną strategią kreowania wizerunku jest prowokatorska legitymizacja. Polega ona na wywołaniu zaplanowanego pseudowydarzenia medialnego, często wykorzystującego instrumentalnie najprostsze emocje (niechęć, zazdrość, podejrzliwość, strach), w celu zaistnienia na scenie politycznej, stworzenia wrażenia prawowitości mandatu społecznego. To działanie, którego celem jest uzasadnienie roszczeń określonej formacji politycznej, występującej np. w imieniu oszukiwanych obywateli, zacnych przodków, skrzywdzonych osób, prawdziwych patriotów. Wiedza na temat teatralności gry politycznej jest wykorzystywana w strategii demaskatorskiej. Nadawca, przechodząc na poziom metadyskursywny, obnaża sztuczność działań polityka oraz jego ukryte motywacje (chwyt: „odkryłem twoją grę”).

Spektakl medialny rządzi się również swoimi prawami. W prezentowaniu informacji dziennikarze stosują strategię, którą nazwano narratywizowaniem rzeczywistości. Polega ona na budowaniu $\mathrm{z}$ oderwanych faktów opowieści, w której rzeczywistość jawi się jako uporządkowana całość. Opowieść dziennikarska staje się atrakcyjna dzięki wykreowaniu intrygi osnutej wokół wyraźnie zarysowanego konfliktu, osadzenia narracji na osi przeciwstawnych działań antagonisty i protagonisty. 
Schematem poznawczym, metaforą pojęciową, która racjonalizuje polityczną rywalizację, jest ujęcie polityki jako gry. Najczęściej jest to gra rywalizacyjna, w której wygrana jednej strony wiąże się z przegraną drugiej, a nawet z jej symbolicznym wyeliminowaniem. Działania uczestników gry, do których zalicza się nie tylko polityków, ale również dziennikarzy i media, są ujmowane i kategoryzowane jako różnego typu dyskredytacje i prowokacje (które z kolei stanowią bardziej zaawansowane strategie zagrożenia twarzy, sposoby ataku). Należą do nich następujące strategie i techniki ${ }^{26}$ :

- prowokacja demobilizacyjna, która ma sparaliżować zdolność przeciwnika do działania, spowodować jego dezorientację i zachwianie wiary w siebie,

- prowokacja dyskredytacyjna, która polega na wyeliminowaniu przeciwnika poprzez utrwalanie negatywnych stereotypów na jego temat i podsycanie uprzedzeń,

- prowokacyjna manipulacja, zmierzająca do zdobycia przewagi taktycznej i pozbawienia przeciwnika podmiotowości,

- prowokacyjna nagonka medialna, której istotą jest sterowanie naciskiem społecznym dzięki wzbudzaniu emocji i ocen,

- prowokacyjne „podpuszczenie” wiążące się z podjęciem gry, która polega na zachęcaniu przeciwnika do określonych działań w złej wierze,

- prowokacja prewencyjna, której celem jest udaremnienie działań przeciwnika, uprzedzenie jego posunięć, odwetem,

- prowokacja reaktywna jako typ zachowania sprowokowanego, będącego

- dyskredytacja demaskatorska, zmierzająca do odkrycia (rzekomo) prawdziwego oblicza przeciwnika,

- dyskredytacja identyfikacyjna, która ma na celu podważenie autentyczności kreowanego wizerunku, zakwestionowanie podawanej przez podmiot tożsamości,

- dyskredytacja moralna, polegająca na narzucaniu otoczeniu wrażenia, że przeciwnik kieruje się niskimi pobudkami, jego działania są moralnie naganne, a intencje niegodziwe,

- dyskredytacja światopoglądowa, sugerująca, że przeciwnik należy do grupy obcej światopoglądowo,

- dyskredytacja zawodowa, w której podważa się profesjonalizm przeciwnika, jego kwalifikacje zawodowe, umiejętności i predyspozycje.

${ }^{26}$ Relacja między strategią a techniką ma charakter hierarchiczny. Strategia wyznacza globalny kierunek działania, natomiast taktyka określa praktyczne lub cząstkowe rozwiązanie problemu. Zatem np. określony typ dyskredytacji może być w jednym przypadku globalnym celem działania (strategia), a w drugim - tylko chwytem taktycznym, elementem innej ogólniejszej strategii. 
Różnego typu prowokacje i dyskredytacje mają często charakter niejawny. Politycy bowiem ukrywają rywalizacyjny charakter swoich działań, starając się zachować pozory kooperacji ze względu na wymogi komunikacji publicznej. Postrzeganie ich aktywności werbalnej jako realizującej określone strategie nie jest zatem możliwe bez uwzględnienia kontekstu pragmatyczno-społecznego i kulturalno-poznawczego. 


\section{RozDZIAE 3}

\section{Uwarunkowania strategii związane $\mathrm{z}$ charakterem sytuacji}

Ważnym determinantem zachowań komunikacyjnych jest oficjalność sytuacji komunikacyjnej, rozumiana jako kategoria regulująca występowanie nadawcy i odbiorcy $\mathrm{w}$ roli reprezentantów jakichś grup czy organizacji, nie zaś jako osób prywatnych ${ }^{1}$ (Markowski 1992: 11). Charakter sytuacji i rodzaj kontaktu stały się podstawą wyróżnienia odmian współczesnej polszczyzny ${ }^{2}$. Powtarzalność odmiany potocznej, swobodnej w wielu typologiach i brak jednolitych ustaleń co do dalszych podziałów skłoniła współcześnie językoznawców do wyodrębnienia dwóch wariantów odmiany ustnej języka ogólnego: wariantu nieoficjalnego ${ }^{3}$ i oficjalnego (Dunaj 1981; Markowski 1992).

Jednocześnie kategoria oficjalności i nieoficjalności została przesunięta w stronę uwarunkowań sytuacyjnych, do których mają być dostosowane zachowania komunikacyjne (Grabias 2003: 282). Tak więc oficjalność/nieoficjalność stała się nie tyle kategorią stylistyczną̧, ile socjolingwistyczną. Za czynniki decydujące uznano układ interakcyjny, a szczególnie występowanie rozmówców w rolach społecznych oraz odgraniczenie od sfery prywatnej.

Rozpoznanie sytuacji w studiu telewizyjnym jako oficjalnej zakłada wejście rozmówców w role oraz uznanie instytucjonalizacji i formalizacji interakcji, co

1 Jan Mazur rozróżnia atrybuty: oficjalny/nieoficjalny i publiczny/prywatny. Autor twierdzi, że prywatny charakter rozmowy jest możliwy w warunkach nieoficjalnego kontaktu, choć nie każdy taki kontakt musi mieć charakter prywatny. Prywatny charakter sugeruje szczególne więzi, zaufanie (Mazur 1986: 25).

${ }^{2}$ Mówiony język ogólny jest zróżnicowany. W opracowaniach Antoniego Furdala, Teresy Skubalanki, Walerego Pisarka, Danuty Buttler, Aleksandra Wilkonia pojawiają się różne określenia jego odmian, np.: język mówiony literacki, język mówiony zawodowy, język mówiony potoczny (Furdal 1973), ogólnopolski styl mówiony potoczny, ogólnopolski styl mówiony retoryczny (Skubalanka 1976), mówiona odmiana swobodna, mówiona odmiana staranna (Pisarek 1991), mówiony podtyp oficjalny, mówiony podtyp obiegowy (standardowy) (Buttler 1982), mówiony język oficjalny, mówiony język kulturalny, mówiony język potoczny (Wilkoń 1987).

${ }^{3}$ Nieoficjalny charakter wypowiedzi powoduje, że nadawca nie jest sytuacyjnie ograniczony zarówno w wyborze kodu, jak i środków językowych (Mazur 1986: 25).

${ }^{4}$ Biorąc pod uwagę językowy kształt wypowiedzi uczestników analizowanych programów można stwierdzić, że wypowiedzi dziennikarza realizują prymarnie odmianę konwersacyjną, staranną, retoryczny styl mówiony, wtórnie - odmianę potoczną. Rozmówcy natomiast realizują (w zależności od kompetencji) retoryczny styl mówiony, odmianę staranną, odmianę profesjonalną lub odmianę potoczną. 
przejawia się w przewidywalności tematu, zachowaniu dystansu, rytualizacji zachowań, większej dbałości o formę językową wypowiedzi. Jacek Warchala postuluje uznanie oficjalności za rodzaj postmodernistycznie rozumianej gry, którą podejmują uczestnicy, aby budować swój status: „trafniej będzie ująć problem oficjalności w pragmatycznych kategoriach strategii interakcyjnej, a zatem nie tylko jako właściwość subsystemu językowego, ale rodzaj reguły budowania tekstu adekwatnego do stopnia sformalizowania sytuacji” (Warchala 2003: 125). Analiza publicystycznych programów politycznych wskazuje na takie właśnie taktyczne wykorzystanie opozycji oficjalność/nieoficjalność w kształtowaniu i interpretowaniu zachowań komunikacyjnych oraz w kreowaniu mikrosytuacji komunikacyjnej.

\subsection{Dostosowanie zachowań dziennikarza do charakteru sytuacji}

W niniejszym punkcie rozpatrujemy układ interakcyjny w programach publicystycznych pod kątem równorzędności bądź nierównorzędności rozmówców po to, by określić pozycję dziennikarza związaną z występowaniem w roli społecznej. Ma ona charakter z jednej strony społeczny, publiczny (gdyż dziennikarz jest reprezentantem społeczeństwa, rzecznikiem interesu publicznego), a z drugiej - instytucjonalny (gdyż reprezentuje instytucję medialną, jest jej pracownikiem). Niezależnie od przyjmowanych w konkretnej interakcji ról komunikacyjnych $^{5}$ pozycja dziennikarza jest zawsze nadrzędna ${ }^{6}$. Nadrzędność ta ujawnia się w działaniach organizacyjnych, które można obrazowo nazwać panowaniem nad polem interakcji w zakresie: rozpoczynania, kończenia programu (modelowanie ramy tekstu), wyznaczania tematu programu i kierowania rozwojem linii tematycznej, wyznaczania rozmówców, wzmacniania lub wygaszania wątków. Nadrzędność roli dziennikarza staje się wyraźniejsza w sytuacjach, które ten

${ }^{5}$ Badacze gatunków dziennikarskich w ramach (ogólniejszej) społecznej roli dziennikarza wyodrębniają bardziej szczegółowe role, które można nazwać nietrwałymi, konwersacyjnymi. Barbara Sobczak wyodrębnia cztery takie role: pośrednika (reprezentanta widzów), rzecznika interesu publicznego, polemisty, moderatora (Sobczak 2006: 72). Są one obrazowym nazwaniem postawy, jaką w zakresie celów i środków przyjmuje prowadzący wobec gości, np. w roli pośrednika pomniejsza swoją wiedzę, aby wydobyć ją od rozmówcy dla widza, w roli polemisty odgrywa osobę o przeciwnych poglądach, aby skłonić gościa do przekonującej argumentacji, obnażyć słabe punkty wywodu. Zbigniew Bauer natomiast wyróżnia role: pośrednika, pośrednika-pełnomocnika, partnera-ucznia, partnera-eksperta, partnera-reprezentanta opinii publicznej (Bauer 2000: 171).

${ }^{6}$ Przeświadczenie o nadrzędnej pozycji dziennikarza jest podzielane przez wielu badaczy interakcji medialnych. Ewa Szkudlarek-Smiechowicz twierdzi, że: „We wszystkich medialnych rozmowach społeczno-politycznych [...] uprzywilejowana nadrzędna komunikacyjna rola dziennikarza prowadzącego program polega na jego stałej interakcyjnej supremacji [...]” (Szkudlarek-Śmiechowicz 2010: 251). Agnieszka Oskiera wymienia m.in. takie przejawy dominacji dziennikarza, jak: inicjowanie, monitorowanie przebiegu rozmowy, przedstawianie gości, bycie sędzią rozjemczym, kontrolowanie czasu antenowego (Oskiera 2006: 33-34). 
odczytuje jako próby naruszenia swojej pozycji. Reaguje wówczas werbalnie ${ }^{7}$, odnosząc się wprost do zachowań komunikacyjnych gości.

AC: [...] więc jeśli ta nasza dzisiejsza debata będzie przebiegała tak, jak przebiegała debata w nocy z 12 na 13 grudnia, to myślę, że nasz czas jest po prostu stracony. Proponuję wobec tego, żebyśmy zaczęli rozmawiać spokojnie, sensownie, w sposób [wyważony

KD: [Dobrze. Jeśli pan pozwoli, to przebieg tej debaty będziemy jednak próbowali moderować wspólnie z redaktorem Baronem. Głos drugiej strony.

(„Debata”, TVP 1, 16.12.2004; dziennikarz - KD: Kamil Durczok; gość - AC: Andrzej Całkiewicz)

Rozmówca próbuje ingerować w organizację debaty. Jego postulaty można uznać nawet za zbieżne z celami dziennikarzy (apel o spokojną, sensowną, wyważoną rozmowę), a mimo to spotyka go ostra reprymenda dziennikarza. Wypowiedź zostaje zrozumiana nie jako apel o spokojną debatę, ale jako ingerencja w zakres kompetencji dziennikarza. Jako dominujący zostaje odebrany nie przekaz przedmiotowy (jaka debata?), ale przekaz interakcyjny (z intencją: ja mówię tobie, jak masz robić). Reakcja dziennikarza świadczy o jego nadrzędnej roli w zakresie organizowania interakcji, pewnym przywileju wytyczania jej reguł i dopuszczalnych zachowań. $\mathrm{Z}$ tego powodu dziennikarz pozycjonuje interwencję organizacyjną rozmówcy jako niestosowną (Jeśli pan pozwoli, to przebieg tej debaty będziemy jednak próbowali moderować wspólnie z redaktorem Baronem). Z kilku wątków, jakie poruszył rozmówca, dziennikarz reaguje na ten, który jest dla niego najistotniejszy.

KD: Czy ten poziom emocji/ [gwar] [zwracając się do publiczności] Już skończyliśmy. Przepraszam, ale ten dialog zakończyliśmy. Czy poziom emocji, który jest tutaj $w$ studiu, poziom emocji argumentów, którymi obydwie strony się postuguja, nie dowodzi jednak tego, że gdzieś $w$ tym procesie dochodzenia do takiego poczucia sprawiedliwości zostat popetniony btąd? [...]

TN: Ja bym chciat, żeby pan poset Lityński mi powiedziat, dlaczego zabójstwa generała Zagórskiego nie uważa za zbrodnię polityczną? [głośny gwar]

JL: Ja uważam za zbrodnię polityczna, tylko że ryzykowne porównanie.

$\mathrm{TN}$ : Ale dlaczego ryzykowne?

KD: Dobrze, jeśli można zostawmy ten spór, bo on jednak dla tej sprawy jest nie/ panie profesorze, nie, proszę, on jednak dla tej sprawy/to jest nieistotne. Zgodzi się pan, rozmawiamy o rozliczeniu stanu wojennego. [w tle głośne rozmowy]

(„Debata”, TVP 1, 16.12.2004; dziennikarz - KD: Kamil Durczok; goście - JL: Jan Lityński, TN: Tomasz Nałęcz)

${ }^{7} \mathrm{~W}$ socjolingwistyce uznaje się, że język jest symbolicznym sposobem wpływania na innych ludzi i kontrolowania ich. W dynamicznym modelu dominacji konwersacyjnej wpływ i kontrola podlegają negocjacji. Można wyróżnić trzy domeny językowej władzy, czyli kontroli w interakcji: zmiany toku rozmowy (kto mówi i jak długo), treść (kto decyduje o temacie i sposobie jego ujęcia) oraz wartościowanie treści (kto narzuca wartości lub kryteria wartościowania) (Ng, Reid 2001, za: Wasilewski 2006: 36). 
W kolejnym przykładzie dziennikarz podejmuje zdecydowaną interwencję organizacyjną: zamyka sekwencje dialogowe (ten dialog zakończyliśmy), nadaje sekwencjom kwalifikację generyczną (spór), decyduje o istotności wątków dla rozwoju linii tematycznej, przypomina temat rozmowy. Działania organizacyjne dziennikarza świadczą o jego nadrzędnej roli w kierowaniu przebiegiem polilogu.

\subsection{Dostosowanie zachowań gości do charakteru sytuacji}

Oficjalność sytuacji medialnej jest różnie rozumiana przez uczestników interakcji. Najczęściej rozpoznają oni tę specyficzną odmienność w relacji do sytuacji nieoficjalnej (która ma charakter pierwotny). Pojęcie oficjalności łączone jest z oficjalną etykietą oraz dystansem, który jest pochodną asymetrii statusów społecznych $^{8}$ osób komunikujących się (Warchala 2003: 115). Na zależność zachowań komunikacyjnych, regulujących porządek interakcji w zależności od stopnia oficjalności kontaktu, wskazuje socjolingwistyka (Skudrzykowa, Urban 2000: 107; Grabias 2003: 253-254).

Umiejętność budowania wypowiedzi odpowiednich do społecznych sytuacji (np. sytuacji oficjalnych) określa poziom kompetencji komunikacyjnej ${ }^{9}$, nabytej w trakcie socjalizacji. Za niestosowne uchodzą np. wszelkie akty naruszenia twarzy pozytywnej ${ }^{10}$ rozmówcy, które w sytuacji oficjalnej, a zwłaszcza w kontakcie publicznym są odczuwane jako szczególnie dotkliwe. Jak stwierdza Maria Peisert: „[...] ofiara odczuwa zniewagę o wiele silniej, jeśli zostanie ona wypowiedziana na forum publicznym, w obecności obserwatorów, ponieważ, co podkreślają również psycholodzy, człowiek ma silną potrzebę dobrej i korzystnej oceny własnego «ja» [...]” (Peisert 2004: 25). Z drugiej strony oskarżenie o niestosowność zachowania (słuszne lub nie) może stać się

8 Jacek Warchala wskazuje na dwa rodzaje statusów: obiektywny (który ujawnia sytuację materialną, wykształcenie, pozycję zawodową) i subiektywny (zależny od aktualnej sytuacji mówienia, np. chwilowej przewagi wynikającej z wiedzy). Status subiektywny podlega modelowaniu przez zachowania językowe. Poziom asymetrii statusów wpływa wprost proporcjonalnie na dystans - im większa asymetria, tym większy dystans (Warchala 2003: 115).

9 Jednym z autorów teorii kompetencji komunikacyjnej był Dell Hymes (Hymes 1971). Wyróżnił cztery jej poziomy, od których zależy formalny i znaczeniowy kształt wypowiedzi. Podkreślał integracyjny charakter wszystkich dostrzegalnych aspektów kompetencji komunikacyjnej, która zawiera w sobie nie tylko kod językowy, ale również kod socjalny i kod kulturowy. Obok kompetencji gramatycznej istnieje również kompetencja użycia, bez której reguły gramatyczne byłyby bezużyteczne (por. Piotrowski 1980: 90-108; Czechowska 2004: 17; Zając 2004: 4).

${ }_{10}$ Pojęcie twarzy w socjolingwistyce oznacza publiczny wizerunek siebie i jest rozpatrywane $\mathrm{w}$ dwu aspektach: twarzy pozytywnej (symbolizuje m.in. prawo do pozytywnego, zintegrowanego obrazu samego siebie) i twarzy negatywnej (symbolizuje m.in. prawo do niezależności, nieingerencji i samostanowienia) (Brown, Levinson 1987: 13, za: Antas 2000: 245). 
podstawą wykluczenia rozmówcy na podstawie dyskredytacji komunikacyjnej (Karwat 2006b: 224).

G I: Gdzie jest miejsce ojca? Jest pytanie zasadnicze, gdzie jest miejsce ojca w tej decyzji na temat aborcji, zabójstwa, ludobójstwa? Gdzie jest miejsce dla ojców? Nie ma w tej ustawie miejsca dla ojców.

G III: Przepraszam, ale jak do tej pory to kobiety, matki, nie ojcowie zajmuja się noszeniem ciązy i rodzeniem dzieci. Dlatego ja tutaj życzę sobie mieć większe prawo do wypowiedzenia się $w$ tej kwestii.

G IV: No, ale bez mężczyzny wiele by pani nie zrobiła. [śmiech]

G III: No wie pan, a in vitro?

G I: No, mężczyzna też wtedy jest potrzebny.

G III: Nie osiagajmy tej ptaszczyzny w dyskusji, bo to nie o to chodzi.

(„Debata”, TVP 1, 18.11.2004; G: gość z publiczności)

Konfrontacja jest dynamiczna i zaczyna się w ten sposób, że rozmówcy na poziomie ogólnym opowiadają o rolach społecznych (matki, ojca). Rozmówczyni, chcąc uzyskać przewagę, dość niefortunnie przechodzi na płaszczyznę indywidualną (ja tutaj życzę sobie mieć większe prawo do wypowiedzenia się $w$ tej kwestii) i tutaj spotyka się z atakiem. Jest on zrealizowany na poziomie interpersonalnym jako strategia dyskredytacji prześmiewczej - szyderstwo ${ }^{11}$. Rozmówca wykorzystuje niedopowiedzenie rozmówczyni (pominięcie roli mężczyzny) i z tej pozycji dość obcesowo demonstruje swoją wyższość (bez mężczyzny wiele by pani nie zrobiła). Norma dyskursu, dotycząca ról rozmówców, ujawnia się w momencie jej naruszenia. Ujawnienie to implikuje różne formy protestu (od form niewerbalnych do werbalnych). Tutaj zmniejszenie dystansu w celu dyskredytacji prześmiewczej jest połączone z naruszeniem tabu kulturowego (aluzja do aktu seksualnego), co powoduje sprzeciw rozmówczyni. Warte odnotowania jest również to, że naruszenie norm dyskursu jest bodźcem do przejścia na poziom metadyskursu (Nie osiagajmy tej płaszczyzny w dyskusji). To, o czym nie należy rozmawiać, i to, w jaki sposób nie należy rozmawiać, determinuje przebieg interakcji. Wynika z tego, że normy dyskursu modyfikują zachowania rozmówców zarówno jako dyrektywy, jak i jako zakazy.

Inną sprawą jest to, że normy te mogą być użyte instrumentalnie, do obrony przed atakiem. W podanym przykładzie rozmówczyni początkowo dostosowuje swoją strategię do strategii rozmówcy, pozostaje na poziomie odniesienia przedmiotowego, podejmuje próbę przekomarzania się (no wie pan, a in vitro?). Dopiero kiedy okazuje się to nieskuteczne, przechodzi na poziom dyskredytacji rozmówcy z perspektywy braku umiejętności komunikacyjnych („ta płaszczyzna

11 Szyderstwo jest formą agresji werbalnej, która przyjmuje postać urągliwych, zjadliwych żartów. Jako działanie językowe implikuje nadrzędność nadawcy, który nie spodziewa się korzyści ze strony odbiorcy, ponieważ jest on słaby i nie może mu zaszkodzić (por. Peisert 2004: 140). Szyderstwo „żeruje” więc na bezkarności nadawcy i słabości, poniżeniu odbiorcy. 
komunikacji” to eufemistyczne określenie zbytniej dosadności, pospolitości w odczuciu nadawcy), co jest równoznaczne z uzasadnionym protestem, słusznym wycofaniem się. Takie posunięcie jest w ogóle możliwe, gdyż istnieje w świadomości rozmówców repertuar zachowań dozwolonych i niedozwolonych w sytuacji oficjalnej, publicznej, do którego można się odwołać w sytuacji zagrożenia twarzy.

W poniższym przykładzie rozmówczyni nazywa zachowanie komunikacyjne adwersarzy obraza. O naruszeniu normy oficjalności świadczy asekuracyjna reakcja jednego z rozmówców.

G: Więc ja wtaśnie nie zgodze się z pogladem pani profesor [...] nie zgodzę się z tym, że ktokolwiek pragnie umrzeć. [...] To jest wydumane przez humanistów, jakichś pseudohumanistów. którzy nie maja serca [...].

DK: [...] uderza mnie fakt takiej obsesyjnej fiksacji, bo ja przy bardzo podobnej dyskusji spotkatem się niedawno $z$ pania profesor przy okazji dyskusji aborcyjnej $w$ jednym $z$ sasiednich studiów [...] mam wrażenie, że ta fiksacja na wypadkach, tu nie mam wątpliwości, trudnych//

MS: Przepraszam, ale ja zostatam obrażona. Najpierw przez paniq jako pseudohumanista, teraz przez pana, jako osobę sfiksowana ${ }^{12}$. [Ja stanowczo protestuję.

DK: [Nie, nie, nie. Przepraszam, to stowo byto użyte//

MS: Pan pozwoli, że teraz ja [powiem kilka stów.

DK: [Nie, to ja przepraszam. Wycofuje sie. [Chodzito mi o skoncentrowana//

MS: [Nie ma żadnego fanatyzmu ani zacietrzewienia w tym, jeżeli ja, szanując różnorodność pogladów w naszym spoteczeństwie, chciatabym zapewnić chociaż jednej osobie/ chociaż gdyby się jedna osoba na dziesięć lat znalazła taka, która rzeczywiście nie chce dalej żyć. Jakież my mamy prawo odebrać jej prośbę o eutanazję. To nie ma nic wspólnego z fanatyzmem.

(„Debata”, TVP 1, 24.02.2005; goście - G: gość z publiczności, DK: Dariusz Karłowicz, MS: Maria Szyszkowska)

Rozmówczyni zdecydowanie protestuje w sytuacji, w której publicznie naruszono jej pozytywny wizerunek (ja zostałam obrażona. Najpierw przez pania jako pseudohumanista, teraz przez pana, jako osobę sfiksowana. Ja stanowczo protestuję). Rozmówca, którego zachowanie zostało nazwane obraza, jest świadom tego, że został oskarżony o naruszenie normy dyskusji publicznej. Sytuację taką odczytuje on jako zagrożenie twarzy pozytywnej Właśnie świadomość uwewnętrznionej, implicytnej normy nakazuje mu bronić swojej twarzy (ja przepraszam. Wycofuje się). Strategia obrony twarzy pozytywnej jest tu realizowana za pomocą strategii metatekstowej. Rozmówca negocjuje aktualizację znaczeniową wyrazu „fiksacja” i negocjuje intencję wypowiedzi ${ }^{13}$ (słowo byto użyte [domyślnie: w innym sensie],

12 Poziom pobudzenia emocjonalnego, tu: oburzenia, przejawia się m.in. rozchwianiem poprawności wypowiedzi (por. naruszenie składni rządu, powinno być: jako osoba sfiksowana).

${ }^{13}$ Rozmówca wykorzystuje fakt, że wrażenie obrazy może powstać tylko u odbiorcy, ponieważ (jak podkreślają badacze) akty agresji są każdorazowo aktualizowane przez rodzaj relacji między nadawcą a odbiorcą i są podporządkowane regułom sytuacyjno-kontekstowym (por. Peisert 
chodziło mi o skoncentrowana//). Celem strategii jest nieznaczne, ale funkcjonalne z perspektywy założonego celu, przesunięcie tematu rozmowy. Chodzi o to, aby nie rozmawiać o zachowaniu komunikacyjnym, ale o odbiorze zachowania komunikacyjnego i wywołać wrażenie, że profesor Szyszkowska źle zrozumiała wypowiedź. W ten sposób rozmówca odwraca uwagę od swojego nagannego zachowania i koncentruje się na rzekomym nieporozumieniu przy jego odbiorze. Wysiłek włożony (przez ofiarę i przez agresora) w neutralizację sytuacji zagrożenia twarzy świadczy o kreowaniu sytuacji komunikacyjnej na poziomie wyższym, mniej emocjonalnym, bardziej intelektualnym ${ }^{14}$.

Kontakt w sytuacji dyskusji nie przewiduje ujawniania ewentualnych interpersonalnych animozji. Przypadkowa zbieżność nazwisk staje się powodem gafy i powoduje protest, który potwierdza istnienie normy zakazującej ataków personalnych.

RL: [...] Co to ja mam w ogóle się ustosunkowywać się [sic!] do homoseksualistów jako grupy, prawda? Ja mogę się do Kowalskiego ustosunkować, którego lubię albo do Nowaka, którego nie znosze. prawda. Jeden może robić $w$ swojej sypialni to, drugi co innego.

KD: Rozumiem, że powyższa uwaga nie dotyczyła księdza Nowaka (uczestnik dyskusji w studiu, ksiądz Arek Nowak).

RL: Bardzo pana przepraszam, bardzo pana przepraszam, Kowalskiego powiedzmy.

(„Debata”, TVP 1, 9.12.2004; dziennikarz - KD: Kamil Durczok; gość - RL: Ryszard Legutko)

Sytuacja staje się komiczna, kiedy nazwa własna użyta intencjonalnie jako wyrażenie argumentowe nieidentyfikujące (jakiś Nowak, czyli po prostu ktoś, referent zindywidualizowany, ale nie zidentyfikowany jednoznacznie) może zostać odebrana jako prymarne wyrażenie argumentowe, które identyfikuje uczestnika dyskusji w studiu (Topolińska 1984: 304-315). Przypadkowa zbieżność staje się powodem gafy, czyli niedostosowania się do zasad grzeczności, braku taktu, niedopasowania zachowań werbalnych lub niewerbalnych do sytuacji, w tym do cech rozmówcy (Kita 2005: 115). Komiczny charakter sytuacji ${ }^{15}$ nie zmienia faktu, że nawet jako niezamierzona, zbieżność taka zostaje odebrana jako niestosowna. Rozmówca zatem, upomniany przez dziennikarza, reaguje stosownie do sytuacji (Bardzo pana przepraszam, bardzo pana przepraszam).

2004: 13). Ważną przesłanką w zdiagnozowaniu aktu agresji jest intencja nadawcy, stąd budowanie strategii obrony polega na podkreślaniu nieintencjonalności działania odebranego jako obraza.

${ }^{14}$ Na zjawisko kreowania sytuacji komunikacyjnej poprzez sposób językowego kształtowania wypowiedzi zwraca uwagę Barbara Boniecka, która podaje przykład wyszeptywania wulgaryzmów, skracania ich jako znak kreowania sytuacji na poziomie wyższym (Boniecka 1999: 61). Jest to również dobitny przykład na wzajemną determinację zachowania językowego i sytuacji: sytuacja narzuca formy zachowania, ale formy te mogą przedefiniować sytuację, która (zwłaszcza w dialogu) ma charakter dynamiczny.

15 Podobny przykład przytacza Małgorzata Kita. Otóż mądrość ludowa „Lepszy wróbel w garści niż gołąb na dachu” wypowiedziany w obecności pana Wróbla staje się powodem konsternacji (Kita 2005: 117). 
Nie może natomiast być mowy o nieintencjonalnym zachowaniu w poniższych przykładach, w których rozmówcy okazują dominację nad przeciwnikiem, a nawet go obrażają. Jest to przykład zachowań agonicznych ${ }^{16}$.

RB: Chrześcijaństwo przetrwa. Absolutnie nie jest zagrożone. Oczywiście, że nie. I takich. prawda, dyskutantów jak pan doktor, i wytrwa// [oklaski]

KD: Panie profesorze, panie profesorze, nie lekceważmy rozmówców. Wszyscy siedzimy przy jednym stole i to też przejaw braku dyskryminacji, albo tolerancji.

(„Debata”, TVP 1, 9.12.2004; dziennikarz - KD: Kamil Durczok; gość - RB: Ryszard Bender)

JL: Ta sprawę po decyzji komisji sejmowej $w$ sprawie zbrodni stanu wojennego można byto załatwić w przeciagu roku i prawdopodobnie wtedy nie mielibyśmy do czynienia z tymi namiętnościami, które mamy teraz po obu stronach. Prawdopodobnie nie mielibyśmy//

SN: Nie, nie nie, ci ludzie sa nieprzemakalni, nie, to cokolwiek by byto, ci ludzie sa nieprzemakalni [wskazuje jedną stronę publiczności, oklaski, śmiech].

KD: Ale to już kończymy wątek ad personam. Pan profesor Natęcz.

(„Debata”, TVP 1, 16.12.2004; dziennikarz - KD: Kamil Durczok; goście - JL: Jan Lityński, SN: Stefan Niesiołowski)

Zdecydowana reakcja dziennikarza świadczy o negatywnej ocenie ataków personalnych, lekceważenia rozmówców. Małgorzata Marcjanik stwierdza, że: „W dyskusjach i sporach obowiązują w istocie te same zasady grzeczności, niezależnie od układu sił oraz bez względu na szczegółowe cele prowadzenia działań słownych. Sprowadzają się one - ogólnie rzecz biorąc - do nadrzędnej wobec norm obyczajowych normy etycznej nakazującej szanowanie partnera” (Marcjanik 2007: 108). Jak podkreślają językoznawcy, dyskusja, debata polityczna należy do gatunków agonistycznych ${ }^{17}$, a więc konfrontacji nie da się uniknąć. W ferworze walki rozmówcy mogą zachowywać się niezgodnie z konwencją $^{18}$. Na obowiązywanie norm grzeczności wskazują jednak protesty uczest-

${ }^{16}$ Według Małgorzaty Kity, jako agonizm określa się wymiar afektywny dyskursu, charakteryzującego się tym, że występują w nim liczne wskaźniki złej woli i niechęci mówiącego wobec rozmówcy. Za przejaw agonizmu traktuje się taki typ interakcji werbalnej, którego cechą charakterystyczną jest dominacja postawy konfliktowej nad kooperacyjną. Przejawia się ona eskalacją uczuć negatywnych (Kita 2005: 13-30). Jest jeszcze jeden aspekt potyczek słownych, który w mediach może być decydujący, a mianowicie ich spektakularność.

17 Bożena Witosz wyodrębnia grupę gatunków agonistycznych ze względu na rozbieżność celów nadawcy i odbiorcy. Są to: negocjacje, spór, kłótnia, dyskusja, polemika, awantura, sprzeczka. Gatunki te są pod względem struktury illokucyjnej przeciwstawne do gatunków o nastawieniu empatycznym. Należy do nich rozmowa, plotkowanie, flirt, pogaduszki (Witosz 2005: 171). Aleksander Wilkoń twierdzi, że uczestnicy dyskusji zmierzają do pewnego konsensusu, ale dyskusja może również przerodzić się w kłótnię, co współcześnie jest zjawiskiem nagminnym w dyskusjach politycznych. Jako cechy kłótni podaje: emocjonalność, nietolerancję, chęć dominacji nad partnerem, tendencję do obrażania rozmówcy (Wilkoń 2002: 231-232).

$18 \mathrm{~W}$ trakcie sporów politycznych zasady grzeczności ulegają często zawieszeniu. Nie świadczy to jednak o tym, że grzeczność nie obowiązuje, ale co najwyżej o tym, że zasady nie są respektowane (por. Marcjanik 2007: 108). 
ników, a zwłaszcza dziennikarza, który ma obowiązek dbać o dobrą organizację interakcji. Świadczą one o rozpoznaniu sytuacji komunikacyjnej debaty jako sytuacji oficjalnej, w której osoby występują w rolach społecznych. Dla oficjalnej sytuacji dyskusji konieczne jest, aby ewentualne ataki były stosowane z pozycji roli, nie naruszały prywatności, godności dyskutanta jako osoby (chodzi o oddzielenie przedmiotu sporu od osoby, która go prezentuje). Powstrzymanie się od ataków personalnych jest zatem normą dyskursu publicznego, która ujawnia się wyraźniej w sytuacji jej naruszenia.

\subsection{Sfera prywatna (osobista, intymna) w interakcjach}

Poniżej analizujemy fragmenty pod kątem oddzielenia wątków pochodzących ze sfery prywatnej od tematów ze sfery publicznej. Badacze stosujący metodę analizy konwersacyjnej wskazują na względy etyczne, które nakładają istotne ograniczenia dostępności materiału badań: „[...] członkowie społeczeństwa ustalają takie normy, które stawiają i podtrzymują granice między światem prywatnym i publicznym [...], a w światach tych rządzą odmienne prawa” (Rancew-Sikora 2007: 28). Respektowanie tych norm przez dziennikarza i rozmówców odczytujemy jako strategię kreowania sytuacji komunikacyjnej na odpowiednim poziomie $^{19}$.

KD: Proszę pani, ale ja nie chcę się postugiwać przyktadami, z którymi ja się spotkatem, bo to byty bardzo indywidualne zwierzenia i rozmowy osób, ale jeśli pani zerknie do wielu artykułów, choćby w „Polityce”, we „Wprost”, które ja czytatem i przypadków, które tam zostaty opisane, to znajdzie pani co najmniej kilkanaście przypadków ludzi, którzy po prostu nie chca żyć, bo ból $i$ cierpienie sa nie do zniesienia. [...]

RS: Ja obawiam się, przepraszam, ja nie rozstrzygnę. Boję się, że nikt $z$ nas nie rozstrzygnie, bo siedzimy tutaj $w$ olbrzymim gronie i młodych ludzi, i ludzi w średnim wieku, i rozmawiamy my $w$ miarę ludzie zdrowi. Nawet pan, panie redaktorze, który przeszedt te gehenne choroby nowotworowej-przepraszam za osobisty wtret - jesteśmy w miarę zdrowi i rozmawiamy o zasadach ogólnych.

(,Debata”, TVP 1, 24.02.2005; dziennikarz - KD: Kamil Durczok; gość - RS: Ryszard Szaniawski)

KD: Ja chcę tylko jedna rzecz powiedzieć panu postowi Kurskiemu: nie wspomnę pewnej rozmowy, bo to byta rozmowa prywatna. Nie mam w zwyczaju ujawniać treści rozmów prywat$\underline{n y c h}$, ale pan sobie przypomina, panie pośle, rozmowę w ośrodku Telewizji Polskiej w Katowicach, gdzie mówit pan o kryteriach, jakie rzadzity doborem dziennikarzy do programu „Puls Dnia”. Pan pamięta tę rozmowę, ja ja pamiętam doskonale i zostawmy, bo//

19 Poszanowanie prywatności stanowi jeden z aspektów ochrony wolności i godności człowieka. Podsłuchiwanie cudzych rozmów i wykorzystywanie ich do własnych celów przypomina kradzież dobra osobistego i jest złamaniem bardzo ważnej w świecie społecznym normy (Rancew-Sikora 2007: 29). 
JK: Ale proszę mnie nie oszczędzać. Jeżeli ma pan coś sensacyjnego do ujawnienia, o czym widzowie powinni wiedzieć, proszę walić. Proszę mnie nie oszczędzać. [Ja nie mam nic do ukrycia, tylko po prostu nie pamiętam tej rozmowy.

KD: [Panie pośle, otóż proszę nie sądzić, że to wynika z tego, że ja pana chcę oszczędzić. To wynika z zasad, które ja mam. Uważam, że prywatnych rozmów sie nie ujawnia i tyle.

(„Debata”, TVP 1, 8.02.2006; dziennikarz - KD: Kamil Durczok; gość - JK: Jacek Kurski)

Z treści wypowiedzi, a w szczególności z komentarzy metadyskursywnych wynika, że w debacie publicznej istnieje norma mówiąca o odgraniczeniu sfery prywatnej i publicznej ${ }^{20}$. Dziennikarz może co najwyżej ogólnie zasygnalizować ten rodzaj wiedzy (to były bardzo indywidualne zwierzenia i rozmowy osób), ale nie ma pozwolenia na ich wykorzystanie (ja nie chcę się postugiwać przykładami, z którymi ja się spotkatem). Nawet zdawkowe i mimowolne nawiązanie do informacji o charakterze prywatnym (pan, panie redaktorze, który przeszedt tę gehennę choroby nowotworowej) wiąże się ze świadomością naruszenia normy (brak dyskrecji) i uruchamia strategię obrony twarzy negatywnej ${ }^{21}$ dziennikarza (przepraszam za osobisty wtręt).

Ujawnianie incydentów ze sfery prywatnej staje się szczególnie skuteczną bronią w kontakcie agonistycznym, o czym świadczy ostatni przykład (ale pan sobie przypomina, panie pośle, rozmowę w ośrodku Telewizji Polskiej $w$ Katowicach, gdzie mówit pan o kryteriach, jakie rządzity doborem dziennikarzy do programu „Puls Dnia”). Celem dziennikarza jest prowokacja. Chodzi o wzbudzenie niepewności i szantaż przez insynuację, która pobudza wyobraźnię odbiorców (niejednokrotnie bardziej niż konkretna informacja). Moralna dwuznaczność tego typu działań (wykorzystanie poufnych wiadomości, nadużycie zaufania, nielojalność) nie musi być dla widza oczywista, gdyż prowadzący stosuje wyrażenia asekurujące (Nie mam w zwyczaju ujawniać treści rozmów prywatnych; To wynika z zasad, które ja mam. Uważam, że prywatnych rozmów się nie ujawnia). Działanie dziennikarza jest przykładem zachowania komunikacyjnego, w którym prowadzący musi realizować (jednocześnie) niezgodne cele: zamiar dyskredytacji przeciwnika przez ujawnienie poufnych informacji i obronę własnej twarzy pozytywnej (gdyż dziennikarz naraża się na opinię osoby niedyskretnej). Realizacja niezgodnych celów jest pewną trudnością komunikacyjną. Jest problemem, który rozmówca rozwiązuje dzięki zastosowaniu strategii, którą

20 Sfera prywatna obejmuje relacje osobiste i rodzinne. Sfera publiczna obejmuje relacje w ramach państwowych przedsiębiorstw, np. służby zdrowia, szkolnictwa, w tym mediów państwowych (por. Dobek-Ostrowska 2006: 274).

${ }^{21}$ Aspekt publicznego wizerunku zwany twarza negatywna symbolizuje prawo rozmówcy do własnej przestrzeni życiowej, niezależności, nieingerencji (Brown, Lewinson 1987: 13, za: Antas 2000: 246). Zachowania, które respektują odrębność rozmówcy, przyczyniają się do wykreowania pozytywnego wizerunku partnera. Tak więc szanując rozmówcę, uczestnik sygnalizuje odpowiedni poziom własnych kompetencji. 
można nazwać strategią balansu ${ }^{22}$. Określamy ją jako taki sposób działania, który polega na lawirowaniu, oscylowaniu między różnymi celami (najczęściej niezgodnymi) bez wyraźnego opowiedzenia się po jednej ze stron ${ }^{23}$.

Nie zawsze ujawnienie wątków o charakterze prywatnym wiąże się z naruszeniem normy grzecznościowej. W pewnych sytuacjach prywatność może zostać upubliczniona. Warunkiem niekonfliktowego przejścia tematu do sfery publicznej jest przyzwolenie osoby, której sprawa dotyczy. Wydaje się jednak, że instrumentalizacja tego typu wątków jest nieunikniona. Poniżej podajemy przykład relacji o wykorzystaniu wątku o charakterze jednostkowym w inicjacji procesu legislacyjnego.

KD: Byt rok'73. Mtoda holenderska lekarka, Gertruda Postma, zabita wtasna matke. Na procesie, który jej wytoczono mówiła, że pomogła matce umrzeć, bo ta nieuleczalnie chora wielokrotnie prosita ja o skrócenie życia. Sąd skazat lekarkę na tydzień więzienia i rok nadzoru sądowego. Tak zaczęła się w Holandii wielka debata, która po blisko 30 latach doprowadzita do catkowitej legalizacji eutanazji. [...]

JH: Natomiast jest jeszcze drugi powód, dla którego takie prawo bywa tworzone. To wynika z bardzo wysokiej kultury prawnej w niektórych krajach. Jeżeli ktoś wystapi z jakimś roszczeniem prawnym, powotując się na konstytucję, to uruchamia pewna machinę prawna, która się kończy nawet legislacja.

(„Debata”, TVP 1, 24.02.2006; dziennikarz - KD: Kamil Durczok; gość - JH: Jan Hartman)

Światy społeczne w sposób naturalny przenikają się i ludzie przekraczają wiele symbolicznych granic. Wydarzenia o charakterze jednostkowym mogą stać się precedensem, który uzyska szczególne znaczenie w sferze instytucjonalnej, sferze prawnej. Dochodzi wówczas do zmiany kategoryzacji (już nie zabójstwo, ale eutanazja: zabiła wtasna matkę [...]; debata [...] doprowadzita do catkowitej legalizacji eutanazji) i uzyskania konwencjonalnej zgody społecznej na dany rodzaj działania. Zmiany te znajdują odzwierciedlenie w dyskursie (Tak zaczęta się $w$ Holandii wielka debata).

Instrumentalizacja wątków o charakterze jednostkowym, prywatnym (obok wymiaru społecznego) może mieć również wymiar doraźny. Działanie to jest związane z typami argumentacji. Otóż w każdym dowodzeniu retorycznym uwzględnia się argumenty z różnych źródeł (por. Arystoteles 2004: 48; Barłowska 2010: 71). Są argumenty o charakterze intelektualnym, tzw. artystyczne, które, angażując inwencję mówcy, muszą zostać przez niego wynalezione. Obok nich są argumenty, takie jak zeznania świadków, dokumenty, ustawy,

22 Balans to przechylanie się w różne strony w celu utrzymania równowagi; skłanianie się na przemian ku różnym możliwościom lub sprawom z zachowaniem równowagi między nimi.

${ }^{23}$ Dynamika sytuacji sprawia, że strategia może mieć charakter jedynie optymalizacji efektu komunikacyjnego. Niemożliwe jest bowiem stuprocentowe zrealizowanie żadnego z celów. Jeśli dziennikarz przeprowadzi druzgocącą dyskredytację, to utraci twarz. Jeśli będzie chciał za wszelką cenę zachować twarz - utraci podstawę prowokacji. 
które trzeba tylko zastosować. Jak się jednak okazuje, nie mają one charakteru oczywistych argumentów „za” lub „przeciw”, ale jako elementy o dużej mocy perswazyjnej są przedmiotem działań strategicznych obu stron. W strategiach wykorzystywana jest opozycja prywatny/publiczny. Przeanalizujmy przykłady.

Gop: Ja jestem osoba wtaśnie, która leczy się w ośrodku. Wtaśnie zaczynatem od miękkich narkotyków, prawda, od marihuany. No i to prowadzi do jednego, prawda. Nie ma czegoś takiego, że marihuana $i$ ten/ i na tym się skończy, prawda, że jest// [gwar]

Gpr: Przez marihuanę? Ale powiedz, dlaczego? [gwar, wielogłos]

KD: Momencik, niech przedstawi/ okay? Momencik, bo bardzo mnie interesuje ten/ i co? I jaki jest pański poglad?

Gop: Zaczynatem wtaśnie od marihuany i, no, wedtug mnie nie powinno być czegoś takiego, że jest dozwolone posiadanie jakiejkolwiek znikomej dawki, prawda. Nawet jakiejś tam na przeżycie, bo to jest po prostu danie przyzwolenia.

Gop: Co ci sie stało, że przeszedteś od narkotyków miẹkkich do twardych? [wielogłos]

Gop: Oczywiście moim zdaniem należy karać, bo jeżeli ja bym kiedyś, prawda, szedt i miat przyzwolenie na posiadanie, no to ja bym mógt iść sprzedawać równie dobrze, bo biorę ze soba// [wielogłos]

Gpr: Ale powiedz o sobie.

Gop: I czułbym się bezkarnie. I ten, idąc po ulicy/ i czułbym się bezkarnie. [gwar]

KD: Dobra, ale jedna rzecz bym chciat ustyszeć - przyktad też was nie przekonuje? Człowiek mówi, że zaczynat od miękkich, kończyt na twardych. I co?

(„Debata”, TVP 1, 10.02.2005; dziennikarz - KD: Kamil Durczok; goście - Gop: gość z grupy oponentów, Gpr: gość z grupy proponentów)

Dość ważną grupę rozmówców w analizowanych programach stanowią osoby, których uczestnictwo jest uzasadnione szczególnymi doświadczeniami. Włączanie takich świadectw do struktury debaty odbywa się zawsze z przypisaniem im konkretnej funkcji retorycznej. Podany przykład pełni funkcję argumentu na poparcie określonej tezy nadawcy medialnego, którą forsuje dziennikarz (przykład też was nie przekonuje? Człowiek mówi, że zaczynat od miękkich, kończyt na twardych. I co?). Przykład ma uzasadniać tezę, że prawo nie powinno zezwalać na posiadanie nawet najmniejszej dawki narkotyku, a zatem nie należy również legalizować miękkich narkotyków, bo są etapem do uzależnienia od narkotyków twardych. Świadectwo osoby doświadczonej jest bardzo mocnym argumentem w dyskusji, wiarygodnym przez swoją naoczność i autentyzm ${ }^{24}$. Z tego powodu zarówno proponenci, jak i oponenci starają się włączyć ten sam przykład do swojej argumentacji lub przynajmniej osłabić wymowę argumentacji przeciwnika. Stosują więc taktykę neutralizacji tych elementów, które zagrażają ich pozycji dyskursywnej.

Świadectwu nie da się zaprzeczyć, można je jedynie zneutralizować retorycznie tak, żeby nie było argumentem przeciwko określonej tezie. W podanym

${ }^{24} \mathrm{~W}$ teorii argumentacji jest to typ argumentu z przykładu (argumentum ab exemplo), który polega na wskazaniu właściwości jakiegoś obiektu jako dostarczającego przesłanek uzasadniających daną tezę (Szymanek 2004: 46). 
fragmencie mamy do czynienia z działaniem proponentów zmierzającym do osłabienia wymowy świadectwa. Technikę osłabienia można określić jako rozszerzenie kontekstu z wykorzystaniem opozycji jednostkowy/ogólny i prywatny/ publiczny. Świadek i dziennikarz stosują argumentację opartą na związkach następstwa ${ }^{25}$ : „ten, kto zaczyna od narkotyków miękkich, przejdzie do twardych”. Argument ma w ich intencji zasięg ogólny (to prowadzi do jednego [w domyśle: zawsze], nie ma czegoś takiego, że marihuana i na tym się skończy). Proponenci dla odmiany rozszerzają kontekst i kierują uwagę odbiorców ku argumentacji opartej na związkach współistnienia ${ }^{26}$ : „nawet, jeśli ktoś przejdzie od narkotyków miękkich do narkotyków twardych, to jest to spowodowane czynnikami indywidualnymi. Nałóg jest przejawem cech jednostkowych, a więc w gruncie rzeczy sprawą prywatną”. Argument osłabiający tezę przeciwnika ma zatem odniesienie jednostkowe, indywidualne (co ci się stało, że przeszedteś od narkotyków miękkich do twardych; ale powiedz o sobie). Czynniki indywidualne przynależą do sfery prywatnej, a więc można powiedzieć, że nastąpiło tu również symboliczne wyparcie problemu ze sfery publicznej do prywatnej. Z pewnością tego typu działanie ma osłabić wymowę świadectwa w doraźnej argumentacji i obniżyć rangę problemu, który miał być rozwiązany systemowo ${ }^{27}$.

Nieoficjalny charakter wypowiedzi to taki, w którym nadawca nie jest sytuacyjnie ograniczony zarówno w wyborze kodu, jak środków językowych (Mazur 1986: 25). Nie występują również ograniczenia o charakterze komunikacyjno-instytucjonalnym związane z pełnieniem roli społecznej. Stąd nieco inne są kryteria oceny wypowiedzi osoby występującej w roli społecznej i osoby prywatnej. Różnice te mogą być wykorzystywane strategicznie. Dobitnie pokazują to kolejne przykłady.

KD: No, ostro pan poszedt, panie redaktorze.

SM: No, taki już jestem, panie redaktorze. Tak, że ja odpowiadam sam za to, co piszę. Jestem prywatna osoba. Nikt mi nic nie zleca, nikt się ze mna nie konsultuje, ani ja z nikim, w zwiazku z tym biorę odpowiedzialność za to, co napisatem.

(„Debata”, TVP 1, 11.01.2006; dziennikarz - KD: Kamil Durczok; gość - SM: Stanisław Michalkiewicz)

Dziennikarz stosuje zwrot adresatywny „panie redaktorze”, czym przypisuje rozmówcy rolę społeczną. Określenie wypowiedzi jako „ostrej” należy rozumieć jako kwalifikację odnoszącą się do konwencji dyskursu publicznego. Coś

${ }^{25}$ Związki następstwa to relacje przyczynowo-skutkowe; oparta na nich argumentacja polega na poszukiwaniu przyczyn i określaniu skutków (Perelman 2004: 97)

${ }^{26}$ Związki współistnienia ustalają więź między rzeczywistościami różnych poziomów, z których jedna pokazana jest jako wyraz lub przejaw innej (Perelman 2004: 106).

$27 \mathrm{~W}$ analizie dyskursu tego typu działania omawiane są w ramach niejawnych uprzedzeń, które przejawiają się m.in. w skupianiu uwagi na działaniach i opiniach jednostek w oderwaniu od społecznego kontekstu. Określa się to jako dysymulację rzeczywistej natury różnych działań zbiorowych, działań władzy, procesów społecznych (Lisowska-Magdziarz 2006: 94). 
jest „ostre”, ponieważ jest skrajne - jak na dyskurs publiczny i rolę nadawcy. Rozmówca odbiera opinię dziennikarza jako zarzut, o czym świadczy podjęcie strategii obrony twarzy pozytywnej. Skoro wytknięto mu niezgodność między rolą a zachowaniem, to symbolicznie odcina się od roli i przechodzi na bezpieczniejsze pozycje osoby prywatnej (jestem prywatna osoba). Sfera prywatna funkcjonuje w tej sytuacji jako azyl, a więc miejsce, w którym nie obowiązują tak rygorystyczne konwencje zachowań komunikacyjnych. Oczywiście jest to gra, strategia obrony twarzy pozytywnej, gdyż roli społecznej (tu: redaktora) nie można tak po prostu zignorować.

Opozycja prywatny/publiczny bywa wykorzystywana strategicznie nie tylko do asekuracyjnej obrony niekonwencjonalnych zachowań, lecz także do selekcji tematów, które nadają się do debaty. Norma dyskursu publicznego mówiąca, że należy w nim podejmować tematykę publiczną, polityczną, a unikać spraw prywatnych - może być wykorzystana strategicznie do delegitymizacji dyskusji na temat niewygodny dla jednej ze stron.

O ważności tejże normy świadczy fakt, że wiele fragmentów debat poświęconych jest temu, czy postawione zagadnienie ma charakter publiczny, czy też przynależy wyłącznie (lub przede wszystkim) do sfery prywatnej. Arbitralność granic między sferami widać najlepiej, kiedy nie ma zgody co do ich ustanowienia. To, czy dane zagadnienie może stanowić temat debaty publicznej, czy pozostaje poza nią, jest przedmiotem negocjacji. W poniższym przykładzie $\mathrm{z}$ debaty na temat tolerancji dziennikarz określa problem postawiony w ramach tematu jako publiczny, natomiast rozmówca przesuwa go w stronę sfery prywatnej. Działanie to jest realizacją strategii oponowania.

KD: Pan profesor Legutko.

RL: Tak, więc ja sądzę, że stowo tolerancja w ogóle nie ma żadnego sensu. To jest stowo pozbawione znaczenia. Podobnie jak słowo nietolerancja. Tak mniej więcej, ja sadzę, ono stracito, oba te pojęcia stracity znaczenie pod koniec XVIII wieku, na początku wieku XIX, kiedy zakończyty się te wielkie spory religijne. Natomiast obecnie to funkcjonuje jako taka moralistyczna inwektywa, powiedziałbym. Bo to jest tak, postużmy się tą definicja, która tutaj padta: że ja, nie wiem, znoszę coś, co mi się nie podoba, prawda. No ale przepraszam, dlaczego ja mam znosić, dlaczego ja mam znosić? Mogę znosić coś, do czego muszę mieć pewien stosunek, muszę to jakoś zdiagnozować, prawda? Ja mogę coś znosić, co jest obojętne, albo uważam za nieszkodliwe, prawda, albo uwa$\dot{z} a m$, że nie mogę sobie żadnego pogladu wyrobić na ten temat, prawda?

KD: Panie profesorze, to jak wedle przyjętej przez pana definicji powinni się zachowywać ci, którzy nie akceptuja postaw homoseksualnych $i$ są świadkami takiego marszu?

RL: Co to jest postawa homoseksualna? Przepraszam, ale dajemy się wciagać w jakieś niemadre spory ideologiczne. Ja nie znam tych państwa. Ja nic nie jestem w stanie o nich powiedzieć, z niczym mi się nie kojarzą. Jeżeli oni jakoś, nie wiem, swoje poglądy będa starali się określić, ja będę musiat się odnieść się [sic!] do tych poglądów, ale ja ich nie znam. To co ja mam powiedzieć, czy ja ich lubie czy nie lubię. [...] Co to w ogóle jest za identyfikacja? Czy ktoś ma, nie wiem, czuje pożadanie do mężczyzn, co to za identyfikacja jest? Spory sa innej natury, nie wiem, zasadnicze jakieś spory światopoglądowe. A to, co ktoś robi w swojej sypialni, a cóż mnie to obchodzi? [...] To ustalam z takiej pozycji, ja moge sobie oceniać: a Polacy sa tolerancyjni, a Polacy nie sa 
tolerancyjni. To przeciez jest bez sensu, to jest jak takie pie/ pytanie, przepraszam pana, panie redaktorze, [jak byśmy się] zastanawiali: czy Francuzi są erotomani [sic!] czy nie są erotomanami. No i tak: jedni twierdza, że sa, inni, że nie sa.

KD: Tak, tylko ta dyskusja, panie profesorze, to byłoby uprawnione porównanie, tylko, ze ta dyskusja [o Francuzach] nie prowadzi do takiej sytuacji, w której w kierunku osób walczacych $w$ ich mniemaniu o swoje prawa nie leca kamienie//

(„Debata”, TVP 1, 9.12.2004; dziennikarz - KD: Kamil Durczok; gość - RL: Ryszard Legutko)

Przedmiotem negocjacji jest m.in. prywatny bądź publiczny charakter wprowadzonego przez dziennikarza zagadnienia, które ogólnie można określić jako „społeczne/indywidualne postrzeganie grupy o odmiennej orientacji seksualnej”. Dziennikarz sytuuje zagadnienie w sferze publicznej, o czym świadczą oficjalne sformułowania (akceptacja postaw homoseksualnych, walka o swoje prawa, demonstracja), natomiast rozmówca wypiera je ku sferze prywatnej (znać kogoś, lubić kogoś, ktoś robi coś w swojej sypialni, nie obchodzi kogoś [domyślnie: życie intymne]).

Zachowanie komunikacyjne rozmówcy należy analizować w ramach układu interakcyjnego debaty jako jedną ze strategii oponowania. Jest to jednak oponowanie rozszerzone, w którym oponent nie tylko ustosunkowuje się do określonego tematu, ale odmawia prawa do publicznego roztrząsania, podważa adekwatność rozpoznania rzeczywistości przez przeciwników. Argumentem jest właśnie przyporządkowanie tematu do sfery prywatnej, a nie publicznej ${ }^{28}$. Można tu zatem mówić o strategicznym wykorzystaniu normy dyskursu, która zawęża zakres możliwych tematów (nie mówi się w debacie publicznej np. o tym, jak wygląda życie intymne).

Tak więc podstawą tej strategii jest zmiana zasad organizacji i uporządkowania treści pojęciowych w ramach tematu. Rozmówca przenosi się z poziomu przedmiotowego na poziom metadyskursywny. Stosuje strategie metadyskursywne, które dotyczą samych reguł postrzegania rzeczywistości i organizacji dyskursu:

- podważa zasadność stosowania terminu „tolerancja”, „postawa homoseksualna”. Jest to negocjowanie zakresu, odniesienia i treści pojęć, używanych w debacie,

- określa postawiony przez dziennikarza problem jako nierozstrzygalny, wręcz absurdalny ${ }^{29}$. Jest to negocjowanie tematu debaty.

${ }^{28}$ Rozmówca przenosi status sprawy ze status qualitatis (status jakości, polegający na ocenie charakteru sprawy) do status translationis (status przeniesienia, polegający na skoncentrowaniu się na okolicznościach sprawy, tu: na odpowiedniości tematu) (por. Lausberg 2002: 69; Barłowska 2010: 48).

${ }^{29}$ Rozmówca sprowadza dyskusję do absurdu (argumentum ad absurdum). Istotą argumentu jest wykorzystanie analogii między stanowiskiem przeciwnika a stanowiskiem określonym jako absurdalne (Szymanek 2004: 48) (To przecież jest bez sensu, to jest jak takie pie/ pytanie, przepraszam pana, panie redaktorze, [jak byśmy się] zastanawiali: czy Francuzi sa erotomani [sic!] czy nie sq erotomanami. No i tak: jedni twierdza, że sa, inni, że nie sa). 
Strategia metadyskursywna służy negocjowaniu reguł samego dyskur$\mathrm{su}$, ale w tym przykładzie jest również związana z dyskredytacją poznawczą (Karwat 2006b: 196). Rozmówca kwestionuje zdolności poznawcze przeciwnika. Sugeruje, jakoby nieadekwatnie stosował termin „tolerancja”, bo termin ten się zdezaktualizował; bezpodstawnie stosuje termin „postawa homoseksualna”, który jest według rozmówcy pojęciem pustym. Pośrednio jest to również dyskredytacja zawodowa, ponieważ dziennikarz jako organizator debaty jest oskarżany o stawianie bezsensownych pytań, inicjowanie nieinteresujących tematów (dajemy się wciagać $w$ jakieś niemądre spory ideologiczne, to [czyli takie rozważanie] przecież jest bez sensu).

Okazuje się, że usytuowanie omawianego zagadnienia w sferze publicznej bądź prywatnej niesie poważne konsekwencje nie tylko dla struktury, układu interakcyjnego debaty, ale również dla jej zaistnienia. Zwłaszcza w tym przykładzie widać, że symboliczne wyparcie tematu ze sfery publicznej do prywatnej jest $\mathrm{w}$ istocie odmawianiem prawa do jego zaistnienia również $\mathrm{w}$ przestrzeni debaty publicznej. Taką strategię rozszerzonego oponowania nazwiemy delegitymizowaniem debaty.

Charakter sytuacji komunikacyjnej, której podstawowym wyznacznikiem jest oficjalność rozumiana jako kategoria socjolektalna, stanowi ważną determinantę strategii językowych. Wpływ można dostrzec na poziomie dostosowania form językowych do wymogów sytuacji oraz na poziomie strategicznego wykorzystania opozycji: oficjalny/nieoficjalny, publiczny/prywatny w realizacji celów komunikacyjnych, np. w sporach publicznych. Oficjalność sytuacji dla gości oznacza przede wszystkim dbałość o staranną formę wypowiedzi i realizację strategii obrony twarzy pozytywnej. Brak wystarczających kompetencji komunikacyjnych w sytuacji oficjalnej może stać się powodem dyskredytacji rozmówcy. W interakcjach o charakterze rywalizacyjnym trudno jest rozmówcom uniknąc aktów zagrożenia twarzy, dlatego w realizacji niezgodnych celów stosują strategię balansu. Rywalizacja musi przyjąc takie formy, które są dopuszczalne w sytuacji oficjalnej. Należy unikać form ocenianych jako naganne (np. ataków personalnych). Dla dziennikarza istotna jest nie tylko oficjalność, ale i sformalizowanie sytuacji. W tym zakresie można odnotować dominację dziennikarza w kreowanym układzie interakcyjnym ze względu na instytucjonalny charakter jego roli społecznej. Charakter sytuacji wyznacza również typowy zakres tematyczny rozmów publicznych i reguluje zasady wprowadzania wątków o prymarnym charakterze prywatnym. Granica między sferą prywatną a publiczną jest nie tylko podstawą selekcji tematów odpowiednich i nieodpowiednich w obu sferach, ale sama stanowi przedmiot dyskusji. 


\section{ROZDZIAE 4 \\ Strategie $\mathrm{i}$ ich uwarunkowania wynikające $\mathrm{z}$ organizacji tekstu mówionego}

W rozdziale czwartym rozważamy, w jaki sposób działania, a więc i strategie komunikacyjne dziennikarza i rozmówców, są uwarunkowane, determinowane przez przynależność tekstów do języka mówionego ${ }^{1}$. Z substancjalną formą znaku językowego wiąże się m.in.: sekwencyjność, dialogowość i sytuacyjność (Bartmiński, Niebrzegowska-Bartmińska 2009: 99-106; Ożóg 2001: 85; Nieckula 2001: 99).

\subsection{Uwarunkowania wynikające z sekwencyjności}

Urzeczywistnianie języka (i tworzonych w nim tekstów) przez kanał foniczny wiąże się z faktem, że to dźwięk, a nie pismo, jest substancją służącą do przenoszenia znaków językowych. W związku z tym wyodrębnia się substancjalną odmianę ustną, percypowaną słuchowo. Jak podkreślają badacze (Ong 1992: 129; Ożóg 2001: 88; Bartmiński, Niebrzegowska-Bartmińska 2009: 99), z właściwości substancji dźwiękowej wynika szereg specyficznych cech tej odmiany, m.in. linearność i sekwencyjność. Akcentuje się również ważną rolę wyrażeń metatekstowych w uprzystępnianiu tekstu mówionego, a więc w przygotowaniu go do bardziej efektywnego odbioru (Pisarkowa 1975: 18-45; Ożóg 1990; Warchala 1991: 104-113; Winiarska 2001; Boniecka 1999: 199-204). Jan Mazur wskazuje na rodzaj realizacji tekstu jako na jeden z najważniejszych czynników wpływających na jego organizację (Mazur 1986: 22-24). Wynika to z odmienności kodu, który z kolei determinuje repertuar dostępnych środków wyrażania intencji nadawcy (chodzi głównie o środki prozodyczne, takie jak linia intonacyjna, akcent logiczny, pauza) oraz wpływa na stopień trwałości tekstu.

Tekst ustny jest percypowany przez odbiorcę $\mathrm{w}$ trakcie wypowiadania go przez nadawcę. Odbiorca nie ma możliwości powrotu do wcześniejszych

${ }^{1}$ Nie utożsamiamy języka mówionego z pojęciem języka potocznego. Chodzi raczej o ustność, która jest właściwa żywej mowie. Różnice między mową a pismem skłaniają badaczy do wyodrębnienia dwu równoległych odmian języka - mówionej (lub ustnej) i pisanej oraz związanych z tym dwu typów komunikacji - ustnej i pisanej (Nieckula 2001: 100-102). 
fragmentów tekstu (jak w formie pisanej), co może stanowić utrudnienie całościowego odbioru. Tekst percypowany kanałem słuchowym, zwłaszcza dłuższy, nie jest dany odbiorcy jako całość. Dociera do niego w kolejnych fragmentach. Jak pisze Krystyna Pisarkowa: „[...] wyłączenie sygnałów graficznych, jak układ wierszy, podział na akapity, «światło», sygnałów interpunkcyjnych, wielkich liter, kroju czcionki (kursywa, wersaliki), jej rozstawienie (spacje), brak możliwości wybiegania naprzód, brak możliwości ogarnięcia, przewidzenia całej objętości tekstu, który dopiero nastąpi - oznacza rezygnację z całego kompletu jednostek informacyjnych” (Pisarkowa 1974: 41-42). Wszystkie te uwarunkowania są uwzględniane przez nadawcę tekstu mówionego, który zwiększa częstotliwość sygnałów segmentacji, spójności i podtrzymania kontaktu.

Sekwencyjność i linearność tekstu ustnego ma zatem odzwierciedlenie w jego organizacji. Jak twierdzi Jerzy Bartmiński: „sekwencyjność wypowiedzi ustnej znajduje odbicie w jej segmentacji, a z drugiej strony stwarza zapotrzebowanie na mechanizmy integrujące tekst" (Bartmiński, Niebrzegowska-Bartmińska 2009: 100). Mechanizmy te mogą być stymulowane przez świadome działania nadawcy. Według Marii Renaty Mayenowej „Suma energii (wkładanej w rozumienie tekstu) jest tym mniejsza, im więcej tekst wprowadza explicite wyrażonych na powierzchni środków spójnościowych, prawdziwie orientujących odbiorcę w stosunkach semantycznych w danym tekście; energia jest tym mniejsza, im mniej operacji musi dokonać odbiorca, by ujawnić mechanizm spójności” (Mayenowa 1971: 199). Tak więc integralność tekstu, która zasadza się na następstwie i logicznym porządku myśli jest wspierana przez działania o charakterze metatekstowym, realizowane na poziomie lokalnym i globalnym ${ }^{2}$.

Na poziomie lokalnym ważnym przejawem organizacji tekstu jest jego segmentacja, która realizuje się w inny sposób niż w tekście pisanym ${ }^{3}$. Już same próby delimitacji tekstu mówionego napotykają na problemy, takie jak wydzielenie wypowiedzeń czy ponadzdaniowych segmentów (Mazur 1986: 21). W języku mówionym realizowane są bowiem teksty, których przynależność do jednostek zdaniowych lub ponadzdaniowych (tzw. jednostek tekstowych ${ }^{4}$ ) jest sporna. Jako wskaźniki segmentacji wymienia się elementy prozodyczne (pauza, intonacja) oraz różnego typu sygnały słowne. Mogą być one określane jako: leksykalne

2 Pojęcia poziomu lokalnego i poziomu globalnego pozwalają na zróżnicowanie perspektywy oglądu: od kontekstu sekwencyjnego (wypowiedzi bezpośrednio poprzedzające analizowaną wypowiedź i następujące po niej) do całościowej organizacji tekstu (analiza wypowiedzi w szerszych strukturach rozmowy).

${ }^{3}$ Jan Mazur wymienia cechy odróżniające tekst mówiony od tekstu pisanego: spontaniczność, zależność od sytuacji, rodzaju kontaktu, czynników pozajęzykowych, takich jak gest i mimika (Mazur 1986: 19).

${ }^{4}$ Pojęcie ,jednostki tekstowej” wprowadza Jan Mazur, który dla jej przybliżenia adaptuje definicję tekstu Weinricha: „sensowne następstwo znaków językowych między dwoma wyraźnymi przerwaniami aktu komunikacji” (Weinrich 1971: 222, za: Mazur 1986: 21). 
ekwiwalenty interpunkcji (Pisarkowa 1975: 36), wyrażenia metatekstowe, których zadaniem jest organizowanie procesu przekazu (Ożóg 1990: 23), operatory metatekstowe wskazujące, jaki rodzaj relacji semantycznej łączy poszczególne części tekstu (Winiarska 2001: 21).

Na poziomie globalnej organizacji należy przypisać tę funkcję głównie interwencjom organizacyjnym dziennikarza. Tego typu sygnałów, tzn. sygnałów zapowiedzi, przypomnienia, komentowania, podsumowania, nie są również pozbawione wypowiedzi bardziej kompetentnych uczestników interakcji. Ulotność mowy żywej sprawia, że rozmówcy, chcąc się odnieść do wcześniejszych fragmentów tekstu, muszą je przypomnieć. Elementy komentarza, które dotyczą jakiejś jednostki tekstu: wyrazu, zdania, akapitu, fragmentu tekstu, mają charakter metatekstowy ${ }^{5}$. Ogniskowaniu uwagi i regulacji przebiegu interakcji służą również działania o charakterze metadyskursywnym, kiedy rozmówcy odnoszą się bezpośrednio i całościowo do kontekstu komunikacyjnego, np. intencji nadawcy, odbiorcy, wzorów działań językowych odpowiednich w danej sytuacji.

Sekwencyjność i linearność właściwa tekstom przynależnym do substancjalnej odmiany języka, jaką jest odmiana mówiona, powodują, że rozmówcy, a zwłaszcza dziennikarz z racji roli organizatora, podejmują różne działania, które za Urszulą Żydek-Bednarczuk nazywamy strategiami nadawczo-odbiorczymi. Szczególnie chodzi tu o sygnały metatekstowe, za pomocą których nadawca wspomaga odbiór tekstu tak, aby był on zgodny z zamierzonymi celami (Żydek-Bednarczuk 2005: 166-186). Funkcją owych sygnałów jest zatem umożliwienie, ułatwienie i ukierunkowanie odbioru tekstu mówionego (wypowiedzi, sekwencji, całego tekstu). Również Aleksander Wilkoń dostrzega sterowniczopomocniczą funkcję elementów metatekstowych: „Metatekst nie zajmuje się tylko samą wypowiedzią, ale także i tym, czego ona dotyczy: światem przedstawionym. Komentuje wydarzenia przedstawione, zapowiada przyszłe, zszywa w postaci ogólnej relacji streszczającej opuszczone ogniwa fabularne. [...] W partiach wstępnych całości, rozdziałów, akapitów zapowiada temat, w końcowych sumuje przedstawione wydarzenia. Są to jego istotne, bo semantyczne funkcje, związane przede wszystkim ze zjawiskiem werbalizacji uogólniającej i streszczającej [...]" (Wilkoń 2002: 93-98). W odniesieniu do programów telewizyjnych można mówić o nasileniu tego typu działań, zwiększeniu rygoru organizacyjnego z myślą o odbiorcy masowym. Przejawem strategii nadawczo-odbiorczych są m.in. powtórzenia, nawiązania do fragmentów, zapowiedzi i streszczające podsumowania.

BW: [...] Ten polityk pokazat przez te dziesięć lat bycia prezydentem, jak wspaniale można tączyć naród polski, jak można świetnie prowadzić politykę zagraniczna która/ i poprzez to

${ }^{5}$ Por. rozważania Anny Wierzbickiej, która ujmuje metatekst jako „wypowiedź o wypowiedzi” uwydatniającą związki między elementami tekstu (Wierzbicka 1971: 106). 
wptywać tė̇ na politykę wewnętrzną. To byt człowiek, który zasypywat konflikty, a ich nie tworzyt. Starat się być prezydentem wszystkich Polaków, a nie tak jak niektórzy uważaja, że tylko forowat jakby [jedną część, jedna stronę//

KD: [Krytycy tej prezydentury bez żadnego problemu pokaża panom pięć punktów, które powinny zobrzydzić panom tę prezydenturę.

BW: Jakich pięć punktów?

KD: No proszę bardzo. [gest wskazania grupy przeciwników]

ZK: Przede wszystkim wspominat pan [odnosi się do wypowiedzi zwolennika] o tym, że prezydentura Kwaśniewskiego tączyła Polaków, a nie dzieliła. Znam przykłady, przede wszystkim polityka historyczna, ta polityka historyczna, która prezydent Kwaśniewski uprawia, do tej pory Polaków dzieli.

(„Debata”, TVP 1, 21.12.2005; dziennikarz - KD: Kamil Durczok; goście - BW: Bartłomiej Wichniarz, ZK: Zofia Kabas)

Rozmówczyni przypomina fragment wypowiedzi zwolennika, z którą zamierza polemizować. Komentarz metatekstowy semantycznie spaja rozdzielone czasowo wypowiedzi. Sprzężenie zwrotne, które polega na reakcji odbiorcy na wypowiedź nadawcy, zostało rozluźnione przez interwencję organizacyjną dziennikarza. Komentarz metatekstowy ma przywrócić dialogowość, rozumianą tu jako związek, wzajemne odniesienie. Ma tym samym dobudować kontekst sytuacyjny do aktualnej wypowiedzi i przez to umożliwić jej sensowny odbiór (mówię X w związku z konkretną wypowiedzią). Oczywiście, związek semantyczny między dwoma replikami jest niezależny od komentarza, odbiorca dostrzega (powinien dostrzec) powiązanie, ale eksplicytne przypomnienie zwiększa efektywność odbioru.

ZK: No nieee. Nie można zapominać, że sukces również ukraiński byt tak naprawdę sukcesem wielu osób. To nie tylko prezydent Kwaśniewski. Na Ukrainę pojechat również były prezydent Wałęsa, cata administracja w Polsce. Myślę, że jest naprawdę wielu ojców tego sukcesu. Oczywiście, nie można odmówić prezydentowi Kwaśniewskiemu, że dużo tutaj w tej kwestii zrobit, natomiast nie można tego/ tej chwały przypisywać tylko jemu.

$\mathrm{KD}: M h m$. [wzrokiem wskazuje rozmówcę z grupy zwolenników]

ZP: Ja myślę, że jeszcze dochodzi kwestial tak na dobra sprawę/ Pan redaktor pytat, jakiego wyboru dokonaliśmy w'95. Mieliśmy pewien kontrast, a mianowicie odchodzacego prezydenta Watęsę, który wiele osób rozczarowat i ludzie szukali nowych możliwości wyboru. No i Kwaśniewski tutaj się wpasowat w tą możliwość dokonania wyboru.

(„Debata”, TVP 1, 21.12.2005; dziennikarz - KD: Kamil Durczok; goście - ZK: Zofia Kabas, ZP: Zbigniew Pisarski)

Rozmówca rozpoczyna wypowiedź, która nie jest bezpośrednio związana z poprzednią wypowiedzią (poprzedniczka mówiła na temat mediacji na Ukrainie). Chcąc nawiązać, powrócić do wcześniejszego wątku, musi go przypomnieć. Bardzo ogólne sygnały włączenia wątku jako dodanego (jeszcze dochodzi kwestia) lub wnioskowania, uszczegółowienia (tak na dobra sprawę) okazują się niewystarczające. Natomiast powtórzenie pytania, do którego odnosi się wypowiedź, gwarantuje lepszą kontekstualizację, a więc i odbiór komunikatu. 
Fragment ten jest również zobrazowaniem spontanicznego tworzenia tekstu. Spontaniczność, jako cecha tekstów ustnych, polega na tym, że rozmówca mówiąc, podejmuje decyzje co do wyboru środków językowych. Proces ten jest o tyle widoczny, że dwie próby zostają odrzucone, dopiero trzecia zostaje przez mówiącego uznana za funkcjonalne włączenie się w kontekst rozmowy.

KD: To były opinie osób, którzy [sic!] $w$ swoje doroste życie, ale także ocierając się o politykę, wchodzity już wtedy, kiedy Aleksander Kwaśniewski sprawowat urząd prezydenta. Spróbujemy na 24 godziny niemalże przed końcem tej prezydentury/ spróbujemy ja podsumować. A ponieważ naszym narodowym sportem jest narzekanie, to zaczniemy od sukcesów tej prezydentury.

(„Debata”, TVP 1, 21.12.2005)

Dziennikarz przypomina przebieg dotychczasowej interakcji. Informuje o uczestnikach, charakteryzuje ich, wskazuje na rodzaj zaangażowania komunikacyjnego, zgodnego z wymogami debaty (wygłoszenie opinii), zapowiada temat (podsumowanie prezydentury) i częściowo ujawnia plan rozmowy (zaczniemy od sukcesów).

Rozmówcy, a zwłaszcza dziennikarz, są świadomi nietrwałości tekstu mówionego. Z myślą o odbiorcy podejmują strategie nadawczo-odbiorcze ułatwiające sensowny odbiór. Za pomocą komentarzy metatekstowych, powtórzeń, podsumowań tworzą „rusztowanie dla treści”, które pełni m.in. funkcję mnemotechniczną, a więc ułatwiającą zapamiętywanie ${ }^{6}$.

\subsection{Uwarunkowania wynikające $\mathrm{z}$ dialogowości}

Do ważnych właściwości ustnej odmiany języka ogólnego, wynikających z typu komunikacji „twarzą w twarz”, zalicza się dialogowość. Jak twierdzi Kazimierz Ożóg: „Dialog jest najbardziej naturalną formą komunikacji ludzkiej. Opozycja dialog - monolog jest w odmianie ustanej mało wyrazista, gdyż ostatecznie formy monologowe, np. wykład, lekcję, kazanie, można sprowadzić do takiego dialogu, w którym druga osoba jest obecna, ale milczy” (Ożóg 2001: 91-95). Aleksy Awdiejew i Grażyna Habrajska, powołując się na Bronisława Malinowskiego, określają bezpośrednią interakcję werbalną jako tę, która realizuje podstawowe przeznaczenie języka w tzw. pierwotnej sytuacji pragmatycznej. Jest nią koordynowanie wspólnej działalności ludzi w procesie bezpośredniego kontaktu werbalnego (Awdiejew, Habrajska 2006: 23). Praktyczny aspekt zostaje pogłębiony w filozoficznej koncepcji dialogu ${ }^{7}$, która ujmuje go jako współpracę, negocjowanie znaczeń, wymagające umiejętności reagowania i monitorowania sygnałów płynących od rozmówcy.

\footnotetext{
${ }^{6}$ Mnemotechnika to 'zespół środków i prawideł ułatwiających zapamiętywanie jakiegoś materiału (należy do nich np. nadanie rytmicznego układu trudnemu tekstowi)' (SJPSz, t. 2: 195).

7 Filozoficzne koncepcje dialogu omawia Aneta Załazińska, która sytuuje w tym nurcie m.in. koncepcje Bachtina, Wittgensteina, Bubera (Załazińska 2006: 23).
} 
W komunikacyjnych zachowaniach uczestników programów publicystycznych dają się zauważyć nieświadome odwołania do różnych płaszczyzn dialogowości, a tym samym można mówić o różnych poziomach dialogowości. Współistnieją co najmniej trzy przeplatające się poziomy rozumienia dialogu i dialogowości lub dialogiczności w komunikacji: dialog sensu largo, dialog jako forma podawcza wypowiedzi i dialog sensu stricto (Labocha 1996a; Kita 1998; Mukařovský 1970). Dialogiczność jest naczelną zasadą komunikacji z racji tego, że nie zachodzi ona w próżni. Każda wypowiedź odnosi się jakoś do wypowiedzi wcześniejszych i antycypuje wypowiedzi następcze, przy czym odległość czasowa i przestrzenna nie jest w tym odniesieniu istotna ${ }^{8}$. W tym sensie każdy rodzaj komunikacji ustnej ma charakter dialogiczny (Labocha 1996a: 56).

Powiązanie między aktami komunikacji językowej typu: bodziec - reakcja, przyczyna - skutek nie ma charakteru oczywistego. Jest raczej efektem aktywności umysłowej odbiorcy-interpretatora, umiejętności dostrzeżenia związków między komunikacyjnymi wystąpieniami. Może też przybrać charakter taktyczny - służyć jako punkt odniesienia wyboru strategii komunikacyjnej, w tym jako usprawiedliwienie nagannego zachowania. Dostrzegamy strategiczne wykorzystanie przez uczestników komunikacji zasady dialogiczności dla polepszenia swojej pozycji dyskursywnej. Polega ono na powołaniu się na mechanizm korelacji między akcją i reakcją, czyli na odpowiedniości akcji i reakcji oraz na dopasowaniu strategii nadawcy do strategii poprzednika. Najłatwiej dostrzec wpływ zasady dialogiczności w wypowiedziach relacjonujących przebieg zdarzeń komunikacyjnych.

AC: [...] tam [przed domem generała Jaruzelskiego] się nauczytem bardzo wielu nowych stów na ka, cha, pe i tak dalej. I chciatem je potem obejrzeć w telewizji, no ale jakoś się tak zdarzyto, że obejrzałem tylko jeden krzyk ze strony moich młodych przyjaciót z lewicy. Już nie pamiętam, to byto przerobione hasto wzięte od was, mam nadzieję, że nie ogtosiliście patentu na to hasto „Sierpem i mtotem w czarna hotote”. Byta to odpowiedź na „Sierpem i mtotem w czerwona hotote”. Tego też nie obejrzatem $w$ żadnej relacji telewizyjnej.

(„Debata”, TVP 1, 16.12.2004; gość - AC: Andrzej Całkiewicz)

Rozmówca przywołuje różnice między medialną relacją z przebiegu wydarzenia, którego był świadkiem, a samym wydarzeniem. Medialna relacja postawiła w niekorzystnym świetle grupę o orientacji lewicowej (zagrożenie twarzy pozytywnej). Powołanie się na różnice pozwala podjąć rozmówcy strategię obrony pozytywnego wizerunku grupy (młodzi przyjaciele z lewicy), z którą sympatyzuje. Strategia polega na neutralizowaniu niekorzystnej sytuacji, niekorzystnego

${ }^{8}$ Można tu odwołać się do teorii dialogiczności mowy Michaiła Bachtina, który twierdzi, że podmiot mówiący nie jest nigdy pierwszym mówiącym, a więc „pierwszym, który naruszył wieczne milczenie wszechświata” (Bachtin 1986: 361). Zbieżna z takim podejściem jest teoria intertekstualności, przypisująca międzytekstowy wymiar każdej wypowiedzi (por. Gajda 2010a: 13-23). 
wrażenia, które mogło powstać na skutek przekazu telewizyjnego. W tym celu rozmówca wykorzystuje nie tylko zasadę dialogiczności, ale również powołuje się na właściwości dyskursu medialnego. Działania te mają trojaki wymiar:

1. Dotyczą tendencyjnej selekcji elementów obrazu, prowadzącej do zniekształcenia. Rozmówca przekonuje, że przekaz medialny nie oddaje rzeczywistości. Wykorzystano tu typowe w strategiach obrony, dokładniejsze podziały pól pojęciowych, bardziej szczegółowe kategoryzacje: rzeczywistość a przekaz medialny o rzeczywistości.

2. Dotyczą usytuowania zachowania komunikacyjnego w obrębie schematu bodziec - reakcja. Rozmówca przekonuje, że naganne zachowanie było sprowokowaną reakcją, a nie zachowaniem samoistnym. Rozszerzanie kontekstu ma funkcję balansującą, bowiem dodatkowe uwarunkowania stanowią okoliczności łagodzące. Przesuwają odpowiedzialność podmiotu z uwarunkowań wewnętrznych (zachowali się nagannie, bo to wynika $\mathrm{z}$ ich natury) na uwarunkowania zewnętrzne (zostali sprowokowani).

3. Dotyczą samodzielności wypowiedzi. Naganne hasło („Sierpem i młotem $w$ czarna hołotę") miało stanowić zmodyfikowany cytat hasła strony przeciwnej („Sierpem i młotem w czerwona hołotę”). Autorstwo obraźliwego tekstu zostaje podzielone między obie skonfliktowane strony, a więc rozkłada się odpowiedzialność za słowo (to byto przerobione hasło wzięte od was).

PB: Ja chciatem jeszcze powiedzieć, że jesteśmy dalecy od ironizowania, natomiast musimy zapytać druga stronę, za co ta „Pała na generała”?

JK: Ale ja chciatem powiedzieć, że to byt incydent $i$ nie wiem, kto dopuścit się tego, że użyt tych słów, ale przede wszystkim te osoby daty sie sprowokować, między innymi tutaj panu Walkiewiczowi, który, kiedy my czciliśmy pamięć polegtych minuta ciszy, podszedt i powiedziat „może ktoś przyjdzie tutaj ze mna podyskutować, o proszę bardzo” [rozmówca przytaczając, naśladuje arogancką, w jego odbiorze, intonację prowokatora].

(„Debata”, TVP 1, 16.12.2004; dziennikarz - PB: Piotr Baron; gość - JK: Jarosław Krajewski)

Dziennikarz przypomina hasło przeciwników („Pała na generała”), które poprzez swoją agresywną wymowę naruszyło konwencję debaty publicznej. Stawia to autorów hasła w złym świetle. Rozmówca stosuje strategie obrony twarzy pozytywnej, które polegają na:

- kategoryzacji uogólnionej, tj. nazwaniu wydarzenia „incydentem” (a nie np. skandalem),

- pomniejszaniu kompetencji, odwoływaniu się do niewiedzy (nie wiem, kto dopuścit się tego),

- strategicznym wykorzystaniu schematu bodziec - reakcja. Naganne zachowanie było odpowiedzią na wcześniejszą prowokację (te osoby dały się sprowokować).

Jak wynika z przytoczonych przykładów, rozmówcy wyczuwają dialogiczność mowy, rozumianą jako łańcuchowe powiązanie wypowiedzi-bodźców 
i wypowiedzi-reakcji. Są mniej lub bardziej świadomi tej zasady komunikacyjnej i wykorzystują ją strategicznie ${ }^{9}$ do polepszenia swojej pozycji dyskursywnej, np. w ramach strategii obrony twarzy pozytywnej.

Również w dopasowaniu strategii komunikacyjnych na różnych płaszczyznach (np. stylistycznej, retorycznej ${ }^{10}$ ) można dopatrywać się przejawów dialogiczności mowy. Korelacja wynika stąd, że kolejny rozmówca kieruje się w dokonywaniu wyborów ukształtowania wypowiedzi własnej - formą wypowiedzi poprzednika.

[Wypowiedź pierwsza] MZ: Oczywiście, problem leży zupetnie gdzie indziej. Problem leży nie $\underline{w}$ tym, że katolicy, zwtaszcza katolicy świeccy, maja jakieś poglądy polityczne $i$ te poglady wyra$\dot{z} a j a$. Problem leży raczej $w$ retoryce i $w$ tym, kto te poglady wygłasza, ponieważ troska Kościoła, $i$ tak rozumiem głos kardynata Glempa, jest pytanie, na ile skuteczne, na ile autentyczne jest nasze świadectwo o Jezusie Chrystusie, ponieważ Kościoła polityka nie interesuje. I teraz pytanie brzmi: czy to świadectwo jest autentyczne, chociażby wobec niewierzacych, kiedy jeden $z$ duchownych, bardzo znanych, popularnych $w$ Polsce, mówi, że ugrupowanie polityczne X należy zatopić.

[Wypowiedź druga, w której antagonista dopasowuje swoją strategię komunikacyjna] SM: Wydaje mi się, że problem nie polega na tym, na temat jakich ustaw się instytucje kościelne maja wypowiadać, czy nie. Problem nie polega na tym, czy Kościót się interesuje polityka, Stolica Apostolska utrzymuje ambasadorów, więc siła rzeczy się polityka interesuje, w zwiazku z tym nie jest to prawda po prostu, co panowie mówicie. Problem polega na autentyczności, na autentyczności zaangażowania politycznego.

(„Debata”, TVP 1, 11.01.2006; goście - MZ: Marek Zając, SM: Stanisław Michalkiewicz)

Dopasowanie strategii polega na różnym treściowo, ale analogicznym formalnie wykorzystaniu uporządkowania retorycznego typu problem/rozwiązanie. Reakcją na zarzut nieadekwatnego rozpoznania sytuacji dyskursywnej postawiony przez pierwszego rozmówcę (problem leży zupetnie gdzie indziej) jest podobnej rangi zarzut postawiony przez rozmówcę drugiego (Problem nie polega na tym). Rywalizacyjny charakter dyskusji sprawia, że w tego typu działaniach nie chodzi tylko o negocjowanie struktury retorycznej (ustalmy, na czym polega problem), ale celem jest również dyskredytacja komunikacyjna rozmówcy, podważanie jego kompetencji w zakresie rozpoznania ważnych etapów rozwoju dyskursu o charakterze problemowym.

${ }^{9}$ Strategiczność środka językowego to cecha polegająca na możliwości wykorzystania go do realizacji różnych celów.

10 Chodzi w tym wypadku o mechanizm dostosowawczy, taki jak w strategii ,wet za wet”. Jest to strategia z teorii gier, która zaleca: „na początku współpracuj, potem rób dokładnie to, co przeciwnik”. Dostosowanie nie jest, oczywiście, jedynym możliwym zachowaniem. Agata Małyska, która opisuje zależności między stosowanymi przez interlokutorów strategiami konwersacyjnymi a dokonywanymi przez nich wyborami stylowymi, odnotowuje przypadki zarówno dostosowania, jak i zmiany (Małyska 2006: 161-169). 
[Wypowiedź pierwsza] SM: Przepraszam. Jeżeli na przykład arcybiskup Życiński, czy arcybiskup Goctowski mówi, że kompromis osiagnięty w ramach ustawy aborcyjnej jest dobrym kompromisem, to wypowiada się na temat konkretnej ustawy, czy nie? No naprawdę, porzućmy trochę tę obtudna retorykę!

[Wypowiedź druga] KD: No tak, ale z drugiej strony, panie pośle, i panie redaktorze, jeśli $\underline{w}$ Radiu Maryja styszymy, że tej wtadzy warto powierzyć nasze wspólne pieniądze, czyli podatki, które co prawda w/ jako aparat przymusu, ale jednak sa/ dlatego, że ona będzie mądrzej i roztropniej te pieniadze dzieliła, tak jakby było zatożenie, że poprzednia nie dzielita madrze i roztropnie. No to, to jednak jest wyraźne opowiedzenie sie w sprawie czysto, czysto politycznej! [wysoki ton głosu, emocjonalna wypowiedź]

(„Debata”, TVP 1, 21.12.2005, dziennikarz - KD: Kamil Durczok; gość - SM: Stanisław Michalkiewicz)

Dziennikarz przyjmuje maskę polemisty i stosuje analogiczną strategię argumentacji do strategii poprzednika. Argument jest oparty na strukturze rzeczywistości, na związkach współistnienia. Rozmówca ustala więź „między rzeczywistościami różnych poziomów, z których jedna pokazana jest jako wyraz lub przejaw innej” (Perelman 2004: 106). Oba przykłady, różne treściowo, wskazują na jeden rodzaj powiązania: konkretna wypowiedź na określony temat jako przejaw działania politycznego. Reakcją na wypowiedź pierwszego rozmówcy, w której zarzuca on zaangażowanie jednych przedstawicieli Kościoła w politykę, jest wystosowanie analogicznego zarzutu pod adresem innych przedstawicieli Kościoła (to jednak jest wyraźne opowiedzenie się w sprawie czysto, czysto politycznej!).

Dialogowość można również rozumieć jako rodzaj struktury tekstu, która jest odzwierciedleniem sprzężenia zwrotnego między aktywnością nadawcy a aktywnością odbiorcy. Sprzężenie to można sobie wyobrazić jako rodzaj siły dośrodkowej, która koncentruje uwagę na bieżącej sytuacji komunikacyjnej (tu i teraz) i każe odnosić wypowiedzi do uczestników stojących naprzeciw siebie (ja, ty). Mówienie w sytuacji bezpośredniego kontaktu jest zawsze mówieniem do kogoś i z tego względu jest odbierane tak, jakby dotyczyło bieżącego układu interakcyjnego ${ }^{11}$. Jest to interpretacja prymarna, narzucająca się jako oczywista. Jeśli więc rozmówca chce, aby było inaczej, musi za pomocą komentarza metadyskursywnego odwołać to domniemanie.

KD: Panie profesorze, takie hipotetyczne założenie o pańskiej złej woli gdybyśmy przyjęli na chwile, może być?

PK: Proszę bardzo.

KD: Dobrze. Zatóżmy, że pan ma taka złą wolę. Gdyby się pan upart i zastosowat swoja ogromna, znakomita wiedzę prawnicza//

11 Prymarność bieżącego układu interakcyjnego w interpretacji niejawnych aktów mowy podkreślają Aleksy Awdiejew i Grażyna Habrajska. Twierdzą, że: „kiedy samo wypowiedzenie nie określa adresata, to należy przyjąć, że jest skierowane do TY uczestniczącego w układzie interakcyjnym" (Awdiejew, Habrajska 2006: 29). 
PK: Dziękuję bardzo ${ }^{12}$.

KD: -doprowadziłby pan do przedawnienia części zarzutów w procesie afery FOZZ-u, czy nie?

PK: Panie redaktorze, no mnie jest bardzo trudno wypowiadać sie, gdyż jak pan stusznie zauważyt, jestem jednym z obrońców w tej sprawie i ja akurat/ no, nie zdradzę żadnej tajemnicy, sytuacja moich klientów jest o tyle szczęśliwa, że przy najgorszym układzie ich czyny przedawniają się w dniu 30 kwietnia bieżącego roku, więc//

KD: A bo pan nie jest obrońca dwójki głównych oskarżonych, ale gdyby pan byt? Caty czas powiadam: budujemy model abstrakcyjny.

PK: [Aha, rozumiem.

KD: [-żeby doprowadzić do takiego katalogu chwytów na przedawnienie.

PK: Panie redaktorze, odpowiem panu w ten sposób i państwu wszystkim: obrońca powinien robić wszystko, co działa na korzyść oskarżonego, by wygrać w granicach dopuszczalnych przez prawo.

(„Debata”, TVP 1, 3.03.2005; dziennikarz - KD: Kamil Durczok; gość - PK: Piotr Kruszyński)

Dziennikarz kieruje pytanie ogólne (takie hipotetyczne założenie o pańskiej złej woli gdybyśmy przyjęli na chwilę), niedotyczące konkretnie rozmówcy, ale ten, mimo wyraźnych sygnałów, odnosi pytanie do siebie (mnie jest bardzo trudno wypowiadać się, gdyż [...] jestem jednym z obrońców). Rozmówca nie chce przyjąć roli, w jakiej stawia go dziennikarz, roli obiektywnego eksperta, ponieważ został uprzednio $\mathrm{w}$ bieżącej sytuacji komunikacyjnej przedstawiony jako obrońca w procesie FOZZ-u. Rola obrońcy jest elementem, który uzasadnia udział rozmówcy w programie i to przesądza o jej nadrzędności. Możliwa jest też bardziej skomplikowana interpretacja sekwencji, która jednak opiera się na strategicznym wykorzystaniu zasady dialogiczności. Dziennikarz stosuje strategię prowokacyjnego „podpuszczenia”: zadaje ogólne pytanie po to, żeby wydobyć poufne informacje i potem wykorzystać je przeciwko rozmówcy. Rozmówca natomiast rozpoznaje „podpuszczenie” i stosuje strategię uniku, zasłaniając się rolą obrońcy. Kategoria roli społecznej jest więc wykorzystana strategicznie do uchylenia się od odpowiedzi (wewnętrzne tajemnice profesjonalistów, tajemnica służbowa). Cecha dialogowości, rozumiana jako przemienność ról nadawcy i odbiorcy, jako interakcyjność - okazuje się ważnym regulatorem aktywności rozmówców oraz determinantem odbioru, rozumienia tekstu.

Konsekwencją dialogowości związanej ze strukturą interakcji, a polegającej na wymienności ról nadawczo-odbiorczych, jest tworzenie tekstu przez dwa podmioty lub kilka podmiotów (dialog i polilog). Strukturalną formę dialogu mogą przyjmować interakcje osób, które prezentują ten sam punkt widzenia. Takie dialogi są właściwie monologiem rozpisanym na głosy, czy też dwoma równoległymi, luźno powiązanymi monologami przeplatającymi się nawzajem. Zjawisko braku kooperacji zostało zauważone przez językoznawców i określone

12 Rozmówca odczytał intencję aktu mowy, jaką był komplement, o czym świadczy reakcja podziękowania. 
jako „mówienie w obecności Drugiego” (w odróżnieniu od dialogu sensu stricto, w którym dochodzi do wspólnego negocjowania znaczeń) (Loewe 2003: 124).

W odróżnieniu od tego dialogowość rozumiana jako ciągła zmiana perspektyw polega na negocjowaniu treści, intencji, co wynika z „ostrych zwrotów znaczeniowych” w replikach dialogu (Mukařovský 1970: 193). Jest to dialog sensu stricto, który wymaga specjalnej postawy wobec świata i rozmówcy, nacechowanej otwartością oraz szacunkiem. Zmiany kontekstu nie mają nic wspólnego z unikiem czy zmianą tematu, ale służą zwielokrotnieniu perspektyw oglądu problemu, poszerzeniu tematu o nowe aspekty, stanowią dla rozmówcy pozytywny bodziec do poszukiwania lepszych rozwiązań.

SN: Unia Europejska to także wielka zasługa, ale także nie samego prezydenta Kwaśniewskiego. Sa fatalne niektóre/ ja nie mówię o incydentach. Zostawmy to, może nie jest to dobry moment. Ale no na przykład wetowanie ustawy podatkowej. To byt wielki bład. Gdyby jej nie wetowat wtedy, $w$ czasach $A W S-u$, to dzisiaj bytyby podatki mniejsze. Wetowanie ustawy reprywatyzacyjnej ogromny błąd. No Polska nie ma/ jedyny kraj, który nie ma reprywatyzacji. Takich rzeczy może by się więcej dało wyciagnać, ale z drugiej strony rzeczywiście, to byta prezydentura taka koncyliacyjna. On nie prowokowat konfliktów, to nie byt prezydent, który się wyraźnie konfrontowat. I ja generalnie nie gtosowatem/ mam ten komfort//

$\mathrm{KD}$ : A pan, panie senatorze, jest autorem bardzo ostrego [sformutowania pod adresem pana prezydenta i jego ministra.

$\mathrm{SN}$ : [No tak, ale panie redaktorze, ja przepraszatem, przepraszatem no za to wiele razy. No nie wiem, czy mam za każdym razem o tym mówić. [...]

KD: [Pan senator Niesiotowski mówit o tym, że/l

$\mathrm{SN}$ : Już kończę. Ale to nie jest naprawdę/ nie zamyka mojej oceny to niestuszne powiedzenie. Ja bym podsumowat tak, że ta kadencja z cata pewnościa wymyka się jednoznacznym ocenom zarówno negatywnym, jak i pozytywnym.

KD: Ale jednocześnie pan powiedziat, że to byta prezydentura budowania kompromisów. Czy skłonności do szukania [kompromisów.

SN: [Tak, tak.

KD: Czy pańskim zdaniem, panie profesorze, [zwraca się do następnego rozmówcy] prezydent miat inne wyjście [niż budowanie kompromisu] po tym, jak/ zanim jesienia czy zima wtaściwie już '95 roku byt taki wynik wyborczy, wtaściwie niemal na pót się podzielita grupa, która wtedy poszła do wyborów, grupa wyborców?

(„Debata”, TVP 1, 21.12.2005; dziennikarz - KD: Kamil Durczok; gość - SN: Stefan Niesiołowski)

Dziennikarz z wielowątkowej i długiej wypowiedzi wybiera jeden wątek (kompromisowość) i przekazuje go do ustosunkowania następnemu rozmówcy. Przekazanie wątku wiąże się jednak ze zmianą perspektywy. Działanie dziennikarza należy rozpatrywać w kilku aspektach:

- nawiązanie do wypowiedzi zwiększa spójność tekstu dialogowego, a przypomnienie, parafrazowanie fragmentu pełni funkcję mnemotechniczną względem odbiorcy (por. strategie związane z sekwencyjnością tekstu ustnego),

- selekcjonowanie wątków jest związane z kierowaniem linią tematyczną, ponieważ wybór zawsze oznacza waloryzację ze względu na jakiś cel. W tym 
przykładzie chodzi o prowokację: skierowanie pytania z tezą do zwolennika prezydenta,

- podstawą prowokacji jest zmiana kontekstu i wartościowania, tak ważna dla interakcji dialogowych. Dziennikarz zmienia sens charakterystyki: z uwarunkowanej cechami indywidualnymi (prezydent był po prostu koncyliacyjny) na uwarunkowaną sytuacją zewnętrzną (musiał być koncyliacyjny w sytuacji, gdy wyborcy podzielili się na pół).

O strategiczności jego działania dodatkowo świadczy konsekwencja - po pierwszej nieudanej próbie dziennikarz podejmuje następną. Gdyby dziennikarz przekazał wątek w takiej postaci, jak wygłosił go S. Niesiołowski, czyli pochwałę wobec zwolennika prezydenta, to nie wniosłoby to nic nowego ponad potwierdzenie. Zostałaby dodana kolejna pochwała. Zmiana perspektywy połączona ze zmianą wartościowania zapewnia dynamiczny zwrot i zmierzenie się z nowym spojrzeniem (być może pochwała jest niezasłużona, bo cecha została wymuszona przez sytuację zewnętrzna). Zmiana perspektywy stanowi bodziec dla rozmówcy, który powinien głębiej i bardziej przekonująco odnieść się do opinii. Działanie dziennikarza w tym przypadku można również rozpatrywać jak budowanie superstruktury tekstu, ponieważ zakwestionowanie, podważenie jakiegokolwiek stwierdzenia w dyskusji zmienia jego ogólną kategorię z zaakceptowanej przesłanki na tezę. Powoduje, że przesłanka sama wymaga uzasadnienia, bo rozmówcy nie chcą jej w określonym momencie przyjąć jako oczywistej danej. Mamy wtedy do czynienia z argumentacją złożoną (Tokarz 2006: 138).

MS: [Nieee. Ja mówię, żebyśmy się kłócili o styl prezydentury. O styl prezydentury. Nie, ale proszę pana, jeżeli 80 procent Polaków popierato ta prezydenturę/ zwracam się do pani, bo pani powiedziała, że nie jest prezydentem wszystkich Polaków - nie da się być prezydentem 100 procent. Rzecz w tym, żeby przynajmniej starać się komunikować z większością i to chyba się udato prezydentowi Kwaśniewskiemu.

(„Debata”, TVP 1, 21.12.2005; gość - MS: Marek Siwiec)

Rozmówca przypomina opinię, która została wygłoszona kilka minut wcześniej i umieszcza ją w nowym kontekście: kontekście normy dyskursu politycznego (nie da się być prezydentem 100 procent). Jak widać, ze strukturą polilogową tekstu związane są wyrażenia służące nawiązaniu kontaktu, poprzez wyróżnienie jednej osoby z większej grupy. Przypomnienie fragmentu wypowiedzi, z którą zamierza się polemizować, to wyróżnianie relewantnego w danym momencie kontekstu słownego, do którego nadawca zamierza się odnieść.

Szeroko rozumiana dialogiczność mowy, jak również dialogowa forma wypowiedzi, która jest związana na trwałe z odmianą mówioną języka, stanowią istotne determinanty zachowań komunikacyjnych. Rozmówcy postrzegają (mniej lub bardziej świadomie) swoje działania językowe jako wynik innych działań, dostosowują strategie komunikacyjne do strategii poprzednika (np. odpowiadają dyskredytacją na dyskredytację czy oskarżeniem na oskarżenie). 
Dynamika dialogu, a zwłaszcza dyskusji, wymaga od uczestników ciągłej zmiany perspektyw i współpracy w negocjowaniu znaczeń, co stanowi cel interwencji organizacyjnych prowadzącego (konfrontowanie rozmówców o różnych poglądach, przekazywanie kontrowersyjnych opinii stronie przeciwnej). Sytuacja komunikacji bezpośredniej stanowi również wskazówkę interpretacyjną, która prymarnie nakazuje odnosić wypowiedzi do tejże sytuacji (ja, ty, tu, teraz), a nie do obiektów spoza niej.

\subsection{Uwarunkowania wynikające z sytuacyjności}

Sytuacja komunikacyjna może być rozumiana jako fizyczne otoczenie wypowiedzi1 ${ }^{13}$, na które składa się miejsce, czas, uczestnicy i sposób przekazu. W przypadku tekstów mówionych, które rozwijają się w czasie jako dynamiczna interakcja, można obserwować wpływ pewnych elementów otoczenia na tworzenie tekstu. Jest to jeden z przejawów sytuacyjności, stanowiący typową ${ }^{14}$ cechę tekstów mówionych (Boniecka 1999: 49-81; Bartmiński, Niebrzegowska-Bartmińska 2009: 102-104; Warchala 2003: 81-102). Sytuacyjność skutkuje redukcją tych elementów werbalnych, które stają się oczywiste w zestawieniu z sytuacją. Wypowiedzi ustne są często tak stowarzyszone z sytuacją, że stanowią „synkretyczną całość sytuacyjno-przedmiotowo-werbalną” (Bartmiński, Niebrzegowska-Bartmińska 2009: 102). Należy to rozumieć jako ścisłe zintegrowanie sytuacji i słowa, w wyniku czego nie nazywa się charakteryzowanych elementów sytuacji, zakładając, że są znane. Wypowiedzi tego typu poza sytuacją są zupełnie niezrozumiałe ${ }^{15}$.

Rozmówcy, tworząc wypowiedź, mogą obserwować otoczenie, zwłaszcza zachowanie publiczności, przeciwników, po to, aby uczynić je tematem

13 Według Urszuli Żydek-Bednarczuk sytuacja stanowi ramę zewnętrzną dla tekstu, w której można wyróżnić trzy pola. Fizyczne otoczenie wchodzi w zakres tła wypowiedzi. Oprócz tego autorka wyróżnia uwarunkowania społeczne i instytucji oraz uwarunkowania (tło) kulturowe (Żydek-Bednarczuk 2005: 231).

${ }^{14}$ Udziałem sytuacji w rozumieniu tekstu pisanego zajmuje się m.in. Ewa Miczka w artykule Sytuacja - tekst - rozumienie tekstu. Stwierdza, że jakkolwiek sytuacja wypowiedzi jest odnoszona do przekazu ustnego, to przy zmianie parametrów sytuacji można ją również odnieść do tekstu pisanego. Istotne będzie wówczas źródło informacji kontekstualnych, które tworzą: sytuacja wypowiedzi (lokalizacja tekstu, aspekt wizualny tekstu), otoczenie językowe oraz wiedza o świecie odbiorcy (Miczka 1996: 113-126).

15 Używamy sformułowania „zupełnie niezrozumiałe”, mając na myśli brak jasnego odniesienia referencjalnego (sytuacja rozumiana jako kolekcja wspólnych referencji). W sensie ogólniejszym sytuacja zawsze warunkuje zrozumienie, gdyż określa zespół wspólnych odniesień kulturowo-społecznych: „Sytuacja jest sensotwórcza, tzn. nadaje (wyznacza) sens znaczeniom, które są potencjalne, dopóki nie zostaną umieszczone w sytuacji [...]. Sens wyrażenia jest rozpoznawany dopiero po zdefiniowaniu sytuacji, która znaczenie uaktualnia i przetwarza w sens [...]" (Warchala 2003: 85). 
wypowiedzi lub nawet całej sekwencji. Jacek Warchala twierdzi, że: „Sytuacja jest tematyzowana czy - precyzyjniej mówiąc - tematyzowane są jej wybrane i wzajemnie zatwierdzone elementy, gdy sytuacja «otacza» rozmawiających, co należy rozumieć tak, że w najbliższym fizycznym otoczeniu znajdują się referenty ad oculos, tematyzowane następnie w wypowiedziach" (Warchala 2003: 91). Relatywizację sytuacji do nadawcy i odbiorcy podkreśla wyraźnie Urszula Żydek-Bednarczuk: „[...] sytuację trzeba zawsze rozpatrywać z punktu widzenia interlokutorów w danym miejscu i czasie. Należą więc do sytuacji te fakty, które są relewantne dla komunikacji i jednocześnie właśnie one zostały wybrane i właściwie zinterpretowane w trakcie procesu tworzenia tekstu” (Żydek-Bednarczuk 2005: 231).

W analizowanych interakcjach sytuacyjność staje się najbardziej widoczna wtedy, kiedy rozmówcy spontanicznie przerywają swój wywód, aby zareagować na zachowanie publiczności bądź przeciwnika. Dochodzi wówczas do utekstowienia tego, co dzieje się w trakcie interakcji. Badamy, jak elementy sytuacji danej „tu i teraz” przenikają do wypowiedzi jako treści informacyjne, a więc jak otoczenie komunikacyjne staje się źródłem tematu. Można jednocześnie dostrzec taktyczne wykorzystanie tych elementów dla osiągnięcia różnych celów komunikacyjnych.

KD: Ale taka sytuacja powstałaby wtedy, gdyby zostały ujawnione te materiaty, o których mówiliśmy [teczki SB]?

KK: Dobrze, tylko jeżeli na jednej liście postawimy tego nieszczęsnego Malinowskiego, prawda, czy żeby już użyćl dobrze, mówmy już o nazwiskach, przerażona, zaszantażowana Niezabitowska [śmiech na widowni po stronie zwolenników ujawnienia teczek] 15 grudnia '85 roku. Taaak, taaak!

$\mathrm{KD}:$ A z czego panowie się śmieją? [z poirytowaniem]

KK: Tak, tak proszę panów. Gdybyście raz w życiu wpadli//

$\mathrm{KD}$ : Umiejętność stuchania jest bardzo cenna umiejętnościa, której nam w życiu publicznym mocno brakuje. Jak by panowie zechcieli jej nabyć, to bytbym ogromnie zobowiazany.

KK: Gdybyście raz wykazali sie prawdziwa odwaga, to moglibyście sie potem śmiać z innych. Otóż stawianie Niezabitowskiej z kapitanem Piotrowskim w jednej liście rzuconej do Internetu jest niemoralne. [...]

(„Debata”, TVP 1, 20.01.2005; dziennikarz - KD: Kamil Durczok; gość - KK: Krzysztof Kozłowski)

Zachowanie niewerbalne publiczności (śmiech po stronie zwolenników ujawnienia akt SB) staje się spontanicznie tematem kilku wymian. Rozmówca reaguje emocjonalnie, odmawia publiczności prawa do komentowania wydarzeń, w których nie uczestniczyła (jest to przejaw racjonalności potocznej). Dziennikarz natomiast odbiera zachowanie jako naruszenie standardów sytuacji dyskusji i realizuje na tej podstawie cel edukacji społecznej. Tego typu działania dziennikarzy są związane z edukacyjną misją mediów publicznych, które powinny kształtować dobre wzory uczestnictwa w debacie publicznej. 
KD: Jest pan pewien, że to, co zostanie ujawnione, nie będzie stużyto do walki politycznej?

ZF: Tylko $w$ ten sposób przestanie.

$\mathrm{KD}:$ A może dopiero wtedy się rozpocznie?

ZF: Jak, panie redaktorze? Do tej pory sa wtajemniczeni mniej, bardziej, ja trochę czytatem, pan profesor $z$ racji tego, gdzie jest - więcej. [...]

KD: Ja panu powiem, jak. Dat mi do myślenia śmiech moich gości na widowni, dlatego, że ten sam fakt, o którym pan minister Kozłowski mówi jako o dramacie kobiety tamanej przez SB, przez kogoś zostaje odebrany jako ponury żart: „To musiata być wspótpraca” - brzmi konkluzja, prawda? Myśli pan, że nie będzie w życiu politycznym takich sporów? Że te same dokumenty nie będa czytane $w$ tę albo we $w$ tę?

(„Debata”, TVP 1, 20.01.2005; dziennikarz - KD: Kamil Durczok; gość - ZF: Zbigniew Fijak)

W kolejnym fragmencie debaty o teczkach dziennikarz przyjmuje rolę polemisty i wchodzi w spór z rozmówcą. Skutecznie włącza zachowanie komunikacyjne jako argument na poparcie swojego stanowiska. Śmiech gości na widowni ma być przesłanką w uzasadnieniu tezy, że ujawnienie teczek nie przyniesie prostej prawdy, ale spowoduje różne reakcje, rozpięte między podejściem dramatycznym a szyderczym. Tak więc mamy tu do czynienia z funkcjonalizowaniem elementów sytuacji tak, aby uczynić z nich środek do realizacji własnych celów komunikacyjnych. Podobnie w następnym przykładzie.

KD: I tu dotykamy tematu, o którym dowiedzieliśmy się kilka tygodni temu, czyli śledztwa $w$ sprawie stanu wojennego, prowadzonego przez katowicki oddziat Instytutu Pamięci Narodowej. I zastanawiam się, czy dla panów, dla pana Jana Lityńskiego, dla pana profesora i dla panów - to jest dopetnienie sprawiedliwości, czy to jest działanie polityczne?

AP: No, wedtug mnie jest to pewna konsekwencja tego, że parlament tej sprawy nie rozstrzygnat tak jak//

KD: Rozstrzygnat. Umorzyt, panie profesorze. Jak to nie rozstrzygnat?

LK: Prawomocnie.

AP: Prawomocnie rozstrzygnąt. Oczywiście, ale nie kończy to sporu//

JW: Nie po pana myśli, ale rozstrzygnąt.

AP: Nie kończy to sporu, czego jesteśmy świadkami, prawda. [wskazuje na publiczność, nawiązując do gorących sporów toczonych przed momentem] [...] Mogę tylko ubolewać, że tak powiem, nad swoim losem, nie jest to może zbyt dobre pociagnięcie wobec opinii, że tadnych pare lat zajęto mi zbieranie dokumentów, analizowanie tego, napisanie ksiażki. Ta ksiaż̇ka się ukazała trzy lata temu. I wtaściwie po obu stronach/ wtaściwie nie widze jakby śladów mojej argumentacji i zebranych tam dokumentów. A na iks różnych okrzyków tutaj, które padaty, o których mówitem, z lewej strony, po prostu w tej ksiażce sa dokumenty przytoczone [...].

(„Debata”, TVP 1, 20.01.2005; dziennikarz - KD: Kamil Durczok; goście - AP: Andrzej Paczkowski, JW: Jerzy Wiatr, LK: Leszek Kubicki)

Rozmówca dwukrotnie włącza do swojego wywodu zachowanie publiczności. Raz na poparcie tezy, że ocena stanu wojennego wciąż budzi emocje i przez to nie jest zamknięta, a następnie jako potwierdzenie ignorancji przynajmniej części społeczeństwa, nieprzekładalności badań naukowych na społeczne wyobrażenia. W nazwaniu aktywności komunikacyjnej „okrzykami” (na iks 
różnych okrzyków) można dopatrywać się dyskredytacji komunikacyjnej zachowań strony przeciwnej. Jest to dyskredytowanie zachowań jako nieodpowiadających regułom dyskusji. Tego typu dyskredytacje mają charakter dominacyjny i zmierzają do wyeliminowania przeciwnika na podstawie braku kompetencji komunikacyjnych, nawet bez potrzeby zagłębiania się w jego poglądy. Jeszcze wyraźniej strategia ta jest widoczna w poniższym przykładzie.

JW: [...] W końcu generat Kiszczak zostat skazany. Prawda, że//

G: Ale na ile?

JW: Nie o to chodzi, na ile. Chodzi o to, że zostat skazany. Apeluje od tego wyroku, przy czym nikt tu nie udowodnit, ani nawet nie zarzucit wydania rozkazu strzelania, bo nie taki byt zamiar.

G: My też nie udowodnimy//

JW: Jeżeli pan/ jak pan się nauczy kulturalnie dyskutować, to może będziemy mogli dyskutować, jeżeli pan tego nie umie, to niech pan siedzi cicho! [gwar, oklaski]

(„Debata”, TVP 1, 16.12.2004; goście - G: gość z publiczności, JW: Jerzy Wiatr)

Jerzy Wiatr początkowo podejmuje dyskusję z oponentem, ale potem zmienia strategię na metadyskursywną i dyskredytuje go w obcesowy sposób z racji rzekomego braku kompetencji komunikacyjnych. Sposób, w jaki to czyni (niech pan siedzi cicho!) okazuje się przeciwskuteczną autoprezentacją, która budzi odpowiednią reakcję publiczności.

TC: [...] Ja bym powiedziat, że polskie media i świat mediów jest bardzo wyraźnie przechylony na stronę bardzo liberalna. Mało jest treści narodowych, katolickich. Może nawet/ [śmiech części widowni] Ja gratuluję dobrego humoru młodym socjalistom. Tak, ja tutaj nie mam nic napisane [rozchyla marynarkę], ale zachęcatbym, żeby sie tė̇ otworzyć, bo ja z przyjemnościa postucham innych racji. Natomiast przyszłość należy do dialogu, a nie do pośmiewiska. Proszę pamiętać. Ja bardzo szanuję poglądy różne, ale trzeba/ o tym mówimy, mówimy tu o tolerancji. Nie musimy akceptować tego radia, ale powinniśmy tolerować. Natomiast ocena Kościoła $w$ sprawach dotyczących kwestii kościelnych [kamera pokazuje antagonistów, którzy się już nie śmieją, są ubrani w koszulki z napisem Młodzi Socjaliści] to jest jedna ocena i ona dotyczy procedur. To, co jest $w$ informacji, bo to nie tyle ostrzeżenie, co informacja, przypomnienie, jakie prawa, jakie obowiazki dotycza ludzi Kościoła, którzy funkcjonują na przykład na niwie mediów//

(„Debata”, TVP 1, 11.01.2006; gość - TC: Tadeusz Cymański)

Grupa z publiczności reaguje śmiechem na fragment wypowiedzi polityka. Ten przerywa wywód i komentuje jej zachowanie. Wyśmianie kogoś stanowi sytuację zagrożenia jego twarzy pozytywnej, stąd rozmówca podejmuje strategię obrony twarzy:

- stosuje ironię (gratuluję dobrego humoru),

- sugeruje brak kompetencji komunikacyjnych przeciwnika (nieprzyjmowanie argumentów, brak dialogu),

- wzmacnia swoją pozycję poprzez odniesienie krytyki nie do siebie, ale do instytucji. Można to nazwać przekierowaniem odniesienia, zmianą adresata. Socjaliści śmiali się z polityka, tymczasem on stara się wywołać wrażenie, że 
chodziło o nietolerowanie Radia Maryja (Nie musimy akceptować tego radia, ale powinniśmy je tolerować). Konieczność doraźnego zneutralizowania niekorzystnej sytuacji wyraźnie jednak rozstraja polityka, o czym świadczy mało spójna i słabo powiązana z kontekstem jego dalsza wypowiedź. Z racji ostrych starć w dyskursie politycznym umiejętność „rozbrajania” sytuacji tego typu, reagowania na niespodziewane akty zagrożenia twarzy, okazuje się ważnym składnikiem kompetencji komunikacyjnej polityka.

SN: [...] Jeszcze przy okazji, mnie zdumiewa agresja z tej strony, jakaś niepojęta agresja do ofiar. Jeżeli ja się dowiaduję, że śpiewa się „Szła dzieweczka do laseczka”, że/ i to, co pani tutaj zaprezentowata, jakieś komunistyczne, [w tle gwar protestu] zwietrzałe mity o agresji Solidarności. jakichś listach, jeżeli to się dzisiaj powtarza, to rzeczywiście debata na takim poziomie/ prosze państwa, [gwar, głośne rozmowy w tle]) no, nawet nie umiecie wystuchać, no debata na takim poziomie/ ktoś tu powiedziat, że nie ma sensu, ja się z tym/

(„Debata”, TVP 1, 16.12.2004; gość - SN: Stefan Niesiołowski)

Rozmówca określa opinię przeciwnika w dyskusji jako komunistyczne zwietrzałe mity, a gwar protestu przeciwko swojemu zachowaniu komentuje jako brak kompetencji komunikacyjnych (nie umiecie wystuchać, debata na takim poziomie nie ma sensu). Przy relacjonowaniu zdarzeń z pikiety przed domem generała Jaruzelskiego uczestnik odnosi zachowanie protestujących do ofiar stanu wojennego, a nie do prowadzących pikietę. Relację taką należy przyjąć jako nieneutralną interpretację zdarzenia, która ma służyć polepszeniu pozycji dyskursywnej jednej strony i dyskredytacji drugiej strony.

$\mathrm{SN}$ : [...] no, poziom agresji ciagle kierowany do ludzi, którzy walczyli w końcu o wolna Polskę, o to, żeby bez cenzury w wolnym państwie mogła się toczyć taka dyskusja - poziom agresji dla mnie jest niepojęty.

KD: Pan profesor Wiatr.

JW: Ja myślę, że ten poziom agresji, jak tutaj widzimy, no, nie jest tylko z tej strony.

$\mathrm{SN}$ : Ale większy jest z tej.

JW: Nie wiem, nie wiem, bo ja przed chwila styszatem tego pana, który mówit: „Mam nadzieję, że będziecie siedzieli $w$ więzieniu" ${ }^{16}$. No więc jeżeli to nie jest poziom agresji, to/ Ale wróćmy do meritum.

(„Debata”, TVP 1, 16.12.2004; dziennikarz - KD: Kamil Durczok; goście - JW: Jerzy Wiatr, SN: Stefan Niesiołowski)

Okazuje się, że sytuacja komunikacyjna, wprawdzie dostępna jednakowo wszystkim uczestnikom, nie jest przez nich jednakowo odbierana. Jest to najdobitniejszy przykład na kreowanie sytuacji w studiu przez każdą ze stron konfliktu i na użytek własnej argumentacji. Każdy z rozmówców włącza zachowanie

16 Tej wypowiedzi nie wychwycił mikrofon studyjny, nie usłyszeli jej zatem odbiorcy telewizyjni. Fakt ten potwierdza rozbieżność między mikrosytuacją w studiu, a przekazem medialnym, w którym to nadawca decyduje o zakresie przekazywanych treści. 
publiczności jako argument na poparcie swojej tezy o agresywności przeciwnika. S. Niesiołowski podkreśla agresję w stosunku do swojej grupy, J. Wiatr to neguje (ten poziom agresji jak tutaj widzimy, no, nie jest tylko $z$ tej strony) i pokazuje, że i on (oni, komuniści) też są obiektem agresji (Mam nadzieję, że będziecie siedzieli $w$ więzieniu). W wypowiedziach argumentacyjnych wszystkie elementy sytuacji wprowadzane do wypowiedzi są podporządkowane czynności argumentacji. Dzieje się tak poprzez nakładanie na elementy wprowadzane - funkcji retorycznych, najczęściej przesłanek na poparcie odpowiednich tez.

W sumie sytuacyjność tekstów ustnych w debacie jest dużo bardziej sfunkcjonalizowana, niż sytuacyjność tekstów potocznych. Goście komentują nawzajem swoje zachowania w sposób tendencyjny, zaś ich zachowanie komentuje publiczność zgromadzona w studiu. Kreowanie sytuacji w studiu służy obronie twarzy, wzmocnieniu własnej pozycji dyskursywnej, zdobyciu dominacji nad przeciwnikiem, a nawet symbolicznej eliminacji przeciwnika z przestrzeni interakcyjnej.

Ustność tekstu jest zatem ważnym determinantem zachowań uczestników komunikacji bezpośredniej. Wpływa zarówno na organizację tekstu jako sekwencji wymian w mikrosytuacji, jak i organizację spójnego oraz całościowego przekazu kierowanego do widza w makrosytuacji. Ulotność mowy, jej linearność zwiększa częstotliwość stosowania strategii metatekstowych, a więc działań, które porządkują przestrzeń komunikacji. Mają one charakter retrospektywno-prospektywny i polegają na przywoływaniu tych fragmentów, do których rozmówca zamierza się odnieść; wprowadzają podsumowanie bądź zapowiedź planowanych czynności komunikacyjnych. Nadawca wspomaga integrację tekstu, podejmując dodatkowo strategie metadyskursywne, które odnoszą się do kontekstu komunikacyjnego, np. intencji nadawcy, odbiorcy, obowiązujących w danym typie dyskursu wzorów działań językowych. Osadzenie tekstu w wyraźnie zdefiniowanej sytuacji, jasne określenie intencji i celów jest bowiem czynnikiem budującym sens wypowiedzi. Ustność realizacji tekstu wiąże się z dialogowością, która eksponuje dynamikę w rozwoju zdarzeń komunikacyjnych, w tym współzależność reakcji językowej od akcji rozpatrywanej w kategoriach przyczynowych, dopasowanie strategii komunikacyjnych, ciągłą zmianę perspektyw w ujmowaniu tematu. Dialogowość komunikacji bezpośredniej to jednocześnie dynamika współtworzonej przez rozmówców sytuacji, w której wszelkie działania komunikacyjne są interpretowane funkcjonalnie i wykorzystywane do realizacji partykularnych celów. 


\section{Część II}

\section{STRATEgie W PROGRAMIE „Debata”}

W części drugiej przedmiotem badań będą strategie rozpatrywane w aspekcie tekstu. Uwagę skierowano na działania związane $\mathrm{z}$ organizacją wybranego programu (strategie strukturalne), a w ich obrębie - na kształtowanie tekstu jako spójnej, całościowej struktury (strategie tekstotwórcze). Formuła cyklicznego programu, który został wybrany do analizy, odznaczała się wystarczającą regularnością, zróżnicowaniem uczestników i stosunkowo dużym udziałem dziennikarzy w kreowaniu sytuacji zgodnie z wymogami dyskursu medialnego.

„Debata” była programem publicystycznym wyróżniającym się aktywnym udziałem publiczności. Już sam podział przestrzeni w studiu był znaczący. Uczestnicy zostali rozmieszczeni w okręgu i podzieleni na dwie główne grupy: gości i publiczność. Goście to przedstawiciele elit symbolicznych: publicyści, dziennikarze, twórcy kultury, duchowni, naukowcy, eksperci, intelektualiści, politycy. Rodzaj uczestnictwa w programie wynika z roli społecznej elit symbolicznych. Janina Fras, powołując się na P. Bourdieu i T. A. van Dijka, określa ją jako ustalanie hierarchii spraw ważnych i nieważnych, publicznie prawomocnych hierarchii wartości moralnych i estetycznych, wzorców recepcji prawd naukowych (Fras 2005: 38). Publiczność natomiast występuje w programie jako reprezentacja obywateli, którzy są nieprofesjonalnymi i nieinstytucjonalnymi uczestnikami komunikacji publicznej. Obywatele mogą być stowarzyszeni w różnych organizacjach społecznych, ich uczestnictwo uzasadnia również bycie świadkiem lub uczestnikiem wydarzeń, a przede wszystkim zainteresowanie kwestiami publicznymi i wyrobione zdanie na ich temat. Ważnym sygnałem gatunkowym debaty jest to, że publiczność jest podzielona na dwie podgrupy, które można nazwać proponentami i oponentami (lub zamiennie: zwolennikami i przeciwnikami, krytykami i obrońcami, protagonistami i antagonistami).

Tego rodzaju uporządkowanie interakcji znajduje odzwierciedlenie w definicji gatunku. Debata to taki rodzaj dyskusji, która ma charakter publiczny i jest prowadzona zgodnie $\mathrm{z}$ formalnymi procedurami. W typowej debacie, jaką jest debata parlamentarna, debata przedwyborcza, biorą udział dwie strony zajmujące przeciwne stanowiska, reprezentowane przez pojedyncze osoby lub kilkuosobowe drużyny (Szymanek 2004: 92).

Tytuł „Debata” jest charakterystyczny ze względu na połączenie funkcji nominacyjnej oraz perswazyjnej. Sprawia to podwójne odniesienie tytułu: po pierwsze, 
do jednostkowego widowiska i, po drugie, pośrednio - do cyklu widowisk oraz do rzeczywistości generycznej typologii tekstów. Pierwsza funkcja, nominacyjna, jest dla tytułu obligatoryjna. W funkcji perswazyjnej ujawnia się zamiar nadawcy instytucjonalnego, który zawarł w tytule kwalifikację generyczną widowiska, będącą jednocześnie ważną wskazówką interpretacyjną. To, czy mamy w przypadku „Debaty” do czynienia z prostą kwalifikacją generyczną przekazu, czy jedynie z indeksalizacją gatunku w tytule bez wypełnienia cech wzorca debaty w konkretnym przekazie, stanowi ważne pytanie, które wytycza kierunek dalszych analiz.

Stałe miejsce $\mathrm{w}$ ofercie programowej wiązało się $\mathrm{z}$ wypracowaniem konwencji przekazu, która z jednej strony kształtowała nastawienia widza, $\mathrm{z}$ drugiej - umożliwiała optymalny odbiór. Formuła programu zawierała elementy stałe i zmienne:

- metatekst jako element ramy widowiska i ramy dyskusji oraz paratekst ${ }^{1}$ jako element poprzedzający widowisko lub poprzedzający dyskusję zasadniczą; element stały to wprowadzenie wygłaszane przez dziennikarza głównego i, fakultatywnie, poprzedzająca je zapowiedź dziennikarza pomocniczego lub krótki, zapowiedni felieton filmowy; fakultatywnie, zapowiedź dziennikarza głównego przed czołówką (por. punkt 6.1),

- rozmowa publiczna, dyskusja jako główny element widowiska: element stały to rozmowa dziennikarza z gośćmi (por. punkt 6.3), element fakultatywny to dyskusja typu forum z udziałem publiczności (por. punkt 6.2); publiczność była obecna prawie we wszystkich programach; różnice dotyczyły sposobu jej włączania: rozmowa z publicznością mogła stanowić osobny segment lub mogły być włączane pojedyncze wypowiedzi; niezależnie od tego publiczność dodatkowo reagowała niewerbalnie (np. oklaskami, śmiechem, buczeniem).

W trakcie ponad półtorarocznej emisji formuła programu ulegała zmianom:

- w początkowych programach (od września 2004 do lutego 2005 r.) pojawiało się dwóch dziennikarzy, z których jeden (Kamil Durczok - skrót: KD) był głównym prowadzącym, a drugi (Piotr Baron - skrót: PB) pełnił funkcję pomocniczą. Od marca 2005 r. program prowadził tylko dziennikarz główny,

- w drugim sezonie emisji (od września 2005 r.), najpierw nieobligatoryjnie, potem jako stały element, pojawiły się na początku (lub wyjątkowo w środku) krótkie felietony filmowe,

${ }^{1}$ Paratekst to termin wprowadzany dla nazwania tekstów okalających tekst główny (otoka tekstu). Do paratekstu należą np. tytuł, podtytuł, śródtytuł, przedmowy, posłowia, wstępy, ilustracje (por. Genette 1992). Paratekst wiąże tekst główny z kontekstem. Można więc zaliczyć go do sygnałów orientacyjnych, które sugerują kierunek interpretacji tekstu (Duszak 1998: 127). Przyjmujemy, że paratekst jest pojęciem głównie strukturalnym i jako taki nie koliduje z pojęciem metatekstu, które zostało wyodrębnione ze względu na odniesienie - metatekst odnosi się nie do rzeczywistości pozajęzykowej, ale do samego tekstu. I. Loewe rozgranicza jednak paratekst od metatekstu, m.in. w oparciu o kryteria braku symultaniczności odbioru paratekstu i tekstu głównego, braku jedności nadawcy paratekstu i tekstu głównego (Loewe 2007: 73). 
- w większości programów (zwłaszcza na tematy społeczne) czynnie uczestniczyła publiczność. Uczestnictwo publiczności nie tylko jako grupy reagującej niewerbalnie, ale jako zbioru podmiotów reprezentujących organizacje społeczne, rozmaite stowarzyszenia, była znakiem rozpoznawczym programu; publiczność była dopuszczana do głosu w pierwszej lub środkowej części dyskusji (nigdy na końcu) jako głos opinii publicznej². Zmiany w formule programu były wyrazem procesów ogólnokulturowych. Dodanie felietonu filmowego można uznać za strategię nadawczo-odbiorczą zwiększającą atrakcyjność przekazu.

${ }^{2}$ Od grudnia 2005 r., obok emisji w TVP 1, program był równolegle emitowany na stronach telewizji interaktywnej iTVP. W niniejszej pracy nie zajmujemy się emisją w Internecie. 



\section{RozDZiAe 5 \\ Ogólne techniki budowania struktury tekstu - strategie tekstotwórcze}

Budowanie struktury tekstu polegające na jego całościowej organizacji jest ważnym zadaniem dziennikarza, które warunkuje spójny odbiór zdarzenia komunikacyjnego przez widzów. Zadanie to - w sytuacji wielości rozmówców o często różnych celach komunikacyjnych - stanowi sprawdzian profesjonalnych umiejętności prowadzącego. Jego aktywne działania zmierzające do integracji wypowiedzi kolejnych rozmówców w sensowną całość mają charakter tekstotwórczy. Również rozmówcy, w różnym stopniu i w zależności od poziomu kompetencji komunikacyjnych, starają się realizować tego typu działania. Integracja tekstu polega na wzajemnym nawiązywaniu do wypowiedzi, reagowaniu na nie, nazywaniu i komentowaniu zachowań mownych swoich oraz partnera, rozwijaniu wątków tematycznych podjętych przez partnera, parafrazowaniu jego wypowiedzi, wskazywaniu tła pozajęzykowego, które motywuje działania komunikacyjne. Efektywność działań integrujących oraz wynikająca stąd gęstość wzajemnych odniesień między elementami tekstu zwiększa jego spójność, a więc i poziom sensowności.

Budowanie koherentnej struktury tekstu to tworzenie systemu wzajemnych odniesień, relacji pomiędzy jego elementami na poziomie gramatycznym, semantycznym i pragmatycznym. Bez powiązań formalnych i zbudowania sensów pozwalających łączyć fragmenty tekstu nie można mówić o spójności (Żydek-Bednarczuk 2005: 75). Zasadnicze działania „uspójniające”, które są podejmowane przez dziennikarza w ramach budowania struktury globalnej tekstu, należą do poziomu spójności wynikającej z jego kompozycji. Urszula Żydek-Bednarczuk stwierdza jednak, że między typami spójności zachodzi kontinuum (Żydek-Bednarczuk 2005: 87), a więc na spójność kompozycyjną mają wpływ także inne typy spójności, takie jak: spójność pragmatyczna, spójność semantyczno-tematyczna i spójność strukturalna.

O ile w momencie powstawania tekstu dialogowego podstawowym zadaniem jego twórców jest integracja pojedynczych wypowiedzi w spójną całość, o tyle odbiór tekstu przez widza wiąże się również z koniecznością wyodrębnienia określonych części i przypisania im funkcji. Korelacja tych dwóch czynności, czyli integracji tekstu przez jego twórców i delimitacji przez odbiorców 
medialnych, jest tak ścisła, że procesy nadawania i odbioru stanowią dopełniającą się całość, a wskaźniki budowania koherentnej struktury są jednocześnie sygnałami rozczłonkowania.

Budowanie struktury tekstu jest procesem dynamicznym, który dokonuje się $\mathrm{w}$ trakcie przebiegu zdarzenia komunikacyjnego. Wobec tego zasadne wydaje się wyodrębnienie w tym zakresie technik według kryterium kierunku odniesienia tekstowego. Podstawowe sposoby łączenia pojedynczych wypowiedzi w większe sekwencje (np. ze względu na skład uczestników, zawartość treściową, funkcję retoryczną) to działania o charakterze prospektywnym i retrospektywnym.

\subsection{Działania o charakterze prospektywnym}

Działania o charakterze prospektywnym polegają na zapowiadaniu określonej części interakcji i zachęcaniu do jej wysłuchania. Zapowiedziom towarzyszy charakterystyka elementu, np. ze względu na rodzaj uczestników. Zapowiedziana może być zarówno grupa (publiczność, goście), jak i konkretna osoba pochodząca z tej grupy. Rozpatrzmy przykłady.

KD: Chciatbym, żebyśmy postuchali tego, co mają do powiedzenia dziś nasi goście.

KD: Przepraszam, ale tu sie toczy dyskusja [uwaga skierowana do publiczności, która stara się włączyć w dyskusję z gośćmi]. Pan profesor Natęcz.

KD: Panowie, ale dajcie teraz pozwolić odpowiedzieć [do publiczności]. Stuchamy dyskusji $\underline{w}$ tej części.

Dziennikarz, kierując debatą, zapowiada segment z udziałem gości oraz dyscyplinuje publiczność, która chce brać udział w dyskusji w sposób ciągły. Tymczasem organizatorzy wyraźnie oddzielają segmenty ze względu na rodzaj rozmówców (goście a publiczność). O tożsamości segmentu wydzielonego ze względu na rodzaj rozmówców w równym stopniu świadczą zarówno zapowiedzi włączające ten segment w strukturę debaty, jak i odrzucanie zachowań dezintegrujących zaplanowany układ.

KD: Jeśli panowie pozwola [do gości], ja bym chciat jeszcze zapytać tych, którzy, jak rozumiem, w części stuchaja Radia Maryja, w każdym razie maja na jego temat swoja wyraźna $i$ zdecydowana opinię. My styszeliśmy: fundamentalizm, niebezpiecznie, porzadnie, ewangelizacja - duży zbiór rozmaitych pojęć. A dla państwa [do publiczności] czym jest to radio? Dla pani?

(11.01.2006)

Dziennikarz podejmuje szereg czynności tekstotwórczych: nie tylko zapowiada segment z publicznością, ale również budzi oczekiwania odbiorców co 
do charakteru rozmówców (mają zdecydowaną opinię, są słuchaczami) i formy ich uczestnictwa (wygłoszenie opinii). Nawet podsumowanie makrostruktury dotychczasowego tekstu (działanie o charakterze retrospektywnym, które będzie omówione szerzej w punkcie 5.2) jest podjęte ze względu na kolejnych rozmówców. Sposób tego podsumowania cechuje minimalne uporządkowanie elementów: niezhierarchizowane, o otwartym układzie kolekcji (fundamentalizm, niebezpiecznie, porzadnie, ewangelizacja).

Elementy strukturalne programu „Debata” oddzielane są nie tylko ze względu na rodzaj rozmówców (goście, publiczność), ale również ze względu na temat i organizację retoryczną.

KD: Dokładnie tak. Wróćmy do tego, bo chciatbym jeszcze poznać panów opinie na temat tego, czy Kościót/ hierarchowie Kościoła/ czy Episkopat ma problem z Radiem Maryja? Jeśli tak, to jak poważny jest to problem?

We fragmencie dziennikarz podejmuje różnorodne działania integrujące fragment tekstu w ramach aktualnej sytuacji komunikacyjnej: włącza go jako kolejną część segmentu nieciąłłego (wróćmy do tego; zaimek anaforyczny „tego” odsyła do poprzednich elementów segmentu), pozycjonuje zapowiedziany krok rozmówcy jako opinię (jest to budowanie struktury debaty, w której opinia, fakt, argument, teza są podstawowymi elementami konstrukcyjnymi). Następnie określa makrostrukturę zapowiadanego fragmentu (uogólniona kategoria makrostrukturalna (KM) to „relacje między instytucjami”), zapowiada temat sekwencji z kolejnymi rozmówcami i jednocześnie sygnalizuje organizację retoryczną, mianowicie narzuca uporządkowanie formalne typu: problem/ rozwiązanie. W celu uzmysłowienia czynności dziennikarza można dokonać sztucznego ich wyodrębnienia z syntetycznej wypowiedzi:

a) poziom poznawczy, odzwierciedlony w makrostrukturze tekstu: są określone relacje między Episkopatem i Radiem Maryja,

b) poziom organizacji retorycznej, superstruktura: te relacje stanowią problem dla Episkopatu, dla Kościoła,

c) poziom organizacji tematycznej (problem w relacjach będzie tematem kolejnych wypowiedzi),

d) poziom ogólnej struktury debaty (wypowiedzi będą opiniami w debacie).

Wynika z tego, że tło pozajęzykowe jest przedstawiane w taki sposób, aby zainicjować dyskusję: temat musi zostać sproblematyzowany, aby otwierał miejsce dla różnych opinii. W ten sposób uwarunkowania gatunkowe kształtują zarówno warstwę przedstawieniową tekstu, jak i interakcyjną. Mają też bezpośrednie odzwierciedlenie w strukturze debaty. Podobne działania obserwujemy w kolejnym przykładzie. 
IK: Kiedy zastanawiam się nad sprawa owej Dunki, która nie chciała żyć w ten sposób, ona pragnęta samobójstwa, ponieważ nie chciata być żyjąca głowa, odbierało to jej godność życia. [...] Dla tej dziewczyny byto to coś, co jej życie pozbawiato, no, podstawowego ludzkiego, no i powiedziatbym boskiego wymiaru.

KD: No i pojawia się kwestia tego indywidualnego wyboru. Piotrze.

IK: To sa dopiero problemy, które stawiały problem eutanazji $w$ zupetnie zreszta nowym świetle niż w ubiegtym wieku.

PB: Wielokrotnie w naszej dyskusji wracat ten moment, kiedy zastanawialiśmy się nad tymi konkretnymi przypadkami. Wśród publiczności są osoby, które na co dzień się spotykają z takimi przypadkami i to zdaje się będzie głos polemiczny do tego, co powiedziała pani profesor.

(24.02.2005; gość - IK: Ireneusz Krzemiński)

W dyskusji poprzedzającej przytoczony fragment zostały otwarte dwa ujęcia tematu eutanazji: rozważania ogólne i przypadki indywidualne. Dwudzielne ujęcie tematu wpisuje się w schemat poznawczy: aspekt jednostkowy/ogólny, konkretny/ teoretyczny. Dziennikarz główny (KD) wskazuje drugi kierunek rozwoju linii tematycznej. Dziennikarz pomocniczy (PB) kwalifikuje zapowiedziany fragment:

a) pod względem strukturalnym jako segment nieciągły (wielokrotnie w naszej dyskusji wracat ten moment),

b) pod względem rodzaju uczestników - jako segment z publicznością, dodatkowo uzasadnia uczestnictwo jej reprezentantów w debacie z uwagi na doświadczenia (Wśród publiczności sa osoby, które na co dzień się spotykaja z takimi przypadkami),

c) pod względem organizacji retorycznej debaty - jako głos polemiczny do wcześniejszej wypowiedzi.

Zapowiedzi dziennikarzy zawierają wiele sygnałów, które umożliwiają zintegrowanie segmentów debaty pod względem struktury formalnej, makrostruktury, organizacji retorycznej. Są wskazówkami, jak należy usytuować dany segment w strukturze całości i jaką funkcję on pełni (kontynuacja aspektu tematu, głos opinii publicznej, polemika z wcześniejszym stanowiskiem). Zatem sygnał zapowiedzi, determinujący kształt segmentu, jest jednocześnie sygnałem oddzielającym ten segment, markującym jego początek. Tekstotwórcza integracja dokonywana na bieżąco przez organizatora „Debaty” i pomocna przy odbiorze tekstu delimitacja to dwie strony tego samego zjawiska. Aktywizowaniu odbiorcy służy również budowanie relacji między wątkami tematycznymi poruszanymi wcześniej i wątkami zapowiadanymi.

PB: Zaczęliśmy od tego, kiedy człowiek staje się narkomanem i czy jest możliwy uchwytny taki moment. Ja chcę pana zapytać, bo przy okazji tego typu dyskusji zwykle pojawia się także problem narkotyków miękkich i twardych, czy pana zdaniem taki podziat w ogóle ma sens?

(10.02.2005)

W podanym przykładzie dziennikarz wprowadza nowy watek tematu, uzasadniając to strukturą debaty pozastudyjnej na podjęty temat. Jego działanie 
wpisuje się zatem w taktykę kreowania debaty w studiu jako części większej całości - debaty publicznej na dany temat. Cząstka tematu zostaje wprowadzona jako problem, a nie np. zwykłe stwierdzenie, co od początku antycypuje strukturę argumentacyjną. Wprowadzenie tematu w ten sposób powoduje, że wszelkie wypowiedzi następcze są odbierane jako argumenty, a nie np. opis. Tak więc dla budowania struktury debaty, która uwzględnia uwarunkowania gatunkowe i dyskursywne, ważne są nie tylko same treści przedstawieniowe (tu: podział narkotyków na miękkie i twarde), ale sposób ich wprowadzenia (jako kontynuacja debaty pozastudyjnej, relacja część/całość, jako problem antycypujący dyskusję, a nie np. fakt potwierdzony badaniami).

JW: [...] a druga strona sprawy, od której nie można uciekać, to jest kwestia historycznej. politycznej odpowiedzialności za stan wojenny//

KD: I tu dotykamy tematu, o którym dowiedzieliśmy się kilka tygodni temu, czyli śledztwa $w$ sprawie stanu wojennego, prowadzonego przez katowicki oddziat Instytutu Pamięci Narodowej. I zastanawiam się, czy dla panów, dla pana Jana Lityńskiego, dla pana profesora $i$ dla panów to jest dopetnienie sprawiedliwości, czy to jest dziatanie polityczne?

(16.12.2004; gość - JW: Jerzy Wiatr)

W kolejnym przykładzie dziennikarz wprowadza cząstkę tematu, motywując to wypowiedzią rozmówcy ( $i \underline{\text { tu }}$ dotykamy). Jest to przykład hierarchizowania elementów tematu: w ramach tematu głównego (rozliczenie stanu wojennego) rozmówca (JW) wprowadził aspekty (kwestia historycznej i politycznej odpowiedzialności w odróżnieniu od wcześniej omawianej odpowiedzialności karnej). Dziennikarz w ramach tych aspektów włącza jako temat podrzędny aktualne wydarzenie - śledztwo w sprawie stanu wojennego. Podrzędność wynika z uporządkowania elementów rzeczywistości na ogólnej zasadzie zjawisko/przejaw zjawiska, czy też bardziej szczegółowo - norma ogólna/realizacja normy. Zjawiskiem, normą jest tu kwestia (konieczność) rozliczenia stanu wojennego w wymiarze karnym i/lub historyczno-politycznym, a przejawem zjawiska (realizacją normy) jest wszczęcie śledztwa w tej sprawie. Wypowiedź dziennikarza oprócz wprowadzenia cząstki tematu z usytuowaniem jej w strukturze debaty (hierarchizacja elementów tematu) zawiera również zapowiedź planu strukturalnego i ukierunkowanie rozwoju linii tematycznej:

a) zapowiedź fragmentów zaprojektowanych jako opinie rozmówców (czy dla panów),

b) wyznaczenie rozmówców poprzez podanie nazwiska, tytułu i/lub wskazanie za pomocą odpowiedniego gestu,

c) określenie makrostruktury wypowiedzi: zawężenie jej do kategoryzacji aktualnego wydarzenia (wszczęcia śledztwa w sprawie stanu wojennego),

d) kategoryzacja wydarzenia przez przyporządkowanie go do kategorii ogólnej, oznaczającej działanie w sferze karno-prawnej (dopetnienie sprawiedliwości) lub działanie polityczne, 
e) ujęcie kategoryzacji w typowy dla debaty schemat - schemat alternatywy: albo działanie karno-prawne, albo działanie polityczne.

Działania dziennikarza o charakterze prospektywnym inicjują kolejne etapy interakcji w mikrosytuacji oraz sterują ich przebiegiem, natomiast działania retrospektywne służą uporządkowaniu, strukturyzacji zakończonych etapów.

\subsection{Działania o charakterze retrospektywnym}

Dziennikarz wspomaga integrację tekstu retrospektywnie, poprzez odniesienie się do sekwencji, którą zamierza zakończyć. Wówczas podsumowanie, przypisanie kwalifikacji stylistycznej lub gatunkowej fragmentowi jest sygnałem zamknięcia. Działania tego typu są również sposobem na funkcjonalne włączenie do struktury debaty tych fragmentów interakcji, które wymknęły się spod kontroli prowadzącego, np. bezpośredniej konfrontacji między uczestnikami, kłótni, retorycznych zwrotów do widza mało związanych z tematem, a obliczonych na kreowanie wizerunku. Działania o charakterze retrospektywnym mogą być podejmowane także w celu przypomnienia wątku, do którego prowadzący chciałby nawiązać. Nawiązanie to może polegać na budowaniu różnego rodzaju relacji, np. przeciwstawienia, koniunkcji, włączenia, czasu, wynikania ${ }^{1}$. Relacje mogą być budowane zarówno między fragmentami tekstu (środki wyrazu spójności logicznowiążącej), jak i między pojęciami rzeczywistości pozajęzykowej (środki wyrazu spójności poznawczej) (Gajda 1982: 130). W poniższym przykładzie można odtworzyć sygnały relacji z obu poziomów.

PB: Zaczęliśmy od tego, kiedy człowiek staje się narkomanem i czy jest możliwy uchwytny taki moment. [teraz] Ja chce pana zapytać, bo przy okazji tego typu dyskusji zwykle pojawia sie także problem narkotyków miękkich i twardych, czy pana zdaniem taki podziat w ogóle ma sens?

$(10.02 .2005)$

Do relacji, które nie wymagają od prowadzącego głębszego wnikania w konfigurację sensów, należą te oparte na następstwie czasu (najpierw mówiliśmy o X, teraz będę mówił o Y) w zakresie więzi logicznowiążącej i relacje koniunkcji w zakresie spójności poznawczej (problem popadania w narkomanię i (także) problem podziału narkotyków na miękkie i twarde). W kolejnym przykładzie dziennikarz strukturyzuje relacje między pojęciami, wykorzystując schemat alternatywy rozłącznej (albo X, albo Y).

${ }^{1}$ Stanisław Gajda, pisząc o relacjach głębokich, wymienia następujące stosunki odnoszące się do dwumiejscowych relacji logicznych: ekwiwalencja, koniunkcja, dysjunkcja, przeciwstawienie, porównanie, włączanie, wyłączanie, czas, przyczyna, warunek, cel, przyzwolenie, miejsce, sposób (Gajda 1982: 135). 
KD: Proszę państwa, czy to jest dyskusja zero : jeden, czy to jest dyskusja/ czy jest przestrzeń do debaty na ten temat? Czy to sa jasno zarysowane stanowiska: tak albo nie, czy też możemy na ten temat dyskutować $i$ coś z tej dyskusji może wynikać?

DK: Znaczy, ja wierzę, że istnieje obszar do wspótdziałania.

KD: Gdzie on mógtby się pojawić?

(24.02.2005; gość - DK: Dariusz Karłowicz)

Relacja alternatywy rozłącznej ma dotyczyć spolaryzowanych opinii (albo opinia „zero”, albo opinia „jeden”) oraz typów dyskusji (albo stanowiska są jasno zarysowane, albo nie). Jest to jednocześnie bardzo znamienny przykład negocjowania schematu strukturalnego interakcji, który jest zależny od uwarunkowań gatunkowych. Dziennikarz, stosując strategię metadyskursywną, zwraca uwagę na układ interakcyjny i jego wpływ na możliwość kooperacji. Wyróżnia dwa porządki:

- dyskusja zero : jeden, jasno zarysowane stanowiska, nie ma możliwości dyskusji (w sensie negocjowania stanowisk),

- przestrzeń do debaty, możemy dyskutować (domyślnie: stanowiska elastyczne, większa złożoność poznawcza).

Z ukształtowania pytania wynika, że tylko drugi schemat jest przedstawiony jako funkcjonalny dla dyskusji w takim kształcie, jak zaplanował ją nadawca. Strategia dziennikarza ma jednak kilka celów. Cel doraźny polega na kreowaniu sytuacji komunikacyjnej w programie „Debata” według reguł gatunkowych. Dla rodzaju dyskusji, jaką jest debata, typowe jest to, że strony mają wyrobiony pogląd na kwestię sporną (por. Szymanek 2004: 92) i nie przewidują rozstrzygania wątpliwości. Dyskusja rzeczowa, jaką zamierza wykreować nadawca (jest to sterowanie sytuacją komunikacyjną) projektuje uczestników jako rozmówców bez założonych z góry tez, ale poszukujących prawdy. Tylko wówczas otwiera się pole do negocjacji i można wypracować nowe rozwiązanie, jakościowo różne od stanowisk wyjściowych. Nadawca wyraźnie przeciwstawia zatem dwie sytuacje: jeśli są zdecydowane stanowiska, to można je tylko zaprezentować i to jest typowa debata, do dyskusji natomiast potrzeba przestrzeni negocjacji, „odsztywnienia”, uelastycznienia stanowiska. Celem dalekosiężnym nadawcy jest również edukacja, podwyższanie kompetencji komunikacyjnych uczestników debaty publicznej (przede wszystkim odbiorcy masowego). Biorąc pod uwagę funkcję organizacyjną, można powiedzieć, że dziennikarz komentuje formę dotychczasowej interakcji w programie, ale jednocześnie wnioski z tego płynące mają konsekwencje dla dalszego jej przebiegu.

$\mathrm{W}$ przypadku wypowiedzi mało powiązanej z tematem, dziennikarz może odrzucić wątki w niej poruszane (relacja wyłączenia) albo odnieść się całościowo do zachowania komunikacyjnego rozmówcy.

GS: Szanowni państwo, oczywiście Samoobrona stoi na stanowisku, że należy zrobić wszystko, aby demokracja zwyciężyła na Ukrainie, to po pierwsze. My już miesiac temu daliśmy ku temu sygnat. Wówczas Andrzej Lepper, będac gościem Kijowskiej Wyższej Uczelni, na której otrzymat 
doktorat honoris causa [śmiech widowni] odwiedzit również// [oklaski widowni, gwar, rozbawienie]. Ale szanowni państwo, ja naprawdę/ troszeczkę kultury. Apeluję o kulturę, a szczególnie do kolegów z Platformy Obywatelskiej//

PB: Dobrze, [proszę do//

GS: [Do czego zmierzam, do czego zmierzam. Do tego zmierzam, że wówczas Andrzej Lepper odwiedzit gtodujacych, strajkujacych dziennikarzy z telewizji, z kanału piatego. Tu sa wtaśnie zdjęcia, kiedy ich wspierat $i$ tak dalej. I szkoda, że wtaśnie politycy PO wówczas, jeszcze przed pierwsza turą wyborów, nie pojechali na Ukrainę i nie naświetlali tego problemu, bo tu się okazu$j e, \dot{z} e / /$

G: Ale Andrzej Lepper byt też na Biatorusi. [śmiech widowni]

GS: -i jeszcze na koniec powiem jedno: szkoda że wówczas, tego faktu/ że tym tropem nie poszli inni politycy. [Szkoda, że tego faktu nie ujawniła telewizja.

KD: [Dobrze, ale może spróbujmy wrócić do tego, co się dzieje na Ukrainie. Zostawmy szlak wędrówek pana przewodniczacego na razie [śmiech widowni]. Ja jestem ciekaw opinii naszych gości, którzy pochodza z Ukrainy. Co oni myśla na temat tego, czym dla Ukraińców jest obecność polskich polityków w Kijowie?

(25.11.2004; goście - G: gość z publiczności, GS: Grzegorz Skwierczyński)

Rozmówca, działacz partii, wykorzystuje debatę w celu promowania wizerunku przewodniczącego, co jest natychmiast rozpoznane przez publiczność, która reaguje najpierw śmiechem, potem szyderczymi oklaskami. Rozmówca zmienia płaszczyznę odniesienia wypowiedzi na metadyskursywny komentarz do zachowania publiczności (zachowanie jest tekstotwórcze dzięki komentarzowi oraz służy celom retorycznym [dyskredytacja komunikacyjna przeciwnika w celu uzyskania lepszej pozycji dyskursywnej]), poucza ją w obcesowy sposób, posługuje się nazwą partii (jest to taktyka instrumentalnego wykorzystania zasad grzeczności, na tyle nieudolna, że sama wypowiedź staje się zaprzeczeniem owych zasad). Dziennikarz ingeruje z dwóch powodów:

- konfliktu międzygrupowego (konflikt w relacji między partiami jest naruszeniem zasad debaty, bo nadrzędna powinna być linia sporu, a nie podziałów partyjnych - świadczy o tym moment przerwania, tzn. wtedy, kiedy pojawia się nazwa partii),

- odejścia od tematu. O tej przyczynie ingerencji można wnioskować z reakcji rozmówcy, który natychmiast dokonuje metatekstowego uzasadnienia swoich czynności mownych (do czego zmierzam. Do tego zmierzam, że [...]). Autokomentarz metatekstowy stanowi swoisty podgląd celów komunikacyjnych rozmówcy, który je ujawnia, aby stanowiły przeciwwagę dla dyskwalifikacji wypowiedzi jako nierelewantnej wobec wytyczonej wcześniej linii tematycznej.

Strategia metatekstowa okazuje się nieskuteczna, bo wątek zostaje przez dziennikarza głównego uplasowany mimo wszystko jako nierelewantny dla debaty (Spróbujmy wrócić do tego, co się dzieje na Ukrainie), a nawet komiczny (Zostawmy szlak wędrówek pana przewodniczącego na razie). Dziennikarz stosuje tu ważną strategię strukturalną, polegającą na nakładaniu na wypowiedź (na przypisywaniu wypowiedzi) kwalifikacji stylistycznej i gatunkowej: 
- nazywa elementy tła pozajęzykowego wprowadzone przez rozmówcę nie działaniem politycznym, co byłoby zgodne z pierwotną intencją, lecz „szlakiem wędrówek". W tej sytuacji przemianowanie wywołuje efekt ironiczny, jest deprecjonującym obniżeniem rangi, implikuje rolę nie polityka, ale co najwyżej wędrowca,

- można powiedzieć, że dziennikarz wykorzystuje stylistyczną kategorię ironii w celu zmiany prymarnej funkcji zachowania komunikacyjnego polityka osłabia perswazyjność, a wzbudza funkcję ludyczną,

- pośrednio dziennikarz nakłada też kwalifikację gatunkową na wypowiedź rozmówcy, której nie zostaje przyznany status argumentacji, ale raczej opowieści, relacji o szlaku wędrówek.

W sumie strategiczne działanie dziennikarza zmierza do tego, aby zagospodarować strukturalnie, tzn. włączyć w strukturę debaty, element niefunkcjonalny merytorycznie jako pełniący inną funkcję - w tym przypadku funkcję ludyczną.

Zabiegi tekstotwórcze dziennikarza zmierzające do włączenia wypowiedzi rozmówców, sekwencji, segmentów w strukturę debaty mogą nosić znamiona perswazji. Dziennikarz wychodzi z roli jedynie organizatora programu, a zaczyna sterować przekazem na poziomie poznawczym.

CB: [...] To jest rzeczywiście chichot historii, że kraj, który doprowadzit do tej jesieni ludów '90 roku, kraj, który zapoczątkowat rozkład i koniec komunizmu w Europie, i można powiedzieć nawet na świecie, jako globalnego totalitaryzmu, który miat zdobyć wtadzę nad światem, że to $w$ tym kraju z powodu braku konsekwencji, braku rozwagi, znaleźliśmy się w sytuacji, kiedy podnosza się głosy ludzi, którzy kompletnie, jak większość z państwa, tamtych czasów nie pamiętaja, lub też bardzo dobrze je pamiętaja, jak Zbyszek Bujak, ale są zaczadzeni jakąś idea wszechogarniajacego ekumenizmu i fraternizacji wszystkich ze wszystkimi, że oto $w$ tym kraju nagle mamy problem zupetnie elementarny, bo mówimy o agentach na przykład służb specjalnych, zapominając, $\dot{z} e$ czym innym jest być ptatnym funkcjonariuszem, wykonywać funkcję bycia stróżem brata swego jako policjant, tajny agent, a czymś zupetnie innym jest donosić na kogoś. Podobnie czymś zupetnie innym jest być pokrzywdzonym obywatelem, który uległ szantażowi, naciskowi, presji, przestraszyt się, a być obywatelem, który uległszy tej presji, przestraszywszy się, nieważne już czego i w jakich okolicznościach, nagle pretenduje do jakiejś roli pewnego przewodzenia w życiu publicznym, bycia nauczycielem innych, podczas gdy nie miat nawet dość odwagi, żeby swój intymny stosunek z aparatem tajnych stużb nie zataić przed swoimi towarzyszami walki, przyjaciótmi, rodzina [...].

KD: Pan minister Kozłowski. Brak konsekwencji, brak rozwagi, mówit pan Czesław Bielecki. No jest trochę tak, że łajdactwo w tym stanie pozostałoby ukryte, że ci, którzy donosili, jeśli tylko nie chca zostać posłami albo ministrami, to już moga spać spokojnie, a ofiary nie, bo, bo co? Bo będziemy siegali do materiatów i nie będziemy w stanie ich ocenić, tylko dlatego? Jak pan myśli, panie ministrze?

KK: Nie, myślę, że, no, jest jakieś głębokie nieporozumienie, bo ja pomimo wszystko będę się upierał, że człowiek, który tamie drugiego człowieka i doprowadza go do sytuacji, w której/ ochotników, ludzi, którzy donosili z wtasnej, nieprzymuszonej woli jest około/ niewielu. Natomiast gros to sa ludzie złamani, zaszantażowani, przerażeni.

(20.01.2005; goście - CB: Czesław Bielecki, KK: Krzysztof Kozłowski) 
Dziennikarz wyznacza kolejnego rozmówcę, ale ponieważ poprzednia wypowiedź była stosunkowo długa, a przez to wielowątkowa, wieloaspektowa, przypomina pojęcia i rekapituluje fragmenty, które mogą być funkcjonalne w dalszej dyskusji. Nie jest to jednak działanie neutralne, ale taktyczne. Czynności dziennikarza można określić jako:

a) prowokację, gdyż powtórzenie opinii o braku konsekwencji i braku rozwagi (domyślnie: elit rządzących) w odniesieniu do ministra pierwszego niekomunistycznego rządu ma taki właśnie charakter, jest wzmocnieniem zarzutu; jego celem jest taktyczne kreowanie układu interakcyjnego, skierowanie pytania do odpowiedniej osoby, podkreślenie jej uwikłania w sprawę,

b) wybiórcze streszczenie argumentacji rozmówcy ze wzmocnieniem pewnych punktów i marginalizowaniem innych; dziennikarz akcentuje wątek niesprawiedliwego ukrywania donosicieli, a pomniejsza wątek niesprawiedliwego (niemiarodajnego) wykorzystania materiałów służb specjalnych,

c) zamianę wyrażeń łagodnych na dosadne: nazwanie „braku odwagi” - „łajdactwem”, „intymnego stosunku z aparatem tajnych służb” - „donoszeniem”.

Delimitacja tekstu i funkcjonalizacja jego elementów jest równoznaczna z docieraniem do globalnego sensu. Segmentacja jest więc nie tyle ułatwieniem odbioru, co w istocie jego umożliwieniem. Pojedynczy element tekstu zyskuje globalny sens dopiero w kontekście całości. Zadaniem dziennikarza jest wykorzystanie wszelkich technik na poziomie metatekstowym w celu strukturyzacji potoku treści informacyjnych, a zwłaszcza wskazywanie relacji semantyczno-tematycznych między fragmentami tekstu i określanie ich funkcji. Zatem do technik budowania struktury tekstu zaliczamy następujące czynności:

A. Działania o charakterze prospektywnym:

- zapowiedź elementu strukturalnego ${ }^{2}$ wydzielonego ze względu na rodzaj uczestników (jako grupa, jako indywiduum, z podaniem charakterystyki rozmówców), np. publiczność, goście, jeden z gości,

- zapowiedź elementu strukturalnego wydzielonego ze względu na temat, cząstkę tematu (z podaniem relacji do cząstek wcześniejszych), np. zapowiedź wątku jako podrzędnego względem wątków wcześniejszych, alternatywnego, następczego,

- zapowiedź elementu strukturalnego z określeniem jego funkcji retorycznej, np. jako głos polemiczny, zdecydowane opinie.

B. Działania o charakterze retrospektywnym:

- przypomnienie, podsumowanie, streszczenie wcześniejszych elementów strukturalnych,

- przypisanie elementowi strukturalnemu kwalifikacji stylistycznej, gatunkowej,

- przypisanie elementowi strukturalnemu funkcji w debacie studyjnej lub pozastudyjnej debacie publicznej.

${ }^{2}$ Element strukturalny jest pojęciem ogólnym, które może odnosić się do jednostkowej wypowiedzi, wymiany, sekwencji, segmentu wyodrębnionego np. ze względu na kryterium tematyczne, skład rozmówców, formę interakcji. 


\section{RozDZIAE 6 \\ Strategie strukturalne}

Formuła organizacji programu narzucona przez nadawcę medialnego ma wpływ na kształt podejmowanej w jego ramach interakcji, a więc i formę tekstu jako jego głównego elementu. W strukturze programu i tekstu wyodrębniamy ramę widowiska (zawierającą elementy pozatekstowe i tekstowe - por. punkt 6.1) oraz część środkową (zawierającą głównie elementy tekstowe). W części środkowej wyraźnie oddzielone są dwa segmenty: segment z udziałem publiczności (punkt 6.2) i segment z udziałem gości (punkt 6.3).

\subsection{Rama programu i tekstu}

Rama obejmuje wskaźnik inicjalny i finalny tekstu. Według Stanisława Gajdy „spójność ramowa polega na tym, że cały tekst lub jego jednostki (akapit, rozdział itd.) tworzą całość składającą się z trzech części: z tworzących ramę części początkowej i końcowej oraz części środkowej. Ramy o mniejszym zakresie wchodzą w ramy o większym zakresie aż do całego tekstu czy nawet cyklu tekstów" (Gajda 1982: 130). W ramie utworzonej z części początkowej i końcowej pojawia się informacja metatekstowa (Mayenowa 2004: 21), która wspomaga wydzielenie jednostki i włączenie jej w skład jednostek wyższego rzędu. Dla ukształtowania się ram ważne są specjalne środki zwane delimitatorami tekstowymi. Ich celem jest nie tylko wyznaczenie granic tekstu jako całości, ale również odgraniczenie elementów tekstu i pomoc w ich identyfikacji (Wyrwas, Sujkowska-Sobisz 2005: 25).

Delimitatory są zatem znakami początku i końca występującymi w wypowiedziach językowych oraz elementami uwydatniającymi segmentację tekstu. Teresa Dobrzyńska dzieli je na sygnały delimitacyjne, czyli wyrażenia leksykalne o charakterze metatekstowym oraz symptomy początku i końca, które przez stałe występowanie na początku i końcu tekstu są rozumiane podobnie jak sygnały (Dobrzyńska 1971: 115-127). Według powyższego opisu do sygnałów delimitacyjnych zaliczamy zapowiedzi metatekstowe, np. Zaczynamy „Debatę, Kończymy program, a do symptomów - powitanie, zachętę, zaproszenie do udziału w programie na początku i podsumowanie oraz podziękowanie na koń- 
$\mathrm{cu}^{1}$. Należy dodać, że znakowość delimitatorów realizuje się za pomocą środków typowych dla formy komunikacji. W tekstach mówionych dominują środki audialne, takie jak pauza, intonacja (Dobrzyńska 1978: 102; Nocoń 2009: 63), a także tempo mówienia i stopień przygotowania tekstu. Funkcję delimitacyjną tytułów w tekstach pisanych przejmują w tekstach mówionych zapowiedzi, które mają na celu skupienie uwagi na komunikacie.

Medialne uwarunkowania analizowanych przekazów powodują, że momenty graniczne przekazu, a zwłaszcza początkowe, pełnią funkcję reklamową, są decydujące dla nawiązania kontaktu z odbiorcą. Teoria tekstu posługuje się tu pojęciem strategicznych pozycji tekstowych (Duszak 1998: 128). Tak ważne zadanie realizowane jest nie tylko przez dziennikarza, ale również stację i wydawców programu. Działania prezentacyjne i reklamowe obliczone na skuteczne zainteresowanie odbiorcy noszą miano strategii prefacjalnych i polegają na skutecznym uprzedzaniu, wprowadzaniu, eskortowaniu tekstu zasadniczego (Loewe 2007: 9). Złożona natura masowych przekazów polisemiotycznych, a więc udział wielu kodów, wielopłaszczyznowość nadawcy², sprawiają, że rama programu ma charakter heterogeniczny: składa się z ramy widowiska (realizowanej głównie środkami wizualno-dźwiękowymi) i ramy dyskusji w jego obrębie (realizowanej głównie środkami werbalnymi). Można zatem mówić o podwójnej ramie przekazu, co odpowiada podwójnej sytuacji programu telewizyjnego (mikrosytuacja w studiu wpisana jest w makrosytuację telewizyjną). Rama widowiska łączy go ze strumieniem telewizyjnym, natomiast rama dyskusji bardziej koreluje z sytuacją w studiu.

Ukształtowanie elementów odgraniczających (takich jak czołówki, zapowiedzi, wprowadzenia, podsumowania fragmentów, zakończenia) świadczy, co postaramy się wykazać, o ich związku z konwencjami rodzajowymi i gatunkowymi. Ramą widowiska telewizyjnego jest powtarzalna każdorazowo, identyfikowana przez odbiorcę czołówka, składająca się z ruchomego obrazu i głośnego dźwięku oraz elementu finalnego programu o dopasowanej formule obrazowo-dźwiękowej $^{3}$. Elementy te można uznać za sygnały delimitacyjne typowe dla strumienia

1 Analiza delimitatorów i delimitacji tekstu według T. Dobrzyńskiej powinna uwzględnić m.in. takie zagadnienia, jak: ujawnienie tożsamości funkcjonalnej elementów będących znakami delimitacji; wykrycie ich związków z kontekstami rodzajowymi i gatunkowymi; ukazanie fakultatywności wyboru delimitatora w ramach gatunku, czyli opis repertuaru znaków granic możliwych w danym kontekście; badanie opozycji delimitatorów początkowych i końcowych (Dobrzyńska 1974: 5).

2 Dziennikarz jest indywidualną jednostką, ale również firmuje swoją twarzą program, stację i media w ogóle, czy też dziennikarzy w ogóle. Role te ujawniają się w różnych interakcjach ze zmiennym nasileniem.

3 Dopasowanie rozumiemy jako utrzymanie ruchomego obrazu, a zwłaszcza dźwięku, w podobnej stylistyce. Obrazowe figury początkowe i motywy dźwiękowe zostają powtórzone z niewielkim przetworzeniem. 
telewizyjnego, ponieważ wpisują się w ciąg sygnałów innych programów publicystycznych, które również wykorzystują kod obrazowo-dźwiękowy. Stała czołówka programu jest najbardziej charakterystycznym indeksem medialnym „Debaty”, zawierającym symboliczny przekaz w postaci logotypu (dynamicznie zmieniający się model globu ziemskiego) oraz planszę z tytułem programu. Nieobligatoryjnym i heterogenicznym względem dyskusji elementem początkowym jest felieton filmowy, pojawiający się od drugiego sezonu emisji programu.

W ramie widowiska osadzona jest dyskusja, będąca jego zasadniczą częścią i mająca również swoją ramę. Tworzą ją zachowania komunikacyjne dziennikarza lub dziennikarzy usytuowane w początkowej i końcowej części dyskusji. Ze względu na dominującą illokucję, działania w fazie początkowej można nazwać zapowiedzią (por. punkt 6.1.1) oraz wprowadzeniem (6.1.2), a pod koniec programu fazą końcową (6.1.3) oraz zakończeniem (6.1.4).

\subsubsection{Zapowiedź}

Zapowiedź w znaczeniu obiegowym to ogłoszenie, oznajmienie czegoś, co ma nastąpić ${ }^{4}$. Jako prymarne działanie mowne, odnoszące się bezpośrednio do „Ja-Tu-Teraz” mówiącego ${ }^{5}$, jest prostym gatunkiem mowy realizującym illokucję zapowiedzi i bywa wyrażone pojedynczym wypowiedzeniem ${ }^{6}$. Wejście prymarnego gatunku mowy w orbitę komunikacji medialnej powoduje jego zmiany strukturalne (np. obudowanie zapowiedzi pierwotnej dodatkowymi elementami) i funkcjonalne, zmierzające do wykształcenia się sekundarnego gatunku zapowiedzi medialnej. Terminu „zapowiedź” można zatem używać dla nazwania illokucji, która jest realizowana przez jednostkowe wypowiedzenie, oraz jako nazwy gatunku sekundarnego, występującego w układzie komunikacji masowej, gatunku paratekstowego, bogatszego strukturalnie i illokucyjnie od swojego poprzednika (zapowiedzi pierwotnej).

W związku ze zmianami struktury programu ${ }^{7} \mathrm{w}$ początkowym okresie emisji zapowiedź pojawiała się bezpośrednio po czołówce (przykłady w grupie A), a następnie przed czołówką (przykłady w grupie B).

${ }^{4}$ Słowniki ogólne (por. np. SJPSz, t. 3: 946) podają trzy znaczenia leksemu zapowiedź: 'ogłoszenie, oznajmienie czegoś, co ma nastąpić', 'oznakę czegoś, co ma nastąpić, wróżbę'. Trzecie znaczenie (zapowiedź w kościele) odnosi się do prawa kościelnego i, podobnie jak zapowiedź widowiska telewizyjnego, stanowi sekundarny gatunek mowy.

5 Prymarne gatunki mowy rodzą się w warunkach komunikacji „twarzą w twarz”. Gatunki sekundarne pojawiają się w warunkach wysoko rozwiniętej komunikacji kulturowej i są derywowane od gatunków prymarnych (Gajda 2004: 151-152).

${ }^{6}$ W zapisie wyróżniono podkreśleniem to wypowiedzenie, które realizuje illokucję zapowiedzi.

${ }^{7}$ Funkcja elementów programu, pojawiających się bezpośrednio po czołówce (lub fakultatywnie przed nią), jest stała (zapowiedź programu, dyskusji, wprowadzenie w jej temat), ale ich 


\section{A. Typ zapowiedzi występujący po czołówce (chronologicznie wcześniejszy)}

Fragment 1 (18.11.2004)

[Czołówka: symultanicznie nadany motyw muzyczny, ruchomy obraz m.in. z logotypem programu, następnie na tle logotypu pojawia się napis zawierający tytuł programu].

[Zapowiedź po czołówce] [dziennikarz pomocniczy] PB: Czy prawo powinno gwarantować kobiecie możliwość wyboru? Dziś o aborcji. „Debatę” prowadzi Kamil Durczok.

Fragment $2(25.11 .2004)$

[Czołówka]. [Zapowiedź po czołówce] [dziennikarz pomocniczy] PB: „Tu się czuje rewolucję" - tak powiedziat jeden z polskich polityków, przebywający w Kijowie. Rewolucja w kolorze pomarańczowym. „Debata”. Program prowadzi Kamil Durczok.

\section{Fragment 3 (9.12.2004)}

[Czołówka]. [Zapowiedź po czołówce] [dziennikarz pomocniczy] PB: Tolerancja. Czy naprawdę znamy znaczenie tego stowa? Dziś na ten temat „Debata”. Prowadzi Kamil Durczok.

\section{Fragment 4 (20.01.2005)}

[Czołówka]. [Zapowiedź po czołówce] [dziennikarz pomocniczy] PB: Krzywda czy sprawiedliwość dziejowa? Teczki powracaja dziś w „Debacie”. Program prowadzi Kamil Durczok.

\section{Fragment 5 (13.01.2005)}

[Czołówka]. [Zapowiedź po czołówce] [dziennikarz pomocniczy] PB: Legalizować czy zwalczać? Prostytucja w Polsce. „Debata”. Program prowadzi Kamil Durczok.

\section{Fragment $6(10.02 .2005)$}

[Czołówka]. [Zapowiedź po czołówce] [dziennikarz pomocniczy] PB: Nie ma na świecie idealnych rozwiązań. Jakie proponowane są w Polsce? W „Debacie” o narkotykach. Program prowadzi Kamil Durczok. [oklaski $\left.{ }^{8}\right]$

kształt i usytuowanie ulegało zmianie w trakcie ponad półtorarocznej emisji programu. Ze względu na kształt fazy otwarcia można wyróżnić kilka jej typów strukturalnych:

- przy dwóch dziennikarzach występował ciąg linearny: czołówka, zapowiedź wygłoszona przez dziennikarza pomocniczego, wprowadzenie wygłoszone przez dziennikarza głównego (formuła obowiązująca od września 2004 do lutego 2005),

- przy jednym dziennikarzu: czołówka, felieton filmowy, wprowadzenie dziennikarza głównego (od marca do listopada 2005),

- przy jednym dziennikarzu i równoległej emisji programu w TVP 1 i na stronach internetowych www.itvp.pl: zapowiedź dziennikarza głównego, czołówka, felieton filmowy, wprowadzenie dziennikarza głównego (od grudnia 2005 do lutego 2006).

8 Oklaski wystąpiły w kilku „Debatach”, zawsze po zapowiedzi programu i zaanonsowaniu dziennikarza głównego. Jako zbiorowe zachowanie publiczności oklaski są wpisane w formułę widowiska, służą zdefiniowaniu mikrosytuacji w studiu, a szczególnie wyeksponowaniu osoby prowadzącego. $\mathrm{Z}$ perspektywy formuły programu nie widać korelacji wystąpienia oklasków z tematem (por. oklaski po zapowiedzi trudnego tematu o eutanazji). Można to uznać za przejściowy etap reżyserskiej koncepcji co do formuły programu. 
Fragment 7 (24.02.2005)

[Czołówka] [Zapowiedź po czołówce] [dziennikarz pomocniczy] PB: Czy lekarz ma prawo być panem życia i śmierci. Dziś „Debata” o eutanazji. Program prowadzi Kamil Durczok. [oklaski] niejszy)

B. Typ zapowiedzi występujący przed czołówką (chronologicznie póź-

Fragment 8 (3.03.2005)

[Zapowiedź przed czołówka] [dziennikarz główny] KD: Dobry wieczór państwu. Już za chwile „Debata” w pierwszym programie Telewizji Polskiej. Zapraszam. [Czołówka]

Fragment 9 (21.12.2005)

[Zapowiedź przed czołówką [dziennikarz główny] KD: Już za chwilę zaczynamy „Debatę”, w pierwszym programie Telewizji Polskiej oczywiście, a także na stronie internetowej www.itvp.pl. Zapraszam. [Czołówka]

Fragment 10 (18.01.2006)

[Zapowiedź przed czołówka] [dziennikarz główny] KD: Dobry wieczór. Już za chwile „Debata” $w$ pierwszym programie Telewizji Polskiej i na stronach internetowych www.itvp.pl. Zapraszam. [Czołówka]

Fragment 11 (25.01.2006)

[Zapowiedź przed czołówka] [dziennikarz główny] KD: Dobry wieczór państwu. Już za chwile zaczynamy .Debate”, oczywiście w pierwszym programie Telewizji Polskiej, ale także na stronach internetowych www.itop.pl. Zapraszam. [Czołówka]

Fragment 12 (8.02.2006)

[Zapowiedź przed czołówka] [dziennikarz główny] KD: Już za chwile zaczynamy „Debate”. w pierwszym programie Telewizji Polskiej. Zapraszam. [Czołówka]

W ukonstytuowaniu się zapowiedzi medialnej decydującą rolę odgrywa płaszczyzna odniesienia, bowiem zapowiedź ta odsyła do dyskursu telewizyjnego, jego fragmentu w postaci programu, a dopiero pośrednio do świata pozamedialnego. Odniesienie jest zatem decydujące również w wyodrębnieniu typów zapowiedzi: typ występujący przed czołówką (chronologicznie późniejszy) odnosi się do całego widowiska i pośrednio całego cyklu widowisk, natomiast typ występujący po czołówce zapowiada dyskusję na określony temat w obrębie programu. Świadczy o tym chociażby kontekst składniowy nazwy programu, który aktywizuje jej dwa odcienie znaczeniowe $\mathrm{w}$ dwu typach zapowiedzi. W typie pierwszym (grupa A) nazwa „Debata” występuje jako tekstowy korelat dyskusji, interakcji (por. „Debata” na temat X, „Debata” o X, analogicznie do: dyskusja na temat $\mathrm{X}$, dyskusja o X). W typie drugim (grupa B) pojawia się jako korelat programu (por. zaczynamy „Debatę” analogicznie do: zaczynamy program).

Oprócz odniesienia, również schemat zapowiedzi w „Debacie” zależy od jej usytuowania względem czołówki. Zapowiedź wygłoszona przez dziennikarza 
pomocniczego po rozpoczęciu widowiska (o rozpoczęciu świadczy wystąpienie sygnału delimitacyjnego początku w postaci czołówki) składa się najczęściej z trzech elementów: ekspozycji tematu, wykładnika struktury podstawowej zapowiedzi (będącego nośnikiem illokucji), zaanonsowania dziennikarza w roli prowadzącego. Ekspozycja tematu przybiera najczęściej formę pytania ${ }^{9}$. Zapowiedź jako gatunek mowy, który jest realizowany przez dziennikarza głównego przed czołówką, składa się zazwyczaj z trzech elementów: powitania, struktury podstawowej zapowiedzi programu (z obligatoryjnym podaniem czasu i podwójnego miejsca emisji) oraz zaproszenia (brak więc ekspozycji tematu). Zarówno powitanie, jak i zaproszenie są oficjalne, dostosowane do sytuacji i rytualnej ramy widowiska. Jądro zapowiedzi zwraca uwagę charakterystyczną dla tekstów rekomendujących inwersją, polegającą na wyeksponowaniu pierwszoplanowego określenia czasu. Wraz z modulantem „już” tworzą one typową formułę konatywną służącą kreowaniu pożądanej rzeczywistości telewizyjnej. Formuła ,już za chwilę X” implikuje oczekiwanie odbiorcy na X, a sugerując, zarazem je wzbudza.

Płaszczyzna odniesienia i mniej lub bardziej rozbudowany schemat są wyróżnikami zapowiedzi medialnej, natomiast jej cechą konstytutywną jest wartość illokucyjna. Polega ona na wyznaczaniu obiektu oraz usytuowaniu go w czasie i przestrzeni (decydująca jest tu kategoria czasu, która podlega ograniczeniu do czasu przyszłego, natomiast przestrzeń jest kategorią komunikacyjną, przestrzenią interakcji). Wyznaczanie obiektu odbywa się za pomocą nazwy własnej tytułu ${ }^{10}$ programu, który jednoznacznie odnosi nazwę do obiektu, a więc jest prymarnym wyrażeniem argumentowym (Topolińska 1984: 304). Spośród dwu wskaźników illokucji (nazwy programu i lokalizacji w czasie i przestrzeni) obligatoryjnie musi wystąpić co najmniej jeden element (może być to nazwa - por. przykł. 2 i 5: „Debata”; czas - przykł. 1: Dziś o aborcji; łącznie - przykł. 4: Teczki powracaja dziś $w$ „Debacie”). Wypowiedzenie, będące wykładnikiem illokucji zapowiedzi, może dodatkowo zawierać ekspozycję tematu (w pierwszym typie) lub metatekstowy sygnał delimitacyjny początku: zaczynamy (w drugim typie zapowiedzi). Analiza wskazuje, że sekundarny gatunek mowy, jakim jest zapowiedź medialna, zawiera w swojej strukturze nieredukowalny element, który jest głównym nośnikiem illokucji. W ujęciu diachronicznym jest to pozostałość pierwotnego gatunku mowy, zwanego tu zapowiedzią właściwą (pierwotną) ${ }^{11}$.

${ }^{9}$ Schemat ten jest dość spetryfikowany, ale wyjątkowo może zostać zastąpiony schematem zmodyfikowanym (por. przykł. 2, w którym nie pojawia się pytanie, a funkcję prezentacyjną pełni cytat; ma on wydobywać walor zdarzeniowości, aktualności i wyjątkowości przywołanego kontekstu wydarzeń na Ukrainie; zapowiedź podchwytuje też (nową wówczas) medialną nominację wydarzeń jako „pomarańczowej rewolucji”).

10 Tytuły są obiektami, które nazywają, związane czysto konwencjonalnie arbitralnym aktem decyzji ich twórcy czy twórców (Topolińska 1984: 305).

11 Odwołujemy się w tym miejscu do M. Bachtina, który wprowadził rozróżnienie na gatunki, formy proste i złożone (w ujęciu relacyjnym) lub prymarne i wtórne (w ujęciu diachronicznym). 
W ujęciu synchronicznym można mówić o strukturze podstawowej gatunku zapowiedzi złożonej z elementów koniecznych do jego zidentyfikowania. Musi się w niej pojawić rodzaj podejmowanego działania językowego. Konieczność wyodrębnienia struktury podstawowej zapowiedzi, będącej nośnikiem illokucji, wynika także z tego, że - jako ważny element funkcjonalny - jest ona powtarzana w innych momentach interakcji, np. we wprowadzeniu. Zapowiedź jako gatunek sekundarny, rozbudowany o nowe elementy, występuje tylko przed całym widowiskiem lub bezpośrednio przed dyskusją.

Typ pierwszy zapowiedzi jest bogatszy strukturalnie o element zapowiedzi tematu. Sposób jego ekspozycji i uszczegółowienie aspektu tematu stanowią ważne wskazówki interpretacyjne dla odbiorcy, wskazówki co do konwencji programu, a nawet wprost co do gatunku. W analizowanych przykładach ze względu na większą częstotliwość (ale nie bezwyjątkowość) symptomatyczne jest:

- dialektyczne ujęcie tematu (w znaczeniu 'takie, które eksponuje przeciwieństwa’); jego wykładnikiem formalnym jest użycie pytania o rozstrzygnięcie, o formule „Czy powinno być X?” (przykł. 1 i 7), „Czy znamy X” (przykł. 3), „X czy Y” (przykł. 4 i 5); forma pytania podkreśla potencjalne różnice, zapowiada schemat interakcyjny w postaci dialogu (nawet wewnętrznego, ale jednak nie schemat monologu), polemiki, dyskusji,

- polaryzacja obrazu rzeczywistości; uproszczenie złożonej rzeczywistości do możliwych dwu skrajnych rozwiązań (legalizować/zwalczać, powinien/nie powinien, znamy/nie znamy, krzywda/sprawiedliwość, życie/śmierć, idealny/ realny) w największym stopniu strukturyzuje układ interakcyjny, dzieli bowiem uczestników na proponentów (którzy są „za”) i oponentów (którzy są „przeciw”),

- zarówno dialektyczne ujęcie tematu, jak i związana z tym polaryzacja kreowanego obrazu rzeczywistości stanowią ważne sygnały gatunkowe debaty,

- preferowanie aspektu prawnego omawianego tematu; przyjęcie przez realizatorów programu roli podmiotu inicjującego regulację stosunków społecznych jest próbą wypełnienia misji publicznej mediów, związane jest zatem z permanentną debatą publiczną rozumianą jako proces ciągły; w tej roli media chętnie kreują się jako widzące więcej i głębiej (por. Tolerancja. Czy naprawde znamy znaczenie tego stowa?),

\footnotetext{
Uczony twierdził, że w procesie rozwoju gatunki złożone absorbują gatunki proste, wykształcone $\mathrm{w}$ bezpośrednim językowym porozumiewaniu się. Gatunki proste ulegają modyfikacji, tracą swe bezpośrednie odniesienie do realnej rzeczywistości, zaczynają zyskiwać tożsamość w odniesieniu do gatunku złożonego, podlegają rekontekstualizacji, modyfikacji w nowym otoczeniu. Liczne podstawowe formy ustnego obcowania językowego zostają wchłonięte np. przez gatunki retoryczne, publicystyczne (Bachtin 1986: 350-425). S. Skwarczyńska słusznie zauważa, że formy wypowiedzeń obsługujących potrzeby życia codziennego wraz ze zmianą sytuacji komunikacyjnej „awansują”, pretendując do rangi gatunków komunikacji oficjalnej. Gatunki obsługujące sytuacje praktyczne to formy proste, inaczej gatunki proste, pozostające w opozycji do gatunków rozwiniętych (Skwarczyńska 1965: 227).
} 
- poruszanie się w płaszczyźnie prawnej, której powinien towarzyszyć wybór neutralnych wariantów nominacyjnych, jeśli chodzi o nazwanie tematu i aspektu tematu; jeśli przyjąć neutralność za standard w debacie publicznej, to autorom nie zawsze udaje się go utrzymać; obok neutralnych nominacji („eutanazja” zamiast „zabójstwo”) pojawiają się wyrażenia nieneutralne („być panem życia i śmierci”); w odniesieniu do silnie zideologizowanych dyskursów (np. o aborcji) można zaobserwować polaryzację całej przestrzeni werbalnej, odnoszącej się do obrazu rzeczywistości, będącego przedmiotem sporu. Wtedy każde użycie środka językowego sytuuje nadawcę po konkretnej stronie sporu (por. „możliwość wyboru” a „zabójstwo”).

W obrębie pierwszego typu zapowiedzi można doszukać się strategii, która dotyczy jej ukształtowania, a związana jest z uporządkowaniem informacji pod kątem stopnia ogólności, ważności i przewidywalności. W tym wypadku zastosowanie strategii jest umotywowane względami pragmatycznymi, a przejawia się w odejściu od szyku naturalnego opisu. Zamiast neutralnego kierunku od informacji znanej do nowej ${ }^{12}$, od ogółu do szczegółu, dziennikarz stosuje inwersję i rozpoczyna od informacji szczegółowej, ale za to nieprzewidywalnej, nowej, a przez to ważnej.

Jak już podano, schemat zapowiedzi typu pierwszego jest następujący: ekspozycja tematu (1 lub 2 wypowiedzenia) + struktura podstawowa zapowiedzi, zawierająca wykładnik (wykładniki) illokucji + zaanonsowanie dziennikarza w roli prowadzącego. Uporządkowanie linearne zapowiedzi jest takie, aby temat programu jako informacja nowa pojawił się na początku. Kolejne informacje cechuje większy stopień przewidywalności. Tytuł programu, czas, miejsce i nazwisko prowadzącego pojawiają się bowiem w ramówce, w zapowiedziach prezenterów stacji, ewentualnie $\mathrm{w}$ zajawkach ${ }^{13} \mathrm{z}$ udziałem autora programu. Ekspozycja tematu nie zawsze zawiera słowo kluczowe (por. przykł. 1, 4, 5, 6, 7). Częściej zaczyna się od zaprezentowania kontrowersyjnego aspektu tematu w formie pytania: Czy prawo powinno gwarantować kobiecie możliwość wyboru? (przykł. 1), Krzywda czy sprawiedliwość dziejowa? (przykł. 4), Legalizować czy zwalczać? (przykł. 5), Nie ma na świecie idealnych rozwiazań, jakie proponowane sa w Polsce? (przykł. 6), Czy lekarz ma prawo być panem życia i śmierci? (przykł. 7). Wówczas temat jest podawany w drugiej kolejności i może pojawić się w osobnym wypowiedzeniu (przykł. 2, 5)

12 Pojęcie nacechowania szyku odnosi się zarówno do zdania, jak i tekstu. Za nienacechowaną progresję tematyczną zdania uważa się przejście od tematu do rematu, co zazwyczaj interpretuje się jako przejście od informacji znanej lub presuponowanej do informacji nowej (Duszak 1998: 46), przechodzenie od ogółu do szczegółu, od zbioru do elementu, od całości do części. Naruszenie szyku naturalnego opisu jest wynikiem działania strategii pragmatycznych, zależnych od typu i celów dyskursu (van Dijk, Kintsch 1983: 274, za: Duszak 1998: 47-48).

13 Termin zajawka ma charakter środowiskowy i oznacza 'krótki fragment audycji, filmu lub artykułu zachęcający do zapoznania się z całością’ (por. sjp.pwn.pl). 
lub nawet w strukturze podstawowej (przykł. 1, 4, 6, 7). Strategia inwersji jest zatem stosowana nie tylko w linearnym uporządkowaniu zapowiedzi jako całości, ale również w sposobie ekspozycji tematu.

Neutralne w tym zakresie byłoby podanie najpierw kluczowego słowa tematycznego, a dopiero potem doprecyzowanie szczegółowego ujęcia w pytaniu (por. przykł. 3: Tolerancja. Czy naprawdę znamy znaczenie tego słowa?). Częściej jednak dziennikarz rozpoczyna od elementu bardziej szczegółowego, co może nawet chwilowo zakłócić odbiór komunikatu (por. przykł. 1: Czy prawo powinno gwarantować kobiecie możliwość wyboru? Dziś o aborcji; przykł. 5: Legalizować czy zwalczać? Prostytucja w Polsce; podobnie przykł. 6, 7). Porcja informacji szczegółowej bez wskazania zakresu odniesienia tematycznego jest niepełna semantycznie (szyk nacechowany przypomina trochę zagadkę, kiedy orzeka się coś o niezidentyfikowanym w danym momencie obiekcie). Strategia inwersji naturalnego szyku opisu służy celom pragmatycznym: ma zogniskować uwagę odbiorcy, zaciekawić go tematem. Jest pierwszym krokiem do kreowania sytuacji komunikacyjnej w studiu i makrosytuacji w układzie z odbiorcą masowym.

Iwona Loewe ogólnie zalicza zapowiedzi do gatunków paratekstowych ${ }^{14}$, które cechuje m.in. autorstwo inne niż autorstwo korpusu, prefacjalność (uprzedniość wobec korpusu), funkcja prezentacyjno-rekomendująca (Loewe 2007: 78). Warunki te spełnia (z małym zastrzeżeniem) drugi typ zapowiedzi, a więc zapowiedź autorska poprzedzająca czołówkę programu. Zastrzeżenie mogłoby dotyczyć warunku obowiązkowego rozdzielenia nadawcy paratekstu i tekstu zasadniczego. Niezgodność ta okazuje się pozorna wobec faktu, że dziennikarz główny w zapowiedzi występuje przede wszystkim jako reprezentant stacji. Świadczyć o tym może jej promowanie (w pierwszym programie Telewizji Polskiej oczywiście), a jeszcze dobitniej - używanie formy 1. osoby liczby mnogiej (zaczynamy „Debate”).

Zapowiedź po czołówce spełnia następujące warunki gatunku paratekstowego względem dyskusji zasadniczej (ale nie widowiska jako całości): ma innego autora niż korpus zasadniczy, poprzedza ten korpus i pełni względem niego funkcję prezentacyjną, rekomendującą, informacyjną. Natomiast nietypowe usytuowanie zapowiedzi po ramie widowiska (czołówce) zbliża analizowane zachowanie do metatekstu ${ }^{15}$, jako stowarzyszonego z tekstem głównym, włączonym w obręb widowiska. Sytuacja taka spowodowana jest, jak można sądzić, wystąpieniem podwójnej ramy delimitacyjnej: ramy widowiska telewizyjnego

${ }^{14}$ Pojęcie paratekstu oznacza taki tekst, który eskortuje tekst właściwy (korpus, bazę, tekst pełny), ma innego niż ten tekst autora, może być wielokodowy, chociaż z przewagą kodu werbalnego. Paratekst ma za zadanie uczynić korpus łatwo dostępnym i zachęcić do jego odbioru (Loewe 2007: 23).

15 Metatekst pojawia się wewnątrz korpusu. Jego udział w budowie ramy tekstu podkreślali niejednokrotnie badacze (por. Dobrzyńska 1974). Metatekst stanowi autokomentarz, jest zatem stowarzyszony z tekstem, przystaje do niego czasowo, a więc stanowi z nim całość (Loewe 2007: 76). 
i ramy dyskusji toczącej się w programie ${ }^{16}$. Drugi typ zapowiedzi stanowi werbalny poprzednik wizualno-muzycznej czołówki, zatem rozbudowuje ramę widowiska, natomiast pierwszy typ, który zawiera ekspozycję tematu, jest nakierowany na zawiązanie dyskusji, a więc wraz z wprowadzeniem wzmacnia jej ramę. Podsumowując, zapowiedź przed czołówką ma charakter paratekstowy względem całego programu, natomiast paratekstowość zapowiedzi po czołówce dotyczy tylko relacji do tekstu, będącego elementem widowiska ${ }^{17}$.

\subsubsection{Wprowadzenie}

Wprowadzenie jest drugim, obok zapowiedzi, elementem ramy tekstu. W znaczeniu obiegowym jest to przedmowa do czegoś, zawierająca podstawowe informacje, czynność rozpoczynająca jakiś inny rodzaj czynności ${ }^{18}$. Na płaszczyźnie komunikacyjnej wprowadzenie ma nawiązać interakcję i zaznajomić odbiorcę $\mathrm{z}$ obiektem dalszych czynności. Informacja podawana we wprowadzeniu powinna ogólnie ujmować charakter i intencję następczych czynności komunikacyjnych. Analizowane przykłady wprowadzenia stanowią realizację sekundarnego gatunku mowy, wyspecjalizowanego w pełnieniu funkcji prezentacyjnej, rekomendującej tekst oraz funkcji fatycznej i konatywnej względem odbiorcy. Za typowy dla wprowadzenia (jako sekundarnego gatunku mowy) należy uznać następujący schemat: (akt grzecznościowy powitania) ${ }^{19}+$ ekspozycja tematu + akt nakłaniający.

\section{Fragment 1 (18.11.2004)}

[Wprowadzenie] [dziennikarz główny oraz (wyjątkowo) dziennikarz pomocniczy] KD: Niewiele jest tematów obecnych $w$ naszym życiu publicznym tak długo jak aborcja, niewiele jest tematów tak emocjonujacych, jak prawo do usuwania ciązy, ale też niewiele jest spraw tak intymnych, indywidualnych rozpatrywanych $w$ naszym sumieniu, jak decyzja o poddaniu się kobiety zabiegowi usunięcia ciaży. Dziś temat wrócił. Kilka godzin temu, dostownie, sejmowa komisja ustawodawcza zdecydowata, że postowie będa pracować nad propozycjami tagodzenia ustawy antyaborcyjnej. Można się spodziewać, że sejmowa debata na ten temat będzie rozpalać tak samo, jak rozpalata 8 czy 11 lat temu, kiedy najpierw tworzono, a potem próbowano poprawiać ustawe antyaborcyjna. Debata będzie rozpalać, ale jak mi się wydaje, dziś w tej debacie używamy jednak innego nieco języka, języka pozbawionego nienawiści.

${ }^{16}$ Por. uwagę S. Gajdy na temat spójności ramowej i hierarchizacji ram: „Ramy o mniejszym zakresie wchodzą w ramy o większym zakresie aż do całego tekstu czy nawet cyklu tekstów" (Gajda 1982: 130).

17 W niniejszym rozdziale (wobec płynnej, jak się okazuje, granicy między para- i metatekstem) omówiono oba rodzaje zapowiedzi w obrębie ramy tekstu.

18 „Wprowadzenie” to leksem występujący w interesującym nas znaczeniu z kwalifikatorem książkowy 'wstęp, przedmowa do czegoś’ (por. USJP, t. 5: 181).

${ }^{19}$ Nawias okrągły oznacza element fakultatywny. Wprowadzenie może rozpoczynać się od ekspozycji tematu. 
[wypowiedź polemiczna] PB: Bardzo chciałbym, aby tak byto, ale wydaje mi się, że ciagle o sprawach aborcji nie potrafimy rozmawiać spokojnie, a przede wszystkim rzeczowo.

KD: Spróbujmy zatem dzisiaj w programie.

\section{Fragment 2 (25.11.2004)}

[Wprowadzenie] [dziennikarz główny] KD: Nagle zrobiło się pomarańczowo: pomarańczowe wstążki, szaliki stały się od trzech dni elementem naszych strojów. Najwyraźniej zapatrzeni w walki wokót komisji śledczej nagle dostrzegliśmy, że nasi sąsiedzi walczą o uczciwe państwo $i \dot{z} e$ ta walka tak bardzo przypomina nam to, o czym sami marzyliśmy, najpierw w' 80 , potem w '89 roku. Ale oprócz prostej sympatii $i$ sentymentu do naszych ukraińskich sąsiadów dostrzegliśmy też, jak chyba nigdy dotad, że demokratyczne, uczciwie rzadzone państwo ukraińskie to także gwarancja naszego bezpieczeństwa.

\section{Fragment 3 (9.12.2004)}

[Wprowadzenie] [dziennikarz główny] KD: Dobry wieczór państwu. Czy jesteśmy tolerancyjni? Oczywiście tak, z naszą historią Rzeczpospolitej kultur i narodów nie możemy, bo nie potrafimy być nietolerancyjni. To jedna opinia. Inna głosi, że mało jest krajów tak nietolerancyjnych, jak Polska, $z$ protestami przeciwko marszom i paradom gejów, ale także z nietolerancja dla obcokrajowców i niepetnosprawnych jesteśmy w światowej czołówce nietolerancji. I jedni, i drudzy moga podać mnóstwo przykładów, by udowodnić swoją tezę. Porozmawiajmy zatem o tych przykładach, by potem móc zapytać, czy nietolerancja polska jest, czy jest groźna i skąd się bierze.

\section{Fragment 4 (20.01.2005)}

[Wprowadzenie] [dziennikarz główny] KD: Prostokątna torba z krótkim uchwytem, przeznaczona do przenoszenia różnych przedmiotów, czyli, jak stanowi stownik, po prostu „teczka”, budzi dziś zupetnie inne skojarzenia i emocje, a u niektórych nawet strach. Czy dotychczasowy atrybut ucznia stanie się symbolem najbliższych kampanii wyborczych, a jeśli/ jeśli tak, to czy się przystuży dobrym, mądrym $i$ sprawiedliwym wyborom? Czy gdyby ujawnić to, co kryją akta służb specjalnych PRL-u, wrzawa w sprawie teczek ucichnie, czy przeciwnie, dopiero wtedy naprawde rozgorzeje? Wszystko o teczkach dziś w „Debacie” Jedynki.

\section{Fragment 5 (13.01.2005)}

[Wprowadzenie] [dziennikarz główny oraz (wyjątkowo) dziennikarz pomocniczy] KD: Dobry wieczór państwu. Holandia ma w Amsterdamie Dzielnicę Czerwonych Latarni, Hamburg ma Sankt Pauli. Takich dzielnic $i$ takich ulic $w$ Polsce nie ma. Czy to znaczy, że $w$ Polsce nie ma prostytucji i nie ma domów publicznych? Oczywiście sa, wystarczy wziać do ręki jedna z gazet i natkniemy się na setki ogtoszeń w samej tylko Warszawie. Tyle, że u nas takie przybytki nazywane sa „agencjami towarzyskimi”. To jest dobry przykład pokazujacy, jak w Polsce traktuje się prostytucję: $z$ jednej strony kodeks karny i kary, $z$ drugiej agencje. Wszyscy wiedza, co się $w$ nich oferuje, ale nikt nie nazywa tego po imieniu. Co zrobić z prostytucją?

PB: No, jest jeszcze trzeci pogląd na cała tę sprawę: mianowicie, kiedy w Polsce rozmawia się o prostytucji, pojawiaja się dość takie dziwne uśmieszki. Ale pojawiają się także głosy, aby legalizować prostytucję. Dlaczego zalegalizować prostytucję?

\section{Fragment 6 (10.02.2005)}

[Wprowadzenie] [dziennikarz główny] KD: Dobry wieczór państwu. 80 procent Polaków uważa, że za posiadanie nawet najmniejszej ilości narkotyków należy karać. Każda osoba 
przytapana z towarem może więc pójść siedzieć. Nieważne, czy znalezione przy niej narkotyki ma dla siebie, czy na sprzedaż. Czy złagodzenie ustawy, nawet wbrew pogladom opinii publicznej, może pomóc $w$ walce $z$ narkomania, czy wręcz przeciwnie: dopiero wtedy fala narkotyków wleje się do szkót, dyskotek, klubów i na ulice, a skutkiem będą kolejne tragedie. Tragedie, których i tak jest mnóstwo. O tym dziś w „Debacie”, w której wezma udziat także ci, którzy sami już się przekonali, jak ryzykownie i niebezpiecznie może skończyć się na pozór niewinne spróbowanie matego odlotu.

\section{Fragment 7 (24.02.2005)}

[Wprowadzenie] [dziennikarz główny] KD: Dobry wieczór państwu. Byt rok '73, młoda holenderska lekarka Gertruda Postma zabiła własna matkę. Na procesie, który jej wytoczono, mówita, że pomogła matce umrzeć, bo ta nieuleczalnie chora wielokrotnie prosita ja o skrócenie życia. Sąd skazat lekarkę na tydzień więzienia i rok nadzoru sądowego. Tak zaczęta się w Holandii wielka debata, która po blisko 30 latach doprowadziła do całkowitej legalizacji eutanazji. Pod tym obco brzmiacym stowem kryje się różnego rodzaju pomoc, jakiej lekarz udziela pacjentowi, by ten mógt umrzeć. Czy nieuleczalnie chorzy i czasem straszliwie cierpiacy ludzie powinni mieć prawo do godnej $i$ dobrej śmierci wtedy, kiedy nie sa już w stanie wytrzymać bólu, który towarzyszy chorobie? O tym dziś będziemy debatować.

\section{Fragment 8 (3.03.2005)}

[Wprowadzenie] [dziennikarz główny] KD: Dobry wieczór państwu. Meta w sprawie afery FOZZ-u jest coraz bliżej, a my, którzy obserwujemy tę największa aferę III Rzeczpospolitej, staliśmy się świadkami wyścigu, kto będzie pierwszy: sędzia Kryże czy przedawnienie. Proces w sprawie afery sam staje się aferalna porażka wymiaru sprawiedliwości, który nie potrafi uporać się z FOZZ-em od ponad 12 lat. Ile może trwać postępowanie przed polskim sądem wiedza ci, którzy pozywali lub byli sadzeni. Niekiedy w tym czasie upadaja firmy, umieraja uczestnicy procesów albo po prostu sprawa się przedawnia. Czy wobec tego jest sens mówić o Polsce jako o państwie prawa? Czy sa szanse na uczciwe osądzenie największych polskich afer: tych, które już znamy i tych, o których dopiero ustyszymy? O tym dziś w „Debacie”.

\section{Fragment 9 (21.12.2005)}

[Wprowadzenie] [dziennikarz główny] KD: Z jednej strony autor wielu sukcesów, z drugiej negatywny bohater zdarzeń, o których nie chce rozmawiać. Jeden z ojców sukcesu pomarańczowej rewolucji na Ukrainie. Przyjaciel bytego prezydenta tego kraju, wplatanego w niejasne powiazania $i$ śmierć dziennikarza. Lubiany w Waszyngtonie, Londynie, Berlinie. Nielubiany w Moskwie, która jednak odwiedzit $w$ rocznicę zakończenia wojny na propagandowej imprezie prezydenta Putina. Znany z szorstkiej przyjazni z politykami lewicy i jako autor ułaskawienia Zbigniewa Sobotki, skazanego za udziat $w$ aferze starachowickiej. Ateista $i$ świadek w procesie beatyfikacji Jana Pawła II. Jaka prezydenturę dat Polakom przez 10 lat Aleksander Kwaśniewski? Zapraszam na „Debatę”.

\section{Fragment 10 (18.01.2006)}

[Wprowadzenie] [dziennikarz główny] KD: Dobry wieczór państwu. Od tygodnia dominuje poglad, że kryzys $w$ polskiej polityce doprowadzi do nowych wyborów. Być może bierze się on stą, że niemal co godzinę jesteśmy zaskakiwani kolejnymi pomysłami na wyjście z kryzysu. Gtówni gracze w tym kryzysie, czyli PiS i Platforma, nadal nie znajdują pomysłu na przełamanie wzajemnych animozji. We wszystkim doszukuja się podstępu przeciwnika. Styszymy o świadomym zamieszaniu z data gtosowania nad budżetem, celowym straszeniu wcześniejszymi wyborami, po to, żeby zmusić do wspótpracy partie zagrożone wypadnięciem z Sejmu, wreszcie o tym, 
$\dot{z}$ e przedstawiony dzisiaj plan stabilizacyjny powstat po to, żeby go Platforma odrzucita i na nia spadta odpowiedzialność za rozwiązanie Sejmu. Czy jest jeszcze jakieś mniej radykalne wyjście $z$ tej sytuacji niż wcześniejsze wybory? Zapraszam na „Debatę”.

\section{Fragment 11 (25.01.2006)}

[Wprowadzenie] [dziennikarz główny] KD: Dobry wieczór państwu. W Stanach Zjednoczonych szykuje się kampania prezydencka, która, choć jeszcze się nie zaczęta, wywotuje niespotykane emocje. Najpoważniejszymi kandydatkami do białego domu sa bowiem kobiety: Hilary Clinton $i$ Condoleezza Rice. Sukces jednej z nich bytby z pewnościa pokonaniem kolejnej bariery $w$ społeczeństwie, $w$ którego historii kobieta zajmowata się przede wszystkim domem, a jej mężczyzna troszczyt się o pracę i dobrobyt rodziny. Bytby to też z pewnościa impuls do debaty wykraczajacej poza granice Ameryki, dlatego dziś w Jedynce zapytam, czy kobieta na czele państwa to krok do wizji świata, która znamy z „Seksmisji”, czy też naturalna zmiana roli. Kobieta w domu czy w polityce? Matka czy prezes korporacji, a może nie trzeba tego przeciwstawiać, może i jedno, i drugie? Zapraszam na „Debatę”.

\section{Fragment 12 (8.02.2006)}

[Wprowadzenie] [dziennikarz główny] KD: Dobry wieczór państwu. Witam w „Debacie”. Kiedy Jarosław Selin opowiadat jakiś czas temu o siedemdziesięciu siedmiu świetnych kandydatach do Krajowej Rady Radiofonii i Telewizji, których nazwiska ma w głowie, na Woronicza zgadywano, kogo może mieć na myśli. Niedawno ten sam minister Selin komentowat gtosowanie w sprawie jednego z członków tejże rady i mówit, że trochę mu wstyd, ale dyscyplina w klubie to święta rzecz. Mamy nowa Krajowa Radę i zapowiedzi nowego porządku w mediach. W Sejmie też nowe porządki - jedna z telewizji zdecydowanie wyprzedza w wyścigu pozostałe. „Dziennikarze, którzy protestują, winni być ukarani przez marszatka" - tak uważa lider jednej z partii, a Rzeczpospolita solidarna z gazetami z innych krajów publikuje karykatury Mahometa. Taki jest obraz polskich mediów na początku 2006 roku, a co dalej? O tym dzisiaj będa dyskutować goście „Debaty”.

Przywilej powitania, a tym samym nawiązania kontaktu z widzami i gośćmi, przysługuje dziennikarzowi głównemu, chociaż zabiera on głos jako drugi (po zapowiedzi). Akt grzecznościowy zajmuje pozycję inicjalną we wprowadzeniu, co czyni z niego ważny składnik ramy tekstu zasadniczego oraz symptom delimitacji. Akt powitania pełni zatem kilka funkcji: względem odbiorców - służy nawiązaniu kontaktu, otwarciu kanału komunikacyjnego (funkcja fatyczna); względem tekstu jest jednym ze składników ramy, poprzez stałe występowanie w pozycji początkowej staje się symptomem inicjalnym tekstu.

Powitanie przyjmuje oficjalną i schematyczną formę: Dobry wieczór państwu, ewentualnie rozbudowaną dodatkowym wyrażeniem powitalnym: Dobry wieczór państwu. Witam w „Debacie”. Rozbudowanie ciągu powitalnego jest częściowo redundantne (Dobry wieczór, Witam), ale jednocześnie dziennikarz przedstawia siebie $\mathrm{w}$ roli gospodarza programu. Nie tylko nawiązuje kontakt, ale wskazuje przestrzeń kontaktu ( $w$ „Debacie”). W tych programach, w których dziennikarz główny wygłaszał zapowiedź przed czołówką (od grudnia 2005 do lutego 2006), powitanie mogło pojawić się dwukrotnie, i to w takiej samej formie: Dobry wieczór państwu w zapowiedzi i we wprowadzeniu (por. fragm. 10, 11) 
lub też nie pojawić się wcale (por. fragm. 9 oraz we wcześniejszych programach - fragm. 1, 2). Pomijanie aktów grzecznościowych może mieć kilka przyczyn, niekoniecznie rozłącznych. Najbardziej oczywisty jest czynnik indywidualny, a więc niewystarczające kompetencje komunikacyjne dziennikarza. Poza tym decydują uwarunkowania komunikacji na żywo, czyli konieczność jednoczesnego panowania dziennikarza nad makro- i mikrosytuacją, realizowania funkcji fatycznej i funkcji informacyjnej. Decydujące jednak okazują się uwarunkowania pragmatyczne, gdyż formuły grzecznościowe, zwłaszcza oficjalne, są wysoce zrytualizowane, sformalizowane, stanowią wynik przymusu społecznego i jako takie są przewidywalne oraz mało dynamiczne.

W pominięciu rytualnej formuły powitania można zatem dopatrywać się strategii inwersji, zwiększającej dynamizm wypowiedzi. Zamiast elementu przewidywalnego, rytualnego, pojawia się element nieprzewidywalny, nowy, co wiąże się z atrakcyjną ekspozycją tematu. Ocena tego, czy mamy do czynienia z niekompetencją i naruszeniem standardów (dziennikarz nie przywitał się!) czy ze świadomą strategią inwersji, zależy od oczekiwań odbiorcy, od jego tolerancji na zachowania nieschematyczne. Niezależnie od oceny, pominięcie formuły powitalnej jest przykładem skutecznej rywalizacji strategii informacyjnej ze strategią grzecznościową w newralgicznym punkcie tekstu, jakim jest rozpoczęcie interakcji ${ }^{20}$.

Rezygnacja z powitania nie musi oznaczać braku realizacji funkcji fatycznej i funkcji delimitacyjnej, przejmują ją bowiem inne środki wyrażania. Telewizja w porównaniu z radiem dysponuje, jak wiadomo, nie tylko kanałem audialnym, ale również wizją, co przyczynia się do skrócenia występujących w niej formuł powitalnych ${ }^{21}$. Za nawiązanie kontaktu imitującego komunikację twarzą w twarz odpowiadają dodatkowo sygnały niewerbalne, np. kontakt wzrokowy, uśmiech, pozycja ciała zwrócona do odbiorcy (Marcjanik 2007: 125). Funkcję delimitacyjną z kolei pełnią (na prawach symptomu ${ }^{22}$ ) akty nakłaniające do uczestnictwa w interakcji lub akty zapowiedzi. Jak wynika z rozważań, ważne cele illokucyjne gatunku, takie jak nawiązanie kontaktu i rozpoczęcie interakcji, muszą być zrealizowane, natomiast wybór optymalnych środków jest kwestią ustalenia priorytetów i dobrania odpowiedniej strategii.

${ }^{20}$ Pewnym złagodzeniem braku powitania werbalnego jest zachowanie niewerbalne dziennikarza, który podchodzi i staje naprzeciw kamery, wykonuje gest kiwnięcia głową, któremu towarzyszy uśmiech. Jeśli przyjąć za Małgorzatą Marcjanik, że powitanie jest sygnałem: „mówię, że rozpoczynam kontakt z tobą” (Marcjanik 2000: 283), to należy uznać, że funkcję tę mogą kontekstowo przejąć inne środki wyrażania, w tym wypadku środki niewerbalne.

21 Porównania takiego dokonuje M. Marcjanik, twierdząc, że radio w realizacji funkcji fatycznej musi rekompensować brak wizji rozbudowywaniem formuł powitalnych (Marcjanik 2007: 121).

22 Podstawą oznaczania są wówczas konwencje kulturowe, według których proponowanie, zachęcanie, zapraszanie do interakcji raczej ją poprzedza. Akty te są zatem symptomami początku. 
W porównaniu ze schematycznością elementów początkowych wprowadzenia, o wiele ciekawiej prezentuje się ekspozycja tematu. Nadawca powołuje się na wydarzenia w Polsce i na świecie, porusza ważne dla obywatela zagadnienie pogranicza sfery publicznej i prywatnej. Ważnym ustaleniem dla niniejszych rozważań jest stwierdzenie, że pole tematyczne ${ }^{23}$ stanowi przede wszystkim sytuacja komunikacyjna debaty publicznej, a dopiero pośrednio - tło społeczne, polityczne, historyczne, kulturowe. Dziennikarz buduje sytuację debaty (na razie mówimy o debacie publicznej, rozumianej szerzej niż sam program) poprzez sytuowanie w niej społecznych percepcji wydarzeń, opinii, komentarzy. Jako modelowy przykład wprowadzania obiektu w kolejne konteksty odniesienia, aż do umieszczenia go w strukturze debaty, może posłużyć wprowadzenie z fragmentu 4.

Punktem wyjścia jest obiekt rzeczywistości percypowanej zmysłowo: Prostokątna torba z krótkim uchwytem przeznaczona do przenoszenia różnych przedmiotów, czyli, jak stanowi słownik, po prostu „teczka”. Następnie obiekt jest sytuowany w przestrzeni społecznej percepcji, która nadaje mu szczególne znaczenie: budzi dziś zupetnie inne skojarzenia i emocje, a u niektórych nawet strach. Kolejnym krokiem jest umieszczenie obiektu w kontekście politycznym, w którym staje się on instrumentem działania politycznego: Czy dotychczasowy atrybut ucznia stanie się symbolem najbliższych kampanii wyborczych, a jeśli/ jeśli tak, to czy się przystuży dobrym, mądrym i sprawiedliwym wyborom? Ostatecznym punktem odniesienia dla dziennikarza jest funkcjonowanie obiektu jako tematu w strukturze debaty publicznej: Czy gdyby ujawnić to, co kryja akta stużb specjalnych PRL-u, wrzawa w sprawie teczek ucichnie, czy przeciwnie, dopiero wtedy naprawde rozgorzeje? Podjęty temat teczek jest przedstawiany jako budzący żywe zainteresowanie (wrzawa, rozgorzeje), co odpowiada wymogom gatunkowym kreowanej sytuacji komunikacyjnej.

Nie zawsze dziennikarz tak jawnie przeprowadza odbiorcę przez wszystkie etapy nadawania społecznego sensu. We wprowadzeniu z fragmentu 1 obiekt rzeczywistości pozajęzykowej (działanie, procedura medyczna) od razu jest rozpatrywany jako potencjalny temat debaty publicznej: Niewiele jest tematów obecnych w naszym życiu publicznym tak długo jak aborcja [...]. Próby uchwycenia rzeczywistości komunikacyjnej, zdefiniowania głównych tematów są obciążone dużą dozą subiektywizmu, jest to bowiem rzeczywistość wtórna, wytworzona społecznie. W jej kreowaniu dziennikarz ma pole do negocjacji i modelowania przekazu pod kątem realizacji strategii gatunkowych i strategii dyskursu.

Zobrazowaniu wskazanych działań dziennikarza służą przykłady pochodzące z przytoczonych uprzednio zapisów wprowadzeń. Są one konkretnymi

${ }^{23}$ Temat, najszerzej ujmując, jest dziedziną przedmiotów i stanów rzeczy, których aktualizacja i uporządkowanie zależą od celów komunikacyjnych nadawcy i odbiorcy. Pole tematyczne jest pojęciem zrelatywizowanym do konkretnej sytuacji interlokutorów i oznacza te elementy świata otaczającego, które mogą zostać zaktualizowane, tzn. wprowadzone do rozmowy (Warchala 1991: 62). 
realizacjami strategicznego kreowania sytuacji komunikacyjnej debaty publicznej poprzez podkreślanie niektórych cech omawianych zjawisk (poziom odniesienia do rzeczywistości pozajęzykowej) i cech tematów ich dotyczących (poziom odniesienia do rzeczywistości komunikacyjnej). Strategiczne wykreowanie sytuacji ma służyć uzasadnieniu aktywności dyskusyjnej prowokowanej w mediach. Cechy zjawisk i tematów to:

a) stała obecność tematu w debacie publicznej: Niewiele jest tematów obecnych w naszym życiu publicznym tak dtugo jak aborcja (fragm. 1),

b) powtarzalność zjawisk: [...] nagle dostrzegliśmy, że nasi sąsiedzi walcza o uczciwe państwo i $\dot{z}$ e ta walka tak bardzo przypomina nam to, o czym sami marzyliśmy, najpierw w'80, potem w'89 roku (fragm. 2),

c) trwałość i rozległość zjawisk, które były, są i - w domyśle - będą: [...] z nasza historia Rzeczpospolitej kultur i narodów nie możemy, bo nie potrafimy być nietolerancyjni (fragm. 3); [...] dopiero wtedy fala narkotyków wleje się do szkót, dyskotek, klubów i na ulice, a skutkiem będa kolejne tragedie. Tragedie, których i tak jest mnóstwo (fragm. 6); Ile może trwać postępowanie przed polskim sadem wiedza ci, którzy pozywali lub byli sądzeni. Niekiedy w tym czasie upadaja firmy, umieraja uczestnicy procesów albo po prostu sprawa się przedawnia (fragm. 8); Sukces jednej z nich bytby z pewnościa pokonaniem kolejnej bariery $w$ spoteczeństwie, w którego historii kobieta zajmowała się przede wszystkim domem, a jej mężczyzna troszczyt się o pracę i dobrobyt rodziny (fragm. 11).

Powyższe przykłady sygnalizują, że debata na tematy społeczne ma charakter permanentny, ciągły, podobnie jak stanowiące jej przedmiot problemy i konflikty, które na trwałe są wpisane w obraz społeczeństwa. Mamy tu do czynienia z przenoszeniem cech zjawisk rzeczywistości na cechy komunikowania o tejże rzeczywistości. Tematy są aktualne, więc i komunikowanie o nich jest ciągle zasadne, np. o narkomanii, aborcji, systemie prawnym, prostytucji.

Trwałość i niezmienność problemów (które dostarczają tematów debaty) z jednej strony uzasadnia permanentną debatę, ale z drugiej - implikuje statyczność, która jest mało atrakcyjna w rzeczywistości medialnej. Dla zwiększenia dynamiczności wprowadzana jest kategoria nowości. Stąd zabiegi dziennikarza zmierzające do uaktualnienia tematu. Częstą strategią uaktualnienia jest uzasadnienie podjęcia debaty dzięki przywołaniu aktualnego wydarzenia politycznego, społecznego, medialnego, np.:

a) rozpoczęcia lub planowania procesu legislacyjnego: Dziś temat wrócit. Kilka godzin temu dosłownie sejmowa komisja ustawodawcza zdecydowała, że postowie będa pracować nad propozycjami łagodzenia ustawy antyaborcyjnej (fragm. 1); Czy złagodzenie ustawy, nawet wbrew pogladom opinii publicznej, może pomóc $w$ walce z narkomania, czy wręcz przeciwnie? (fragm. 6),

b) medialnie nagłośnionego wydarzenia: Nagle zrobiło się pomarańczowo: pomarańczowe wstażki, szaliki stały się od trzech dni elementem naszych strojów (fragm. 2). 
Mniej wyraźnym sposobem uaktualnienia tematu jest inicjowanie debaty pod wpływem wzbierającego niezadowolenia społecznego (aglutynacji, artykulacji interesów grup społecznych). Wtedy problemy są znane, ale ich społeczny odbiór podlega dynamicznej zmianie. Poczucie potrzeby zmian jest pierwszym ogniwem procesu decyzyjnego $\mathrm{w}$ demokracji i w takiej misji media z powodzeniem pośredniczą. Służy temu przedstawianie wydarzeń z tła pozajęzykowego jako niezadowalających, np. z powodu:

a) martwego prawa: [...] u nas takie przybytki nazywane sa „agencjami towarzyskimi”. To jest dobry przyktad pokazujacy, jak w Polsce traktuje sie prostytucję: $z$ jednej strony kodeks karny $i$ kary, $z$ drugiej agencje. Wszyscy wiedza, co się $w$ nich oferuje, ale nikt nie nazywa tego po imieniu (fragm. 5),

b) niedostosowania prawa do oczekiwań obywatela: Czy nieuleczalnie chorzy i czasem straszliwie cierpiacy ludzie powinni mieć prawo do godnej $i$ dobrej śmierci wtedy, kiedy nie sa już w stanie wytrzymać bólu, który towarzyszy chorobie? (fragm. 7),

c) nieefektywności wymiaru sprawiedliwości: Proces $w$ sprawie afery sam staje się aferalna porażka wymiaru sprawiedliwości, który nie potrafi uporać się z FOZZ-em od ponad 12 lat (fragm. 8).

Niezadowalająca, w odbiorze społecznym, sytuacja może stanowić punkt zwrotny, być zapowiedzią zmiany, jej konieczności, wreszcie (co ważne dla mediów) konieczności krytycznego przedyskutowania ewentualnej zmiany. Tak więc dziennikarz, kreując kontekst wypowiedzi, nieustannie balansuje między stałością i zmiennością odtwarzanych wydarzeń, ich dawnością i nowością. Nasuwa się wniosek, że wymienione kategorie ekstralingwistyczne, zestawione w opozycyjne pary (stałość/zmienność, dawność/nowość), stanowią podstawę strategicznego kreowania tła pozajęzykowego we wprowadzeniu.

W relacji do odbiorcy szczególnego znaczenia nabiera z kolei kategoria ważności, czy też może subiektywnej istotności prezentowanych tematów. Media dystrybuują informacje o różnym stopniu przydatności dla przeciętnego obywatela. Sprawy obiektywnie ważne mogą wydawać się przeciętnemu odbiorcy subiektywnie mało istotne. Zadaniem mediów jest m.in. ukazanie, jak wydarzenia wielkiej polityki, skali makro, przekładają się na życie zwykłych ludzi. W celu rozszerzenia relewancji tematów stosuje się strategię przybliżenia: Ale oprócz prostej sympatii i sentymentu do naszych ukrainskich sąsiadów dostrzegliśmy te $\dot{z}$, jak chyba nigdy dotąd, że demokratyczne, uczciwie rządzone państwo ukraińskie to także gwarancja naszego bezpieczeństwa (fragm. 2); Czy złagodzenie ustawy, nawet wbrew poglądom opinii publicznej, może pomóc w walce z narkomania, czy wręcz przeciwnie: dopiero wtedy fala narkotyków wleje się do szkót. dyskotek, klubów i na ulice, a skutkiem będą kolejne tragedie (fragm. 6).

Sposób kreowania tła sytuacyjnego jest zdeterminowany nie tylko potrzebą uzasadnienia aktywności komunikacyjnej dziennikarzy i ich gości w oferowanym programie, ale również formą gatunkową tego programu. Wydawcy 
zawarli w tytule wskazówkę interpretacyjną, nazywając program właśnie „Debatą”. Niezależnie od tego, czy nazwane tak zdarzenie komunikacyjne w całości wypełnia wymogi wskazanego wzorca, czy też stanowi jedynie nawiązanie do niego, przynajmniej we wprowadzeniu można bez trudu odnaleźć wskaźniki gatunkowe debaty. $\mathrm{W}$ warstwie przedstawieniowej najbardziej typowe (podobnie jak w zapowiedzi) jest dialektyczne ujęcie rzeczywistości, czyli zestawienie dwóch przeciwstawnych punktów widzenia, którym często towarzyszy kontrastowanie treści, pojęć, ukazywanie ich jako przeciwstawnych, a nawet rozłącznych.

Niewiele jest tematów obecnych w naszym życiu publicznym tak dtugo jak aborcja, [...] ale też niewiele jest spraw tak intymnych, indywidualnych rozpatrywanych w naszym sumieniu [...]. (fragm. 1)

Czy jesteśmy tolerancyjni? Oczywiście tak, z nasza historia Rzeczpospolitej kultur i narodów nie możemy, bo nie potrafimy być nietolerancyjni. To jedna opinia. Inna głosi, że mało jest krajów tak nietolerancyjnych, jak Polska, z protestami przeciwko marszom i paradom gejów, ale także $z$ nietolerancja dla obcokrajowców i niepełnosprawnych jesteśmy w światowej czołówce nietolerancji. (fragm. 3)

Holandia ma $w$ Amsterdamie Dzielnice Czerwonych Latarni, Hamburg ma Sankt Pauli. Takich dzielnic i takich ulic w Polsce nie ma. Czy to znaczy, że w Polsce nie ma prostytucji $i$ nie ma domów publicznych? Oczywiście są, wystarczy wziać do ręki jedna z gazet i natkniemy się na setki ogłoszeń $w$ samej tylko Warszawie. Tyle, że u nas takie przybytki nazywane sa „agencjami towarzyskimi”. To jest dobry przykład pokazujacy, jak w Polsce traktuje się prostytucję: $\underline{z}$ jednej strony kodeks karny $i$ kary, $z$ drugiej agencje. Wszyscy wiedza, co sie $w$ nich oferuje, ale nikt nie nazywa tego po imieniu. (fragm. 5)

$\underline{Z}$ jednej strony autor wielu sukcesów, $z$ drugiej negatywny bohater zdarzeń, o których nie chce rozmawiać. Jeden z ojców sukcesu pomarańczowej rewolucji na Ukrainie. Przyjaciel bytego prezydenta tego kraju, wplątanego w niejasne powiązania i śmierć dziennikarza. (fragm. 9)

Kobieta $\underline{w}$ domu czy w polityce? Matka czy prezes korporacji, a może nie trzeba tego przeciwstawiać, może i jedno, i drugie? (fragm. 11)

We fragm. 1 wykorzystano człony opozycji publiczny/prywatny jako dwa pełnoprawne, współistniejące wymiary sytuacji związanej z aborcją. Natomiast we fragm. 3 skontrastowano dwie przeciwstawne, spolaryzowane opinie na temat naszej tolerancyjności/nietolerancyjności. Kontrast i niezgodność stały się we fragm. 4 dominantą kompozycyjną, którą jeszcze uwypukla paralelizm składniowy. Nadawca, tworząc kontekst, wykorzystuje w celu skontrastowania następujące określenia: w innych krajach/w Polsce, jest/nie ma, jawny/ukryty, zjawisko/przejaw zjawiska. Wskazuje również na relację niezgodności: między obiektem i mylącą nazwą, kodeksem karnym a stanem faktycznym, tudzież między przekonaniem społecznym a wyrażaniem tego przekonania. Podobnie całe wprowadzenie pomieszczone we fragm. 9 jest skonstruowane na zasadzie kontrastu przeciwstawnych charakterystyk, opinii, powiązań i faktów. 
W podanych fragmentach kontrast i niezgodność są wywołane przez podanie obu członów spolaryzowanej rzeczywistości, ale podobny efekt dziennikarz osiąga przez wywołanie tylko jednego członu, np. pytanie: Czy prawo powinno gwarantować kobiecie możliwość wyboru? (fragm. 1) implikuje ujęcie dialektyczne: tak lub nie. Ciekawy jest przykład 11, w którym dziennikarz, przyjmując postawę deliberatywną: Kobieta $w$ domu czy $w$ polityce? Matka czy prezes korporacji?, ujawnia relatywizm samego przeciwstawienia jako relacji ustanowionej w odniesieniu do określonego układu. Zatem dopuszcza możliwość zniesienia niezgodności na skutek zmiany układu odniesienia ${ }^{24}$ : a może nie trzeba tego przeciwstawiać, może i jedno, i drugie?

Spolaryzowana rzeczywistość staje się domeną wyraźnych podziałów i ostrych kategoryzacji: W Sejmie też nowe porzadki - jedna z telewizji zdecydowanie wyprzedza w wyścigu pozostate. „Dziennikarze, którzy protestuja, winni być ukarani przez marszatka" - tak uważa lider jednej z partii (fragm. 12); Główni gracze w tym kryzysie, czyli PiS i Platforma, nadal nie znajduja pomystu na przetamanie wzajemnych animozji. We wszystkim doszukuja się podstęu przeciwnika (fragm. 10). To prowadzi często do emocjonalizacji debat, co dziennikarze podkreślają we wprowadzeniach: [...] niewiele jest tematów tak emocjonujacych, jak prawo do usuwania ciąży [...]. Można się spodziewać, że sejmowa debata na ten temat będzie rozpalać tak samo, jak rozpalała 8 czy 11 lat temu (fragm. 1); Prostokątna torba z krótkim uchwytem, przeznaczona do przenoszenia różnych przedmiotów, czyli, jak stanowi stownik, po prostu „teczka” budzi dziś zupetnie inne skojarzenia i emocje, a u niektórych nawet strach (fragm. 4); W Stanach Zjednoczonych szykuje się kampania prezydencka, która, choć jeszcze się nie zaczęta, wywotuje niespotykane emocje (fragm. 11).

Interakcja uczestników życia społecznego i politycznego przedstawiana jest raczej w kategoriach emocjonującej akcji, starcia, gry, konfliktu, niż racjonalnego procesu decyzyjnego (wydaje mi się, że ciagle o sprawach aborcji nie potrafimy rozmawiać spokojnie, a przede wszystkim rzeczowo). Stąd apel dziennikarzy o spokojną, rzeczową debatę (Spróbujmy zatem dzisiaj w programie [porozmawiać, podebatowaćl).

Jak wynika z podanych przykładów, sposób kreowania sytuacji debaty publicznej podporządkowany jest parametrom dyskursu medialnego:

- kreacja tła realizuje wymóg nowości, dynamizmu; debaty na tematy polityczne mają walor aktualności i nowości z racji charakteru tematu (por. fragm. 9, $10,12)$, natomiast debaty na tematy społeczne cechuje permanentny charakter, wobec tego nadawca stosuje strategie uaktualniające zagadnienie,

${ }^{24}$ Używając sformułowania „układ odniesienia”, mamy na myśli różne typy racjonalności, np. w ramach dyskursów ideologicznych (skrajne przykłady to dyskurs feministyczny i dyskurs tradycjonalistyczny). 
- zagadnienia (subiektywnie) mało związane z życiem przeciętnych obywateli muszą zostać przedstawione jako jednak ważne z jakichś względów; służy temu strategia przybliżenia problemów, wciągnięcia ich w orbitę zainteresowania społecznego,

- na poziomie przedstawieniowym pojęcia odnoszące się do sytuacji debaty porządkowane są na zasadzie kontrastu, niezgodności, przeciwieństwa,

- na poziomie interakcji grup społecznych i osób najczęściej werbalizowaną relacją jest rozbieżność poglądów, spór, konflikt,

- ogólnie rzeczywistość pozajęzykowa konceptualizowana jest jako niezadowalająca, chaotyczna, wymagająca regulacji, nowych rozwiązań,

- ten niezadowalający stan rzeczy (system wytrącony z równowagi) jest paradoksalnie optymalny dla podjęcia aktywności komunikacyjnej w debacie „tu i teraz"; zatem skuteczne przekonanie rozmówców, że sytuacja społeczna, polityczna wymaga zmiany, jest argumentem na rzecz zasadności bieżącej interakcji.

Można zatem postawić tezę, że sposób kreowania tła sytuacyjnego, zakodowanego jako kontekst wypowiedzi, podporządkowany jest celom legitymizacji ${ }^{25}$ samej debaty. Strategie dyskursu medialnego (legitymizacja debaty, eksponowanie nowości, aktualności tematu oraz eksponowanie starcia, konfliktu, gry w obrazie polityki), w tym również strategie gatunkowe debaty publicznej (podkreślanie permanentności debaty, ujęcie dialektyczne tematu), są ważnym elementem budowania relacji z odbiorcą w układzie komunikacji masowej.

Celem dziennikarza jest wzbudzenie odpowiednich obrazów i nastawień u odbiorcy, który „odtwarza” tło sytuacyjne (dla uwyraźnienia nazywamy je również sytuacją przywołaną) na podstawie wskazówek dziennikarza. Odbiorca ma postrzegać politykę z perspektywy mediów (starcie, gra, konflikt), a sytuację komunikacyjną debaty publicznej - według strategii gatunkowych (polaryzacja stron, poglądów, dialektyczne ujęcie tematu, permanentny charakter debaty).

Posługiwanie się kategorią sytuacyjności w analizie działań komunikacyjnych dziennikarzy wymaga oddzielenia tła sytuacyjnego (odtwarzanego z pamięci, relacjonowanego bez udziału bezpośrednich bodźców z otoczenia komunikacyjnego) od „sytuacji rozwijającej się ad hoc” (Boniecka 1999: 69). Dziennikarz nie tylko wprowadza do przestrzeni komunikacyjnej pojęcia obiektów, zdarzeń, stanów, czynności spoza otoczenia fizycznego aktu komunikacji, ale również kieruje zdarzeniem komunikacyjnym w studiu i prezentuje je jako całość widzom w układzie komunikacji masowej.

Biorąc pod uwagę powyższe ustalenia, w analizie zachowań komunikacyjnych dziennikarza (we wprowadzeniu, ale również w dyskusji zasadniczej)

25 Uzasadnianie aktywności mediów zostało nawet utrwalone w nazwie innego widowiska, „Warto rozmawiać” (TVP 2). W centrum znaczeniowym nazwy umieszczono samą czynność jako wartość autoteliczną, gdyż media realizują funkcję fatyczną i stają się w coraz większym stopniu autotematyczne. 
należy odwołać się do dwóch przenikających się nawzajem rzeczywistości komunikacyjnych:

1. Tła sytuacyjnego (nazwanego przez nas również sytuacją przywołaną), odtwarzanego z pamięci, zakodowanego następnie jako kontekst wypowiedzi; czas wydarzeń relacjonowanych nie pokrywa się z momentem aktu komunikacji.

2. Sytuacji bieżącej, rozgrywającej się jako interakcja „tu i teraz”; elementami sytuacji rozwijającej się ad hoc są rekwizyty (napisy, plakaty przyniesione przez publiczność), uczestnicy wydarzenia komunikacyjnego, ich zachowania, reguły zdarzenia komunikacyjnego i jego organizacja; również tło sytuacyjne jest ostatecznie włączane do sytuacji bieżącej aktu komunikacji.

Kreowanie bieżącej sytuacji komunikacyjnej dziennikarz może rozpocząć od bezpośrednich obserwacji wzrokowych, zwerbalizowania cech obiektów, znajdujących się w studiu (publiczność ma stroje we wskazanym kolorze): Nagle zrobiło się pomarańczowo: pomarańczowe wstażki, szaliki stały się od trzech dni elementem naszych strojów (fragm. 2). Elementem sytuacji są uczestnicy debaty: [...] wezma udziat takíe ci, którzy sami już sie przekonali, jak ryzykownie i niebezpiecznie może skończyć się na pozór niewinne spróbowanie małego odlotu (fragm. 6). Charakterystyczne jest wyznaczanie uczestników jako uwikłanych w sytuację. Rodzaj tego uwikłania (w podanym przykładzie chodzi akurat o osobiste doświadczenie) jest podstawą kategoryzacji uczestników.

Oprócz odwzorowania obiektów dostępnych zmysłowo, dziennikarz nazywa ogólnie czynności komunikacyjne uczestników zdarzenia w studiu ( $O$ tym dziś będziemy debatować; O tym dzisiaj będa dyskutować goście „Debaty”) lub projektuje szczegółowo zdarzenie: I jedni, i drudzy moga podać mnóstwo przykładów, by udowodnić swoją tezę. Porozmawiajmy zatem o tych przykładach, by potem móc zapytać, czy nietolerancja polska jest, czy jest groźna $i$ skąd się bierze (fragm. 3). Nazwanie czynności „debatowaniem”, „dyskutowaniem”, a kolejnych etapów zdarzenia - „podawaniem przykładów”, „udowadnianiem tezy”, stanowi ważny sygnał gatunkowy. Odsłania zamiar organizacyjny dziennikarza, który projektuje sytuację komunikacyjną jako sytuację debaty, dyskusji. Z tego względu oczekuje od rozmówców określonych zachowań, przygotowuje ich do takiej, a nie innej formuły interakcji. Pomocne dla uczestników i odbiorców jest podanie planu tematycznego programu, w którym projektowane są kolejne etapy interakcji (według schematu: porozmawiajmy o X, by potem móc zapytać o Y, a następnie o Z).

Bieżącą sytuację komunikacyjną uwyraźniają potencjalne różnice w ujmowaniu rzeczywistości (Boniecka 1999: 67). Wówczas widoczny staje się sam proces werbalizacji rzeczywistości pozajęzykowej: Matka czy prezes korporacji, a może nie trzeba tego przeciwstawiać, może i jedno, i drugie? Dziennikarz ujawnia „przeciwstawienie” jako czynność podmiotu postrzegającego, a nie obiektywny opis rzeczywistości. Kreuje tym samym sytuację komunikacyjną jako 
roztrząsanie, rozważanie. Wykaz sygnałów sytuacyjności dopełniają pytania deliberatywne, które są stałym elementem ekspozycji tematu: Czy dotychczasowy atrybut ucznia stanie się symbolem najbliższych kampanii wyborczych, a jeśli/ jeśli tak, to czy się przystuży dobrym, mądrym i sprawiedliwym wyborom? Czy gdyby ujawnić to, co kryja akta stużb specjalnych PRL-u, wrzawa $w$ sprawie teczek ucichnie, czy przeciwnie, dopiero wtedy naprawdę rozgorzeje? (fragm. 4); Czy złagodzenie ustawy, nawet wbrew pogladom opinii publicznej, może pomóc $w$ walce $z$ narkomania, czy wręcz przeciwnie [...]? (fragm. 6). Treść propozycjonalna pytań wytycza linię tematyczną dalszej dyskusji (zapowiada, o czym będzie mowa), natomiast forma pytania służy sproblematyzowaniu zagadnienia, przedstawia temat jako otwarty na różne interpretacje, potencjalnie dwojaki ${ }^{26}$. W ten sposób illokucja pytania służy kreowaniu sytuacji komunikacyjnej jako sytuacji rozważania, dyskusji.

Jak już nadmieniono, tło sytuacyjne jest również włączane do bieżącej sytuacji komunikacyjnej, ale sposób tego włączania jest podporządkowany regułom gatunku.

Rozpatrzmy następujący przykład: [...] z nasza historia Rzeczpospolitej kultur i narodów nie możemy, bo nie potrafimy być nietolerancyjni. To jedna opinia. Dziennikarz przywołuje tło sytuacyjne, które ma charakter historycznokulturowy (twierdzenie: istnienie Rzeczpospolitej kultur i narodów [domyślnie: różnych] świadczy o tym, że Polacy są tolerancyjni), a następnie wprowadza twierdzenie do bieżącej sytuacji komunikacyjnej, nakładając na nie kategorię ogólniejszą, porządkującą strukturę debaty - kategorię opinii. Przykład ten pokazuje, w jaki sposób tło sytuacyjne jest włączane do bieżącej sytuacji komunikacyjnej. Moment przejścia, polegający na przypisaniu danemu twierdzeniu kategorii ogólniejszej, kategorii budującej strukturę debaty, jest ważnym działaniem dziennikarza, w którym ujawnia się jego zamysł organizacyjny. Oprócz kategorii opinii pojawiają się takie nazwy działań komunikacyjnych, jak: teza, argumenty, uzasadnienie. Można uznać je za istotne wskaźniki sytuacji dyskusji i związanej z nią czynności argumentacji.

Trzecim elementem strukturalnym wprowadzenia jest akt nakłaniający. Przyjmuje postać propozycji, zachęty do interakcji (Spróbujmy zatem dzisiaj $w$ programie, Porozmawiajmy zatem o tych przykładach) oraz zaproszenia do udziału w programie (Zapraszam na „Debatę”). W zróżnicowaniu aktów nakłaniających nadal utrzymuje się podwójne odniesienie czynności mownych dziennikarza: do widowiska jako całości i do dyskusji w jego ramach. Odbiorca może być zachęcany do interakcji również przez otwarte pytanie (Co zrobić $z$ prostytucją?), najsłabiej jest aktywizowany przez zapowiedź, która jest

${ }^{26}$ Strategiczność właśnie problematycznego, a nie jednoznacznego ujęcia tematu widać w dalszej dyskusji, kiedy inni rozmówcy akceptują tylko jedno rozwiązanie, np. twierdzą, że ujawnienie teczek rozwiąże wszystkie problemy. 
powtórzeniem aktu z wcześniejszego segmentu zapowiedzi medialnej ( $O$ tym dziś w „Debacie”, O tym dziś będziemy debatować, O tym dzisiaj będa dyskutować goście „Debaty”). Akty grzecznościowe, akty nakłaniające (propozycji, zaproszenia), a nawet zduplikowane akty zapowiedzi pełnią ważną funkcję fatyczną, gdyż służą nawiązaniu i podtrzymaniu kontaktu przede wszystkim $\mathrm{z}$ widzami.

Kreowanie sytuacji komunikacyjnej (w makro- oraz mikrosytuacji) to główne zadanie dziennikarza, które jest podejmowane ze względu na odbiorcę masowego. Służą temu bezpośrednie zwroty do widza w aktach grzecznościowych, nakłaniających, jak również funkcjonalne ujmowanie tła pozajęzykowego i projektowanie układu interakcyjnego. Funkcjonalne ujęcie tła przejawia się w tym, że wszelkie przywołane elementy rzeczywistości spoza pola obserwacji rozmówców odnoszą się do aktualnego układu komunikacyjnego. Tak więc sytuacja bieżąca jest nadrzędna. Dziennikarz projektuje, zapowiada sytuację jako rozmowę publiczną, debatę, dyskusję, przez co wzbudza i ukierunkowuje oczekiwania odbiorcy. Elementy tła sytuacyjnego są wprowadzane do przestrzeni komunikacyjnej jako opinie, tezy, obserwacje, spostrzeżenia, argumenty. Tego rodzaju kategorie porządkują strukturę interakcji i projektują ją jako zdarzenie komunikacyjne o określonych cechach gatunkowych.

\subsubsection{Faza końcowa}

Analiza „Debat” wykazuje, że kilka minut przed zakończeniem programu zmienia się zachowanie uczestników interakcji. Zmiana przebiegu rozmowy związana jest ze zbliżającym się zakończeniem programu. Chociaż część kompozycyjna fazy końcowej nie jest tak wyraźnie wyodrębniona jak faza początkowa, to jednak uznajemy, że w pewnym momencie faza rozwinięcia przechodzi w fazę końcową. Początek fazy końcowej jest niezbyt wyraźny, bo nie wspierają go środki wizualno-dźwiękowe (jak czołówka w przypadku segmentów początkowych). Symptomami są pewne zachowania dziennikarza zmierzające do podsumowania dyskusji, scalenia wątków poruszonych w jej trakcie, skłonienia rozmówców do konkluzji. Uprzywilejowaną pozycję zajmuje ostatni głos w mikrosytuacji przed segmentem zakończenia. W pewnym momencie fazy końcowej, przed wygłoszeniem ostatniej kwestii, dziennikarz symbolicznie przechodzi do makrosytuacji (sygnalizuje to plan kamery: dziennikarz zaczyna mówić twarzą do kamery, w zbliżeniu, publiczność i goście są już na dalszym planie). Ten segment makrosytuacyjny można nazwać zakończeniem (por. punkt 6.1.4). Jest on symetryczny do wprowadzenia, zawiera podsumowanie oraz zamknięcie kontaktu.

Z 45 minut, jakie przeciętnie trwa program, jak już nadmieniono, ostatnie 5-10 minut można uznać za naznaczone odmiennym zachowaniem dziennikarza i rozmówców. Jest to faza końcowa, w której pojawiają się zapowiedzi 
zamknięcia kontaktu i końca programu. Są to sygnały wejścia w tę fazę (Ja bym chciat na koniec zapytać; Proszę mi na koniec odpowiedzieć; mamy ostatnie minuty). Pod koniec zwykle rozmówcy ożywiają się, zwiększa się tempo i intensywność rozmowy, co przejawia się wielogłosem, licznymi przerwaniami, nałożeniami tur. Reakcją na zachowanie rozmówców są częstsze interwencje porządkowe dziennikarza. Nasilenie tego typu zachowań uznajemy za symptomy ${ }^{27}$ fazy zakończenia.

KD: Ja bym chciat na koniec zapytać pana Piotra, czy faktycznie ma pan takie wrażenie, że rozmawialiśmy o zupetnie różnych światach, kiedy rozmawialiśmy o braku akceptacji dla osób niepetnosprawnych i kiedy rozmawialiśmy o prawach gejów i lesbijek? Czy to na pewno sa dwa zupetnie różne problemy?

PP: [...] Jeśli mówimy o tolerancji//

RB: To nie tylko tolerancja, ale//

KD: Panie profesorze, bardzo prosze.

PP: Ewidentnie to jest tak, że często, ja mówitem o tym na poczatku, badania pokazuja zupetnie co innego, życie jest zupetnie inne. I warto na to zwrócić uwagę//

RB: I tutaj nie tylko o [tolerancje

KD: [I warto zawsze//

RB: -powinniśmy apelować, ale jakieś/ o wspótpracę, wspótdziatanie, docenienie, prawda, tych niepetnosprawnych. Tolerancja tutaj, $w$ odniesieniu do tego, tej kwestii, która pan poruszyt, to jest mało. [Chrześcijańska miłość, chrześcijańska mitość//

KD: [I warto zawsze o tym dyskutować/ bardzo przepraszam, bo czas nam się skończyt. [...]

(9.12.2004; goście - PP: Paweł Pawłowski, RB: Ryszard Bender)

KD: Jak byśmy mogli już te Czechy zostawić.

JM: Ja zostawiam, oczywiście, że tak. [...] [Jest to decyzja polityczna i nie mówmy, że//

KD: [Ponieważ mamy ostatnie minuty, ja bym chciat, żeby pan poset Pitka odpowiedziat mi na jedno pytanie.

JM: Panie redaktorze. [ja musze, ale jedno zdanie, jedno zdanie. To sa decyzje polityczne, które nie mają żadnego uzasadnienia ani gospodarczego, ani militarnego.

KD: [Panie pośle, nie! Nie, bo my rozmawiamy/ wie pan, ja tu jestem niestety od tego, żeby czasu pilnować i niestety nie moge już panu pozwolić skończyć nawet jednym zdaniem $i$ dlatego muszę zadać pytanie panu posłowi.

JM: [Ale panie redaktorze//

KD: [No, możemy tak próbować równolegle jeszcze, ale to się nie uda. W każdym razie z mizernym skutkiem dla widzów.

(4.01.2006; gość - JM: Janusz Maksymiuk)

${ }^{27}$ Symptomy mają charakter implicytny, ich znakowość powstaje jako wynik obserwacji podmiotu interpretującego, który łączy powtarzalne przejawy ze zjawiskiem (np. podjęcie czynności podsumowania ze zbliżaniem się końca programu). Sygnały natomiast mają charakter eksplicytny, przekazują informację w trybie komentarza metatekstowego (np. Musimy kończyć). Pojęcia symptomu i sygnału wprowadziła w opisie ramy tekstu Teresa Dobrzyńska (por. Dobrzyńska 1971: 115). 
KD: Proszę mi na koniec odpowiedzieć [na pytanie: czy jakikolwiek/ jeśli pani mi pozwoli// JS: [Również prostytutki ufundowały w Notre-Dame witraż.

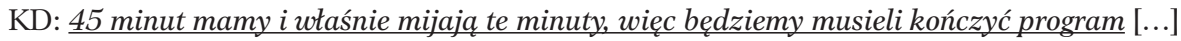

(13.01.2005; gość - JS: Joanna Senyszyn)

Rozmówcy (RB, JM, JS) naruszają konwencję programu, według której to dziennikarz kieruje rozmową. Bezwzględnie realizują swój cel komunikacyjny, jakim jest chęć wygłoszenia przesłania w strategicznym, końcowym momencie programu (można go nieco żartobliwie nazwać przywilejem „ostatniego słowa”). W tym celu stosują różne techniki przejmowania głosu w niesprzyjającej sytuacji. Mimo upomnień, przejmują turę w nieuprawniony sposób, np. przerywając kilkakrotnie wyznaczonemu przez dziennikarza rozmówcy, rozpoczynając wypowiedź przed zakończeniem poprzedniej, wbrew intencji dziennikarza. Odpowiedzią dziennikarza są strategie metadyskursywne, mające przywrócić $\mathrm{mu}$ panowanie nad bieżącą interakcją (Panie profesorze, bardzo proszę; bardzo przepraszam, bo czas nam się skończyt; jeśli pani mi pozwoli; Panie pośle, nie!). Zwroty grzecznościowe (wyłączając ostatni przykład) zawierają ukrytą implikaturę dyskredytacji i w istocie realizują intencję upomnienia. Faktyczne pozbawianie rozmówcy głosu zagraża jego twarzy pozytywnej, więc dziennikarz stosuje strategie asekuracyjne, powołując się na swoją rolę moderatora, ograniczony czas programu i interes publiczności: [...] ja tu jestem niestety od tego, żeby czasu pilnować $i$ niestety nie mogę już panu pozwolić skończyć nawet jednym zdaniem [...]; 45 minut mamy i wtaśnie mijaja te minuty; No, możemy tak próbować równolegle jeszcze, ale to się nie uda. W każdym razie z mizernym skutkiem dla widzów.

Ogólnie w końcowej fazie daje się zauważyć usztywnienie struktury programu, przejawiające się tym, że prowadzący bardziej restrykcyjnie zarządza czasem interakcji: udziela głosu według własnego planu i zasadniczo nie pozwala na spontaniczne włączanie się rozmówców (chyba że uda im się to wynegocjować), limituje długość wypowiedzi, wysyła werbalne i niewerbalne sygnały ponaglenia, skraca wypowiedzi.

KD. Ksiądz Arek Nowak. (9.12.2004)

KD: Pan profesor Nałęcz i pan profesor Niesiołowski. (16.12.2004)

KD: Dobrze, ostatni głos należy do pani i wracamy do stolika naszych ekspertów. (18.11.2004)

KD: Panie pośle, dwa ostatnie głosy, pan senator i pan redaktor. Pan senator Gowin.

(11.01.2006)

Dziennikarz wskazuje konkretnych rozmówców, wyznacza kolejność, najczęściej przez imienne zaanonsowanie (podczas gdy w części środkowej możliwe są sekwencje wymian tylko między rozmówcami, w które dziennikarz nie 
ingeruje). Charakterystyczne dla fazy końcowej jest planowanie kilku wypowiedzi do przodu w celu usprawnienia interakcji. Pojawiają się również oznaczenia wypowiedzi jako ostatnich (jest to nadawanie statusu wypowiedzi w strukturze całości interakcji, nazywamy to również pozycjonowaniem), co jest zapowiedzią zakończenia. Wydaje się, że oznaczenie wypowiedzi jako ostatniej stanowi wskazówkę dla nadawcy, że powinien uformować swoją wypowiedź według konwencji zakończenia (raczej synteza niż analiza; raczej uogólnienie niż szczegóły; nie zaczynanie nowych wątków, ale podsumowanie; forma krótka, a nie rozwlekła; prymat treści pierwszoplanowych nad tłem).

PB: Mamy jeszcze tutaj panią któral

KD: Ale dostownie jedno zdanie. (18.11.2004)

KD: Jednym zdaniem. (20.01.2005)

LS: [Jeśli prostytucja//

KD: [Jednym zdaniem, pani Liliano, dobrze?

LS: Ja chciałam tylko jedno zdanie wtaśnie powiedzieć. Dlaczego kraje europejskie, cywilizowane, bo pan tak mówit, tak wszędzie jest w [cywilizowanym świecie//

KD: [Pani Liliano, musimy kończyć. (13.01.2005; gość - LS: Liliana Sonik)

AF: Panie profesorze, ale ja mam jeszcze jedna sprawę, o której [koniecznie muszę powiedzieć.

KD: [Proszę ojca, to jednym zdaniem, bo czas nam kończyć.

AF: Jednym zdaniem. [...] (24.02.2005; gość - AF: Artur Filipowicz)

KD: Panie profesorze, [trzy ostatnie zdania.

RB: [Już kończę. I dzisiaj żadnych nie będzie stosów [...].

(9.12.2004; gość - RB: Ryszard Bender)

Udzieleniu głosu w fazie końcowej towarzyszy akt stanowczej prośby (lub nawet żądania), obligujący rozmówcę do krótkiej wypowiedzi (jednym zdaniem, dostownie jedno zdanie $)^{28}$. Dziennikarz, używając formuły metakomunikacyjnej, projektuje, jak ma się zachować mówca, aby dostosować się do konwencji stylistycznej fazy końcowej. Rozmówcy akceptują tę konwencję, dlatego podejmują

${ }^{28}$ Duża frekwencja tego typu wyrażeń, ich niedosłowne odczytanie, frazeologizacja (rozmówcy zawsze wygłaszają dłuższą wypowiedź, kilkuzdaniową), wyraźna funkcja organizacji interakcji (regulowanie przejmowania tur w fazie końcowej) i, co najważniejsze, konwencjonalizacja w tej funkcji (rozmówcy zdają sobie sprawę z umowności wyrażenia i jego funkcji) powodują, że wyrażenia typu jednym zdaniem można uznać za operatory. Według Awdiejewa i Habrajskiej: „Operatorami organizacji dyskursu są wyspecjalizowane jednostki językowe przeznaczone do nawiązywania, podtrzymania i kończenia kontaktu oraz różne zrytualizowane formy, wprowadzające z góry ustalone sposoby zachowania się werbalnego" (Awdiejew, Habrajska 2006: 174). Charakterystyka temporalna wypowiedzi narzucana z góry jest niewątpliwie ustalaniem sposobu zachowania się, swoistym aktem żądania: „powiedz to w określony sposób, krótko”. 
strategię metadyskursywną negocjowania głosu (ja tylko jednym zdaniem, już kończę), zapewniają o chęci zabrania głosu (koniecznie muszę powiedzieć). Umowność konwencji sprawia, że nie realizują zapewnień, przedłużają wypowiedź i dziennikarz jest zmuszony interweniować, przerywając (musimy kończyć).

Ożywienie aktywności rozmówców i limitowanie czasu przez dziennikarza towarzyszą głównym wyróżnikom fazy końcowej, mianowicie metatekstowym formułom zapowiedzi zakończenia. Są one zwiastunem, pierwszym etapem realizacji makrointencji fazy końcowej, intencji zakończenia kontaktu (ostatecznym zakończeniem kontaktu są akty grzecznościowe pożegnania). Zapowiedzi zakończenia mają inną funkcję niż zapowiedzi w fazie otwarcia. Służą dyscyplinowaniu rozmówców pod względem długości wypowiedzi (jak w przytoczonych już przykładach) oraz wprowadzają rygory, ograniczenia dotyczące treści oraz doboru wątków.

KD: Puentujemy, puentujemy. Pani poset [...].

KD: Dobrze. Do puenty zmierzamy. Zmieniamy prawo? W jakim obszarze i co w pierwszej kolejności? Jednym zdaniem. (25.01.2006)

KD: Ale zostawmy Wtochy. I proszę już tylko o odpowiedź na koniec//

IK: Ja powiem tylko króciutko, że w Polsce też jest sfera kompromisów.

(18.01.2006; gość - IK: Ireneusz Krzemiński)

JL: [...] jedna strona miała rację $i$ ta druga strona nigdy tego nie powiedziata. Rację miała opozycja, rację miata „Solidarność”. I to nie zostato po drugiej stronie nigdy powiedziane.

KD: Dobrze. I co teraz zrobić? Mamy pięć minut do końca programu. Trzeba się/ spróbujmy do jakiejś konkluzji.

JL: [...] nigdy to nie zostało powiedziane: „Komunizm byt złem. Byliśmy po złej stronie”.

$\mathrm{KD}$ : Ale to się nie wydarzyto. Co teraz? Co trzeba zrobić?

KD: Pan profesor Kubicki. Co trzeba zrobić, pan ma odpowiedź na to pytanie? Potrafi pan sobie odpowiedzieć na pytanie, co trzeba zrobić żeby//

(16.12.2004; gość - JL: Jan Lityński)

KD: Dobrze, ale wróćmy do referendum, bo program się zbliża do końca, trzeba jakąś konkluzję. $[\ldots]$

KD: Musimy wrócić do mojego pytania, bo program się nam kończy, a chciałbym, żeby pań-

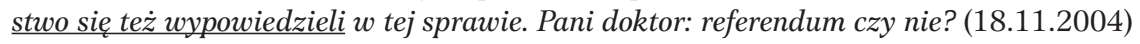

KD: To jest pytanie do tych osób ${ }^{29}$, które się zajmują tym na co dzień: jaki instrument/ wyposażenie $w$ jaki instrument państwa, ludzi, którzy zajmują się narkomanami, pracują z narkomanami, mógłby tę sytuację poprawić? (10.02.2005)

${ }^{29}$ Pytania w fazie końcowej są najczęściej ukierunkowane i zamknięte. Są skierowane do tego, kto może coś ciekawego na dany temat powiedzieć, ze względu na uwikłanie w sprawę, kompetencje. W części środkowej padają pytania ogólne, skierowane do wszystkich, ich charakter jest otwarty. 
Dziennikarz selekcjonuje wątki pod kątem ważności, istotności (Ale zostawmy Włochy). Wątki istotne dla poszczególnych rozmówców (jedna strona miała rację i ta druga strona nigdy tego nie powiedziała) zostają uznane przez dziennikarza za niefunkcjonalne z perspektywy celów debaty (Ale to się nie wydarzyto. Co teraz?). Jak widać, ważność nie jest cechą bezwzględną, należy więc doprecyzować, że chodzi o przydatność konkretnych treści do sformułowania konkluzji, wniosku. Uwarunkowania gatunkowe debaty publicznej powodują, że dziennikarz najczęściej uznaje za ważne praktyczne procedury rozwiązania konkretnego problemu, wypracowanie instrumentów kontroli, regulacji (Zmieniamy prawo? W jakim obszarze i co w pierwszej kolejności? Co teraz? Co trzeba zrobić? [...] referendum czy nie? [...] wyposażenie w jaki instrument [...] mógłby tę sytuację poprawić?).

Strategie strukturalne dziennikarza zmierzające do podsumowania dyskusji, wypracowania konkluzji, należy zatem uznać za priorytetowe w fazie końcowej. O ile jednak zmierzanie do jakiejś konkluzji jest realizacją kolejnej fazy interakcji, to sterowanie sytuacją tak, aby ta konkluzja miała określoną treść, niejako zaprojektowanie jej, jest już intencją perswazyjną dziennikarza. Rola prowadzącego debatę zasadniczo nie pozwala na bezpośrednie angażowanie się w merytoryczne rozstrzygnięcia, więc jako porte parole nadawcy medialnego występuje ostatni mówca w mikrosytuacji. Po zachowaniach dziennikarza broniących tego głosu widać, że realizuje on określony plan.

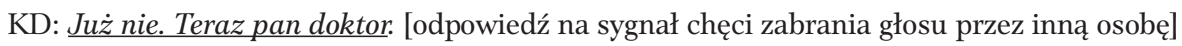

PŁ: Mam wrażenie, że tutaj cały czas lawirujemy, żonglujemy jakimiś takimi strasznie wielkimi słowami, ogólnymi pojęciami w rodzaju „życie”, „człowiek jako taki” itd. Tymczasem wydaje mi się, że tak naprawdę najczęściej mamy do czynienia z losami konkretnych osób. Konkretnych osób, które znajdują się w bardzo szczególnej często sytuacji życiowej. I wydaje mi się, że jeśli mamy żyć $w$ państwie demokratycznym, w którym ma być swoboda na to, abyśmy żyli wedle swoich przekonań o tym, jakie jest dobre życie, to wydaje mi się, że pewien/ miejsce na wybór musi być. Obecna sytuacja takiego wyboru nie daje. [oklaski]

(18.11.2004; gość - PŁ: Paweł Łuków)

TC: I panie senatorze zgodzimy się, rezygnujemy z odprysku, rezygnujemy z fundamentalizmu. Zgadzamy się, że jest to fala, okay?

JG: No, fala która jest//

TC: Która nie tonie.

KD: I specjalista od fali i tej retoryki tsunami tutaj jest akurat pan redaktor Zajac.

MZ: Ja chciałbym dokończyć zdanie, którego, niestety, pan poset nie zdołał dokończyć. Kto sieje wiatr, ten zbiera burzę. I niestety, kłopot z Radiem Maryja, moim zdaniem, polega tylko na jednym: nie na katechezie, która popierają wszyscy biskupi, nie na modlitwie, która popieraja wszyscy biskupi - polega na tym, że jeżeli pojawiaja się tam treści nasycone nienawiścia, to potem ta nienawiść jak bumerang uderza również $w$ Kościót.

(11.01.2006; goście - JG: Jarosław Gowin, MZ: Marek Zając, TC: Tadeusz Cymański)

Dziennikarz wyraźnie wyreżyserował końcowy fragment. Nie pozwala na zakłócenie planu, odrzuca głosy konkurencyjne bądź kończy bieżące 
wypowiedzi ${ }^{30}$. Wypowiedzi rozmówców mają cechy tekstu mówionego, częściowo przygotowanego (przemyślana budowa, płynne wygłaszanie). Dziennikarz pod koniec programu nie zadaje pytań otwartych, które prowokują dłuższe wypowiedzi o trudnym do przewidzenia kierunku, lecz stawia pytania zamknięte ${ }^{31}$, pytania o rozstrzygnięcie, wręcz pytania z tezą.

KD: $\underline{\text { Czy to nie jest tak, }}$ że to podsycanie/ znaczy, że te emocje tak/ tak ogromne jednak sa na rękę niektórym politykom, bo one umożliwiają rozgrywanie/ umożliwiają pobudzanie, umożliwiaja kierowanie dyskusji czasami na tory, które są mało istotne w catej sprawie? Pan Jan Lityński i pan profesor. (20.01.2005)

Dziennikarz w fazie końcowej prezentuje własną perspektywę. Jest to perspektywa gospodarza debaty publicznej, który dostrzega nie tylko rzeczywistość polityczną, ale przede wszystkim rzeczywistość komunikacyjną debaty, w której temat zyskuje wtórną funkcję, jest instrumentalnie wykorzystywany do partykularnych celów.

KD: Mhm. A żeby pozostać już przy tych ocenach, które sa dość jasne. Ale to bardzo istotne, co pan profesor powiedziat. Jeśli jest taki podziat, on się raz wyraża w większych emocjach, raz $w$ mniejszych emocjach - to co należy zrobić, żeby pomiędzy tymi skrajnymi zupetnie i niedopuszczajacymi żadnych argumentów postawami, gdzieś w środku, znalazła się przestrzeń, po pierwsze, do spokojnej dyskusji na ten temat, a po drugie, co mi się wydaje istotniejsze, do historii, której można uczyć młodzieży, tych młodych ludzi, którzy w tej chwili uczą się o stanie wojennym w szkołach? (16.12.2004)

KD: Dobrze. Panowie, czy jest miejsce między tym pogladem prezentowanym przez pana: „Publikujemy. Otwarte archiwa” a panów punktem widzenia? Czy zmiana dzisiejszych przepisów, rozszerzenie na przykład uprawnień IPN-u, rozszerzenie kategorii osób, które moga do tego zagladać, czy to jest wyjście? (20.01.2005)

KD: Miejsce na kompromis? [wskazuje Czestawa Bieleckiego].

CB: Otóz to. Miejsce na kompromis jest [...]

(20.01.2005; gość - CB: Czesław Bielecki)

${ }^{30}$ Zwraca uwagę taktyka płynnego, ale jednak podstępnego przejmowania tury: dziennikarz niby podejmuje temat rozmówcy (fala), ale tak naprawdę buduje sobie tylko most do odebrania mu głosu.

${ }^{31}$ Ze względu na sposób wyznaczenia przez pytanie struktury odpowiedzi odróżnia się pytania otwarte od pytań zamkniętych (por. Boniecka 1978, 2000; Sobczak 2006; SzkudlarekŚmiechowicz 2010). Pytania otwarte nie wyznaczają swoim kształtem postaci odpowiedzi, pozostawiając pytanemu swobodę w jej konstruowaniu, np. Jak pan ocenia wydarzenie?, Co sądzi pan o zdarzeniu? Pytania zamknięte pod względem formalno-semantycznym mogą mieć postać pytań do rozstrzygnięcia (np. Czy widzi pan możliwość porozumienia?) lub postać pytania o uzupełnienie (np. Kiedy rząd przygotuje ustawę?). Ze względu na intencje komunikacyjne pytającego Krzysztof Szymanek wyodrębnia (niezależnie od kryteriów formalno-syntaktycznych) m.in. pytania sugestywne, pseudopytania. Ich celem jest narzucenie też, informacji (Szymanek 2004: 260). 
Dziennikarz wyraźnie kreuje sytuację komunikacyjną jako sytuację debaty publicznej, którą wypełniają nie tyle zjawiska i wydarzenia, co związane z nimi postawy, punkty widzenia, oceny, emocje. Do ważnych wskaźników gatunkowych debaty w zakresie kreowanego obrazu świata należy eksponowanie skrajności, jednoznaczności postaw, różnicy, podziałów. Jednocześnie w fazie końcowej prowadzący steruje sytuacją komunikacyjną debaty: nakłania rozmówców do poszukiwania kompromisu i optymalnych dla obu stron rozwiązań.

W fazie końcowej następuje podsumowanie dyskusji i wygaszenie kontaktu w mikrosytuacji. Ostatnim segmentem tej fazy jest (wyodrębnione za pomocą sygnałów delimitacyjnych) zakończenie, w którym następuje wygaszenie kontaktu z widzami w makrosytuacji i skończenie programu. Fazę końcową wyodrębniają symptomy delimitacyjne, takie jak zmiana zachowań rozmówców (większa aktywność, chęć zabrania głosu w strategicznym momencie końcowym) i dziennikarza (usztywnienie struktury interakcji, limitowanie czasu, ustalanie kolejności rozmówców, ich dyscyplinowanie). Do sygnałów delimitacyjnych można zaliczyć oznaczanie wypowiedzi jako ostatniej, metatekstowe formuły zapowiedzi zakończenia, metatekstowe formuły korygujące zachowania rozmówców pod kątem dostosowania do konwencji zakończenia. Konwencję tę realizują takie cechy wypowiedzi, jak: krótkość, zwięzłość, ważność, syntetyzm, uogólnienie, wreszcie funkcjonalność w realizacji celów gatunkowych debaty.

\subsubsection{Zakończenie}

Zakończenie jest finalnym elementem ramy tekstu, zwieńczeniem fazy końcowej, w której następuje stopniowe wygaszanie ${ }^{32}$ kontaktu. Pod względem strukturalnym jest to segment makrosytuacyjny, symetryczny do wprowadzenia (oba segmenty łączy ten sam nadawca, sposób wygłaszania, plan kamery). W znaczeniu obiegowym o zakończeniu mówi się jako o 'ostatniej części czegoś, końcowej części przedmiotu'. Zakończyć to znaczy 'doprowadzić do końca, przestać coś robić, być ostatnią częścią czegoš’33. Treść denotacyjna pojęcia „zakończenie” jako rezultatu czynności eksponuje aspekt strukturalny, bycie ostatnią częścią całości, natomiast motywacja czasownikowa utrzymuje w tle aspekt czynnościowy. Zakończenie jest bowiem również działaniem mownym dziennikarza i jako takie podlega analizie komunikacyjnej.

32 Termin „wygaszanie kontaktu” jest użyty w znaczeniu specjalistycznym, jako działanie zmierzające do zakończenia kontaktu, inicjujące jego zamknięcie (Pałka 2009: 219). W tym znaczeniu spotyka się również termin „wyciszanie dialogu”. Jego formuły mają charakter metatekstowy. Funkcją formuł jest sygnalizowanie intencji zakończenia dialogu, np. Przepraszam, ale muszę już kończyć; Niestety zmuszony jestem kończyć rozmowę (Ożóg 1990: 29).

${ }^{33}$ Leksem zakończenie oznacza 'ostatnią, końcową część jakiejś historii, sprawy, jakichś działań, itp.; koniec, epilog’ (USJP, t. 5: 479). 


\section{Fragment 1 (18.11.2004)}

KD: Poziom emocji tutaj $w$ studiu, jak państwo styszeli i pewnie podczas tej debaty [na temat aborcji], która w najbliższym czasie w Sejmie się pojawi, będzie ogromny. Chyba jednak aż takich emocji w tej sprawie uniknać się nie da. To byta „Debata”. Bardzo państwu dziękuję. Następna za tydzień.

\section{Fragment 2 (25.11.2004; gość - HK-S: Hanna Kowalska-Stus)}

HK-S: No wszystko jedno, $w$ każdym razie/ $w$ każdym razie może/ może szkoda. [... $]^{34}$

KD: Pani profesor, wiem, czego na pewno nie szkoda: wszyscy mają nadzieję, że ten konflikt na Wschodzie rozwiąże się pokojowo $i$ że zakończy się po prostu dobrze dla Ukraińców. Ale takim ubocznym, chociaż bardzo dobrym efektem i polskiej obecności na Ukrainie, i polskiego zaangażowania, jest fakt, że te cztery dość dramatyczne dni chyba jednak zbliżyty Ukraińców i Polaków tak, jak już dawno w historii nie bywało i przynajmniej z tego się cieszmy. To była „Debata”. Dziękuję państwu bardzo. Dobrej nocy.

\section{Fragment 3 (9.12.2004; gość - RB: Ryszard Bender)}

RB: [...] [Chrześcijańska mitość, chrześcijańska miłość//

KD: [I warto zawsze o tym dyskutowaćl bardzo przepraszam, bo czas nam się skończyt. Warto zawsze o tym dyskutować także dlatego, żeby te pojęcia, wśród których się dzisiaj obracaliśmy: tolerancji, braku tolerancji, dyskryminacji nabraty być może bardziej/ znaczy większego wyrazu czy większej wyrazistości. Dyskusja na ten temat zawsze jest potrzebna. Bardzo państwu dziękuję. To byta „Debata”. Do zobaczenia za tydzień.

\section{Fragment 4 (16.12.2004)}

[w tle słychać gwar rozmów, który nie cichnie podczas wygłaszania zakończenia]

KD: I to ciekawe, że jednak zaczęliśmy, proszę państwa, że zaczęliśmy i kończymy od dwóch zupetnie różnych opinii i spieramy się jednak o ocenę. Wydaje mi się, że długa i bardzo trudna dyskusja czeka nas jeszcze przez wiele lat, żebyśmy o skadinad bardzo bolesnych wydarzeniach naszej najnowszej historii [stan wojenny] potrafili ze soba spokojnie i na argumenty rozmawiać. To byta „Debata”. Dziękuję państwu.

\section{Fragment 5 (13.01.2005; gość - LS: Liliana Sonik)}

LS: -dlaczego kraje europejskie odchodza od legalizacji [prostytucji], mato tego, ida $w$ strone dosyć mocnych zakazów?

KD: No tak, ale Czesi akurat ida w stronę legalizacji, czy poszli wtaściwie w stronę legalizacji. Sporu nie rozstrzygniemy. Proszę państwa, argumenty państwo poznali [gwar rozmów w tle]. Dyskusja jeszcze trwa [śmiech widowni]. Wtaśnie się skończyta. Ja myślę, że skoro ta dyskusja trwała przez kilka tysięcy lat $i$ spór trwat tak dtugo, to obawiam się, że także w najbliższym czasie nie zostanie rozwiązany. W każdym razie nie jednoznacznie. W tej sprawie niewatpliwie potrzeba albo pozostawienia dzisiejszego stanu prawnego, albo uregulowań nowych, ale to jest w rękach polityków. I nie wiadomo, jak ta dyskusja będzie przebiegała. W każdym razie na pewno niespokojnie, sądząc z dzisiejszego przebiegu. Dziękuję bardzo. To byta „Debata”. Do zobaczenia za tydzień o tej samej porze.

Fragment 6 (10.02.2005; G: gość z publiczności [bez podania nazwiska])

G: [...] Tworzenie wielu ośrodków, gdzie ludzie moga zmieniać siebie, plus praca z rodzina, plus perspektywy//

34 Jeśli inicjacja zakończenia jest motywowana kontekstem językowym, to przed zakończeniem dodano odnośny fragment tekstu. 
KD: No więc wtaśnie praca z rodzina, bo zanim nasze dziecko, albo nasz syn dwunastoletni, trafi do takiego ośrodka [dla narkomanów] i poddany tam zostanie terapii i leczeniu, to najpierw pewnie daje jakieś sygnały w domu, że coś dzieje się nie tak. Więc po prostu, nie chciałbym, żeby to zabrzmiało jakoś szczególnie banalnie, ale warto patrzeć na swoje dzieci, warto obserwować swoje dzieci, a przede wszystkim warto kochać swoje dzieci. Dziękuję bardzo. To byta „Debata”.

Fragment 7 (24.02.2005; goście - AF: Artur Filipowicz, IK: Ireneusz Krzemiński)

AF: [...] wystarczy bliskość drugiego, żeby nie musiat prosić o eutanazję.

KD: Prosze państwa,

IK: Czasem tak, a czasem nie.

KD: - to jest tak, że rozpoczęta się dyskusja. Ona się rozpoczęta w takim miejscu, które zdaje się nie jest najwłaściwszym miejscem do jej inauguracji, czyli w Sejmie, wśród polityków. Jedno jest niewatpliwie dobre $w$ odrzucaniu tego projektu i mam nadzieję, że pani profesor tutaj się ze mna zgodzi, że być może to jest początek dyskusji, która najpierw będzie prowadzona w zupetnie innych gronach i w zupetnie innych środowiskach, a dopiero potem, po wnioskach z tej dyskusji ptynacych, dotrze taki albo inny, albo podobny projekt [dotyczący eutanazji] do Sejmu i dopiero wtedy zajma się nim politycy. Wtedy, czyli na końcu. Dziękuję bardzo, to byta „Debata”. Do zobaczenia.

\section{Fragment 8 (4.01.2006; gość - JM: Janusz Maksymiuk)}

JM: [Żotnierzy zostawmy.

KD: [Wszyscy byśmy chcieli ${ }^{35}$, żeby 900 naszych żotnierzy $w$ dobrym zdrowiu wrócito 31 grudnia 2006 roku, czyli tego roku, do Polski i nie musiato wracać do Iraku. To była „Debata”. Bardzo państwu dziękuję za uwagę. Przypominam, że jeszcze „Debata” na stronie internetowej www.itvp.pl będzie się toczyła przez kilka minut. Tam między innymi pytania internautów. Dziękuję bardzo. Życzę dobrej nocy.

\section{Fragment 9 (11.01.2006)}

KD: Mhm. Bardzo panom dziękuję i państwu także za tę dyskusję. Ja przypominam tylko, $\dot{z} e$ „Debata” będzie trwała jeszcze przez kilka minut w Internecie na stronie www.itvp.pl. I myśle sobie, że jeśli rozmawiamy o różnych poglądach, i różnicy $w$ poglądach [na temat Radia Maryja], to problemem chyba nie jest to, że te poglady się pojawiaja, ale to, czy potrafimy budować mosty, czy podstawy, na których toczy się dialog między tymi, którzy różne poglądy prezentują. Ale to już zupetnie inna kwestia. To byta „Debata” dziękuję bardzo. Do zobaczenia.

\section{Fragment 10 (18.01.2006)}

KD: [zwracając się do gości w studiu] Bardzo panom dziękuję. [zwracając się do kamery, tyłem do gości] Proszę państwa, dalszy ciagg „Debaty” to już nie w pierwszym programie Telewizji Polskiej, ale można wejść $w$ Internet: www.itvp.pl. Tam jeszcze kilka minut rozmowy z naszymi gośćmi, później czat z Bronistawem Wildsteinem. A ja zapraszam już za chwilę/ chwil kilka na program Moniki Olejnik „Prosto w oczy”, w którym gościem będzie, no, człowiek, którego nazwisko przewijało się dzisiaj wielokrotnie w „Debacie”, czyli Jarosław Kaczyński. Dzisiaj to wszystko. Bardzo dziękuję. Do zobaczenia. Dobrej nocy.

35 Dziennikarz zaczyna zakończenie pomimo toczącej się dyskusji. To świadczy o realizowaniu inicjacji motywowanej sytuacją, ograniczonym czasem, a nie wyczerpaniem tematu. 
Fragment 11 (25.01.2006)

KD: Bardzo paniom dziękuję. Paniom dzisiaj. [zwracając się do kamery, tyłem do gości] Myślę, że to byty ciekawe uwagi, ciekawe opinie, nawet jeśli czasem trudno mi było zadać pytanie. Rozmaite, ciekawe trendy docieraja do nas z Zachodu, w zwiazku z czym przypomnijmy, kto jest kanclerzem naszych bezpośrednich zachodnich sąsiadów i przypomnijmy, jaka kampania wyborcza i kto przeciwko komu szykuje się w Stanach Zjednoczonych. Swoja drogą kampania wyborcza $w$ Polsce, w której bytyby dwie kandydatki na najwyższy urząd w państwie - to musiatoby być coś bardzo ciekawego, żeby nie powiedzieć fascynującego. A to byta „Debata”. Bardzo państwu dziękuję. Do zobaczenia. Aha ${ }^{36}$, i jeszcze przypominam, że dalszy ciąg „Debaty” jest w Internecie: www.itvp.pl. Jeszcze przez kilka minut internauci moga nas oglądać. Dziękujemy. Dobrej nocy.

\section{Fragment 12 (8.02.2006)}

KD: Pewnie o telewizji i także o mediach moglibyśmy jeszcze bardzo dtugo, ale ten program ma 45 minut i się kończy. Zresztą wszystko, proszę państwa, się kiedyś musi skończyć. Zwykle o tej porze $w$ „Debacie” mówitem państwu dobranoc $i$ do zobaczenia. Przez osiem lat pracy w pierwszym programie Telewizji Polskiej, przez 10 lat pracy na Woronicza, pewnie kilka tysięcy razy powiedziatem państwu dobranoc i do zobaczenia. To jest ostatnia „Debata” i ostatni mój program w TVP. Chcę państwu podziękować. Podziękować za zaufanie. Podziękować, że byli państwo ze mna wtedy, kiedy byto naprawdę trudno. Dziękuję i do zobaczenia.

Analizowane przykłady zakończenia stanowią zachowania komunikacyjne motywowane makrosytuacją, których makrointencją jest skończenie programu i zamknięcie kontaktu. Minimalną realizacją zakończenia mogłyby być zatem formuły skończenia programu typu: To byta „Debata” i akty grzecznościowe pożegnania: Dobrej nocy. Jednak cele komunikacyjne dziennikarza, być może również wydawcy programu, powodują rozbudowanie segmentu o element, który bywa wypełniony różnymi treściami (podsumowanie, wniosek, puenta), ale jego dominującą funkcją jest wyciszanie kontaktu poprzez oddalenie perspektywy i globalizację ujęcia. Mówiąc bardziej obrazowo - jest to wyhamowanie żywiołowej interakcji poprzez rzut oka na całość sytuacji, przy czym może to być sytuacja bieżącej interakcji lub globalna sytuacja debaty publicznej w ujęciu retrospektywnym lub prospektywnym.

Wystąpienie elementu wyciszającego jest motywowane polską normą grzecznościową, a właściwie jej użyciem do imitowania kontaktu bezpośredniego. Do dobrego obyczaju, świadczącego o więzi między rozmówcami, należy bowiem uzasadnianie okoliczności skończenia rozmowy. Gwałtownie skończyć rozmowę po prostu nie wypada. Według Małgorzaty Marcjanik: „Samo zakończenie poprzedzone bywa - zgodnie z ogólnymi normami grzecznościowymi - zwiastunem zakończenia, będącym formą wyciszania kontaktu” (Marcjanik

36 „Aha” w inicjacji sygnalizuje wprowadzenie nowej, niewiążącej się z kontekstem informacji. J. Warchala uznaje to wyrażenie za sygnał inicjacji kontekstualnie niezależnej (Warchala 1991: 73). 
2007: 126). W komunikacji interpersonalnej formy wyciszania są zróżnicowane i zależne od sytuacji, natomiast w komunikacji masowej są to najczęściej formuły stereotypowe (Dziś to już wszystko, Musimy już kończyć). Na tle innych programów ${ }^{37}$ publicystycznych, zwłaszcza krótszych, „Debata” ma dość rozbudowany segment zakończenia. Można postawić tezę, że dziennikarz wykorzystuje strategicznie rozbudowaną formę zakończenia do kreowania bardziej bezpośredniego kontaktu $\mathrm{z}$ widzami ${ }^{38}$. Na taką interpretację naprowadzają również zachowania niewerbalne dziennikarza, który mimiką, gestem, barwą głosu buduje więź z odbiorcą masowym.

Za maksymalny dla repliki dziennikarza, zawierającej zakończenie ${ }^{39}$, należy uznać następujący schemat o umiarkowanej przestawialności elementów:

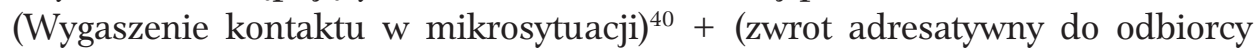
$\mathrm{w}$ makrosytuacji) + element treściowy, wyciszający interakcję + [skończenie programu + podziękowanie + pożegnanie $]^{41}$.

Najwyraźniejszym sygnałem delimitacyjnym zakończenia jest sygnał wizualny, polegający na zmianie ustawienia kamery: z planu ogólnego, obejmującego postacie i otoczenie - na plan średni, który pokazuje postać dziennikarza głównego od pasa, oraz zmiana ujęcia osoby prowadzącego: z ujęcia „z profilu” na ujęcie „en face”. Plan średni jest sposobem prezentacji, który według kodu planów oznacza kontakt społeczny (o dystansie 1,2 do 3,6 m) (por. Mrozowski 2001: 281).

Dużą trudność stanowi grzeczne, ale stanowcze zakończenie interakcji w mikrosytuacji. Zmienność sytuacji wyznacza tu zachowanie widzów oraz umiejętności dziennikarza. Prowadzący stosuje różne techniki: podstawowym zachowaniem jest wykorzystanie zmiany planu kamery przez oddalenie się od publiczności (plan ogólny) i podejście do kamery (plan średni). Przeorientowaniu się dziennikarza z interakcji w studiu (gdzie tylko pośrednio przekaz jako całość jest kierowany do widza) na układ z odbiorcą masowym (gdzie prowadzący mówi wprost do widza) może towarzyszyć podziękowanie jako ostatni element

37 W innych typach programów, np. „Kwadrans po ósmej”, „Kwadrans po jedenastej”, „Prosto w oczy”, które są programami krótszymi od „Debaty”, trwają do 15 minut, zakończenie jest realizowane w wersji minimalnej, np. „Dziękuję bardzo. Gościem programu «Prosto w oczy» był premier Kazimierz Marcinkiewicz”. Zapowiedzią zakończenia jest oznaczenie ostatniego pytania: „I ostatnie pytanie [...]”, „Na koniec proszę powiedzieć [...]”.

38 Intencja ta staje się jawna w zakończeniu cyklu programów, w którym pojawiają się wątki wręcz osobiste (por. fragm. 12: [...] byli państwo ze mna wtedy, kiedy było naprawdę trudno; jest to nawiązanie do wsparcia, jakiego widzowie udzielili dziennikarzowi, gdy ten ujawnił w mediach informację o swojej chorobie nowotworowej).

39 Ostatnia replika dziennikarza tak naprawdę nie musi być wypełniona w całości zakończeniem. Może rozpoczynać się wygaszeniem interakcji w mikrosytuacji.

${ }^{40}$ Nawias okrągły symbolizuje nieobligatoryjność elementu.

41 W nawiasie kwadratowym umieszczono trzy elementy, z których obligatoryjnie występują co najmniej dwa; pominięte może być pożegnanie lub skończenie programu. 
mikrosytuacji i/lub zwrot adresatywny do widzów jako uwyraźnienie makrosytuacji. Podziękowanie gościom i zwrot do widzów to werbalne sygnały delimitacyjne oddzielające korpus zasadniczy od zakończenia, mikrosytuację od makrosytuacji: Bardzo panom dziękuję (do gości w studiu, plan ogólny). Proszę państwa, dalszy ciag „Debaty” to już nie w pierwszym programie [...] (tyłem do gości, bezpośrednio do kamery, plan średni). Czasem dziennikarz dziękuje osobno gościom i osobno publiczności w studiu, czym podkreśla inny status tych grup w organizacji debaty: Bardzo panom dziękuję (do gości za stołem) i państwu także za tę dyskusję (do publiczności).

Zachowanie dziennikarza jest w podanych przykładach motywowane zdecydowanie kontekstem sytuacyjnym, a mianowicie ograniczonym czasem programu (por. Pewnie o telewizji i także o mediach moglibyśmy jeszcze bardzo dtugo, ale ten program ma 45 minut i się kończy - fragm. 12). Według Jacka Warchali, inicjacje motywowane sytuacyjnie wprowadzają do struktury dialogu pewne rozluźnienie, podważają jego zwartość (Warchala 1991: 77). Czasem dziennikarz stosuje więc taktykę uspójniania, polegającą na motywowaniu inicjacji dodatkowo kontekstem językowym. Wówczas część jego wypowiedzi koreferuje z częścią wypowiedzi przedmówcy.

HK-S: No wszystko jedno, w każdym razie/ w każdym razie może/ może szkoda. [...]

KD: Pani profesor, wiem, czego na pewno nie szkoda: wszyscy maja nadzieję, że ten konflikt na Wschodzie rozwiąże się pokojowo, i że zakończy się po prostu dobrze dla Ukraińców. (fragm. 2)

G: [...] Tworzenie wielu ośrodków, gdzie ludzie moga zmieniać siebie, plus praca z rodzina, plus perspektywy//

KD: No więc wtaśnie, praca z rodzina, bo zanim nasze dziecko, albo nasz syn dwunastoletni, trafi do takiego ośrodka [...]. (fragm. 6)

Nawiązanie pierwsze ma charakter bardzo ogólny i raczej formalny - na zasadzie przeciwstawienia obiektów (szkoda X, a Y nie szkoda). Zaimek kataforyczny „czego” otwiera przestrzeń dla nowej informacji, która jest już realizacją intencji zakończenia i nie jest tematycznie powiązana z poprzednią wypowiedzią. Niemniej jednak dążenie do stworzenia formalnego pozoru spójności, właściwie „zahaczenia” o kontekst, może świadczyć o poziomie kompetencji komunikacyjnych dziennikarza, który dostrzega kategorię spójności jako podstawową kategorię tekstotwórczą.

Większy stopień powiązania, tym razem również tematycznego, obserwujemy w drugim przykładzie. Replika dziennikarza rozpoczyna się od sygnału fatycznego (No więc wtaśnie) ${ }^{42}$, którego dodatkową funkcją jest nawiązanie do

${ }^{42}$ Wyrażenie metatekstowe „no” pełni rolę incipitu, jest sygnałem rozpoczęcia przez odbiorcę nowej repliki. Jego interpretacja jest następująca: „Zapowiadam nową replikę, zajmuję kanał”. „Więc” jest dodatkowym wskaźnikiem nawiązującym. „Właśnie” należy do sygnałów fatycznych akceptujących i hierarchizujących treści, za jego pomocą nadawca podkreśla ważność jednego 
poprzedniej wypowiedzi i hierarchizacja treści (podkreślenie ważności informacji). Informacja uznana za ważną zostaje powtórzona (właśnie, praca z rodzina), po czym nadawca wprowadza pole tematyczne „rodzina”. Aktualizuje on inne elementy pola niż przedmówca: nie w układach instytucjonalnych (ośrodek, terapia), ale sferze prywatnej (nasze dziecko). Jak wynika z powyższych przykładów, to dziennikarz inicjuje zakończenie programu, które jest motywowane sytuacyjnie i może być dodatkowo motywowane kontekstem językowym. Typ inicjacji motywowany sytuacyjnie i kontekstowo świadczy o zastosowaniu przez dziennikarza taktyki uspójniania tekstu, co ułatwia odbiorcy scalanie informacji i imituje bardziej naturalny przebieg rozmowy.

Nie zawsze rozmówcy w studiu akceptują organizację programu i wobec ewidentnego niewyczerpania tematu kontynuują rozmowy. Medium rejestruje je jako niezróżnicowany semantycznie gwar w tle głośnej wypowiedzi dziennikarza, który może to zignorować lub nie: I to ciekawe, że jednak zaczęliśmy, proszę państwa [głośny gwar rozmów], że zaczęliśmy $i$ kończymy od dwóch zupetnie różnych opinii i spieramy się jednak o ocenę. Dziennikarz zaczyna wygłaszać zakończenie pomimo gwaru trwających rozmów ${ }^{43}$. Prowadzący może też zareagować werbalnie na zachowanie publiczności: Proszę państwa, argumenty państwo poznali [gwar rozmów w tle]. Dyskusja jeszcze trwa [gest wskazujący publiczność ${ }^{44}$ ], [publiczność przerywa dyskusję, reaguje śmiechem] Wtaśnie się skończyła (fragm. 5). Nadawca uznał spontaniczną dyskusję za wartą wydzielenia z tła poprzez jej wskazanie, ponieważ sytuacja ta stanowi egzemplifikację projektowanego obrazu debaty publicznej. Kreowanie obrazu debaty jako spontanicznej, permanentnej komunikacji zaangażowanych obywateli stanowi przykład strategii dziennikarza, który właśnie te parametry sytuacji uznaje za pożądane w medialnym dyskursie publicznym.

We fragmencie ujawnia się też różnica między rozmowami potocznymi i medialnymi. W naturalnej scenerii zakończenie i pożegnanie następują zazwyczaj za obopólną zgodą i w sytuacji wyczerpania tematu. Rozmowa zostaje zakończona, kiedy nadawca reagujący nie wprowadza nowej inicjacji, a nadawca inicjujący nie kontynuuje linii tematycznej ani nie podejmuje zabiegów wprowadzających

\footnotetext{
ze składników (Ożóg 1990: 17-110). Połączenie kilku wyrażeń metatekstowych ma charakter wzmocnienia.

${ }^{43}$ Gwar stanowi jednak przeszkodę i prawdopodobną przyczynę błędu językowego. Jest to błąd składniowy w zakresie składni rządu, będący wynikiem nieuprawnionego skrótu (zaczęliśmy i kończymy od dwóch opinii, poprawnie: zaczęliśmy od dwóch opinii i kończymy na dwóch opiniach).

44 Wyodrębnianie z percypowanej przestrzeni tego, co według nadawcy jest dla niego istotne, tworzy według Bonieckiej deskrypcyjny model sytuacji (Boniecka 1999: 50). Wykładniki wyznaczoności wyrażeń argumentowych (Topolińska 1984: 304) są jednocześnie sygnałami sytuacyjności. Jeśli wyznaczanie odbywa się za pomocą nazwy pospolitej, to stowarzyszenie jej z gestem odniesienia ułatwia identyfikację obiektu.
} 
nową linię tematyczną (Warchala 1991: 66). W rozmowach publicznych prowokowanych w mediach podstawą sytuacyjnego uzależnienia pożegnania jest czas trwania programu, ponieważ temat nie ulega wyczerpaniu, a rozmówcy najczęściej zgłaszają chęć kontynuowania zdarzenia komunikacyjnego.

[Mikrosytuacja] AF: [...] wystarczy ręka, wystarczy bliskość drugiego, żeby nie musiat prosić o eutanazję.

[Makrosytuacja] KD: Proszę państwa [wprost do kamery].

[Mikrosytuacja] IK: Czasem tak, a czasem nie.

[Makrosytuacja] KD: -to jest tak, że rozpoczęta się dyskusja [...]. (fragm. 7)

We fragmencie mamy do czynienia z nałożeniem się interakcji w mikrosytuacji (rozmowa $\mathrm{AF}$ z IK), która jeszcze trwa w czasie już rozpoczętej wypowiedzi w makrosytuacji (wygłaszania zakończenia). Brak reakcji ${ }^{45}$ dziennikarza na wtrącenia, zakłócenia stanowi dodatkowy symptom delimitacyjny, który stabilizuje oddzielenie segmentu zakończenia.

Omówione zachowania dziennikarza, zmierzające do zamknięcia interakcji w mikrosytuacji i zwrot adresatywny do widzów, uwyraźniają oddzielenie ramy tekstu. Ich fakultatywność powoduje jednak, że często pierwszym elementem zakończenia jest element treściowy odwołujący się (najczęściej) do sytuacji komunikacyjnej debaty. Wyróżnikiem jest tu nie tyle sama treść, co sposób jej ujęcia: uogólniający, syntezujący. Nadaje on działaniu mownemu charakter podsumowania, wniosku, puenty. $\mathrm{O}$ istnieniu swoistej konwencji stylistycznej zakończenia może świadczyć uwaga metakomunikacyjna wpleciona w tekst: Więc po prostu, nie chciałbym, żeby to zabrzmiało jakoś szczególnie banalnie, ale warto patrzeć na swoje dzieci, warto obserwować swoje dzieci, a przede wszystkim warto kochać swoje dzieci (fragm. 6). Dziennikarz wybiera na puentę programu stwierdzenie, które oddaje emocjonalną perspektywę rodzica, ale jednocześnie nie współgra (według prowadzącego) z konwencją stylistyczną zakończenia w sytuacji publicznej. Autorefleksja nad adekwatnością twierdzenia w danej, określonej gatunkowo sytuacji komunikacyjnej, zwiększa wyrazistość tej sytuacji. Komentarz metatekstowy, który jest oceną własnej wypowiedzi pod względem oryginalności/szablonowości, stanowi realizację strategii asekuracyjnej. Sens metakomentarza można wyeksplikować następująco: „mówię X, bo jestem o tym przekonany”, „wiem, że wy też wiecie X”" , „wiem, że w tej sytuacji komunikacyjnej powinienem powiedzieć coś innego, powinienem powiedzieć inaczej, ale mówię X”.

${ }^{45}$ Brak reakcji na wypowiedź jest równoznaczny z jej niewłączeniem w strukturę dialogu. Nawet reakcja zaprzeczenia, odrzucenia jest korzystniejsza dla budowania struktury interakcyjnej niż pominięcie. Bez reakcji dialog staje się pozorny, zbliża się do monologu.

${ }^{46}$ Domniemanie to wynika ze znaczenia słowa banalny (pospolity, szablonowy, pozbawiony wszelkiej oryginalności). 
Za nadrzędną, i zgodną z konwencją zakończenia, perspektywę podsumowania należy uznać punkt widzenia obserwatora debaty publicznej (fragm. 1, 3, 4, 5, 7, 9). Ogólny ogląd może ulec uszczegółowieniu, kiedy dziennikarz przyjmuje perspektywę Polaka (fragm. 2, 8), rodzica (fragm. 6), przedstawiciela stacji (fragm. 10), mężczyzny (fragm. 11), wreszcie w ostatnim zakończeniu, które jest zakończeniem cyklu programów, występuje również jako indywiduum (fragm. 12).

Zakończenia odnoszą się do całościowego charakteru debaty publicznej lub do jej celów retorycznych. Dotyczą jej zasadności, ogólnego poziomu; zawierają podsumowanie tego, czy strony zdołały zaprezentować swoje racje i czy zostały one lepiej zrozumiane dzięki debacie; czy osiągnięto zbliżenie stanowisk lub kompromis ${ }^{47}$. Poniższe fragmenty egzemplifikują następujące zagadnienia szczegółowe:

a) potwierdzenie zasadności dyskusji, legitymizacja debaty: I warto zawsze o tym dyskutować [...]. Dyskusja na ten temat zawsze jest potrzebna (fragm. 3); Jedno jest niewatpliwie dobre $w$ odrzucaniu tego projektu [...], że być może to jest poczatek dyskusji (fragm. 7); [...] problemem chyba nie jest to, że te poglady się pojawiaja, ale to, czy potrafimy budować mosty, czy podstawy, na których toczy się dialog między tymi, którzy różne poglądy prezentują (fragm. 9),

b) diagnoza ogólnego poziomu dyskusji w studiu i toczonej poza nim debaty publicznej na dany temat: Poziom emocji tutaj $w$ studiu, jak państwo styszeli i pewnie podczas tej debaty, która w najbliższym czasie w Sejmie się pojawi, będzie ogromny (fragm. 1); Wydaje mi się, że dtuga i bardzo trudna dyskusja czeka nas jeszcze przez wiele lat, żebyśmy o skądinąd bardzo bolesnych wydarzeniach naszej najnowszej historii potrafili ze soba spokojnie $i$ na argumenty rozmawiać (fragm. 4); Myślę, że to byty ciekawe uwagi, ciekawe opinie, nawet jeśli czasem trudno mi byto zadać pytanie (fragm. 11); Dyskusja jeszcze trwa ${ }^{48}$ [...]. I nie wiadomo, jak ta dyskusja będzie przebiegata. W każdym razie na pewno niespokojnie, sądząc $z$ dzisiejszego przebiegu (fragm. 5),

c) podsumowanie szczegółowe dotyczące realizacji celu retorycznego debaty:

- wskazywanie procedury podejmowania decyzji, w tym negocjowanie podmiotów uprawnionych do decydowania: $W$ tej sprawie niewątpliwie potrzeba albo pozostawienia dzisiejszego stanu prawnego, albo uregulowań nowych, ale to jest $\underline{w}$ rękach polityków (fragm. 5); [dyskusja] się rozpoczęła w takim miejscu, które zdaje się nie jest najwłaściwszym miejscem do jej inauguracji, czyli w Sejmie, wśród polityków. [...] [dyskusja] najpierw będzie prowadzona

47 Według Szymanka po zakończeniu wystąpień stron następuje podsumowanie debaty, które ma przynieść odpowiedzi na pytania: Czy osiągnięto zbliżenie stanowisk? Czy można mówić o lepszym wzajemnym zrozumieniu racji? Czy w przebiegu debaty panowała właściwa atmosfera? Arbiter omawia krytycznie argumenty, a powołani sędziowie wydają werdykt (Szymanek 2004: 93).

48 Stwierdzenie to w określonym kontekście sytuacyjnym jest wskazaniem cech debaty. Dziennikarz nie może zakończyć dyskusji, bo jest ona żywiołowa, spontaniczna. 
$\underline{w}$ zupetnie innych gronach $i$ w zupetnie innych środowiskach, a dopiero potem, po wnioskach z tej dyskusji płynacych, dotrze taki albo inny, albo podobny projekt do Sejmu i dopiero wtedy zajma się nim politycy. Wtedy, czyli na końcu (fragm. 7),

- podsumowanie, dotyczące tego, czy strony lepiej zrozumiały swoje racje, czy nastąpiło zbliżenie stanowisk lub kompromis: Ale takim ubocznym, chociaż bardzo dobrym efektem i polskiej obecności na Ukrainie, i polskiego zaangażowania, jest fakt, że te cztery dość dramatyczne dni chyba jednak zbliżyty Ukraińców i Polaków tak, jak już dawno w historii nie bywało i przynajmniej $z$ tego się cieszmy (fragm. 2); Warto zawsze o tym dyskutować, takíe dlatego, żeby te pojęcia, wśród których się dzisiaj obracaliśmy: tolerancji, braku tolerancji, dyskryminacji nabraty być może bardziej/ znaczy większego wyrazu, czy większej wyrazistości (fragm. 3); I to ciekawe, że jednak zaczęliśmy, proszę państwa, że zaczęliśmy $i$ kończymy od dwóch zupetnie różnych opinii $i$ spieramy się jednak o ocenę (fragm. 4); Sporu nie rozstrzygniemy [...]. Ja myślę, że skoro ta dyskusja trwata przez kilka tysięcy lat i spór trwat tak dtugo, to obawiam się, $\dot{z}$ e także $w$ najbliższym czasie nie zostanie rozwiazany. W każdym razie nie jednoznacznie (fragm. 5); I myślę sobie, że jeśli rozmawiamy o różnych pogladach, i różnicy w pogladach, to problemem chyba nie jest to, że te poglady się pojawiaja, ale to, czy potrafimy budować mosty (fragm. 9).

Bardzo ważnym celem programu jest legitymizacja debaty publicznej na dany temat. Uzasadnienie konieczności debaty jest skorelowane $\mathrm{z}$ aspektem temporalnym (zawsze, dtuga dyskusja, dyskusja trwała przez kilka tysięcy lat, czeka nas jeszcze przez wiele lat, toczy się dialog, o mediach moglibyśmy jeszcze bardzo dtugo, poczatek dyskusji, rozpoczęta się dyskusja, ciekawe trendy docieraja do nas z Zachodu). Jak widać, w tym zakresie możliwe są dwa ujęcia: program wpisuje się $\mathrm{w}$ debatę przedstawioną jako permanentna, zawsze aktualna; program ma inicjować debatę, reagować na bieżące wydarzenia, po to by nadać im znaczenie i włączać w obieg publiczny. Projektowane cele debaty tworzą złożoną konfigurację w zależności od charakteru tematu: od celu minimalnego, jakim jest rozpoczęcie dyskusji, przełamanie tabu społecznego (np. na temat eutanazji, prostytucji), poprzez artykulację opinii (np. o stanie wojennym, udziale polskich wojsk w Iraku, roli kobiety), do celu maksymalnego, jakim jest wypracowanie propozycji nowych regulacji (np. w zakresie walki z narkomanią, aborcji).

Ostatecznym zakończeniem kontaktu są pożegnalne elementy rytualne: formuła skończenia programu, w której powtórzony zostaje tytuł (To była „Debata”), podziękowanie (Dziękuję państwu bardzo) i pożegnanie z wyrażeniem chęci wznowienia kontaktu (Do zobaczenia za tydzień). Elementy te mogą wystąpić łącznie lub z pominięciem jednego z nich. Kolejność elementów nie jest stała. Nagromadzenie aktów grzecznościowych jest typowe dla wygaszania kontaktu w fazie końcowej (Marcjanik 2000: 243). Ich motywację stanowi w większym 
stopniu obyczaj niż konkretna wartość komunikacyjna. W strukturze programu akty te pełnią funkcję końcowych sygnałów delimitacyjnych.

W kreowaniu sytuacji komunikacyjnej „Debaty” dziennikarz uwzględnia parametry medialnego dyskursu publicznego. Eksponowanie wątków, które są zgodne $\mathrm{z}$ wymogami atrakcyjnego widowiska (a należą do nich: emocjonalność, dramatyzm, sensacja, oryginalność, nowość) zostało nazwane przez medioznawców „logiką mediów” (Mrozowski 2001: 131). Można tu dostrzec również typową dla gatunków telewizji formułę serialowości, czyli „powtórzenie ze zmianą" (Godzic 2004: 40), o czym świadczy brak zamknięcia tematów w programie i zachęcanie do oglądania następnych realizacji. Heterogeniczność natury mediów, które pełnią ważną rolę w inicjowaniu debat, edukacji obywatelskiej, ale jednocześnie muszą dbać o komercyjną atrakcyjność oferty, powoduje pewną wyczuwalną dla metaobserwatora niekonsekwencję. Otóż z jednej strony dziennikarz postuluje spokojną i rzeczową debatę (żebyśmy potrafili ze soba spokojnie $i$ na argumenty rozmawiać), a z drugiej - wzmacnia jej postrzeganie jako emocjonalnej, trudnej do opanowania. Z jednej strony deklaruje chęć przezwyciężenia konfliktu i realizacji celów merytorycznych debaty, a z drugiej - odnosi się sceptycznie do możliwości porozumienia. Wydaje się, że dziennikarz skłania się na przemian ku różnym celom i stara się zachować równowagę między nimi. W sytuacji godzenia niezbieżnych celów taka strategia komunikacyjna, czyli strategia balansu, wydaje się optymalnym rozwiązaniem.

Zakończenie jest ustabilizowaną formą finalną tekstu, o rozpoznawalnych cechach treściowych (uogólnienie, puenta), strukturalnych (elementy rytualne pożegnania, podziękowania), funkcjonalnych (skończenie programu, wygaszenie kontaktu w obu sytuacjach). Jest to typ działania mownego skorelowany z typem sytuacji (kończenie kontaktu), w którym realizowane są strategie dyskursywne, odpowiedzialne za nadanie interakcji gatunkowych cech debaty. Wyznacznikami sytuacji są komentarze, w których dziennikarz nazywa czynności komunikacyjne uczestników - argumentowaniem, dyskutowaniem, debatowaniem, wygłaszaniem opinii, ocen, spieraniem się, rozmową o różnych poglądach i rozmową o różnicy w poglądach. Dziennikarz przyjmuje w zakończeniu perspektywę metaobserwatora debaty publicznej, stawia diagnozy co do jej przebiegu, poziomu, snuje prognozy na temat realnych i nierealnych celów. Komentarz prowadzącego, uwzględniający cechy gatunkowe debaty (instytucjonalizowanie konfliktów społecznych, niezacieranie różnic, permanentność, zaangażowanie obywateli), jest jednocześnie kreacją sytuacji debaty w studiu i próbą kierowania pozastudyjną debatą publiczną.

Elementy składowe ramy widowiska telewizyjnego i tekstu, będącego jego częścią, są - w porównaniu z późniejszą dyskusją zasadniczą - elementami odtwarzanymi (czołówka odtwarzana jest w niezmiennej postaci, podobnie kończący program ciąg wizualno-dźwiękowy), przewidywalnymi 
(przynajmniej jeśli chodzi o illokucję gatunków, takich jak zapowiedź, wprowadzenie, zakończenie), przygotowanymi (o czym świadczy płynność ich wygłaszania przez dziennikarza), a przez to podlegającymi w największym stopniu rytualizacji. Cechą delimitatorów początkowych oraz końcowych jest wyraźne i prymarne osadzenie ich bardziej w makro- niż w mikrosytuacji komunikacyjnej, co podkreśla przekaz kinetyczny, a mianowicie zwrócenie się dziennikarza twarzą do kamery i zbliżenie jego postaci, imitujące bliski kontakt z telewidzami. Schemat organizacji strukturalnej został zobrazowany na rys. 10 .

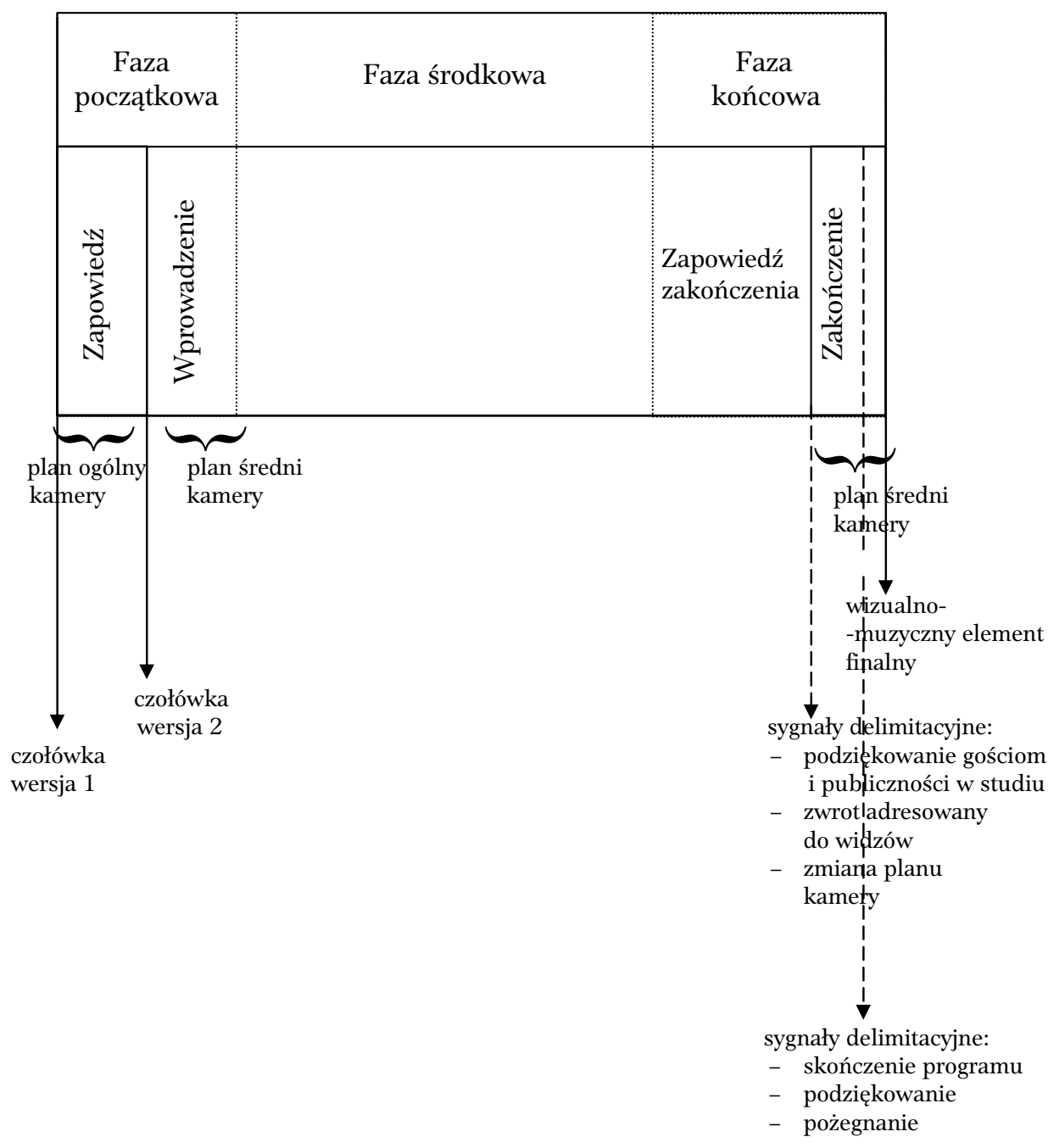

Rys. 10. Schemat organizacji strukturalnej „Debaty” 


\subsection{Segment $\mathrm{z}$ udziałem publiczności}

W przeważającej liczbie programów brała udział publiczność ${ }^{49}$. Segment z jej udziałem najczęściej otwierał środkową część programu ${ }^{50}$, tylko w nielicznych „Debatach” pojawiał się po krótkiej dyskusji z gośćmi. Nigdy jednak nie kończył programu, co znajduje uzasadnienie w funkcji, jaką przypisał mu nadawca medialny.

Ogólnie segment z udziałem publiczności spełnia wszystkie warunki wyodrębnienia: jest oddzielony, ma wewnętrzną strukturę inną od struktury pozostałych segmentów oraz pełni określoną funkcję w całości programu. Tak więc o tożsamości segmentu świadczy jego oddzielenie od pozostałych elementów, odrębne strategie dziennikarzy, inny status reprezentantów publiczności w porównaniu ze statusem gości, jak również funkcja segmentu w całym programie wynikająca z uwarunkowań dyskursu publicznego i celów mediów. Warunki te, składające się na specyfikę segmentu, a realizowane za pomocą określonych technik, zostaną omówione w kolejnych punktach.

\subsubsection{Gatunkowe i dyskursywne uwarunkowania wprowadzenia segmentu z publicznością}

Pojawienie się segmentu z udziałem publiczności znajduje uzasadnienie w tytule programu „Debata”, który odsyła zarówno do gatunku wypowiedzi, jak i do podstawowego makroaktu mowy w komunikacji publicznej - debaty publicznej. Makrostrategie komunikacyjne, które dziennikarz realizuje w programie, a zwłaszcza w segmencie z udziałem publiczności, są bowiem osadzone w medialnym dyskursie publicznym i politycznym. Debatę jako gatunek mowy określa się jako rodzaj takiej dyskusji, która ma charakter publiczny (co nie jest jeszcze konieczne dla dyskusji w ogólności) i jest prowadzona zgodnie z formalnymi procedurami (skutkuje to powtarzalnymi strategiami strukturalnymi, które zostaną omówione w punkcie o konstytuowaniu grup). Według Krzysztofa Szymanka debata jako gatunek mowy dotyczy jednego kontrowersyjnego problemu, wyraźnie sprecyzowanego za pomocą pytania do rozstrzygnięcia. W typowej debacie (rozprawa sądowa, debata parlamentarna, debata przedwyborcza) biorą udział dwie zajmujące przeciwne stanowiska strony, reprezentowane przez pojedyncze osoby lub kilkuosobowe drużyny (Szymanek 2004: 92).

49 Spośród wybranych do analizy 15 programów tylko w jednym nie było aktywnej publiczności. Była to ostatnia „Debata” na temat stanu polskich mediów z 8.02.2006 r.

50 Spośród 15 programów, w 12 segment z publicznością był zaraz po wprowadzeniu. W trzech programach (na temat sytemu prawnego, Radia Maryja i przyspieszonych wyborów) rozdzielał segment $\mathrm{z}$ udziałem gości. Zawsze jednak był oddzielony. 
Analiza przebiegu interakcji $\mathrm{w}$ segmencie $\mathrm{z}$ udziałem publiczności, a zwłaszcza działania dziennikarzy, wskazują na kształtowanie w nim sytuacji komunikacyjnej zgodnie $\mathrm{z}$ wymogami gatunku debaty. Przemawia za tym przede wszystkim podział publiczności na dwie przeciwstawne grupy (podziałowi opinii odpowiada podział przestrzenny, gdyż grupy siedzą osobno, na wprost siebie), redukcja problemu do jednej kwestii spornej, wyrażonej często jednym pytaniem oraz formalizacja przebiegu interakcji.

O ile organizacja przebiegu interakcji w segmencie z udziałem publiczności jest zależna od cech gatunkowych, o tyle funkcja segmentu w strukturze całości programu jest związana $\mathrm{z}$ ideą debaty publicznej jako podstawowego aktu komunikacji politycznej (Fras 2005: 88). Tym samym wpisuje się w cele mediów publicznych, które pośredniczą w przekazywaniu systemowi politycznemu wiedzy na temat odbioru komunikatów politycznych, potrzeb i oczekiwań publiczności (Dobek-Ostrowska 2006: 119). Wprowadzenie do studia telewizyjnego nie tylko polityków, ekspertów (segment z gośćmi, punkt 6.3), ale również zwykłych obywateli, wyrazicieli opinii publicznej, reprezentantów społeczeństwa - ma w założeniu zawiązać, wzbudzać, kontynuować debatę publiczną. Ta platforma porozumienia społecznego, która jest podstawą demokracji, powinna obejmować jak najszersze kręgi społeczeństwa, stąd wynika ważna rola segmentu z udziałem publiczności.

Nadawca medialny oprócz celów publicznych realizuje również cele komercyjne, które nie zawsze są zgodne z misją publiczną. Problem ten sprowadza się w gruncie rzeczy do pytania, czy media tworzą rzeczywistą platformę do debaty publicznej, czy też organizują widowiska, w których strony odgrywają przypisane im role. Niezgodność celów może wynikać z tego, że istotą spektaklu jest nie tyle reprezentatywność opinii, ich merytoryczność, co efektowność, barwność. Problem ma charakter otwarty, jest często przedmiotem rozważań metadyskursywnych. Dla niniejszych badań przyjmujemy, że idea merytorycznej debaty publicznej (powszechnej, jawnej) jest często manifestowana przez dziennikarzy, należy do reguł dyskursu publicznego i przez to jest wykorzystywana do kreowania sytuacji komunikacyjnej o wyższym prestiżu, standardzie. Istnieje zatem przede wszystkim w sferze normatywów. Jeśli chodzi o jej realizację, to należy stwierdzić, że barwność, ludyczność interakcji jest dla widowiska medialnego na tyle ważna, że często bywa przedkładana ponad inne cele mediów.

\subsubsection{Charakterystyka publiczności jako grupy uczestników}

Udział aktywnej publiczności w programie „Debata” stanowił jego cechę wyróżniającą w porównaniu z innymi programami publicystycznymi. Publiczność nie tylko reagowała zbiorowo oklaskami, śmiechem, buczeniem podczas całego programu, ale jej reprezentanci brali udział w debacie w sposób zindywidualizowany. 
Hipotezy na temat rozmówców stanowią równorzędne, obok rozpoznania sytuacji komunikacyjnej, determinanty strategii komunikacyjnych (Hannappel, Melenk 1990, za: Żydek-Bednarczuk 2005: 232). Publiczność, w założeniu nadawcy medialnego, stanowi symboliczną reprezentację społeczeństwa w studiu telewizyjnym. Jej przedstawiciele przez swoją żywiołowość, zaangażowanie, często brak kompetencji komunikacyjnych koniecznych w dyskusji, mają stanowić punkt odniesienia dla przeciętnego odbiorcy masowego, który może się z nimi utożsamić. Reprezentanci publiczności cechują się zdecydowanymi, wyraźnymi poglądami, mają często emocjonalny stosunek do poruszanego tematu. Zaangażowanie i mocne przekonanie są szczególnie funkcjonalne, jeśli chodzi o emocjonalizację i widowiskowość debaty. Wskazane cechy publiczności wynikają z analizy przebiegu interakcji, ale są też często werbalizowane wprost $\mathrm{w}$ komentarzach, dotyczących tonacji debaty: Jeśli panowie pozwola, ja bym chciat jeszcze zapytać tych, którzy, jak rozumiem, w części stuchają Radia Maryja, w każdym razie mają na jego temat swoja wyraźna $i$ zdecydowana opinię (11.01.2006); Momencik, momencik, momencik, powstrzymujemy emocje, a ja jestem teraz ciekaw spokojnej odpowiedzi, bo emocje w tej sprawie rozumiem, że sa, ale nie musza być zbędne (16.12.2004); A na widowni dzisiejszego programu młodzi ludzie, którzy w swoich teczkach czy teczkach z czasów PRL-u z pewnościa niczego by nie znaleźli, bo byli wtedy jeszcze dziećmi, ale jak się okazuje, o czym pewnie sie za chwile przekonamy, ta sprawa teczek także u nich budzi emocje (20.05.2005).

Wprowadzenie „Zwykłych ludzi” do studia niezmiernie ożywia i emocjonalizuje debatę, ale też stanowi wyzwanie dla dziennikarza ze względu na ich żywiołowość, nieprzewidywalność, czasem brak wymaganych w debacie kompetencji komunikacyjnych. Dziennikarz musi pełnić rolę nie tylko kierującego debatą, ale często pouczającego lub wręcz nauczyciela konwencji gatunkowych. W interakcji z żywiołową publicznością obserwujemy ścieranie się rywalizujących strategii:

- z jednej strony dyskusja, debata wymaga chłodnej, merytorycznej rozmowy, powstrzymania się od ataków personalnych, osobistych tematów (kreowanie interakcji według reguł gatunkowych dyskusji/debaty),

- z drugiej strony taka tonacja może być nieatrakcyjna dla odbiorcy masowego, za to atrakcyjne są emocjonalne starcia, efektowne popisy oratorskie, kłótnie (strategie dyskursu medialnego).

Dziennikarz musi zatem stosować strategię balansu w realizacji niezgodnych celów.

Dla przebiegu programu i stosowanych w nim strategii strukturalnych ważne są dwa założenia: że publiczność będzie brała udział w sposób zindywidualizowany (o czym już wspomniano) oraz że zostanie podzielona na dwie grupy o przeciwstawnych poglądach. Ze względów widowiskowych są to często 
poglądy skrajne, nieodzwierciedlające (w opinii niektórych) przekonań większości społeczeństwa:

LK: Tak. I ja sądzę tak, że dzisiaj te dwie grupy, które pokazują ten, powiedzmy, no, jakiś taki maksymalny czy skrajny/ skrajna postać emocji/ ja zadaję sobie pytanie, stuchajac dyskusji państwa, czy to jest stan nastrojów w polskim spoteczeństwie? Czy rzeczywiście w polskim społeczeństwie mamy do czynienia z taka polaryzacją i z taka/ ja sądzę, że nie.

(16.12.2004; gość - LK: Leszek Kubicki)

W podziale publiczności na dwie przeciwstawne grupy zasadniczą rolę odgrywa ustosunkowanie się do jednego problemu, najczęściej poprzez odpowiedź na pytanie, które określamy jako makrostrukturalne. Ogólnie można stwierdzić, że aspekt poznawczy przedstawionego problemu jest podporządkowany aspektowi pragmatycznemu, strukturalnemu oraz perswazyjnemu. Tematy podejmowane $\mathrm{w}$ debacie są z natury rzeczy wieloaspektowe (np. mają aspekt prawny, medyczny, społeczny, moralny, polityczny), cechuje je wielość perspektyw (perspektywa zwykłego człowieka, decydenta, polityka, eksperta), niejednoznaczność ujęcia (wynikająca ze zmienności zjawisk, konieczności integracji czasem niezgodnych aspektów i perspektyw). W części z publicznością dziennikarz, mając na uwadze funkcję tego segmentu w strukturze całości, musi wybrać jeden problem i najczęściej zamknąć go w formie pytania do rozstrzygnięcia. Dokonuje w ten sposób uproszczenia, swoistej redukcji rzeczywistości, tak aby przez odpowiedź na pytanie „czy jesteś za $\mathrm{X} /$ czy jesteś przeciw X” lub „X czy Y” - ukonstytuować grupę proponentów i oponentów. Działanie takie nie zawsze spotyka się z aprobatą rozmówcy i dziennikarz musi wprost wyrazić intencję.

KD: Na to pytanie: czy przepisy, czy kary? Mamy studentów prawa, prawda. Studenci prawa? Studenci prawa. Tak. Zagratby pan na takie przedawnienie jak FOZZ-ie czy nie?

BN: Absolutnie nie chciałbym sie skupiać na takiej pojedynczej kwestii, [bo//

KD: [Ale ja bym chciat, żeby pan sie przez chwile spróbowat wcielić $w$ role adwokata. Zagratby pan czy nie?

(16.12.2004; gość - BN: Bartosz Niemczynowicz)

Czasem uproszczenie dokonane na potrzeby debaty okazuje się wręcz przekłamaniem $^{51}$, a alternatywa zaproponowana przez dziennikarza bywa pozorna ${ }^{52}$. Dzieje się tak dlatego, że aspekt poznawczy debaty musi zostać podporządkowany

51 Tak jest w debacie o prostytucji, w której pytanie „Czy zalegalizować prostytucję?” okazuje się skrótem myślowym. Goście w późniejszej dyskusji wyjaśniają, że prostytucja w Polsce jest legalna, ale nielegalne jest czerpanie korzyści z cudzego nierządu i właśnie tej drugiej kwestii miała dotyczyć legalizacja.

52 Tak jest w debacie o teczkach, w której pytanie „Krzywda czy sprawiedliwość dziejowa?” pozostaje nierozstrzygnięte. Okazuje się figurą retoryczną, mającą aktywizować publiczność. 
aspektowi pragmatycznemu: dziennikarz dokonuje uproszczeń w konstrukcji rzeczywistości po to, aby wytyczyć wyraźną linię sporu. Jest to zabieg typowo strategiczny, a przez to jego efekt może okazać się nietrwały. W toku dyskusji, zwłaszcza z ekspertami, a nierzadko już z publicznością, wypływają wszystkie niuanse i niejednoznaczności, demaskowana jest pozorność alternatywy i przekłamane uproszczenia.

Strategiczne wytyczanie linii sporu kosztem uproszczeń, a nawet przekłamań wiąże się z kształtowaniem typowych i charakterystycznych dla dyskusji oraz debaty ról proponentów i oponentów. Za kontekstowo odpowiadające określeniu proponent uznajemy nazwy: stronnik, zwolennik, orędownik, wnioskodawca składający ofertę, protagonista. Oponenta można nazwać przeciwnikiem w dyskusji, adwersarzem, antagonistą, tym, który jest odmiennego zdania, przeczy, wyraża swój sprzeciw. Ról proponenta i oponenta nie uznajemy za symetryczne, ale raczej dopełniające się. Proponent w ogniu krytyki oponenta wyostrza swoją argumentację. Oponent natomiast, chcąc być skuteczny, musi odnosić się do działań proponenta i na nich budować swój sprzeciw. Zadaniem oponenta jest przede wszystkim wyrażanie wątpliwości, ale niekiedy rozszerza on repertuar działań, o czym będzie mowa w dalszej części.

Proponent jest stroną inicjującą $\mathrm{w}$ dyskusji, co przejawia się tym, że to właśnie na nim spoczywa ciężar dowodu. Rola proponenta jest przydzielana w dyskusji na podstawie pewnych wytycznych: zostaje nim ten, kto ma dostęp do danych, dokumentów, był świadkiem wydarzenia lub ten, kto dowodzi tezy bardziej szczegółowej, albo też ten, komu bardziej zależy na wykazaniu swoich racji. W sytuacji dyskusji zawsze uprzywilejowany jest stan aktualny. Tak więc ta strona, która chce przeprowadzić zmiany, musi wykazać ich zasadność, a więc przyjmuje rolę proponenta (Szymanek 2004: 220). Podstawowym zadaniem oponenta jest podważanie argumentacji proponenta. Jak wynika z przeprowadzonych analiz, strategie oponenta mogą jednak ulec rozbudowaniu o dodatkowe elementy.

Poniżej zamieszczono tabelę, w której zestawiono główne informacje dotyczące kryteriów podziału publiczności na grupy proponentów i oponentów ${ }^{53}$ w wybranych programach. W pierwszej kolumnie podano temat debaty, typ tematu (np. temat dotyczący regulacji prawnych, polityki zagranicznej, diagnozy zjawisk społecznych, oceny zdarzeń i osób) oraz informacje o usytuowaniu segmentu z publicznością w strukturze programu. W drugiej kolumnie znajduje się wskazanie głównego problemu, pytania, które wytycza linię podziału między oponentami a proponentami. Kolumny trzecia i czwarta zawierają krótkie zasygnalizowanie poglądów i postaw obu grup.

53 Zamiennie używamy określeń: zwolennicy i przeciwnicy, obrońcy i oskarżyciele, jednak pojęciami nadrzędnymi pozostają nadal terminy: proponenci i oponenci. 


\begin{tabular}{|c|c|c|c|}
\hline $\begin{array}{c}\text { Temat programu } \\
\text { [typ tematu] } \\
\text { Pozycja członu } \\
\text { w strukturze debaty }\end{array}$ & $\begin{array}{c}\text { Problem/pytanie(a) } \\
\text { w segmencie z pu- } \\
\text { blicznością, które wy- } \\
\text { tyczają linię podziału } \\
\text { na proponentów } \\
\text { i oponentów }\end{array}$ & $\begin{array}{c}\text { Proponenci } \\
\text { (cyfrą „,” zaznaczono } \\
\text { grupę wprowadzoną } \\
\text { jako pierwsza)* }\end{array}$ & $\begin{array}{c}\text { Oponenci } \\
\text { (strategia symetrycznego } \\
\text { oponowania, strategia } \\
\text { rozszerzonego } \\
\text { oponowania) }\end{array}$ \\
\hline 1 & 2 & 3 & 4 \\
\hline $\begin{array}{l}\text { Aborcja } \\
\text { [regulacje prawne] } \\
\text { Segment z publicz- } \\
\text { nością otwiera część } \\
\text { środkową. }\end{array}$ & $\begin{array}{l}\text { Czy kobieta powinna } \\
\text { mieć prawo do decy- } \\
\text { dowania o przerwaniu } \\
\text { ciąży? } \\
\text { [pytanie konstytuuje } \\
\text { grupę proponentów, } \\
\text { grupa oponentów jest } \\
\text { zbudowana przez usto- } \\
\text { sunkowanie się do po- } \\
\text { glądów proponentów] }\end{array}$ & $\begin{array}{l}\text { 1. Zwolennicy prawa } \\
\text { do aborcji, zwolenni- } \\
\text { cy złagodzenia ustawy } \\
\text { antyaborcyjnej. } \\
\text { [proponenci postulują } \\
\text { zmianę dotychczaso- } \\
\text { wego stanu prawnego] }\end{array}$ & $\begin{array}{l}\text { 2. Przeciwnicy prawa } \\
\text { do aborcji, przeciwnicy } \\
\text { zmiany dotychczasowej } \\
\text { ustawy. } \\
\text { [oponenci bronią obec- } \\
\text { nego stanu prawnego] } \\
\text { Strategia pogłębionego } \\
\text { oponowania, dotyczące- } \\
\text { go postrzegania: oponen- } \\
\text { ci inaczej kategoryzują } \\
\text { i nazywają elementy tła } \\
\text { pozajęzykowego. }\end{array}$ \\
\hline $\begin{array}{l}\text { Pomarańczowa rewo- } \\
\text { lucja na Ukrainie } \\
\text { [polityka zagraniczna] } \\
\text { Segment z publicz- } \\
\text { nością otwiera część } \\
\text { środkową. }\end{array}$ & $\begin{array}{l}\text { Czy dobrze, że anga- } \\
\text { żujemy się aż tak bar- } \\
\text { dzo w sprawy Ukra- } \\
\text { iny? }\end{array}$ & $\begin{array}{l}\text { 2. Zwolennicy moc- } \\
\text { nego angażowania się } \\
\text { Polski po stronie okre- } \\
\text { ślonej siły politycznej } \\
\text { na Ukrainie. }\end{array}$ & $\begin{array}{l}\text { 1. Przeciwnicy angażo- } \\
\text { wania się Polski w we- } \\
\text { wnętrzne konflikty poli- } \\
\text { tyczne na Ukrainie. } \\
\text { Strategia symetrycznego } \\
\text { oponowania. }\end{array}$ \\
\hline $\begin{array}{l}\text { Tolerancja } \\
\text { [diagnoza i analiza zja- } \\
\text { wisk społecznych] } \\
\text { Segment z publicz- } \\
\text { nością otwiera część } \\
\text { środkową. }\end{array}$ & $\begin{array}{l}\text { Czy homoseksualiści } \\
\text { mają prawo do wyra- } \\
\text { żania swoich poglą- } \\
\text { dów na ulicach? } \\
\text { [nie jest to problem } \\
\text { stanowienia prawa, ale } \\
\text { jego egzekwowania] }\end{array}$ & $\begin{array}{l}\text { 2. Popierający prawo } \\
\text { mniejszości seksual- } \\
\text { nych do manifestowa- } \\
\text { nia poglądów na ulicy. }\end{array}$ & $\begin{array}{l}\text { 1. Przeciwnicy „promo- } \\
\text { wania homoseksualizmu } \\
\text { i narzucania poglądów } \\
\text { normalnym ludziom”. } \\
\text { Strategia pogłębionego } \\
\text { oponowania: oponenci } \\
\text { inaczej kategoryzują i na- } \\
\text { zywają elementy tła po- } \\
\text { zajęzykowego. }\end{array}$ \\
\hline $\begin{array}{l}\text { Stan wojenny } \\
\text { [ocena historyczna, } \\
\text { przypisywanie winy } \\
\text { kryminalnej] } \\
\text { Segment z publicz- } \\
\text { nością otwiera część } \\
\text { środkową. }\end{array}$ & $\begin{array}{l}\text { Problem: ocena gene- } \\
\text { rała Jaruzelskiego. } \\
\text { Do proponentów: za } \\
\text { co chcieliby państwo } \\
\text { podziękować genera- } \\
\text { łowi Jaruzelskiemu? } \\
\text { Do oponentów: za co } \\
\text { ta „Pała na generała”? } \\
\text { [napis na transparen- } \\
\text { cie przyniesionym do } \\
\text { studia] }\end{array}$ & $\begin{array}{l}\text { 1. Obrońcy genera- } \\
\text { ła uważają, że należy } \\
\text { podziękować genera- } \\
\text { łowi Jaruzelskiemu za } \\
\text { wprowadzenie stanu } \\
\text { wojennego. }\end{array}$ & $\begin{array}{l}\text { 2. Obciążają generała } \\
\text { odpowiedzialnością za } \\
\text { ofiary stanu wojennego. } \\
\text { Proponują rozliczenie } \\
\text { go przed sądem. } \\
\text { Nie tylko przeciwnicy, ale } \\
\text { oskarżyciele generała. } \\
\text { [oponenci nie tylko wy- } \\
\text { rażają sprzeciw, ale żą- } \\
\text { dają rozliczenia stanu } \\
\text { wojennego] } \\
\text { Strategia rozszerzonego } \\
\text { oponowania. }\end{array}$ \\
\hline
\end{tabular}




\begin{tabular}{|c|c|c|c|}
\hline 1 & 2 & 3 & 4 \\
\hline $\begin{array}{l}\text { Prostytucja } \\
\text { [regulacje prawne] } \\
\text { Segment z publiczno- } \\
\text { ścią otwiera część środ- } \\
\text { kową. }\end{array}$ & $\begin{array}{l}\text { Czy należy zalegalizo- } \\
\text { wać prostytucję? }\end{array}$ & $\begin{array}{l}\text { 1. Zwolennicy legalizacji } \\
\text { prostytucji. }\end{array}$ & $\begin{array}{l}\text { 2. Przeciwnicy legalizacji } \\
\text { prostytucji. Zwolennicy } \\
\text { walki z prostytucją. } \\
\text { Strategia rozszerzonego } \\
\text { oponowania: propozycja } \\
\text { zaostrzenia represji. }\end{array}$ \\
\hline $\begin{array}{l}\text { Teczki, ujawnienie akt } \\
\text { służb specjalnych } \\
\text { [regulacje prawne] } \\
\text { Segment z publiczno- } \\
\text { ścią otwiera część środ- } \\
\text { kową. }\end{array}$ & $\begin{array}{l}\text { Czy należy ujawnić } \\
\text { akta służb specjalnych? }\end{array}$ & $\begin{array}{l}\text { 2. Zwolennicy ujawnie- } \\
\text { nia teczek, zwolennicy } \\
\text { pełnego ujawnienia akt } \\
\text { służb specjalnych. }\end{array}$ & $\begin{array}{l}\text { 1. Przeciwnicy dekomuni- } \\
\text { zacji. Przeciwnicy pełnego } \\
\text { ujawnienia akt służb spe- } \\
\text { cjalnych. } \\
\text { Strategia miękkiego opo- } \\
\text { nowania: ujawnianie te- } \\
\text { czek, ale w określony spo- } \\
\text { sób, pod kontrolą. }\end{array}$ \\
\hline $\begin{array}{l}\text { Narkomania } \\
\text { [regulacje prawne] } \\
\text { Segment z publiczno- } \\
\text { ścią otwiera część środ- } \\
\text { kową. }\end{array}$ & $\begin{array}{l}\text { Temat główny: czy zła- } \\
\text { godzenie ustawy pomo- } \\
\text { że w walce z narkoma- } \\
\text { nią? } \\
\text { Temat poboczny: czy } \\
\text { należy zalegalizować } \\
\text { miękkie narkotyki? }\end{array}$ & $\begin{array}{l}\text { 1. Zwolennicy złago- } \\
\text { dzenia ustawy, zwolen- } \\
\text { nicy legalizacji narkoty- } \\
\text { ków miękkich. }\end{array}$ & $\begin{array}{l}\text { 2. Przeciwnicy złagodze- } \\
\text { nia ustawy i legalizacji } \\
\text { narkotyków. } \\
\text { Strategia pogłębionego } \\
\text { oponowania, dotyczące- } \\
\text { go postrzegania: oponen- } \\
\text { ci inaczej kategoryzują } \\
\text { i nazywają elementy tła } \\
\text { pozajęzykowego. Podwa- } \\
\text { żają podział na narkotyki } \\
\text { miękkie i twarde. }\end{array}$ \\
\hline $\begin{array}{l}\text { Eutanazja } \\
\text { [regulacje prawne] } \\
\text { Segment z publiczno- } \\
\text { ścią otwiera część środ- } \\
\text { kową. }\end{array}$ & $\begin{array}{l}\text { Do proponentów: na } \\
\text { czym polega wolność, } \\
\text { której przejawem jest } \\
\text { prawo do eutanazji? } \\
\text { Do oponentów: czy dys- } \\
\text { kusja na temat ustawy } \\
\text { o eutanazji jest w Pol- } \\
\text { sce możliwa? }\end{array}$ & $\begin{array}{l}\text { 1. Zwolennicy prawa do } \\
\text { eutanazji. }\end{array}$ & $\begin{array}{l}\text { 2. Przeciwnicy prawa do } \\
\text { eutanazji. } \\
\text { Strategia pogłębionego } \\
\text { oponowania: delegitymi- } \\
\text { zacja debaty, kategoryza- } \\
\text { cja eutanazji jako zabój- } \\
\text { stwa. }\end{array}$ \\
\hline $\begin{array}{l}\text { System prawny } \\
\text { [regulacje prawne] } \\
\text { Segment z publicznością } \\
\text { w środku programu. }\end{array}$ & $\begin{array}{l}\text { Czy można mówić } \\
\text { o Polsce jak o państwie } \\
\text { prawa? } \\
\text { Do proponentów: czy } \\
\text { należy zmienić prze- } \\
\text { pisy; czy wprowadzić } \\
\text { kary dla adwokatów, } \\
\text { aby usprawnić pracę } \\
\text { sądów? }\end{array}$ & $\begin{array}{l}\text { 1. Zwolennicy zmiany } \\
\text { przepisów, wprowadze- } \\
\text { nia dodatkowych upraw- } \\
\text { nień w celu dyscyplino- } \\
\text { wania adwokatów. }\end{array}$ & $\begin{array}{l}\text { 2. Przeciwnicy wprowadza- } \\
\text { nia zmian na kanwie jedne- } \\
\text { go procesu. } \\
\text { Strategia miękkiego opono- } \\
\text { wania (ulepszajmy system } \\
\text { prawny, ale nie przez repre- } \\
\text { sjonowanie adwokatów). } \\
\text { Strategiczne kategoryzo- } \\
\text { wanie zjawisk: to, co pro- } \\
\text { ponenci kategoryzują jako } \\
\text { konsekwencję złego prawa } \\
\text { (adwokat nie stawia się na } \\
\text { sprawę), oponenci katego- } \\
\text { ryzują jako jednostkową } \\
\text { patologię i bagatelizują. }\end{array}$ \\
\hline
\end{tabular}




\begin{tabular}{|c|c|c|c|}
\hline 1 & 2 & 3 & 4 \\
\hline $\begin{array}{l}\text { Prezydentura A. Kwa- } \\
\text { śniewskiego } \\
\text { [ocena historyczna] } \\
\text { Segment z publiczno- } \\
\text { ścią otwiera część środ- } \\
\text { kową. }\end{array}$ & $\begin{array}{l}\text { Jak oceniasz prezyden- } \\
\text { turę Aleksandra Kwa- } \\
\text { śniewskiego? }\end{array}$ & $\begin{array}{l}\text { 1. Pozytywna ocena pre- } \\
\text { zydentury. }\end{array}$ & $\begin{array}{l}\text { 2. Negatywna ocena pre- } \\
\text { zydentury. } \\
\text { Strategia symetrycznego } \\
\text { oponowania. }\end{array}$ \\
\hline $\begin{array}{l}\text { Radio Maryja } \\
\text { [diagnoza i analiza zja- } \\
\text { wisk społecznych] } \\
\text { Segment z publicznością } \\
\text { w środku programu. }\end{array}$ & $\begin{array}{l}\text { Czym jest dla państwa } \\
\text { Radio Maryja? }\end{array}$ & $\begin{array}{l}\text { 2. Zwolennicy, obrońcy } \\
\text { Radia Maryja. }\end{array}$ & $\begin{array}{l}\text { 1. Przeciwnicy, krytycy } \\
\text { Radia Maryja. } \\
\text { Strategia symetrycznego } \\
\text { oponowania. }\end{array}$ \\
\hline
\end{tabular}

* Chodzi o to, której z grup dziennikarz zadaje pierwsze pytanie. Nie zawsze bowiem rozpoczyna od proponentów, jak można by sądzić.

W związku z odgrywanymi w debacie rolami można dostrzec określone strategie stosowane przez jej uczestników. W strategii proponenta ważne jest dynamiczne operowanie tłem pozajęzykowym. Szczególne sfunkcjonalizowanie tła wynika $\mathrm{z}$ faktu, że proponent dąży do przeprowadzenia zmian, występuje krytycznie przeciwko obecnej sytuacji. $\mathrm{Z}$ tego powodu charakteryzuje ją jako negatywną:

PB: Dlaczego zalegalizować prostytucję?

BW: Ze względów spotecznych. Kobiety, które pracuja, świadcza ustugi seksualne, nie maja ubezpieczenia, nie sa pod żadna kontrola medyczna. [...] W momencie, kiedy to nie jest zalegalizowane, bądź kiedy to jest zupetnie poza jakimkolwiek systemem prawnym, normami prawnymi, to sie wdziera tam kryminalizacja tego zjawiska. (13.01.2005; gość - BW: Bartek Widawski)

Sytuacja przyszła, która pojawi się w wyniku proponowanych zmian, projektowana jest dla odmiany jako pozytywna:

MW: To dlatego legalizując prostytucję, sutenerów pozbawiamy szans. W tym momencie sutener jest pod ochroną. Jeżeli tylko myśli, jest w stanie obejść ustawodawstwo w bardzo prosty sposób [...].

WG: Czyli co się zmieni po legalizacji? Trzeba ich będzie dalej ścigać.

MW: Nie bẹdzie sutenerów w Polsce!

WG: A kto to sprawi, że ich nie będzie? Kto im zabroni działać? Policja, która dzisiaj działa, tak jak działa, zacznie działać lepiej? Mając legalne domy publiczne zacznie działać lepiej policja $w$ tym kraju?

MW: Ale legalne domy publiczne dadza to, że policja nie będzie musiała interweniować, tak jak dzisiaj interweniuje.

(13.01.2005; goście - MW: Michał Więckiewicz, WG: Wojciech Gałązka) 
Argumentacja proponeta zostaje oparta na strukturze rzeczywistości ${ }^{54}$, na związkach następstwa przyczynowo-skutkowego. Proponent wskazuje na związek przyczynowy między zjawiskami: brak uregulowań prawnych powoduje rozwój przestępczości. Zachętą do podjęcia nowych uregulowań mają być pozytywne skutki zmian: legalizacja zjawiska spowoduje likwidację przestępczości. Potwierdzeniem strategii argumentacyjnej opartej na związkach następstwa jest sposób postępowania oponentów. Muszą oni bowiem dopasować swoją kontrargumentację do tego, co przedstawił proponent i dlatego podważają relację przyczynowo-skutkową zbudowaną przez niego. Jak widać, podstawową strategią proponenta jest funkcjonalne porządkowanie tła pozajęzykowego. Jego celem jest budowa argumentacji opartej na relacji następstwa.

Strategia oponenta, jak wspomniano, aby być skuteczna, musi odnosić się do sposobu budowania argumentacji przez proponenta. Jeśli oponent jedynie odrzuca rozwiązania proponenta, to taki typ działań można nazwać strategią symetrycznego oponowania. Ze względu na kategoryczność stanowiska można wyróżnić dwie strategie oponowania. Stanowisko twarde, które zdecydowanie odrzuca propozycje proponentów (zdecydowanie i pod żadnym pozorem nie) i stanowisko miękkie, inaczej mówiąc asekuracyjne (najczęściej pozornie) ugodowe (dobrze, ale nie w ten sposób; dobrze, ale nie teraz; dobrze, ale nie wy). Ugodowość związana jest na ogół z regułami dyskursu publicznego, z sytuacją, kiedy ze względów wizerunkowych nie można zająć stanowiska twardego, aby nie utracić twarzy i nie zasłużyć na negatywne etykiety (np. obrońców tajnych współpracowników, zwolenników patologii w sądownictwie, obrońców złych adwokatów itd.). Wtedy oponent stosuje strategię miękkiego oponowania. Wyraża (lub wyraziłby) chęć współpracy, ale wskazuje na niedociągnięcia proponowanych rozwiązań, braki proceduralne, czyli w sumie przerzuca odpowiedzialność na nieudolność proponenta.

Ze względu na akceptację lub brak akceptacji wspólnych założeń, można z kolei wyróżnić strategię pogłębionego oponowania, kiedy oponenci nie tylko wyrażają sprzeciw wobec zmian, ale inaczej kategoryzują i nazywają zjawiska, o które toczy się spór (np. w debacie na temat aborcji, eutanazji, tolerancji). Innym typem działań jest strategia rozszerzonego oponowania, kiedy oponenci nie tylko nie zgadzają się na nowe rozwiązania, ale żądają ostrzejszych represji (np. w debacie na temat rozliczenia stanu wojennego, prostytucji). Omówione powyżej zależności obrazuje schemat (rys. 11), w którym zebrano zachowania oraz strategie proponentów i oponentów.

${ }^{54}$ Por. rozdział: Argumenty oparte na strukturze rzeczywistości (Perelman 2004: 97). 


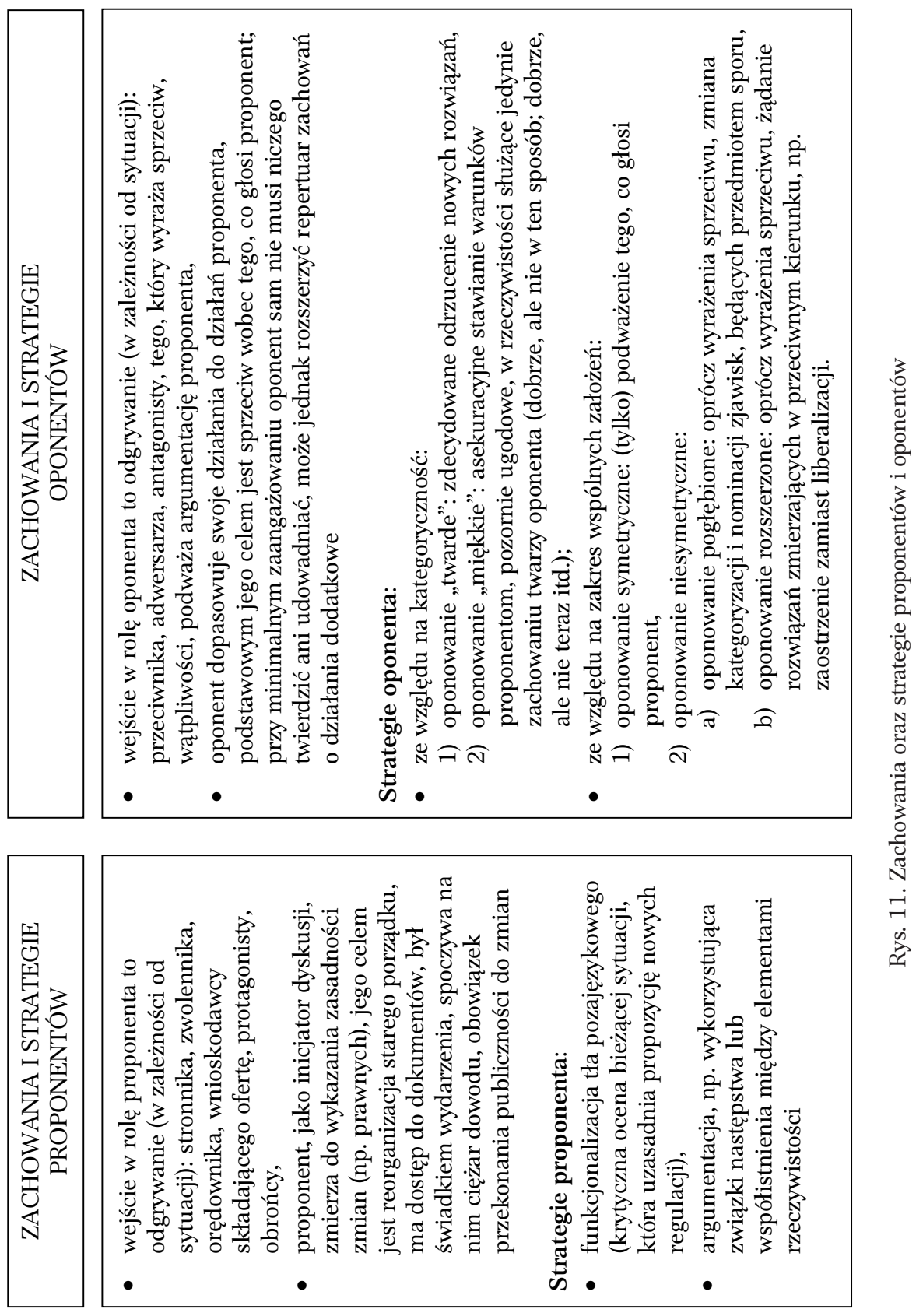




\subsubsection{Delimitacja segmentu z publicznością}

Segment z udziałem publiczności może pojawiać się zaraz po wprowadzeniu, czyli rozpoczynać część środkową debaty lub - rzadziej - rozdzielać segment z gośćmi.

\section{A. Segment z publicznością po wprowadzeniu}

Wprowadzenie, które poprzedza część środkową, jest elementem ramy tekstu, dziennikarz wygłasza je wprost do kamery. Jest to element motywowany makrosytuacyjnie i wymaga (najlepiej płynnego) przejścia do mikrosytuacji w studiu. Pod względem treściowym wprowadzenie zawiera zazwyczaj tło pozajęzykowe, globalne pytanie dotyczące tekstu i zapowiedź tematu debaty. Często dziennikarz w ostatniej części wprowadzenia przechodzi już do opisu (kreowania) mikrosytuacji: prezentuje publiczność w studiu, sygnalizuje jej związek $\mathrm{z}$ tematem, zaangażowanie $\mathrm{w}$ problematykę, precyzuje oczekiwania związane z jej udziałem. Ostatecznym przejściem do mikrosytuacji jest przekazanie głosu dziennikarzowi pomocniczemu (lub - w razie obecności tylko jednego dziennikarza - zwrócenie się do publiczności). Rozpatrzmy przykład z debaty, której tematem było ujawnienie teczek.

KD: [...] Czy gdyby ujawnić to, co kryja akta służb specjalnych PRL-u, wrzawa $w$ sprawie teczek ucichnie, czy przeciwnie - dopiero wtedy naprawdę rozgorzeje? Wszystko o teczkach dziś $w$ „Debacie” Jedynki. A na widowni dzisiejszego programu młodzi ludzie, którzy w swoich teczkach, czy teczkach z czasów PRL-u, z pewnościa niczego by nie znaleźli, bo byli wtedy jeszcze dziećmi, ale jak się okazuje, o czym pewnie się za chwile przekonamy, ta sprawa teczek także u nich budzi emocje. Piotr Baron.

PB: No emocje i to nieduże [sic!]. Pan mi powiedziat ${ }^{55}$, że dekomunizacja $w 2005$ roku to absurd. Dlaczego?

PS: Ja uważam, że teraz spotkaliśmy się, po pierwsze, o 16 lat za późno. [...]

(20.01.2005; gość - PS: Paweł Sochacki)

Rama tekstu, wprowadzenie:

[pytanie globalne, dotyczące tekstu] Czy gdyby ujawnić to, co kryją akta stużb specjalnych PRL-u, wrzawa $w$ sprawie teczek ucichnie, czy przeciwnie - dopiero wtedy naprawdę rozgorzeje?

[zapowiedź tematu] Wszystko o teczkach dziś w „Debacie” Jedynki.

[kreowanie mikrosytuacji w studiu: prezentacja publiczności, wyjaśnienie jej związku z tematem, precyzowanie oczekiwań] A na widowni dzisiejszego programu młodzi ludzie, którzy w swoich teczkach, czy teczkach z czasów PRL-u, z pewnościa niczego by nie znaleźli, bo byli wtedy jeszcze dziećmi, ale jak się okazuje, o czym pewnie się za chwile przekonamy, ta sprawa teczek także u nich budzi emocje.

[przekazanie prowadzenia dziennikarzowi pomocniczemu] Piotr Baron.

55 Wypowiedź świadczy o uprzednim przygotowaniu dziennikarza do rozmowy, o przeprowadzeniu rozmów o charakterze rozpoznawczym. 
Tekst zasadniczy:

[tło sytuacyjne (tu: powtórzenie charakterystyki publiczności, zasygnalizowanie wcześniej pozyskanych opinii)] No emocje i to nieduże. Pan mi powiedziat, że dekomunizacja w 2005 roku to absurd.

[pierwsze pytanie konstytuujące grupę oponentów] Dlaczego [domyślnie: dekomunizacja to absurd]?

Schemat ten jest powielany $\mathrm{z}$ nieznacznymi modyfikacjami $\mathrm{w}$ kolejnych przykładach:

- przykład z debaty o narkomanii:

KD: [...] Czy złagodzenie ustawy, nawet wbrew pogladom opinii publicznej, może pomóc $w$ walce z narkomanią? [...] O tym dziś $w$ „Debacie”, w której wezmą udziat także ci, którzy sami już się przekonali, jak ryzykownie i niebezpiecznie może skończyć się na pozór niewinne spróbowanie matego odlotu.

PB: A to niewinne spróbowanie często kończy się dtugoletnia gehenna. Pan pracuje $w$ środowisku narkomanów. Być może pan zna odpowiedź na pytanie, czy jest możliwy uchwytny taki moment, kiedy człowiek staje się narkomanem?

KJ: No nie. Ten moment/ w zasadzie nie da się go zauważyć. [...]

(10.02.2005; gość - KJ: Kuba Jędrachowicz)

Rama tekstu, wprowadzenie: [pytanie globalne] + [zapowiedź tematu] + [prezentacja publiczności]

Tekst zasadniczy: [tło sytuacyjne (tu: zarysowanie problemu, charakterystyka rozmówcy)] + [pytanie rozpoczynające pierwszy segment]

- przykład z debaty o eutanazji:

KD: Czy nieuleczalnie chorzy i czasem straszliwie cierpiacy ludzie powinni mieć prawo do godnej i dobrej śmierci ? [...]. O tym dziś będziemy debatować.

PB: Zwolennicy eutanazji uważaja, że to prawo, to jeden z obszarów naszej wolności. Chciatem pana zapytać, panie Arturze, na czym ta wolność polega?

AC: Uważamy, że prawo do eutanazji, że problem eutanazji jest bardzo skomplikowany i niejednoznaczny, i delikatny. [...] (24.02.2005; gość - AC: Artur Chludziński)

Rama tekstu, wprowadzenie: [pytanie globalne] + [zapowiedź tematu]

Tekst zasadniczy: [tło sytuacyjne (tu: charakterystyka poglądów grupy proponentów) + [pierwsze pytanie konstytuujące grupę proponentów]

- przykład z debaty o tolerancji:

KD: [...] I jedni, i drudzy moga podać mnóstwo przykładów, by udowodnić swoja teze [że jesteśmy tolerancyjni/nie jesteśmy tolerancyjni]. Porozmawiajmy zatem o tych przykładach, by potem móc zapytać, czy nietolerancja polska jest, czy jest groźna $i$ skąd się bierze. Piotr Baron.

PB: Marsz równości w Poznaniu. Wszyscy o nim styszeliśmy, ale jako, że działo się to kilka tygodni temu, przypomnijmy jak było, co się stato w Poznaniu. (9.12.2004)

Rama tekstu, wprowadzenie: [tło sytuacyjne] + [zachęta z podaniem tematu (rozmowa o przykładach na tolerancję i nietolerancję)] + [plan tematyczny rozwinięcia] + [oddanie głosu dziennikarzowi pomocniczemu]

Tekst zasadniczy: [tło sytuacyjne] + [plan tematyczny pierwszej sekwencji] 
Zakończenie segmentu z publicznością może być okazją do podsumowania:

KD: Zanim się zarysuje w tym sporze bardziej osobisty watek $i$ bardziej intymny [z rozbawieniem], to może spuentujmy te część rozmowy w ten sposób: spór ewidentnie toczy się na dwóch ptaszczyznach - pierwsza to ptaszczyzna prawna, od niej zaczęliśmy, ale dość szybko dotarliśmy do ptaszczyzny pewnej moralnej oceny tego, czym jest zjawisko prostytucji i czym jest seks za pieniądze. Jeśli państwo pozwola, to zaproszę do wystuchania rozmowy z naszymi ekspertami.

(13.01.2005)

Element organizacyjny zawiera funkcjonalne komentarze metadyskursywne, które nazywają bieżące działania prowadzącego (spuentujmy tę część rozmowy), odsłaniają makrostrukturę segmentu (zaczęliśmy od płaszczyzny X, dotarliśmy do płaszczyzny Y), nadają segmentowi kwalifikację generyczną (spór). Po dokonaniu podsumowania dziennikarz zapowiada nowy segment, wyodrębniony ze względu na rodzaj rozmówców. Nazywa ich ekspertami (w innych debatach także używa sformułowania goście).

KD: Dobrze, jeśli państwo pozwola, chciałbym, żeby państwo i nasi widzowie postuchali teraz rozmowy z zaproszonymi gośćmi. Dyskusja, czy 3-4 tygodniowy embrion to człowiek czy nie, jest bardzo dtuga, $i$ toczy się także na tym poziomie emocjonalnym, jakiego świadkami byliśmy przez chwilę. I nie zanosi się na to, żeby to się szybko skończyto. Spór będzie więc trwat, ale prawo $\underline{w}$ tej materii musi istnieć, $i$ szczerze powiedziawszy, wyglada na to, że będa to ustalali politycy, tak to $w$ demokracji wygląda. Przyznam się państwu, że trochę mnie to przeraża. Nie wiem, czy państwa także. (18.11.2004)

$\mathrm{W}$ interwencji organizacyjnej dziennikarz zamyka segment $\mathrm{z}$ publicznością i zapowiada segment z gośćmi. Dokonuje też podsumowania segmentu jako fragmentu szerszej debaty: określa jej charakter, przypomina główną linię sporu. Z podsumowania wynika również funkcja, jaką dziennikarz nadał segmentowi z publicznością. Miała to być próbka debaty, naoczne pokazanie tego, jak w Polsce wygląda debata na temat aborcji. Następnie prowadzący zmienia tło sytuacyjne (z kontekstu moralnego na kontekst prawny i polityczny) z myślą o następnym segmencie. Ten przykład elementu organizacyjnego realizuje optymalny schemat działania: widz wie, jak ma odebrać to, co właśnie usłyszał i dowiaduje się, o czym za chwilę będzie mowa.

KD: Żeby spróbować ukonkretnić jakoś tę dyskusję, przyjrzyjmy się krajom, w których legalizacja eutanazji nastapiła jakiś czas temu i w których eutanazja jest legalna. Ja poproszę o te dane [pokazuje tablicę], które przygotowaliśmy: to jest Holandia, 3500 zabiegów mniej więcej rocznie, i Belgia już ze znacznie mniejsza liczba 170 zabiegów. To sa dokonane w świetle prawa oficjalnie zabiegi eutanazji. [przechodzi do stolika ekspertów, tyłem do publiczności, staje naprzeciw] № $\underline{i}$ to jest pytanie do naszych gości również tutaj, czy te liczby i te dane, które tutaj przytaczaliśmy, to sa przypadki, w których pomaga się ludziom uwolnić od cierpienia, czasami nie do zniesienia, czy to sa przypadki zabójstwa? (24.02.2005) 
W podanym przykładzie brak jest podsumowania segmentu z publicznością. Dziennikarz wprowadza nowy segment, rozpoczynając kolejną cząstkę tematu (eutanazja w innych krajach). Dopiero sformułowanie pytania zostaje poprzedzone wskazaniem gości jako następnej grupy rozmówców.

PB: A zastanawiat się pan, jak będzie wyglądat krajobraz po tej „bitwie teczkowej” w Polsce?

MB: Myślę, że będzie wygladat podobnie do tego, co teraz, tylko niektóre fakty z przeszłości będa jaśniejsze. [...]

KD: To, co pan powiedziat, „krajobraz po bitwie”, nie będzie specjalnie różnit się od tego dzisiejszego. Mamy wieczny krajobraz po bitwie. Witam naszych gości. Gości za stołem głównym.

(20.01.2005; gość - MB: Marek Bosak)

Dziennikarz, komentując stanowisko proponentów, używa perswazyjnych określeń „bitwa teczkowa”, „krajobraz po bitwie”. Jest to przykład nieneutralnego odniesienia się nadawcy do jednej ze stron debaty i przykład stronniczego podsumowania segmentu z publicznością.

KD: [...] Panowie, [przechodzi od publiczności do stolika z gośćmi] protesty przeciwko paradzie równości, protesty i gwizdy, kiedy na boisku pojawia się obcokrajowiec, Murzyn, piłkarz, protesty, kiedy dziecko ma chodzić do klasy integracyjnej z dziećmi niepetnosprawnymi. Czy wspólnym mianownikiem tych opisywanych przeze mnie zdarzeń i zachowań jest nietolerancja? (9.12.2004)

Dziennikarz zwraca się do gości (delimitację wspomaga sygnał wizualny przemieszczenie się dziennikarza w przestrzeni studia), dokonując quasi-podsumowania. W segmencie z publicznością była bowiem mowa tylko o protestach przeciwko paradzie równości, natomiast pozostałe elementy zostały dodane przez dziennikarza. Efekt nagromadzenia pełni funkcję perswazyjną, która jest tym skuteczniejsza, że umieszczona w punkcie strategicznym, delimitacyjnym. Początek i koniec tekstu, segmentu jest zawsze miejscem wzmożonej uwagi odbiorcy.

\section{B. Segment z publicznością rozdziela segment z gośćmi}

$\mathrm{W}$ nielicznych programach segment $\mathrm{z}$ publicznością jest usytuowany w środkowej części debaty. Taki schemat strukturalny cechuje się wyraźnym wprowadzeniem segmentu, któremu może towarzyszyć podsumowanie dotychczasowej dyskusji z gośćmi.

KD: Jeśli panowie pozwola, ja bym chciat jeszcze zapytać tych, którzy, jak rozumiem, w części stuchaja Radia Maryja, w każdym razie maja na jego temat swoja wyraźna i zdecydowana opinię. My styszeliśmy: fundamentalizm, niebezpiecznie, porządnie, ewangelizacja - duży zbiór rozmaitych pojęć. A dla państwa czym jest to radio? Dla pani? (11.01.2006)

[zwrot do gości z wyrażeniem intencji zmiany rozmówców] + [charakterystyka rozmówców wraz z uzasadnieniem ich uczestnictwa] + [podsumowanie części segmentu z gośćmi] + [pytanie o opinię skierowane ogólnie do publiczności] + [skierowanie pytania do konkretnej osoby] 
KD: A te środki dyscyplinujące/[gwar] już idziemy do publiczności/ a te środki dyscyplinujące dla adwokatów, to też temu ma stużyć? [...] Na to pytanie: czy przepisy, czy kary? Mamy studentów prawa, prawda. Studenci prawa? Studenci prawa. Tak. Zagrałby pan na takie przedawnienie jak FOZZ-ie czy nie?

BN: Absolutnie nie chciałbym się skupiać na takiej pojedynczej kwestii [...]

(3.03.2005; gość - BN: Bartosz Niemczynowicz)

[zapowiedź segmentu z publicznością] + [pytanie o opinię skierowane ogólnie do publiczności] + [prezentacja rozmówców w rolach społecznych] + [uszczegółowienie tematu i skierowanie pytania do konkretnej osoby]

Dla schematu strukturalnego, w którym segment z publicznością rozdziela segment z gośćmi, typowy jest brak podsumowania segmentu z publicznością. Sygnałem zakończenia segmentu jest wygaszenie wątku ostatniego rozmówcy z publiczności i zainicjowanie dyskusji z gośćmi.

ŁP: Ja się nie zgadzam. Uważam, że ta sprawa trwa dlatego tak długo//

KD: Przepraszam, musimy wrócić do/ nie, nie będziemy dyskutować, dlaczego ta sprawa trwa tak dtugo, bo musielibyśmy się wgtębiać/ ile jest tomów akt?

ZW: Wyglacda, że 260 [...].

$\mathrm{KD}$ : Co robimy? Zmieniamy prawo, ilekroć ono nie działa, tak jak w sprawie FOZZ-u? [pytanie skierowane do gościa]

(3.03.2005; goście - ŁP: Łukasz Pałucki, ZW: Zbigniew Wasserman)

[przerwanie wypowiedzi osobie z publiczności] + [wyrażenie intencji przerwania wątku] + [skierowanie pytania do gościa]

KD: No tak, ale jest jednak wyraźna granica i nawet na użytek barwności dyskusji nie powinniśmy przeprowadzać znaku równości między partiami poprzedniego ustroju a Kościołem katolickim, bo to sa dwa zupetnie różne światy [...]. Wróćmy do tego, bo chciałbym jeszcze poznać panów opinie [zwracając się do gości przy stoliku głównym]. (11.01.2006)

[zamknięcie wątku podjętego przez publiczność] + [wyrażenie intencji zmiany grupy rozmówców] + [skierowanie pytania do gości]

Delimitacja segmentu z publicznością wymaga zdecydowanych działań prowadzącego, gdyż jej reprezentanci sygnalizują chęć bardziej otwartego udziału w dyskusji, mają własne propozycje ujęcia tematu. Tymczasem dziennikarz wyraźnie ogranicza ich swobodę argumentowania, obsadzając w roli proponentów i oponentów.

\subsubsection{Konstytuowanie grup proponentów i oponentów przez dziennikarza}

Działania, jakie podejmuje dziennikarz, mają na celu konstytuowanie grup proponentów i oponentów. Cel ten dziennikarz osiagga poprzez działania progresywne (eksplikacja stanowiska proponentów i oponentów) oraz regresywne 
(korygowanie lub wyłączanie zachowań rozmówców, którzy wychodzą z roli). Działania progresywne można dodatkowo podzielić na te, które mają charakter obligatoryjny, a więc są podstawowe, i działania fakultatywne o charakterze wspomagającym.

1. Działania podstawowe zmierzające do eksplikacji stanowiska (pytania otwarte o opinię, o uzasadnienie opinii, prośby o zdefiniowanie zjawiska z własnej perspektywy).

2. Działania wspomagające eksplikację zgodnie z kierunkiem argumentacji rozmówcy (przez interpretowanie, parafrazowanie wypowiedzi tak, aby jaśniej wyrazić intencję, przez werbalizowanie implikatur) oraz działania wspomagające eksplikację niezgodne z kierunkiem argumentacji rozmówcy (przez podawanie w wątpliwość wypowiedzi, dodawanie innej - niezgodnej z dotychczasową - perspektywy, innego aspektu zjawiska).

3. Działania korygujące zachowanie rozmówców (interweniowanie, kiedy wychodzą z roli proponenta lub oponenta i np. chcą kierować debatą, zmieniać temat, zmieniać pytanie, próbują podważać sens debaty czy niwelować różnice między przeciwnymi grupami).

W ramach działań dziennikarza dostrzegamy pewne strategie, które w tym kontekście oznaczają różne sposoby osiągania celów w zakresie kształtowania struktury debaty.

\subsubsection{Działania podstawowe zmierzające do eksplikacji stanowiska rozmówcy}

Na etapie działań podstawowych dziennikarz dokonuje wyboru, którą grupę konstytuuje jako pierwszą. Naturalna kolejność wskazuje na proponentów, ponieważ to oni występują z nową ofertą, propozycją zmiany. Czasem jednak dla spotęgowania emocji dziennikarz zaczyna od stanowiska odrzucającego dyskutowane rozwiązanie, czyli stanowiska oponentów - stosuje więc strategię inwersji. Kolejność konstytuowania grup jest ważna nie tylko ze względu na dramaturgię programu, ale również z uwagi na stosowane strategie strukturalne. W układzie interakcyjnym: dziennikarz - proponenci oraz dziennikarz - oponenci nie ma całkowitej symetrii, ponieważ to zawsze grupa wywołana jako pierwsza stanowi punkt odniesienia dla tej drugiej. Druga grupa ma niejako obowiązek ustosunkować się do tego, co wniosła do debaty ta pierwsza.

W konstytuowaniu grup dziennikarz wykorzystuje dwie główne strategie: albo zadaje kolejno obu grupom uprzednio przygotowane (te same lub podobne) pytania, albo przekazuje grupie drugiej argumenty pierwszej grupy (argumenty, które pojawiły się na żywo w dyskusji). Widać, że strategie są dostosowane i do sytuacji planowanych, i do sytuacji nieplanowanych, a ich wspólnym celem jest budowanie płaszczyzny wzajemnych odniesień między grupą proponentów i grupą oponentów. 


\section{A. Strategia polegająca na stawianiu obu stronom tych samych lub podobnych pytań}

\section{a) pytanie o opinię, o uzasadnienie opinii}

PB: No wtaśnie, to jest pytanie: czy dobrze, że angażujemy sie aż tak bardzo w sprawy Ukrainy? [...]

TR: Polska musi wspótpracować z każda wtadza na Ukrainie, niezależnie jaka ona będzie. A jeżeli wygra Janukowycz, to odbije się to negatywnie na polskich stosunkach z Ukraina, a ofiara tego, o czym się zapomina w tej chwili, będzie polska mniejszość, która mieszka na Ukrainie, a to jest najważniejsza w tej chwili naszego rządu powinność i najważniejsza sprawa. Więc jeżeli wygra Janukowycz, a my angażując się tam mocno po stronie Juszczenki doprowadzimy do ochtodzenia stosunków polsko-ukraińskich - Ukraina już de facto wpadnie w sidła Rosji.

(25.11.2004; gość - TR: Tomasz Rola)

Pytanie zasadnicze poprzedza zapowiedź metatekstowa (No wtaśnie, to jest pytanie), która jest przejawem strategii strukturalnej i świadczy o doniosłości pytania w strukturze debaty. Odpowiedź świadczy o przyjęciu przez rozmówcę stanowiska oponenta.

PB: Czy zbyt mocno angażujemy się na Ukrainie? Co państwo na to? Proszę bardzo.

BW: Otóż sądzę, że kolega z Ligi Polskich Rodzin myli się, mówiąc, że nie ma dowodów. Dowody sa na oszustwa, które zdarzaty się przy urnie. Obserwatorzy OBWE sa najlepszym przykładem. Nie ma chyba takich obserwatorów OBWE z Zachodu, którzy stwierdziliby, że nie byto oszustw.

(25.11.2004; gość - BW: Błażej Wojnicz)

Interwencja dziennikarza zawiera jednocześnie aż trzy sygnały konstytuowania grupy: pytanie, formułę konatywną z zaimkiem anaforycznym „to”, odsyłającym do dotychczasowej dyskusji: co państwo na to? i sygnał konatywny: prosze bardzo. Odpowiedź jest niedopasowana strukturalnie (wyprzedza fazę konfrontacji), więc dziennikarz pomija ją i zadaje pytanie następnemu propnentowi.

PB: Dobrze, powtórzę pytanie: czy powinniśmy się/ może inaczej: czy powinniśmy się tak bardzo angażować na Ukrainie?

MSz: Proszę państwa, koledzy i koleżanki, musimy sobie $w$ tym miejscu, w obecności tutaj kamer uświadomić, że to, co dzieje się w tej chwili na Ukrainie, to co się działo na Ukrainie w momencie wyborów, podczas drugiej tury - to jest kontrofensywa imperium zła. Tak to nazwat jeden z publicystów. Ja się catkowicie pod tym podpisuję i uważam, że polityka w tej chwili zagraniczna ma wymiar przede wszystkim moralny. Powinna być polityka odwagi i polityka aktywności. Ostatnie lata, proszę państwa, lata polityki, która prowadzit Aleksander Kwaśniewski to byta polityka deklaracji i polityka uścisków. To nie byta polityka realnego wspierania wolnej Ukrainy, wolnych mediów na Ukrainie i wolnych przemian rynkowych.

(25.11.2004; gość - MSz: Michał Szczerba)

Odpowiedź świadczy o przyjęciu przez rozmówcę stanowiska proponenta (Ja się catkowicie pod tym podpisuję). 
KD: Jeszcze jedno tylko pytanie: czy te marsze moga sie mijać w sposób pokojowy: wy możecie demonstrować swój światopogląd, swoje poglądy na życie, a druga strona swoje i nie musi dochodzić między nimi do starcia?

WSz: Ale tutaj tylko jedna strona jest, nazwijmy to, prowokujaca, druga strona jest strona odpowiadająca [śmiech] i w tym momencie no, taka sytuacja, że te marsze mogłyby się minać bez większych zgrzytów jest raczej fikcją.

(9.12.2004; gość - WSz: Wawrzyn Szczepaniak)

PB: Dobrze, wróce do tego pytania, które już padto $i$ skierowane byto do Mtodzieży Wszechpolskiej: czy te marsze moga się odbyć równolegle bez tego, co się stało w Poznaniu czy Krakowie?

KF: Wedtug mnie moga, pod warunkiem, ze obie strony będą nieagresywne. No to, co mówię, oczywiście w tej chwili odnosi się do tego, co się działo w Poznaniu, gdzie jednak agresywna strona byta strona przeciwna.

(9.12.2004; gość - KF: Krzesimir Florek)

PB: Dlaczego zalegalizować prostytucję?

BW: Ze względów społecznych. Kobiety, które pracuja, świadcza usługi seksualne, nie maja ubezpieczenia, nie sa pod żadna kontrola medyczna [...]. W momencie, kiedy to nie jest zalegalizowane, bądź kiedy to jest zupetnie poza jakimkolwiek systemem prawnym, normami prawnymi, to się wdziera tam kryminalizacja tego zjawiska.

(13.01.2005; gość - BW: Bartek Widawski)

PB: [...] dlaczego nie legalizować prostytucji w Polsce?

TK: Chciatbym się nie zgodzić z kolega, który na początku się wypowiadat na temat legalizacji, to oczywiście nie należy legalizować prostytucji. Prostytucja jest rzecza nienaturalna, rzecza sprzeczna $z$ praw/ z normami naturalnymi, z życiem, i legalizowanie prostytucji to jest tak naprawdę przyzwalanie na zło. Jeżeli ktoś uprawia prostytucję, to jest tak jak gdyby chory na duszy i może zastanówmy się, jak leczyćl jak leczyć ludzi, którzy są chorzy na prostytucję, co zrobić, żeby oni mogli powrócić do normalnego życia, a//

(13.01.2005; gość - TK: Tomasz Kot)

\section{b) pytanie o definicję zjawiska z perspektywy - raz proponentów, raz oponentów}

KD: Jeśli mógtbym prosić o jednozdaniowa definicję wtasnego rozumienia tolerancji. Wedtug panów, co to jest tolerancja?

WSz: Tolerancja jest to wykazanie zrozumienia $i$ znoszenie $z$ niechęcia, z wyrozumiatościa zjawiska, które jest, no, z gruntu antynormatywne, tak to nazwijmy, niewykazujące, tak jak w tym przypadku, elementarnego poszanowania $i$ tej wtaśnie tolerancji dla poglądów i sposobu myślenia większości.

(9.12.2004; gość - WSz: Wawrzyn Szczepaniak)

PB: Czym jest dla państwa tolerancja?

PC: Wydaje mi się, że tolerancja tak naprawdę, w pewnym sensie muszę się zgodzić z panem, bo tak naprawdę tolerancja jest/ nawet nie mówię o szacunku, bo jakby tutaj szacunek tak nie do końca jest, moim zdaniem, tak naprawdę znaczacy. Ważne jest to, że jeżeli nawet, nie wiem, nie 
pochwalamy stanowiska drugiej strony, to tolerancja polega na tym, żeby akceptować ja w pewnym sensie, to znaczy, żeby wyjść na ulicę i tak jak mówię wtaśnie przejść obok geja//

(9.12.2004; gość - C: Piotr Cywiński)

\section{B. Strategia polegająca na przekazywaniu stronom argumentów stro- ny przeciwnej}

\section{a) przekazanie stwierdzenia, opinii, argumentu do ustosunkowania wraz z komentarzem metadyskursywnym}

TR: No, powinniśmy zachować spokój. Nie angażować się tak mocno, bo my de facto $w$ tej chwili wzywamy do rewolucji. [...]

PB: No a co państwo na to stwierdzenie, że polscy politycy wywotuja na Ukrainie rewolucję?

BW: Znaczy, to może jest tak, że polscy politycy to sa dorośli ludzie. Oni na podstawie własnego doświadczenia wiedza, jak to jest żyć w niepodległym państwie [...]. Może z tego względu chca, żeby na/ również i na Wschodzie istniało suwerenne państwo.

(25.11.2004; goście - TR: Tomasz Rola, BW: Błażej Wojnicz)

PB: [...] wróćmy do tego, co powiedziat pan [z grupy oponentów]. Czy nie przekonuje pana to, $\dot{z} e$, niezależnie od finatu, jaki on będzie, polskie wtadze będa musiaty wspótpracować z jakąś władza na Ukrainie? Czy opowiedzenie się jednoznacznie po jednej stronie nie jest dla Polski niekorzystne?

MSz: Jak powiedziałem, $w$ tej chwili polityka zagraniczna ma wymiar moralny. Ja się bardzo cieszę, że Lech Watęsa byt dzisiaj na Ukrainie, że jest tam Bronisław Komorowski z PO, że sa politycy Unii Wolności, Prawa i Sprawiedliwości. Politycy, którzy mają autorytet moralny do tego, aby zabierać głos $w$ sprawach, które są istotne dla wspólnoty międzynarodowej.

(25.11.2004; gość - MSz: Michał Szczerba)

PB: Chciatbym, żeby państwo ustosunkowali sie do tego, że to państwo sprowokowali przebieg tej manifestacji.

ZS: Jestem jednym z organizatorów marszu. Jestem przedstawicielka organizacji zrzeszającej osoby homoseksualne, jak również inne organizacje też wzięty udziat $w$ organizacji tego marszu, byli to Zieloni 2004 i Nowa Lewica. Po pierwsze: niczego nie promowaliśmy. Państwo chyba nie rozumieja hasta „promocja”. Poza tym homoseksualizmu promować się nie da, tego się nie można nauczyć. Nie wyjdę na ulicę i nie pomyślę sobie: tak, będę od dzisiaj lesbijka. Panowie tutaj dają ewidentne świadectwo pewnego niedouczenia.

(9.12.2004; gość - ZS: Zofia Stanecka)

KF: [...] No to, co mówię, oczywiście w tej chwili odnosi się do tego, co się działo w Poznaniu, gdzie jednak agresywna strona byta strona przeciwna.

PB. To zupetnie inaczej niż Mtodzież Wszechpolska. Oni uważaja, że to państwo//

KF: No nie, tutaj musimy sobie jednak jasno powiedzieć, że to nie my rzucaliśmy kamieniami, to nie my biliśmy się z policja, to nie nas zatrzymano.

(9.12.2004; gość - KF: Krzesimir Florek)

PB: Ale pana nie przekonuje ta argumentacja, że bardzo wiele osób przy tej okazji można $\underline{\text { skrzywdzić? }}$ 
PZ: Myślę, że nie. Ja nie styszatem o żadnym przypadku wskazującym na to, że ktoś niestusznie znalazt się $w$ tych teczkach. Niech ludzie sami ocenia, widzac te materiaty - kto byt rzeczywiście wspótpracownikiem, a kto nie.

(20.01.2005; gość - PZ: Paweł Zanin)

PB: A nie przekonuje państwa argument, że należy te teczki ujawnić, żeby przez najbliższe 20, 30 lat one nie byty instrumentem gry politycznej?

PBn: Można teczki ujawnić pod wszakże jednym warunkiem, że nie otrzyma teczki na przykład pan Giertych, pan Macierewicz, pan Kaczyński, którzy teczki te wykorzystaja do własnych, prywatnych celów [...].

(20.01.2005; gość - PBn: Przemysław Banachowicz)

\section{b) przekazywanie stwierdzenia, opinii, argumentu do ustosunkowania bez komentarza metadyskursywnego}

[stwierdzenie proponenta] PM: Skoro nie możemy tego zjawiska zwalczyć, bo prostytucja przetrwała $i$ średniowiecze, $i$ Stalina, i tak samo Kaczyńskiego przetrwa, to powinniśmy przynajmniej czerpać jakieś korzyści. [...]

[przekazanie stwierdzenia proponenta - oponentom] KD: No dobrze, A nie martwi państwa jednak fakt, że skoro rezultaty walki z prostytucja toczonej przez kilka tysięcy lat/ na dobra sprawe przez kilka tysięcy lat, sa, nazwijmy rzecz bardzo delikatnie, mierne, to jakiekolwiek zabranianie [jest po prostu nieskuteczne?

TK: [Panie redaktorze, panie redaktorze, nie no, nie można tak powiedzieć. Również ludzie zawsze kradli i nikt nie legalizuje kradzieży. Tak samo nie należy legalizować prostytucji. [oklaski] To jest zło.

(13.01.2005; goście - PM: Piotr Mieśnik, TK: Tomasz Kot)

[stwierdzenie proponenta] BW: [...] W momencie, kiedy to [prostytucja] nie jest zalegalizowane, bądź kiedy to jest zupetnie poza jakimkolwiek systemem prawnym, normami prawnymi, to się wdziera [ruch ramion do góry] tam kryminalizacja tego zjawiska. [...]

[stwierdzenie oponenta] ML: Ale nie musimy każdego zjawiska społecznego legalizować, prawda? [...] Jest jednak podział na dobro $i$ zło, uznawany przez ludzi i jakoś spotecznie akceptowany. Być może jest to różnie uznawane przez różne grupy społeczne, [ale jest podziat//

[przekazanie stwierdzenia proponenta do ustosunkowania się] PB: [No dobrze, ale czy tego typu zjawisko, jakim jest prostytucja, nie zostaje wtedy pod ${ }^{56}$ kontrola?

(13.01.2005; goście - BW: Bartek Widawski, ML: Maciej Lis)

\section{c) przekazanie definicji zjawiska z perspektywy proponentów bądź oponentów stronie przeciwnej}

[pytanie do proponenta] PB: A próbowat pan kiedyś sobie odpowiedzieć na pytanie, co tak naprawde legalizujemy, legalizujac prostytucje?

BW: Tak, oczywiście, legalizujemy stosunki seksualne mężczyzn i kobiet za pieniądze.

PB: Stucham? [z niedowierzaniem]

[wyrażenie konatywne, przekazanie stanowiska proponentów do ustosunkowania się] PB: Proszę bardzo. [wskazując ręką grupę oponentów]

${ }^{56}$ Błąd składniowy, powinno być: czy tego typu zjawisko, jakim jest prostytucja, nie zostaje wtedy poza kontrola. 
TK: Chciatbym się nie zgodzić $z$ kolega, który na początku się wypowiadat na temat legalizacji, to oczywiście nie należy legalizować prostytucji. Prostytucja jest rzecza nienaturalna, rzecza. sprzeczna z praw/z normami naturalnymi, z życiem, i legalizowanie prostytucji to jest tak naprawdę przyzwalanie na zło. Jeżeli ktoś uprawia prostytucję, to jest tak jak gdyby chory na duszy [...].

\section{(13.01.2005; goście - BW: Bartek Widawski, TK: Tomasz Kot)}

[definicja oponenta] WG: Chyba nie ma między nami różnic co do stwierdzenia faktu, że prostytucja jest zła, prawda? I/ i ja myślę, że wszyscy jak tu siedzimy nie [chcielibyśmy/ No wtaśnie, czy chcielibyśmy, żeby nasze siostry, koleżanki byty prostytutkami?

[przekazanie definicji proponentom do ustosunkowania się] KD: [To sprawdźmy ${ }^{57}$, czy prostytucja jest ztem, czy nie?

PM: Prostytucja nie jest złem.

(13.01.2005; goście - PM: Piotr Mieśnik, WG: Wojciech Gałązka)

Aby wykazać istotność konstytuowania „na żywo” grup proponentów i oponentów, podajemy przykład negatywny. W dotychczasowych przykładach dziennikarz konstruował typowy układ interakcyjny debaty (proponenci/oponenci) niejako na oczach widzów (przez zadawanie pytań i przekazywanie argumentów). W poniższym przykładzie rozmówcy relacjonują przebieg debaty publicznej poza studiem. Grupy proponentów i oponentów nie są tworzone na żywo $\mathrm{w}$ studiu, ale widz dowiaduje się o nich $\mathrm{z}$ relacji.

KD: Teraz wracajac do Radia Maryja i Telewizji Trwam.

TK: [...] dużo osób się nie zgadza z tym, że Radio Maryja propaguje jakieś złe poglądy, no, niestuszne poglady. To od razu to jest argument do zbicia [...].

KD: To skad $w$ takim razie hierarchowie Kościoła katolickiego, skąd biskupi maja taki problem z Radiem Maryja? Dlaczego są tak różne głosy różnych biskupów? Dlaczego tak krytycznie się wypowiada o tym radiu ksiądz biskup Pieronek na przyktad, a są biskupi, którzy radia bronią?

TK: Ja myślę, że to jest całkowicie naturalne. W społeczeństwie jest tak, że wiele osób ma różne poglądy. To jest catkowicie naturalne, tym bardziej w demokratycznym państwie. Nikogo nie możemy zmusić do tego, żeby miat poglądy jedynie stuszne.

(11.01.2006; gość - TK: Tomasz Kot)

Rozmówca i dziennikarz przechodzą na poziom opowiadania o debacie publicznej. Jest to inne działanie niż demonstrowanie, prowokowanie debaty w studiu. W takim trybie nie tworzy się grupy dyskusyjnej na oczach widzów, lecz widz dowiaduje się o istniejących różnicach stanowisk w komunikowaniu publicznym. Różnica między przykładami dotychczasowymi a ostatnim sprowadza się w gruncie rzeczy do różnicy między naoczną demonstracją a relacją.

Konstruowanie na oczach widzów, na żywo, grup proponentów i oponentów jest zadaniem dziennikarza wynikającym z gatunkowych uwarunkowań interakcji, której należy nadać formę debaty. Strategie strukturalne stosowane w tym zakresie przez prowadzących zmierzają do wytyczenia linii podziału między grupami,

57 Użycie wyrażenia „sprawdźmy” potwierdza tezę, że dziennikarz na oczach widzów konstytuuje grupy dyskutantów. 
dzięki ustosunkowaniu się do określonego zagadnienia. W dobrze zorganizowanej debacie musi bowiem istnieć płaszczyzna odniesień do wspólnego problemu, inaczej mamy do czynienia z mijaniem się (przykładem jest rozkład opinii uniemożliwiający zdefiniowanie relacji, np. jedna grupa twierdzi A, B, a druga grupa C, D). Warto zaznaczyć, że nie wszystkie wątki, problemy są jednakowo ważne dla konstytuowania grup. Dla wyrazistości dziennikarz oznacza jako relewantne dla ich odróżnienia jeden, maksymalnie dwa problemy (i wyłonione z nich pytania, np. czy dobrze, że angażujemy się a $\dot{z}$ tak bardzo w sprawy Ukrainy? Czy marsze moga się mijać w sposób pokojowy? Dlaczego zalegalizować prostytucję?).

Strategie stosowane przez dziennikarzy polegają na zadawaniu obu stronom analogicznych pytań o opinię, o definicję zjawiska. Tego typu pytania mogą być przygotowane przed programem. Zdarza się, że w trakcie debaty pojawi się kontrowersyjna teza, która może dodatkowo uwyraźnić różnice poglądów, ubarwić widowisko (np. stwierdzenie, że polscy politycy wywołują na Ukrainie rewolucję), wówczas dziennikarze przekazują tę tezę do ustosunkowania stronie przeciwnej. Może towarzyszyć temu komentarz metadyskursywny uwyraźniający intencję: a co państwo na to stwierdzenie, że [...]; wróćmy do tego, co powiedziat pan. Czy nie przekonuje pana to, że [...]; chciałbym, żeby państwo ustosunkowali się do tego, że [...]; ale nie przekonuje pana ta argumentacja, $\dot{z} e$ [...]; a nie przekonuje państwa argument, że [...]; to zupetnie inaczej niż [oponenci], oni uważaja, że to państwo [...]. Przekazywanie stronom przeciwnych stanowisk utrzymuje pożądaną w debacie różnicę i nie pozwala na narzucanie poglądów oraz zachwianie równowagi. Jeśli jedna ze stron przedstawia tezę w sposób nieuprawniony jako wniosek, prowadzący reaguje w oczekiwany sposób, a więc zgodnie z konwencją debaty:

WG: Chyba nie ma między nami różnic co do stwierdzenia faktu, że prostytucja jest zła, prawda? [...]

KD: To sprawdźmy, czy prostytucja jest złem, czy nie?

\subsubsection{Działania wspomagające eksplikację stanowiska rozmówcy}

Do tej grupy należą działania dziennikarza polegające zarówno na interpretowaniu i parafrazowaniu wypowiedzi rozmówcy, formułowaniu na ich podstawie wniosków, werbalizowaniu implikatur, jak również na podawaniu w wątpliwość wypowiedzi, zmianie perspektywy, dodawaniu wątków niezgodnych z dotychczasową wiedzą, doświadczeniem rozmówcy. Wszystkie te działania, niezależnie od tego, czy dziennikarz podąża za tokiem argumentacji rozmówcy, czy też przeciwstawia się mu, mają jeden cel usytuowany na płaszczyźnie organizacji strukturalnej debaty. Jest nim wspomaganie eksplikacji stanowiska grupy oponentów i proponentów, w ścisłym nawiązaniu do tego, co już zostało od nich wyegzekwowane podczas działań podstawowych. 
Działania dziennikarza wspomagające eksplikację stanowiska mają swój ważny aspekt tekstotwórczy, ponieważ wyraźnie nawiązują do wypowiedzi rozmówców, dzięki czemu wzmacniają spójność tekstu, budują jego strukturę przez zagęszczanie siatki relacji między wypowiedziami uczestników debaty. Budowanie koherentnej struktury jest zaś warunkiem nie tylko sprawnego odbioru tekstu, ale również tworzenia jego sensu.

Kryterium opisu strategii w zakresie działań wspomagających eksplikację stanowiska czynimy zbieżność lub rozbieżność kierunku działań dziennikarza z działaniami rozmówcy. Wyróżniamy zatem strategie zgodne z kierunkiem argumentacji rozmówcy i strategie z nim niezgodne. Obie strategie zupełnie inaczej wyglądają w odbiorze, bo w jednej dziennikarz jakby ${ }^{58}$ współpracuje z rozmówcą, a w drugiej - jakby polemizuje. Jednak ich cel usytuowany na poziomie struktury jest wspólny: wspomaganie eksplikacji stanowiska każdej ze stron.

\section{A. Strategia polegająca na działaniu zgodnym $\mathrm{z}$ kierunkiem argumen- tacji rozmówcy}

Dzięki tej strategii dziennikarz, który ma określony plan debaty, czuwa nad jasnością i wyrazistością wyrażania stanowisk przez strony. Prowadzący, kierując debatą, dokonuje pewnych zabiegów na wypowiedziach swoich rozmówców, swoistych transpozycji tych wypowiedzi, tak aby ułatwić ich zrozumienie i odbiór, połączyć je z dotychczasową linią tematyczną. Wnioskowanie, streszczanie, parafrazowanie wypowiedzi jest nie tylko strategią ułatwiającą odbiór, ale może również służyć wzmocnieniu niektórych wątków, a nawet sterowaniu odbiorem. Streszczanie, wnioskowanie jest bowiem zawsze jakąś interpretacją, a transpozycja tekstu nigdy nie będzie po prostu jego zwykłym odwzorowaniem.

\section{a) interwencja dziennikarza polegająca na sformułowaniu wniosku}

PS: Ten temat [ujawnienie teczek] ja wiem, że wzbudzat zawsze wiele kontrowersji. Jest to temat zawsze, powiedzmy, na topie. Niedtugo mamy kampanię wyborcza, być może dlatego też pojawit się. Ja uważam, że tak naprawdę jest to temat, który budzi duże kontrowersje, po pierwsze dlatego, gdyż może ranić osoby, które tak naprawdę nie brały udziału świadomie $w$ tych wszystkich akcjach, po drugie zaś uważam, że opinie publiczna tak naprawde bardziej interesuje to życie codzienne, to, co teraz jest ważne, czyli problem bezrobocia, problemy stużby zdrowia, problemy, które sa teraz aktualne//

PB: Ale sadzi pan, że teczki należy zostawić historykom?

58 Użyto sformułowania ,jakby” dla zaznaczenia faktu, że dziennikarz nie działa spontanicznie i z przekonania, ale stosuje różne strategie w ramach pełnienia roli. Jego działań nie można więc uznać za emanację rzeczywistych poglądów, bo trzeba by przyjąć, że zmienia je wielokrotnie $\mathrm{w}$ trakcie jednego programu. 
PS: Ja uważam wtaśnie, że teczki należy zostawić historykom i niech oni sprawuja się wtaśnie tymi kwestiami/ nad tym zawładna, a dla ludzi naprawdę ważne kwestie to są kwestie, które wymieniłem. (20.01.2005; gość - PS: Paweł Sochacki)

G: [...] przedstawię taki argument, który jest bardzo istotny, ale wielokrotnie ignorowany: nie można stawiać na równi ludzi, którzy świadomie wspótpracowali z SB, a ludzi, którzy byli do tego zmuszani.

PB: Czyli podnosi pan tę kwestię, że przy okazji wrzucania tych wszystkich teczek do jednego worka i potem wysypania tych teczek, można bardzo wiele osób skrzywdzić.

(20.01.2005; gość - G: gość z publiczności)

KF: [...] przed marszem Młodzież Wszechpolska na konferencji prasowej radnych prawicy, nie pamiętam dokładnie, czy to byt LPR tylko czy razem z PiS-em - powiedziata, że zorganizuje kontrdemonstrację, w której będa brać udziat ich znajomi kibice i oni nie odpowiadaja za zachowanie kibiców. To byto jasnym sygnałem tego, że oni dopuszczaja możliwość chuligańskich wybryków.

PB: Czyli pan sugeruje, że to tė̇ było zorganizowane, tak?

KF: Tak, jak najbardziej. (9.12.2004; goście - KF: Krzesimir Florek)

G: [...] uważamy, że również ludzie, którzy maja inne poglądy niż uczestnicy marszu równości, czyli nie chca promować homoseksualizmu, mają prawo do wyrażenia swoich pogladów na ulicach Poznania.

KD: A homoseksualiści, rozumiem, też maja prawo do wyrażania swoich pogladów na ulicach $w$ takich marszach i paradach? (9.12.2004; gość - G: gość z publiczności)

G: My dwa tygodnie przed tym marszem już powiedzieliśmy, że rozumiemy, że sa tacy ludzie, którzy cierpia na chorobę zwana homoseksualizmem [poruszenie, pomruki], ale jako zachowanie, które nie powinno być przenoszone na polskie ulice, nie powinno się tego promować. [...]

KD: Dobra, rozumiem, że tego marszu nie powinno być. Nie mają prawa do tego, żeby wyjść na ulicę i zamanifestować to, że chcą takich postulatów, realizacji innych jeszcze i jeszcze.

WSz: Jeśli przyjmiemy, bo tak na pewno byto, że marsz byt tylko punktem kulminacyjnym bardziej zorganizowanej akcji homoseksualistów, to z pewnościa nie musiat mieć miejsca.

(9.12.2004; goście - G: gość z publiczności, WSz: Wawrzyn Szczepaniak)

JS: [...] dyskusja o/ dyskusja o życiu, o możliwości odbierania życia, to w Polsce byta już w latach 80. Ja/ tutaj wielu nie pamięta tych lat, ale ja ja prowadzitem wtedy, miałem takiego adwersarza, uczonego kolegę, który wtaśnie próbowat mi udowodnić/ i tak sobie dyskutowaliśmy, ja szukałem argumentów, $i$ to trwato, to nawet długo trwało. Ja szukatem argumentów za życiem, on przeciw. Po drodze zauważytem, że/ na szczęście, że to robi się yyy takie sportowe zajęcie, to igrzyska, więc same argumenty tutaj $w$ takiej debacie/ no nie [wystarczaja.

PB: [Ale co, sadzi pan, że dyskusja w Polsce o aborcji ma charakter powierzchowny?

(18.11.2004; gość - JS: Józef Statkiewicz)

Rozmówcy z publiczności wyrażają swoje stanowisko często w sposób zbyt zawiły, rozwlekły i niejednoznaczny, jak na wymogi medialnego widowiska. Dziennikarz, dążąc do zogniskowania i zdynamizowania interakcji, podejmuje strategie strukturalne sygnalizowane w warstwie metadyskursywnej (ale sadzi pan, $\dot{z} e$ [...]; czyli podnosi pan te kwestię, $\dot{z} e$ [...]; czyli sugeruje pan, że [...]). 
W ten sposób angażuje się w budowanie struktury debaty poprzez streszczające parafrazowanie, wyciąganie wniosków z dłuższych wypowiedzi rozmówców. Podsumowania mają być zwięzłe i tak ukierunkować odbiór treści, aby łatwiej było zakwalifikować osobę do grupy proponentów lub oponentów.

\section{b) interwencja dziennikarza polegająca na zwerbalizowaniu implikatury}

G: [...] Młodzież Wszechpolska na pót godziny przed rozpoczęciem marszu równości zorganizowata pikiete promująca tradycyjny model polskiej rodziny, ponieważ uważaliśmy, że ludzie normalni również musza mieć $w$ tym dniu swobode i prawo do wygtoszenia swoich pogladów [pomruk niezadowolenia].

KD: Ludzie normalni - to znaczy, ci po drugiej stronie byli nienormalni.

G: Powiedzmy, ludzie, którzy/ których poglądy sa zgodne z taka większą opinią [sic!] spoteczeństwa.

(9.12.2004; gość - G: gość z publiczności)

W ostatnim przykładzie ujawniają się normy dyskursu publicznego, a mianowicie konieczność powstrzymania się od obrażania przeciwnika. Dziennikarz, wyciągając implikaturę (to znaczy, ci po drugiej stronie byli nienormalni), stawia rozmówcę w sytuacji zagrożenia twarzy. Rozmówca podejmuje strategię obrony twarzy pozytywnej i wycofuje się z identyfikacji swojej grupy jako „ludzi normalnych".

\section{B. Strategia polegająca na działaniu niezgodnym z kierunkiem argu- mentacji rozmówcy}

W tej strategii dziennikarz przyjmuje maskę polemiczną. Podważa tezy rozmówcy po to, aby skłonić go do głębszej refleksji: zastanowienia się nad nieścisłościami, zweryfikowania uproszczeń i stereotypów, wreszcie - do wzięcia pod uwagę dodatkowych aspektów lub innych perspektyw. Celem dziennikarza jest krytyka merytoryczna, która ma przyczynić się do wykrystalizowania poglądów. Dowodem na strategiczność działań jest przyjmowanie różnych masek w zależności od dyskutanta ${ }^{59}$.

\section{a) interwencja dziennikarza polegająca na podaniu w wątpliwość wy- powiedzi rozmówcy}

G: Ja chciałabym tu wrócić na chwileczkę do pani wypowiedzi, ponieważ pani zadała dość proste pytanie: „Czy jest zgoda tutaj forum naszego na twierdzenie, ̇̇e aborcja zagraża

${ }^{59}$ Interakcje takie dostarczają cennych informacji na temat kompetencji uczestnika. Widz może wtedy ocenić umiejętności komunikacyjne rozmówcy, bo ten nie wygłasza przygotowanych wcześniej wystąpień, lecz musi reagować na żywo. Odbiorca medialny ma szansę zaobserwować, jak uczestnik reaguje na sprzeczne informacje, jak potrafi integrować niezgodne wątki, aspekty, przekonująco uzasadnić swoje stanowisko. 
życiu kobiety?” Oczywiście na tak proste pytanie jest możliwa tylko jedna prosta odpowiedź: nie. [śmiech] [...] Pytanie jest oczywiście źle postawione, bo na pewno jest szereg przypadków, $w$ których aborcja zagraża życiu kobiety, podobnie jak mogą być przypadki, w których operacja wyrostka robaczkowego zagraża życiu pacjenta $i$ szereg tego typu przypadków, $i$ to jest/ ciąza

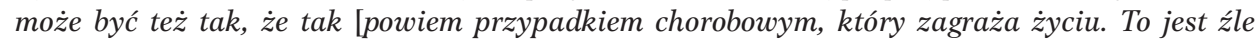
postawione pytanie.

KD: [A ja mam do pani takie pytanie: czy sadzi pani, że liczba depresji, a przede wszystkim samobójstw po operacjach wyrostka robaczkowego jest tak duża jak po zabiegach usunięciach ciaży? [oklaski]

G: Ja, niestety, absolutnie nie mam informacji statystycznych, ponieważ się tym nie zajmuję, więc to pytanie należy//

KD: O 5,8\% rosna po zabiegach aborcyjnych. (18.11.2004; gość - G: gość z publiczności)

Dziennikarz podaje w wątpliwość trafność porównania operacji wyrostka robaczkowego do usunięcia ciąży. Czyni to w sposób ironiczny, co nie zostaje jednak odczytane przez rozmówczynię, która odbiera pytanie ironiczne w sposób dosłowny (Ja, niestety, absolutnie nie mam informacji statystycznych, ponieważ się tym nie zajmuję). Widownia odbiera jednak intencję dziennikarza jako zakwestionowanie stanowiska, o czym świadczą (nagradzające celny odwet) oklaski.

\section{b) interwencja dziennikarza polegająca na wprowadzeniu wątków nie- zgodnych z kierunkiem argumentacji rozmówcy}

AC: Przede wszystkim [jesteśmy wdzięczni generałowi Jaruzelskiemu] za uratowanie kraju od destabilizacji i interwencji obcych sit. Dzięki wprowadzeniu stanu wojennego uratowano kraj od wojny.

KD: A te wszystkie ofiary trudne dzisiaj do udokumentowania, za to wszystko, co wtaściwie można nazwać zbrodnia stanu wojennego, za to też państwo chcieliby podziękować?

(16.12.2004; gość - AC: Andrzej Całkiewicz)

Dziennikarz do argumentu proponentów (uratowanie kraju) dodaje wątek niepasujący do pozytywnej oceny generała (zbrodnie stanu wojennego). Działania te można określić jako poszerzanie kontekstu o kolejne wątki, ale w tonacji kpiarsko-ironicznej. Forma pytania jest tu bardzo ważna, gdyż ma na celu zaktywizowanie rozmówcy do wzięcia pod uwagę wątków niezgodnych z własnym postrzeganiem.

\section{c) interwencja dziennikarza polegająca na zmianie perspektywy opisu zdarzeń}

G: Organizatorzy [prowokowali nas] poprzez promocję homoseksualizmu pod pojęciem tolerancji, której tak naprawdę tam nie było.

$\mathrm{KD}$ : A czy prowokacja nie byto to, że organizujecie te pikiete pót godziny przed demonstracja drugiej strony? 
G: Nie, organizatorzy marszu domagali się wręcz, żebyśmy zorganizowali kontrmanifestację $[\ldots]$.

(9.12.2004; gość - G: gość z publiczności)

Dziennikarz przyjmuje w tym fragmencie perspektywę strony przeciwnej po to, aby zaktywizować rozmówcę, skłonić do wnikliwszej argumentacji.

\subsubsection{Działania korygujące zachowanie rozmówców}

W grupie tej znalazły się interwencje dziennikarza, które są reakcją na zachowania rozmówców świadczące o wyjściu z roli proponenta lub oponenta. Dziennikarz negatywnie reaguje, kiedy uczestnicy chcą kierować debatą, zmieniać temat, realizować swoje cele, np. wizerunkowe.

\section{A. Strategia polegająca na odrzuceniu, pominięciu niefunkcjonalnego zachowania rozmówcy}

AC: [...] myśmy spodziewali się, że to dzisiejsze spotkanie, w przeciwieństwie do wielu innych spotkań, w tym także stynnego spotkania przed domem generała/ tam się nauczytem bardzo wielu nowych słów na ka, ha, pe i tak dalej [...]. Więc jeśli ta nasza dzisiejsza debata będzie przebiegata tak, jak przebiegała debata $w$ nocy z 12 na 13 grudnia, to myślę, że nasz czas jest po prostu stracony. Proponuję wobec tego, żebyśmy zaczęli rozmawiać spokojnie, sensownie, w sposób [wyważony.

KD: [Dobrze. Jeśli pan pozwoli, to przebieg tej debaty będziemy jednak próbowali moderować wspólnie z redaktorem Baronem.

(16.12.2004; gość - AC: Andrzej Całkiewicz)

Rozmówca wychodzi z roli proponenta i wchodzi w zakres kompetencji dziennikarza. Próbuje ingerować w organizację debaty. Dziennikarz reaguje kategorycznym upomnieniem.

TK: [...] Jeżeli ktoś uprawia prostytucje, to jest tak jak gdyby chory na duszy i może zastanówmy sie, jak leczyćl jak leczyć ludzi, którzy sa chorzy na prostytucję, co zrobić, żeby oni mogli powrócić do normalnego życia, a//

PB: No dobrze, ale tak jak powiedziat na poczatku Kamil, ta prostytucja w Polsce jest, co $z$ nia zrobić?

(13.01.2005; gość - TK: Tomasz Kot)

Rozmówca wchodzi w kompetencje dziennikarza i proponuje zmianę przebiegu linii tematycznej. Dziennikarz odrzuca proponowany temat jako nieadekwatny do sytuacji (ta prostytucja $w$ Polsce jest) i powtarza pierwotne pytanie.

KD: Potrafia państwo sobie w takim razie wyttumaczyć, dlaczego to radio jest tak stuchane, jest tak referencyjne? [...]

TJ: Mnie się wydaje, że to bierze się z wychowania katolickiego. To znaczy z wychowania wtaściwie już od przedszkola, które uczy, że innowierca to jest ktoś, kogo trzeba nawracać, czyli ktoś//

MG: Ale pan senator Gowin też jest katolikiem i nie stucha Radia Maryja. To nie chodzi o to. 


\section{KD: To o co chodzi?}

TJ: Ale chodzi mi o to, że po prostu dziecko już od matego, od przedszkola jest nauczone, że ktoś, kto nie jest katolikiem, jest kimś gorszym.

KD: O co chodzi w takim razie?

(11.01.2006; goście - MG: Maciej Gdula, TJ: Teresa Jakubowska)

Wyjście z roli oponenta polega na tym, że rozmówca rozszerza płaszczyznę oponowania na te obszary, które nie były tematem debaty. Dziennikarz pyta o Radio Maryja, a rozmówczyni dwukrotnie podejmuje krytykę Kościoła katolickiego. Reakcja dziennikarza świadczy o niewłączeniu wypowiedzi w strukturę debaty, pominięciu jej jako nierelewantnej dla dyskusji ${ }^{60}$ (świadczy o tym ponawianie pytań, jak gdyby odpowiedź w ogóle nie padła).

KD: O co chodzi w takim razie?

MG: Nie, ja myślę że Radio Maryja odgrywa bardzo ważna rolę w organizacji protestu. W tym, że ludzie dzięki Radiu Maryja maja poczucie godności, maja poczucie tego, że ktoś mówi ich głosem, ktoś mówi o ich problemach, ktoś wypowiada ich doświadczenie. To jest bardzo ważne doświadczenie. Ja $w$ tym sensie sympatyzuję najbardziej spośród gości ze Stanistawem Michalkiewiczem, który mówi że Kościót, ten toruński, poszukuje instrumentów w polityce, żeby przywrócić pewnym kategoriom ludzi, których się określa tak pogardliwie „moherowymi beretami” poczucie godności. To jest ważne. Ale to trzeba rozdzielić, taki słuszny ludowy gniew, taki słuszny antyestablishmentowy odcień tego radia trzeba rozdzielić od, po prostu, niestusznych pogladów. Znaczy, jeżeli/ tam rzeczywiście występuja//

KD: Poglady sa różne, no. [gest objęcia obiema rękami dużej przestrzeni]

MG: Nie, nie, to nie sa różne po prostu poglady. To jest nienawiść rzeczywiście wobec Żydów, to jest spiskowa teoria/ taka wizja rzeczywistości, to jest niechęć wobec gejów. To nie są takie po prostu poglądy, takie się ma. Nie.

Rozmówca, który jest po stronie oponentów, częściowo przyznaje jednak rację proponentom. Stanowi to rozchwianie wyraźnego podziału na oponentów i proponentów. W dalszej części niefortunnie używa sformułowania „niesłuszne poglądy”61, co natychmiast budzi sprzeciw dziennikarza (Poglądy sa różne). Odbiera on bowiem to określenie jako próbę ograniczenia wolności debaty.

60 Wypowiedź ta zostanie włączona w dalszej dyskusji, ale nie jako równoprawne stanowisko, lecz instrumentalnie, jako przejaw niechęci do Kościoła lub skutek działalności Radia Maryja. Jest to włączenie nie podmiotowe, ale przedmiotowe, różni się układem interakcyjnym, nie rozmawia się z daną osobą, nie polemizuje z nią, lecz rozmawia się o niej, tak jakby nie była pełnoprawnym dyskutantem.

61 Propagowanie nienawiści, niechęci wobec grup mniejszościowych ze względu na społeczną szkodliwość treści nie nazwiemy „poglądami”, lecz opatrzymy mocniejszym określeniem, a mianowicie mową nienawiści. Pojęcie to szeroko omawia Grażyna Zarzycka w pracy na temat dyskursu prasowego o cudzoziemcach. Powołując się na Sergiusza Kowalskiego i Magdalenę Tulli (Kowalski, Tulli 2003), określa mowę nienawiści jako mowę adresowaną do zbiorowości, a nie jednostek, ze względu na rasę, pochodzenie etniczne, narodowość, płeć, tożsamość płciową, wiek, światopogląd religijny (Zarzycka 2006: 268-270). 
EM: Uważam, że my [...] w ogóle jesteśmy w takiej sytuacji, że ktoś chce nas wyrzucić, że my im coś sypiemy, oni nam i tak dalej. Sprawa zasadza się głębiej, ponieważ brak przestrzegania prawa, brak państwa polskiego, powoduje to, że rówieśnicy z mojego rocznika mogą sobie spokojnie przychodzić do telewizji i na oczach całego spektrum polskiego dewastować umysty tej mtodzieży $i$ dla mnie to jest tragiczniejsze niż tam jakieś kalafiory fruwające.

KD: No tak, ale młodzież uczy sie historii także stuchajac jednej i drugiej strony.

(16.12.2004; gość - EM: Edward Mizikowski)

Rozmówca delegitymizuje debatę, ponieważ wygłaszanie opinii przez proponentów nazywa dewastowaniem umystów młodzieży. Można to uznać za wyjście z roli oponenta, za dezawuowanie dyskusji w ogóle, co spotyka się z protestem dziennikarza. Jak wynika z analizy przykładów, dziennikarz zawęża zakres akceptowanych działań komunikacyjnych proponentów i oponentów, o czym świadczą jego negatywne reakcje na próby wyjścia poza narzucony, a oczekiwany schemat. Prowadzący nie pozwala na zmianę ujęcia tematu, zbyt szerokie oponowanie, podważanie istnienia różnicy lub sensu debaty.

\section{B. Strategia polegająca na ironicznym skomentowaniu niefunkcjonal- nego zachowania}

PB: Proszę bardzo.

GS: Szanowni państwo, oczywiście Samoobrona stoi na stanowisku, ze należy zrobić wszystko, aby demokracja zwyciężyta na Ukrainie, to po pierwsze. My już miesiac temu daliśmy ku temu sygnat. Wówczas Andrzej Lepper, będac gościem Kijowskiej Wyższej Uczelni, na której otrzymat doktorat honoris causa [śmiech widowni] odwiedzit również// [oklaski widowni, gwar, rozbawienie] Ale szanowni państwo, ja naprawdę/ troszeczke kultury. Apeluję o kulture, a szczególnie do kolegów z Platformy Obywatelskiej//

PB: Dobrze, [prosimy/ do czego zmierzam//

GS: [Do czego zmierzam. Do tego zmierzam, że wówczas Andrzej Lepper odwiedzit głodujacych, strajkujących dziennikarzy z telewizji, z kanatu piątego. Tu są wtaśnie zdjęcia, kiedy ich wspierat i tak dalej. I szkoda, że wtaśnie politycy Platformy Obywatelskiej wówczas, jeszcze przed piervszą tura wyborów, nie pojechali na Ukrainę i nie naświetlali tego problemu, bo tu się okazuje, że//

G: Ale Andrzej Lepper byt też na Białorusi. [śmiech widowni]

GS: -i jeszcze na koniec powiem jedno: szkoda że wówczas, tego faktu/ że tym tropem nie poszli inni politycy. [Szkoda, że tego faktu nie ujawnita telewizja.

KD: [Dobrze, ale może spróbujmy wrócić do tego, co sie dzieje na Ukrainie. Zostawmy szlak wędrówek pana przewodniczacego na razie. [śmiech widowni]

(25.11.2004; goście - G: gość z publiczności, GS: Grzegorz Skwierczyński)

Rozmówca narusza kilka standardów zachowania: podaje stanowisko na tyle ogólne, że może być przypisane i proponentom, i oponentom (należy zrobić wszystko, aby demokracja zwyciężyła na Ukrainie), zamiast uwyraźniać różnicę stanowisk, eksponuje różnice polityczne (Samoobrona a Platforma Obywatelska), wchodzi w kompetencje dziennikarza i strofuje publiczność, wreszcie - realizuje 


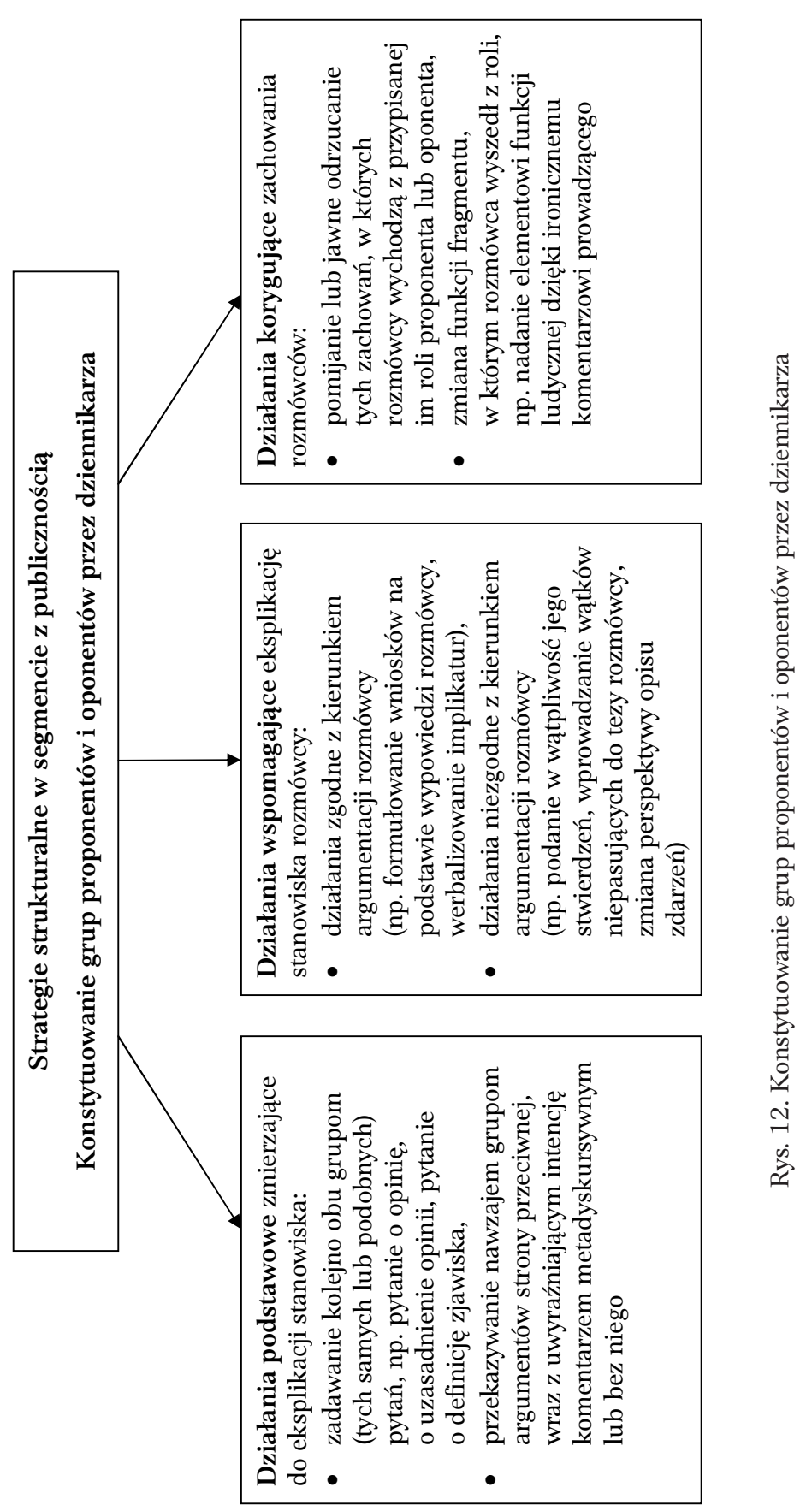


cel wizerunkowy, uprawia marketing polityczny ${ }^{62}$. Jego strategia zostaje rozpoznana przez dziennikarza oraz publiczność. Jeden z dziennikarzy stara się bezskutecznie ukierunkować rozmówcę, natomiast drugi zagospodarowuje w inny sposób to wystąpienie. Włącza całą wypowiedź do struktury debaty jako element peryferyjny, moduł ludyczny. Świadczy o tym sygnał wyjścia z dygresji (wróćmy do tego, co się dzieje na Ukrainie), dowcipny komentarz kwalifikujący wypowiedź polityka pod względem generycznym jako opis „szlaku wędrówek” oraz reakcja publiczności (śmiech, oklaski).

Publiczność zaproszona do studia ma, zgodnie z koncepcją nadawcy medialnego, reprezentować obywateli zainteresowanych kwestiami publicznymi. Dziennikarze stosują strategie w zakresie budowania struktury interakcji, których celem jest ukonstytuowanie grup proponentów i oponentów, gdyż właśnie te role są kluczowe dla nadania sytuacji w studiu gatunkowych cech debaty. Zebranie i podsumowanie działań prowadzącego o charakterze strategicznym z perspektywy budowy struktury interakcji zawiera rys. 12 .

\subsection{Segment $\mathrm{z}$ udziałem gości}

Segment z udziałem gości jest obligatoryjnym elementem środkowej części „Debaty”. Jego wprowadzenie jest uwarunkowane celami medialnego komunikowania publicznego i politycznego w nieco innym wymiarze, niż to miało miejsce w segmencie z publicznością (por. punkt 6.3.1). Tożsamość segmentu jest konstytuowana przez sygnały wyodrębnienia (por. punkt 6.3.3) oraz inny status uczestników w porównaniu ze statusem publiczności, co wiąże się również ze zmianą organizacji programu.

Zarówno dobór gości, jak i sposób prowadzenia interakcji wskazują na funkcję omawianej części w strukturze całości programu. Jest nią rozwinięcie tematu z wykorzystaniem wiedzy specjalistycznej, eksperckiej, z uwzględnieniem uwarunkowań ekonomicznych, politycznych, międzynarodowych. Segment z udziałem gości ma stanowić przeciwwagę dla segmentu z publicznością, w którym dominuje racjonalność potoczna i upraszczające, dwudzielne ujęcie tematu.

\subsubsection{Gatunkowe i dyskursywne uwarunkowania wprowadzenia segmentu z udziałem gości}

Zamysł organizacyjny nadawcy medialnego, który znajduje odzwierciedlenie w działaniach inicjowanych przez prowadzącego, a zatem również w strukturze interakcji, jest zależny przede wszystkim od uwarunkowań pragmatycznych.

\footnotetext{
62 Marketing polityczny to zespół metod, technik i praktyk, których celem jest oddanie głosu wyborców na kandydata lub partię polityczną. Nasila się proces personalizacji polityki, to znaczy ograniczenia roli partii i ich programów na rzecz jej liderów (por. Dobek-Ostrowska 2006: 301).
} 
Cele komunikowania publicznego, w tym politycznego i cele mediów determinują kształt gatunkowy, tematykę programów oraz wpływają na rozwój linii tematycznej. Z kolei uwarunkowania społeczne, decydujące o różnicy zdań i niezgodności interesów, znajdują odzwierciedlenie w agonistycznym typie interakcji ${ }^{63}$. Od poziomu rozmówców i umiejętności negocjacyjnych prowadzącego zależy to, czy interakcja przybierze kształt kooperacyjny czy rywalizacyjny ${ }^{64}$.

Inicjowanie debaty publicznej stanowi ważny cel mediów. W założeniach (idealnego) modelu demokracji liberalnej społeczeństwo wyraża swoją wolę w wyborach powszechnych, w wyniku których powierza swoim przedstawicielom kierowanie organami władzy państwowej i samorządowej. Prawidłowe funkcjonowanie demokracji jest uzależnione m.in. od realizacji dwóch warunków: uczestnictwa obywateli w życiu publicznym i racjonalnego wyboru (Mrozowski 2001: 124). Media masowe powinny zapewnić obywatelom (jako jednostkom oraz jako członkom związków i stowarzyszeń) aktywny udział w sprawach publicznych. Po to, aby ten udział był oparty na racjonalnych przesłankach, a nie np. jedynie na emocjach, potrzebna jest wiedza na temat zasad ustrojowych, kwestii publicznych itd. O ile segment $\mathrm{z}$ udziałem publiczności ma dać wyobrażenie na temat tzw. opinii publicznej (czyli nawet naiwnych, emocjonalnych przekonań przeciętnych obywateli na daną sprawę), o tyle segment $\mathrm{z}$ udziałem gości ma za zadanie poszerzenie wiedzy i kształtowanie kompetencji uczestników życia społecznego.

Zarysowane powyżej założenia modelu demokracji stanowią istotny element sytuacji komunikacyjnej prowokowanych w programie interakcji. Są podstawą kontraktu o charakterze instytucjonalnym, który determinuje relacje pomiędzy podmiotami komunikacji65 (zarówno w makro-, jak i mikrosytuacji). Rodzaj tych relacji jest związany z obszarem aktywności społecznej (medialny dyskurs publiczny i polityczny) oraz kategorią podmiotową uczestników (dyskurs ekspertów, dyskurs polityków).

W segmencie $\mathrm{z}$ udziałem gości występuje więcej niż dwu rozmówców (forma polilogowa: dziennikarz + goście). Dziennikarz kształtuje interakcję według

63 Bożena Witosz, omawiając strukturę illokucyjną wypowiedzi jako wyznacznika gatunkowego, wskazuje na kryterium zbieżności bądź rozbieżności celów nadawcy i odbiorcy. Jest ono podstawą wyodrębnienia gatunków agonistycznych (takich jak negocjacje, spór, kłótnia, dyskusja, polemika, awantura, sprzeczka) oraz gatunków o nastawieniu empatycznym (rozmowa, plotkowanie, flirt, pogaduszki) (Witosz 2005: 171).

${ }^{64}$ Kompromis jest celem dyskusji kooperacyjnej, w której rozmówcy dążą do porozumienia, uzgodnienia stanowisk, podjęcia decyzji (Kita 1998: 176). W momencie, kiedy nadrzędnym celem rozmówców staje się nie dojście do prawdy, ale zwycięstwo za wszelką cenę, pokonanie przeciwnika, dyskusja przyjmuje charakter rywalizacyjny (Lachowiecki 1997: 4).

${ }^{65}$ Pojęcie kontraktu jest istotnym elementem definicji dyskursu w tzw. szkole francuskiej: „Dyskurs jest zinstytucjonalizowany. A to oznacza, że jego analiza nie może być utożsamiana z badaniem każdej dowolnej wypowiedzi - dla niej samej, lecz wyłącznie takiej, która powstaje w sytuacji i w relacji podmiotów zwanej kontraktem. Kontrakt ma charakter społeczno-językowy, a więc wyznacza partnerom role, miejsca dyskursywne” (Grzmil-Tylutki 2007: 22). 
podstawowego wzorca debaty, o czym świadczą jego zabiegi zmierzające do dyscyplinowania rozmówców, zachowania odpowiednich wymogów formalnych ${ }^{66}$. W zależności od roli społecznej uczestników przyjmuje ona wariant debaty eksperckiej i/lub salonu politycznego (por. Uszyński 2004: 131). Należy bowiem zauważyć, że rola społeczna uczestnika (zwłaszcza jego wiedza i cele komunikacyjne) determinuje rodzaj uczestnictwa w programie (szerzej na ten temat w punkcie 6.3.2).

Debata nie jest jedynym wzorcem gatunkowym, którego realizacje można odnaleźć w segmencie z udziałem gości. Ewa Szkudlarek-Śmiechowicz, która badała publicystykę polityczną opartą na formach dialogowych w bezpośredniej komunikacji na poziomie mikrosytuacji, dostrzega w niej trzy dominujące gatunki tekstu: wywiad, dyskusję i debatę (Szkudlarek-Śmiechowicz 2010: 49). Badaczka stwierdza, że w obrębie medialnych realizacji tekstowych mamy do czynienia z kontaminacją wzorców gatunkowych: „publiczne (medialne) dyskusje o tematyce społeczno-politycznej mogą być bardziej lub mniej uporządkowane i sformalizowane, wykazując podobieństwo do debaty jako gatunku tekstowego o wysokim stopniu formalizacji lub do rozmowy publicznej (rozmowa $\rightarrow$ dyskusja $\leftarrow$ debata)" (Szkudlarek-Śmiechowicz 2010: 56). Ustalenia te znajduja potwierdzenie w analizowanym materiale. W segmencie z udziałem gości zdarza się, że dziennikarz oprócz roli moderatora przyjmuje maskę polemiczną, a rozmówcy, pomijając prowadzącego, nawiązują interakcję między sobą. Mamy wówczas do czynienia z bardziej dynamiczną dyskusją. Z kolei kiedy dochodzi do zatarcia różnicy między stanowiskami, dygresyjności, wielotorowości rozwoju linii tematycznej - interakcja zaczyna przypominać rozmowę publiczną.

\subsubsection{Charakterystyka gości jako grupy uczestników (status rozmówców: ekspert, polityk)}

Odmienność segmentu z udziałem gości jest związana z koncepcją organizacyjną nadawcy medialnego, polegającą na zestawieniu opinii publiczności (segment z jej udziałem) ze stanowiskiem osób publicznych o szerszym zakresie wiedzy. Istotna jest tu zatem rola społeczna gościa, która determinuje rodzaj jego uczestnictwa w programie pod względem przekazywanych treści oraz realizowanych celów. Nie bez znaczenia jest ranga i liczba gości ${ }^{67}$, co ma wpływ

${ }^{66}$ Dziennikarz wyznacza kolejność zabierania głosu, wskazuje rozmówców, dyscyplinuje ich, jeśli chodzi o długość i treść wystąpień. W większości interakcji przyjmuje rolę arbitra, starając się zachować dystans. Te zachowania i działania organizacyjne prowadzone są jednak ze zmienną skutecznością.

${ }^{67}$ Goście, w odróżnieniu od reprezentantów publiczności, którzy mogą pozostać anonimowi, występują wyłącznie jako osoby przedstawiane widzom w trakcie programu. Przedstawiciele 
na działania dziennikarza. W omawianej grupie pojawiają się pracownicy instytucji państwowych, działacze społeczni, politycy, naukowcy, osoby duchowne, prawnicy, dziennikarze.

Nadawca medialny zaprojektował w programie określone role komunikacyjne dla różnych kategorii gości (co nie zawsze jest wypełniane w rzeczywistych zachowaniach). Ze względu na sytuację komunikacyjną przyjęto, że istotnym kryterium identyfikacji ról gości jest ich zaangażowanie w polityczną rywalizację. Kryterium to pozwala uznać rolę eksperta za jakościowo różną od roli polityka. Na podstawie celów działalności pozajęzykowej zakłada się, że politycy wykorzystują instrumentalnie problemy społeczne do kreowania wizerunku, formułowania oferty politycznej oraz dyskredytacji opozycji. Przeświadczenie to jest wpisane trwale w dyskurs polityczny. Jeśli czynny polityk chce przekonać odbiorców, że $\mathrm{w}$ danym momencie nie podejmuje rywalizacji, to musi taką presupozycję dyskursywną odwołać wprost (jak w poniższym przykładzie).

SN: [...] No, proces stuży temu, żeby ukarać przestępcę. [...] Ale koncentrujemy się na kopalni „Wujek”. No, mnie nie satysfakcjonuje ta argumentacja, dlatego, że ja mam prawo oczekiwać, że to będzie wszystko szybciej. Dla mnie wymiar sprawiedliwości III Rzeczpospolitej jest chyba jednym z najstabszych $i$ to bez wzgleddu na to, jaka partia. To żeby byto jasne. Ja pod tym wzgledem nie widze, niestety, większych różnic. Wszystkie chyba partie miały już swojego ministra sprawiedliwości, prawie wszystkie, które były w parlamencie. Ja większych różnic, niestety, nie dostrzegłem.

(16.12.2004; gość - SN: Stefan Niesiołowski)

Rozmówca wygłasza negatywną opinię na temat wymiaru sprawiedliwości. W ustach polityka jest ona odbierana prymarnie (nawet bez wyraźnych sygnałów) jako zarzut wobec konkurencji politycznej. Stąd wyraźne wskazanie, do kogo opinia się odnosi (bez względu na to, jaka partia. To żeby byto jasne). Zachowanie takie nie jest typowe dla polityków, którzy najczęściej nie mają skrupułów przed rozciąganiem pola rywalizacji politycznej na kwestie społeczne. W poniższym przykładzie takim tematem jest zwalczanie zjawiska narkomanii. Przedstawiciel jednej z partii formułuje negatywną ocenę ustawy o karaniu za posiadanie nawet najmniejszej ilości narkotyku. Polityk z partii konkurencyjnej, która tę ustawę uchwalała, odbiera to jako zarzut, a następnie sam podejmuje atak w ramach rywalizacyjnej strategii odwetu.

PG: [...] I to nie jest tak, że jeżeli czegoś zakażemy/ to jest takie myślenie magiczno-zamordystyczne. [...] to jest typowe spychanie śmieci pod dywan.

publiczności są przede wszystkim przypisani do grup proponentów i oponentów, co widz rozpoznaje m.in. po miejscu zajmowanym przez nich w studiu. Tylko niektórzy z nich są przedstawiani widzom z imienia i nazwiska (te informacje podawane są na pasku). W przypadku gości informacje o imieniu i nazwisku są podawane obligatoryjnie. Liczba gości wynosi średnio od 4 do 6 osób. Siedzą oni za stołem w półkolu, przodem do publiczności. Dziennikarz przemieszcza się po studiu, zbliżając się do publiczności bądź gości. 
TC: [...] Jeżeli ja tu stucham takich argumentów/ i pan poset w tej chwili w sposób wierutny/ Zreszta, panie pośle, absolutnie nie jest tak, że ta ustawa i penalizacja byta wprowadzona po to, żeby typowego, nieszczęsnego narkomana na rok do więzienia zmykać.

PG: Panie pośle, ale//

TC: -ale niech pan nie przerywa!

PG: Ale ja nie przerywam, tylko powiem, że dobrymi chęciami jest piekto wybrukowane.

(10.02.2005; goście - PG: Piotr Gadzinowski, TC: Tadeusz Cymański)

Polityk wykorzystuje dyskusję o ustawie do dyskredytacji poznawczej i zawodowej przeciwników. Stosuje w tym celu pogardliwą kategoryzację ich postawy mentalnej (myślenie magiczno-zamordystyczne). Oskarża przeciwnika również o nieprofesjonalne i nieuczciwe działanie (spychanie śmieci pod dywan).

TC: [...] Dobrze, ja mam jedno pytanie, jeżeli mówimy o leczeniu, to może pan poset Gadzinowski sie pochwali w tak dramatycznej sytuacji, ile zostaty zwiększone środki na leczenie narkomanii w Polsce. Może pan powie.

PG: Dlaczego//

TC: Niech pan się nie w/ cina! Proszę powiedzieć. Niech pan się pochwali, bo to jest dopiero sytuacja//

JS: Co roku sa zmniejszane.

TC: My tu mówimy: „Nie do więzien, tylko na leczenie”. Na jakie leczenie? [Dlatego niech pan powie.

PG: [Panie pośle Tadeuszu, jesteśmy w Sejmie od dwóch kadencji i proszę nie używać takich argumentów.

TC: Niewygodne zapytanko. Niewygodne, prawda, prawda? [oklaski]

PG: Nie, nie, nie. Proszę bardzo, wspólnie przegłosujmy!

(10.02.2005; goście - JS: Janusz Sierosławski, PG: Piotr Gadzinowski, TC: Tadeusz Cymański)

Zaatakowany polityk dostosowuje swoją strategię do strategii przeciwnika i realizuje dyskredytację, która polega na podsunięciu sugestii, że przeciwnik jest odpowiedzialny za zmniejszanie środków na realizację omawianych właśnie celów społecznych i w dodatku chce to ukryć (niewygodne zapytanko). Dyskredytacja jest realizowana poprzez technikę insynuacji, czyli przypisywania komuś motywów, intencji, czynów, niemających odzwierciedlenia w rzeczywistości (Karwat 2006b: 149). Nieadekwatna kreacja tła pozajęzykowego, a więc i ufundowana na niej insynuacja, zostaje ujawniona w strategii metadyskursywnej (proszę nie używać takich argumentów).

Przyjmowanie postaw rywalizacyjnych przez polityków oznacza podejmowanie działań (taktyki dyskredytacji, prowokacji), które zmierzają do realizacji celów partykularnych (wykreowanie własnego wizerunku, podważenie wiarygodności przeciwnika). Działania takie są odbierane przez prowadzącego jako niesprzyjające realizacji publicznych celów debaty. Tak więc pomimo tego, że kłótnie medialne są widowiskowe i budzą żywą reakcję publiczności (np. śmiech, oklaski), dziennikarz poczuwa się do zaznaczenia ich ludycznego, niemerytorycznego charakteru. 
KD: Panie pośle, bo panu wytaczę mikrofon i będziemy mieli powtórkę z Sejmu, a to jest rozmowa, jak mi się zdaje, na poważny temat, za którym [kryją się ludzkie tragedie.

PR: [Wtaśnie o to chodzi, dramat ludzki.

KD: Wolatbym, żeby nie zmieniata się w cyrk. I wtaśnie o to wszystkich państwa proszę. Pani Jolanto, pani kończy swoją wypowiedź.

(10.02.2005; gość - PR: Paweł Rosiak)

KD: Proszę państwa, dobra tradycja tej debaty jest to, że o polityce mówi sie tu jak najmniej, więc gdybym mógt prosić pania poset o powstrzymanie emocji i uwag kierowanych pod adresem innych uczestników tego programu, a pana Krzysztofa o zakończenie tego wątku, to będę bardzo wdzięczny. (13.01.2005)

Politycy stanowią kategorię gości różną pod względem celów i strategii komunikacyjnych od pozostałych uczestników. Rodzaj ich uwikłania w działalność pozajęzykową determinuje sposób zachowania pod względem kreacji tła pozajęzykowego i budowania interakcji. Determinanty te są wpisane w dyskurs polityczny, stanowią podstawę oczekiwań związanych z rolą polityka i ukierunkowują odbiór jego działań komunikacyjnych.

Drugą grupę gości (niepolityków) tworzą specjaliści różnych dziedzin, uczestnicy życia publicznego, którzy pełnią rolę ekspertów. Ich zadaniem jest poszerzanie wiedzy na omawiany temat, naświetlanie go z różnych perspektyw. Typowym ekspertem jest naukowiec, ale może nim być również osoba pełniąca funkcje publiczne, np. pracownik instytucji publicznej, prawnik, osoba duchowna, wreszcie dziennikarz jako gość ${ }^{68}$. Cechą charakterystyczną szeroko rozumianej kategorii ekspertów jest wyższy poziom wiedzy, większe doświadczenie, co odróżnia ich od publiczności (oraz dodatkowo niezaangażowanie w rywalizację polityczną, co odróżnia ich od polityków ${ }^{69}$ ).

Rola eksperta nie jest w sposób konieczny związana z opowiedzeniem się po którejś ze stron (proponentów lub oponentów). Często ekspert zwraca uwagę na większą złożoność problemu, konieczność znalezienia zupełnie innych rozwiązań niż te, które przedstawiono uprzednio. Niechętnie odnosi się do spekulacji, które nie są poparte badaniami naukowymi, weryfikuje kreowanie tła pozajęzykowego w celach perswazyjnych. Autorytet eksperta wynikający z jego wiedzy, kompetencji zawodowych, doświadczenia sprawia, że dziennikarz przyjmuje wobec niego postawę reprezentanta opinii publicznej o niższych kompetencjach. Dość typową sekwencję wymian dziennikarz + ekspert obrazuje poniższy przykład.

KD: Jeśli pan pozwoli/ tączymy się z Zieloną Górą. Tam jest profesor Izdebski. Pan badat zjawisko prostytucji $w$ Polsce, zajmowat się pan takimi badaniami. Proszę powiedzieć, jak duży

68 Zaproszony dziennikarz może być komentatorem zdarzeń życia publicznego i jeśli zachowuje obiektywizm, to w tym zakresie można go zaliczyć do szerokiej kategorii ekspertów.

${ }^{69}$ Niezaangażowanie ekspertów w rywalizację polityczną jest założeniem, idealnym modelem, który nie zawsze znajduje odzwierciedlenie w rozkładzie sił. 
jest ten rynek prostytucji? Ile osób w nim pracuje, ilu mężczyzn, albo ile kobiet także korzysta $z$ ustug prostytutek?

ZI: Bardzo trudno jest jednoznacznie oszacować/ jednoznacznie, jaki jest rynek prostytucji $\underline{w}$ Polsce, ale z różnych źródet możemy powiedzieć, że jest - jedne źródta podaja, że osób prostytuujących się jest około dziesięciu tysięcy, inne zródta mówia również, że tych kobiet prostytuujących się, i Polek, i cudzoziemek, może być nawet ponad 15 tysięcy.

(13.01.2005; gość - ZI: Zbigniew Izdebski)

Dziennikarz zapowiada gościa z uzasadnieniem jego uczestnictwa w programie oraz podejmuje strategię informacyjno-weryfikacyjną w celu uzyskania wiedzy mającej pomóc w rozwiązaniu problemu. Ekspert przyjmuje postawę kooperacyjną i w typowy dla swojej roli asekuracyjny sposób udziela wyjaśnienia: zastrzega niepewność danych, podaje badania z dwu różnych źródeł.

KD: Panie profesorze, czy Polacy uważaja, że kontakty z prostytutkami/ za coś niemoralnego?

ZI: Polacy coraz liberalniej podchodza do korzystania z usług zwiąanych z seksbiznesem $i$ obserwujemy także, że $w$ ostatnich latach $w$ Polsce wzrasta liczba osób korzystajacych z prostytutek. $Z$ badań wynika, że $w$ ostatnim okresie $w$ Polsce korzysta ponad 12 procent mężczyzn $z$ ustug prostytutek.

KD: A czy w takim razie jest jakaś sugestia ze strony, czy ptynie jakiś wniosek z pańskich badań, sugestia co do tego, jak rozwiązywać w Polsce problem prostytucji: legalizować czy wręcz przeciwnie?

ZI: Pytaliśmy również Polaków w badaniach ogólnopolskich na próbie reprezentatywnej, jaki jest stosunek do legalizacji agencji towarzyskich, mając świadomość, że właśnie tam także świadczone są przecież ustugi seksualne. Ponad 74 procent mężczyzn i ponad 50 procent kobiet $w$ Polsce opowiada się za tym, aby zalegalizować działalność agencji towarzyskich, i w porównaniu $z$ kilkoma laty wcześniej prowadzonym badaniem, widzimy, że wzrasta przyzwolenie spoteczne w Polsce na legalizację agencji towarzyskich. [...]

KD: A pan, panie profesorze, jest zdania, że należałoby egzekwować ten obowiazujacy $w$ Polsce system prawny czy go zmieniać?

ZI: Ja myślę, że zdecydowanie korzystniej bytoby, gdybyśmy poszli w kierunku legalizacji działań agencji towarzyskich [...].

Dziennikarz nie podważa sądów wygłaszanych przez eksperta, przechodzi do strategii aksjologiczno-emotywnej (ocena moralna zjawiska), a w następnych pytaniach - do strategii behawioralnej (ustalanie sposobu działania). Kolejne wymiany przypominają zatem konsultację, w której dziennikarz uzyskuje odpowiedzi na pytania: jaka jest sytuacja, jak ją ocenić, co należy zrobić. Postawa eksperta jest wysoce asekuracyjna: powołuje się on na badania, stara się powstrzymać od wygłaszania własnych opinii. Dopiero na wyraźne powtórzenie pytania podejmuje strategię behawioralną i ujawnia popieraną przez siebie propozycję sposobu działania.

Z rolą eksperta związane są również strategie metadyskursywne, które polegają na weryfikowaniu i komentowaniu wypowiedzi mniej kompetentnych rozmówców, lub też demaskowaniu działań o charakterze perswazyjnym. 
ZI: Ja myślę, że w całej tej dyskusji przejawiało się i przejawia bardzo wiele watków. Warto sobie uświadomić, że zjawisko prostytucji w Polsce wyraźnie się zmienia, i że mówienie o prostytucji w kategorii niewolnictwa jest jednak pewna forma nadużycia. Ja mogę się z panem postem zgodzić $w$ sytuacji, kiedy jest kobieta zmuszana do prostytucji, kiedy jest to zjawisko handlu ludźmi. Owszem, z takimi zjawiskami także się spotykamy, z takimi zjawiskami się taki̇e spotykamy w Polsce. Natomiast zdecydowana większość kobiet, która pracuje w seksbiznesie to sa kobiety, które zdecydowały się dobrowolnie pracować w tym seksbiznesie i głównym powodem podjęcia pracy $w$ charakterze prostytutki sa czynniki o charakterze ekonomicznym: dla jednych jest to podwyższenie ich standardów życia, dla innych kobiet jest to jedyne $w$ tej fazie życia/ możliwość zarabiania pieniędzy. Niektóre prostytutki nie traktuja tego $w$ kategoriach przymusu do pracy [...] natomiast mówienie o zjawisku dotyczacym prostytucji dziecięcej. związanej $z$ agencjami towarzyskimi, myślę, i pornografii dziecięcej, myślę, że to jest troszeczkę inne zjawisko. Problem prostytucji dziecięcej niewatpliwie istnieje i zjawisko pornografii dziecięcej niewatpliwie istnieje, natomiast to nie jest aż tak zwiazane, jak pan tu sugeruje z agencjami towarzyskimi.

Ekspert komentuje wcześniejszą wypowiedź posła, oponenta, dotyczącą nowych rozwiązań prawnych. Podważa nietrafną, jego zdaniem, kategoryzację zjawiska, a więc operuje na poziomie reprezentacji poznawczych. Następnie podważa ścisły związek między dwoma zjawiskami. W wyniku zastosowanej strategii metadyskursywnej sądy polityka, które ten przedstawił jako adekwatny opis rzeczywistości, zostały ukazane jako nadużycie i bezpodstawne sugestie. Zaprezentowane powyżej sekwencje stanowią przykład typowego wypełnienia roli eksperta, jakim jest osoba naukowo zajmująca się określoną dziedziną, przygotowana teoretycznie oraz prowadząca badania.

Do szeroko rozumianej kategorii ekspertów zaliczamy również osoby mające doświadczenie o charakterze zawodowym w danej dziedzinie. Chęć uzupełnienia badań teoretycznych wskazówkami wynikającymi z praktycznego działania skłania dziennikarza do podjęcia strategii informacyjno-weryfikacyjnej wobec gościa zajmującego się danym problemem.

KD: Pan Kajetan Dubiel jest z nami. Jak to jest z tymi osadzonymi, kto siedzi w więzieniach - ci, którzy posiadaja, ci którzy handlowali?

KDub: Chciatbym powiedzieć, że podziwiam beztroskę państwa, jak tutaj tak lekko dyskutujecie: „Karać, nie karać”. Proszę państwa, ustawa w 2000 roku zakładała, że policja dostanie narzędzie, [...] radykalnie wzrosła liczba, [tych] którzy odbywają karę, ludzi z ustawy o przeciwdziataniu narkomanii. Jeszcze kilka lat temu było 200 osób. Pót na pót, połowa to jest prawomocnych wyroków/ jest wykonywanych $w$ chwili obecnej 2000. Tylko proszę pamiętać, że ta druga połowa, która za handel siedzi to są drobni ćpacze, którzy na ulicy sprzedaja po to, żeby mieć na kolejna dziatkę. [...]

KD: Panie Kajetanie, ile osób przebywa na takich oddziałach, w których możliwe jest leczenie narkomanów, więźniów narkomanów, a ile powinno się na nich znaleźć?

KDub: W chwili obecnej otwieramy dwa kolejne oddziaty - 440 miejsc. W skali roku skróciliśmy już do minimum, 6 miesięcy tam człowiek przebywa. Ponad 1000 osób odbywa tą terapię, i to z zastrzeżeniem, że ona powinna być kontynuowana po wyjściu na wolność w Monarze. [...] Drugi problem, proszę państwa, to, co myśmy się spodziewali - radykalnie wzrosła liczba prób przemytu narkotyków [do więzień.

PB: [Wtaśnie o to chciatem zapytać, o dostęp do narkotyków [w polskich więzieniach. 
KDub: [No my możemy powiedzieć, ile my przechwytujemy. W ciagu tych czterech lat o 300 procent wzrosła liczba narkotyków, które my przechwytujemy, a zdajemy sobie sprawę, że czarna liczba jest o wiele większa. I my jako//

PB: Jednym stowem, $w$ polskich więzieniach narkotyki sa obecne.

KDub: [...] Proszę państwa, narkotyki są w szkołach, w wojsku, w więzieniu, sa wszędzie. I zacznijmy od tego, że to jest trwały element życia w Polsce. Ijeżeli będziemy dyskutować, że wprowadzimy kolejny zapis prawny i zlikwidujemy narkotyki/ Nie, może bardziej skupmy się nad tym, żeby byto jak najmniej szkód wyrządzanych przez narkotyki i ludzi biorących narkotyki. [oklaski]

JW: Ogromnie szanuję pana i pana wypowiedź, ale nie można sobie tak ułatwiać życia. Wie pan, bo my wszyscy chcemy, żeby byto dobrze, prawda? I wszyscy możemy powiedzieć: „Ale nie róbmy tego przepisami prawa, tylko jakimiś innymi [o wiele lepszymi metodami”.

KDub: [Bo pan chce dobrze, a ja sobie z tym muszę radzić! [oklaski]

JW: Ja sobie też muszę z tym radzić, bo ja jestem nauczycielem i dyrektorem szkoty, wie pan, a nie postem. To, że siedzę blisko posta, nic jeszcze się ze mna nie dzieje.

(10.02.2005; goście - JW: Jan Wróbel, KDub: Kajetan Dubiel)

Dziennikarz przyjmuje postawę ucznia po to, aby pozyskać informacje konieczne do oceny elementów tła pozajęzykowego. Ocena ta (przyczyniająca się do określonego wykreowania tła) wpływa na układ interakcyjny w mikrosytuacji, bowiem wśród gości znajdują się osoby uwikłane w omawiane wydarzenia (np. politycy, działacze społeczni, którzy wprowadzili, popierali określone regulacje prawne i tacy, którzy je z różnych względów krytykują). Gość podtrzymuje strategię informacyjno-weryfikacyjną (udziela odpowiedzi właściwych, to znaczy takich, które wypełniają niewiadomą pytania). Następnie wprowadza strategię aksjologiczno-emotywną, bowiem negatywnie ocenia działania proponentów (jeżeli będziemy dyskutować, że wprowadzimy kolejny zapis prawny i zlikwidujemy narkotyki/ Nie) i strategię behawioralną, w której składa propozycję podjęcia działania (skupmy się nad tym, żeby byto jak najmniej szkód wyrządzanych przez narkotyki i ludzi bioracych narkotyki). Tak więc ekspert wnosi znaczący wkład do debaty: poszerza wiedzę odbiorców, przyjmuje postawę oponenta wobec omawianych uregulowań prawnych i proponuje zmianę kierunku debaty.

Przyjęcie przez eksperta postawy oponenta uaktywnia proponenta, który spontanicznie włącza się do interakcji i nie tyle podejmuje kontrargumentację, ile wykpiwa stanowisko rozmówcy (,Ale nie róbmy tego przepisami prawa, tylko jakimiś innymi, o wiele lepszymi metodami”). Ekspert dostosowuje strategię komunikacyjną i również odpowiada kpiną (Bo pan chce dobrze, a ja sobie z tym muszę radzić). Sugeruje w ten sposób teoretyzm, który podważa wiarygodność poglądów proponenta. Ten odczytuje intencję dyskredytacji i podejmuje dopasowaną strategię uwiarygodnienia swojego stanowiska. Określa się jako osoba zaangażowana w działania praktyczne (jestem nauczycielem i dyrektorem szkoły). Znamienne jest odcięcie się od postawy polityka, która pośrednio zostaje uznana za mniej wiarygodną. To krótkie starcie pokazuje, jak istotna w debacie jest rola społeczna gościa i związane $\mathrm{z}$ nią stereotypowe wyobrażenia o motywach i celach postaci życia publicznego. 
Z rolą eksperta związane są pewne oczekiwania dotyczące nie tylko wyższych kompetencji poznawczych, ale również kompetencji komunikacyjnych. Od przedstawicieli elit wymaga się przestrzegania zasad dyskusji, powstrzymania się od emocjonalnych ocen oraz od wygłaszania sądów niemających naukowego uzasadnienia. Potwierdzeniem tych oczekiwań są protesty, będące reakcją na zachowania naruszające standardy.

IK: Albo realizujemy pewne dtugofalowe interesy społeczne, albo załatwiamy wtaśnie interesy partyjne. To czwarta RP miata być zaprzeczeniem tego, a mamy trzecia RP do kwadratu!

TŻ: Ja chciatem powiedzieć, że jednak tutaj myśle, że nadmiernie ulegamy emocjom. I jeśli mieliśmy coś wyjaśnić, to zdaje sie pokazaliśmy, że emocje udzielaja się również nam. [...]

(18.01.2006; goście - IK: Ireneusz Krzemiński, TŻ: Tomasz Żukowski)

Jeden z ekspertów podejmuje działanie komunikacyjne, które zostaje uznane za niefortunne ze względu na niedostosowanie tonacji i w rezultacie niewypełnienie związanego z rolą zadania. Ekspert wygłasza sąd diagnostyczny, który skłania drugiego eksperta do krytycznego komentarza. Jego przedmiotem jest nieodpowiedni, według niego, niedostosowany do wymogów dyskursu eksperckiego (mieliśmy coś wyjaśnić), ton dyskusji (nadmiernie ulegamy emocjom). Również w kolejnym przykładzie rozmówca zwraca uwagę na niedostosowanie zachowania komunikacyjnego do roli społecznej oraz do związanych z nią oczekiwań.

PR: Panie pośle, możemy debatować w taki sposób, ale nie o to chodzi! [krzyczy, przedrzeźniając rozmówcę]

TC: Może pan nie krzyczeć?

KD: [Proszę księdza, spokojnie, spokojnie, spokojnie.

PR: [No wtaśnie, panie pośle! [krzyczy]

TC: Mato, że nie pasuje, to jeszcze ksiadz. Dlatego taka reakcja.

(10.02.2005; goście - PR: Paweł Rosiak, TC: Tadeusz Cymański)

Podnoszenie głosu, przedrzeźnianie rozmówców to zachowania budzące sprzeciw nie tylko dziennikarza, ale również pozostałych uczestników, co znajduje potwierdzenie w podjętej przez jednego $\mathrm{z}$ nich strategii metadyskursywnej (Mało, że nie pasuje, to jeszcze ksiądz).

Wysoki stopień legitymizacji roli eksperta, a więc poparte wiedzą i poziomem kompetencji uprawomocnienie jego działań, stały się podstawą ukształtowania społecznego stereotypu roli, który może być strategicznie wykorzystywany przez rozmówców do polepszenia sytuacji dyskursywnej. Poprzez realizację określonych działań komunikacyjnych nawet politycy zaangażowani w bieżącą rywalizację mogą nakładać „maskę eksperta”.

JS: [...] na tą sprawę trzeba spojrzeć historycznie, jak to się w ogóle układało. No, tak jak pan redaktor powiedziat, prostytucja/ prostytutka to zawód uprawiany od paru tysięcy lat. No i powiedzmy, $w$ starożytnych Atenach Solon $w$ VI w. p.n.e. zalegalizowat prostytucję i państwo pobierało podatki. Podobnie $w$ starożytnym Rzymie Katon, Cyceron czy Seneka uważali, że prostytucja 
jest niezbędna, że nawet stuży trwatości matżeństwa i zreszta ten poglad zostat przyjęty przez chrześcijaństwo. Także/ proszę się nie śmiać [...] w starożytnym Rzymie jak gdyby skomercjalizowano $i$ znacjonalizowano prostytucję, wydawano licencje, otwierano domy publiczne//

$\mathrm{KD}:$ A dzisiaj, a co dzisiaj?

JS: No nie, ale proszę postuchać, jak się do tego chociażby Ojcowie Kościoła odnosili [śmiech, oklaski]. Dziękuję. Święty Augustyn uważat, że prostytucja jest konieczna, święty Tomasz uważat, $\dot{z}$ e grzech popetniany $z$ prostytutka jest znacznie mniejszy niż z kobieta uczciwa, w zwiazku $z$ tym prostytucja jest wtaśnie potrzebna. Wprawdzie wieki średnie na prostytucję pewne takie piętno hańby natożyli [!], niemniej może warto powiedzieć, [jednak chcę powiedzieć, że sobór w Bazylei, to jest bardzo ważne, no ale sobór w Bazylei uznat tę instytucję za niezbędna.

KD: [Pani profesor, ja uznaję, że pani wywody historyczne sa nadzwyczaj interesujące, ale jednak wróćmy do dzisiejszego stanu prawnego.

(13.01.2005; gość - JS: Joanna Senyszyn)

Odgrywanie roli eksperta jest w powyższym przykładzie o tyle ułatwione, że czynny polityk ma tytuł profesora (chociaż nie w tej dziedzinie, w jakiej się na eksperta kreuje ${ }^{70}$ ). Wypowiedź ma cechy gatunkowe wykładu, który wkomponowany w strukturę debaty zyskuje inny sens i funkcję. Staje się wyrafinowanym argumentem na rzecz określonych rozwiązań i elementem kreowania wizerunku.

Analiza zachowań komunikacyjnych gości wykazuje wyraźną korelację z ich rolą społeczną, i to zarówno w zakresie oczekiwań z nią związanych, jak i rzeczywistych realizacji. Społecznie ukształtowane stereotypy roli polityka i roli eksperta są ujawniane przez rozmówców w trakcie strategii metadyskursywnych. Ich zadaniem jest regulowanie przebiegu interakcji poprzez komentowanie, ocenianie konkretnych posunięć taktycznych. I tak, wypowiedzi polityka są odbierane przez pryzmat jego bieżącej działalności politycznej. Na przykład negatywne oceny zdarzeń tła pozajęzykowego są prymarnie odbierane jako atak na przedstawicieli władzy (inna intencja musi być bowiem specjalnie werbalizowana). Sądy wygłaszane przez polityka cechuje duży stopień pewności i kategoryczności, co odróżnia je od sądów eksperta. Dla tej roli z kolei jest charakterystyczna postawa asekuracyjna: ostrożne i warunkowe wygłaszanie sądów, wielointerpretacyjność, relatywizm, niechęć do spekulacji i bezpodstawnych ocen. Należy jednak pamiętać, że rola społeczna jest pewnym konstruktem, który może być również strategicznie wykorzystany w realizacji doraźnych celów komunikacyjnych, np. w taktycznym kreowaniu się polityka na eksperta.

\subsubsection{Delimitacja segmentu z udziałem gości}

W większości programów segment z udziałem gości jest zaplanowany po segmencie z publicznością ${ }^{71}$. Oddzielenie obu segmentów jest wyraźne, gdyż wiąże się

70 Joanna Senyszyn jest członkiem SLD i profesorem ekonomii.

${ }^{71} \mathrm{~W}$ punkcie 6.3 .3 zostaną omówione tylko sygnały początkowe segmentu z udziałem gości w takich programach, w których omawiany segment wystąpił po segmencie z publicznością. W pozostałych programach (kiedy segment z publicznością rozdziela segment z gośćmi) początkowe 
z sygnałami niewerbalnymi o charakterze kinezycznym (dziennikarz oddala się od publiczności siedzącej na ławkach i przechodzi ku gościom siedzącym za stołem głównym) oraz sygnałami werbalnymi o charakterze retrospektywno-prospektywnym. Sygnały kinezyczne mają charakter obligatoryjny, ponieważ widzowie obserwują na ekranach moment zmiany grupy rozmówców. Wobec tego sygnały werbalne nie są obligatoryjne, ale ich pojawienie się uwyraźnia delimitację tekstu dzięki temu, że orientuje odbiorcę w jego organizacji i zmianie przebiegu linii tematycznej.

Maksymalnie rozbudowany ciąg werbalnych sygnałów delimitacyjnych zawiera: podsumowanie segmentu z publicznością (wygłoszone bezpośrednio do kamery) (por. przykłady z punktu 6.2.3, w których analizowano zakończenie segmentu z publicznością), prośbę o wysłuchanie rozmowy z gośćmi, zapowiedź tej rozmowy, zapowiedź nowego wątku tematycznego, powitanie gości. Minimalnym symptomem rozpoczęcia segmentu jest towarzyszące sygnałom kinezycznym wprowadzenie, motywujące pierwsze pytanie skierowane ogólnie do wszystkich gości lub wybranego gościa. Rozpatrzmy kilka przykładów, w których pojawiają się $\mathrm{w}$ różnych konfiguracjach sygnały i symptomy delimitacji segmentu z udziałem gości.

KD: To były opinie osób, którzy [sic!] $w$ swoje doroste życie, ale także ocierajac się o politykę, wchodziły już wtedy, kiedy Aleksander Kwaśniewski sprawowat urząd prezydenta. Spróbujemy na 24 godziny niemalże przed końcem tej prezydentury/ spróbujemy ja podsumować [...]. Odchodzi ze swojej funkcji polityk, który miewat zaufanie społeczne wyższe niż osiemdziesiąt procent [...]. Czy to oznacza, że Aleksander Kwaśniewski jest wyjątkowo zdolnym politykiem? Czy to jest/ to oznacza, że Aleksander Kwaśniewski świetnie wpasowat się w oczekiwania obywateli $i$ czasy, w których przyszło mu rządzić? Panie Tomaszu? (21.12.2005)

[dziennikarz oddala się od publiczności, mówi wprost do kamery] [podsumowanie segmentu z publicznościal KD: To byty opinie osób, którzy w swoje dorosłe życie, ale także ocierając się o politykę, wchodzity już wtedy, kiedy Aleksander Kwaśniewski sprawowat urząd prezydenta.

[zapowiedź czynności komunikacyjnych w nowym segmencie] Spróbujemy na 24 godziny niemalże przed końcem tej prezydentury/ spróbujemy ja podsumować [...].

[wprowadzenie, motywujące pytanie] Odchodzi ze swojej funkcji polityk, który miewat zaufanie spoteczne wyższe niż osiemdziesiąt procent [...].

[sformułowanie pytania i wskazanie pierwszego rozmówcy spośród gości] Czy to oznacza, że Aleksander Kwaśniewski jest wyjątkowo zdolnym politykiem? Czy to jest/ to oznacza, że Aleksander Kwaśniewski świetnie wpasowat się w oczekiwania obywateli i czasy, w których przyszło mu rządzić? Panie Tomaszu?

KD: Chciatbym, żebyśmy postuchali tego, co maja do powiedzenia dziś nasi goście. Panie profesorze, panie ministrze, doktadnie 23 lata temu strzelano do górników w kopalni „Wujek”. I dzisiaj, 23 lata po śmierci tych górników, nikt w tej sprawie nie został skazany prawomocnym wyrokiem sądu. Czy my żyjemy w państwie prawa? (16.12.2004)

sygnały delimitacyjne są usytuowane w ramie tekstu i z tego względu zostały omówione w punkcie 6.1. Takie usytuowanie mają również sygnały końcowe segmentu z gośćmi. 
[akt mowy nakłaniający do wysłuchania rozmowy z gośćmi] Chciatbym, żebyśmy postuchali tego, co mają do powiedzenia dziś nasi goście.

[wskazanie rozmówcy spośród gości] Panie profesorze, panie ministrze,

[wprowadzenie, motywujące pytanie] dokładnie 23 lata temu strzelano do górników w kopalni „Wujek”. I dzisiaj, 23 lata po śmierci tych górników, nikt w tej sprawie nie zostat skazany prawomocnym wyrokiem sadu.

[pytanie skierowane do gościa] Czy my żyjemy w państwie prawa?

KD: „30 procent zwolenników, 70 procent przeciwników”. Te sondaże czytają też politycy. Panie pośle, zdecydowana większość Polaków jest przeciwko tej wojnie, przeciwko naszej obecności w Iraku, ale druga już ekipa polityczna decyduje się jednak na to, żeby polskie wojska w tym kraju pozostaty. Czy pan potrafi objaśnić, dlaczego rzady tak konsekwentnie ida pod prad opinii publicznej? (4.01.2006)

[nawiązanie do wątku omawianego z publicznością] „30 procent zwolenników, 70 procent przeciwników”.

[wprowadzenie, motywujące pytanie] Te sondaże czytaja też politycy. [...] zdecydowana większość Polaków jest przeciwko tej wojnie, przeciwko naszej obecności w Iraku, ale druga już ekipa polityczna decyduje się jednak na to, żeby polskie wojska w tym kraju pozostały.

[pytanie skierowane do gościa] Panie pośle [...]. Czy pan potrafi objaśnić, dlaczego rządy tak konsekwentnie ida pod prąd opinii publicznej?

Delimitacja segmentu z udziałem gości, który jest usytuowany po segmencie $\mathrm{z}$ publicznością, wiąże się ze zmianą scenerii (dziennikarz zmienia grupę rozmówców, podchodzi do stolika gości) oraz mniej lub bardziej rozbudowanym zestawem elementów werbalnych. Podsumowanie poprzedzającego segmentu, zapowiedź nowych czynności komunikacyjnych i nowych rozmówców, wprowadzenie w kolejne wątki tematyczne należy zaliczyć do działań tekstotwórczych prowadzącego, które zaznaczają strategiczny punkt w organizacji strukturalnej tekstu. Jednocześnie komentowanie przebiegu interakcji na poziomie metadyskursywnym wspomaga odbiór tekstu jako spójnej całości o zaplanowanym przebiegu.

\subsubsection{Organizacja segmentu ze względu na liczbę i rodzaj uczestników}

W segmencie z udziałem gości występują dwa podstawowe typy sekwencji o układach rozmówców: dziennikarz + gość (w tym: dziennikarz + polityk i dziennikarz + ekspert) oraz gość + gość. Gatunkowe uwarunkowania debaty, a zwłaszcza wymóg formalizacji przebiegu interakcji, powodują, że oś konstrukcyjną segmentu stanowią sekwencje [dziennikarz + gość1] + [dziennikarz + gość2] itd. Nie znaczy to, że goście nie mogą odnosić się nawzajem do swoich wypowiedzi (dziennikarz + gość $\leftrightarrow$ gość), ale powinni czynić to po oddaniu im głosu przez prowadzącego. Często jednak konfrontacyjne nawiązanie przez 
gościa do wypowiedzi innych rozmówców stanowi dla nich bodziec wywołujący natychmiastową reakcję, z naruszeniem kolejności ustalanej przez dziennikarza.

KD: Przepraszam, ale tu się toczy dyskusja. Pan profesor Nałęcz.

$\mathrm{TN}$ : Z pewnym zaktopotaniem się przystuchuję tej dyskusji, bo moim zdaniem poziom emocji jest taki, że nie da się rzeczywistej refleksji o stanie wojennym w tej atmosferze uczynić. [...] Mnie się w ogóle nie podoba pomyst czczenia pamięci ofiar zbrodni stanu wojennego pod domem generała Jaruzelskiego. Nie znajduję $w$ historii takiego przyktadu, żeby czczono pamięć ofiar $w$ tak nietypowym miejscu. No państwo jednak/l

Gpr: Pod domem mordercy. To jest symboliczne miejsce.

TN: To proszę mi pokazać w historii, dramatycznej polskiej historii, jeśli przyjąć wasza optykę już, przyjmijmy wasza optykę, chociaż ja generata Jaruzelskiego za mordercę nie uważam, to pokażcie mi w polskiej historii, gdzie zbrodni byto bez liku, gdzie czczono pamięć ofiar pod domem mordercy? Bo ja nie znajduję innego takiego przykładu. Nie, nie, szanowni państwo, moim zdaniem, jeśli chcemy potępić tę zbrodnię, a moim zdaniem zbrodnia musi być potępiona, bo jak zbrodnia nie jest potępiona, to zło może wrócić, to naprawdę//

LK: Panie profesorze, byty zbrodnie niepotępione. No po zamachu majowym zginęto około 400 osób.

TN: Nie, panie profesorze, chciałem użyć tego przyktadu [...].

KD: Jeśli panowie pozwola, to mnie jednak bardzo interesuje tutaj opinia//

TN: I przepraszam, i moim zdaniem, jeśli chcemy doprowadzić do tego, żeby zbrodnię potępić i przestępców ukarać, to nie przez tego typu demonstracje!

(16.12.2004; goście - LK: Leszek Kubiki, Gpr: gość w roli proponenta, TN: Tomasz Nałęcz)

Dziennikarz zgodnie w wymogami debaty typuje kolejnego rozmówcę, który w swojej wypowiedzi polemizuje z uczestnikami demonstracji. Jeden z nich bez pozwolenia przejmuje turę, włączając się z polemiką, co rozpoczyna sekwencję polilogową z udziałem dwóch dodatkowych rozmówców. Spontaniczne włączanie się gości do interakcji powoduje rozbudowanie początkowo zaplanowanych wymian dialogowych (dziennikarz + gość) do postaci polilogu (dziennikarz + gość + gość + gość). Tak więc nieingerowanie dziennikarza jako organizatora $\mathrm{w}$ tego typu sekwencje polilogowe, bardziej spontaniczne i nieprzewidywalne, skutkuje odejściem od sztywnej formuły debaty jako gatunku. Zbliża natomiast interakcję bądź do merytorycznej dyskusji, bądź niemerytorycznej, bardziej dygresyjnej rozmowy publicznej.

Poszerzanie się grona rozmówców oraz ich przynależność do różnych partii politycznych lub identyfikowanie się z różnymi opcjami światopoglądowymi i wynikające stąd różnice stanowisk, różnice interesów, powodują, że interakcja może stać się polem walki, rywalizacji, zamiast polem współpracy. Profesjonalne przygotowanie dziennikarza, instytucjonalny charakter interakcji, która jest prowokowana w studiu oraz jej ramy gatunkowe powinny sprzyjać podejmowaniu takich strategii konwersacyjnych, w których respektowana jest podstawowa zasada kooperacji.

Zasada ta powinna być zachowana nawet wtedy, gdy interlokutorzy realizują różne cele, ale w ramach współpracy komunikacyjnej podejmują 
ciągi negocjacyjne, stosują argumentację, która ma na celu zbliżenie stanowisk. Według A. Awdiejewa i G. Habrajskiej zachowanie zasady kooperacji jest na tyle ważne, że w ogóle odróżnia strategię od tzw. antystrategii: „Można też mówić o antystrategiach konwersacyjnych, kiedy partner blokuje każde posunięcie rozmówcy lub w sposób ukryty dąży do uniemożliwienia prowadzenia strategii oponenta” (Awdiejew, Habrajska 2006: 59). Należy zauważyć, że w sekwencjach polilogowych z udziałem spontanicznie włączających się rozmówców dochodzi do naruszania zasady kooperacji częściej, niż w sekwencjach dialogowych $\mathrm{z}$ udziałem dziennikarza.

JK: Natomiast panie redaktorze Gauden, no jest jakaś hipokryzja w tym pańskim podpisywaniu się $w$ proteście przeciwko rzekomej segregacji mediów przy tamtej/ parafowaniu i podpisywaniu umowy paktu stabilizacyjnego, bo to przecież pan wyrzucit z Rzeczpospolitej dziennikarza, który wtaśnie usitowat udostępnić spoteczeństwu, umożliwić szerszy dostęp do informacji - Bronistawa Wildsteina - za ujawnienie list w IPN-e [...].

KK: Ale po co pan to opowiada?

JK: Ale panie marszatku, pan nie może pót minuty wytrzymać, kiedy niewygodne teksty dla pana padaja.

KK: Nie niewygodne, tylko pan mówi stare fakty, które sa nieistotne, nieinteresujace [...].

KD: Panie redaktorze, czy pan się uważa za bezstronnego dziennikarza? Byt pan wtedy/ kiedy rozstat się pan z firma, byt pan bezstronnym dziennikarzem?

(8.02.2006; goście - JK: Jacek Kurski, KK: Kazimierz Kutz)

Rozmówcy nie odnoszą się do tematu cząstkowego, jakim było podpisanie paktu stabilizacyjnego, lecz stosują taktykę podważania wiarygodności przeciwnika oraz istotności przekazywanych treści. Działania takie można uznać za przejaw blokowania posunięć interlokutora. Warto zauważyć, że dziennikarz przyłącza się do ataku na gościa (zadając sugestywne pytanie), co w tym momencie sprawia wrażenie naruszenia zasady bezstronności. Można to interpretować $\mathrm{w}$ konwencji na serio jako brak profesjonalizmu dziennikarza lub też w konwencji nie na serio - jako strategię prowokacji w celu wykreowania bardziej efektownego widowiska. Obok pytań insynuacyjnych skutecznym sposobem na wytrącenie przeciwnika z równowagi jest wykpiwanie jego stanowiska.

AC: To już nie jest tylko model szwedzki, tylko dzieje się to coraz szerzej w Europie. Niedawno $w$ Hiszpanii minister wziąt urlop ojcowski, żeby pierwsze tygodnie życia dziecka spędzić razem $z \mathrm{nim} / /$

MB: A co, mama wtedy poszła do pracy? [śmiech]

AC: Nie, przebywali wtedy razem.

IJ-N: Moga razem, to w ogóle nie jest śmieszne.

AC: To nie jest w ogóle zabawne.

MB: Tak naprawdę w tej Szwecji, o której pani mówi, korzysta z tego prawa 18 procent ojców, więc to nie jest jakieś/ a oni przecież mogą.

KD: No to może aż 18 procent ojców. Może 18 procent dzieci jest szczęśliwszych przez to, że [mają oboje rodziców obok siebie. 
AP-S: [Przeważnie korzystaja z tego urlopu ojcowie, żeby pojechać na polowanie na tosie. To podobno tak jest. [uśmiech]

(25.01.2006; goście - AC: Anna Czerwińska, AP-S: Anna Pakuła-Sacharczuk, IJ-N: Izabela Jaruga-Nowacka, MB: Małgorzata Byzdra)

Rozmówczyni przytacza argument na poparcie swojego stanowiska (jest to argument odwołujący się do przykładu). Przeciwniczka wykpiwa przykład ( $A$ co, mama wtedy poszła do pracy?), co zostaje zauważone przez dwie rozmówczynie (to $w$ ogóle nie jest śmieszne; To nie jest w ogóle zabawne). Następnie oponentka dostosowuje swoją strategię do strategii proponentów i również wysuwa argument odwołujący się do przykładu. Reakcją na niego są dwa działania, z których jedno ma charakter polemiczny, a drugie - charakter wspierający stanowisko oponentów. Są to: aksjologiczno-emotywna strategia dziennikarza, w której dąży on do zmiany wartościowania zjawisk podanych w przykładzie (to może a 18 procent ojców) oraz stosowana już taktyka wykpienia argumentów przeciwnika (korzystaja z tego urlopu ojcowie, żeby pojechać na polowanie na tosie). Dyskredytacja prześmiewcza ma nie tylko zdezorientować rozmówcę, pozbawić go pewności siebie, ale również dać sygnał odbiorcy medialnemu: „mój przeciwnik jest śmieszny, zatem lekceważ go”. Właśnie makrosytuacyjne uwarunkowania interakcji w studiu sprawiają, że tak często repliki interlokutorów, zwłaszcza wtrącane konfrontacyjnie, odbierane są jako przeszkadzanie.

\section{KD: Pan profesor Wiatr.}

JW: Przede wszystkim chciałem powiedzieć, że, trochę na boku tego głównego nurtu, ja mam krytyczne zdanie o pewnych elementach działalności Instytutu Pamięci Narodowej i bardzo pozytywne zdanie o innych elementach. I dlatego//

AC: Pan jest bardzo eleganckim mówca, panie profesorze, i dziękujemy za to. $n y[\ldots]$.

JW: A niech mi pan nie przeszkadza [śmiech widowni], bo problem nie jest jednoznacz-

(16.12.2004; goście - AC: Andrzej Całkiewicz, JW: Jerzy Wiatr)

Włączenie się oponenta stanowi przykład wyrafinowanego blokowania strategii przeciwnika. Pozorny komplement zostaje użyty z intencją dyskredytacji prześmiewczej, a mianowicie szyderstwa (potwierdzeniem tego jest zarówno obronna reakcja zaatakowanego, jak i reakcja publiczności). Rozmówca nie daje się jednak sprowokować. Nie wdaje się w polemikę z dyskredytującym, gdyż nie on jest tu najważniejszym odbiorcą, ale po zneutralizowaniu ataku (niech mi pan nie przeszkadza), kontynuuje wypowiedź.

Różnego rodzaju dyskredytacje (moralne, prześmiewcze) stanowią naruszenie zasady kooperacji. To, czy rzeczywiście takie działania zablokują posunięcia przeciwnika (dojdzie do kłótni czy nawet przerwania interakcji) zależy również od kompetencji komunikacyjnych uczestników. Zwykle większa świadomość konwencji widowiska pozwala powstrzymać naturalną irytację i odbierać ataki personalne jako wkalkulowane w medialne przedstawienie. Wydaje się, że 
najkorzystniejsze dla zaatakowanego jest zdemaskowanie chwytów przeciwnika, przejście na poziom metadyskursywnego komentarza dotyczącego jego działań. Chodzi o wysłanie komunikatu do widzów: „odkryłem jego grę”. Widać zatem, że podwójna sytuacyjność zwiększa poziom skomplikowania strategii komunikacyjnych. Dotyczy to nie tylko działań gości, ale również dziennikarza.

Zachowania komunikacyjne prowadzącego są dostosowane do celów realizowanych w segmencie z gośćmi (por. punkt 6.3.2). Ich istotnym determinantem jest rola społeczna gościa, a zwłaszcza jego zaangażowanie (lub też brak zaangażowania) w bieżącą rywalizację polityczną. Deklaratywnie nadawca medialny mnimalizuje aspekt polityczny omawianych spraw w celu wyeksponowania aspektu publicznego (dobro ogółu, interes publiczny) (por. przytaczany już cytat: dobra tradycją tej debaty jest to, że o polityce mówi się tu jak najmniej). Niemniej jednak sam udział polityków sprawia, że w programie realizowane jest komunikowanie polityczne.

Na wybór strategii komunikacyjnych mają wpływ hipotezy dotyczące rozmówcy (Żydek-Bednarczuk 2005: 232). Pomijamy w tym momencie indywidualne sympatie i antypatie, które też zapewne nie są bez znaczenia i koncentrujemy się na roli społecznej rozmówcy. Otóż, w rozmowie z politykami dziennikarz (częściej niż w rozmowie z ekspertami) przyjmuje postawę sceptyczną i występuje w roli krytycznego dyskutanta lub nawet prowokatora. Wynika to z przyjęcia założenia, że polityk koncentruje się na działaniach marketingowych, wizerunkowych, wręcz propagandowych. Z kolei rolą dziennikarza w relacji do wyborców jest konfrontowanie stanowisk, zderzanie różnych punktów widzenia w celu zdemaskowania polityka lub odwrotnie: uzyskania od niego wiarygodnej argumentacji i klaryfikacji stanowiska.

KD: Jeśli panowie pozwola, to przerwiemy na chwilę dyskusję o wyższości bądź niższości pót litra od dziatki marihuany, albo innego narkotyku i zapytam pana posta Gadzinowskiego, czy pan kiedyś próbowat?

PG: Ale czego? [Pót litra?

$\mathrm{KD}$ : [Miękkich narkotyków.

PG: Nie. Pót litra tak.

KD: Pót litra tak, a miękkich narkotyków/ [To śmiałe wyznanie, ale co z narkotykami?

PG: [Ja jestem niepalacy/ ja jestem generalnie niepalacy.

KD: Jest pan niepalacy i nie próbowat pan, to może dlatego tak tatwo przychodzi panu mówienie o tym, że legalizacja miękkich narkotyków to jest coś, co powinno zostać zaakceptowane.

PG: Nie, nie. Bo ja znam takich, którzy próbowali. I znam takich, którzy wpadli w nałóg. Ale to, że ktoś jest alkoholikiem czy narkomanem, czy nawet ma depresję, nie zależy od tego, czy napit się wódki, czy zapalit, czy żyje. Po prostu to jest uwarunkowane sprawami społecznymi $i$ konstrukcja psychiczną.

(10.02.2005; gość - PG: Piotr Gadzinowski)

Dziennikarz stosuje taktykę prowokacyjnego „podpuszczenia”: zadaje osobiste pytanie po to, by wykorzystać poufne informacje przeciwko politykowi, 
zarzucić mu teoretyzm i brak doświadczenia ${ }^{72} \mathrm{w}$ zakresie podejmowanych decyzji. Prowokacja, oprócz tego, że jest widowiskowa, skłania polityka do precyzyjniejszej argumentacji, która może trafić do przekonania widzom o niezbyt ugruntowanych poglądach na dany temat. Edukacyjny cel tego rodzaju aktywizacji polityka został ujawniony wprost przez prowadzącego w kolejnym przykładzie.

KD: Ale wtaśnie dlatego chciałbym zapytać, czy wyjściem z tej sytuacji jest legalizacja prostytucji, czy nie?

JS: Oczywiście, że to jest wyjście z tej sytuacji [...].

KD: Czy posta na Sejm Rzeczpospolitej nie przeraża fakt, $\dot{z} e$ państwo wystepuje w roli wielkiego sutenera?

JS: Nie. Na to nie można patrzeć w ten sposób. Dlatego, że to nie to, że państwo jest wielkim sutenerem. [...] Natomiast oczywiście argumenty, że państwo się stanie wtedy sutenerem $i$ będzie czerpato zyski z tego, no to sa absolutnie chybione, bo to po prostu tak nie można patrzeć na to! Podatki po prostu przyczyniają się//

KD: Poglad już poznatem, a argumentacja? Jednym zdaniem: dlaczego jest chybiony, skoro dziś stan prawny jest taki, że czerpanie korzyści z cudzego nierzaddu jest karalne, po zmianie prawa ma być zalegalizowane?

(13.01.2005; gość - JS: Joanna Senyszyn)

Dziennikarz wykorzystuje odpowiedź rozmówczyni do prowokacyjnego ata$\mathrm{ku}$, wskazując na niezgodność roli posła z popieraniem działania moralnie nagannego (państwo występuje w roli wielkiego sutenera). Porównanie jest przejaskrawione, ale nie o adekwatność opisu tu chodzi. Głównym celem dziennikarza jest nakłonienie polityka do przekonującej argumentacji, co sygnalizuje wprost (Pogląd już poznatem, a argumentacja?). Wyegzekwowanie uzasadnienia poglądów jest bowiem elementem racjonalnego wyboru, który stanowi jedno z zadań mediów.

Organizacja interakcji w segmencie z gośćmi jest zależna przede wszystkim od liczby rozmówców, a w dalszej kolejności - od ich roli i wynikających stąd celów komunikacyjnych. Przyjęta w założeniach nadawcy formuła debaty (na co może wskazywać tytuł programu) jest realizowana ze zmiennym powodzeniem. Spontaniczne włączanie się rozmówców i podejmowanie wymian między sobą, z pominięciem pośrednictwa dziennikarza, nadaje interakcji formę rozmowy publicznej lub dyskusji o formie polilogu. Nieprzestrzeganie zasady kooperacji może mieć formę mniej lub bardziej jawną. Przybiera postać blokowania posunięć przeciwnika. Należy jednak pamiętać, że analizowana interakcja jest elementem widowiska medialnego i to, co jest niefunkcjonalne dla dyskusji, może znaleźć uzasadnienie makrosytuacyjne. Świadomość tego rodzaju uwarunkowań należy

72 Zarzut należy odbierać w ramach kreowania widowiska, a nie merytorycznej dyskusji. Chodzi o postawienie polityka w sytuacji zagrożenia twarzy, co wywołuje jego reakcję obronną i wzmaga emocjonalność, dynamikę interakcji. 
do kompetencji komunikacyjnej osób występujących w mediach. Jak wynika z analizowanych przykładów, ich działania nakierowane są bardziej na widzów niż uczestników bezpośredniej interakcji.

Zmienność organizacji dotyczy również dwóch podstawowych kategorii gości: polityków i ekspertów. W interakcji z ekspertami dziennikarz podejmuje strategie nieantagonistyczne, w których zachowana zostaje podstawowa zasada kooperacji (por. punkt 6.3.2). Przyjmuje postawę ucznia, dążąc do pozyskania informacji, ocen i wskazówek co do sposobu działania. Występuje jako reprezentant opinii publicznej i przedstawiciel instytucji medialnej, która kreuje się na podmiot organizujący debatę publiczną dotyczącą ważnych społecznie tematów. Politycy są częściej uczestnikami strategii antagonistycznych, co wynika z dostosowania strategii dziennikarza do celów ich działalności pozajęzykowej. Dziennikarz stosuje wobec nich taktykę prowokacji, przyjmuje postawę sceptyczną.

\subsubsection{Organizacja problemowa segmentu z udziałem gości}

Niezależnie od ukształtowania interakcji ze względu na rodzaj i liczbę uczestników, można postawić pytanie o orientację problemową w przebiegu interakcji, która pozwoliłaby dostrzec etapy w realizacji intencji retorycznej nadawcy medialnego. Etapy te odpowiadałyby segmentom interakcji o określonej funkcji komunikacyjnej i znaczeniu w całym tekście ${ }^{73}$. Ze względu na nadrzędną rolę dziennikarza jako organizatora interakcji należy przyjąć, że to właśnie jego działania mowne realizują plan strategiczny (czasem zgodnie z celami rozmówców, a czasem wbrew nim). Na jego powstanie mają wpływ czynniki unifikujące i różnicujące. Do czynników unifikujących należy sytuacja komunikacyjna, a zwłaszcza cele mediów, takie jak informacja, edukacja, organizowanie platformy debaty publicznej, perswazja oraz cele komunikacji publicznej, w tym politycznej, np. regulacja form życia społecznego, przekazywanie oferty politycznej wyborcom. Różnicujący wpływ ma natomiast rodzaj tematu i wynikający z niego stopień uwikłania rozmówców w wydarzenia motywujące temat.

Na podstawie analizy uwarunkowań sytuacyjnych oraz wynikających z nich działań komunikacyjnych rozmówców w programie „Debata”, w tym strategii metadyskursywnych, można postawić tezę, że przebieg sterowanej przez dziennikarza interakcji naśladuje scenariusz procesu opiniotwórczego i (ewentualnie) decyzyjnego w życiu publicznym i politycznym. Używając sformułowania „naśladuje” (a nie „realizuje”), odwołujemy się z jednej strony do teatralizacji i karnawalizacji medialnych debat publicznych, w tym politycznych, do nasilającego

73 Ustalenie globalnej funkcji segmentu tekstowego i jego znaczenia w całym tekście stanowi istotny element składowy strategicznego modelu dyskursu (van Dijk, Kintsch 1983: 92, za Duszak 1998: 173). 
się zjawiska politeinmentu, a z drugiej - do zjawiska kreowania wizerunku mediów jako podmiotu inicjującego debatę publiczną i sterującego nią. Chociaż media upraszczają i banalizują przekaz polityczny, to jednocześnie zależy im na podtrzymaniu opinii o sobie jako o podmiocie organizującym i stymulującym artykulację interesów grup społecznych, stwarzającym platformę porozumienia między nimi. Komunikowanie publiczne zajmuje bowiem pozycję uprzywilejowaną w procesach społecznych (Dobek-Ostrowska 2006: 123), a zatem jest podstawą legitymizacji mediów.

Etapy w rozwoju dyskursu nie mają charakteru wyraźnie zdelimitowanych segmentów, ale raczej są bliższe elastycznym schematom superstrukturalnym i makrostrukturalnym (Duszak 1998: 173-197). Docieranie do nich jest uzależnione od kompetencji użytkownika oraz przyjmuje postać domniemań i przypuszczeń. Według Anny Duszak, idea schematu superstrukturalnego „zakłada wyższy stopień abstrakcji wzorców tekstowych i strategii komunikacyjnych w analizie dyskursu. Chodzi w nich o ustalenie generalnego kierunku pytań i odpowiedzi, który stanowić mógłby o tożsamości i koherencji całych typów zachowań komunikacyjnych” (Duszak 1998: 182). Jako przykłady globalnych schematów superstrukturalnych wymienia się strukturę opowiadania, argumentacji i opisu (Duszak 1998: 177-181; Witosz 1997: 25; Ostaszewska 1991). „Ewolucja znaczeń makrostrukturalnych musi być przede wszystkim zgodna z ogólnym kierunkiem rozwoju linii tematycznej tekstu, toteż przebiega ona pod kontrolą jakiejś strategii komunikacyjnej” (Duszak 1998: 190). Znaczenia globalne nie wynikają z obiektywnych cech tekstu, ale są mu przypisywane w drodze subiektywnego osądu użytkownika, na który ma wpływ typ sytuacji. Względność makrostruktur wynika z tego, że odbiorca wnosi do tekstu treści pozatekstowe. Na kształt makrostruktur wpływa odniesienie między mówieniem a działaniem oraz stwierdzenie: „na ile sądy o tym, co nadawca chce zrobić (osiągnąć) za pomocą tekstu, wpływają na interpretację tego, o czym jest mowa" (Duszak 1998: 193).

Superstruktury i makrostruktury są rodzajem struktur globalnych, tworzonych w procesie odbioru tekstu jako wyższe i skonwencjonalizowane formy organizacji problemowej. W analizie przebiegu debat starano się dotrzeć do wskaźników o charakterze superstrukturalnym za pomocą ustalenia generalnego kierunku pytań i odpowiedzi. Z uwagi na fakt, że w tekstach, zwłaszcza w komunikacji potocznej, przejawiają się różne schematy superstrukturalne, niekoniecznie ostro wyodrębnione (por. Bartosiewicz 2002: 124), punktem wyjścia rozważań będzie organizacja problemowa interakcji przez dziennikarza.

Organizacja problemowa interakcji, która momentami przebiega żywiołowo, ma wielu nadawców o różnym statusie i często rozbieżnych celach komunikacyjnych, stanowi ważne zadanie prowadzącego. Działania dziennikarza w zakresie jej uregulowania należy odbierać jako działania tekstotwórcze. Integracja tekstu jako makroznaku dokonuje się bowiem w płaszczyźnie tematycznej, semantycznej 
i strukturalnej (Bartmiński, Niebrzegowska-Bartmińska 2009: 203). W przypadku organizacji problemowej, którą można też nazwać semantyczno-tematyczną, trudno o wyraźnie oddzielone segmenty, choć działania prowadzącego zmierzają do nadania jej regularności. Progresja tematyczna może przybierać zarówno formy sekwencyjne, jak i hierarchiczne ${ }^{74}$. Należy zgodzić się ze stwierdzeniem, że: „w dynamicznym procesie komunikacji autonomia poszczególnych segmentów jest względna. Segmentacja jest i wieloaspektowa, i wielopoziomowa, hierarchiczna” (Bartmiński, Niebrzegowska-Bartmińska 2009: 206).

\subsubsection{Etapy organizacji problemowej}

Odtworzenie etapów problemowej organizacji interakcji w programie „Debata” wymaga odpowiedzi na pytanie, czy różnym treściowo wypowiedziom dziennikarza (tzn. występującym w ramach różnych programów, tematów) można przyporządkować powtarzalne formy działań komunikacyjnych. Chodzi o interpretację interwencji dziennikarza w kategoriach strategicznego organizowania interakcji w studiu ze względu na cel związany z typem dyskursu publicznego. Interesuje nas, czy w rozwoju dyskursu pojawiają się etapy, które świadczyłyby o próbach uporządkowania aktywności komunikacyjnej uczestników debat. Zwracamy uwagę na to, jakim ogólnym, globalnym pytaniom można podporządkować działania prowadzącego, jakie wskazówki orientacji w dyskursie formułuje dziennikarz (czasem rozmówcy), jak prowadzący nazywa strategiczne działania komunikacyjne.

$\mathrm{W}$ celu wstępnego zarysowania zagadnienia zestawiono w tabeli fragmenty różnych „Debat” zawierające wypowiedzi dziennikarza (rzadko rozmówców). Zwracano uwagę na inicjowanie etapów o podobnej funkcji w strukturze interakcji. Podobieństwo jednak nie dotyczy zawartości treściowej, ale kompozycji fragmentów odpowiadających na podobne pytanie (pytania) globalne.

\begin{tabular}{|c|c|}
\hline $\begin{array}{c}\text { Ogólne, globalne pytanie, } \\
\text { które tkwi w strukturze } \\
\text { wypowiedzi }\end{array}$ & \multicolumn{1}{|c|}{$\begin{array}{c}\text { Fragment tekstu z wypowiedzią dziennikarza } \\
\text { (rzadziej rozmówcy) }\end{array}$} \\
\hline 1 & 2 \\
\hline $\begin{array}{l}\text { Co się stało? Co to oznacza } \\
\text { w kontekście prawnym? (ka- } \\
\text { tegoryzacja wydarzeń, z wyko- } \\
\text { rzystaniem wiedzy eksperta) }\end{array}$ & $\begin{array}{l}\text { Kowej przy okazji afery FOZZ-u, to co to było: upadek obycza- } \\
\text { jówalna gra obliczona na zabezpieczenie interesów swo- } \\
\text { jego klienta. Powinniśmy się przyzwyczaić do takich postaw? } \\
(3.03 .2005)\end{array}$ \\
\hline
\end{tabular}

74 Anna Duszak wyodrębnia dwa schematy progresji tematycznej: prosty, który uwypukla aspekt sekwencyjny, opierający się na relacji dodawania oraz rozwinięty, o strukturze hierarchicznej (Duszak 1998: 184). 


\begin{tabular}{|c|c|}
\hline 1 & 2 \\
\hline $\begin{array}{l}\text { Co się dzieje? Co z tego wyni- } \\
\text { ka w kontekście historycznym } \\
\text { i współczesnym? Kto ponosi } \\
\text { straty? }\end{array}$ & $\begin{array}{l}\text { KD: [...] Witam naszych gości. Gości za stołem głównym. I za- } \\
\text { cznijmy od fragmentu listu przywódców „Podziemnej Solidar- } \\
\text { ności” do prezesa IPN-u: „Coraz częściej ofiary zrównywane sa } \\
\text { z prześladowcami. Zapowiedź dziatalności Fundacji i Ośrodka } \\
\text { Dokumentacji Czynu Niepodległościowego w Krakowie jest tego } \\
\text { dobrym przykładem. Jeden z jej zatożycieli zapowiada opubli- } \\
\text { kowanie listy agentów”. Czy pan chce przeprowadzić prywatna } \\
\text { lustrację? (20.01.2005) }\end{array}$ \\
\hline $\begin{array}{l}\text { Kto odnosi korzyści, kto po- } \\
\text { nosi straty? Co się stało? Co } \\
\text { to oznacza dla Polski w kon- } \\
\text { tekście międzynarodowym? }\end{array}$ & $\begin{array}{l}\text { KD: Rozmawiamy o korzyściach, rozmawiamy o stratach roz- } \\
\text { mawiamy o bilansie. Więc dlatego stawiam tezę/ stawiam py- } \\
\text { tanie: czy bilansem naszej obecności w Iraku jest uzyskanie } \\
\text { trwałego, wiernego sojusznika w postaci Stanów Zjednoczonych, } \\
\text { czy bilansem tych dwóch lat ponad jest pogorszenie stosunków } \\
\text { z krajami Unii Europejskiej? (4.01.2006) }\end{array}$ \\
\hline $\begin{array}{l}\text { Co się dzieje? Co to oznacza } \\
\text { w kontekście politycznym? }\end{array}$ & $\begin{array}{l}\text { KD: Dobry wieczór panom. Zacznijmy od ustalenia faktów } \\
\text { w sprawie „Wiadomości”. Dwie godziny temu w „Wiadomo- } \\
\text { ściach” Jarostaw Kaczyński powiedziat tak: „Niewatpliwie } \\
\text { mamy poważny kryzys wtadzy” i za chwile } w \text { tym samym ma- } \\
\text { teriale powiedziat: „Jako żywo, w parlamencie żadnego bataga- } \\
\text { nu nie ma. Wszystko toczy się normalnie”. No to ustalmy: jest } \\
\text { normalnie czy mamy kryzys? Bronistaw Wildstein. (18.01.2006) }\end{array}$ \\
\hline $\begin{array}{l}\text { Co się dzieje? Co to oznacza } \\
\text { dla funkcjonowania parla- } \\
\text { mentu? }\end{array}$ & $\begin{array}{l}\text { KD: Gdybyśmy się jeszcze spróbowali odnieść do tego, co się } \\
\text { faktycznie w tej chwili dzieje w parlamencie. To państwa zda- } \\
\text { niem, czy to jest jakiś poważniejszy kryzys, czy to jest normalne } \\
\text { ścieranie się racji, którym towarzysza w naturalny sposób silne } \\
\text { emocje? (18.01.2006) }\end{array}$ \\
\hline $\begin{array}{l}\text { Dlaczego tak się dzieje? Cze- } \\
\text { mu to służy? }\end{array}$ & $\begin{array}{l}\text { IK: [...] Jest to gra, żeby wpędzić swoich przeciwników w taka } \\
\text { sytuację, że wtaściwie oni nie wiedza, co maja robić. Takie wta- } \\
\text { śnie te [gest ilustrujący*] ze zmiennymi bodźcami, sznurki ze } \\
\text { zmiennymi bodźcami. }(18.01 .2006)\end{array}$ \\
\hline Kto za to odpowiada? & $\begin{array}{l}\text { MR: [...] To wobec tego trzeba postawić inne pytanie: kto jest } \\
\text { winien temu, że nie można byto utworzyć koalicji? } \\
\text { KD: A kto jest winien? Wtaśnie. (18.01.2006) }\end{array}$ \\
\hline Dlaczego tak się dzieje? & $\begin{array}{l}\mathrm{KD}:[\ldots] \text { Ja się bardziej zastanawiam nad tym/ bo to, że sa } \\
\text { wszczynane takie postępowania, to umacnia we mnie jako } \\
\text { w obywatelu wiarę } w \text { to, że instytucje w moim państwie pracuja } \\
\text { prawidtowo, pytanie - dlaczego } 14 \text { lat? }(16.12 .2004)\end{array}$ \\
\hline $\begin{array}{l}\text { Dlaczego tak się dzieje? Co to } \\
\text { oznacza w kontekście praw- } \\
\text { no-instytucjonalnym? }\end{array}$ & $\begin{array}{l}\text { KD: [...] Chciałbym, żeby panowie spróbowali przedstawić swój } \\
\text { punkt widzenia i powiedzieli panu marszatkowi Natęczowi, dla- } \\
\text { czego akurat pod domem generała Jaruzelskiego odbywa się ta } \\
\text { demonstracja. Czy to jest wyraz nieufności dla polskiego wymia- } \\
\text { ru sprawiedliwości, dla osądzenia tej zbrodni? (16.12.2004) }\end{array}$ \\
\hline Jaka jest ocena zdarzenia? & $\begin{array}{l}\text { KD: [...] Czy pan uważa, że jest w porzadku, że lider partii poli- } \\
\text { tycznej mówi: „Gdybym byt marszatkiem Sejmu, to bym ukarat } \\
\text { dziennikarzy, którzy wczoraj tak relacjonowali?” (8.02.2006) }\end{array}$ \\
\hline
\end{tabular}




\begin{tabular}{|c|c|}
\hline 1 & 2 \\
\hline $\begin{array}{l}\text { Jaka jest ocena zdarzenia? } \\
\text { Na czym polega problem? }\end{array}$ & $\begin{array}{l}\text { KD: Czy to jest poważna próba rozwiązania poważnego proble- } \\
\text { mu? Bo ten problem jest poważny. } \\
\text { WK: Nie, ja myślę, że tu się pojawit pewien ważny problem } \\
\text { wspótpracy między politykami a mediami. I widocznie nie ukła- } \\
\text { dała się ona najlepiej i doprowadziła do takiej sytuacji [do kon- } \\
\text { fliktu]. (8.02.2006) }\end{array}$ \\
\hline Czy na tym polega problem? & $\begin{array}{l}\text { KD: [...] No wtaśnie, robi karieré cytowane, przypominane po- } \\
\text { wiedzenie „Naród ma prawo znać swoich kapusiów”. Ma prawo } \\
\text { czy nie? } \\
\text { MK: [...] kiedy zajrzymy w te [sic!] bagienko, że tak powiem, } \\
\text { ani Polska się nie zawali, ani nie poniesie większego uszczerbku. } \\
\text { Ja odnoszę wrażenie, że my rozwiąujemy problemy, których nie } \\
\text { ma. }(20.01 .2005)\end{array}$ \\
\hline $\begin{array}{l}\text { Na czym polega problem? } \\
\text { Jak go rozwiązać? } \\
\text { Czy określone rozwiązanie } \\
\text { jest skuteczne (dopuszczalne } \\
\text { itd.)? }\end{array}$ & $\begin{array}{l}\text { MS: Bo tu jest problem polegajacy na tym, czy [jeśli] mamy do } \\
\text { czynienia z niedowtadem wymiaru sprawiedliwości, czy z sytu- } \\
\text { acja, która budzi niepokój, to czy panaceum jest zmiana prawa? } \\
(3.03 .2005)\end{array}$ \\
\hline $\begin{array}{l}\text { Jak rozwiązać problem? } \text { Czy } \\
\text { określone rozwiązanie jest } \\
\text { dobre? }\end{array}$ & $\begin{array}{l}\text { KD: Co robimy? Zmieniamy prawo, ilekroć ono nie działa, tak } \\
\text { jak w sprawie FOZZ-u? (3.03.2005) }\end{array}$ \\
\hline Jak rozwiązać problem? & $\begin{array}{l}\text { KD: Niech pan pomyśli, panie Zbigniewie, ile razy będziemy } \\
\text { jeszcze puszczali oko i mówili, że lepiej to [ujawnienie archiwów } \\
\text { SB] zostawić, lepiej tego nie ruszać. Czy jednak wyjściem nie jest, } \\
\text { tak jak panowie, opublikowanie tego wszystkiego i przecięcie tych } \\
\text { rozmaitych spekulacji, przynajmniej na jakiś czas? (20.01.2005) }\end{array}$ \\
\hline $\begin{array}{l}\text { Co się stanie po wdrożeniu } \\
\text { określonego rozwiązania? }\end{array}$ & $\begin{array}{l}\text { KD: Ale załóżmy taka sytuację, że te materiaty z zasobów } \\
\text { IPN-u jednak są dostępne w Internecie. Każdy może wejść, każdy } \\
\text { się może zapoznać, poza technicznymi kwestiami, rozwiąania- } \\
\text { mi, co by się wtedy stało? (20.01.2005) }\end{array}$ \\
\hline $\begin{array}{l}\text { Czy proponowane rozwiąza- } \\
\text { nie problemu jest sprawied- } \\
\text { liwe? }\end{array}$ & $\begin{array}{l}\text { KD: Dobrze, ale panie redaktorze, sa zamieszczane w Internecie } \\
\text { cztery nazwiska**. Jedno nazwisko to jest ktoś, kto skwapliwie, } \\
\text { chętnie donosit za pieniądze, za karierę. Drugie nazwisko to jest } \\
\text { ktoś złamany szantażem. Myśli pan, że w myśl tych projektów, } \\
\text { które dzisiaj sa artykutowane, jest możliwe rozróżnienie takich } \\
\text { dwóch osób? (20.01.2005) }\end{array}$ \\
\hline
\end{tabular}

Goście - IK: Ireneusz Krzemiński, MK: Marek Król, MR: Mieczysław Rakowski, MS: Marek Safian, WK: Witold Kołodziejski.

* Gest ilustrujący, w którym rozmówca naśladuje czynność pociągania obiema rękami za sznurki.

** We fragmencie jest błąd logiczny (z zapowiedzianych czterech nazwisk dziennikarz odwołuje się do dwu). W wypowiedziach komponowanych spontanicznie zdarzają się tego typu niezgodności. 
W przebiegu środkowej części „Debaty” prowadzący podejmuje działania komunikacyjne zmierzające do zrealizowania określonego planu. Kształt tego planu zależy od uwarunkowań sytuacyjnych, a mianowicie typu dyskursu publicznego i politycznego oraz celu mediów. Analiza treści oraz kolejności pytań wskazuje na to, że strukturę interakcji cechuje uporządkowanie hierarchiczne. $\mathrm{Z}$ uwagi na celowość i uporządkowanie działań dziennikarza można je uznać za realizację strategii strukturalnych.

Na najogólniejszym, najwyższym poziomie strukturalnym pytania są uporządkowane według schematu problem/rozwiązanie. Ta dwudzielna struktura o charakterze nadrzędnym rozszczepia się na podkategorie. Sformułowanie problemu wymaga etapu diagnozy, który polega na odpowiedzi na globalne pytania: co się stało lub dzieje, co się z tym wiąże, co z tego wynika, kto i jakie odnosi z tego korzyści lub ponosi straty? Sądy diagnostyczne zostają wzbogacone o wyjaśnienie, które odpowiada na pytania: jakie przyczyny spowodowały dany stan rzeczy, kto za to ponosi odpowiedzialność, czemu ma to służyć? Diagnozie i wyjaśnieniu często towarzyszy ocena stanu rzeczy. Powstający w wyniku diagnozy konstrukt wydarzeń społecznych, publicznych, politycznych prowadzi do sformułowania problemu. W zakres nadrzędnej kategorii „rozwiązanie” wchodzi proponowanie różnych rozwiązań, ich weryfikacja (np. poprzez prognozy dotyczące skutków określonych działań) oraz wybór ostatecznego rozwiązania.

problem
$\begin{array}{r}\text { diagnoza, wyjaśnienie, ocena, } \\ \text { sformułowanie problemu }\end{array}$

Etapy rozwoju interakcji wskazują na to, że podstawą wyboru strategii strukturalnych przez dziennikarza jest kreowanie sytuacji komunikacyjnej w programie jako tej, w której zachodzi komunikowanie publiczne i polityczne. Prowadzący, dzięki inicjowaniu określonych wątków, stymuluje uczestników programu do sformułowania problemu i szukania jego rozwiązań.

$\mathrm{Z}$ perspektywy makrosytuacji, a więc skierowania komunikatu do odbiorcy masowego, bardzo ważny wydaje się etap diagnozy. Wydarzenia motywujące podjęcie tematu programu należą do rzeczywistości społeczno-politycznej, która ma charakter złożony, wieloaspektowy i niejednoznaczny. Ich zrozumienie wymaga wiedzy odnoszącej się do faktów (wiedza deklaratywna), sposobów działania (wiedza proceduralna) i norm (wiedza normatywna) (Reykowski 2002b: 118). Hipotezy na temat odbiorcy masowego, a zwłaszcza poziomu jego kompetencji poznawczych we wskazanym zakresie, skłaniają nadawcę medialnego do określonych działań strategicznych ${ }^{75}$.

75 Drugim ważnym determinantem strategii dziennikarza jest rozpoznanie sytuacji komunikacyjnej (por. Żydek-Bednarczuk 2005: 232). 
Diagnoza wydarzeń z tła pozajęzykowego (potocznie można je nazwać sytuacją społeczno-polityczną) w sytuacji debaty telewizyjnej jest najczęściej zawężana do alternatywy (upadek obyczajów czy normalna gra; prawa ofiar czy prawa prześladowców; korzyści czy straty; jest normalnie czy mamy kryzys). Etap diagnozy ma nie tylko odpowiedzieć na pytania: co się stało lub co się dzieje, ale powinien prowadzić do odczytania sensu zachodzących zjawisk w kontekście instytucjonalnym, politycznym, prawnym itd. Dziennikarz posługuje się w tym celu zawężonym zestawem cech semantycznych, np.: legalny/nielegalny, sprawiedliwy/niesprawiedliwy, korzystny/niekorzystny, normalny/nienormalny, wyjątkowy/typowy. Tak więc diagnoza wydarzeń zainicjowana przez dziennikarza, o ile nie zostanie rozwinięta przez ekspertów, jawi się jako dość uproszczona. Adekwatność diagnozy musi jednak ustąpić innym jej cechom, istotnym z uwagi na dyskursywne i gatunkowe właściwości interakcji. Dla tego rodzaju uwarunkowań ważne jest takie wykreowanie tła pozajęzykowego przez nadawcę medialnego, które wywoła emocje, zdziwienie, oburzenie, które wyeksponuje różnice oraz kontrowersje, umożliwiające zainicjowanie dyskusji i przyciągające uwagę widza.

Jak ważne jest odpowiednie wykreowanie tła pozajęzykowego, niech świadczy reakcja dziennikarza na działania rozmówców, które są niezgodne ze wskazanymi celami. Ilekroć goście starają przekonać widzów, że przywołana rzeczywistość jest normalna, typowa, prawidłowa, bezkonfliktowa, na tyle oczywista, że nie wymaga dyskusji, nie stanowi problemu - spotykają się z wyraźną interwencją polemiczną dziennikarza. Niemal w każdym programie dochodzi do tego typu interwencji, ponieważ odpowiednie wykreowanie tła rzutuje na układ interakcyjny w studiu, np. może powodować zagrożenie twarzy pozytywnej osób uwikłanych w zdarzenia.

TŻ: Ja nie sądzę, żeby Polska byta mistrzem świata w kłóceniu się w parlamencie. Ja już nie będę mówit o naszych sąsiadach ze Wschodu, bo oni nie są najlepszym przyktadem, ale przecież sa te ż przykłady ze stałych, stabilnych demokracji zachodnich, gdzie poziom temperatury konfliktu, ostrość jest nieporównywanie większa.

KD: No panie Tomaszu, ale nie otworzyt pan szeroko ze zdumienia oczu, podobnie zreszta jak duża część postów tego Sejmu, jak się nagle okazato, że rozmawiamy o 19 dniu lutego jako o tym terminie, $w$ którym trzeba złożyćl i nagle jest jakiś fenomen w ogóle z terminami! Okazuje się, że 30 stycznia/ ale wie pan, można się spierać co do racji $w$ polityce i/ ale jakiś porządek powinien być, na którym to się opiera.

(18.01.2006; gość - TŻ: Tomasz Żukowski)

Rozmówca uważa, że wydarzenie, które dziennikarz przedstawił uprzednio jako wyjątkowe, jest w gruncie rzeczy dość typowe dla określonego rodzaju dyskursu. Przesunięcie charakterystyki wydarzeń w obrębie kategorii wyjątkowy/ typowy i wewnętrzny/zewnętrzny uwalnia oceniany obiekt od odpowiedzialności za dany stan rzeczy. Wskazuje bowiem na typowe uwarunkowania zewnętrzne, a odsuwa wyjątkowe uwarunkowania wewnętrzne (na takiej zasadzie, że 
konflikty w Sejmie nie wynikają z wyjątkowej kłótliwości obecnej partii rządzącej, ale są typowe w ogóle dla działalności politycznej). Widać zatem, że kreacja tła pozajęzykowego ma wpływ na bieżącą sytuację komunikacyjną. Ekspert, reinterpretując wydarzenia z tła pozajęzykowego, realizuje jednocześnie strategię obrony podmiotu spoza układu interakcyjnego.

Reakcja dziennikarza polega na działaniu przeciwnym: na wykreowaniu wydarzeń motywujących temat jako niezwykle emocjonujących, nieoczekiwanych, oburzających, świadczących o wyjątkowym nieporządku. Takie z kolei wykreowanie tła odpowiada celom dyskursu medialnego ze względu na dynamizm i emocjonalność.

MC: [...] w toku procesu nie byto takiej sytuacji, która mogtaby świadczyć o tak zwanej obstrukcji sądowej [...].

KD: Panie sędzio, to jeśli jest tak łagodny oglad sprawy, jak go pan w tej chwili przedstawia, to o co ta awantura? O co się denerwuje sędzia Kryże, prowadzacy to postępowanie? Po co się wprzęga $A B W w$ dostarczanie prostych kwitów, czyli $w$ rolę listonosza tak naprawdę, $w$ tym procesie? Po co to wszystko?

(3.03.2005, gość - MC: Marek Celej)

Prowadzący reaguje na strategię obrony twarzy rozmówcy. Nazywa jego działanie komunikacyjne „łagodnym oglądem sprawy”. Reinterpretuje tło pozajęzykowe, używając określeń takich jak „awantura”, „denerwować się”. Steruje odbiorem wydarzeń, sugerując, że są dziwne, nadzwyczajne, kontrowersyjne.

KD: Wracamy do relacji świata polityki $i$ świata mediów. Czy możemy się spodziewać, że ze świata polityki $i$ z Krajowej Rady będa ptynęty zalecenia dla dziennikarzy, jak powinni traktować swoje rzemiosto?

WK: O tym byta dzisiaj mowa cały czas. Takie zalecenia powinny ptynać przede wszystkim zdomu, prawda, natomiast//

KD: No tak, ale to już się umówiliśmy, że skoro o tym dyskutujemy, to w końcu jest to jakiś problem.

(8.02.2006; gość - WK: Witold Kołodziejski)

Dziennikarz wprowadza wątek, jakim jest instytucjonalny nadzór polityków nad mediami. Rozmówca reprezentujący instytucję nadzorującą uchyla się od odpowiedzi, stosując typową strategię uniku. Przesuwa mianowicie problem do sfery prywatnej (zalecenia powinny ptynać przede wszystkim $z$ domu), kładąc nacisk na uwarunkowania wewnętrzne (nabyte w toku wychowania standardy etyczne), a nie uwarunkowania zewnętrzne (nadzór instytucjonalny). Dziennikarz odczytuje te działania jako próbę wyparcia problemu i dlatego podejmuje odpowiednią strategię. Przechodząc na poziom metadyskursywny, wprost określa relacje jako jednak problematyczne ${ }^{76}$, czyli mogące budzić kon-

${ }^{76}$ Problematyczność rozumiemy jako cechę kreacji rzeczywistości, eksponującą jej niejednoznaczność, kontrowersyjność. Jest wynikiem możliwości wprowadzenia różnych wyjaśnień 
trowersje ( $w$ końcu jest to jakiś problem). Tym samym nie pozwala zamknąć wątku i wyciszyć głosów grupy uważającej się za grupę poddaną dominacji ${ }^{77}$. W kolejnych przykładach dziennikarz również broni prawa do podważania sądów, które inni rozmówcy określają jako oczywiste.

ZF: Cały czas próbuję w nieco innym kierunku rozmowę, debatę przesunąć. Otóż uważam, po zapoznaniu się z istotna częścia dokumentów zgromadzonych $w$ archiwum IPN-u, że należy je otworzyć, dlatego, że ludzie ci, którzy będa chcieli sobie to przeczytać zrozumieja, że SB byta organizacja przestępcza [...], każdy czytelnik moim zdaniem będzie miat jasność, że SB byta przestępcza//

KD: No wtaśnie, wie pan, tylko pytanie, czy na pewno będzie miat jasność, bo powiedzenie: „Jak jest dwóch Polaków, to sa trzy poglądy”/ Na fakty, które wydają się bezsporne, w Polsce patrzy się z czterech punktów widzenia.

(20.01.2005; gość - ZF: Zbigniew Fijak)

Proponent przedstawia swoje rozwiązanie jako niezawodny sposób uzyskania jasnej wiedzy na określony temat. Uznanie porcji wiedzy za oczywistość zamyka możliwość argumentacji. Wobec oczywistości nie potrzeba bowiem uzasadnień (Perelman 2004: 18). Przeciwko temu oponuje prowadzący. Broniąc prawa do podważenia quasi-oczywistości, broni jednocześnie prawa do dyskusji.

BS: Nie mamy szans nie tylko na kompromis, ale nawet na rozumienie się nawzajem, dopóki nie ustalimy znaczeń słów. Jeżeli jedna strona rozumie słowo „człowiek” inaczej niż druga, to mówimy w dwu różnych językach. Podobnie ze stowem „dziecko”, stowem „zabójstwo” i tak dalej. Nie warto! Spór się staje jałowy, czysto werbalny. Trzeba się umówić co do jakiegoś znaczenia tego stowa $i$ wtedy jest szansa na rozmowe $i$ kompromis jako jej efekt.

KD: No, tylko jak się umówić?

BS: Otóż, jak się umówić. Wydaje się rozsądna propozycja, aby przyjąć znaczenia słownikowo-encyklopedyczne, bo te są na ogót respektowane przez prawo. W myśl stowników i encyklopedii zapłodniona komórka jajowa to zygota, z której następnie rozwija się zarodek, z którego w trzecim miesiącu rozwija się płód ludzki, który staje się człowiekiem w momencie urodzenia. Dokładnie tak pisza stowniki i encyklopedie. [Dokładnie to znaczenie słowa „człowiek” przyjęto prawo, kiedy artykut kodeksu karnego, zaczynający się od stów: „Kto zabija człowieka...” nie jest przecież stosowany do aborcji.

PW: [Pani profesor, tu się nie zgadzam. Niech pani ciagnie dalej: noworodek, niemowlak, przedszkolak, osoba dorosta, człowiek stary.

KD: Już pani profesor widzi, że tu też nie ma zgody. Te [sic!] encyklopedyczne podejście też nie gwarantuje recepty, że będziemy mieli zgode.

(18.11.2004; goście - BS: Barbara Stanosz, PW: Paweł Wosicki)

i różnych ocen w odniesieniu do tych samych wydarzeń. W toku dyskusji każdy sąd, który zostaje podany w wątpliwość, traci status danej czy przesłanki i sam staje się tezą, która wymaga uzasadnienia. Według Tokarza, tego typu sytuacje zdarzają się w argumentacjach złożonych, w których „niektóre z użytych przesłanek same wymagają uzasadnienia” (Tokarz 2006: 138).

${ }^{77} \mathrm{~W}$ sumie przykład obrazuje dość typowe mechanizmy działające w relacjach nadrzędno-podrzędnych. Ilekroć grupa, określająca się jako podrzędna, wysuwa zastrzeżenia, a więc poddaje problem pod dyskusję, to grupa typowana jako nadrzędna stara się ten problem pominąć, wyprzeć do sfery prywatnej, a co najmniej zbagatelizować. 
Rozmówczyni, która występuje w roli eksperta, daje proste rozwiązanie kryzysu komunikacyjnego między stronami konfliktu. Wynika ono z podejścia racjonalnego, które zaleca przyjęcie oczywistych (ze względu na słownikowo-encyklopedyczne uprawomocnienie) założeń. Protest oponenta zostaje zręcznie wykorzystany przez dziennikarza jako dowód na nieoczywistość tego typu założeń (Już pani profesor widzi, że tu tė் nie ma zgody).

Problematyzowanie wydarzeń $\mathrm{z}$ tła pozajęzykowego jest uwarunkowane wymogami dyskursu. Stanowi element stymulowania dyskusji, ponieważ eksponuje różnicę stanowisk, poglądów. Podobną funkcję pełni taktyczne porządkowanie relacji między pojęciami ważnymi dla realizacji celów retorycznych. W przytoczonym powyżej przykładzie intencją rozmówczyni jest oddzielnie pojęć odnoszących się do człowieka przed urodzeniem i po urodzeniu. Oddzielenie to jest warunkiem zrealizowania celu komunikacyjnego proponentów. O istotności działania świadczy reakcja oponentów, którzy dążą do połączenia pojęć (niech pani ciagnie dalej). Reorganizacja konfiguracji pojęć jest ważnym etapem uzasadniania stanowisk, ale najczęściej ma charakter implicytny. Stąd ciekawy jest kolejny przykład, w którym rozmówcy wprost nazywają i negocjują ustanawiane relacje.

KD: Tak, tylko pytanie, czy to jest dobre dla państwa, że sa takie światy równoległe: $z$ jednej strony świat problemów, o których/ którymi powinien się zajmować rzad, którymi powinni sie zajmować politycy $i z$ drugiej strony gra, po to, żeby wytonić//

$\mathrm{BW}$ : Ale to nie sa równoległe. [One nie sa równolegte.

KD: [-w dtugich negocjacjach jakass większość, która będzie mogła te problemy wreszcie rozwiazzywać.

IK: Równolegte nie sa, bo sa catkowicie sprzeczne po prostu.

TŻ: Nie, nie, one nie sa ze soba sprzeczne.

IK: Albo realizujemy pewne dtugofalowe interesy społeczne, albo załatwiamy właśnie interesy partyjne. [...]

BW: Polityka ma być ta gra, ale po to, żeby mogła rozwiazywać realne problemy, to musi spetnić pare warunków. [Ktoś musi mieć wtadze.

(18.01.2006; goście - BW: Bronisław Wildstein, IK: Ireneusz Krzemiński,

TŻ: Tomasz Żukowski)

Arbitralność, a niekiedy i strategiczność ustanawiania relacji między pojęciami, widać w zderzeniu różnych stanowisk. Fragmenty rzeczywistości, do których odsyłają dwa wyrażenia argumentowe nieprzedmiotowe: „świat ludzkich problemów” i „gra polityczna”, są przez trzech rozmówców różnie porządkowane (czwarty rozmówca występuje tylko w roli oponenta). Dziennikarz odbiera to uporządkowanie jako równoległość, a właściwie rozbieżność (z jednej strony X, z drugiej strony Y). Kolejny rozmówca (IK) widzi relację jako alternatywę (nazwaną tu „sprzecznością”: Albo realizujemy pewne dtugofalowe interesy spoteczne, albo załatwiamy właśnie interesy partyjne). Ostatni rozmówca (BW) twierdzi, że między elementami rzeczywistości zachodzi implikacja (jeżeli politycy 
mają rozwiązywać problemy, to muszą mieć władzę; jeżeli chcą zdobyć władzę, to muszą prowadzić grę). Jak wynika z przytoczonego fragmentu, percepcja rzeczywistości pozajęzykowej ma charakter funkcjonalny. Dostrzegają to również uczestnicy „Debaty”.

BW: Ja tylko takie krótkie zdanie, bo zaraz ustapię głosu. Profesor Krzemiński mówi, że: „Wszyscy powtarzają to”. Ja styszę dokładnie coś innego! Ja nie wiem, żyjemy zdaje się w dwóch różnych krajach i czytamy różne gazety, [oglądamy różne programy//

KD: [No bo kazdy styszy to, co chce styszeć.

Diagnoza wydarzeń z tła pozajęzykowego jest podporządkowana realizacji celów pragmatycznych. Dziennikarz zmierza do wykreowania obrazu, który odpowiadałby wymogom dyskursu medialnego i realizował wymogi gatunkowe dyskusji. Politycy i eksperci dostosowują obraz wydarzeń do realizacji celów perswazyjnych. Sugestywne i przekonujące wykreowanie tła pozajęzykowego, a więc korzystna kategoryzacja i nominacja wydarzeń, stworzenie odpowiedniej konfiguracji pojęć, stanowi przygotowanie do kolejnego etapu interakcji w studiu, jakim jest wyjaśnienie.

Pytania ogólne, które inicjują ten etap to: dlaczego tak się dzieje, po co, czemu to ma służyć, kto za to odpowiada?

KD: No więc właśnie, panie profesorze, bo to jest trochę tak, że myślę, że zupetnie inny byłby ton tej dyskusji i pewnie byśmy tyle razy nie powtarzali słowa „nowa ordynacja wyborcza”, gdyby PO z PiS-em się dogadały i dzisiaj byta stabilna większość, która razem by - ilu posłów liczyła? Trochę ponad 300, prawda. I bytaby w stanie przeprowadzić wszystkie ustawy, które by sobie rzad wymyślit i wtedy byśmy nie rozmawiali o tej ordynacji wyborczej. Wiẹc pytanie: czy jednak instytucje i ordynacje, czy jednak ludzie? (18.01.2006)

KD: Jak się przyglądacie polskiemu wymiarowi sprawiedliwości, jak się przygladacie temu, jak dziata, co myśla o nim ludzie, że sześciu na dziesięciu Polaków mówi, że to w ogóle fatalne i że sądy działają okropnie, $i \dot{z}$ e tam wszystkiego można poszukać, $w$ tych polskich sądach, tylko nie sprawiedliwości, to co sobie myślicie? To kwestia przepisów, ludzi? (3.03.2005)

MC: [...] sa znane przypadki, ja z autopsji znam, że adwokat nie stawia się na salę sądowa, a $w$ pobliżu sądu $w$ kawiarence sobie siedzi spokojnie i pije kawę.

PK: No, to jest patologia.

MC: To jest patologia. Wtaśnie dla tej patologii chcieliśmy te przepisy tworzyć [...].

KD: Jak się będzie bat, to nie będzie pit kawy? Ludzie czy przepisy?

(3.03.2005; goście - MC: Marek Celej, PK: Piotr Kruszyński)

Dziennikarz nie inicjuje wyczerpujących analiz, ale upraszczając, ujmuje wyjaśnienie w schemat alternatywy: czy przyczyną stanu rzeczy są (wadliwe) rozwiązania systemowe, czy indywidualne cechy ludzi? W ten sposób stara się wybrać płaszczyznę odniesienia. Sfera publiczna bowiem to przede wszystkim sfera regulacji prawnych, instytucjonalnych, w odróżnieniu od sfery prywatnej, w której motywem działań są indywidualne cechy jednostek. 
Prowadzący dąży do wyjaśnienia obserwowalnych wydarzeń raczej jako przejawów funkcjonowania systemu instytucjonalnego, politycznego. Wykorzystuje więc relację zjawisko/przejaw zjawiska. W momencie, kiedy rozmówcom uda się przekonać odbiorcę medialnego, że taki, a nie inny przebieg wydarzeń wynika z jednostkowych cech ludzkich, dyskusja publiczna staje się nieefektywna, ponieważ nie prowadzi do usprawnienia systemu.

Jak wynika $\mathrm{z}$ analizy przebiegu interakcji sterowanej przez dziennikarza, etap wyjaśnienia w debacie publicznej stanowi ważne pole rywalizacji. Przeforsowanie korzystnego dla jednej ze stron wyjaśnienia wydarzeń może obciążać przeciwnika lub stanowić podstawę własnej strategii obrony. Tym skuteczniejszej, że mniej widocznej.

KD: Dobrze. Ale niech pani powie, dlaczego w takim razie $w \dot{z} y c i u$ publicznym jest więcej mężczyzn niż kobiet? To wynika z chẹci, czy z możliwości?

MB: No ja myślę, że to trochę wynika z chẹci, dlatego, że w prawie polskim nie ma, nie wiem, jakichś takich dyskryminacji.

(25.01.2006; gość - MB: Małgorzata Byzdra)

KD: I jest pani przekonana, że to jest tylko kwestia chẹci, a nie możliwości? [...] Ale myśli pani, [że kobieta] dlatego rezygnuje z części tej aktywności, bo nie ma ochoty się bić z jakaś masa. przepisów, które jej uniemożliwiają petnienie funkcji i jednej, i drugiej, czyli i matki opiekującej się dziećmi, $i$ aktywnej zawodowo kobiety, bo nie ma specjalnych ulg dla takich kobiet, bo sa traktowane w pracy tak samo. Myśli pani, że to dlatego?

AP-S: Panie redaktorze, to nie przepisy, tylko samo życie stawia ja w takiej roli.

(25.01.2006; gość - AP-S: Anna Pakuła-Sacharczuk)

Dziennikarz eksponuje wyjaśnienie systemowe zjawiska społecznego, jakim jest mały udział kobiet w życiu publicznym. Wskazanie na niewydolne prawo jest pośrednim zarzutem wobec decydentów, przedstawicieli władzy. Jej reprezentantki obecne w studiu nie dostrzegają dyskryminacji i wyjaśniają zjawisko brakiem chęci kobiet do udziału w życiu publicznym. Wypieranie problemu do sfery prywatnych decyzji jest elementem obrony twarzy tych rozmówców w studiu, którzy reprezentują władzę i od których można oczekiwać rozwiązań instytucjonalnych.

W tego typu działaniu można dostrzec przejawy techniki dysymulacji rzeczywistej natury, np. procesów społecznych. Polega ona na skupianiu „uwagi na działaniach i opiniach jednostek (to, co jest ogólne, systemowe, społeczne zostaje przedstawione jako prywatne, jednostkowe, oderwane od społecznego kontekstu)" (Lisowska-Magdziarz 2006: 94). Badacze dyskursu medialnego upatrują w dysymulacji przejawy uprzedzeń i stronniczości.

AC: Tak, owszem, no nie ma kobiet $w$ życiu publicznym [...].

$\mathrm{KD}$ : Ale wie pani, ja się zastanawiam, czy to jest kwestia chęci czy zapisania specjalnych praw? Czy to jest tak, że kobiety musza chcieć, czy to jest//

AC: Chęci są uzależnione także od wielu czynników.

(25.01.2006; gość - AC: Anna Czerwieńska) 
Alternatywa „odpowiedzialny jest system czy człowiek” okazuje się w istocie pozorna (Chęci są uzależnione także od wielu czynników). Uproszczenie wyjaśnienia przyczyn zjawisk społecznych jest jednak przydatne w strategiach interakcyjnych.

Podsumowując, organizacja problemowa programu jest osadzona w kontekście zadaniowym mediów, które kreują swój wizerunek jako podmiotu inicjującego debatę publiczną i sterującego nią. Przebieg prowadzonej przez dziennikarza interakcji, a zwłaszcza stosowane przez niego strategie strukturalne, wykazują cechy podobieństwa do scenariusza procesu opiniotwórczego i decyzyjnego w życiu publicznym. Podobieństwo jest zauważalne w powtarzalności etapów interakcji, takich jak: diagnoza, wyjaśnienie, ocena, sformułowanie problemu, propozycje rozwiązań, weryfikacja propozycji, prognozy, wybór rozwiązania. Etapy interakcji mogą stanowić podstawę ogólnych kategorii makrostrukturalnych tekstu w debacie publicznej. Jednocześnie tekst wykazuje uporządkowanie superstrukturalne typu problem/rozwiązanie. Na etapie diagnozy prowadzący negocjuje sens wydarzeń, o których jest mowa w programie, poprzez odniesienie do kontekstu społecznego, instytucjonalnego, politycznego. Kreacja tła pozajęzykowego jest podporządkowana uzasadnieniu podjęcia debaty (problematyzacja wydarzeń, podkreślanie kontrowersyjności, wyjątkowości, emocjonalności, różnicy stanowisk). W wyjaśnianiu zjawisk społecznych można dostrzec dwa aspekty: jednostkowy oraz systemowy. Upatrywanie przyczyn tych zjawisk jedynie w czynnikach indywidualnych i pomijanie uwarunkowań systemowych może być taktycznie wykorzystywane przez polityków w strategii obrony.

\subsubsection{Sygnały organizacji problemowej}

Plan działań komunikacyjnych ma charakter implicytny, ale może zostać ujawniony na skutek różnych bodźców. Mogą nimi być takie zmiany sytuacji, jak: podważenie zasadności lub racjonalności działań dziennikarza przez rozmówcę, wrażenie nieefektywnej komunikacji, chęć zamknięcia lub rozpoczęcia etapu interakcji. Wówczas nazywanie czynności komunikacyjnych, które stanowią realizację strategii strukturalnej nadawcy, może usprawnić przebieg interakcji.

Do sygnałów organizacji problemowej zaliczamy wyrażenia leksykalne przekazujące eksplicytną informację o podejmowaniu czynności komunikacyjnych. W przebiegu programów „Debata” pojawiają się w różnych jej fazach sygnały uporządkowania struktury według głównego schematu: problem/rozwiązanie. $\mathrm{W}$ ramach podkategorii (o czym była mowa w punkcie 6.3.5.1) sygnalizowane są etapy, takie jak: diagnoza, wyjaśnienie, postawienie problemu, propozycje rozwiązań, weryfikacja rozwiązań. Na każdym z tych etapów może pojawić się różnica zdań, która wymaga dodatkowych uzasadnień. Wówczas wypowiedzi są organizowane według schematu argumentacyjnego, w którym pojawiają się takie części, jak: teza, przesłanka (przesłanki), wniosek. 
Hierarchiczny schemat działań komunikacyjnych jest zatem sygnalizowany $\mathrm{w}$ tekście przez wyrażenia nazywające etapy organizacji problemowej: diagnoza, diagnozować, problem, rozwiązanie. Ogólna struktura argumentacyjna tekstu ujawnia się poprzez takie wyrażenia pełniące funkcję symptomów, jak: wniosek, teza, zastanowić się, dyskusja, dyskutować, kompromis, sugestia, stanowisko, poglad, punkt widzenia, powód, ustalić, optować, przekonać. Zarówno sygnały organizacji problemowej, jak i symptomy struktury argumentacyjnej są najczęściej elementami strategii metadyskursywnych prowadzącego.

KD: Ja mam jeszcze jedno pytanie a propos tego procesu. Czy panowie nie uważaja, że sędzia Kryże trochę jest sam sobie winien? [...]

MS: Myślę, że to jest zły trop. [...]

KD: Tak, panie profesorze, ale diagnoza pozwala uniknać błędu.

(3.03.2005; gość - MS: Marek Safian)

Dziennikarz stara się uzyskać odpowiedź na pytanie, kto jest odpowiedzialny za zaistniały stan rzeczy. Podważenie racjonalności działania dziennikarza (Myślę, że to jest zły trop) powoduje jego przejście na poziom metadyskursywny. Prowadzący ujawnia globalny cel aktualnie realizowanej strategii komunikacyjnej, jakim jest diagnoza.

KD: No dobrze, to caty czas diagnozujemy, diagnozujemy. A co można zrobić w takiej sytuacjį? AP-S: Trzeba wspierać rodzinę [...].

(25.01.2006; gość - AP-S: Anna Pakuła-Sacharczuk)

Dziennikarz zamieszcza bardzo cenną wskazówkę orientacji w dyskursie, a mianowicie nazywa czynności komunikacyjne (i etap przez nie wypełniony), które poprzedzają etap postawienia oraz rozwiązania problemu. Określa je jako diagnozowanie. bym $/ /$

KD: Ale może też sporo powinno zależeć nie tylko od matżonków, ale od państwa, bo chciat-

IJ-N: Bo państwo musi stworzyć takie warunki.

KD: -chciałbym, żebyśmy się zastanowili, czy tu jest jakieś wspólne myślenie, czy nie, bo pani Magdalena Środa odchodząc z urzędu powiedziała tak: „Myślenie PiS-u jest takie: powrót do tradycyjnej roli kobiet, zakaz antykoncepcji, rygoryzacja zakazu aborcji - jednym słowem zmuszanie kobiet do rodzenia dzieci. To jest chore. Ile rodzin stać dzisiaj na to, żeby tylko jedna osoba mogta pracować? Ile kobiet da się zamknać $w$ domach $z$ wiara, że do końca życia będa utrzymywane przez męża?” Pani profesor, to jest dobra diagnoza?

ES: Nie. Absolutnie nie.

(25.01.2006; goście - ES: Ewa Sowińska, IJ-N: Izabela Jaruga-Nowacka)

Dziennikarz rozwija temat w taki sposób, aby marginalizować wątki ze sfery prywatnej (indywidualne decyzje małżonków) i eksponować wątki ze sfery 
publicznej (rola państwa w regulacjach prawnych chroniących kobietę). Chociaż deklaratywnie postuluje poszukiwanie kompromisu, to przytacza kontrowersyjny, krytyczny cytat, który zaostrza antagonizmy. Jest to prowokacja wobec polityków partii rządzącej, która stawia ich w sytuacji zagrożenia twarzy. Przytoczony głos w debacie publicznej dziennikarz określa jako diagnozę. Powstaje ona w rezultacie odpowiedzi na pytania: co się dzieje (Myślenie PiS-u jest takie), co się z tym wiąże (zmuszanie kobiet do rodzenia dzieci), kto ponosi straty (kobieta zamknięta w domu, utrzymywana przez męża).

JK: [...] Otóż instytucja, w której się znajdujemy, TVP, przez prawie siedem lat za prezesa miała szefa sztabu wyborczego Aleksandra Kwaśniewskiego, pana Kwiatkowskiego. Jak by się pan czut, gdybym ja, jeden z szefów sztabu wyborczego PiS, zostat prezesem telewizji. No przecież bytby krzyk niesamowity.

KD: Ale panie pośle, ale ja powiem tylko tak, że naprawdę niech pan nie próbuje mnie przekonać, że to, że politycy stoja na czele mediów publicznych, to jest dobra sytuacja. To szkoda pańskiego czasu, to jest zła sytuacja.

JK: No dobrze, ale pan na temat diagnozy tej sytuacji sie nie zajaknat do tej pory!

(8.02.2006; gość - JK: Jacek Kurski)

W debacie o mediach pada zarzut braku przypomnienia i odpowiedniego rozpoznania określonych wydarzeń jako istotnych elementów kontekstu. Takie przywoływanie znaczących wydarzeń wraz z określeniem, co się z nimi wiąże i co z tego wynika dla obecnej sytuacji, zostaje przez rozmówcę nazwane diagnozą. Widać zatem, że etap debaty wyodrębniony jako diagnoza sytuacji (w sensie tworzących ją wydarzeń tła pozajęzykowego) jest dla rozmówców gwarantem realizacji celów komunikacyjnych, oczekiwanym etapem przeprowadzenia strategii komunikacyjnych.

Z diagnozą łączy się postawienie problemu, który może się odnosić do rzeczywistości pozajęzykowej (na płaszczyźnie społecznej, instytucjonalnej, politycznej) lub rzeczywistości dyskursywnej (np. problemem może być nieefektywna z różnych powodów komunikacja).

KD: Za rząów SLD byt petnomocnik do spraw równego statusu kobiet i mężczyzn, za rzadów PiS jest petnomocnik do spraw kobiety i rodziny. Czy pozycja kobiety w życiu publicznym to jest problem polityczny? Pani poset?

AP-S: W pewnym sensie tak [...].

(25.01.2006; gość - AP-S: Anna Pakuła-Sacharczuk)

Dziennikarz przypomina fakty z życia politycznego (różne nazwy dla jednego w gruncie rzeczy urzędu), po czym stawia sugestywne pytanie, czy z tych faktów wynika określony wniosek. Taki mianowicie, że istnieje problem, który określa się jako „problem pozycji kobiety w życiu publicznym” i jest on rozpatrywany w kontekście politycznym, a nie np. społecznym. Wiedza na temat dyskursu politycznego każe odczytywać interakcyjny sens pytania dziennikarza jako zarzut, gdyż kontekst polityczny implikuje instrumentalizację tematów, 
wykorzystywanie ich do rywalizacji politycznej ${ }^{78}$. Dziennikarz sygnalizuje więc etap dyskursu, którego celem jest wyartykułowanie problemu. Prowadzący, organizując przepływ informacji za pomocą globalnych pytań: „co się wydarzyło?” i „co z tego wynika?”, stawia diagnozę dotyczącą politycznej instrumentalizacji tematów społecznych i wyłaniający się na jej tle problem.

MK: Ale tak jak mówiliśmy, my sie musimy zastanowić, co zrobić, żeby ułatwić tej kobiecie powrót do pracy.

KD: Pani poset, czy pani sobie wyobraża takie rozwiazanie, że u nas obojgu rodzicom przystuguje urlop macie/ No właśnie. Jak to teraz nazwać? Tacierzyński?

IJ-N: Tacierzyński. Rodzicielski.

AP-S: Proszę państwa, ja nie widzę w tym jakiegoś wielkiego problemu [...].

(25.01.2006; goście - AP-S: Anna Pakuła-Sacharczuk, IJ-N: Izabela Jaruga-Nowacka, MK: Maciej Koper)

Gość przypomina cel bieżącej interakcji, jakim jest szukanie rozwiązań kwestii społecznej (my się musimy zastanowić, co zrobić). Dziennikarz podaje przykładowe rozwiązanie i sonduje polityka partii rządzącej, czy je popiera, co powinno stanowić istotną wskazówkę dla wyborców. Zadaniem mediów jest bowiem dostarczanie informacji, które stanowią podstawę racjonalnego wyboru demokratycznego ${ }^{79}$. Przy okazji wynika problem natury nazewniczej, który wiąże się z przełamywaniem stereotypów społecznych (urlop macierzyński czy tacierzyński, ogólnie: rodzicielski).

LS: [...] w ustawodawstwie światowym sa trzy rozwiazania. Pierwszy, bardzo mocny zakaz [...] zbliżmy się może do Europy. Od kilku lat w Szwecji oraz od 2003 roku we Francji, gdzie karany jest klient/ idea polegała na tym, żeby zlikwidować kasę/ żeby zlikwidować sutenerstwo za pomoca kasy, czyli za pomoca walki z klientem. Karany jest klient, nawet więzieniem, a co najmniej bardzo wysokimi mandatami. Ja nie jestem entuzjastka tego rozwiazania.

KD: No więc właśnie, bo może my się poruszamy w zupetnie złym obszarze. Może my się zastanawiamy, czy karać za prostytucję czy nie, a może po prostu należałoby egzekwować stan prawny, który dziś w Polsce obowiąuje.

(13.01.2005; gość - LS: Liliana Sonik)

Dziennikarz, przechodząc na poziom metadyskursu, negocjuje zmianę wątku dyskusji (czy karać za prostytucję) z powodu jego niefunkcjonalności w kontekście prawno-karnym (my się poruszamy w zupetnie złym obszarze). Tu ujawnia się

${ }^{78} \mathrm{Z}$ analizy debat wynika, że istnieje przekonanie, iż ważne kwestie społeczne (np. walka z dyskryminacją, z patologiami) powinny być przedmiotem komunikowania publicznego, którego celem jest realizacja interesu społecznego. Dominuje pogląd, podtrzymywany przez media, że politycy wykorzystują tematy społeczne do rywalizacji, kreowania wizerunku, a więc dochodzi do ich instrumentalizowania.

${ }^{79}$ Według Mrozowskiego, uczestnictwo w życiu publicznym tylko wtedy służy budowie demokratycznego ustroju, gdy jednostki kierują się racjonalnymi przesłankami, a nie emocjami, i gdy dokonują rozumnych wyborów. To zaś wymaga wiedzy o zasadach i działaniu demokratycznego ustroju oraz ciągłego informowania o sprawach publicznych (Mrozowski 2001: 124). 
ważna cecha organizacji tematycznej debat dotyczących spraw publicznych. Otóż kierunek rozwoju linii tematycznej jest wyraźnie podporządkowany zadaniom w sferze publicznej. Na etapie szukania rozwiązań (na który może wskazywać wyrażenie zastanawiać się) dziennikarz na krótko dopuszcza wątki ciekawe, sensacyjne, a więc uzasadnione medialnie, o funkcji ludycznej, ale ostatecznie określa je jako mało istotne dla regulacji społecznych. Jak widać (w ramach kolejnych etapów), rozwój linii tematycznej nie przebiega równomiernie ku rozwiązaniu, ale jest pełen niefunkcjonalnych wątków, niefortunnych zachowań.

Wobec wyczerpania repertuaru form interakcji rywalizacyjnej, jej dalszej nieefektywności, dziennikarz dokonuje diagnozy poziomu samego dyskursu i stymuluje poszukiwanie rozwiązania problemu komunikacyjnego.

KD: Proszę państwa, czy to jest dyskusja „zero : jeden”, czy to jest dyskusja/ czy jest przestrzeń do debaty na ten temat? Czy to sa jasno zarysowane stanowiska: tak albo nie, czy też możemy na ten temat dyskutować i coś z tej dyskusji może wynikać?

DK: Znaczy, ja wierzę, że istnieje obszar do wspótdziałania.

(24.02.2005; gość - DK: Dariusz Karłowicz)

W określonym momencie rozwoju debaty dziennikarz zawiesza rozmowę przedmiotową, aby dokonać refleksji metadyskursywnej. Prowadzący wyraźnie przeciwstawia dwie sytuacje komunikacyjne związane z postawą rozmówców. Sytuacja dotychczasowa polegała na tym, że są zdecydowane stanowiska (dyskusja „zero : jeden”) i wówczas można je jedynie zaprezentować. Sytuacja pożądana wiąże się z „odsztywnieniem” stanowisk, które dopiero stwarza przestrzeń do negocjacji. Jest to niezwykle cenna uwaga generyczna, ujmująca korelację między postawą rozmówców a efektem rozmowy. Znamienne jest również utożsamienie przez rozmówcę dyskusji kooperacyjnej ze współdziałaniem (wierzę, $\dot{z}$ e istnieje obszar do wspótdziatania).

KD: No dobrze, panowie, ale może zamiast przerzucać sie przyktadami, casusami, nazwiskami, argumentami, można się zastanowić/ pytanie: czy można się zastanowić nad tym, jak taki model wspótpracy, żeby tego typu historie [konflikty między politykami i mediami] były jednak zdecydowanie incydentalne, wybudować. (8.02.2006)

Podobnie jak w poprzednim przykładzie, dziennikarz zaznacza moment w rozwoju interakcji, w którym planuje jakościową zmianę. Dotychczasową interakcję określa jako przerzucanie się przykładami, argumentami, co wskazuje na rywalizacyjną odmianę dyskusji. Tego typu działania zostają uznane za mniej funkcjonalne niż postulowany segment, w którym rywalizację ma zastąpić kooperacja w celu wypracowania modelu współpracy. Tak więc organizowanie przebiegu interakcji przez prowadzącego jest podporządkowane (przynajmniej deklaratywnie) celom komunikacji publicznej, takim jak wypracowanie porozumienia, osiągnięcie kompromisu. Swiadczą o tym kolejne przykłady. 
KD: Dobrze. Panowie, czy jest miejsce między tym pogladem prezentowanym przez pana: publikujemy, otwarte archiwa, a panów punktem widzenia? Czy zmiana dzisiejszych przepisów, rozszerzenie na przykład uprawnień IPN-u, rozszerzenie kategorii osób, które moga do tego zagladać. Czy to jest wyjście?

KK: Ale na jakie grupy społeczne? To ustalmy w takim razie.

(20.01.2005; gość - KK: Krzysztof Kozłowski)

KD: Miejsce na kompromis? [wskazuje rozmówcę]

CB: Otóż to. Miejsce na kompromis jest, pod warunkiem, że odpowiemy sobie na dwa pytania: czy chcemy prawdy, prawdy o sobie, lepszej, gorszej, gorzkiej. I drugim pytaniem, to jest pytaniem technicznym [jest]: jak do tego dojść.

(20.01.2005; gość - CB: Czesław Bielecki)

BCh: [...] Pani stawia tutaj wyraźnie tezę, że zarodek nie jest człowiekiem. I jeśli tak, to ja pania rozumiem, że pani się burzy na głos ze strony drugiej, w której pani zarzucaja ludobójstwo, ale niech pani zrozumie, że jeśli na tej drugiej stronie wyraźnie się stwierdza, że ja już mam do czynienia z człowiekiem, to wtedy dla mnie w tym miejscu, proszę pania, ja nie mam wyjścia. To jest wykluczone!

KD: Proszę siostry, tylko jeśli poszukujemy miejsca, w którym możemy znaleźć ten kompromis, o którym rozmawialiśmy, to ja mam takie nieodparte wrażenie, że to nie jest to miejsce, że tutaj podziat jest tak wyraźny na tych, którzy mówia, że to jest człowiek i na tych, którzy mówia, że to absolutnie nie jest człowiek, że tu sie tego kompromisu nie znajdzie. Pytanie, gdzie go można znaleźć?

(18.11.2004; gość - BCh: Barbara Chyrowicz)

KD: [...] Jeśli jest taki podziat, on się raz wyraża w większych emocjach, raz w mniejszych emocjach - to co należy zrobić, żeby pomiędzy tymi skrajnymi zupetnie i niedopuszczajacymi żadnych argumentów postawami, gdzieś w środku, znalazła się przestrzeń, po pierwsze, do spokojnej dyskusji na ten temat, a po drugie, co mi się wydaje istotniejsze, do historii, której można uczyć młodzieży, tych mtodych ludzi, którzy w tej chwili uczą się o stanie wojennym w szkołach?

(16.12.2004)

Szczególnie ważna dla edukacyjnej misji mediów jest diagnoza dziennikarza dotycząca przebiegu samej debaty publicznej (a nie tylko znaczenia wydarzeń stanowiących tło pozajęzykowe). Zastosowanie strategii metadyskursywnych jest szansą na wyjście z kryzysu komunikacyjnego. Propozycje dziennikarza mają charakter taktyczny. Są to: uelastycznienie stanowiska, zawężenie sporu, wyciszenie emocji, zastąpienie rywalizacji kooperacją, poszukiwanie wspólnych punktów odniesienia, uznanie pewnych kwestii spornych za nierozstrzygalne i odwołanie się do innych wartości, zmiana kontekstu dyskusji w trosce o jej funkcjonalność.

Sterowanie przez dziennikarza rozwojem linii tematycznej, które wchodzi w zakres globalnych strategii strukturalnych, zmierza do zintegrowania kolejnych części tekstu. Jest to możliwe dzięki wskazywaniu na relacje między pojęciami odsyłającymi do zjawisk w rzeczywistości pozajęzykowej (referencja). Świadczą o tym poniższe fragmenty. 
AC: Kobiety, które robia karierę $w$ polityce, ciagle jest pan $w$ stanie wymienić $z$ nazwiska. No nie jest pan $w$ stanie wymienić $z$ nazwiska wszystkich mężczyzn polityków, wszystkich mężczyzn $w$ parlamencie. Tymczasem z kobietami nie sprawi to większego kłopotu, bo jest to 20 procent.

$\mathrm{KD}:$ Na co to jest dowód, że kobiety są dyskryminowane?

AC: Tak, owszem, no nie ma kobiet $w$ życiu publicznym.

(25.01.2006; gość - AC: Anna Czerwińska)

$\mathrm{Z}$ uwagi na uwarunkowania gatunkowe interakcji, dziennikarz podejmuje działania zmierzające do uwyraźnienia struktury argumentacyjnej dyskusji ( $\mathrm{Na}$ co to jest dowód). Rozmówcy podejmują działania komunikacyjne intencjonalnie, ale ze względu na odbiorcę masowego nazwanie tych intencji wprost zwiększa efektywność odbioru.

KD: Z prostytucją się przez cate wieki walczy i ta walka jest średnio skuteczna. Czy fakt, że nadal istnieje, penalizowana czy nie, karana przez prawo czy nie, jest dostatecznym powodem. żeby dzisiaj zastanawiać sie $i$ optować czy za legalizacja prostytucji/ i za legalizacja dochodów $z$ prostytucji?

MF: Nie, nie jest to dostateczny powód.

(13.01.2005; gość - MF: Marian Filar)

Prowadzący sygnalizuje jako możliwą (możliwość ma być tematem dyskusji) relację przyczynowo-skutkową między zjawiskami zdiagnozowanymi: postawieniem problemu a podjęciem czynności komunikacyjnych $\mathrm{w}$ celu poszukiwania rozwiązania. Dokonuje więc płynnego przejścia między rzeczywistością pozajęzykową (obserwacje, fakty) a rzeczywistością dyskursu (zastanawianie się, optowanie). Pokazuje to, w jaki sposób rzeczywistość ta jest kontekstualizowana i włączana do tekstu jako motywująca podjęcie danego tematu.

KD: Panie profesorze, czy Polacy uważaja, że kontakty z prostytutkami/ za coś niemoralnego?

ZI: Polacy coraz liberalniej podchodza do korzystania z ustug zwiazanych z seksbiznesem $i$ obserwujemy także, że $w$ ostatnich latach $w$ Polsce wzrasta liczba osób korzystajacych $z$ prostytutek. $Z$ badań wynika, że $w$ ostatnim okresie $w$ Polsce korzysta ponad 12 procent mężczyzn $z$ ustug prostytutek.

KD: A czy w takim razie jest jakaś sugestia ze strony/ czy ptynie jakiś wniosek z pańskich badań, sugestia co do tego, jak rozwiazywać w Polsce problem prostytucji: legalizować czy wręcz przeciwnie?

(13.01.2005; gość - ZI: Zbigniew Izdebski)

Dziennikarz włącza wypowiedź eksperta do struktury tekstu z uwzględnieniem gatunkowych wymogów dyskusji, która jest zogniskowana wokół głównego problemu. Napływające dane, ekspertyzy pozycjonuje jako argumenty za lub przeciw określonemu rozwiązaniu. Podobne działania obserwujemy w kolejnym przykładzie.

AN: [...] Tylko w jednej warszawskiej poradni ja mam rocznie 5,5 tysiaca porad. Jestem również pracownikiem służb więziennych i pracuję na tym właśnie oddziale jedynym dla mężczyzn 
w Warszawie, gdzie jest 36 miejsc dla mężczyzn na Warszawę. Jeśli chodzi o ilości sprzedawanych narkotyków, również mam przykład udokumentowany na taśmie filmowej. Robitem materiat filmowy, jeśli chodzi o dostępność narkotyków syntetycznych, o których tu rzadziej się mówito. Wcześniej mówiło się o marihuanie: „W coffee shopach już palmy wszyscy. Tak będzie najlepiej”. W jednej z warszawskich dyskotek po rozmowie z osoba, która wprowadza kilku swoich dilerów $w$ rynek tej dyskoteki, na imprezie z soboty na niedziele schodzi 5 tysięcy tabletek ekstazy, gdzie tabletka ekstazy w hurcie kosztuje trzy i pót złotego. Ja myślę, że tego typu dane ważne sa dla ludzi, żebyśmy się nie przepychali z młodymi tutaj, że oni mają rację.

KD: Myśli pan, że tak ogromna skala tego zjawiska plus rozmaite inne narkotyki - te, o których tutaj rozmawialiśmy, $i$ te, o których nie rozmawialiśmy - to jest powód, dla którego należatoby, nie wiem, nie zastanawiać sie nad zmiana tego prawa? Albo zastanawiać się, ale w która stronę?

(10.02.2005; gość - AN: Adam Nyk)

Dziennikarz stara się nadać wątkom poruszonym w wypowiedziach rozmówców określoną funkcję w strukturze debaty. Dane statystyczne, obserwacje, badania naukowe nie stanowią tylko opisu ${ }^{80}$, ale powinny zostać zinterpretowane jako przesłanki na rzecz wprowadzenia bądź zaniechania określonych regulacji prawnych. Rozumowanie przyjmuje strukturę argumentacyjną, w której dla uzasadnienia jakiejś tezy $C$ należy się powołać na rozmaite fakty czy też dane (D).

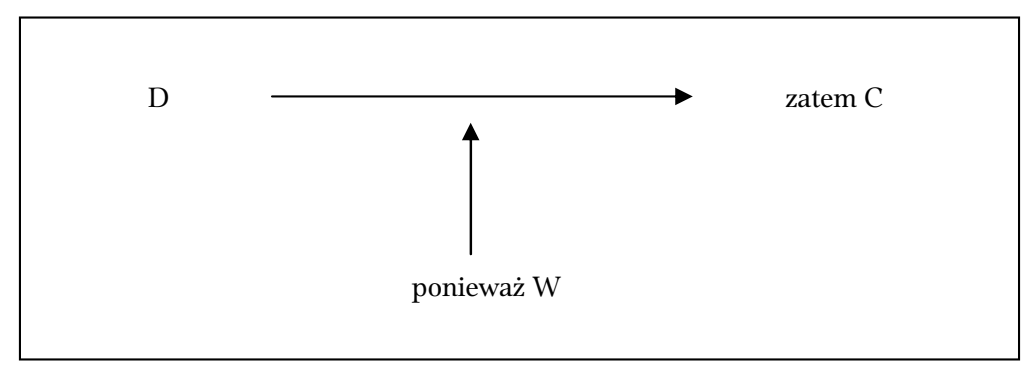

Rys. 13. Struktura argumentacji (Toulmin 1958, za: Tokarz 2006: 132)

Wymowa danych, a więc i włączenie ich w proces wnioskowania, nie są bynajmniej jednoznaczne ani oczywiste. Potrzebne są prawa ogólne (W), czyli przesłanki ogólne, które uprawomocnią przejście od faktów, danych (D), czyli przesłanek szczegółowych, do wniosku. Przesłanek ogólnych, które mają postać sądów normatywnych, dostarcza jakiś zewnętrzny system odniesienia, którego wybór zależy od rozmówców, np. wiedza zdroworozsądkowa, nauka, religia, ideologia. Poniżej zanalizowano ostatni przykład pod kątem dwóch przeciwnych, ale możliwych kierunków argumentacji, aby wykazać konstrukcyjność argumentu.

${ }^{80}$ Dane i obserwacje dotyczące zjawisk społecznych mogłyby zyskać inny sens, kiedy zostałyby wkomponowane w inne gatunki mowy niż dyskusja, np. narzekanie (tu: z intencją dyskredytacji młodzieży, jako dowód na nieskuteczność władzy itd.). 
[możliwość pierwsza] Przesłanka szczegółowa: „ogromna jest skala zjawiska narkomanii” + możliwa przesłanka ogólna: „Jeśli coś jest powszechne, to nie ma sensu z tym walczyć” - wniosek: prawo należy liberalizować;

[możliwość druga] Przesłanka szczegółowa: „ogromna jest skala zjawiska narkomanii” + przesłanka ogólna: „Jeśli patologiczne zjawiska społeczne się nasilają, to należy je zwalczać jeszcze bardziej restrykcyjnie” - wniosek: należy utrzymać maksymalnie restrykcyjne prawo.

Kreowanie sytuacji w studiu według modelu debaty/dyskusji skłania dziennikarza nie tylko do przedstawiania opinii rozmówców jako argumentów na rzecz określonych tez, ale również do traktowania sądów, stwierdzeń jako tez.

MR: No to kto ma wtadzę?

BW: W tej chwili nikt do końca wtadzy nie ma i to jest trudna sytuacja.

IK: To jest bardzo ryzykowna teza.

(18.01.2006; goście - BW: Bronisław Wildstein, IK: Ireneusz Krzemiński,

MR: Mieczysław Rakowski)

Dziennikarz, komentując wypowiedzi rozmówców, nadaje im status zgodny z gatunkowymi wymogami debaty/dyskusji. Sądy, które rozmówcy przedstawiają jako stwierdzenia, fakty ${ }^{81}$, dziennikarz włącza do struktury debaty (jednak) jako tezy, a więc sądy nieoczywiste, co najmniej subiektywne, wymagające uzasadnienia lub też podlegające obaleniu.

TŻ: Natomiast ja chciałem państwu zwrócić uwage, że przecież, po pierwsze, mówimy o formie, a mówimy, że treści nie ma. No, treść jest, tylko tak się składa, że komentując czy debatując i media, i czesść komentatorów przynajmniej i czesść polityków koncentruje się na formie, a nie na

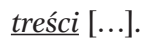

KD: Ryzykowna teze pan snuje, panie doktorze, że media wykoślawiają rzeczywistość [...].

BW: Panie redaktorze, ale ja jako pracownik mediów zauważam, że w Polsce te media rzeczywiście wykoślawiaja rzeczywistość. Nie tylko w Polsce, ale w tej chwili w Polsce mam wrażenie, że te media dość mocno tą rzeczywistość wykoślawiaja.

(18.01.2006; goście - BW: Bronisław Wildstein, TŻ: Tomasz Żukowski)

Uznanie treści wypowiedzi rozmówców za tezy zaprasza niejako do dyskusji, do ich uzasadnienia. Nie pozwala uznać sądów za oczywiste, przez co otwiera pole do negocjacji. W powyższym przykładzie rozmówca podjął strategię informacyjno-weryfikacyjną w celu wynegocjowania stopnia prawdziwości

${ }^{81}$ Nadawca, mówiąc o zdarzeniach rzeczywistych, np. W tej chwili nikt do końca władzy nie ma, nadaje wypowiedzi określoną modalność. Na poziomie logicznym jest to modalność asertoryczna, która orzeka o faktyczności istnienia czegoś. Na poziomie epistemicznym można ją zwerbalizować w postaci hiperzdania modalnego „Ja sądzę, że...”. „Modus” tkwi zawsze w warstwie głębokiej, nawet kiedy nie został wyrażony wprost (Bartmiński, Niebrzegowska-Bartmińska 2009: 172). 
informacji (media wykoślawiaja rzeczywistość). Zanim to jednak nastąpiło, dziennikarz dokonał swoistej parafrazy wypowiedzi eksperta w celu „przykrojenia jej” do upraszczającego schematu poznawczego. Stwierdzenie, że media koncentrują się na formie, a nie na treści, zostało prawdopodobnie uznane przez prowadzącego za mało wyraziste, zbyt abstrakcyjne dla odbiorcy medialnego, stąd posłużenie się metaforą poznawczą (media to zwierciadło rzeczywistości ${ }^{82}$ ).

KD: A nie maja panowie wrażenia, że jednak zawinity ambicje, które w polskiej politycel ja nie wiem, czy $w$ polskiej, $w$ polityce $w$ każdym razie na pewno, odgrywaja nieprawdopodobna zupetnie rolę ostatnio. Czasami mam takie wrażenie, że to, czy ktoś kogoś lubi czy nie, odgrywato tu większa rolę niż powinno.

TŻ: To jest ważne. Można powiedzieć, że historia/ tak niektórzy mówia, że stosunki Ukrainy $i$ Rosji wyglądatyby inaczej, gdyby nie osobiste stosunki między przywódcami.

KD: To jest ryzykowna teza. O wiele silniej ryzykowna niż ta, która ja tu przed chwila artykutowatem.

(18.01.2006; gość - TŻ: Tomasz Żukowski)

Dziennikarz, zmierzając do wyjaśnienia przyczyny zjawisk dotyczących sfery instytucjonalnej, w tym politycznej, najpierw ustala, czy problem wyłoniony w wyniku diagnozy jest spowodowany przez czynnik ludzki czy systemowy. W rozpatrywanej sytuacji dziennikarz wybiera pierwsze wyjaśnienie (zawinity ambicje). Rozmówca stosuje strategię kooperacyjną: potwierdza i rozwija wątek prowadzącego. Dodaje argument z przykładu na potwierdzenie tezy. Działanie, które w tym momencie podejmuje dziennikarz, jest niezrozumiałe z perspektywy spójności semantyczno-tematycznej, ale tłumaczy się realizacją celów w makrosytuacji. Prowadzący nie zważając na to, że rozmówca argumentuje zgodnie z nim, sam zaznacza dystans i odrębność zdania (To jest ryzykowna teza. O wiele silniej ryzykowna niż ta, która ja tu przed chwila artykułowałem). Można to tłumaczyć kreowaniem bieżącej sytuacji komunikacyjnej jako ciągłego kontrastowania, przeciwstawiania stanowisk, problematyzowania stwierdzeń, a nawet dramatyzowania (ryzykowna teza), jak widać, czasem bez uzasadnienia i nieco sztucznie. Jest to kolejny przejaw teatralizacji debat, w których dynamika interakcji jest podporządkowana uwarunkowaniom makrosytuacyjnym.

KD: Ale z drugiej strony te ż zastanawiam się/ bo to jest jednak tak, że te procesy, powoli, to zgoda, ale jednak się tocza, wykorzystując drogę prawna, sa uchylane, kolejne wyroki, sprawa wraca i tak dalej, i tak dalej. W tej chwili też się zreszta toczy. Czy to jednak nie jest tak, że my żyjemy w państwie prawa, tyle tylko, że wykorzystywanie wszystkich jego instrumentów prawnych powoduje, że to tak dtugo trwa?

82 Jedna z popularnych metafor przedstawia media masowe jako zwierciadło, w którym odbija się rzeczywistość. „Gołym okiem wszakże widać, że obraz świata w mediach nie jest tego świata lustrzanym odbiciem, gdyż wiele w nim rozmaitych deformacji, w najlepszym więc razie jest to krzywe zwierciadło” (Mrozowski 2001: 303). 
$\mathrm{SN}$ : Kwestia dyskusji, no, spór o definicję państwa prawa. Ale ostatecznie jaki ma sens w ogóle proces, który trwa 14 lat [...]. No mnie nie satysfakcjonuje ta argumentacja, dlatego, że ja mam prawo oczekiwać, że to będzie wszystko szybciej.

(3.03.2005; gość - SN: Stefan Niesiołowski)

Dziennikarz wprowadza swoją diagnozę i wyjaśnienie jako jedną z perspektyw, opinii, o czym świadczy symptomatyczne wyrażenie (Ale $z$ drugiej strony). Rozmówca nakłada na część tematyczną wypowiedzi dziennikarza (w państwie prawa) status tezy do uzasadnienia (spór o definicję państwa prawa). Sygnalizuje w ten sposób swoje prawo do podważenia którejkolwiek danej lub przesłanki w wywodzie adwersarza. Kolejnym wskaźnikiem organizacji problemowej jest nazwanie działań komunikacyjnych „argumentacją”.

Uczestnicy medialnego programu publicystycznego sygnalizują problemowy charakter wprowadzanych treści, co stanowi ważny sygnał gatunkowy interakcji. W tym zakresie wyraźna jest rola dziennikarza. Strategie metadyskursywne służą prezentowaniu fragmentów wypowiedzi jako przesłanek na rzecz określonej tezy. Widoczne jest również podważanie stwierdzeń, co nadaje im status tezy do uzasadnienia i tym samym stymuluje argumentację będącą istotą dyskusji. Samo bowiem pojawienie się drugiej wersji, perspektywy, powoduje nieoczywistość tej pierwszej. „Twierdzenie oraz prezentacja, które na pierwszy rzut oka wydają się obiektywne i bezstronne, ujawniają swój charakter umyślnie lub nieumyślnie tendencyjny, kiedy zestawimy je z danymi, które im przeczą. Pluralizm wyostrza zmysł krytyczny. To właśnie dzięki ciągłemu oddziaływaniu opinii innych osób możemy najlepiej, aż do nastania nowego porządku, odróżnić subiektywne od obiektywnego" (Perelman 2004: 48).

\subsubsection{Stopień realizacji schematu organizacji problemowej}

Analiza zachowań komunikacyjnych dziennikarza i rozmówców pod kątem organizacji problemowej wskazuje na znaczącą rolę kontekstu zadaniowego $\mathrm{w}$ integracji tekstu jako zwartej, całościowej i sensownej struktury ${ }^{83}$. Kolejne etapy realizacji celów komunikacyjnych (skorelowanych z celami pozajęzykowymi), do których należą: diagnoza wydarzeń, wyjaśnienie, ocena, postawienie problemu, negocjowanie rozwiązań, wybór rozwiązania, tworzą schemat organizacji interakcji zaplanowany przez nadawcę medialnego.

Ten globalny zamysł organizacyjny cechuje się różnym stopniem ujawnienia w tekście. Oznacza to, że poszczególne cykliczne programy, mające

83 Stanisław Gajda wskazuje na trzy podstawowe pojęcia odnoszące się do spójności tekstu: zwartość, całościowość i sensowność. Sensowność, tj. obecność w tekście jednej koncepcji semantycznej, wychodzi poza ścisłą analizę treściową i uruchamia szeroko rozumiany kontekst. Sens tekstu „jest kształtowany przez konfigurację relacji między różnymi bliższymi i dalszymi czynnikami sytuacji aktu mowy a tekstem, stąd ma komunikatywno-pragmatyczny status” (Gajda 1982: 127). 
wspólną nazwę i porę emisji, są w różnym stopniu nasycone komentarzami metatekstowymi i metadyskursywnymi, które eksplicytnie wskazują na intencję nadawcy i zapowiadają cel kolejnych segmentów (por. punkt 6.3.5.2). Z uwagi na cykliczność programów można te komentarze traktować również ponadjednostkowo, jako odnoszące się ogólnie do formuły programu. Według medioznawców bowiem nadawca medialny edukuje odbiorcę do fortunnego odbioru swoich tekstów ${ }^{84}$. Poprzez sygnały i symptomy organizacji problemowej wskazuje punkty strategiczne w przebiegu rozmowy publicznej, w których wzbudza oczekiwania odbiorcy oraz umieszcza wskazówki interpretacyjne.

Na rzeczywisty przebieg interakcji ma jednak wpływ nie tylko plan nadawcy medialnego, ale również cele poszczególnych gości. Niezależnie od tego, że dziennikarz zmierza w kierunku zrealizowania celów kolejnego segmentu, dowolny z rozmówców może w którymś momencie uznać, że wynegocjowane uprzednio ustalenia są dla niego niesatysfakcjonujące i zechce do nich wrócić w celu weryfikacji. Na przykład w trakcie negocjowania rozwiązań gość powraca do etapu diagnozy, czy też w trakcie formułowania problemu rozmówca na nowo podejmuje wątek oceny zdarzeń. Tego typu działania sprawiają, że przebieg linii tematycznej jest pełen nawrotów do omawianych już zagadnień. Biorąc pod uwagę różnorodność opinii i gatunkowe wymogi dyskusji, wydaje się, że nie należy takich nawrotów traktować w kategoriach zakłóceń komunikacji, ale raczej jako naturalną wielotorowość wszelkich negocjacji. Zatem schemat organizacji problemowej powinien uwzględniać elastyczność i wariantywność zachowań, przy jednoczesnym dążeniu do stabilizacji (rys. 14).

Schemat organizacji problemowej ma charakter elastycznego wzorca, oddającego pełny cykl decyzyjny: od diagnozy, wyjaśnienia, oceny poprzez sformułowanie problemu do wytypowania rozwiązania. Proporcje między etapami mogą podlegać wahaniom, na co ma wpływ wiele czynników, m.in. specyfika tematu, stan debaty pozastudyjnej na dany temat, a także cele perswazyjne nadawcy medialnego. Rozbudowanie bądź redukowanie etapów ujmujemy jako różnice w realizacji schematu podstawowego. Ze względu na możliwość wystąpienia wielu konfiguracji, podajemy przykłady realizacji podstawowej (A) i przykład realizacji zredukowanej (B). W celu zobrazowania przebiegu interakcji wybrano reprezentatywne fragmenty wypowiedzi $\mathrm{z}$ dwu programów.

${ }^{84}$ Media kształtują idealnego odbiorcę, wpisującego się w konwencje odbioru danego medium. Przyjęcie roli, jaką wyznacza odbiorcy dany tekst medialny, umożliwia fortunną komunikację. Jej warunkiem jest przestrzeganie - poznawanych w toku obcowania z tekstami medialnymi - reguł uczestnictwa w danej formie komunikacji medialnej. Właściwą ramę tekstu medialnego stanowi to, o co odbiorca może w tym tekście zapytywać i na co może znaleźć w nim sformułowaną bezpośrednio lub możliwą do wywnioskowania odpowiedź (Szczęsna 2007: 23). 


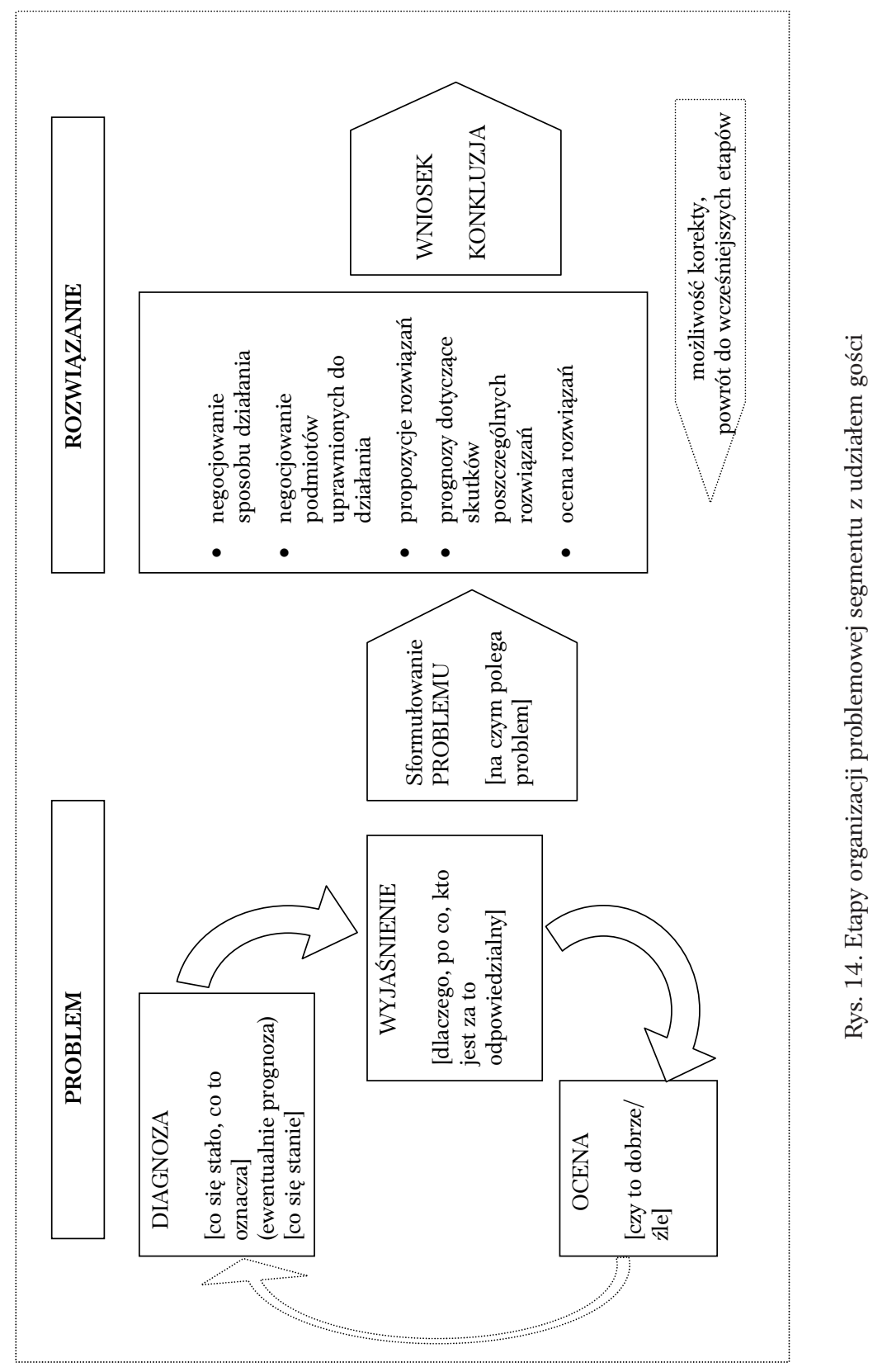




\section{A. Podstawowy schemat organizacji problemowej}

W przykładzie, w którym został zrealizowany pełny schemat, wyodrębniamy dwie nadrzędne części: problem oraz rozwiązanie. W zakres części „problem” wchodzą takie etapy, jak: diagnoza, wyjaśnienie, ocena, postawienie problemu. Część „rozwiązanie” tworzą etapy: negocjowanie rozwiązań, ocena, wybór rozwiązania (bądź rozwiązań). W ramach etapów pojawiają się sekwencje, które realizuje dziennikarz i wybrany rozmówca lub dziennikarz i rozmówcy.

\section{Pierwsza sekwencja etapu „diagnoza”}

KD: Panie profesorze, takie hipotetyczne założenie o pańskiej złej woli gdybyśmy przyjęli na chwilę, może być?

PK: Proszę bardzo.

KD: Dobrze. Załóżmy, że pan ma taka złą wolę. Gdyby się pan upart i zastosowat swoja ogromna, znakomita wiedzę prawnicza//

PK: Dziękuję bardzo.

KD: -doprowadzitby pan do przedawnienia części zarzutów w procesie afery FOZZ-u, czy nie? (3.03.2005; goście - MC: Marek Celej, MS: Marek Safian, PK: Piotr Kruszyński, ZW: Zbigniew Wasserman)

Istotnym elementem sytuacji, który determinuje strategie dziennikarza i rozmówcy jest rodzaj uwikłania rozmówcy w wydarzenia stanowiące tło programu. Dziennikarz na tle groźby przedawnienia procesu FOZZ-u stara się w programie ustalić odpowiedzialność za ten stan rzeczy i powiązać sprawę jednostkową z oceną instytucji sądownictwa (relacja: przejaw zjawiska/rjawisko). Tego typu aktywność jest związana z jego rolą społeczną. Interakcja może zatem potencjalnie doprowadzić do zagrożenia twarzy rozmówcy, który jest obrońcą w procesie. Dziennikarz wybiera taktykę prowokacyjnego podpuszczenia, to znaczy chce skłonić rozmówcę do wypowiedzi, które potem mogą być użyte przeciwko niemu. Obniżeniu krytycyzmu rozmówcy ma służyć przyjęcie konwencji gry „na niby” oraz schlebianie.

PK: Panie redaktorze, no mnie jest bardzo trudno wypowiadać się, gdyż jak pan stusznie zauważyt, jestem jednym z obrońców w tej sprawie [...].

KD: Caty czas powiadam - budujemy model abstrakcyjny

PK: [Aha, rozumiem.

KD: [-żeby doprowadzić do takiego katalogu chwytów na przedawnienie.

PK: Panie redaktorze, odpowiem panu w ten sposób i państwu wszystkim: obrońca powinien robić wszystko, co działa na korzyść oskarżonego, by wygrać, w granicach dopuszczalnych przez prawo. Rola obrońcy jest, i o tym się niestety często zapomina, media zapominaja, nie mówię akurat o Telewizji Polskiej, o pierwszym programie, ale kiedy czytam na temat FOZZ-u, to widzę, że dziennikarze niestety zapominaja, że rola obrońcy jest zrobienie wszystkiego, co w ludzkiej mocy, żeby pomóc oskarżonemu $w$ granicach prawa. Nie wolno obrońcy naruszać prawa.

Rozmówca, rozumiejąc swoje uwikłanie w sytuację, stosuje strategię uniku (odmowa udzielenia wypowiedzi). Dziennikarz przypomina o konwencji „gry na 
niby" i ujawnia swój zamysł organizacyjny (żeby doprowadzić do takiego katalogu chwytów na przedawnienie). Działanie dziennikarza należy uznać za taktykę usprawniającą przebieg interakcji, podjętą ze względu na opór rozmówcy. Rozmówca nie daje się sprowokować, uchyla się od odpowiedzi na pytanie, czy mógłby za pomocą chwytów doprowadzić do przedawnienia procesu. Stosuje kolejną strategię uniku, polegającą na przesunięciu linii tematycznej (nie o konkretnym zachowaniu, ale o normie zachowania).

KD: Jeśli pan pozwoli, to ja mam fragment tutaj/ zbiór zasad etyki adwokackiej, gdzie jest napisane tak: „Naruszeniem godności zawodu adwokackiego jest takie postepowanie adwokata. które mogtoby go poniżyć w opinii publicznej lub poderwać zaufanie do zawodu”. Czy te wszystkie publikacje, które się pokazały po rozgrywce w aferze FOZZ-u: sąd-obrońcy, po tej wymianie ostrych zdań, dostarczaniu, o tym będziemy jeszcze mówili, wezwań przez ABW i tak dalej, i tak dalej, czy to nie jest podrywanie autorytetu zawodu obrońcy, adwokata?

PK: Panie redaktorze, przepraszam, że użyję takiego obrazowego stwierdzenia, tutaj „boks byt po obu stronach", to znaczy, jeżeli nawet tego typu zarzut można bytoby postawić moim kolegom, to muszę powiedzieć, ̇̇e trzeba spojrzeć na praprzyczynę. To nie obrońcy doprowadzili do sytuacji, że proces FOZZ-u może się przedawnić. Taka sytuacja powstała $w$ zwiazku z tym, $\dot{z}$ e ten proces toczy się już lat 12. I w tej chwili obwinianie obrońców za fakt, że proces może się przedawnić jest nieporozumieniem. Ja tutaj nie widzę w każdym razie żadnego poniżania, żadnego zachowania, które mogłoby poniżyć obrońców.

Dziennikarz po nieudanej prowokacji zaostrza atak i stawia (już jawnie) rozmówcę w sytuacji zagrożenia twarzy (czy to nie jest podrywanie autorytetu zawodu obrońcy, adwokata). Rozmówca stosuje strategię obrony twarzy pozytywnej siebie i swojej grupy poprzez reinterpretację tła pozajęzykowego, a mianowicie przez rozszerzenie kontekstu. Negatywnie oceniane działanie (konflikt między sędzią a obrońcami) zostaje przedstawione nie jako działanie jednostronne, ale jako reakcja na bodziec (tutaj „boks byt po obu stronach”), co rozkłada odpowiedzialność na inne podmioty. Poza tym rozszerza kontekst czasowy i przyczynowy (Taka sytuacja powstała $w$ związu z tym, że ten proces toczy się już lat 12).

Strategie uniku stosowane przez rozmówcę mają wpływ na powiązanie wymian, których spójność można rozpatrywać na różnych poziomach ${ }^{85}$. Zachowana jest spójność leksykalna, ale zakłóceniu ulega struktura tematyczno-rematyczna. Do wykładników więzi leksykalnej można zaliczyć wyrazy pochodzące ze wspólnej grupy tematycznej, np.: wiedza prawnicza, proces, obrońca, prawo, oskarżony. Zaburzona jest natomiast spójność tematyczno-rematyczna, gdyż rozmówca pomija niewiadomą pytania i daje odpowiedź wymijającą. Zabiegami mającymi przywrócić spójność są wyrażenia metatekstowe, pozorujące spójność (Panie redaktorze, odpowiem panu $w$ ten sposób i państwu wszystkim). Czynnikami, które spajają sekwencję są: wyraźny zamiar komunikacyjny dziennikarza

${ }^{85} \mathrm{Na}$ charakter spójności jako kontinuum różnych mechanizmów na poziomach syntaktycznym, semantycznym i pragmatycznym wskazuje Urszula Żydek-Bednarczuk (2005: 86-87). 
(prowokacyjne „podpuszczenie”, wykreowanie sytuacji zagrożenia twarzy), dopasowane zachowania rozmówcy (strategie uniku, strategie obrony twarzy pozytywnej), przewidywalność zachowań rozmówców ze względu na ich rolę społeczną i rodzaj uwikłania w sytuację - a więc czynniki o charakterze pragmatycznym. Dodatkowo elementem scalającym jest przypisanie sekwencji funkcji w strukturze debaty, a jest nią prezentacja stanowiska jednej strony (stanowisko obrońcy wobec później wyegzekwowanego stanowiska sędziego i polityka).

\section{Druga sekwencja etapu „diagnoza”}

KD: A pan nie widzi, panie sędzio [poniżania obrońców]? [...] Czy w tym wyścigu adwokaci walcza czysto czy nie?

MC: Panie redaktorze, to jest trudne pytanie, czy walcza czysto. Mnie jako sędziemu trudno jest oceniać kolegów adwokatów. Natomiast mogę/ w toku procesu nie byto takiej sytuacji, która mogłaby świadczyć o tak zwanej obstrukcji sądowej. Wiadoma jest rzecza, zreszta media też skwapliwie donosza, że zawsze każdy proces zaczyna się w wielkim opóźnieniu. Albo to nie przychodza oskarżeni, nie stawiają się, przepraszam, panie profesorze, również obrońcy. Sa różnego rodzaju komplikacje, ale//

Dziennikarz rozpoczyna kolejną sekwencję, która jest wyodrębniona ze względu na skład uczestników (dziennikarz + jeden rozmówca). Zachowana jest ciągłość tematyczna pomiędzy sekwencjami, których tematem jest diagnoza i ocena dotycząca zachowania adwokatów, obrońców w procesie FOZZ-u. Stopień uwikłania rozmówcy w wydarzenie jest bardziej złożony niż obrońcy. Z jednej strony zostaje przeciwstawiony adwokatom jako „pozytywny bohater” sprzyjający zakończeniu procesu, z drugiej - jako sędzia jest odpowiedzialny za całość działań sądu, a więc pośrednio również za zagrożenie procesu przedawnieniem. Tę dwuwartościowość widać w strategii komunikacyjnej rozmówcy, którą cechuje postawa asekuracyjna. Rozmówca stosuje strategię uniku, odmawia odpowiedzi na pytanie, uzasadniając to rolą społeczną (Mnie jako sędziemu trudno jest oceniać kolegów adwokatów). Rozpoznaje sytuację jako zagrażającą jego twarzy i stąd pojawia się reinterpretacja tła pozajęzykowego w celu obrony własnej instytucji (nie było takiej sytuacji, która mogłaby świadczyć o tak zwanej obstrukcji sądowej).

KD: Panie sędzio, to jeśli jest tak łagodny ogląd sprawy, jak go pan w tej chwili przedstawia, to o co ta awantura, o co się denerwuje sędzia Kryże prowadzacy to postępowanie? Po co się wprzęga $A B W w$ dostarczanie prostych kwitów, czyli $w$ rolę listonosza tak naprawdę, $w$ tym procesie? Po co to wszystko?

MC: To wszystko jest po to, żeby ten proces zakończyć. Po to, żeby zakończyć przed okresem przedawnienia i nie ulega wątpliwości, że w momencie, kiedy weszliśmy, używając sportowej terminologii, na ostatnia prosta, to okazuje się, że jedna z podsądnych wypowiada petnomocnictwo swojemu obrońcy, $i$ to już $w$ momencie, kiedy sa głosy stron!

KD: A na pańskie sędziowskie oko jest to umówiony sposób czy nie?

MC: Nie jestem $w$ stanie tego ocenić, ale powiem szczerze, że prawdopodobnie jest to jakaś tendencyjna gra. Nie wnikam $w$ to, że rzeczywiście adwokat wszedt $w$ taka grę ze swoja klientka. Ufam, że nie powinien wchodzić. 
Dziennikarz rozpoznaje taktyczną reinterpretację tła pozajęzykowego (to jeśli jest tak tagodny ogląd sprawy, jak go pan w tej chwili przedstawia). Jest ona zgodna $\mathrm{z}$ interesem rozmówcy (implikatura: sąd, którym kieruję działa prawidłowo), ale niezgodna z kreowaną przez dziennikarza sytuacją komunikacyjną. Jej pożądane cechy to emocjonujące starcie, konfrontacja, czemu służy dramatyczne i konfliktowe wykreowanie zdarzenia, zgodnie z poetyką mediów (Mrozowski 2001: 132-135) oraz zgodnie z wymogami gatunku debaty i/lub dyskusji (eksponowanie różnicy, niezgodności). Emocjonalny ton wypowiedzi okazuje się skuteczną techniką służącą sprowokowaniu rozmówcy, który ostrożnie, ale potwierdza tezę prowadzącego (że prawdopodobnie jest to jakaś tendencyjna gra).

Sekwencja $\mathrm{z}$ udziałem drugiego gościa ma w zamyśle organizacyjnym dziennikarza przynieść diagnozę i ocenę działania adwokatów, tym razem z perspektywy sędziego. Jego rola społeczna i rodzaj uwikłania w sprawę powodują, że stosuje wysoce asekuracyjne strategie komunikacyjne: początkowo uchyla się od odpowiedzi (co zakłóca spójność tematyczno-rematyczna)), stosuje strategię metadyskursywną w celu zmniejszenia kategoryczności sądów (Nie jestem $w$ stanie tego ocenić; nie wnikam $w$ to, że rzeczywiście adwokat wszedt $w$ taka gre ze swoja klientka) oraz poprzedza swoją diagnozę operatorem modalnym (prawdopodobnie).

\section{Trzecia sekwencja etapu „diagnoza” ${ }^{66}$}

KD: Panie pośle, 30 dni aresztu dla obrońców, którzy stosują takie gry?

ZW: Może nie sięgajmy do górnej pótki, ale pomyślmy, jak uczynić, żeby sąd nie byt bezradny w takich sytuacjach.

$\mathrm{KD}:$ A byt?

ZW: Sądzę, że byt. Te wszystkie zdarzenia układaja się w pewien ciag, zmierzajacy do tego, żeby nie można byto tej sprawy zakończyć [...].

KD: Panie pośle, czy byto złamanie zasad etycznych zawodu? Czy adwokaci zachowywali się $w$ porzadku, czy po prostu wykorzystywali wszystkie kruczki prawne.

ZW: Panie redaktorze, przecież z jednej strony była bardzo zdecydowana reakcja okręgowej izby adwokackiej, ale później pan mecenas pojawit się na sali rozpraw, dając do zrozumienia, że jednak to byt btad. Ta postawa na akceptację na pewno nie zastugiwata.

Trzecia sekwencja została zaplanowana jako poszukiwanie rozwiązań (co należy zrobić), ale ostatecznie dziennikarz akceptuje powrót do diagnozy omawianego wydarzenia, tym razem $\mathrm{w}$ interakcji z politykiem. Funkcjonalizacja tła pozajęzykowego okazuje się bowiem ważnym elementem strategii komunikacyjnej

86 Jest to sekwencja przejściowa, niejednorodna, gdyż dziennikarz najpierw zaczyna etap ustalania sposobu działania, a potem pod wpływem wypowiedzi rozmówcy wraca do etapu diagnozy ( $A$ byt [bezradny]?). Wynika z tego, że atrakcyjność wątku wprowadzonego przez polityka (sąd był bezradny) okazała się na tyle funkcjonalna medialnie, że dziennikarz dał się sprowokować i pozwolił politykowi powrócić do etapu diagnozy. 
polityka, który dzięki temu formułuje ofertę polityczną i uzasadnia swoje działania. Podaje dwie przesłanki mające świadczyć o naruszeniu zasad etycznych przez adwokatów w procesie FOZZ-u: reakcja instytucji nadzorującej i autokorekta nagannego zachowania. W tym momencie dziennikarz uzyskuje zadowalająca diagnozę sytuacji, czyli odpowiedź na pytanie: „co się wydarzyło i z czym to się wiąże?”.

W kolejnym etapie interakcji dziennikarz przechodzi do wyjaśnienia wydarzeń, czyli uzyskania odpowiedzi na pytania: „dlaczego tak się stało?”, „czemu to służy?”, „kto jest za to odpowiedzialny?”.

\section{Pierwsza sekwencja etapu „wyjaśnienie”}

KD: To może tak, że jednak przewodniczacy/ pan byt wtedy przewodniczacym wydziału, prawda? To może warunki pracy, jakie stworzono wtedy dla pani sędzi Piwnik byty nie dość dobre, znaczy nie przewidywały takiej sytuacji, $w$ której z powodu jakiejś decyzji, nie wiem, o pójściu na stanowisko ministra sprawiedliwości, ale też wielu innych życiowych decyzji, ten proces nie zostat sparaliżowany?

MC: No niewątpliwie nikt z nas wówczas nie przypuszczat, że pani sędzia Barbara Piwnik zostanie ministrem sprawiedliwości. To byt zupetnie inny okres i wydawało nam się, że skoro ten proces pod jej przewodnictwem ruszyt $z$ kopyta, to nie będzie żadnych problemów, żeby w rozsądnym czasie ten proces zakończyła. Mówię, tej sprawy nikt nie przewidział [...].

KD: Dobra, to kto jest temu winien w takim razie?

MC: My jako sędziowie i sądy polskie nie byliśmy przygotowani na tego rodzaju rozwiązywanie wielkich afer [...]. Tutaj tak się nieszczęśliwie złożyto, że przez 5 lat poszukiwaliśmy dowodów w tejże sprawie. Później też nieszczęście się stało, że pani Barbara Piwnik została ministrem sprawiedliwości $[\ldots]$.

Dziennikarz stara się wyjaśnić przyczyny negatywnego przebiegu wydarzenia. Stawia rozmówcę w sytuacji zagrożenia twarzy z powodu niedopełnienia obowiązków służbowych wynikających z nadzoru nad sprawą. Rozmówca uchyla się od odpowiedzi na pytanie zasadnicze i rozwija marginalny wątek, pozorując związek odpowiedzi z pytaniem (No niewatpliwie nikt z nas wówczas nie przypuszczat). Pomijając własną odpowiedzialność, wskazuje na niezależne uwarunkowania zewnętrzne, niedostosowania systemowe.

\section{Druga sekwencja etapu „wyjaśnienie”}

KD: Ja mam jeszcze jedno pytanie a propos tego procesu. Czy panowie nie uważaja, że sedzia Kryże troche jest sam sobie winien? Ten artykut 376 kpk, który mówi o tym, że nie musi być przecież oskarżonej na rozprawie i wyrok wydany po złożeniu wyjaśnień wcale nie jest wyrokiem zaocznym. Może po prostu nie trzeba byto aresztować tymczasowo oskarżonej, która/ i potem się zaczat caty korowód.

MS: Myślę, że to jest zły trop [...]. Trzeba powiedzieć o problemie ogólnym i podstawowym. Po pierwsze, mamy do czynienia z wadliwościa regulacji prawnych, które paraliżuja sąd w tej sytuacji. One się zmienity stosunkowo niedawno i rzeczywiście uniemożliwity sądowi sprawowanie kontroli nad tym, czy przypadkiem decyzja oskarżonego o zmianie obrońcy, no, nie jest podyktowana wytącznie tym, co bym określit jednak nadużyciem prawa do obrony. 
KD: Czyli gra na przedawnienie.

MS: Tak. To po pierwsze. Po drugie oczywiście, no, mówiliśmy o niedowładzie funkcjonowania instytucji wymiaru sprawiedliwości, trzeba to wyraźnie powiedzieć, że tak się stało. Ale po trzecie, trzeba powiedzieć, że prawo, niestety tak bywa, nie jest panaceum na wszystkie możliwe dramatyczne sytuacje, które się w społeczeństwie zdarzaja.

Dziennikarz konsekwentnie przypisuje odpowiedzialność konkretnym osobom (najpierw przewodniczącemu wydziału, potem sędziemu). Rozmówcy upatrują przyczyn niedowładu instytucji wymiaru sprawiedliwości w niewydolnym systemie, procedurach, wreszcie (co ciekawe) w nadmiernych oczekiwaniach obywateli (prawo, niestety tak bywa, nie jest panaceum na wszystkie możliwe dramatyczne sytuacje).

Diagnoza i wyjaśnienie powinny doprowadzić do sformułowania problemu, który ukierunkuje poszukiwanie rozwiązań (tu: spowodować, żeby nie doszło do przedawnienia procesu).

\section{Pierwsza sekwencja etapu „postawienie problemu”87}

MS: I $w$ tej chwili, jeśli stawiamy jedno pytanie generalne: co zrobić, żeby nie doszło do przedawnienia procesu, to bardzo zła metoda, żeby na tle tej konkretnej sprawy doprowadzać do wprowadzenia w systemie prawnym środków nadzwyczajnych, ekstraordynaryjnych, które maja//

KD: Krótko mówiąc, panie profesorze, nie podoba się panu to, co proponuje PiS.

MS: Nie podoba mi się ze względu na to, że mamy do czynienia ze środkiem, który jest interwencja związana z doraźnie toczaca się sprawa, z konkretnym toczacym się postępowaniem. To jest niedobry obyczaj. [...] ponieważ to burzy zaufanie do państwa prawnego. Burzy zaufanie, ponieważ stwarza sytuację, kiedy mamy do czynienia $z$ nieprzewidywalnościa regut prawa $i$ to w odniesieniu do prawa karnego. To jest niezwykle wrażliwa sfera prawa.

Rozmówca formułuje problem-zadanie, który wynika z diagnozy sytuacji: jak zapobiec przedawnieniu procesu. Następnie dokonuje negatywnej oceny rozwiązania proponowanego przez polityka oraz uzasadnia ją. Wskazuje na przeciwskuteczność proponowanego działania z perspektywy stabilności i przewidywalności systemu.

\section{Pierwsza sekwencja etapu „negocjowanie rozwiązañ”}

KD: To dlaczego pan operuje $w$ tej niezwykle wrażliwej sferze prawa?

ZW: Panie redaktorze, to jest zarzut bardzo poważny. I tak zastanawiam się, czy budzi zaufanie do państwa prawa sytuacja, w której kilkanaście lat prowadzone postępowanie karne i proces moga się niczym skończyć. W którym przegrywa z oskarżonymi prokuratura wielokrotnie, $z$ którymi przegrywa zespót biegtych, kompromitując tą instytucję. W którym dobrego sędziego bierze

87 Jak już wspomniano, proporcje między etapami są zależne od specyfiki podjętego tematu. W rozpatrywanym przykładzie problem, który należy rozwiązać jest oczywisty, więc nie stanowi przedmiotu dłuższych negocjacji. Rozmówcy od razu przechodzą do propozycji i/lub oceny rozwiązań. 
się, przepraszam za określenie, na marnego ministra. Kto na tym skorzystat? Państwo, ministerstwo? Na pewno straciła ta sprawa. My skoncentrowaliśmy się na końcówce tego, co się dzieje. $W$ tej chwili można się licytować, czy bardziej tutaj zawiniła prokuratura, sąd, adwokatura. To nieważne! Ważne, że ciagle trwa wyścig pewnych nieprawidtowości z wymiarem sprawiedliwości. Ten wymiar sprawiedliwości przegrywa. I wracam do tego zaufania, do państwa prawa. To kto, ten, kto jest pokrzywdzony w sprawach, ten, kto widzi, jak przegrywa wymiar sprawiedliwości, ma zaufanie do tego państwa? Zgadzam się, że nie można burzyć systemu prawa, ale prawo ma służyć rozwiązywaniu problemów//

KD: No dobrze, panie pośle, ale za każdym razem, jak będziecie mieli jakiś przyktad drastycznego przestępstwa, to za każdym razem, jak bẹdzie coś, co bẹdzie bulwersowato opinie publiczna, to bedziemy zmieniali prawo?

ZW: Może nie za każdym razem, ale jeżeli pojawiaja się zjawiska, które nie były penalizowane, czyli karane, to $w$ kodeksie znajduje się nowy przepis.

Dziennikarz przyjmuje rolę organizatora dyskusji, gdyż przekazuje proponentowi zarzut oponenta dotyczący oceny rozwiązań (dlaczego pan operuje $w$ tej niezwykle wrażliwej sferze prawa). Proponent-polityk nie odnosi się merytorycznie do zarzutu oponenta. Nie podejmuje negocjacji dotyczących ustalania sposobu działania, lecz zmienia poziom rozmowy. Stosuje strategię metadyskursywną, nazywając ocenę rozwiązania „poważnym zarzutem”, a następnie powraca do etapu diagnozy wydarzeń. Kreuje ich obraz jako wydarzeń nagannych, bulwersujących, kompromitujących, krzywdzących, drastycznych. Buduje relację przyczynowo-skutkową między dramatycznie wykreowanym obrazem wydarzeń a niefunkcjonalnym prawem, które trzeba zmienić (prawo ma służyć rozwiązywaniu problemów). Sąd normatywny jest przesłanką do działania (należy zrobić coś, aby prawo służyło ludziom, pokrzywdzonym, domyślnie: ja to zrobię). Strategia polityka jest nastawiona na oddziaływanie perswazyjne poprzez taktyczne wykreowanie tła pozajęzykowego. Masowy odbiorca nie jest przygotowany (w ocenie polityka) do rozstrzygania specjalistycznych kwestii prawnych. Jako niejednoznaczne i abstrakcyjne nie mają odpowiedniej tonacji dramatycznej.

Następnie dziennikarz, nie otrzymawszy rzeczowej odpowiedzi, przyjmuje rolę dyskutanta i inicjuje ocenę proponowanych przez polityka rozwiązań prawnych.

\section{Druga sekwencja etapu „negocjowanie rozwiązań”}

KD: Pan profesor Kruszyński.

PK: Ja tutaj się zgadzam z panem profesorem Safianem. Po pierwsze, nie powinno się tworzyć prawa ad casu, nie powinno się dokonywać intervencji ustawodawczej dlatego, że jest taka potrzeba wynikajaca z konkretnego procesu.

KD: Panie profesorze, po ludzku, czy pana nie/ czy w panu krew się nie burzy, jak się oka$\dot{z} e$, że z powodu opieszałości jakiegoś urzędnika, z powodu tego, że gdzieś nie byto pieniędzy na ekspertyzę i na biegtych, że gdzieś jakieś akta wpadty za szafę, a potem mówięl że po prostu ktoś wychodzi w majestacie prawa i mówi: „Jestem niewinny, bo objęło mnie przedawnienie”.

PK: We mnie się burzy krew, jeśli się narusza podstawowa zasadę zapisana w Konwencji Europejskiej - uczciwego procesu. 
O schematyzacji i konwencjonalizacji działań komunikacyjnych w debacie świadczy fakt, że przy minimalnym zaangażowaniu dziennikarza (wskazanie kolejnej osoby) rozmówca postępuje zgodnie z uwewnętrznionym modelem zachowania komunikacyjnego. Po pierwsze, realizuje plan strukturalny kolejnego etapu dyskursu, który przewiduje w danym momencie ustalanie sposobu działania poprzez krytyczną weryfikację przedstawianych rozwiązań. Po drugie, rozmówca nawiązuje do wcześniejszych głosów w dyskusji, opowiadając się po jednej ze stron (zgadzam z panem profesorem Safianem). Na specjalistyczne, prawnicze wywody adwokata dziennikarz reaguje również zgodnie z konwencją debaty/ dyskusji, która nakazuje kontrastowanie stanowisk. Stanowisko eksperckie zostaje zderzone z potoczną opinią (po ludzku, czy pana nie/ czy w panu krew się nie burzy). Kontrast jest widoczny w zmianie odmiany języka (odmiana profesjonalna a odmiana potoczna) i związanej z tym racjonalności (racjonalność naukowa, która respektuje profesjonalne procedury a racjonalność potoczna, która kieruje się zdrowym rozsądkiem, ludowym poczuciem sprawiedliwości). Kontrast jest najbardziej widoczny w doborze leksyki (prawo ad casu, interwencja ustawodawcza i krew się burzy, akta wpadty za szafę).

\section{Pierwsza sekwencja etapu „wybór rozwiązania”}

MC: Ja się pytam, czy nie można bytoby zmienić systemu prowadzenia postepowań przygotowawczych. Zrobić reforme posteppowania przygotowawczego. [...] Dokąd nie będzie systemowej zmiany, logistycznego podejścia do wypracowania wtaściwego modelu, tak długo będziemy cierpieć na niedowtad.

KD: No ale to by wymagato, panie sędzio, przemodelowania całego polskiego systemu.

PK: Na to oczekujemy [sic!] od dtuższego czasu.

KD: Tak, ale na razie mamy inne propozycje. [...] Czy nie można byto od poczatku inaczej zorganizować tej sprawy? Wytączyć jednego sędziego do prowadzenia tej sprawy, albo zespót rezerwowy sędziów?

Najbardziej typowymi strategiami w części „rozwiązanie” są strategie behawioralne związane z ustalaniem sposobu działania (Awdiejew, Habrajska 2006: 66). Ze względu na równorzędny układ interakcyjny ${ }^{88}$ nowe rozwiązania mogą być przedkładane jako akty mowy propozycji (a nie np. żądania). Proponowane zmiany ze względu na zasięg dzielą się na dwie grupy: usprawnienia w ramach istniejących regulacji, np. dyscyplinowanie urzędników, oraz nowe rozwiązania systemowe, np. zmiana prawa. Negocjowaniu rozwiązań towarzyszy ich ocena dokonywana $\mathrm{w}$ ramach strategii aksjologiczno-emotywnych (Awdiejew, Habrajska 2006: 63), które polegają na negocjowaniu opinii wartościujących w stosunku do znanych interlokutorom zjawisk.

${ }^{88}$ Mówiąc o równorzędnym układzie interakcyjnym, mamy na uwadze równorzędność podmiotów debaty publicznej, które mogą jako obywatele realizować model komunikacji petycyjnej, proponować pewne rozwiązania. Jeśli chodzi o sytuację medialną, to dziennikarz jako przedstawiciel stacji i organizator programu ma nadrzędna rolę względem rozmówców. 
Zaprezentowane powyżej etapy rozwoju debaty (takie jak: diagnoza wydarzeń, wyjaśnienie, ocena, postawienie problemu, negocjowanie rozwiązań, wybór rozwiązania) mogą podlegać redukcji, z czym wiąże się zmiana proporcji pozostałych elementów. Stopień realizacji schematu jest zależny od czynników pozajęzykowych, przede wszystkim od specyfiki tematu, jego społecznej percepcji oraz koncepcji organizacyjnej nadawcy medialnego.

\section{B. Zredukowany schemat organizacji problemowej}

W programach, w których nie jest realizowany proces decyzyjny ${ }^{89}$, a jedynie proces opiniotwórczy ${ }^{90}$, zredukowana zostaje część „rozwiązanie”, natomiast rozbudowaniu podlega część „problem”. Na etapie diagnozy pojawiają się nie tylko pytania dziennikarzy zmierzające do ustalenia, co się dzieje i jakie to ma znaczenie, ale również pytania o to, czego się można spodziewać po aktorach politycznych i jaki może być przebieg zdarzeń. Zobrazowaniem schematu o rozbudowanym etapie diagnozy niech będą fragmenty programu na temat pomarańczowej rewolucji na Ukrainie.

\section{Pierwsza sekwencja z etapu „diagnoza”}

KD: [...] Ja jestem ciekaw opinii naszych gości, którzy pochodza z Ukrainy. Co oni myśla na temat tego, czym dla Ukrainców jest obecność polskich polityków w Kijowie?

PB: I nasze zaangażowanie na Ukrainie. Panie doktorze, może pan, proszę bardzo.

RKr: Niestychanie ważnym jest to, że w tych dniach akurat sa politycy z różnych politycznych opcji na Ukrainie. I niestychanie ważnym jest to, że jutro będzie prezydent Kwaśniewski [...].

KD: A niech pan powie, jak pan sobie wyobraża zakończenie tego wszystkiego, tych emocji, które w tej chwili na Ukrainie sa, tego sporu, który na Ukrainie jest? Czy dla pana Janukowycz jest człowiekiem, który potrafitby oddać wtadzę?

RKr: Tak prosto nie odda, no ale dlatego sa ci ludzie na placu, dlatego tu jesteśmy i sa/ Jeszcze mamy czas do tego, żeby jednak oddat wtadzę.

(25.11.2004; goście - JC: Jacek Cichocki, JO: Janusz Onyszkiewicz, JP: Jerzy Pomianowski, MS: Marek Siwiec, OH: Ola Hnatiuk, RKr: Rostysław Kramar, RKu: Rafał Kurowski)

Dziennikarze, ustalając kolejność rozmówców, kierują się zasadą stopnia ich uwikłania w omawiane wydarzenia. Na początek wybierani są goście, których

89 Realizowanie procesu decyzyjnego rozumiemy jako włączanie obywateli do publicznej artykulacji problemu, debaty nad nim i negocjowania rozwiązań. Jego skuteczność zależy od siły społecznego nacisku na organa decyzyjne w celu podjęcia oczekiwanych działań. Aktywność obywateli dotyczy tematów, które są związane z ważnymi problemami społecznymi, np. wszelkiego rodzaju patologiami i walką z nimi, zakresem wolności jednostki i ingerencji państwa w jej życie, kontrolą działań instytucji.

90 Proces opiniotwórczy polega na komentowaniu, krytykowaniu, ocenianiu wydarzeń ze sfery publicznej. Tam, gdzie nie ma możliwości wywierania nacisku na władzę lub instytucję w celu uzyskania określonych rozwiązań (realizowanego jako mniej lub bardziej skuteczne włączanie się w proces decyzyjny), pozostaje diagnoza, wyjaśnienie i ocena zdarzeń. 
cechuje zaangażowanie, bezpośredni udział w zdarzeniach lub odpowiedzialność za nie. Taka taktyka w budowaniu struktury gwarantuje odpowiedni dynamizm i emocjonalność przebiegu programu, gdyż omawiane zagadnienia są ważne dla rozmówców. Uwypukleniu osobistego stosunku do omawianych wydarzeń służy sformułowanie pytania o postrzeganie ich z określonej perspektywy (czym dla Ukraińców jest obecność polskich polityków w Kijowie). W diagnozie bowiem, jak już wspomniano, nie chodzi tylko o prosty opis faktów, ale o ustalenie sensu, który w zależności od kontekstu może mieć nieco inne ujęcie. Następnie dziennikarz pyta o diagnozę prognostyczną, czyli ustala, jaki może być przebieg zdarzeń.

\section{Druga sekwencja z etapu „diagnoza”}

KD: Ja myślę, że to jest dobry moment, żebyśmy się potaczyli z Kijowem i porozmawiali $z$ Rafatem Kurowskim [...]. Powiedz, jaka jest w tej chwili sytuacja w Kijowie?

$\mathrm{RKu}$ : Zgodnie z zapowiedziami, po wiecu wieczornym na Placu Niepodległości kilkutysięczny tłum ludzi ruszyt $w$ stronę budynku parlamentu [...].

Dziennikarz ponownie kieruje się zasadą wyboru rozmówcy, który jest zaangażowany w wydarzenia, tym razem jako świadek, naoczny obserwator. Ze względu na bezpośrednie uczestnictwo w wydarzeniach jego diagnoza może być wiarygodna dla widzów.

\section{Trzecia sekwencja z etapu „diagnoza”}

KD: Proszę państwa, konfrontacje czy negocjacje/ konfrontacja czy negocjacje? To jest wybór, przed którym stoją Ukraincy i również dwaj politycy, którzy/ których wybierali Ukraińcy na prezydenta. Czy Janukowycz, powtórzę to pytanie, czy Janukowycz jest człowiekiem gotowym oddać władzę? Tak trudne pytanie, że nikt nie chce odpowiedzieć? [śmiech]

MS: Myślatem, że pan będzie wywotywat.

KD: Czy to jest człowiek, który może usiaść do stołu z Juszczenką?

MS: Pytanie trzeba/ trzeba inaczej postawić: jaki jest wtaściwie uktad sit? Ten układ sit definiuje się z godziny na godzinę, $z$ dnia na dzień, i trwa próba sit [...]. Dzisiaj wiemy, że Ukraina pracuje, tak, że to jest taki trochę inny rodzaj strajku generalnego.

KD: Chce pan powiedzieć, że ten protest jest mniej silny, niż nam się w Polsce wydaje?

MS: Nie, on jest bardzo silny, tylko on się po prostu inaczej realizuje.

KD: No wtaśnie, tylko na razie mamy problem z powiedzeniem kto przegrat, a kto wygrat [...] wyglada na to, że to jest jednak bardziej scenariusz konfrontacji w tej chwili niż rozmów.

JO: Nie wiem, czy to jest scenariusz konfrontacji. Ja sądzę, że istotnie trwa pewna próba sit. $[\ldots]$

KD: Pani doktor, pani téz przewiduje taki scenariusz na zmęczenie?

OH: To znaczy ja wyraźnie widzę, że ten scenariusz jest realizowany [...].

Dziennikarz kontynuuje pytania o diagnozę prognostyczną ${ }^{91}$, poszerzając je tym razem o wskazówki dotyczące możliwych scenariuszy zdarzeniowych. W tej

91 Prognoza może zachodzić w ramach diagnozy sytuacji (co się stało, co się stanie) oraz w ramach weryfikacji rozwiązań (co się stanie, kiedy wprowadzimy rozwiązanie X). 
sekwencji prowadzący zmierza do uszczegółowienia prognozy poprzez wybór jednej z dwu skrajnych możliwości (konfrontacja czy negocjacje). We fragmencie dochodzi do ujawnienia strategii strukturalnej prowadzącego, która polega na wskazywaniu kolejnych rozmówców. Goście, przyjmując formułę debaty, oczekują tego rodzaju uporządkowania (Myślałem, że pan będzie wywotywat). Świadczy to o uwewnętrznieniu wzorców gatunkowych, które stanowią ważną część kompetencji uczestników. O ile w zakresie prowadzenia debaty jest uznawana dominacja dziennikarza, o tyle trafność pytań podlega już negocjacji (Pytanie trzeba/ trzeba inaczej postawić). Jest to kolejne potwierdzenie braku całkowitej spontaniczności tego typu rozmów, gdyż goście przystępują do nich z pewnymi oczekiwaniami, gotowymi tezami do wygłoszenia, które trzeba dopasować do bieżącego wątku.

Wyraźnie uwidacznia się również współzależność etapów organizacji problemowej, ponieważ od trwałości ustaleń na niższych poziomach zależy płynność negocjacji na poziomach wyższych. Wszelkie niedomówienia skutkują koniecznością powrotu do początkowych etapów. I tak, niezgodność dotycząca prognozy rozwoju wydarzeń skłania prowadzącego do weryfikacji oglądu wydarzeń (ten protest jest mniej silny, niż nam się w Polsce wydaje?).

\section{Czwarta sekwencja z etapu „diagnoza”}

KD: Panie profesorze, czy to jest dla pana starcie demokracji takiej zachodnio pojmowanej. tak ja nazwijmy, z taka lekko wodzowska, lekko majaca zapędy do dyktatury, wizja kraju prezentowana przez Janukowycza, czy inaczej wyglada ta rzeczywistość ukraińska dla pana?

JP: To, co widzimy w tej chwili na ekranach i to, co styszymy od naszych korespondentów świadczy, że Ukraińcy dowiedli, iż są społeczeństwem dojrzałym nie tylko do demokracji, ale przede wszystkim do niepodległości [...].

Dziennikarz zmierza do ustalenia sensu wydarzeń przez odniesienie ich tym razem do kontekstu ściśle politycznego. W celu nadania znaczenia nowym zjawiskom posługuje się dobrze znanymi kategoriami pojęciowymi (demokracja zachodnia czy dyktatura).

\section{Piąta sekwencja z etapu „diagnoza”}

KD: No i wtaśnie tu wracamy do tego pytania, które jednak się na początku pojawito, czyli jak to się może skończyć, jak to może zostać rozwiązane?

JC: Ja bym powiedziat tak, znaczy, jeżeli dojdzie do rozwiązania siłowego, to moim zdaniem Ukraina będzie bardzo trudno rządzić [...].

KD: Pan Cichocki jako człowiek dobrze poinformowany/ powinni usiaśś, powinni rozmawiać? Usiąda, będa rozmawiać?

JC: Ja może powiem $w$ ten sposób, znaczy, my ostatnie dwie noce prawie nie spaliśmy, bo obawialiśmy się jakichś dramatycznych wydarzeń. Teraz nam trochę napięcie opadto//

KD: To co, pierwsza diagnoza byta nietrafna? Ośrodek Studiów Wschodnich stawia jakieś nietrafne diagnozy? [śmiech]

JC: Nie o to chodzi. Logika przełomu zaktada, że nie ma scenariuszy, które ktoś realizuje, napisane wcześniej [...]. 
W ostatniej sekwencji poprzedzającej zakończenie programu dziennikarz powraca do tych samych pytań i eksplicytnie nazywa działania komunikacyjne gości „diagnozą”. Zadawanie tych samych pytań kolejnym gościom umożliwia ujęcie tematu z wielu perspektyw, co korzystnie wpływa na poznawczą wartość debat.

Jak wynika $\mathrm{z}$ analizy przykładów, schemat organizacji problemowej ma charakter elastycznego wzorca. Za schemat podstawowy uznano maksymalny układ elementów, który obejmuje wszystkie etapy procesu opiniotwórczego i decyzyjnego. Schemat zredukowany ma charakter przykładowy, gdyż rozbudowanie lub redukcja etapów jest uzależniona od charakteru jednostkowego tematu i intencji nadawcy medialnego. Elastyczność przejawia się również w możliwości powrotu do wcześniejszych etapów, zwłaszcza kiedy wynegocjowane ustalenia nie są satysfakcjonujące dla jednej ze stron. Uczestnicy kreują bowiem taki obraz wydarzeń i podejmują takie działania, aby zrealizować swoje cele komunikacyjne.

Dziennikarz, jako reprezentant nadawcy medialnego, podejmuje strategie strukturalne na poziomie globalnym, zmierzające do całościowej organizacji programu w trzech jakościowo różnych częściach: ramie programu i tekstu, części środkowej z udziałem publiczności i części środkowej z udziałem gości. Działania dziennikarza są podporządkowane celom makrosytuacyjnym, a więc wykreowaniu sytuacji w studiu według parametrów medialnego dyskursu publicznego i reguł debaty (zwłaszcza w części z publicznością). 


\section{Zakończenie}

Podstawowym celem pracy była analiza językowych działań uczestników programów publicystycznych pod kątem stosowanych przez nich strategii. Przyjęto szerokie rozumienie strategii, która jest ujmowana w aspekcie komunikacyjnym jako środek do realizacji celu, rodzaj planu działania językowego, które ma charakter instrumentalny. Wzorce tego rodzaju nie powstają doraźnie i jednostkowo, ale są kształtowane przez wspólnotę komunikacyjną, która w ramach określonego typu dyskursu i gatunków w jego obrębie, wypracowuje sposoby rozwiązywania określonych problemów komunikacyjnych i tworzy techniki realizowania za pomocą języka celów działalności pozajęzykowej, przede wszystkim w ramach aktywności społecznej.

Strategie stosowane przez dziennikarzy i ich rozmówców w medialnym dyskursie publicznym są uwarunkowane substancjalną odmianą języka, oficjalnym charakterem sytuacji komunikacyjnej, celami działalności pozajęzykowej rozmówców oraz typem komunikowania. Różnorodność uwarunkowań powoduje, że w obrębie wypowiedzi trudno mówić o jednej strategii zastosowanej przez rozmówcę. Mamy raczej do czynienia ze strategiami, których wielość wynika z polifunkcjonalnego charakteru każdego działania językowego. Cele illokucyjne wypowiedzi w dyskursie publicznym, a zwłaszcza politycznym, tworzą hierarchiczne układy o różnym stopniu ogólności i eksplicytności. O ile tylko językowy sposób realizacji celów przyjmie formę uschematyzowaną, można mówić o hierarchicznych układach również w odniesieniu do strategii.

W ich obrębie nadrzędne są strategie uwarunkowane kulturowo i społecznie. To one kontrolują przebieg językowych strategii interakcyjnych oraz strategii w zakresie budowania struktury tekstu. Przykładem nadrzędnych strategii o zasięgu ogólnym są strategie grzecznościowe. Służąc obronie twarzy pozytywnej i obronie twarzy negatywnej, są odpowiedzialne za budowanie poprawnych relacji społecznych. Językowe środki, za pomocą których są one realizowane, podlegają jednak selekcji i uporządkowaniu w obrębie dyskursywnie oraz gatunkowo zróżnicowanych typów zdarzeń komunikacyjnych. Na przykład w dyskursie publicznym pogorszenie wizerunku może utrudnić lub uniemożliwić wypełnianie zadań w ramach roli społecznej, dlatego rozmówcy stosują wiele technik służących obronie twarzy pozytywnej. Temu celowi podporządkowane jest funkcjonalne przedstawienie tła pozajęzykowego i wykreowanie sytuacji komunikacyjnej. Na uwagę zasługuje strategiczne operowanie 
kontekstem, który stanowi niezwykle ważny instrument działania komunikacyjnego.

Do najogólniejszych zaliczono uwarunkowania strategii związane z ustną realizacją tekstu, której prymarną formą jest dialog. Tekst realizowany w tej odmianie przechowuje w sobie ślady sytuacji fizycznej, w jakiej odbywa się komunikacja bezpośrednia. Linearność i sekwencyjność tekstu ustnego zwiększa częstotliwość strategii nadawczo-odbiorczych, które wspomagają integrację tekstu. Nadawca, z myślą o ułatwieniu odbioru, podejmuje strategie metatekstowe, polegające na komentowaniu fragmentów tekstu oraz strategie metadyskursywne, polegające na odnoszeniu się do kontekstu komunikacyjnego.

Analiza tekstu dialogowego umożliwia dostrzeżenie jego dynamiczności. Przebiegu interakcji nie da się bowiem całkowicie zaplanować; rozmówcy muszą reagować na zachowania partnera. Replika jest zarówno reakcją na wcześniejsze działania, jak też sama stanowi bodziec dla kolejnych replik. Zależność ta może być wykorzystana np. w interakcyjnej strategii obrony, dzięki wykazaniu relacji przyczynowo-skutkowej między zdarzeniami komunikacyjnymi. Dynamizm interakcji przejawia się w konieczności dopasowania strategii do działań pozostałych uczestników i uwzględnienia, nawet chwilowych, zmian układu sił. Sytuacja komunikacyjna jest tyleż dana, zastana (jako konfiguracja ogólnych czynników wyjściowych), co negocjowana i współtworzona przez podmioty komunikacji (np. kiedy rozmówca w początkowym układzie równorzędnym stara się zdominować przeciwnika albo przedefiniować przypisywaną mu rolę nietrwałą z oskarżonego na ofiarę). Sytuacja (rozumiana zarówno jako obserwowalne otoczenie, jak i tło odtwarzane z pamięci) w komunikacji bezpośredniej ma charakter tekstotwórczy, a jej elementy są kodowane (jako kontekst) przez poszczególnych rozmówców w sposób funkcjonalny, niejednokrotnie właśnie strategiczny. W dyskusji charakterystyczne jest to, że elementy sytuacji (językowo ujęte zdarzenia, zachowania) są włączane jako przesłanki w konstruowanej przez nadawcę argumentacji. W debacie dodatkowo istotne jest wykorzystanie różnicy zdań do ukonstytuowania dwu grup rozmówców: proponentów i oponentów.

Oficjalny charakter sytuacji nakłada na rozmówców wymóg dostosowania form aktywności komunikacyjnej do oczekiwań, konwencji i zadań związanych $\mathrm{z}$ pełnioną rolą społeczną. Funkcjonowanie w tego typu sytuacjach ogranicza repertuar środków językowych do takich, które są społecznie akceptowane, co uwidacznia się w reakcjach na naruszenie norm (reakcja na akty dyskredytacji, ataki personalne). Jako istotna kategoria sytuacyjna, oficjalność jest wykorzystywana taktycznie do budowania statusu, np. do uzasadnienia interakcyjnej supremacji dziennikarza. Z kolei granica między sferą prywatną a sferą publiczną stanowi swoisty punkt strategiczny w selekcji tematów i ustalaniu ich statusu.

Interpretacja czynności, w tym czynności komunikacyjnych, odbywa się dzięki zaangażowaniu szeroko rozumianej wiedzy (deklaratywnej i proceduralnej) 
oraz pod kontrolą celów działalności pozajęzykowej. Oprócz wiedzy o konwencjach komunikowania w obrębie typów dyskursów i gatunków mowy, aktywizowane są bardziej szczegółowe parametry sytuacji komunikacyjnej w ramach kontekstów zróżnicowanych ze względu na dziedzinę (kontekst polityczny, historyczny, społeczny, instytucjonalny, zawodowy), ze względu na zasięg (międzynarodowy, globalny, lokalny, indywidualny, aktualny, ponadczasowy), ze względu na funkcję interakcyjną (kontekst wyostrzający antagonizmy, balansujący, asekuracyjny). W kreacji obrazu zdarzeń z tła pozajęzykowego pojawia się ich interpretacja w kategoriach przyczynowo-skutkowych lub strukturalno-funkcjonalnych.

Znamienny dla dyskursu politycznego jest odbiór działań podmiotów w kategoriach prowokacji (np. prewencyjnej, dyskredytacyjnej, reaktywnej, legitymizacyjnej, manipulacyjnej, demobilizacyjnej, demaskatorskiej). Sama polityka ujmowana jest w kategoriach gry scenicznej i/lub gry rywalizacyjnej. Ogólnie dla dyskursu medialnego charakterystyczne jest dążenie do stworzenia narracji osnutej wokół wyraźnie zarysowanego konfliktu, jak również emocjonalne, dramatyczne i sensacyjne wykreowanie obrazu wydarzeń. W przypadku dyskursu dziennikarskiego ważną kategorię stanowi obiektywizm, na który składa się faktyczność i bezstronność relacji, w tym prawdziwość, istotność, równowaga oraz neutralność w prezentowaniu wydarzeń. Należy jednak wyraźnie podkreślić, że w niniejszej pracy nie traktuje się obiektywizmu jako kategorii opisowej (tzn. nie rozstrzygano tego, czy dziennikarze są obiektywni czy nie są), ale jedynie jako kategorię dyskursywną, która służy głównie do uwiarygodnienia (bądź, w zależności od celu, do dyskredytacji) podmiotu występującego w roli dziennikarza. Ustalenie istotnych kategorii dyskursywnych jest ważne dla realizowania strategii interakcyjnych, np. ataku, obrony, uniku. Kategorie te dostarczają punktów, z perspektywy których można podjąć fortunną krytykę, dyskredytację lub obronę. Decydują również o tym, z jakich pozycji rozmówca powinien się bezwzględnie wycofać (np. poprzez reinterpretację zdarzeń, zmianę kontekstu), aby nie utracić twarzy.

Medialny dyskurs publiczny toczy się w ramach systemów komunikowania, co powoduje, że wzrasta rola form i wzorów ludzkiej interakcji. Do ważnych czynników różnicujących systemy komunikowania, a będących jednocześnie podstawą parametrów dyskursu, zalicza się: uczestników systemu, ich skład, strukturę i cechy, kontrolę zawartości komunikatów przekazywanych w systemie, źródła i drogi dopływu informacji, charakter kontaktów i rodzaj styczności między członkami systemu, zadania, jakie mają do wykonania, reguły, wzory i normy rządzące ich zachowaniem. Wiedza tego rodzaju stanowi ważny składnik kompetencji rozmówców, niejednokrotnie decydujący o powodzeniu komunikacyjnym. Pozwala np. na zmianę przedstawienia charakteru sprawy z jednostkowej na ogólną, z prywatnej na publiczną, co skutkuje zyskaniem nowych instrumentów rywalizacji, umożliwia przedefiniowanie układu interakcyjnego, zwiększenie dystansu i siły. 
Systemy komunikowania regulują dostęp podmiotów, co stwarza zapotrzebowanie na strategie legitymizacji, polegające na tworzeniu wrażenia reprezentatywności i prawowitości mandatu społecznego. Rywalizacyjne nastawienie uczestników debaty publicznej wyzwala z kolei strategie delegitymizacji, które polegają na wykluczeniu jednej ze stron. Jest ona wówczas oskarżana o to, że nie zna reguł debaty bądź je świadomie narusza, źle wypełnia rolę społeczną, kieruje się interesem osobistym, partykularnym, a nie publicznym. Strategie legitymizacji i delegitymizacji są podstawowe dla podmiotów podejmujących aktywność w sferze publicznej. Strategie konwersacyjne (informacyjno-weryfikacyjne, aksjologiczno-emotywne, behawioralne, metadyskursywne) są im podporządkowane, gdyż ani przekazywanie informacji, ani wartościowanie nie są działaniami podejmowanymi dla nich samych, ale ze względu na realizację globalnych celów pozajęzykowych.

Funkcjonowanie systemu komunikowania medialnego jest podporządkowane budowaniu i podtrzymywaniu relacji z odbiorcą masowym. Działania dziennikarzy o charakterze tekstotwórczym podejmowane $\mathrm{w}$ mikrosytuacji, takie jak: organizacja programu, strukturalizacja znaczeń, oddzielanie etapów w rozwoju interakcji, podsumowująco-zapowiadające komentarze metatekstowe, są motywowane makrosytuacyjnie. Można je więc traktować jak realizację strategii nadawczo-odbiorczych, gdyż ich rolą jest ukierunkowanie odbioru tekstu poprzez nadanie mu cech całościowości i sensowności. Przejawem strategii tego rodzaju są również działania polegające na dostosowaniu przekazu do kompetencji odbiorcy masowego oraz kształtowaniu jego kompetencji.

Strategie dziennikarza w zakresie budowania struktury tekstu zmierzają do nadania interakcji określonych cech gatunkowych (np. rozmowy publicznej, debaty, dyskusji eksperckiej, dyskusji typu forum), a jakość tych działań zależy od poziomu kompetencji prowadzącego. Na tle pozostałych programów, które poddano analizie, ciekawie prezentuje się widowisko „Debata”, w którym dziennikarz stosuje powtarzalne zabiegi w celu ukonstytuowania grup proponentów i oponentów: kieruje do obu stron te same pytania, przekazuje stronom argumenty strony przeciwnej, wspomaga eksplikację stanowiska dzięki formułowaniu wniosków, wyciąganiu implikatur lub podawaniu stwierdzeń w wątpliwość. Próby włączenia programu w debatę publiczną skutkują z kolei organizacją problemową interakcji, która naśladuje scenariusz procesu opiniotwórczego i decyzyjnego. Prowadzący inicjuje takie etapy, jak: diagnoza, wyjaśnienie, ocena, sformułowanie problemu, propozycje rozwiązań, weryfikacja propozycji, prognozy, wybór rozwiązania.

Zastosowanie pojęcia strategii do analizy językowych czynności komunikacyjnych uwyraźnia interpretację wypowiedzi w kategoriach działania oraz pozwala powiązać czynniki determinujące ich językowy kształt z bliższymi i dalszymi celami rozmówców. Działanie językowe może być rozpatrywane jako ciąg aktów mowy i wówczas można mówić o strategiach informacyjno-weryfikacyjnych, 
aksjologiczno-emotywnych czy behawioralnych. Szczególne miejsce zajmują strategie metadyskursywne, które, uwyraźniając sytuację komunikacyjną, stają się swoistymi sygnałami orientacji dla odbiorcy. Działania tekstotwórcze, o ile układają się w uschematyzowane i powtarzalne wzory, również dadzą się analizować w kategoriach działan strategicznych, których celem jest całościowa organizacja tekstu. Postawienie w centrum uwagi zagadnień związanych z budowaniem relacji między uczestnikami komunikacji naprowadza badacza na strategie interakcyjne. Ze względu na nastawienie do partnera można wyodrębnić kooperację lub rywalizację, natomiast ze względu na postawę w sytuacji konfliktu - atak, unik, obronę. Priorytetem uczestników komunikacji w sytuacjach oficjalnych jest dbanie o publiczny wizerunek, zatem wszelkie działania można odbierać jako mniej lub bardziej jawnie nastawione na obronę twarzy. Funkcjonowanie w życiu publicznym wymaga jednak czegoś więcej niż pozytywnego wizerunku, dlatego podmioty podejmują strategie legitymizacji.

Analiza działań komunikacyjnych w kategoriach strategii pokazuje, że w miarę komplikacji systemów komunikowania relacja komunikatu do rzeczywistości pozajęzykowej staje się coraz mniej istotna. Wzrasta natomiast rola dyskursywnie ukształtowanej rzeczywistości komunikacyjnej, gdyż to jej konwencje, reguły i formy są wykorzystywane taktycznie przez podmioty życia publicznego w tworzeniu strategii o różnym stopniu ogólności i różnych kryteriach wyodrębnienia. 



\section{Bibliografia}

Antas J., 2000, O kłamstwie i kłamaniu. Studium semantyczno-pragmatyczne, Kraków.

Anusiewicz J., Siciński B. (red.), 1994, Język a kultura, t. 11, Język polityki a wspótczesna kultura polityczna, Wrocław.

Arystoteles, 2004, Retoryka, przekł. H. Podbielski, Warszawa.

Austin J. L., 1962, Jak działać stowami, [w:] tegoż: Mówienie i poznawanie. Rozprawy i wykłady filozoficzne, Warszawa.

Austin J. L., 1993, Mówienie i poznawanie, przeł. B. Chwedeńczuk, Warszawa.

Awdiejew A., 1984, Sytuacja jako struktura sensu, [w:] B. Dunaj, Studia nad polszczyzna mówiona Krakowa 2, Kraków, s. 103-122.

Awdiejew A., 1991, Strategie konwersacyjne (próba typologii), „Socjolingwistyka” XI, s. 7-20.

Awdiejew A., 2004, Gramatyka interakcji werbalnej, Kraków.

Awdiejew A., Habrajska G., 2004, Wprowadzenie do gramatyki komunikacyjnej, t. 1, Łask.

Awdiejew A., Habrajska G., 2006, Wprowadzenie do gramatyki komunikacyjnej, t. 2, Łask.

Awdiejew A., Habrajska G., 2009, Strategie propagandowe i agitacyjne, [w:] Rozmowy o komunikacji 3. Problemy komunikacji społecznej, Łask, s. 9-55.

Bachtin M., 1986, Estetyka twórczości słownej, Warszawa.

Barłowska M., 2010, Rodzaje dowodów, [w:] M. Barłowska, A. Budzyńska-Daca, M. Załęska (red.), Ćwiczenia z retoryki, Warszawa.

Bartmiński J., Panasiuk J., 2001, Stereotypy językowe, [w:] J. Bartmiński (red.), Wspótczesny język polski, Lublin, s. 371-395.

Bartmiński J., Niebrzegowska-Bartmińska S., 2009, Tekstologia, Warszawa.

Bartosiewicz D., 2002, Komunikacyjna funkcja wyktadników spójności tekstu, Warszawa.

Basiuk T., 2003, Stuszny gniew jako strategia polityczna aktywizmu progejowskiego w Stanach Zjednoczonych i w Polsce, [w:] A. Duszak, N. Pawlak (red.), Anatomia gniewu. Emocje negatywne w językach $i$ kulturach świata, Warszawa, s. 201-215.

Baudrillard J., 2005a, O uwodzeniu, przeł. J. Margański, Warszawa.

Baudrillard J., 2005b, Symulakry i symulacja, przeł. S. Królak, Warszawa.

Bauer Z., 2000, Gatunki dziennikarskie, [w:] Z. Bauer, E. Chudziński (red.), Dziennikarstwo $i$ świat mediów, Kraków.

Beaugrande R. A. de, Dressler U. W., 1990, Wstęp do lingwistyki tekstu, Warszawa.

Bilut-Homplewicz Z., Czachur W., Smykała M. (red.), 2009a, Lingwistyka tekstu w Polsce i w Niemczech. Pojęcia, problemy, perspektywy. Antologia ttumaczeń, Wrocław.

Bilut-Homplewicz Z., Czachur W., Smykała M. (red.), 2009b, Lingwistyka tekstu w Niemczech. Pojęcia, problemy, perspektywy. Antologia tłumaczeń, Wrocław.

Bogołębska B., Worsowicz M. (red.), 2010, Styl, dyskurs, media, Łódź.

Boniecka B., 1978, Podstawowe typy struktur pytajnych, [w:] T. Skubalanka (red.), Studia nad składnia polszczyzny mówionej, Wrocław, s. 147-157.

Boniecka B., 1991, Strategia konwersacji, „Poradnik Językowy”, z.1/2, s. 24-37.

Boniecka B., 1994, Tekst w kontekście (problemy metodologiczne), „Polonica” 16.

Boniecka B., 1999, Lingwistyka tekstu - teoria i praktyka, Lublin. 
Boniecka B., 2000, Struktura i funkcje pytań w języku polskim, Lublin.

Bralczyk J., 1986, O języku polskiej propagandy politycznej lat siedemdziesiątych, Kraków.

Bralczyk J., 2007, O języku propagandy i polityki, Warszawa.

Bralczyk J., Mosiołek-Kłosińska K., 2001, Zwyczaje nominacyjne w polityce - autoidentyfikacja i stygmatyzacja, [w:] J. Bralczyk, K. Mosiołek-Kłosińska (red.), Zmiany w publicznych zwyczajach językowych, Warszawa, s. 113-119.

Brown P., Levinson S., 1987, Politeness. Some Universals in Language Use, Cambridge.

Bugajski M., 2006, Język w komunikowaniu, Warszawa.

Buttler D., 1982, Miejsce języka potocznego wśród odmian wspótczesnego języka polskiego, [w:] S. Urbańczyk (red.), Język literacki i jego warianty, Wrocław.

Cap P., 2008, Legitymizacja $w$ dyskursie politycznym: retoryka wojny w Iraku w kontekście pojęcia „proksymizacji”, [w:] N. Fairclough, A. Duszak (red.), Krytyczna analiza dyskursu. Interdyscyplinarne podejście do komunikacji społecznej, Kraków, s. 245-265.

Casetti F., Odin R., 1994, Od paleo- do neo-telewizji. W perspektywie semiopragmatyki, [w:] A. Gwóźdź (red.), Po kinie?... Audiowizualność w epoce przekaźników elektronicznych, Kraków.

Cetwiński O., Karwat M., 2001, Polityka jako homeostat systemu społecznego, [w:] B. Kaczmarek (red.), Metafory polityki, Wrocław.

Chłopicki W., Gajda S. (red.), 2008, Wspótczesny polski dyskurs publiczny w perspektywie międzykulturowej. Dyskusja panelowa, Kraków.

Cockiewicz W., 1994, Język telewizji polskiej jako przykład opracowanej odmiany polszczyzny mówionej, [w:] Z. Kurzowa, W. Sliwiński (red.), Wspótczesna polszczyzna mówiona w odmianie opracowanej (oficjalnej), Kraków.

Condor S., Antaki Ch., 2001, Dyskurs a psychologia postrzegania społecznego, [w:] T. A. van Dijk (red.), Dyskurs jako struktura i proces, Warszawa.

Cwalina W., 1999, Interakcje paraspołeczne między widzami a osobami prowadzacymi programy telewizyjne, [w:] P. Francuz (red.), Psychologiczne aspekty odbioru telewizji, Lublin.

Cwalina W., 2000, Telewizyjna reklama polityczna. Emocje i poznanie w kształtowaniu preferencji wyborczych, Lublin.

Czechowska A., 2004, Kompetencja komunikacyjna w glottodydaktyce, [w:] A. Dąbrowska (red.), Wroctawska dyskusja o języku polskim, Wrocław, s. 13-19.

Czyżewski M., Kowalski S., Piotrowski A. (red.), 1997, Rytualny chaos. Studium dyskursu publicznego, Kraków.

Dijk T. A. van, 1980, Macrostructures, Hillsdale NJ, [za:] A. Duszak, Tekst, dyskurs, komunikacja międzykulturowa, Warszawa 1998.

Dijk T. A. van, 2001, Badania nad dyskursem, [w:] T. A. van Dijk (red.), Dyskurs jako struktura i proces, przekł. G. Grochowski, Warszawa, s. 9-44.

Dijk T. A. van (red.), 2001, Dyskurs jako struktura i proces, przekł. G. Grochowski, Warszawa.

Dijk T. A. van, Kintsch W., 1983, Strategies of Discourse Comprehension, New York.

Dobek-Ostrowska B., 2006, Komunikowanie polityczne i publiczne, Warszawa.

Dobrzyńska T., 1971, O delimitacji tekstu literackiego, „Pamiętnik Literacki” LXII, z. 2, s. 115127.

Dobrzyńska T., 1974, Delimitacja tekstu literackiego, Wrocław.

Dobrzyńska T., 1978, Delimitacja tekstu pisanego i mówionego, [w:] M. R. Mayenowa (red.), Język. Tekst. Poetyka. Zbiór studiów, Wrocław, s. 101-118.

Drożdż M., 2010, Nie ma wolności bez... spojrzenie etyczne na wolność mediów i wolność stowa, [w:] I. Hoffman, D. Kępa-Figura (red.), Wspótczesne media. Wolne media?, t. 1, Lublin.

Dunaj B., 1981, Odmiana oficjalna i nieoficjalna języka mówionego, [w:] tenże (red.), Studia nad polszczyzna mówioną Krakowa, t. 1, Kraków. 
Duszak A., 1998, Tekst, dyskurs, komunikacja międzykulturowa, Warszawa.

Duszak A., 2010, Styl jako kategoria krytycznej analizy dyskursu, [w:] B. Bogołębska, M. Worsowicz (red.), Styl, dyskurs, media, Łódź, s. 33-43.

Dybalska R., Kępa-Figura D., Nowak P, 2004, Przemoc w języku mediów? Analiza semantyczna i pragmatyczna audycji radiowych, Lublin.

Faerch C., Kasper G., 1984, Two ways of defining communication strategies, "Language Learning” 34 (1), s. 45-63.

Fairclough N., Duszak A., 2008, Krytyczna analiza dyskursu - nowy obszar badawczy dla lingwistyki i nauk społecznych, [w:] N. Fairclough, A. Duszak (red.), Krytyczna analiza dyskursu. Interdyscyplinarne podejście do komunikacji społecznej, Kraków, s. 7-29.

Fillomore Ch. J., 1985, Frames and the Semantics of Understanding, "Quaderni di Semantica" 6, s. 222-253.

Fish S., 2002, Interpretacja, retoryka, polityka, Kraków.

Fleischer M., 2003, Polska symbolika kolektywna, Wrocław.

Foucault M., 1977, Archeologia wiedzy, przekł. A. Siemek, Warszawa.

Foucault M., 1995, Historia seksualności, przekł. B. Banasiak i in., Warszawa.

Foucault M., 2006, Trzy typy władzy, [w:] A. Jasińska-Kania, L. M. Nijakowski, J. Szacki, M. Ziółkowski (wybór i oprac.), Wspótczesne teorie socjologiczne, t. 1, Warszawa.

Frankowska M., 1994, Frazeologia i metaforyka w tekstach politycznych lat 1989-1993, [w:] J. Anusiewicz, B. Siciński (red.), Język a kultura, t. 11: Język polityki a wspótczesna kultura polityczna, Wrocław, s. 21-49.

Fras J., 2005, Komunikacja polityczna. Wybrane zagadnienia gatunków i języka wypowiedzi, Wrocław.

Fras J., 2010, Tabloidyzacja a mediatyzacja i logika mediów - wzajemne relacje pojęć, [w:] I. Hoffman, D. Kępa-Figura (red.), Wspótczesne media. Wolne media?, t. 2, Lublin, s. 59-72.

Furdal A., 1973, Klasyfikacja odmian wspótczesnego języka polskiego, Wrocław.

Gajda S., 1982, Podstawy badań stylistycznych nad językiem naukowym, Warszawa.

Gajda S., 2001, Nowe społeczności dyskursywne a edukacja komunikacyjna, [w:] J. Bralczyk, K. Mosiołek-Kłosińska (red.), Zmiany w publicznych zwyczajach językowych, Warszawa, s. $7-13$.

Gajda S., 2004, Gatunki wypowiedzi potocznych, [w:] J. Bartmiński, S. NiebrzegowskaBartmińska, J. Szadura (red.), Wspótczesna polszczyzna. Wybór opracowań, t. 3: Akty i gatunki mowy, Lublin, s. 144-153.

Gajda S., 2005, Tekst/dyskurs oraz jego analiza i interpretacja, [w:] M. Krauz, S. Gajda (red.), Wspótczesne analizy dyskursu. Kognitywna analiza dyskursu a inne metody badawcze, Rzeszów.

Gajda S., 2010a, Intertekstualność a wspótczesna lingwistyka, [w:] J. Mazur, A. Małyska, K. Sobstyl (red.), Intertekstualność we wspótczesnej komunikacji językowej, Lublin, s. 13-24.

Gajda S., 2010b, Nowe media w perspektywie lingwistycznej, [w:] B. Bogołębska, M. Worsowicz (red.), Styl, dyskurs, media, Łódź, s. 25-31.

Genette G., 1992, Palimpsesty. Literatura drugiego stopnia, [w:] Wspótczesna teoria badań literackich za granica. Antologia, red. H. Markiewicz, t. IV, cz. 2, Kraków, s. 316-366.

Giddens A., 1998, Socjologia, Poznań.

Gill A. M., Whedbee K., 2001, Retoryka, [w:] T. A. van Dijk (red.), Dyskurs jako struktura i proces, przekł. G. Grochowski, Warszawa, s. 182-214.

Goban-Klas T., 2004, Media i komunikowanie masowe. Teorie $i$ analizy prasy, radia, telewizji $i$ Internetu, Warszawa.

Godzic W., 2004, Telewizja i jej gatunki. Po „Wielkim Bracie”, Kraków. 
Goffman E., 2000, Człowiek w teatrze życia codziennego, przekł. H. Datner-Śpiewak, P. Śpiewak, Warszawa.

Golec A., 2002, Konflikt polityczny: myślenie i emocje, Warszawa.

Grabias S., 2003, Język w zachowaniach społecznych, wyd. 2 popr., Lublin.

Grice H. P., 1975, Logic and Conversation, [w:] Sytax and Semantics, t. 3: Speech Acts, P. Cole, J. L. Morgan (red.), New York.

Grice H. P., 1980, Logika a konwersacja, [w:] B. Stanosz (red.), Język w świetle nauki, Warszawa. Griffin E., Podstawy komunikacji społecznej, przekł. O. i W. Kubińscy, M. Kacmajor, Gdańsk.

Grzegorczykowa R., 1995, Wprowadzenie do semantyki językoznawczej, Warszawa.

Grzegorczykowa R., Puzynina J., 1998, Stowotwórstwo, [w:] R. Grzegorczykowa, R. Laskowski, H. Wróbel (red.), Gramatyka wspótczesnego języka polskiego. Morfologia, wyd. 2 zmien., Warszawa.

Grzmil-Tylutki H., 2007, Gatunek w świetle francuskiej teorii dyskursu, Kraków.

Gullberg M., 1998, Gestures as a communication strategy in second language discourse, Lund.

Habermas J., 2001, Teoria działania komunikacyjnego, t. 2, przekł. A. M. Kaniowski, Warszawa.

Habrajska G., 2004, Komunikacyjna analiza i interpretacja tekstu, Łódź.

Habrajska G. (red.), 2009, Rozmowy o komunikacji 3. Problemy komunikacji społecznej, Łask.

Halliday M. A. K., Explorations in the Functions of Language, London 1973.

Hannapel H., Melenk H., 1990, Alltagssprache. Semantische Grundbegriffe und Analysebeispiele, Monachium.

Heinemann W., 2009, Lingwistyka tekstu kontra lingwistyka dyskursu?, [w:] Z. Bilut-Homplewicz, W. Czachur, M. Smykała (red.), Lingwistyka tekstu w Niemczech. Pojęcia, problemy, perspektywy. Antologia ttumaczeń, Wrocław, s. 361-374.

Hymes D., 1971, On Communicative Competence, Philadelphia.

Hymes D., 1972, Models of the interaction of language and social life, [w:] J. Gumperz, D. Hymes (red.), Directions in Sociolinguistics: the Ethnography of Communication, New York, za: T. A. van Dijk (red.), Dyskurs jako struktura i proces, Warszawa 2001.

Jabłoński W., 2006, Kreowanie informacji. Media relations, Warszawa.

Jakubowska U., 2002, Przywództwo polityczne, [w:] K. Skarżyńska (red.), Podstawy psychologii politycznej, Poznań, s. 82-110.

Kamińska-Szmaj I., 1994a, Judzi, zohydza, ze czci odziera. Język propagandy politycznej w prasie 1919-1923, Wrocław.

Kamińska-Szmaj I., 1994b, Co to jest kultura polityczna? [w:] J. Anusiewicz, B. Siciński (red.), 1994, Język a kultura, t. 11: Język polityki a wspótczesna kultura polityczna, Wrocław, s. 9-15.

Kamińska-Szmaj I., 2001, Stowa na wolności. Język polityki po 1989 roku, Wrocław.

Kamińska-Szmaj I., Piekot T., Zaśko-Zielińska M. (red.), 2006, Oblicza komunikacji 1. Perspektywy badań nad tekstem, dyskursem i komunikacja, Kraków.

Karwat M., 2006a, Medialna mitologia faktów, [w:] J. Marszałek-Kawa (red.), Wspótczesne oblicza mediów, Torun, s. 44-69.

Karwat M., 2006b, O złośliwej dyskredytacji. Manipulowanie wizerunkiem przeciwnika, Warszawa.

Karwat M., 2007, Teoria prowokacji. Analiza politologiczna, Warszawa.

Kaszewski K., 2006, Język dyskusji radiowej. Analiza wypowiedzi słuchaczy w Programie III Polskiego Radia, Warszawa.

Kita M., 1998, Wywiad prasowy. Język - gatunek - interakcja, Katowice.

Kita M., 1999, „... porozmawiajmy o rozmowie”. Kryteria typologii rozmowy jako interakcji werbalnej, „Stylistyka” VIII, Opole, s. 119-131.

Kita M., 2005, Językowe rytuały grzecznościowe, Katowice.

Kochan M., 2005, Pojedynek na stowa. Techniki erystyczne w publicznych sporach, Kraków.

Kowalski S., Tulli M., 2003, Zamiast procesu. Raport o mowie nienawiści, Warszawa. 
Krupska-Perek A., 2002, Status komunikacyjny dialogowych programów telewizyjnych (Czy telewizyjny program dialogowy „na żywo” jest tekstem?), [w:] K. Michalewski (red.), Język w mediach, Łódź, s. 493-499.

Krzemiński P., 2010, Jeszcze informacja czy już komentarz? Stopień realizacji funkcji perswazyjnej jako wyznacznik podziału tekstów prasowych na komentarz i informację, [w:] I. Hoffman, D. Kępa-Figura (red.), Wspótczesne media. Wolne media?, t. 3, Lublin.

Kudra B., 2001, Kreatywność leksykalna $w$ dyskursie politycznym polskiej prasy lat osiemdziesiatych i dziewięćdziesiątych, Łódź.

Kudra B., Kudra A., 2004, Między manipulacją a perswazją (o funkcjonowaniu antroponimów w tekście prasowym), [w:] P. Krzyżanowski, P. Nowak (red.), Manipulacja w języku, Lublin, s. 91-99.

Kurcz I., 1987, Język a reprezentacja świata w umyśle, Warszawa.

Kurcz I., 2005, Psychologia języka i komunikacji, Warszawa.

Labocha J., 1996a, Odbiorca w tekście i wypowiedzi, [w:] S. Gajda, M. Balowski (red.), Styl a tekst, Opole.

Labocha J., 1996b, Tekst, wypowiedź, dyskurs, [w:] S. Gajda, M. Balowski (red.), Styl a tekst, Opole, s. 49-53.

Labocha J., 2004, Tekst pisany - tekst zapisany, „Biuletyn Polskiego Towarzystwa Językoznawczego", s. 5-10.

Labocha J., 2008, Tekst, wypowiedź, dyskurs w procesie komunikacji językowej, Kraków.

Labocha J., 2009, Lingwistyka tekstu w Polsce, [w:] Z. Bilut-Homplewicz, W. Czachur, M. Smykała (red.), Lingwistyka tekstu w Polsce i w Niemczech. Pojęcia, problemy, perspektywy. Antologia tłumaczeń, Wrocław.

Lachowiecki L., 1997, Sztuka zwycięskiej dyskusji, Warszawa.

Lakoff G., Johnson M., 1988, Metafory w naszym życiu, Warszawa.

Langacker R., 1995, Wykłady z gramatyki kognitywnej, Lublin.

Laskowska E., 1992, Wartościowanie w języku potocznym, Bydgoszcz.

Laskowska E., 2004, Dyskurs parlamentarny w ujęciu komunikacyjnym, Bydgoszcz.

Laskowska E., 2009, Wartościowanie w dyskursie publicznym, [w:] Rozmowy o komunikacji 3. Problemy komunikacji społecznej, Łask, s. 55-73.

Lausberg H., 2002, Retoryka literacka. Podstawy wiedzy o literaturze, przekł. A. Gorzkowski, Bydgoszcz.

Lewicki A. M., Nowak P., 2000, Manipulacja językowa w mediach, [w:] J. Bralczyk, K. Mosiołek-Kłosińska (red.), Język w mediach masowych, Warszawa, s. 34-43.

Lisowska-Magdziarz M., 2006, Analiza tekstu $w$ dyskursie medialnym. Przewodnik dla studentów, Kraków.

Loewe I., 2003, Gtos $w$ sprawie metarozmowy, czyli chciałabym powiedzieć, że..., [w:] M. Kita (red.), Porozmawiajmy o rozmowie, Katowice, s. 121-126.

Loewe I., 2007, Gatunki paratekstowe w komunikacji medialnej, Katowice.

Lyons J., 1984, Semantyka, t. 1, przekł. A. Weinsberg, Warszawa.

Lyons J., 1989, Semantyka, t. 2, przekł. A. Weinsberg, Warszawa.

Maingueneau D., 1991, L'analyse du discours. Introduction aux lectures de l'archive, Paris, [za:] E. Miczka, Kognitywne struktury sytuacyjne i informacyjne $w$ interpretacji dyskursu, Katowice 2002.

Maingueneau D., 1998, Analyser les textes de communication, Paris, Dunod, [za:] H. Grzmil-Tylutki, Gatunek w świetle francuskiej teorii dyskursu, Kraków 2007.

Maingueneau D., 2002, Analysis of an Academic Genre, Discourse Studies, 3, 4, [za:] H. Grzmil-Tylutki, Gatunek w świetle francuskiej teorii dyskursu, Kraków 2007.

Małyska A., 2006, Strategie komunikacyjne a wybory stylowe we wspótczesnych mediach, [w:] B. Witosz (red.), Style konwersacyjne, Katowice, s. 161-170. 
Mandler J. M., 2004, Opowiadania, skrypty i sceny: aspekty teorii schematów, przekł. M. Cierpisz, Kraków.

Marcjanik M., 2000, Polska grzeczność językowa, Kielce.

Marcjanik M., 2007, Grzeczność w komunikacji językowej, Warszawa.

Markowski A., 1992, Polszczyzna końca XX wieku, Warszawa.

Mayenowa M. R., 1971, Spójność tekstu a postawa odbiorcy, [w:] M. R. Mayenowa (red.), O spójności tekstu, Wrocław, s. 189-205.

Mayenowa M. R. (red.), 1974, Tekst i język. Problemy semantyczne, Wrocław.

Mayenowa M. R., 2004, Tekst literacki - pojęcie całości i pojęcie ramy, [w:] J. Bartmiński, S. Niebrzegowska-Bartmińska, J. Szadura (red.), Tekstologia, cz. 2, Lublin, s. 17-32.

Mazur J., 1986, Organizacja tekstu potocznego. Na przykładzie języka polskiego i rosyjskiego, Lublin.

Mazurek K., 2010, Problem etyki $w$ mediach $w$ publicystyce „Tygodnika Powszechnego”, [w:] I. Hoffman, D. Kępa-Figura (red.), Wspótczesne media. Wolne media?, t. 1, Lublin.

McNair B., 1998, Wprowadzenie do komunikowania politycznego, przekł. D. Piontek, Poznań.

McQuail D., 2007, Teoria komunikowania masowego, przekł. M. Bucholc, A. Szulżycka, Warszawa.

Michalewski K. (red.), 2002, Tekst w mediach, Łódź.

Miczka E., 1996, Sytuacja - tekst - rozumienie tekstu, „Stylistyka” V.

Miczka E., 2002, Kognitywne struktury sytuacyjne i informacyjne $w$ interpretacji dyskursu, Katowice.

Mikołajczuk A., 2003, O komunikacji językowej, [w:] E. Bańkowska, A. Mikołajczuk, Praktyczna stylistyka nie tylko dla polonistów, Warszawa.

Mikułowski Pomorski J., 2006, Jak narody porozumiewaja się ze soba w komunikacji międzykulturowej $i$ komunikowaniu medialnym, Kraków.

Minsky M., 1981, A Framework for Representing Knowledge, [w:] J. Haugeland (red.), Mind Design, Cambridge, s. 245-262, [za:] E. Miczka, Kognitywne struktury sytuacyjne i informacyjne w interpretacji dyskursu, Katowice 2002.

Miodunka W., Ropa A., 1979, Z zagadnień socjolingwistycznego opisu sytuacji. Na przykładzie sytuacji telewizyjnych. „Socjolingwistyka” 1979, t. II, s. 63-75.

Mosiołek-Kłosińska K., 2000, Wulgaryzacja języka w mediach, [w:] J. Bralczyk, K. Mosiołek-Kłosińska (red.), Język w mediach masowych, Warszawa, s. 112-120.

Mrozowski M., 2001, Media masowe. Wtadza, rozrywka i biznes, Warszawa.

Mukařovský J., 1970, Dialog a monolog, przeł. J. Mayen, [w:] tenże, Wśród znaków i struktur, Warszawa.

Nęcki Z., 2000, Komunikacja międzyludzka, Kraków.

Ng Sik Hunh, Reid S., 2001, Power, [w:] H. Giles, P. Robinson (red.), The New Handbook of Language and Social Psychology, Oxford, s. 357-369, [za:] J. Wasilewski, Retoryka dominacji, Warszawa 2006.

Nieckula F., 2001, Język ustny a język pisany, [w:] J. Bartmiński (red.), Wspótczesny język polski, Lublin.

Nocoń J., 2009, Podręcznik szkolny w dyskursie dydaktycznym - tradycja i zmiana, Opole.

Nowak P., Tokarski R., 2007, Medialna wizja świata a kreatywność językowa, [w:] P. Nowak, R. Tokarski (red.), Kreowanie światów w języku mediów, Lublin, s. 9-37.

Ong W. J., 1992, Oralność i piśmienność. Stowo poddane technologii, Lublin.

Oskiera A., 2006, Strategie konwersacyjne w dialogu radiowym, Łask.

Ostaszewska D., 1991, Organizacja tekstu a problem gromadzenia $i$ scalania jego informacji, Katowice.

Ostaszewska D. (red.), 2004, Gatunki mowy i ich ewolucja, t. 2, Gatunek a tekst, Katowice. 
Ostromęcka-Frączak B., 2007, Desakralizacja wartości w graffiti, [w:] J. Mazur, A. Małyska, K. Sobstyl (red.), Człowiek wobec wyzwań wspótczesności. Upadek wartości czy walka o wartość?, Lublin.

Ostromęcka-Frączak B., Grochulska E., 2002, Intertekstualność reklamy telewizyjnej, [w:] K. Michalewski (red.), Tekst w mediach, Łódź.

Ożóg K., 1990, Leksykon metatekstowy wspótczesnej polszczyzny mówionej, Kraków.

Ożóg K., 2001, Ustna odmiana języka ogólnego, [w:] J. Bartmiński (red.), Wspótczesny język polski, Lublin.

Ożóg K., 2004, Język w stużbie polityki. Językowy ksztatt kampanii wyborczych, Rzeszów.

Pałka P., 2009, Strategie dyskursywne w rozmowie handlowej, Katowice.

Paveau M. A., Sarfati G. E., 2009, Wielkie teorie językoznawcze. Od językoznawstwa historyczno-porównawczego do pragmatyki, przekł. I. Piechnik, Kraków.

Pawełczyk P., 2000, Socjotechniczne aspekty gry politycznej, Poznań.

Peisert M., 2004, Formy i funkcje agresji werbalnej. Próba typologii, Wrocław.

Perelman Ch., 1971, Analogia i metafora w nauce, poezji i filozofii, „Pamiętnik Literacki”, z. 3.

Perelman Ch., 2004, Imperium retoryki. Retoryka i argumentacja, przeł. M. Chomicz, Warszawa.

Piekot T., 2006, Dyskurs polskich wiadomości prasowych, Kraków.

Piotrowski A., 1980, O pojęciu kompetencji komunikatywnej, [w:] A. Schaff (red.), Zagadnienia socjo- $i$ psycholingwistyki, Wrocław, s. 91-109.

Pisarek W., 1991, Zróżnicowanie języka narodowego, [w:] S. Urbańczyk (red.), Encyklopedia języka polskiego, Wrocław.

Pisarkowa K., 1974, O spójności tekstu mówionego, [w:] M. R. Mayenowa, Tekst i język. Problemy semantyczne, Wrocław.

Pisarkowa K., 1975, Składnia rozmowy telefonicznej, Wrocław.

Pisarkowa K., 1978, Zdanie mówione a rola kontekstu, [w:] Studia nad składnia polszczyzny mówionej. Księga referatów, Wrocław, s. 7-20.

Podracki J., Trysińska M., 2002, Metafora w tekstach mówionych polityków (na podstawie rozmów w TVP), [w:] K. Michalewski (red.), Tekst w mediach, Łódź, s. 540-549.

Podracki J., Wszeborowska H., 2004, Rytualne i nierytualne zachowania językowe w polszczyznie radia i telewizji, [w:] J. Mazur (red.), Rytualizacja w komunikacji społecznej $i$ interkulturowej, Lublin, s. 87-97.

Pratkanis A., Aronson E., 2005, Wiek propagandy. Używanie i nadużywanie perswazji na co dzień, przekł. J. Radzicki, M. Szuster, Warszawa.

Ptaszek G., 2007, Talk show. Szczerość na ekranie?, Warszawa.

Rancew-Sikora D., 2007, Analiza konwersacyjna jako metoda badania rozmów codziennych, Warszawa.

Reykowski J., 2002a, Konflikty polityczne, [w:] K. Skarżyńska (red.), Podstawy psychologii politycznej, Poznań, s. 208-237.

Reykowski J., 2002b, Myślenie polityczne, [w:] K. Skarżyńska (red.), Podstawy psychologii politycznej, Poznań, s. 110-140.

Satkiewicz H., 2000, Językowe przejawy agresji w mediach, [w:] J. Bralczyk, K. Mosiołek-Kłosińska (red.), Język w mediach masowych, Warszawa, s. 28-34.

Searle J. R., 1980, Czym jest akt mowy, „Pamiętnik Literacki”, z. 2.

Searle J. R., 1987, Czynności mowy. Rozważania z filozofii języka, Warszawa.

Skarżyńska K., 2001, Jak porozumiewają się politycy: język ostrych kategoryzacji; psychologiczne przyczyny i konsekwencje, [w:] J. Bralczyk, K. Mosiołek-Kłosińska (red.), Zmiany w publicznych zwyczajach językowych, Warszawa, s. 119-128.

Skarżyńska K., 2002, Aktywność i bierność polityczna, [w:] Skarżyńska K. (red.), Podstawy psychologii politycznej, Poznań. 
Skowronek K., Rutkowski M., 2010, Kim jest Rysio z „Klanu”? Medialne symulakra w dyskursie publicznym, [w:] I. Hoffman, D. Kępa-Figura (red.), Wspótczesne media. Wolne media?, t. 2, Lublin.

Skrzypczak J. (red.), 1999, Popularna encyklopedia mass mediów, Poznań.

Skubalanka T., 1976, Założenia analizy stylistycznej, [w:] H. Markiewicz, J. Sławiński (red.), Problemy metodologiczne wspótczesnego literaturoznawstwa, Kraków.

Skudrzykowa A., Urban K., 2000, Mały stownik terminów z zakresu socjolingwistyki i pragmatyki językowej, Warszawa.

Skwarczyńska S., 1965, Wstęp do nauki o literaturze, t. 3, Warszawa.

Sobczak B., 2006, Wywiad telewizyjny na żywo. Charakterystyka gatunku, Poznań.

Stewart J., 2002, Mosty zamiast murów. O komunikowaniu się między ludźmi, Warszawa.

Szczęsna E., 2007, Poetyka mediów, Warszawa.

Szkudlarek-Śmiechowicz E., 2010, Tekst w radiowej i telewizyjnej debacie politycznej. Struktura. Spójność. Funkcjonalność, Łódź.

Szwabe J., 2008, Odbiór komunikatu jako zadanie poznawcze. Ujęcie pragmatyczno-kognitywne, Poznań.

Szymanek K., 2004, Sztuka argumentacji. Stownik terminologiczny, Warszawa.

Tabakowska E., 2001, Kognitywne podstawy języka i językoznawstwa, Kraków.

Taylor J. R., 2001, Kategoryzacja w języku. Prototypy w teorii językoznawczej, przekł. A. Skucińska, Kraków.

Tokarz M., 2006, Argumentacja. Perswazja. Manipulacja, Gdańsk.

Tomlin R. S., Forrest L., Pu M. M., Kim M. H., 2001, Semantyka dyskursu, [w:] T. A. van Dijk (red.), Dyskurs jako struktura i proces, przekł. G. Grochowski, Warszawa, s. 45-102.

Topolińska Z. (red.), 1984, Gramatyka wspótczesnego języka polskiego. Sktadnia, Warszawa.

Toulmin S. E., 1958, The uses of argument, Cambridge, [za:] M. Tokarz, Argumentacja. Perswazja. Manipulacja, Gdańsk 2006.

Uszyński J., 2004, Telewizyjny pejzaż genologiczny, Warszawa.

Walczak B., 1994, Co to jest język polityki?, [w:] J. Anusiewicz, B. Siciński (red.), Język a kultura, t. 11: Język polityki a wspótczesna kultura polityczna, Wrocław, s. 15-21.

Wasilewski J., 2006, Retoryka dominacji, Warszawa.

Wasilewski J., Skibiński A., 2008, Prowadzeni stowami. Retoryka motywacji w komunikacji publicznej, Warszawa.

Warchala J., 1991, Dialog potoczny a tekst, Katowice.

Warchala J., 2003, Kategoria potoczności w języku, Katowice.

Weinrich H., 1971, Besprochene und erzählte Welt, Stuttgart, [za:] J. Mazur, Organizacja tekstu potocznego. Na przyktadzie języka polskiego i rosyjskiego, Lublin 1986.

Westerstahl G., 1983, Objective News Reporting, "Communication Research" 10, [za:] M. Mrozowski, Media masowe. Wtadza, rozrywka i biznes, Warszawa 2001.

Wierzbicka A., 1971, Metatekst w tekście, [w:] M. R. Mayenowa (red.), O spójności tekstu, Wrocław-Warszawa-Kraków-Gdańsk, s. 105-121.

Wilkoń A., 1987, Typologia odmian językowych wspótczesnej polszczyzny, Katowice.

Wilkoń A., 2002, Spójność i struktura tekstu. Wstęp do lingwistyki tekstu, Kraków.

Winiarska J., 2001, Operatory metatekstowe w dialogu telewizyjnym, Kraków.

Witosz B., 1997, Opis w prozie narracyjnej na tle innych odmian deskrypcji, Katowice.

Witosz B., 2005, Genologia lingwistyczna. Zarys problematyki, Katowice.

Witosz B., 2009, Tekst a/i dyskurs w perspektywie polskiej tradycji badań nad tekstem, [w:] Z. Bilut-Homplewicz, W. Czachur, M. Smykała (red.), Lingwistyka tekstu w Polsce i w Niemczech. Pojęcia, problemy, perspektywy. Antologia tłumaczeń, Wrocław, s. 69-80.

Wojtak M., 2001, Strategie dyskursywne w pewnym typie tekstu dydaktycznego, [w:] G. Habrajska (red.), Język w komunikacji, t. 3, Łódź. 
Wojtak M., 2002, Przejawy mody w sposobie kształtowania informacyjnych gatunków prasowych, [w:] K. Wojtczuk (red.), Moda jako problem lingwistyczny, Siedlce.

Wojtak M., 2004, Gatunki prasowe, Lublin.

Wojtak M., 2006, Interakcyjny styl komunikowania we wspótczesnej prasie (na przykładzie prasy mtodzieżowej), [w:] B. Witosz (red.), Style konwersacyjne, Katowice.

Wojtak M., 2010a, Styl dziennikarstwa prasowego w perspektywie dyskursywnej, [w:] B. Bogołębska, M. Worsowicz (red.), Styl, dyskurs, media, Łódź, s. 81-91.

Wojtak M., 2010b, Gtosy z teraźniejszości. O języku wspótczesnej polskiej prasy, Lublin.

Wojtak M., 2011, Wspótczesne modlitewniki w oczach językoznawcy. Studium genologiczne, Tarnów.

Wolniewicz B., 1985, Ontologia sytuacji. Podstawy i zastosowania, Warszawa.

Wyrwas K., Sujkowska-Sobisz K., 2005, Mały stownik terminów teorii tekstu, Kraków.

Zając J., 2004, Kompetencja komunikacyjna w nauczaniu języków obcych - retrospekcje, introspekcje i prognozy, „Języki Obce w Szkole”, nr 2, s. 3-9.

Załazińska A., 2006, Niewerbalna struktura dialogu, Kraków.

Zarzycka G., 2006, Dyskurs prasowy o cudzoziemcach (na podstawie tekstów o Łódzkiej Wieży Babel i osobach czarnoskórych), Łódź.

Zgółkowa H., Klauzińska K., 2004, Metatekstowe środki karnawalizacji w dyskursie politycznym, [w:] J. Mazur (red.), Rytualizacja $w$ komunikacji społecznej $i$ interkulturowej, Lublin, s. $255-260$.

Ziółkowski M., 1981, Znaczenie, interakcja, rozumienie, Warszawa.

Ziółkowski M., 2006, Teorie konfliktu i teorie władzy. Wstęp, [w:] A. Jasińska-Kania, L. M. Nijakowski, J. Szacki, M. Ziółkowski (wybór i oprac.), Wspótczesne teorie socjologiczne, t. 1, Warszawa.

Żydek-Bednarczuk U., 1994, Struktura tekstu rozmowy potocznej, Katowice.

Żydek-Bednarczuk U., 2004, Od rozmowy do talk show. Uwagi o telewizyjnych gatunkach mowy, [w:] D. Ostaszewska (red.), Gatunki mowy i ich ewolucja, t. 2: Gatunek a tekst, Katowice, s. 424-438.

Żydek-Bednarczuk U., 2005, Wprowadzenie do lingwistycznej analizy tekstu, Kraków.

Żyro T., 2004, Wstęp do politologii, Warszawa.

\section{SŁOWNIKI}

ISJP - Bańko M. (red.), Inny słownik języka polskiego, t. 1-2, Warszawa 2000.

PSWP - Zgółkowa H. (red.), Praktyczny stownik wspótczesnej polszczyzny, t. 1-50, Poznań 19942005.

SJPD - Doroszewski W. (red.), Stownik języka polskiego, t. 1-11, Warszawa 1958-1969.

SJPDun - Dunaj B. (red.), Stownik wspótczesnego języka polskiego, Warszawa 1996.

SJPSz - Szymczak M. (red.), Stownik języka polskiego, t. 1-3, Warszawa 1994.

USJP - Dubisz S. (red.), Uniwersalny słownik języka polskiego, t. 1-4, Warszawa 2003. 



\section{Wykaz rysunków}

Rys. 1. Schemat czynników sytuacyjnych (zastosowany do analizy tekstu z wykorzystaniem strategii).

Rys. 2. Typy strategii w aspekcie tekstu, interakcji i sytuacji (jako determinanta dyskursu).......... 47

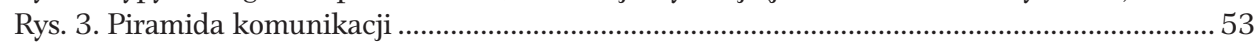

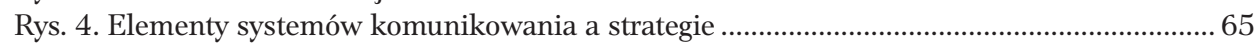

Rys. 5. Relacje systemów komunikowania w systemie społecznym................................................. 67

Rys. 6. Perspektywy ujęcia wydarzenia w zależności od celu strategii .......................................... 83

Rys. 7. Schemat medialnej komunikacji publicznej....................................................................... 123

Rys. 8. Typy strategii ze względu na zasięg i sposób komunikowania ...........................................124

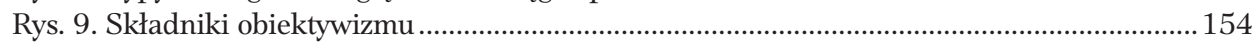

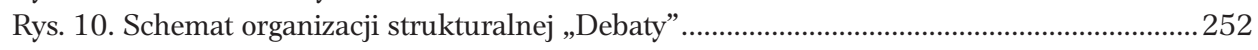

Rys. 11. Zachowania oraz strategie proponentów i oponentów ……..............................................263

Rys. 12. Konstytuowanie grup proponentów i oponentów przez dziennikarza.............................283

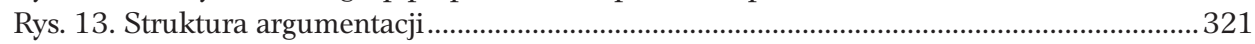

Rys. 14. Etapy organizacji problemowej segmentu z udziałem gości............................................. 326 



\title{
Strategies used by TV presenters and their interlocutors in media-public discourse
}

\author{
(Summary)
}

The research is based on a corpus of Polish current affairs programs from 2004 to 2009. The total length of the analyzed material was 62 hours. The texts were recorded (in writing) in a way that reflected the features of spoken language.

The aim of the research was to analyze the texts with the use of communicative strategies. The author defines strategy as a plan of linguistic activity intended to reach a certain goal. The empirical availability of the strategy as a research tool is limited. Therefore, the texts were examined as communicative events (i.e. as - broadly understood - communicative situations, including their institutional, social, and cultural conditionings). The author assumed that linguistic strategies have several aspects: the textual, the interactional, the situational, and the contextual. These aspects serve as a basis for a typology of strategies.

The research belongs to the area of text linguistics. The author puts special emphasis on a feature of text called discursiveness. Discursiveness connects the text with the parameters of the public discourse in the mass media. Some elements of the communication theory, media studies, sociology and political science were used to support the analysis of the situational conditionings of the analyzed utterances. The author adopts the genological perspective - she analyzed the texts as realizations of a particular genre.

The basic terms used in the dissertation include discourse, situation, context, and strategy. The author uses these terms to construct her own methodology. The terms are first generally described in the introduction and later discussed in relation to the parameters of the public and political discourse in the mass media.

The dissertation consists of two parts. The first part analyzes the conditionings of the strategies used by TV presenters and their interlocutors, which are related to the communicative situation. This part is based on the entire material collected by the author. The second part includes the analysis of communicative behaviors displayed by the participants of a Polish current affairs talk-show "Debata”, based on 15 (45-minute) episodes of this show.

In the first chapter, the analysis is focused on the conditionings resulting from the type of mass communication and public communication. It was especially important to establish how the formalization of institutional communication modifies communicative behavior of the interlocutors and influences their interactional strategies. In the second chapter, the author investigates the influence the interlocutors' professional activity has on their linguistic behavior. The third chapter is devoted to official situation (as opposed to unofficial situation) as a basic sociolinguistic category. The main focus is on how the official situation shapes behaviors and also how the knowledge about the standards of official situation can be used intentionally to achieve particular goals. In the fourth chapter, the question of how certain features of spoken language (i.e. its sequentiality, dialogicality, and narrowly understood situationality) influence the behavior of show participants.

The second part of the dissertation provides an analysis of a Polish periodical current affairs program "Debata". The aim of the analysis was to observe the regularity of the linguistic strategies 
used. The strategies were examined on both the global and local level. The author mainly focuses on how the presenter creates the text frame and the communicative situation within the genre of a debate. Therefore, in the fifth chapter, she describes the activities the presenter performs in order to build a coherent text structure (i.e. the text-forming strategies he uses). Chapter six focuses on the reconstruction of the strategies that he uses within the text frame, the segment with the audience, and the segment with the guests.

The author concludes that the linguistic strategy is an effective tool in text analysis. It allows to incorporate the important parameters of the broadly understood communicative situation and to take into account the aim of communication. The strategies used by TV presenters and their interlocutors in the public discourse in the mass media are influenced by a few factors: the fact that the texts are spoken, that the communicative situation is official, but also by the professional goals of the interlocutors, and the type of communication. Due to the diversity of conditionings, it is impossible to speak about one strategy that is used by an interlocutor. Instead, we rather deal with multiple strategies, whose multitude is a result of the polyfunctional character of every linguistic activity. 


\section{Od Redakcji}

Edyta Pałuszyńska pracuje jako adiunkt w Katedrze Lingwistyki Stosowanej i Kulturowej Uniwersytetu Łódzkiego. Prowadzi zajęcia dydaktyczne z gramatyki opisowej języka polskiego, kultury języka polskiego, leksykologii i leksykografii, stylistyki, retoryki, a także zajęcia specjalizacyjne w zakresie kodów komunikacji społecznej, dziennikarstwa oraz glottodydaktyki.

Stopień naukowy doktora uzyskała w 1999 r. na podstawie rozprawy Ekspresywność nagłówków w „Gazecie Wyborczej”. Zainteresowania naukowe autorki skupiają się wokół takich zagadnień, jak: terminologia naukowa, funkcje języka, komizm językowy, specyfika i funkcjonowanie nazw własnych, komunikacja medialna, gatunki debaty publicznej, reguły dyskursu publicznego, techniki argumentacyjne, kształtowanie kompetencji komunikacyjnej, psycholingwistyczne uwarunkowania nauczania języka jako drugiego. Świadectwem tych zainteresowań są wystąpienia na konferencjach naukowych i publikacje: Językowe środki nominacji $w$ polskiej terminologii zoologicznej (na materiale podręczników szkoty średniej), Nazwy własne w nagłówkach prasowych jako wykładniki funkcji ekspresywnej (na materiale zwiazków frazeologicznych), Nazwy własne w funkcji nieonomastycznej, Nowa formuła debaty telewizyjnej, Językowe strategie stużace zachowaniu „twarzy” $w$ dyskursie publicznym, Felieton radiowy jako gatunek na pograniczu publicystyki i literatury, Humor jako narzędzie dyskredytacji $w$ dyskursie politycznym, Kontratekstualność $i$ kontradyskursywność jako typ relacji intertekstualnej, Ksztattowanie kompetencji dyskursywnej $w$ procesie (glotto)dydaktycznym. 